\title{
BALANÇO HÍDRICO EM ZONA DE AFLORAMENTO DO SISTEMA AQÜÍFERO GUARANI A PARTIR DE MONITORAMENTO HIDROGEOLÓGICO EM BACIA REPRESENTATIVA
}

Dissertação apresentada à Escola de Engenharia de São Carlos da Universidade de São Paulo como parte dos requisitos para obtenção do título de Mestre em Engenharia.

Área de concentração: Hidráulica e Saneamento.

Orientador: Edson Cezar Wendland

SÃO CARLOS 

Dedico este trabatho a todos os meus familiares que sempre me apoiaram nessia caminhada, em especial a meu pai, Eeduardo Gomes Barreto, e a minha mãe, Margaret Andrade Barreto. 



\section{AGRADECIMENTOS}

Ao meu orientador Edson Cezar Wendland, pelo trabalho que pôs em minhas mãos, pelo apoio e cobrança, indispensáveis ao desenvolvimento do mestrado.

Ao meu amigo Luís Henrique Gomes, sem a sua ajuda e perseverança não seria possível a execução dos trabalhos de campo.

Ao meu amigo Saulo Aires de Souza, por toda a amizade e conselhos.

Aos meus colegas de trabalho do Laboratório de Hidráulica Computacional, José Anderson Batista, José Eduardo Quaresma, Jorge Rabelo, Francisco Marcussi (Pira), Marcelo Cavicchia, Fábio "Kerk's”, Paulo Valdivia, Cristiano Almeida, Eudes Arantes e Thiago Maziero, pelas dicas, conselhos e discussões que foram de grande valia para meu aprendizado.

A minhas avós Maria Costa Andrade e Maria de Lourdes Carvalho, meu tio Erasmo Costa Andrade e meus irmãos Paulo Eduardo Barreto e Stella Maria Barreto, que sempre confiaram em mim e me apoiaram nas decisões que tomei.

A todos os meus amigos que moram aqui em São Carlos e fizeram à vida aqui um pouco mais aprazível.

A todos os técnicos que participaram do meu trabalho, em especial a Roberto Bérgamo.

Ao Conselho Nacional de Desenvolvimento Científico e Tecnológico - CNPq - Brasil, pela concessão da minha bolsa de estudos.

Ao GEF (Global Environmental Facility), pelo suporte financeiro para a execução das atividades de campo.

Á Organização dos Estados Americanos (OEA) e à Secretaria Geral do projeto de Desenvolvimento Sustentável e Proteção Ambiental do Sistema Aqüífero Guarani (SG-OEA). 

"Pois as pequenas construções podem ser termınadas por seus arquitetos ınıciaıs; as grandes, as verdadeıras, deixam a pedra final para a posteridade". (HERMAN MELVILLE, MOBY DICK) 



\section{RESUMO}

BARRETO, C. E. A. G. (2005). Balanço hídrico em zona de afloramento do Sistema Aqüífero Guarani a partir de monitoramento hidrogeológico em bacia representativa. Dissertação (Mestrado). Escola de Engenharia de São Carlos, Universidade de São Paulo, São Carlos, 2006.

O objetivo principal deste trabalho é estimar a recarga direta e profunda do Sistema Aqüífero Guarani (SAG) na bacia representativa do Ribeirão da Onça. Paralelamente são analisados os comportamentos do aqǘf́ero e da evapotranspiração na bacia.

A bacia do Ribeirão da Onça apresenta características representativas típicas da região de afloramento do Sistema Aqüífero Guarani (SAG) no Estado de São Paulo. A bacia do Ribeirão da Onça tem a vantagem de ser uma bacia amplamente estudada em vários aspectos referentes à sua hidrologia e hidrogeologia.

Obtiveram-se dados suficientes para fazer um balanço hídrico da bacia monitorada por um ano hidrológico e extrair uma estimativa da recarga direta e profunda nesta zona de afloramento do Sistema Aqüífero Guarani. Utilizaram-se dados da flutuação do nível do aqüífero para estimar a recarga direta e a variação do armazenamento subterrâneo.

Os poços de monitoramento foram distribuídos em diversas culturas, possibilitando uma análise do comportamento do aqüífero por cultura.

Estimou-se que a recarga direta do sistema, na bacia, está em torno de $400 \mathrm{~mm}$ anuais. A estimativa da recarga profunda indica um valor entre zero e $40 \mathrm{~mm}$.

A análise do comportamento do aqüífero mostra que a recarga direta é menor em solos cultivados com eucalipto e maior em áreas cultivadas com pastagem. A variação do nível do aqüífero apresenta forte correlação entre as culturas, exceto a de eucaliptos.

A posição dos poços é fator fundamental para a estimativa da recarga direta. Terrenos mais planos tendem a produzir uma maior recarga direta do aqüífero.

Avaliaram-se métodos de estimativa de evapotranspiração. A avaliação foi realizada entre alguns métodos empíricos e a evapotranspiração obtida através do balanço hídrico. Estimou-se uma evapotranspiração em torno de $900 \mathrm{~mm}$ anuais a partir do balanço hídrico. Todos os métodos empíricos e semi-empiríco, com exceção do de Thornthwaite, superestimaram a evapotranspiração quando comparados ao valor estimado pelo balanço hídrico. O método de Hargreaves-Samani foi o que mais se distanciou, com 1894mm anuais. 
O método de Thornthwaite foi o que mais se aproximou, com 936mm anuais, com discrepância de apenas entre 3\% e -6\% do valor estimado pelo balanço hídrico.

A utilização dos métodos empíricos e semi-empíricos de estimativa da evapotranspiração, para estudos da recarga de aqüíferos na região da zona de afloramento do Sistema Aqüífero Guarani no estado de São Paulo, deve ser vista com cautela. Só uma avaliação prolongada poderá indicar quais os métodos mais se aproximam da realidade.

Pelos resultados obtidos, recomenda-se a revisão das estimativas de disponibilidade hídrica sustentável do Sistema Aqüífero Guarani e a utilização com cautela dos métodos empíricos e semi-empíricos de estimativa da evapotranspiração, para estudos hidrológicos no estado de São Paulo.

A análise do monitoramento da bacia do Ribeirão da Onça só vem a confirmar a representatividade dos estudos feitos nessa região e a grande relevância que esses estudos terão para o gerenciamento desse importante reservatório que é o Sistema Aqüífero Guarani.

Palavras-Chave: Águas Subterrâneas, recarga, hidrogeologia, evapotranspiração. 


\section{ABSTRACT}

BARRETO, C. E. A. G. (2005). Water balance in the outcrop zone of Guarani Aquifer System through hydrogeologic monitoring in a representative basin. M.Sc. Dissertation. Escola de Engenharia de São Carlos, Universidade de São Paulo, São Carlos, 2006.

The main objective of this work is to esteem the recharge direct and deep in the Guarani Aquifer System (GAS) at the representative basin of Ribeirão da Onça. At the same time, the behavior and the evapotranspiration at the water basin have been studied.

The Ribeirão da Onça water basin has typical representative characteristics on the outcrop region in the Guarani Aquifer System (GAS) in the São Paulo State. Its hydrology and hydrogeology have been widely studied under several aspects, what consists of an advantage.

It had been gotten enough data to make a water balance of the monitored water basin for one hydrological year and get out the direct and deep recharge estimate at this outcrop region of the Guarani Aquifer System. It had been used data of the aquifer level fluctuation in order to estimate the direct recharge and the subterranean storage.

The monitoring wells are distributed in several crops, making the behavior in the aquifer per crop analysis possible.

The estimated direct recharge of the system, at the water basin, is about $400 \mathrm{~mm}$. The estimated deep recharge is between zero and $40 \mathrm{~mm}$.

The aquifer behavior analysis shows that the direct recharge is smaller in soils with eucalyptus cultivated than it is in other crops. The wells position is also an important aspect to the direct recharge. Plainer and higher lands tend to produce a greater direct recharge of the aquifer.

Evapotranspiration esteem methods had been also evaluated. The evaluation was made with some empirical methods and the evapotranspiration gotten through to the water balance. The evapotranspiration estimated through the water balance was about $900 \mathrm{~mm}$ per year. All the empirical and semi-empirical methods, excepting Thornthwaite, overestimated the evapotranspiration if compared to the water balance estimated value. The HargreavesSamani's method was the most far-away, with $1894 \mathrm{~mm}$ per year. The Thornthwaite method was the closest, with $936 \mathrm{~mm}$ per year, only between $-6 \%$ and $3 \%$ of the estimated value through the water balance. 
The use of empirical and semi-empirical methods to esteem the evapotranspiration, in order to study the aquifers recharge in the region of the outcrop zone of the Guarani Aquifer System at São Paulo State, must be used with caution. Only a long-term evaluation could say which methods get closer to the reality.

Through the analysis of the gotten results, it is recommended a revision of the estimated sustained water accessibility of the Guarani Aquifer System and the cautious use of the empirical and semi-empirical methods to esteem the evapotranspiration, to hydrological studies at São Paulo State.

The analysis of the monitoring of the Ribeirão da Onça water basin comes to prove the active role of the studies in this region and the importance that this studies will have to the management of this great reservoir that is the Guarani Aquifer System.

Key-words: Groundwater, recharge, hydrogeology, evapotranspiration 


\section{SUMÁRIO}

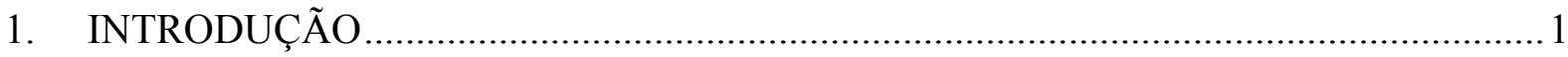

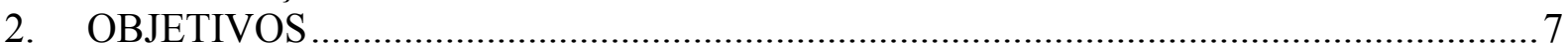

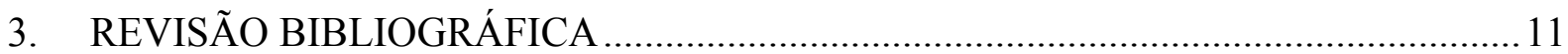

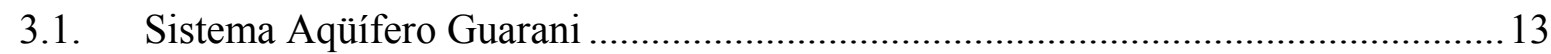

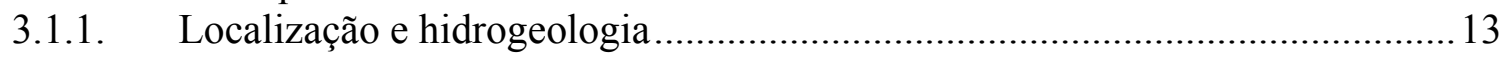

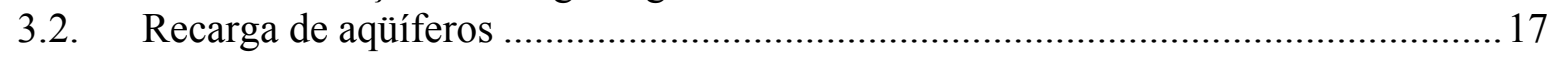

3.2.1. Métodos de estimativa da recarga subterrânea ................................................ 18

3.3. Importância da evapotranspiração na estimativa da recarga ...................................28

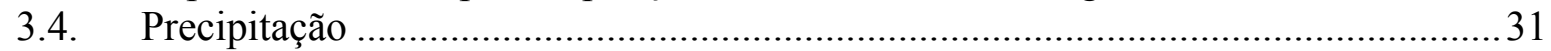

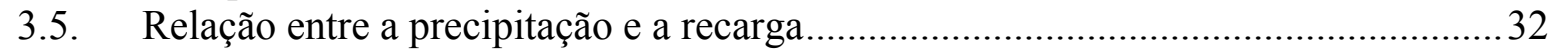

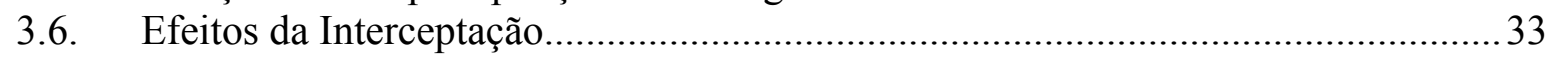

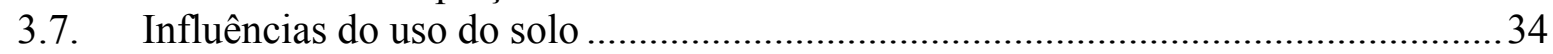

3.8. Quantificação do escoamento superficial ............................................................. 35

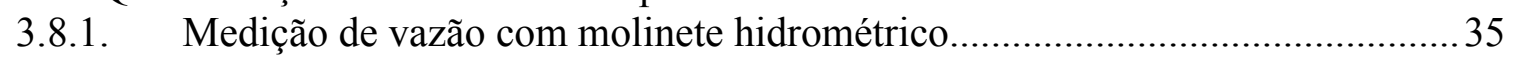

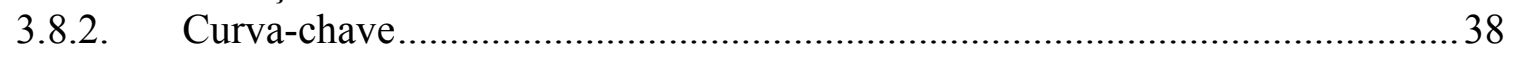

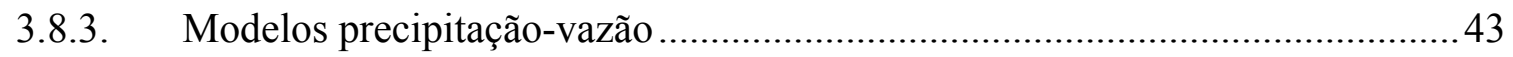

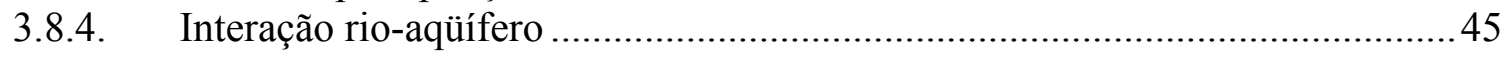

3.9. Revisão de métodos utilizados para cálculo da evapotranspiração ........................... 48

3.9.1. Método de Penman-Monteith ........................................................................ 48

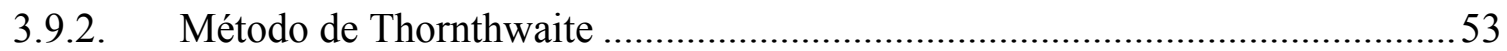

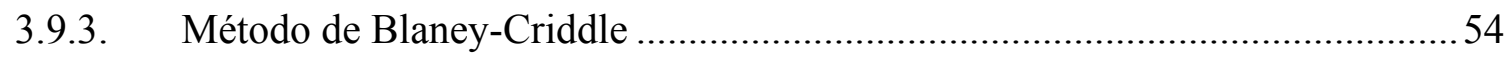

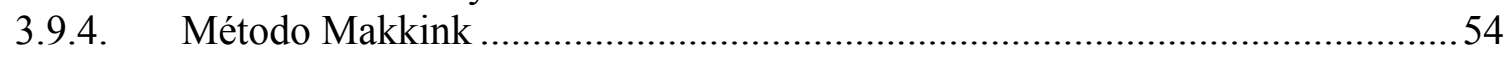

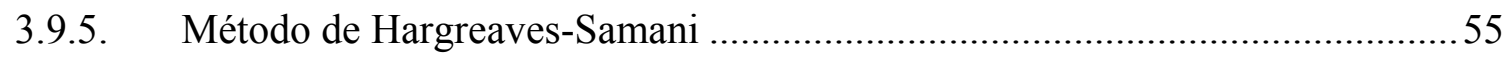

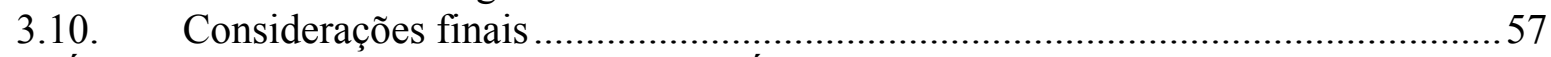

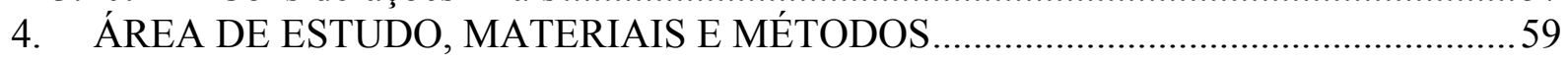

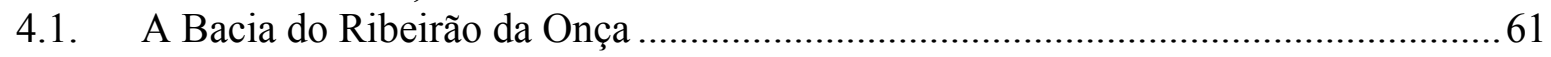

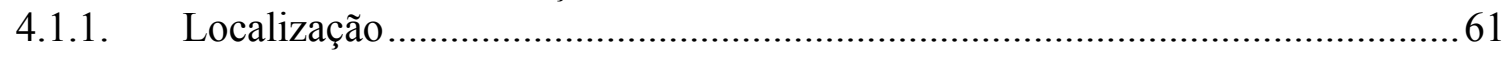

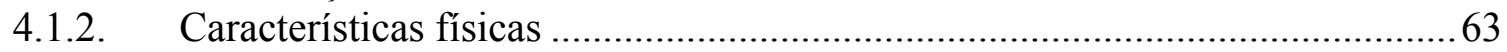

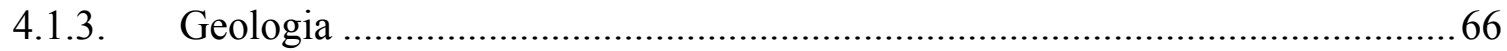

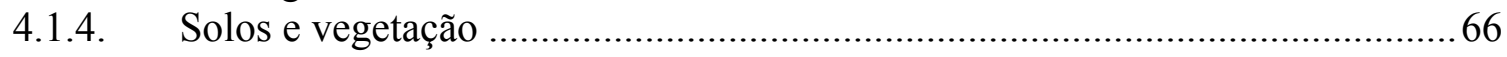

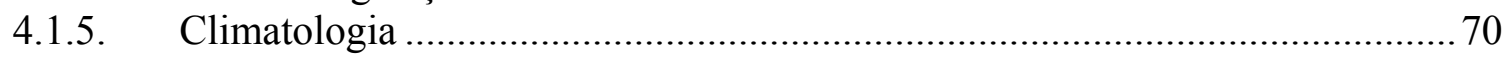

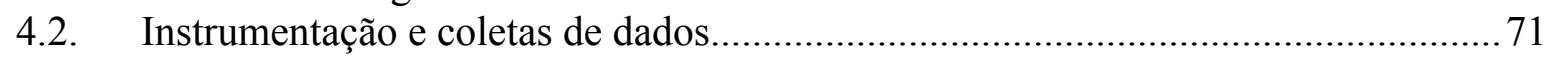

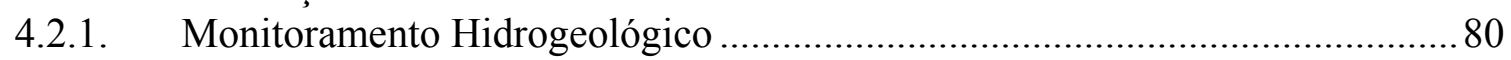

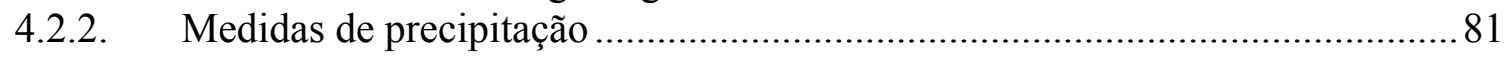

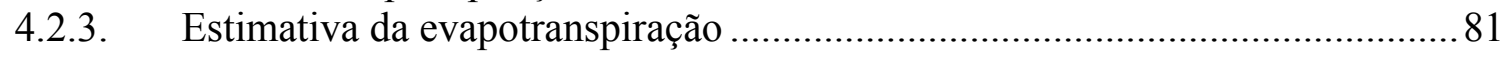

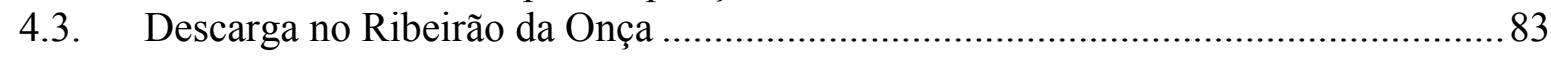

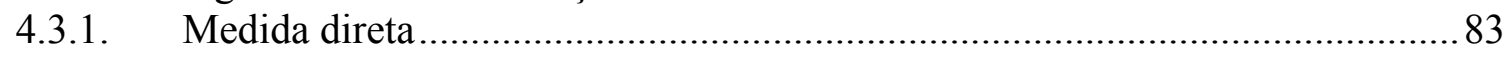

4.3.2. Estimativa da vazão de base pela correlação com o nível do aqüífero...............83

4.3.3. Estimativa do escoamento superficial direto através de modelo chuva-vazão. 86

4.4. Determinação da variação do armazenamento subterrâneo de água .........................92

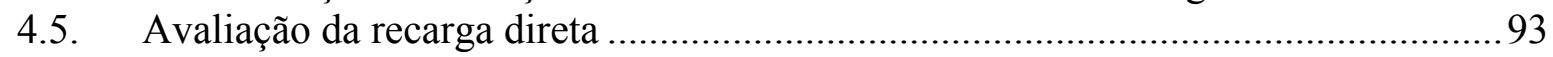

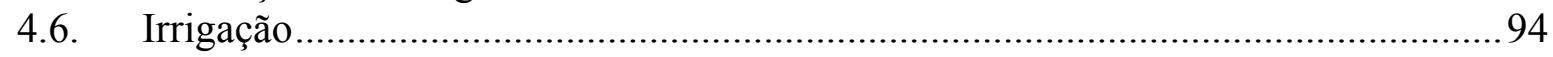

4.7. Balanço Hídrico ............................................................................................ 95

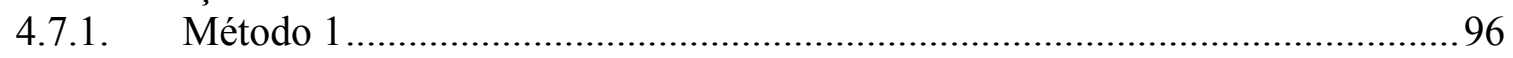

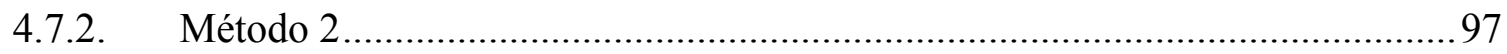

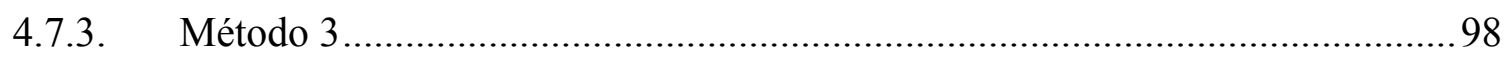

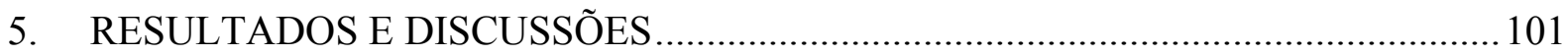


5.1. Nível do aqǘfero ....................................................................................... 103

5.2. Análise da variação do nível do aqüífero.......................................................... 113

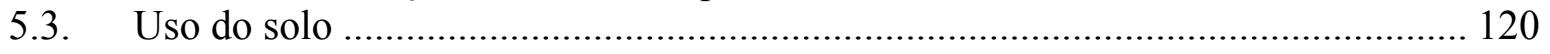

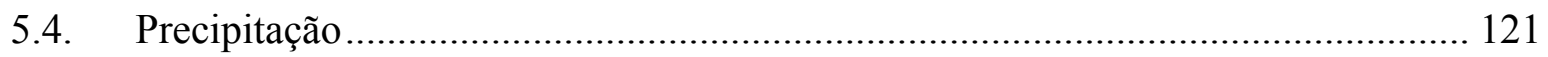

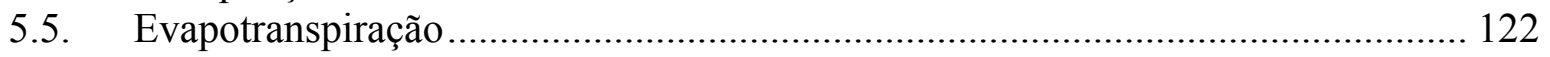

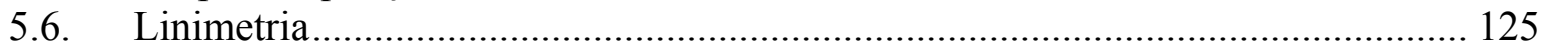

5.7. Medição de vazão líquida ………………………………………………….... 128

5.8. Escoamento de base ................................................................................ 129

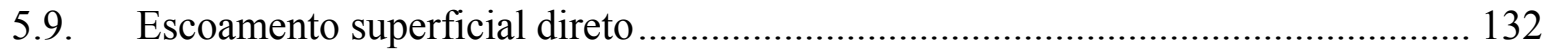

5.10. Variação do armazenamento subterrâneo ……………………………………... 138

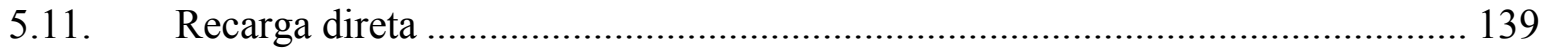

5.12. Balanço Hídrico .................................................................................... 150

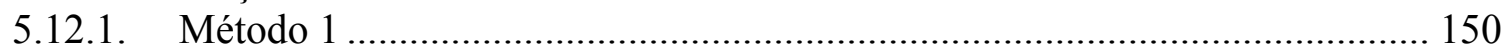

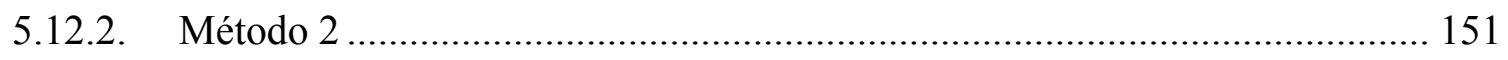

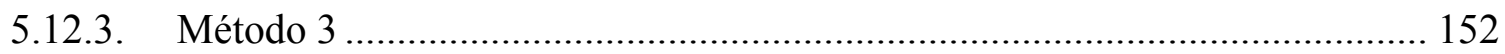

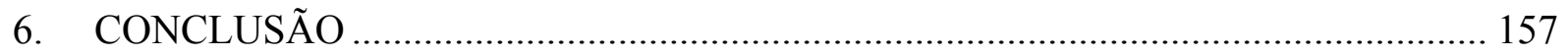

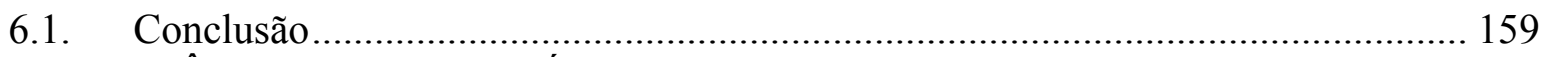

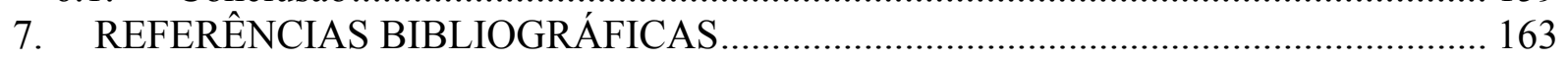

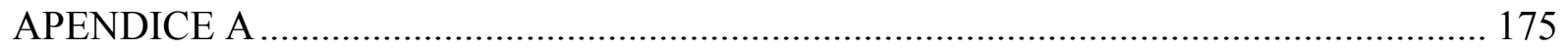

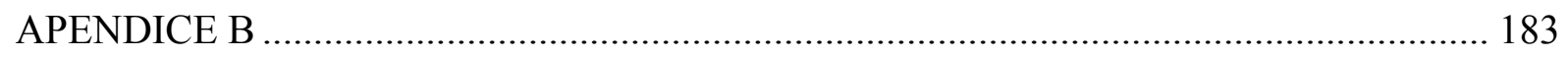

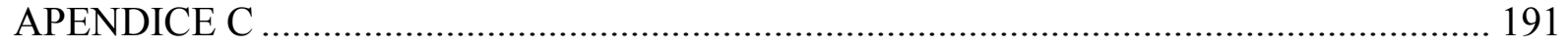

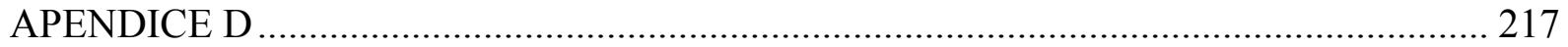

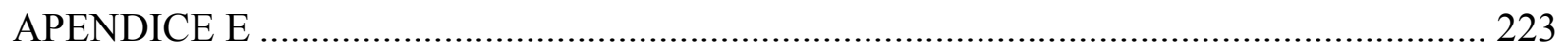

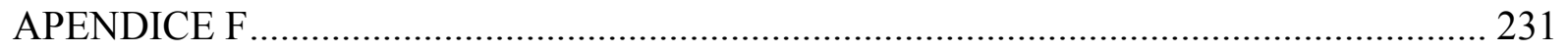

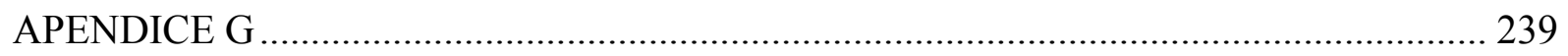

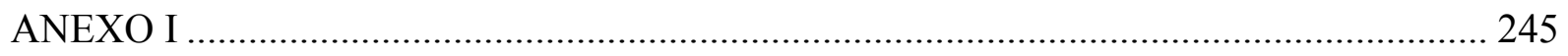




\section{LISTA DE FIGURAS}

Figura 1: Mapa esquemático do Sistema Aqüífero Guarani................................................ 14

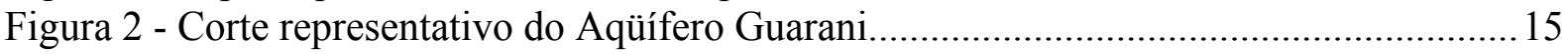

Figura 3: Componentes do ciclo hidrológico para balanço hídrico........................................21

Figura 4: Elevação hipotética do nível d'água em poço em resposta à precipitação ................24

Figura 5: Desenho esquemático de decomposição da seção transversal de um curso de água

para o cálculo de vazão, a partir de medição com molinete hidrométrico ........................ 38

Figura 6: Representação gráfica da extrapolação da curva-chave pelo método logarítmico ...40

Figura 7: representação gráfica da extrapolação da curva-chave pelo método de Stevens ...... 42

Figura 8: representação gráfica da extrapolação da curva-chave pelo método de Manning ....43

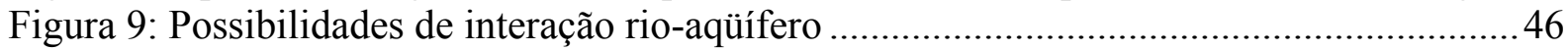

Figura 10: Separação do escoamento de base no Ribeirão da Onça, Brotas-SP, 1985-1986...48

Figura 11: Localização da bacia do Ribeirão da Onça ............................................................62

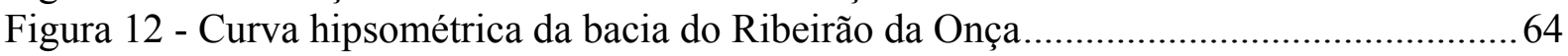

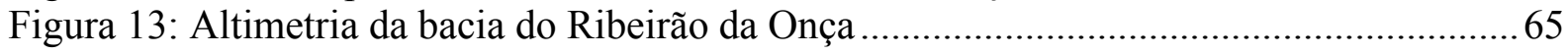

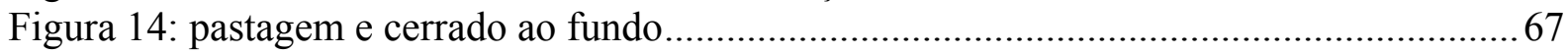

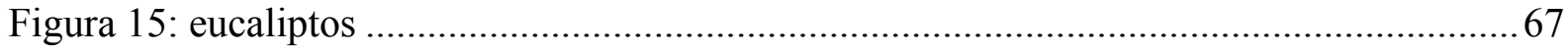

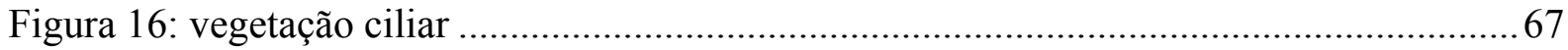

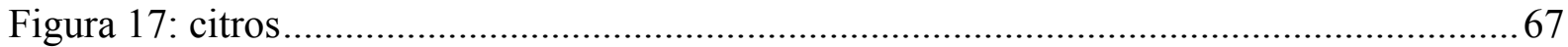

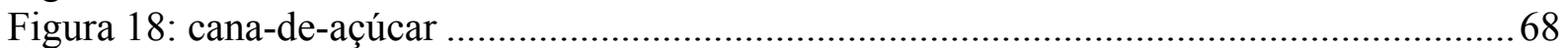

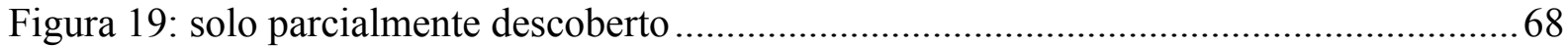

Figura 20: Mapa de uso e ocupação do solo (Dezembro/2004-Abril/2005) ............................69

Figura 21: Imagem de satélite da bacia do Ribeirão da Onça ................................................. 70

Figura 22: localização dos instrumentos de monitoramento instalados na área de estudo.......73

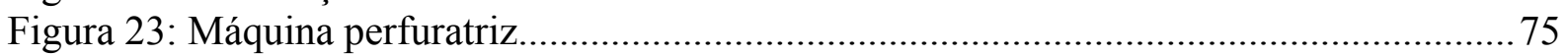

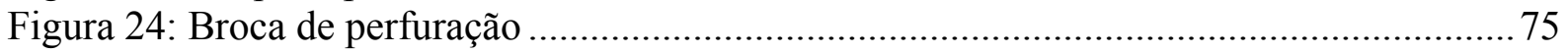

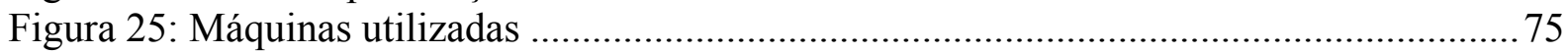

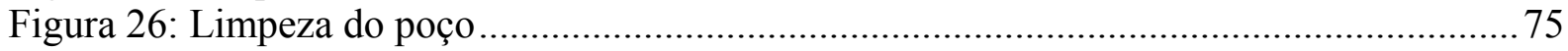

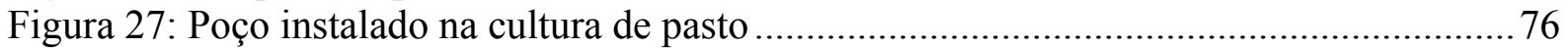

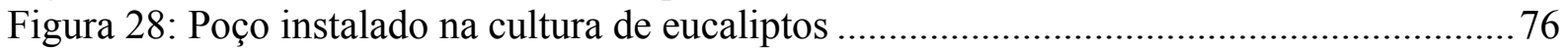

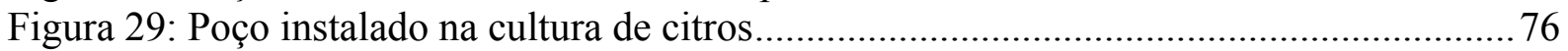

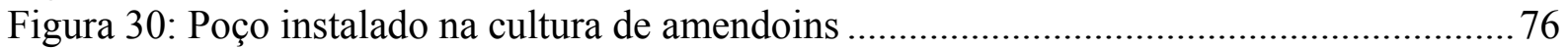

Figura 31: Pluviômetro instalado no centro da bacia ............................................................. 77

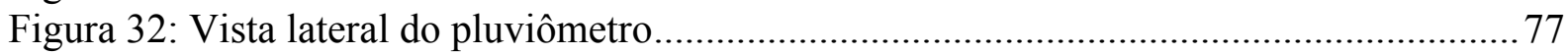

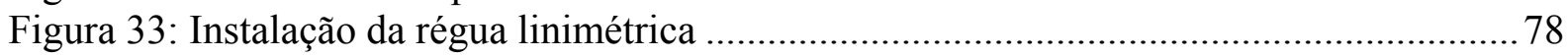

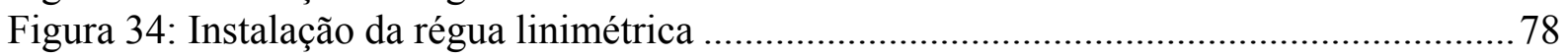

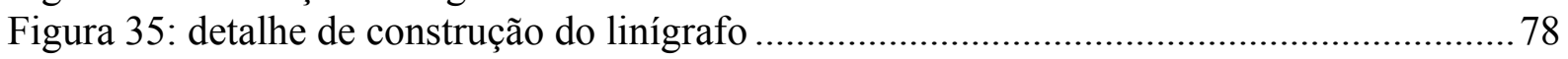

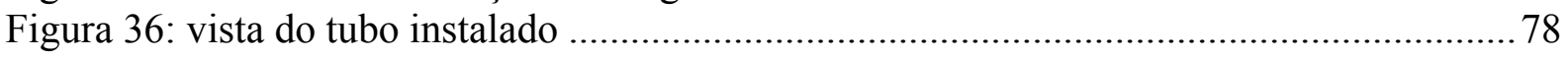

Figura 37: Vista da base de proteção do equipamento de medição e armazenamento.............79

Figura 38: vista geral da Estação Climatológica do CRHEA.................................................... 79

Figura 39: Tanque classe A instalado na Estação Climatológica do CRHEA .......................... 79

Figura 40: Estação Automática de coleta de dados climatológicos do CRHEA .......................80

Figura 41: Heliógrafo instalado na Estação Climatológica do CRHEA ................................... 80

Figura 42: Corte esquemático representativo do fluxo entre um aqüífero e um ribeirão.......... 84

Figura 43: Esquema para determinação do ponto do curso d'água que deve ser considerado como referência para determinação do valor do nível do aqüífero .................................. 85

Figura 44: Representação das sub-bacias utilizadas na simulação do escoamento superficial direto pelo modelo de transformação chuva-vazão IPHS1 …......................................... 87

Figura 45: seção transversal do Ribeirão da Onça durante diferentes medições de vazão. Exagero vertical de aproximadamente $5 \mathrm{x}$. 


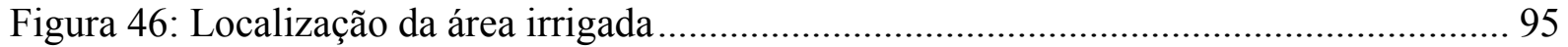

Figura 47: Volume de controle conceitual para balanço hídrico pelo método1 ...................... 96

Figura 48: Volume de controle para balanço hídrico na a bacia do Ribeirão da Onça pelo método 2

Figura 49: Volume de controle para balanço hídrico na a bacia do Ribeirão da Onça pelo método 3

Figura 50: Variação do nível de água em poços de monitoramento locados na cultura de pastagem.

Figura 51: Variação do nível do aqüífero na seção formada pelos poços 16, 18 e 19.......... 115

Figura 52: Variação do nível de água em poços de monitoramento locados na cultura de citros

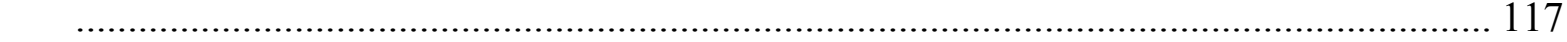

Figura 53: Variação do nível do aqüífero na seção formada pelos poços 09, 08 e 13.......... 117

Figura 54: Variação do nível de água em poços de monitoramento locados nas culturas de eucaliptos, laranja, cana-de-açúcar e pasto.

Figura 55: Esquema de deformação na superfície do aqüífero após evento de chuva............ 131

Figura 56: Detalhe do afloramento da Formação Botucatu na bacia do Ribeirão da Onça ... 150

Figura 57: Mapa de uso e ocupação do solo (Maio/2005-Agosto/2005).............................. 177

Figura 58: Mapa de uso e ocupação do solo (Setembro/2005-Outubro/2005) ....................... 178

Figura 59: Mapa de uso e ocupação do solo (Novembro/2005-Janeiro/2006) ....................... 179

Figura 60: Mapa de uso e ocupação do solo (Dezembro/2004-Abril/2005) ........................... 180

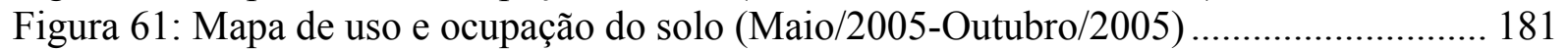

Figura 62: Mapa de uso e ocupação do solo (Novembro/2005-Janeiro/2006) ....................... 182

Figura 63: Planilha de medição de vazão no dia 28/10/2004 ................................................ 193

Figura 64: Planilha de medição de vazão no dia 22/02/2005 ............................................... 194

Figura 65: Planilha de medição de vazão no dia 04/03/2005 ............................................... 195

Figura 66: Planilha de medição de vazão no dia 18/03/2005 ............................................... 196

Figura 67: Planilha de medição de vazão no dia 20/04/2005 ............................................. 197

Figura 68: Planilha de medição de vazão no dia 29/04/2005 ............................................. 198

Figura 69: Planilha de medição de vazão no dia 06/05/2005 .............................................. 199

Figura 70: Planilha de medição de vazão no dia 16/05/2005 ............................................... 200

Figura 71: Planilha de medição de vazão no dia 24/05/2005 ................................................ 201

Figura 72: Planilha de medição de vazão no dia 03/06/2005 ................................................ 202

Figura 73: Planilha de medição de vazão no dia 21/06/2005 ................................................ 203

Figura 74: Planilha de medição de vazão no dia 24/06/2005 ................................................ 204

Figura 75: Planilha de medição de vazão no dia 01/07/2005 ............................................... 205

Figura 76: Planilha de medição de vazão no dia 03/08/2005 ................................................ 206

Figura 77: Planilha de medição de vazão no dia 12/08/2005 ............................................... 207

Figura 78: Planilha de medição de vazão no dia 19/08/2005 ............................................... 208

Figura 79: Planilha de medição de vazão no dia 02/09/2005 ............................................... 209

Figura 80: Planilha de medição de vazão no dia 15/09/2005 .............................................. 210

Figura 81: Planilha de medição de vazão no dia 14/10/2005 .............................................. 211

Figura 82: Planilha de medição de vazão no dia 11/11/2005 ................................................ 212

Figura 83: Planilha de medição de vazão no dia 08/12/2005 ............................................... 213

Figura 84: Planilha de medição de vazão no dia 22/12/2005 ................................................ 214

Figura 85: Planilha de medição de vazão no dia 13/01/2006 ............................................... 215

Figura 86: Seção transversal (batimetria) no ponto de medição de vazão nos dias 28/10/2004,

2/02/2005, 04/03/2005 e 18/03/2005 ......................................................................... 219

Figura 87: Seção transversal (batimetria) no ponto de medição de vazão nos dias 18/03/2005, 20/04/2005, 29/04/2005 e 06/05/2005 
Figura 88: Seção transversal (batimetria) no ponto de medição de vazão nos dias 06/05/2005, 16/05/2005, 24/05/2005 e 03/06/2005 220

Figura 89: Seção transversal (batimetria) no ponto de medição de vazão nos dias 03/06/2005, 21/06/2005, 24/06/2005 e 01/07/2005 221

Figura 90: Seção transversal (batimetria) no ponto de medição de vazão nos dias 01/07/2005,

03/08/2005, 12/08/2005 e 19/08/2005 221

Figura 91: Seção transversal (batimetria) no ponto de medição de vazão nos dias 19/08/2005, 02/09/2005, 15/09/2005 e 14/10/2005 222

Figura 92: Seção transversal (batimetria) no ponto de medição de vazão nos dias 14/10/2005, $11 / 11 / 2005,08 / 12 / 2005,22 / 12 / 2005$ e $13 / 01 / 2006$ 222 



\section{LISTA DE GRÁFICOS}

Gráfico 1: Extrapolação da curva-chave através do método de Manning com K constante e com $\mathrm{K}$ variável.

Gráfico 2: Extrapolação da curva-chave através dos métodos de Manning com $\mathrm{K}$ variável e do método de extrapolação logarítmico............................................................................ 90

Gráfico 3: Nível do aqüífero em relação ao solo no poço 03 , locado entre as culturas de pastagem e de eucalipto.

Gráfico 4: Nível do aqüífero em relação ao solo no poço 05 , locado em cultura de pastagem.

Gráfico 5: Nível do aqüífero em relação ao solo no poço 08, locado em cultura de laranja.. 106 Gráfico 6: Nível do aqüífero em relação ao solo no poço 09, locado em cultura de eucalipto.

Gráfico 7: Nível do aqüífero em relação ao solo no poço 13, locado em cultura de laranja.. 108

Gráfico 8: Nível do aqüífero em relação ao solo no poço 15 , locado em cultura de cana-deaçúcar com rodízio de culturas para amendoim.

Gráfico 9: Nível do aqüífero em relação ao solo no poço 16, locado em cultura de pastagem.

Gráfico 10: Nível do aqüífero em relação ao solo no poço 18 , locado em cultura de pastagem.

Gráfico 11: Nível do aqüífero em relação ao solo no poço 19, locado em cultura de pastagem.

em reǘrero emão ao solo no poço 21 ,

Gráfico 13: Gráfico de correlação mensal entre as precipitações observadas....

Gráfico 14: Estimativas mensais da evapotranspiração potencial de referência para o ano de 2005, a partir dos dados da estação climatológica do CRHEA.

Gráfico 15: Estimativa anual da evapotranspiração na sub-bacia do Ribeirão da Onça no ano de 2005

Gráfico 16: Cotagrama da seção de controle de descarga no Ribeirão da Onça

Gráfico 17: Níveis e vazões em uma seção de controle no Ribeirão da Onça e suas respectivas linhas de tendência

Gráfico 18: Vazão de base simulada através de equação de interação rio-aqüífero................ 130

Gráfico 19: função de melhor ajuste para o fluxo de base .................................................... 130

Gráfico 20: Estimativa mensal do escoamento básico no Ribeirão da Onça para o ano de 2005, utilizando a altura equivalente de água relativa à área de drenagem.

Gráfico 21: Hidrograma simulado a partir da curva-chave traçada e extrapolada pelo método logarítmico....

Gráfico 22: Hidrograma de escoamento superficial separado do escoamento de base a partir do método gráfico

Gráfico 23: Hidrograma de escoamento de base separado do escoamento superficial direto a partir do método gráfico

Gráfico 24: Escoamento superficial direto observado e simulado pelo IPHS1 para os eventos de chuva ocorridos nos dias $25 / 11$ e $26 / 11$.

Gráfico 25: Escoamento direto observado e simulado pelo IPHS1 para os eventos de chuva dos dia 1,2 e $3 / 12$

Gráfico 26: Escoamento direto observado e simulado para os eventos de chuva dos dia 4, 5 e $6 / 12$

Gráfico 27: escoamento superficial mensal simulado pelo método de transformação chuvavazão para o ano de 2005, em altura equivalente de água sobre a área da bacia.

Gráfico 28: Variação do armazenamento subterrâneo mensal no ano de 2005.

Gráfico 29: Cota potenciométrica e curva de recessão extrapolada para o poço 03 
Gráfico 30: Cota potenciométrica e curva de recessão extrapolada para o poço 05 .............. 140

Gráfico 31: Cota potenciométrica e curva de recessão extrapolada para o poço 08 ............... 140

Gráfico 32: Cota potenciométrica e curva de recessão extrapolada para o poço 09............... 141

Gráfico 33: Cota potenciométrica e curva de recessão extrapolada para o poço 13.............. 141

Gráfico 34: Cota potenciométrica e curva de recessão extrapolada para o poço 15 .............. 142

Gráfico 35: Cota potenciométrica e curva de recessão extrapolada para o poço 16 .............. 142

Gráfico 36: Cota potenciométrica e curva de recessão extrapolada para o poço 18 ............... 143

Gráfico 37: Cota potenciométrica e curva de recessão extrapolada para o poço 19.............. 143

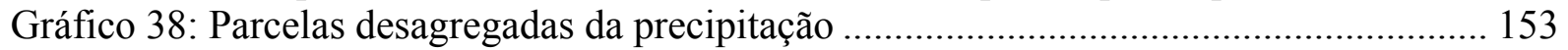

Gráfico 39: parcelas desagregadas da infiltração................................................................... 154

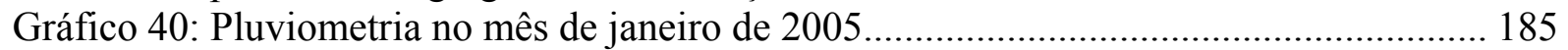

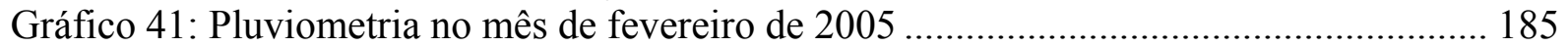

Gráfico 42: Pluviometria no mês de março de 2005 ............................................................... 186

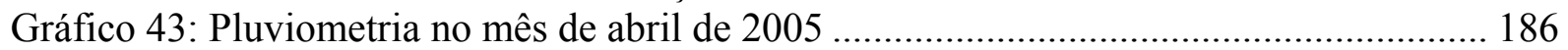

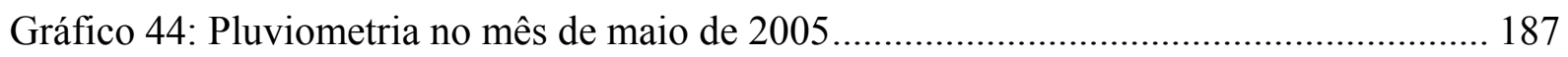

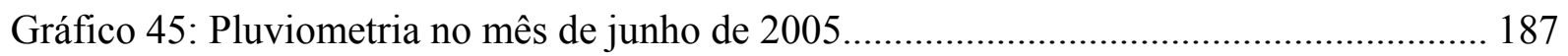

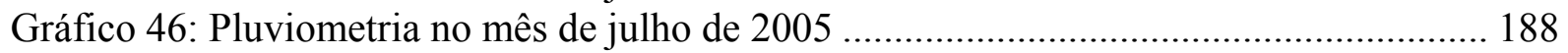

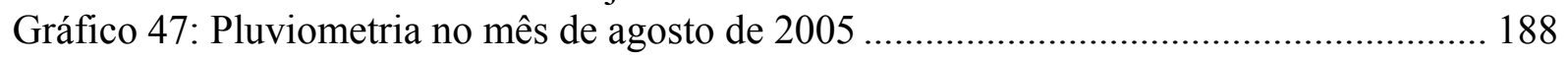

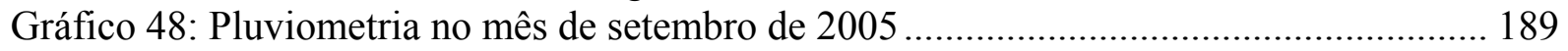

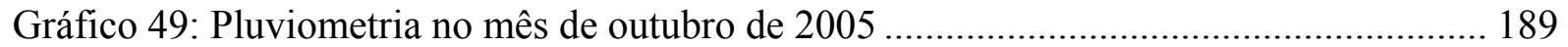

Gráfico 50: Pluviometria no mês de novembro de 2005 ........................................................ 190

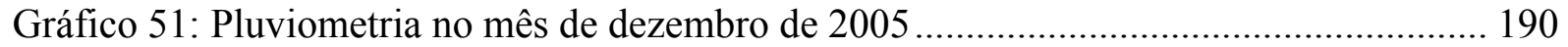

Gráfico 52: Escoamento superficial no Ribeirão da Onça simulado pelo IPHS1 para o mês de

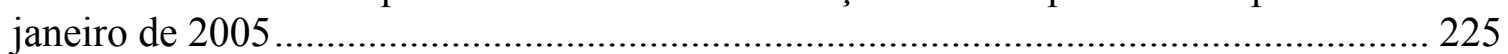

Gráfico 53: Escoamento superficial no Ribeirão da Onça simulado pelo IPHS1 para o mês de

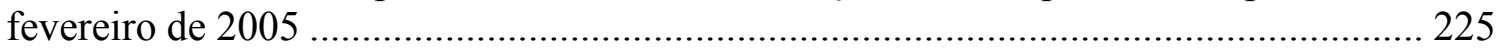

Gráfico 54: Escoamento superficial no Ribeirão da Onça simulado pelo IPHS1 para o mês de

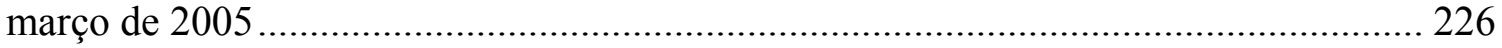

Gráfico 55: Escoamento superficial no Ribeirão da Onça simulado pelo IPHS1 para o mês de

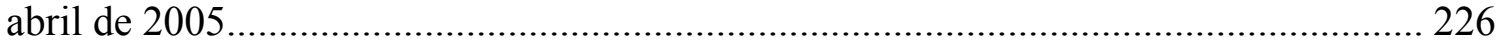

Gráfico 56: Escoamento superficial no Ribeirão da Onça simulado pelo IPHS1 para o mês de

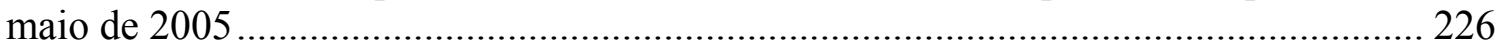

Gráfico 57: Escoamento superficial no Ribeirão da Onça simulado pelo IPHS1 para o mês de

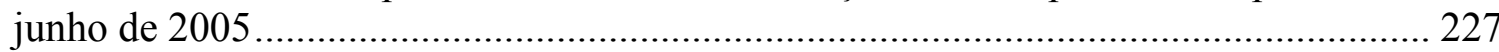

Gráfico 58: Escoamento superficial no Ribeirão da Onça simulado pelo IPHS1 para o mês de

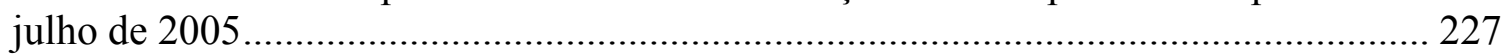

Gráfico 59: Escoamento superficial no Ribeirão da Onça simulado pelo IPHS1 para o mês de

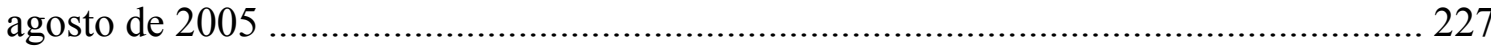

Gráfico 60: Escoamento superficial no Ribeirão da Onça simulado pelo IPHS1 para o mês de

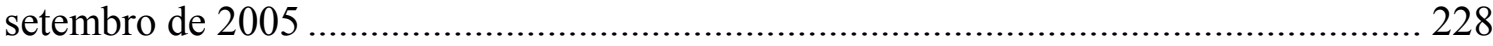

Gráfico 61: Escoamento superficial no Ribeirão da Onça simulado pelo IPHS1 para o mês de

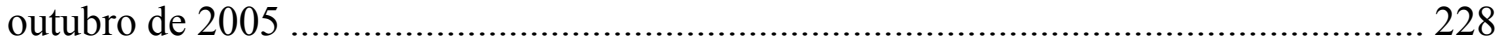

Gráfico 62: Escoamento superficial no Ribeirão da Onça simulado pelo IPHS1 para o mês de

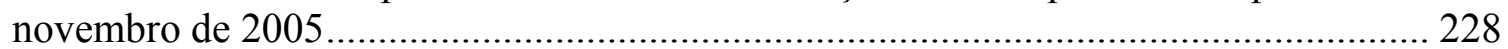

Gráfico 63: Escoamento superficial no Ribeirão da Onça simulado pelo IPHS1 para o mês de

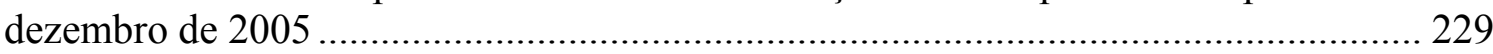




\section{LISTA DE TABELAS}

Tabela 1: Principais parâmetros hidrodinâmicos do SAG 16

Tabela 2: Recomendações da WMO (Fonte: WMO apud PAIVA e PAIVA, 2003) para

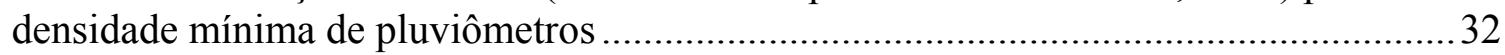

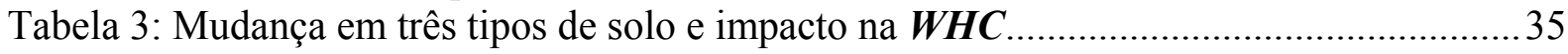

Tabela 4: Parâmetros para o cálculo da velocidade média na vertical ....................................36

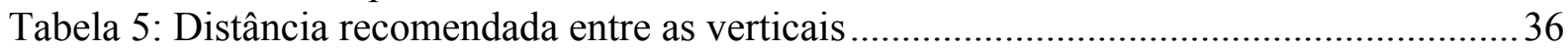

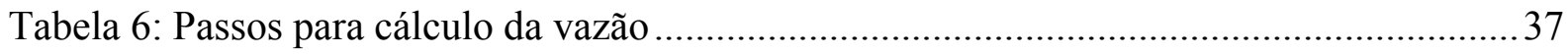

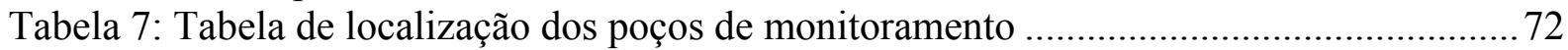

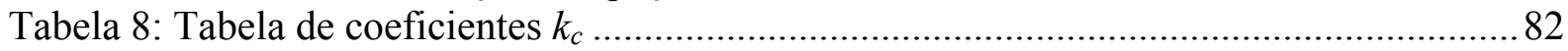

Tabela 9: Vazões medidas representativas da vazão de base ............................................... 86

Tabela 10: Relações geométricas da seção do Ribeirão da Onça.............................................89

Tabela 11: Tabela de correlação entre os dados de nível de água nos poços locados em cultura de pasto entre os dias 16/09/04 e 13/01/2006.

Tabela 12: Tabela de correlação entre os dados de nível de água nos poços locados em cultura de citros entre os dias 16/09/04 e 13/01/2006 ................................................................ 118

Tabela 13: Variação do nível de água em poços de monitoramento para o ano de $2005 \ldots . . . .118$

Tabela 14: correlação entre o nível de água em diferentes poços de monitoramento locados em diversas culturas, no período de 16/09/2004 a 13/01/2006.................................... 119

Tabela 15: Evolução temporal do uso do solo por tipo de cultura .......................................120

Tabela 16: Área de cultivo na sub-bacia do Ribeirão da Onça .............................................. 120

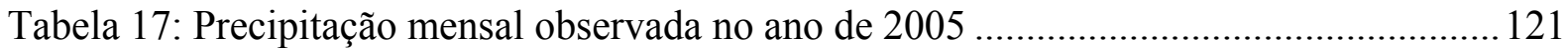

Tabela 18: Dados coletados na estação climatológica do CRHEA …..................................... 122

Tabela 19: Estimativa da evapotranspiração anual na bacia do Ribeirão da Onça em 2005 . 123

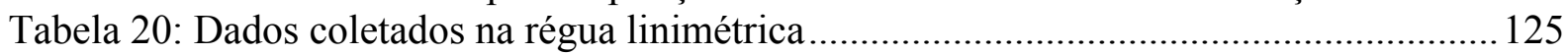

Tabela 21: Vazões medidas na seção "VAZÃO” do Ribeirão da Onça................................... 128

Tabela 22: Valor do CN para transformação chuva-vazão na bacia do Ribeirão da Onça .... 134

Tabela 23: Avaliação do armazenamento subterrâneo anual para diferentes valores de

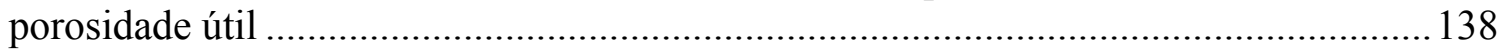

Tabela 24: Valores calculados para a diferença entre o nível real do aqüífero e a curva de

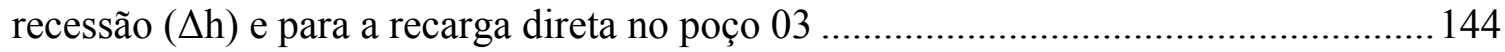

Tabela 25: Valores calculados para a diferença entre o nível real do aqüífero e a curva de recessão $(\Delta \mathrm{h})$ e para a recarga direta no poço 05

Tabela 26: Valores calculados para a diferença entre o nível real do aqüífero e a curva de recessão $(\Delta \mathrm{h})$ e para a recarga direta no poço 08

Tabela 27: Valores calculados para a diferença entre o nível real do aqüífero e a curva de

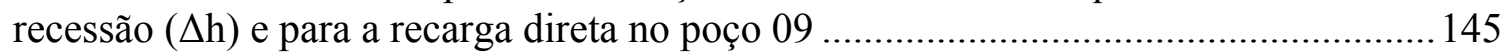

Tabela 28: Valores calculados para a diferença entre o nível real do aqüífero e a curva de recessão $(\Delta \mathrm{h})$ e para a recarga direta no poço 13 ...................................................... 146

Tabela 29: Valores calculados para a diferença entre o nível real do aqüífero e a curva de

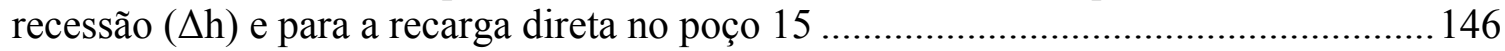

Tabela 30: Valores calculados para a diferença entre o nível real do aqüífero e a curva de recessão $(\Delta \mathrm{h})$ e para a recarga direta no poço 16

Tabela 31: Valores calculados para a diferença entre o nível real do aqǘf́ero e a curva de recessão $(\Delta \mathrm{h})$ e para a recarga direta no poço 18

Tabela 32: Valores calculados para a diferença entre o nível real do aqüífero e a curva de

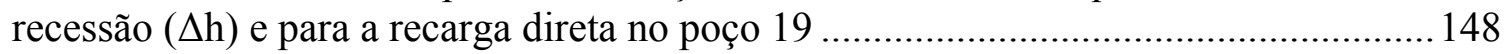

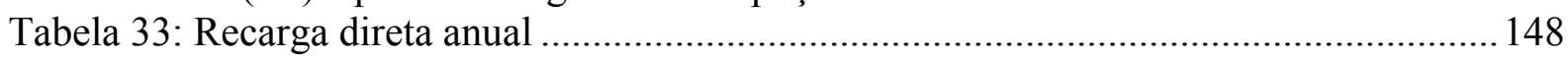

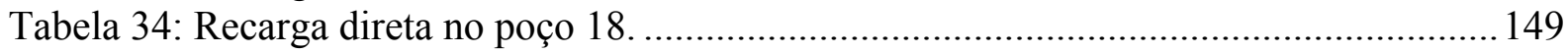

Tabela 35: Recarga profunda estimada pelo método do balanço hídrico............................... 151 
Tabela 36: Recarga Profunda estimada pelo Método $2(\mathrm{~mm})$

Tabela 37: resumo dos valores das componentes do ciclo hidrológico usadas no método 3155

Tabela 38: Medição de nível potenciométrico, 12/03/2004 - 03/08/2004 233

Tabela 39 Medição de nível potenciométrico, 05/08/2004 - 14/10/2004 ............................. 233

Tabela 40: Medição de nível potenciométrico, 28/10/2004 - 17/12/04 ................................ 234

Tabela 41: Medição de nível potenciométrico, 27/12/04 - 18/01/2005 …........................... 234

Tabela 42: Medição de nível potenciométrico, 20/10/2005 - 18/02/2005 …........................ 235

Tabela 43: Medição de nível potenciométrico, 28/02/2005 - 29/04/2005 …........................ 235

Tabela 44: Medição de nível potenciométrico, 06/05/05 - 01/07/2005 …........................... 236

Tabela 45: Medição de nível potenciométrico, 14/07/2005 - 15/09/2005 …........................ 236

Tabela 46: Medição de nível potenciométrico, 28/09/2005 - 25/11/2005 …........................ 237

Tabela 47: Medição de nível potenciométrico, 08/12/2005 - 13/01/06 ............................... 237 
1. INTRODUÇÃO 

O Sistema Aqüífero Guarani (SAG) é um dos aqüíferos transfronteiriços mais importantes do mundo, sendo que em algumas publicações é citado como o de maior importância (GILBOA et al., 1976; REBOUÇAS e AMORE, 2002). Localizado no território de quatro países, Brasil, Uruguai, Argentina e Paraguai, sua área é estimada em 1,2 milhão de $\mathrm{km}^{2}$.

O SAG tem a vantagem de oferecer água de boa qualidade para os consumos doméstico, industrial e irrigação. Além disso, em relação à captação, transporte e tratamento da água extraída dos rios, o custo da sua utilização é, em regra geral, mais baixo, à medida que pode ser captada no local da própria demanda e a sua água não necessita ser, previamente, tratada (REBOUÇAS e AMORE, 2002).

Estima-se que existam mais de dois mil poços perfurados no SAG no Brasil, com profundidades entre 100 e $300 \mathrm{~m}$, e algumas centenas de outros em seus domínios confinados, com profundidades entre 500 e 2.000 m (REBOUÇAS e AMORE, 2002). Muitos deles são clandestinos, sendo executados e operados de maneira inadequada.

Sentiu-se a necessidade da ordenação do uso desse recurso hídrico, tendo em vista a importância estratégica, social e econômica para os quatro países de seu domínio.

Rebouças e Amore (2002) apontam como um dos pontos relevantes para a boa gestão dos recursos do SAG a promoção de estudos hidrológicos em bacias hidrográficas. Faz-se necessário, então, a criação de um sistema de monitoramento que permita obter informações mais detalhadas sobre o estado atual do SAG, ao nível de bacia, para poder se ter um planejamento e uma gestão mais eficientes.

O monitoramento das águas pode ser definido como o acompanhamento contínuo dos aspectos quantitativos e/ou qualitativos das águas, envolvendo uma gama de aspectos de interesse como dados quantitativos, as fontes e elementos impactantes e a avaliação da qualidade do ambiente como um todo (FEAM-FPJ ${ }^{(1)}$ apud MAGALHÃES JR., 2000). 
Pode-se perceber a importância dada ao monitoramento dos recursos hídricos no Brasil pela publicação do Art. $4^{\circ}$ da resolução $N^{\circ} 22$ do Conselho Nacional de Recursos Hídricos, determinando que os Planos de Recursos Hídricos, elaborados por bacia, devem contemplar o monitoramento da quantidade e qualidade dos recursos dos aqǘferos, com os resultados devidamente apresentados em mapa e a definição mínima da:

I - rede de monitoramento dos níveis d'água dos aqǘferos e sua qualidade;

II - densidade dos pontos de monitoramento; e,

III - freqüência de monitoramento dos parâmetros.

$\mathrm{O}$ adequado monitoramento pode ser considerado como um dos pré-requisitos para o sucesso de qualquer sistema de gestão das águas, já que permite a obtenção do arcabouço de informações necessárias, o acompanhamento das medidas efetivadas, a atualização dos bancos de dados e o direcionamento das decisões. Também permite viabilizar projetos de investimentos e de gerenciamento em tempo real das águas (BANCO MUNDIAL, 1998).

O monitoramento de aqüíferos é praticado há décadas. Este trabalho intensificou-se nos últimos anos com os problemas crescentes da contaminação dos aqüíferos, da superexploração e de suas conseqüências ambientais. As informações obtidas de uma rede de monitoramento são essenciais para detectar os impactos de mudanças do clima e de atividades humanas na quantidade e na qualidade dos aqüíferos. Todo o processo de interação entre aqüíferos e o ambiente pode ser observado somente por uma rede de monitoramento (ZHOU, 1996).

Fica evidente a necessidade de medir no campo uma série de variáveis hidrológicas, meteorológicas e hidrogeológicas para permitir o conhecimento da recarga, chuva, vazão e outros eventos hidrológicos, possibilitando estimar a probabilidade associada a eventos raros e quantificar as possibilidades do aproveitamento dos recursos hídricos bem como tendências pertinentes através da aplicação de modelos matemáticos.

Para garantir uma qualidade satisfatória dos dados observados e dos resultados esperados, é necessária a utilização de instrumentos confiáveis, capazes de medir e registrar dados com precisão suficiente para as condições nas quais são operados, e de uma área de estudo bem caracterizada em sua hidrogeologia e geologia.

A área objeto deste estudo localiza-se na porção central do Estado de São Paulo. Por tratar-se de uma região de afloramento, sua importância é aumentada sobremodo pela maior facilidade de exploração e maior vulnerabilidade natural de seu manancial. Estratégicas para a sustentabilidade do aqǘfero, estas zonas de recarga têm merecido atenção de diversos 
trabalhos no sentido de entender o processo e avaliar a quantidade de recarga na região (GIAMPÁ \& SOUZA, 1982; CONTIN NETO, 1987; MATTOS, 1987; CORRÊA, 1995).

Com a intensificação do uso e ocupação das áreas de afloramento (NOVELLI, 1996) e o correspondente crescimento da utilização dos seus mananciais subterrâneos, tornam-se necessárias melhores informações sobre o comportamento do aqüífero nessas áreas, como uma forma de dar suporte ao gerenciamento hídrico subterrâneo adequado à manutenção e expansão das atividades econômicas da região.

A bacia do Ribeirão da Onça foi escolhida por apresentar características representativas típicas da região de afloramento do SAG no estado de São Paulo.

A bacia do Ribeirão da Onça conta com aparelhos capazes de medir automaticamente o nível do aqǘ́fero em poços e o nível superficial no ribeirão. A rede de poços de monitoramento está locada estrategicamente em diversos tipos de culturas existentes na bacia. Medições diárias de precipitação são coletadas em dois postos pluviométricos. No CRHEA (Centro de Recursos Hídricos e Ecologia Aplicada) são coletados todos os dados meteorológicos necessários para aplicação dos métodos de cálculo da evapotranspiração. $\mathrm{O}$ CRHEA está localizado a uma distância de aproximadamente $1,5 \mathrm{~km}$ da bacia do Ribeirão da Onça. O mapeamento das áreas de cultivo é realizado a partir de imagens de satélite, uso de aparelho GPS e utilização do software ARCGIS.

Essa gama de instrumentos instalados e informações geradas fornecem dados indispensáveis para o conhecimento dos mecanismos de recarga do SAG nessa região.

A continuidade da aquisição de dados nesta bacia só vem a favorecer o conhecimento dos processos hidrológicos que atuam nesse importante reservatório e contribuir para a melhor gestão desse recurso hídrico. 
2. OBJETIVOS 

O objetivo principal deste trabalho foi estimar a taxa de recarga direta e profunda em zona de afloramento do Sistema Aqüífero Guarani, com base no estudo de balanço hídrico na bacia do Ribeirão do Onça, localizada no município de Brotas-SP (Brasil). A recarga direta é um processo que acontece abaixo do ponto de impacto da precipitação por movimento vertical através da zona não-saturada. A recarga direta pode ser definida como a parcela da precipitação que vence a zona não-saturada e soma-se à reserva subterrânea. Convencionou chamar por recarga profunda como aquela que, a partir da precipitação, atinge a zona saturada do solo e daí segue linhas de fluxo que não surgirão no curso de água principal da mesma bacia hidrográfica, atingindo camadas mais profundas do aqüífero.

Objetivos secundários:

- implantar uma rede de monitoramento hidrológica e hidrogeológica na bacia;

- avaliar alguns métodos de estimativa da evapotranspiração para uso na quantificação de recarga direta de aqüíferos através do balanço hídrico;

- quantificar a descarga em uma seção de controle da bacia;

- quantificar a interação rio-aqüífero. 
3. REVISÃO BIBLIOGRÁFICA 



\subsection{Sistema Aqüífero Guarani}

\subsubsection{Localização e hidrogeologia}

O Sistema Aqüífero Guarani (SAG) está localizado no centro leste da América do Sul, entre os paralelos $12^{\circ}$ e $35^{\circ}$ de latitude Sul e $47^{\circ}$ e $65^{\circ}$ de longitude Oeste. O Sistema Aqüífero Guarani é um dos maiores mananciais de água doce subterrânea transfronteiriço do mundo, estendendo-se desde a Bacia Sedimentar do Paraná (Brasil, Paraguai e Uruguai) até a Bacia do Chaco Paraná (Argentina)*.

O SAG tem extensão total, preliminarmente definida, da ordem de 1,2 milhão de $\mathrm{km}^{2}$, sendo 840 mil km² no Brasil, 225,5 mil km² na Argentina, 71,7 mil km² no Paraguai e 58,5 mil km² no Uruguai. A porção brasileira é distribuída por oito estados: MS $\left(213.200 \mathrm{~km}^{2}\right)$, RS $\left(157.600 \mathrm{~km}^{2}\right)$, SP $\left(155.800 \mathrm{~km}^{2}\right)$, PR $\left(131.300 \mathrm{~km}^{2}\right.$, GO $\left(55.000 \mathrm{~km}^{2}\right), \mathrm{MG}\left(51.300 \mathrm{~km}^{2}\right), \mathrm{SC}$ ( $\left.49.200 \mathrm{~km}^{2}\right)$ e MT (26.400 km²) (REBOUÇAS e AMORE, 2002).

O SAG, em território brasileiro, abrange duas zonas climáticas: Tropical Brasil Central e o Temperado. Nos estados de Mato Grosso, Mato Grosso do Sul, Goiás, Minas Gerais e São Paulo, a predominância climática varia entre o clima "Tropical Brasil Central Quente e Úmido" e o "Mesotérmico Brando e Superúmido", com precipitação média anual entre $1.200 \mathrm{~mm}$ e $1.800 \mathrm{~mm}$. Nos estados do Paraná, Santa Catarina e Rio Grande do Sul há predominância do clima "Temperado Mesotérmico Superúmido", com precipitação média anual entre $1.200 \mathrm{~mm}$ e $2.000 \mathrm{~mm}$ (CUNHA, 2003).

O manancial subterrâneo, no Brasil, situa-se na Bacia do Paraná, sub-bacia da Bacia do Prata. É possível visualizar na Figura 1 que algumas regiões da Bacia do Prata, não se integram ao $\mathrm{SAG}$, devido à drenagem dessa área não se relacionar com o aqüífero.

O termo Aqüífero Guarani é a denominação formal dada ao reservatório transfronteiriço de água subterrânea doce, formado pelos sedimentos flúvio-lacustres do período Triássico (245 - 208 milhões de anos), Formações Pirambóia e Rosário do Sul, no Brasil, Buena Vista, no Uruguai, e pelos sedimentos eólicos desérticos do Período Jurássico (208 - 144 milhões de anos), Formações Botucatu, no Brasil, Misiones, no Paraguai e Tacuarembó, no Uruguai e Argentina*. 


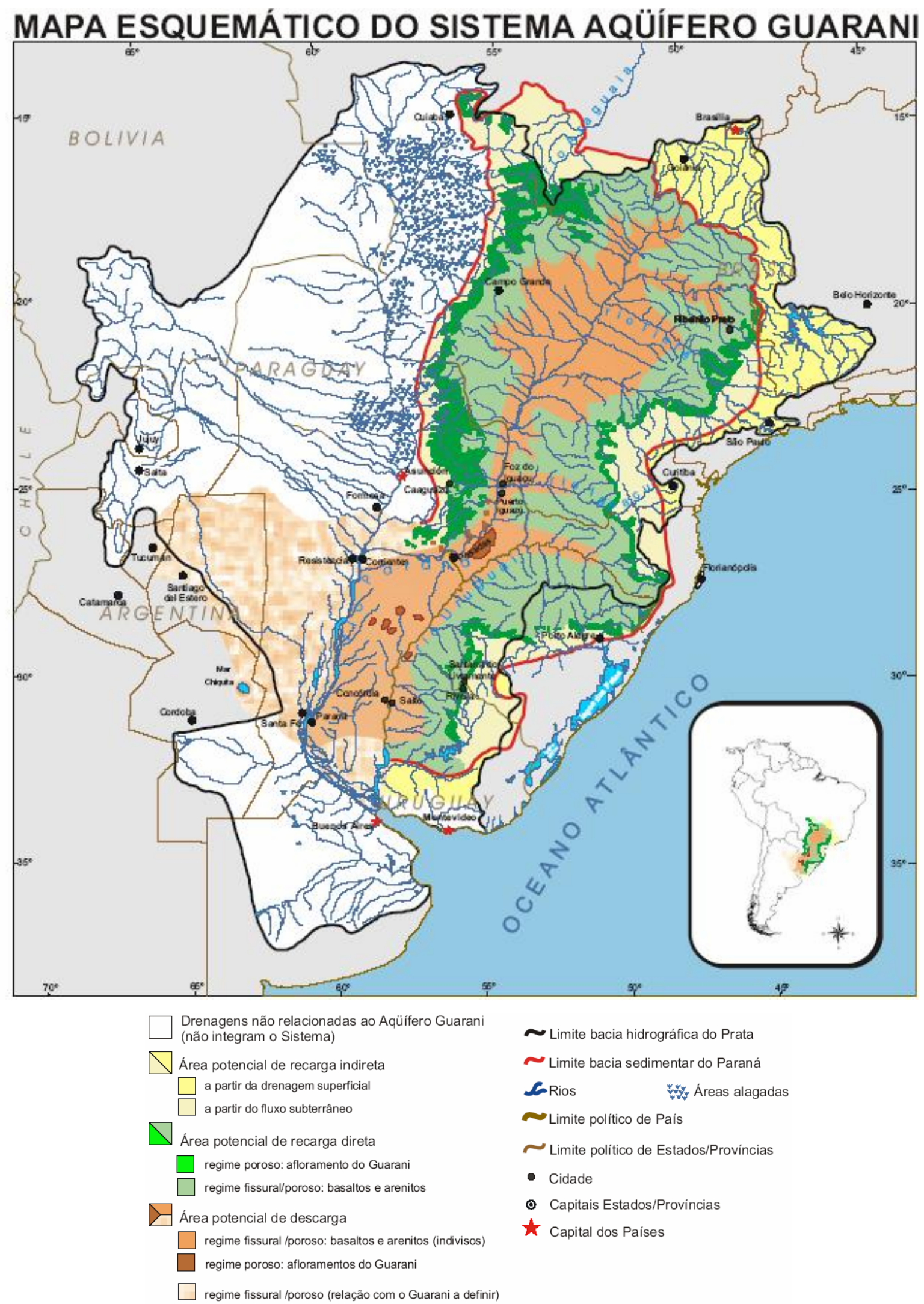

Figura 1: Mapa esquemático do Sistema Aqüífero Guarani

Fonte: http://www.sg-guarani.org/index/site/sistema_acuifero/. Site visitado em 21/01/2006. 
Os arenitos mesozóicos das formações Botucatu, Pirambóia e Rosário do Sul, apresentam espessura média de $250 \mathrm{~m}$ e encontram-se recobertos por espesso pacote de basalto, que chega a atingir $1.500 \mathrm{~m}$ de espessura. O padrão geral de fluxo é marcado por um escoamento controlado pela elevação relativa dos afloramentos, seguindo uma orientação geral de norte para sudoeste, com supostas áreas de descarga, localizadas na Argentina. Em termos hidrogeológicos, $90 \%$ do SAG encontram-se confinado, margeado por faixas alongadas aflorantes, que constituem possíveis zonas de recarga direta do aqüífero (ARAÚJO et al., 1999).

As formações Serra Geral e Bauru-Caiuá podem, ocasionalmente, fornecer alimentação indireta, comportando-se como reservatórios intermediários que, ao atingirem a saturação, oferecem condições de migração das águas através de descontinuidades relativamente permeáveis. Entretanto, nas regiões onde os níveis piezométricos da Formação Botucatu são superiores aos de formações sobrepostas, ocorre fluxo ascendente (POMPÊO, 1990).

De maneira geral, o aqüífero é composto por uma variedade de areias quartzosas, de formato bem arredondado, de granulometria de fina a média e caracterizada pelo baixo teor de argila. Dados granulométricos indicam que mais de 50\% dos grãos apresentam diâmetro entre 0,125 a 0,250mm. Nas partes mais profundas, na Formação Pirambóia, caracteriza-se a presença de silte (CONTIN NETO, 1987).

A Figura 2 caracteriza um corte no aqüífero, passando por dois estados brasileiros São Paulo e Goiás.

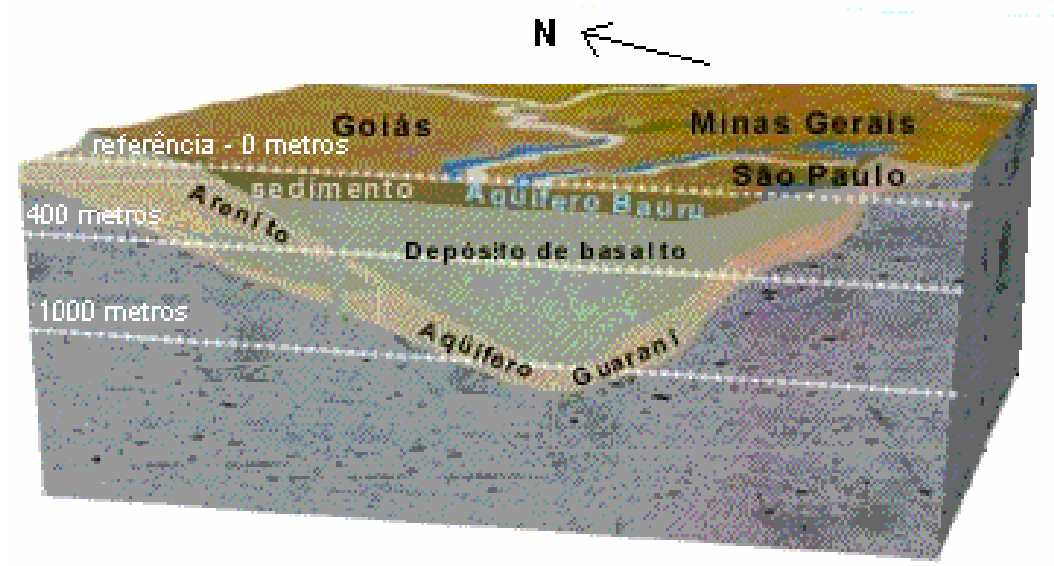

Figura 2 - Corte representativo do Aqüífero Guarani

Modificado de http://www.daaeararaquara.com.br/guarani.htm, última visita em 13/1/2006 
Um resumo dos principais parâmetros hidrodinâmicos do Sistema Aqüífero Guarani é apresentado na Tabela 1.

Tabela 1: Principais parâmetros hidrodinâmicos do SAG

\begin{tabular}{|c|c|c|c|c|}
\hline \multirow{2}{*}{\multicolumn{2}{|c|}{ Parâmetro }} & \multirow{2}{*}{$\begin{array}{c}\text { SAG - São Paulo } \\
\text { (Fonte: SRACEK e } \\
\text { HIRATA }^{(2)} 2002 \\
\text { apud GASTMANS e } \\
\text { KIANG, 2006) }\end{array}$} & \multicolumn{2}{|c|}{$\begin{array}{c}\text { SAG -Bacia do Paraná } \\
\text { (Fonte: ARAÚJO et al. }{ }^{(3)}, 1999 \text { apud } \\
\text { GASTMANS e KIANG, 2006) }\end{array}$} \\
\hline & & & Fm. Botucatu & Fm. Pirambóia \\
\hline Espessura & Máx & 550 & $4-484$ & $25-770$ \\
\hline (m) & Méd & 268 & 138 & 139 \\
\hline \multicolumn{2}{|c|}{ Porosidade } & $10-15 \%$ & $17-30 \%$ & $14-24 \%$ \\
\hline \multicolumn{2}{|c|}{$\begin{array}{c}\text { Condutividade Hidráulica } \\
\text { média }(\mathrm{m} / \mathrm{dia})\end{array}$} & 12,96 & 8,70 & 1,90 \\
\hline \multicolumn{2}{|c|}{ Transmissividade (m²/dia) } & $\begin{array}{c}39-1035 \\
\text { Média } 336\end{array}$ & $2-552$ & - \\
\hline \multicolumn{2}{|c|}{$\begin{array}{c}\text { Coeficiente de } \\
\text { Armazenamento }\end{array}$} & $4 \times 10^{-5}-2 \times 10^{-4}$ & & - \\
\hline
\end{tabular}

${ }^{(2)}$ ARAÚJO, L. M.; FRANÇA, A. B.; POTER, P. E. (1995). Aqüifero gigante do mercosul no Brasil, Argentina, Uruguay e Paraguai; Mapas Hidrogeológicos das Formações Botucatu, Pirambóia, Rosario do Sul, Buena Vista, Missiones e Tauarembó. Mapas UFPR PETROBRÁS, Curitiba, Texto Explicativo.

${ }^{(3)}$ SRACEK, O.; HIRATA, R. (2002). Geochemical and Stable Isotopic Evolution of the Guarani Aquifer System in the State of São Paulo, Brazil. Hydrogeology Journal, 10, 643 - 655, 2002 


\subsection{Recarga de aqüíferos}

Em geral, a recarga das águas subterrâneas vem sendo definida como o fluxo de água que alcança o aqüífero, constituindo uma adição ao reservatório de água subterrânea (LERNER et al., 1990; DE VRIES e SIMMERS, 2002). Pode ainda ser conceituada como apresentado por Paralta et al. (2003), que define recarga como a quantidade de água que em determinado tempo entra na zona saturada (aqüífero), preferencialmente a partir da percolação vertical proveniente da zona vadosa, mas também do escoamento lateral a partir das fronteiras do sistema. Ainda pode ser conceituada como um processo de movimento de água que atinge a zona saturada sob forças gravitacionais, ou em uma direção específica por condicionamento hidráulico.

De Vries e Simmers (2002) classificaram os mecanismos de recarga em três tipos, dependendo da fonte:

- recarga direta: é um processo que acontece abaixo do ponto de impacto da precipitação por movimento vertical através da zona não-saturada. A recarga direta pode ser definida como a parcela da precipitação que vence a zona não-saturada e soma-se à reserva subterrânea;

- recarga indireta: descreve os processos em que a recarga ocorre por características introduzidas pela urbanização, assim como por rios e depressões de superfícies topográficas (reservatórios, lagos, etc.);

- recarga localizada: é um processo pontual de recarga, em que a água move-se em curtas distâncias lateralmente antes da infiltração.

Balek (1988), levando em consideração o fator tempo, identificou quatro tipos de recarga:

- recarga curta: que ocorre após grandes eventos de chuva;

- recarga sazonal: que ocorre durante o degelo em regiões de clima temperado ou em períodos chuvosos em regiões com estações secas e chuvosas bem definidas;

- recarga perene: que ocorre nos trópicos úmidos onde existe um fluxo contínuo de água;

- recarga histórica: aquela que ocorreu há um longo tempo atrás e que foi responsável pela formação dos recursos hídricos subterrâneos existentes.

A quantificação da recarga das águas subterrâneas é um pré-requisito básico para um eficiente manejo dos recursos hídricos e é particularmente vital em regiões semi-áridas e áreas 
onde há superexploração, já que tais recursos são freqüentemente a chave do desenvolvimento econômico.

A diversidade de fatores de influência nos processos de recarga e a dificuldade de quantificação e controle de alguns fatores exigem a utilização de mais de um método para a comparação entre os resultados. Procedimentos utilizados na estimativa da recarga em certa região podem não ser bem sucedidos quando utilizados em outra localidade. É de fundamental importância a identificação das fontes de recarga e a definição de um modelo conceitual dos mecanismos de fluxo.

\subsubsection{Métodos de estimativa da recarga subterrânea}

Existem vários métodos alternativos para a estimativa de recarga e vários trabalhos apresentam uma revisão completa destes métodos, como em Lerner et al. (1990), Allison et al. (1994), Simmers (1997), Kinzelbach (2002) e Scanlon et al. (2002). Embora a maioria desses métodos forneça valiosas informações sobre recarga, eles nem sempre são diretamente aplicáveis. Há situações onde é necessário estimar a recarga de uma maneira prática. A praticidade no cálculo da recarga é um conceito subjetivo, mas pode-se afirmar que é diretamente proporcional aos dados existentes e a tecnologia disponível para análise dos dados, como velocidade e memória dos computadores e softwares disponíveis.considerando.

A escolha do método utilizado depende, em princípio, dos objetivos a serem atingidos, que estão diretamente relacionados com o nível de exigência, no que se refere à precisão dos resultados, à dimensão do sistema envolvido e às características hidrogeológicas locais.

Os métodos de estimativa da recarga podem ser classificados em: métodos diretos, baseados no balanço hídrico, métodos baseados na lei de Darcy e o método dos traçadores (KINZELBACH, 2002).

O processo de estimativa de recarga é interativo e envolve refinamentos contínuos da taxa de recarga quando dados adicionais são coletados. A confiança das estimativas é freqüentemente questionável, resultado de hipóteses simplificadoras e incertezas de alguns parâmetros requeridos. Dado o atual estado da ciência, a precisão de qualquer método é extremamente difícil de ser avaliada. Visto esta dificuldade, a redução das incertezas e o aumento da confiança em estimativas de recarga são atingidos quando são aplicados diversos métodos (LERNER et al., 1990; BEEKMAN et al., 1996; DE VRIES e SIMMERS, 2002; HEALY e COOK, 2002; SCANLON et al., 2002; MAZIERO, 2005). 


\subsubsection{Métodos Diretos}

\section{Lisímetro}

Apesar de alguns trabalhos apresentarem como métodos diretos de estimativa da recarga, o método do balanço de neutros no solo e os métodos baseados na variação do nível superficial do aqüífero (KINZELBACH, 2002), apenas os lisímetros, ou instrumentos com os mesmos mecanismos, são capazes de medir o escoamento diretamente. Um lisímetro consiste em um grande reservatório impermeável lateralmente, colocado em uma área previamente escavada, com profundidade superior à zona de raízes. O reservatório é preenchido com solo e vegetação, de forma a reconstruir uma condição real. Um sistema de drenagem, instalado no fundo do lisímetro, permite a coleta de água percolada pelo solo.

O lisímetro é utilizado para o estudo de evapotranspiração e apresenta um sistema fechado com profundidade limitada. Quando utilizado para estimar a recarga subterrânea, determina-se o volume infiltrado a partir da zona de raízes, obtendo-se uma recarga potencial.

Kinzelbach (2002) apresenta como vantagem da utilização do lisímetro a medida direta da recarga potencial, sendo facilmente estimada.

Segundo Eilers (2004) o uso de lisímetros não é um método prático de estimativa de recarga, devido aos custos associados a sua construção e o tempo necessário para a sua estabilização. O solo perde suas características macro e microscópicas, além do grau de adensamento. Outro fator negativo é o caráter estritamente localizado dos seus resultados.

\subsubsection{Métodos baseados no balanço hídrico}

A técnica de balanço hídrico considera os principais processos hidrológicos como entradas e saídas de um balanço volumétrico. Estas variáveis são baseadas nos fenômenos hidrológicos de maior relevância, controlando o conteúdo volumétrico de um dado solo durante um dado período de tempo.

O balanço hídrico para uma bacia pode ser descrito como:

$$
P+Q_{e}=E T+Q_{s}+\Delta S+I
$$

em que: $P$ é a precipitação (e pode também incluir a irrigação); $Q_{e}$ e $Q_{s}$ são os fluxos de água que entram e saem do sistema, respectivamente; $E T$ é a evapotranspiração; $\Delta S$ é a variação do armazenamento; e $I$ é a interceptação. 
Dividindo a região da superfície terrestre em subcomponentes, é possível reescrever a equação diferenciando a zona saturada $(z s)$, a zona não-saturada (ns) e a zona de superfície livre (sl). Então, os componentes $Q_{e}, Q_{s}, E T$ e $\Delta S$ teriam subcomponentes nas três regiões.

Definido $R_{0}$ como o escoamento superficial direto e $Q^{b}$ como o escoamento de base entre a zona saturada e a superfície livre do ribeirão, a equação do balanço hídrico geral poderia ser descrita como:

O balanço hídrico subterrâneo de uma região requer a quantificação de todos os fluxos de entrada e saída do sistema aqüífero e as mudanças no armazenamento para um dado período de tempo. Para a zona saturada a equação pode ser descrita como (SCHICHT e WALTON $^{(4)}, 1961$ apud SCANLON et al., 2002):

$$
R=\Delta S^{z s}+Q^{b}+E T^{z s}+Q_{s}^{z s}-Q_{e}^{z s}
$$

em que $R$ é a recarga, $\Delta S^{z s}$ é a variação no armazenamento da zona saturada, $Q^{b}$ é o fluxo de base, $E T^{z s}$ é a evapotranspiração da zona saturada, e $Q_{s}^{z s}-Q_{e}^{z s}$ é o fluxo líquido subsuperficial da área de estudo e inclui efeitos de bombeamento. Todas as variáveis são expressas como taxas (por exemplo, $\mathrm{mm} / \mathrm{ano}$ ).

As maiores vantagens dos métodos de balanço hídrico residem no fato da utilização de dados (Figura 3), geralmente, disponíveis (precipitação, escoamento superficial, níveis d'água). Porém, a maior limitação do método do balanço hídrico é que a precisão da estimativa de recarga depende da precisão com que os componentes da equação foram medidos ou estimados (SCANLON et al., 2002).

$$
P+Q_{e}^{s l}+Q_{e}^{z s}=E T^{s l}+E T^{n s}+E T^{z s}+R_{0}+Q_{s}^{z s}+Q^{b}+\Delta S^{s l}+\Delta S^{n s}+\Delta S^{z s}+I
$$

O método do balanço hídrico pode ser usado considerando-se diversos modelos hidrológicos e hidrogeológicos. Entre os mais utilizados estão: o método do balanço hídrico da camada não-saturada, o método do balanço em canais de rios, o método do balanço hídrico na zona saturada, etc. 


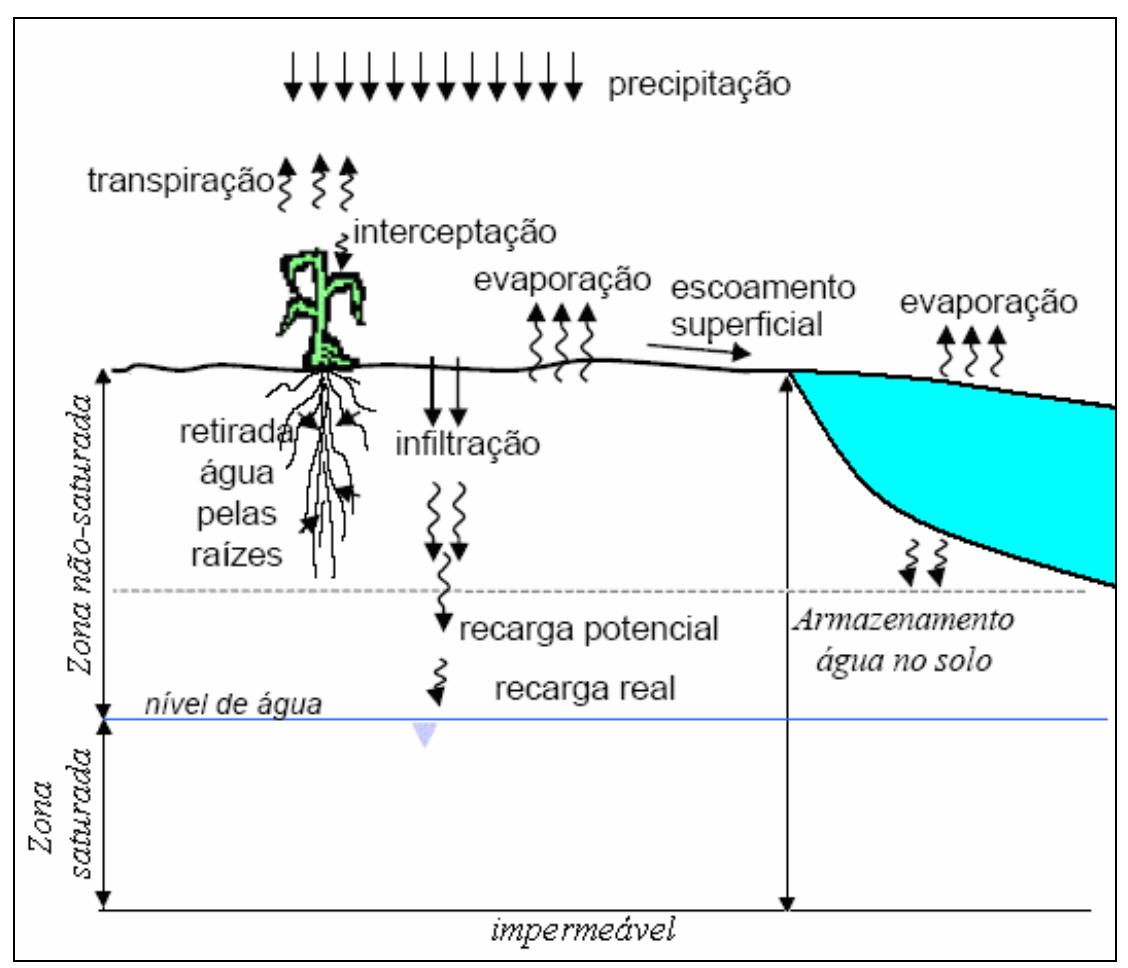

Figura 3: Componentes do ciclo hidrológico para balanço hídrico

\section{Método CRD}

O método CRD (Cumulative Rainfall Departure) é baseado na premissa de que as flutuações do nível d'água nos aqüíferos são causadas apenas por eventos de precipitação. Esta formulação considera que as condições de equilíbrio desenvolvem-se em um aqüífero ao longo do tempo, ou seja, as taxas médias de perdas igualam à taxa média de recarga do sistema (BREDENKAMP et al., 1995).

Bredenkamp e Xu in Xu e Beekman, (2003) afirmaram que o método CRD não fornece somente a resposta temporal do nível freático a um incremento de recarga, como também permite a derivação das características do aqüífero. A recarga estimada representa um valor médio integrado que pode ser encontrado quando o armazenamento do aqüífero (rendimento específico) é determinado com confiança.

Bredenkamp et al. (1995) definiram a seguinte formulação do método CRD:

$$
{ }_{a v}^{1} C R D_{i}=\sum_{i=1}^{n} P_{i}-\kappa \sum_{i=1}^{n} P_{a v} \quad(\mathrm{i}=0,1,2,3, \ldots \mathrm{n})
$$


em que $P_{\mathrm{i}}$ é a precipitação no mês i, $P_{\mathrm{av}}$ é a precipitação média e $\kappa=1+\left(Q_{p}+Q_{\text {out }}\right) /\left(A \cdot P_{\text {av }}\right)$, onde $Q_{\mathrm{p}}$ é a explotação subterrânea, $Q_{\text {out }}$ é a saída natural por escoamento e $A$ é a área doaqüífero, que para este caso é igual a área da bacia hidrográfica. Para $\kappa=1$ não ocorre bombeamento e para $\kappa>1$ ocorre bombeamento e/ou saída natural por escoamento.

Assumindo que uma CRD tem uma relação linear com uma mudança do nível d'água mensal, Bredenkamp et al. (1995) derivaram a seguinte equação:

$$
\Delta h_{\mathrm{i}}=\left(\frac{r}{S_{\mathrm{y}}}\right) \cdot\left({ }_{\text {av }}{ }^{1} C R D_{\mathrm{i}}\right) \quad(\mathrm{i}=0,1,2,3, \ldots \mathrm{N})
$$

em que $r$ é a percentagem da CRD que resulta em recarga com origem na precipitação, $S_{\mathrm{y}}$ é o rendimento específico, $\Delta h_{\mathrm{i}}$ é a mudança no nível d'água no mês i.

A Eq. 5 pode ser usada para estimar a percentagem da precipitação que se transforma em recarga, $r$, através de uma regressão simples entre $\left({ }_{\text {av }}^{1} C R D_{\mathrm{i}}\right)$ e $\Delta h_{\mathrm{i}}$ (BREDENKAMP et al.,1995).

Recentemente, Xu e Van Tonder (2001) revisaram o método CRD a fim de acomodar tendências nas séries pluviométricas, frente ao fato que uma curta série de dados freqüentemente mostra certo grau de tendência, que não pode ser visualizado na Eq. 5. A recarga pode ser obtida pela seguinte equação (XU e VAN TONDER, 2001):

$$
\begin{aligned}
& \Delta h_{i}=\frac{r}{S_{y}} \cdot\left({ }_{t}^{1} C R D_{i}\right)-\left(\frac{Q_{p i}+Q_{\text {outi }}}{\Delta S}\right), \text { com } \\
& { }_{\mathrm{t}}^{1} C R D_{i}=\sum_{i=1}^{n} P_{i}-\left(2-\frac{1}{P_{a v} \cdot i} \sum_{i=1}^{n} P_{i}\right) \cdot \sum_{i=1}^{n} P_{t} \quad(\mathrm{i}=1,2,3, \ldots \mathrm{N})
\end{aligned}
$$

em que $Q_{p i}$ é a explotação subterrânea $\left(\mathrm{L}^{3} \cdot \mathrm{T}^{-1}\right), Q_{o u t i}$ é saída natural por escoamento $\left(\mathrm{L}^{3} \cdot \mathrm{T}^{-1}\right)$, $A$ é a área efetiva de recarga $\left(\mathrm{L}^{2}\right), P_{i}$ é a precipitação para o mês i $\left(\mathrm{L}^{-\mathrm{T}^{-1}}\right)$ e $P_{t}$ é um valor limiar representativo das condições de contorno do aqüífero. $P_{t}$ pode variar de 0 a $P_{a v}$, com 0 representando um aqüífero fechado (sem saída por escoamento) e $P_{a v}$ representando um sistema aqüífero aberto.

Assim, os dados requeridos para aplicação do método são registros de precipitação mensal, níveis d'água, explotação subterrânea e as propriedades do aqüífero (rendimento específico e o tamanho da área de recarga). 
A aplicação do método CRD para diferentes séries de níveis d'água monitorados tem contribuído significativamente para um melhor entendimento da variabilidade espacial da recarga (BREDENKAMP et al., 1995).

\section{Método da Flutuação da Superfície Livre}

O Método da Flutuação da Superfície Livre (WTF - Water Table Fluctuation) é a técnica mais amplamente usada para estimativa da recarga (MAZIERO, 2005). O método WTF só é aplicável aos aqüíferos não-confinados e requer o conhecimento do rendimento específico e das variações nos níveis d'água ao longo do tempo. As vantagens desta aproximação incluem sua simplicidade e uma sensibilidade aos mecanismos do movimento da água na zona não-saturada (HEALY e COOK, 2002).

O método WTF foi usado em vários estudos de recarga subterrânea e é descrito em detalhes por HEALY e COOK (2002) e MAZIERO (2005).

O método de Flutuação da Superfície Livre (WTF) baseia-se na premissa de que as elevações nos níveis d'água em aqüíferos não-confinados são devidas à água de recarga subterrânea chegando na superfície livre. A recarga é calculada como (HEALY e COOK, 2002; SCANLON et al., 2002):

$$
R=S_{\mathrm{y}} \frac{d \mathrm{~h}}{d \mathrm{t}}=S_{\mathrm{y}} \frac{\Delta \mathrm{h}}{\Delta \mathrm{t}}
$$

em que $S_{y}$ é o rendimento específico, $h$ é a altura do nível freático, e $t$ é o tempo. O rendimento específico de um aqüífero livre é, em muitos casos, igual ao coeficiente de armazenamento, sendo da ordem da porosidade útil do meio.

A Eq. 8 assume que a água que atinge o nível freático entra imediatamente em armazenamento e que todos os outros componentes do balanço hídrico subterrâneo (evapotranspiração subterrânea, fluxo de base, entrada e saída de fluxo subsuperficial) são nulos durante o período de recarga.

Healy e Cook (2002) definiram que a aplicação da Eq. 8 para cada elevação individual do nível d'água determina uma estimativa da recarga total, onde $\Delta h$ é igual à diferença entre o pico de subida e o ponto mais baixo da curva de recessão antecedente extrapolada até o instante do pico. A curva de recessão antecedente é o traço que a hidrógrafa do poço de monitoramento teria seguido na ausência de elevação do nível d'água (Figura 4).

Essa manipulação é subjetiva e tenta acomodar a função de defasagem entre o início da precipitação e o conseqüente início do processo de recarga, resultante do processo natural 
de descarga. A diferença entre a recarga total e a recarga líquida é igual à soma da evapotranspiração subterrânea, do escoamento básico e do fluxo líquido subsuperficial da bacia. Com algumas suposições adicionais, o método WTF pode ser usado para calcular quaisquer desses parâmetros (HEALY e COOK, 2002).

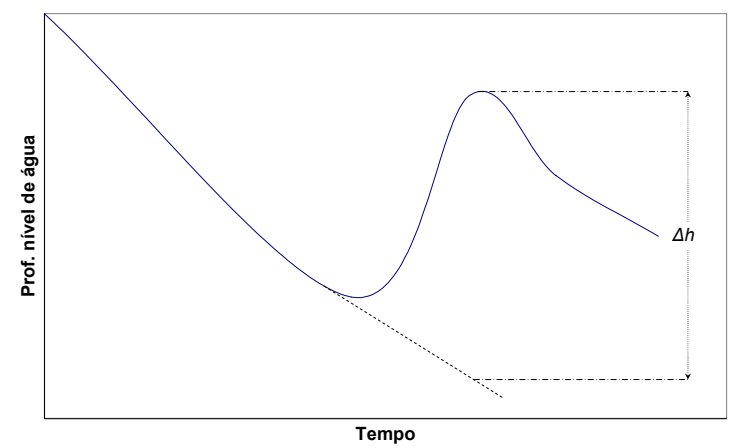

Figura 4: Elevação hipotética do nível d'água em poço em resposta à precipitação

O método WTF pode ser visto como uma aproximação integrada e não como uma medida pontual quando comparado com os métodos aplicados na zona não-saturada (HEALY e COOK, 2002). No entanto, o método tem as seguintes limitações:

- O método é mais bem aplicado a níveis freáticos rasos que exibem súbitas elevações e declínios do nível d'água. Aqüíferos profundos podem não exibir súbitas variações, resultado de frentes de umidade que tendem a dispersar-se ao percorrer longas distâncias verticais (HEALY e COOK, 2002; SCANLON et al., 2002);

- As taxas de recarga variam substancialmente dentro de uma bacia, devido a diferenças na topografia, geologia, declividade da superfície do terreno, vegetação, arranjo da partículas sólidas, grau de cimentação e outros fatores. A maior dificuldade está na locação dos poços de observação que representem espacialmente as fontes de recarga (HEALY e COOK, 2002).

- As taxas de recarga e descarga não podem ser constantes e iguais para o evento. Se a taxa de recarga for constante e igual à taxa de descarga, os níveis d'água não mudariam e o método WTF estimaria recarga nula (HEALY e COOK, 2002).

- O nível da água subterrânea sobe e desce em resposta a muitos fenômenos diferentes e as flutuações nem sempre são indicativas de recarga ou descarga de água subterrânea (HEALY e COOK, 2002). MOON et al. (2004), comentaram que, geralmente, níveis d'água subterrânea flutuam de acordo com as características dos eventos de precipitação (quantidade, duração e intensidade) e de várias variáveis 
hidrogeológicas (topografia, espessura da zona não-saturada e composição dos materiais da zona saturada e não-saturada da formação).

- A incerteza gerada por este método está relacionada à precisão com que o rendimento específico pode ser determinado e até que ponto as suposições inerentes ao método são válidas (HEALY e COOK, 2002).

- Arantes (2003) monitorando aqüíferos muito rasos $(<2 \mathrm{~m})$ observou uma influência da ordem de centímetros nas mudanças na carga hidráulica devido às mudanças na pressão atmosférica.

Healy e Cook (2002) concluíram que uma elevação do nível d'água representa os efeitos combinados da recarga para um evento de precipitação e da precedente condição de descarga. Por isso, taxas de recarga podem ser superestimadas pelo método WTF.

\subsubsection{Aproximação de Darcy}

De acordo com a Lei de Darcy, a velocidade de percolação da água no solo é proporcional ao gradiente hidráulico e a um fator de proporcionalidade, denominado de condutividade hidráulica

$$
q=-K \cdot i
$$

em que:

$q \quad$ : velocidade de Darcy, $\mathrm{m} . \mathrm{s}^{-1}$

$K$ : constante de proporcionalidade ou condutividade hidráulica, $\mathrm{m} . \mathrm{s}^{-1}$;

$i$ : gradiente hidráulico, $(i=\mathrm{d} h / \mathrm{d} l)$, adimensional.

A lei de Darcy pode ser usada para estimar a recarga a partir de dois poços de monitoramento alinhados numa perpendicular a um corpo d'água superficial qualquer. $\mathrm{O}$ método assume fluxo constante e nenhuma extração de água subterrânea. A recarga $(R)$ de um aqüífero não-confinado é igual à velocidade de Darcy $(q)$ multiplicada pelo intervalo de tempo $(\Delta t)$ entre medidas consecutivas:

$$
R=q \cdot \Delta t
$$

A recarga estimada é o somatório dos valores positivos encontrados para cada intervalo de tempo considerado. O método é de fácil aplicação, se existirem informações da condutividade hidráulica e do gradiente hidráulico com razoável confiança. 
As estimativas de recarga baseadas na Lei de Darcy são bastantes imprecisas devido ao fato da grande variabilidade da condutividade hidráulica (SCANLON et al., 2002).

\subsubsection{Métodos dos Traçadores}

O método dos traçadores estima a recarga de um aqüífero, ou a idade da água em um aqüífero, a partir das concentrações de substâncias na água, ou as proporções entre concentrações dessas substâncias.

Um traçador ideal deve ser único para uma fonte particular de recarga, facilmente identificável no sistema subterrâneo, permitindo a quantificação daquela fonte, e ser conservativo em todas as condições (BARRET et al., 1999).

Barret et al. (1999) dividiram os traçadores potenciais em quatro categorias:

- Inorgânicos: Cátions $\left(\mathrm{Ca}^{2+}, \mathrm{Mg}^{2+}, \mathrm{K}^{+} \mathrm{e} \mathrm{Na}{ }^{+}\right)$, Ânions $\left(\mathrm{HCO}_{3}^{-}, \mathrm{SO}_{4}{ }^{2-} \mathrm{e} \mathrm{Cl}^{-}\right)$, espécies de nitrogênio $\left(\mathrm{NO}_{3}{ }^{-}\right.$e $\mathrm{NH}_{4}{ }^{+}$), metais (Fe, Mn e outros) e outros íons ( $\mathrm{B}, \mathrm{PO}_{4}{ }^{3-}, \mathrm{Sr}^{-2}$, $\mathrm{F}^{-}$e $\left.\mathrm{Br}^{-}\right)$

- Orgânicos: Clorofluorcarbono (CFCs), Trihalometanos (THMs), solventes e detergentes.

- Particulados: incluem espécies microbiológicas fecais e várias partículas coloidais;

- Isótopos: particularmente os isótopos estáveis $\left({ }^{2} \mathrm{H},{ }^{15} \mathrm{~N},{ }^{18} \mathrm{O}\right.$ e $\left.{ }^{35} \mathrm{~S}\right)$.

Scanlon et al. (2002) argumentaram que traçadores são muito úteis para estimativa da recarga por longos períodos de tempo, porém, geralmente, não detalham as informações temporais das variações na recarga. 
Allison et al. (1983) ${ }^{(5)}$ apud Tonder e Bean in Xu e Beekman (2003) desenvolveram um método semi-empírico de estimativa de recarga usando os isótopos estáveis ${ }^{2} \mathrm{H}$ e ${ }^{18} \mathrm{O}$. De acordo com Amore et al. (2000) ${ }^{(6)}$ apud Tonder e Bean in Xu e Beekman (2003), o método tem sérias complicações com relação à aplicabilidade em condições de campo. Os fatores que ocasionam essas complicações são a abundância dos respectivos isótopos e as influências exercidas pela evaporação e transpiração, que não são representadas na infiltração de água no solo (ZIMMERMAN et al.(1967) ${ }^{(7)}$ apud XU e BEEKMAN, 2003).

Atualmente o traçador mais utilizado em pesquisas de estimativas de recarga é o cloreto, através do método do balanço de massa de cloreto (CMB - Chloride Mass Balance) (XU e BEEKMAN, 2003).

\subsubsection{Métodos Numérico-Matemáticos}

Muitos modelos matemáticos têm sido desenvolvidos para predizer as flutuações da superfície livre em resposta à recarga de bacias de diferentes formas geométricas, como retangular, circular, etc.

A maioria dos modelos baseia-se na hipótese simplificadora de que a recarga é constante para um dado intervalo de tempo, em que o tamanho do intervalo depende do modelo. De maneira geral o intervalo é da ordem de um mês. Porém, a taxa de recarga na natureza, que depende sensivelmente da taxa de infiltração, varia com o tempo devido a diversos fatores.

Alguns modelos têm sido desenvolvidos para o caso de recarga variando com o tempo, onde a taxa de recarga tem sido representada por funções exponenciais (SANFORD, 2002).

$\mathrm{Su}$ (1994) usou uma função integral de recarga e uma transformação exponencial para gerar uma solução analítica para descrever a resposta de uma bacia hidrográfica sujeita a chuvas intensas em escala semanal. Ostendorf et al. (2004) estudaram a resposta de um aqüífero horizontal profundo não-confinado a uma taxa de recarga constante, mensal e anual.

Dados observados de flutuações do nível do aqüífero e do gradiente hidráulico foram utilizados na calibração do modelo de recarga transiente. Resultados numéricos desses modelos revelam que variações na taxa de recarga provocam um efeito significante na flutuação da superfície livre. De acordo com Raí e Manglik (1999), para simplificar o

${ }^{(5)}$ Allison, G.B., Barnes, C.J., Hughes, M.W. and Leaney, F.W.J., 1984. Effect of climate and vegetation on oxygen-18 and deuterium profiles in soils. In: Isotope Hydrology 1983, IAEA Symposium 270, September 1983, Vienna, 195-123. In: Clark, I.D. and Fritz, P. 1997. Environmental isotopes in hydrogeology. Lewis Publishers, New York, 328 pp.

(6) Amore, F.F., Darling, G, Paces, T., Pang, Z. and Silar, J., 2000. Environmental isotopes in the hydrological cycle:

Principles and applications - Volume 4: Groundwater. IAEA, Vienna, $196 \mathrm{pp}$.

(7) Zimmerman, U., Ehhalt, D. and Munnich, K.G., 1967. Soil water movement and evapotranspiration: changes in the isotopic composition of the water. In: Isotope in Hydrology, IAEA, Vienna, 567-584. In: Amore, F.F., Darling, G, Paces, T., Pang, Z. and Silar, J., 2000. Environmental isotopes in the hydrological cycle: Principles and applications - Volume 4: Groundwater. IAEA, Vienna, $196 \mathrm{pp}$. 
tratamento matemático, a maioria dos modelos numéricos assume que: (i) o aqüífero é homogêneo e isotrópico e (ii) a taxa de recarga é tão pequena, quando comparada à condutividade hidráulica, que a água adicionada verticalmente ao nível do aqüífero flui quase horizontalmente. Gau e Liu (2000) afirmam que desenvolvimentos recentes em métodos estocásticos de análise da hidrologia superficial têm demonstrado que uma aproximação estocástica é útil para caracterização de processos naturais mais complexos e pode ser utilizada para análises da recarga de aqüíferos.

Gau e Liu (2000) desenvolveram uma nova técnica usando aproximação estocástica para analisar a relação entre a precipitação e a variação do nível d'água subterrânea, e, por conseguinte, estimar o coeficiente de recarga efetivo com origem na precipitação. A teoria do modelo baseia-se na aproximação de Dupuit para um modelo de reservatório linear de um sistema de recarga simples. $\mathrm{O}$ aqüífero foi considerado como freático raso, homogêneo e isotrópico.

\subsection{Importância da evapotranspiração na estimativa da recarga}

O processo conjunto de perda de água por evaporação do solo e transpiração da planta denomina-se evapotranspiração. Ocorre quando a água líquida é convertida para vapor de água e transferida, neste estado, para a atmosfera. Este processo somente poderá ocorrer naturalmente se houver ingresso de energia no sistema, proveniente do sol, da atmosfera ou de ambos.

O solo, as plantas e a atmosfera podem ser considerados como componentes de um sistema fisicamente inter-relacionado e dinâmico, no qual os vários processos de fluxo estão interligados. Neste sistema, é valioso e aplicável o conceito de potencial hídrico, ou seja, o fluxo de água ocorre dos pontos de maior potencial para os de menor potencial.

A quantidade de água evaporada, que em algumas regiões representa uma parcela bastante superior do que a água que escoa superficialmente, é uma importante componente no balanço hídrico de uma bacia hidrográfica, mas é extremamente difícil de ser estimada com confiança, devido à inexistência de técnicas diretas e da necessidade de instrumentos de custos elevado para a obtenção de estimativas indiretas. Além disso, "os resultados possíveis de serem obtidos tem que ser vistos com cautela por serem pontuais, tornando seu uso possível apenas por hipóteses simplificadoras ou largos períodos de tempo, casos, estes, onde pequenas variações tornam-se desprezíveis" (MORTON, $1983^{(8)}$ apud POMPÊO, 1989).

\footnotetext{
${ }^{(8)}$ MORTON, F. I. (1983). Operacional estimates of areal evapotranspiration and their significance to the science and practice of hydrology, Journal of hydrology, n. .66 (1/4): 1-76
} 
James (1988) ressalta que, se a água armazenada no solo não for fator limitante e se os estômatos estiverem totalmente abertos, as condições atmosféricas são os fatores que controlam a evapotranspiração. Os fatores atmosféricos mais importantes no processo são: a radiação solar, a umidade relativa, a temperatura, o vento e a precipitação.

Contin Neto (1987), analisando a recarga do aqüífero Botucatu, Formação que faz parte do SAG, na bacia do Ribeirão da Onça, Brotas-SP, estimou que $80 \%$ da precipitação corresponde à evapotranspiração e ao armazenamento de umidade na zona não-saturada.

Cunha (2003) utilizou um lisímetro volumétrico para determinação da recarga potencial. O lisímetro foi preenchido com solo natural da região da bacia do Ribeirão do Lobo, no município de Brotas-SP, e recoberto com pastagem. Mediu-se a evapotranspiração real no lisímetro na ordem de $650 \mathrm{~mm}$ anuais. Estimou-se, também, a evapotranspiração potencial pelos métodos de Penman e Thornthwaite. O método de Penman apresentou uma evapotranspiração potencial de 1667,6 mm anuais, maior que a precipitação no período, que foi de $1416 \mathrm{~mm}$, sendo $260 \%$ maior que o valor obtido no lisímetro. O método de Thornthwaite apresentou uma evapotranspiração potencial de $1170 \mathrm{~mm}$ anuais, sendo $160 \%$ maior que o valor obtido no lisímetro.

Howard e Lloyd (1979) utilizaram o método de Penman para estimativas de recarga com o objetivo específico de estudar a influência dos parâmetros relacionados ao cálculo da evaporação potencial e real, considerando intervalos de tempo de 1 dia, 10 dias e 30 dias para o balanço de umidade do solo. Dentre os dados utilizados, a precipitação foi diretamente medida obtendo-se escoamento superficial através de correlação. Os dados para aplicação da equação de Penman foram obtidos a partir de estação climatológica localizada na bacia, ou estimados. Howard e Loyd (1979) afirmaram que a diferença entre a recarga anual, calculada a partir das equações de Penman, utilizando dados diários, decendiais e mensais, chegou a valores de $-12,4 \%$ a $-42,6 \%$, tendo como base os dados diários. A diferença entre esses valores mostra que, para bacias sem registros significativos de dados hidrológicos, os valores diários nas medições das variáveis são recomendados, pelo menos até que se tenha quantidades suficientes de dados para analisar estatisticamente as séries. Howard e Lloyd (1979) observaram que pequenas variações dos parâmetros da equação de Penman, especificamente da temperatura, albedo e coeficientes de regressão, podem provocar distorções de elevada magnitude nos resultados, havendo evidências de que subestimativas de $10 \%$ acarretam distorções da ordem de $15 \%$ na determinação da recarga. 
Pompêo (1990) aplicou o método do balanço hídrico na zona não-saturada do solo da bacia do Ribeirão da Onça, Brotas-SP. Para estimar a recarga profunda para a região (que foi denominado apenas de recarga), ele utilizou o método de Penman e medidas realizadas em um tanque classe A. O valor encontrado com a equação de Penman ficou na ordem de $1600 \mathrm{~mm}$ anuais, acima da precipitação anual que foi de $1200 \mathrm{~mm}$. O valor encontrado para a evapotranspiração potencial utilizando o tanque classe A foi de $850 \mathrm{~mm}$ anuais, sendo que este valor foi obtido pelo produto das medições no tanque por um coeficiente igual a 0,7 . Pompêo (1990) conclui que os métodos teóricos de evapotranspiração superestimaram a evapotranspiração real da bacia.

Mattos (1991) comparou várias fórmulas empíricas e semi-empíricas de estimativa da evapotranspiração com o método do balanço hídrico na bacia do rio Jacaré-Guaçú, afluente do rio Tietê no estado de São Paulo. O modelo de balanço hídrico usado foi:

$$
E=P-R
$$

em que $E$ é a evapotranspiração média anual, $P$ é a precipitação média anual e $R$ é a vazão média anual.

Os resultados obtidos da comparação das fórmulas empíricas com o balanço hídrico da região variaram de $8,25 \%$ a $-49,45 \%$. O modelo de Penman-Monteith apresentou o resultado mais discrepante. Mattos (1991) associou essa discrepância à sensibilidade do modelo aos valores típicos da resistência da cobertura vegetal (rc).

Um outro fator que interfere na evapotranspiração é a irrigação. Segundo Allen e Pruitt (1986) ${ }^{(9)}$ apud Medeiros (2002), a irrigação modifica as condições climáticas locais resfriando o ar, tornando-o mais úmido, além de reduzir a turbulência nas massas de ar que avançam de áreas não-irrigadas para áreas irrigadas. Isso reduz o potencial evaporativo das massas de ar e, conseqüentemente, a evapotranspiração. Esses autores relatam que estudos anteriores têm demonstrado uma redução na temperatura média do ar de $2^{\circ} \mathrm{C}$ a $5^{\circ} \mathrm{C}$ em áreas irrigadas, quando comparadas com áreas não-irrigadas, com aumento correspondente de umidade relativa e decréscimo no déficit de pressão de vapor. 
Pompêo (1990) expressa que a relação entre a evapotranspiração pontual e espacial em uma área heterogênea é função da variação das disponibilidades hídricas desta área e dos efeitos desta variação na camada de ar imediatamente acima do solo. Uma diminuição da evapotranspiração em uma área pequena torna o ar que passa sobre a mesma mais seco e mais aquecido, conseqüentemente ocorre uma elevação na quantidade de energia disponível, o que vem a produzir elevações compensatórias na evapotranspiração das áreas úmidas ao longo do curso subseqüente dessa massa de ar.

\subsection{Precipitação}

A precipitação é entendida como toda água proveniente do meio atmosférico que atinge a superfície terrestre. As precipitações representam o elo entre os fenômenos meteorológicos, propriamente ditos, e os escoamentos superficial e subterrâneo.

Existem várias possibilidades de medir a precipitação. A mais comum é a utilização de pluviômetros e pluviógrafos. Também podem ser feitas medidas de precipitação através de radares meteorológicos ou imagens de satélite, mas erros associados a esses métodos, quando se deseja a quantificação exata, ainda são relativamente grandes (SANTOS et al.,2001).

O pluviômetro é um aparelho dotado de uma superfície de captação horizontal delimitada por um anel metálico e de um reservatório para armazenar a água recolhida, ligado a essa área de captação. Os pluviógrafos são aparelhos capazes de registrar continuamente de forma analógica ou digital a precipitação local. São usados quando se pretende medir chuvas em pequenos intervalos de tempo (SANTOS et al., 2001).

A precipitação é medida como a altura da lâmina d'água que seria acumulada em superfície plana se nenhuma perda ocorresse (PAIVA e PAIVA, 2003).

As redes fundamentais de coleta de dados de precipitação são constituídas em geral de pluviômetros e um número restrito de pluviógrafos localizados em locais de maior interesse. Entre os hidrólogos tem sido admitido que uma média de uma estação pluviométrica por 500 ou $400 \mathrm{~km}^{2}$ seja suficiente. Com o objetivo de padronizar a forma de coleta de dados, a WMO (World Meteorological Organization) publicou algumas recomendações sobre o número mínimo de postos de observação (Tabela 2).

Porém, a distribuição dos aparelhos em estudos de bacias experimentais e representativas deve ser adensada para melhor representar a distribuição espacial e temporal da chuva. Parâmetros de densidade mínima de pluviômetros para tais bacias ainda não foram estabelecidos. Caberá ao projetista estabelecer pelo bom senso o número de postos a serem 
instalados, que dependerá do clima e da unidade fisiográfica local, e principalmente dos recursos disponíveis.

Tabela 2: Recomendações da WMO (Fonte: WMO apud PAIVA e PAIVA, 2003) para densidade mínima de pluviômetros

\begin{tabular}{|l|cc|}
\hline \multirow{2}{*}{ Unidades fisiográficas } & \multicolumn{2}{|c|}{ Densidade mínima $\left(\mathrm{km}^{2}\right.$ por estação $)$} \\
\cline { 2 - 3 } & Sem registrador & Com registrador \\
\hline Litoral & 900 & 9000 \\
Montanhosa & 250 & 2500 \\
Planície interior & 575 & 5750 \\
Ondulada & 575 & 5750 \\
Pequenas ilhas & 25 & 250 \\
Áreas urbanas & - & $10-20$ \\
Polar/árida & 10000 & 100000 \\
\hline
\end{tabular}

\subsection{Relação entre a precipitação e a recarga}

Conforme visto em capítulos anteriores, a precipitação, em geral, é o principal fenômeno responsável pela recarga. Processos de recarga através da precipitação em aqüíferos livres são complexos, por não haver uma ligação direta entre esses dois fenômenos. O processo envolve o fluxo na zona não-saturada, que está sujeita a evapotranspiração e aos fluxos subsuperficiais. A taxa de infiltração depende de muitos parâmetros que são bastante variáveis no tempo e espaço.

Rennolls et al. (1980) utilizaram um método auto-regressivo linear para relacionar a precipitação com o nível da superfície freática. Concluíram que o modelo ignora fatores relevantes, como precipitação efetiva, interceptação e evapotranspiração, o que altera os resultados. Afirmaram também que a utilização de parâmetros lineares não corresponde à realidade.

Viswanathan (1983) estudou um modelo de relação entre a precipitação e o nível potenciométrico. Ele relacionou os dois fenômenos a três parâmetros, um parâmetro relacionado com o fator de drenagem $\lambda_{t}$, outro relacionado à "distúrbios externos" $\left(\beta_{t}\right)$ e outro relacionado à infiltração devido à precipitação $\left(\alpha_{t}\right)$. Entende-se como “distúrbios externos", a soma de todos os efeitos que não o fator de drenagem e a infiltração devido à precipitação. Foi constatado que os parâmetros $\alpha_{\mathrm{t}} \mathrm{e} \beta_{\mathrm{t}}$ são muito variáveis no tempo, diferentemente do parâmetro $\left(\lambda_{t}\right)$, que permaneceu praticamente constante. Observaram ainda que, durante os períodos secos, as flutuações do nível do aqüífero são determinados pelos parâmetros $\lambda_{t}$ e $\beta_{t}$. 
Bouwer e Rice (1976) estimou que o nível do aqüífero pode variar em até $5 \mathrm{~cm}$ devido a mudanças em componentes atmosféricos.

Esses três trabalhos apontam a dificuldade de associar, pura e simplesmente, a precipitação com o nível da superfície do aqüífero, mesmo sendo a precipitação um fator preponderante para a recarga dos aqüíferos livres. As análises desses três trabalhos ainda estão sujeitas aos questionamentos quanto a sua representatividade, já que para a construção dos modelos foram usados dados de poucos poços de monitoramento.

Contin Neto (1987) verificou uma forte correlação entre a precipitação e a recarga no período chuvoso (100 dias) na bacia do Ribeirão da Onça, Brotas-SP. Nesse período houve um intervalo máximo sem chuvas de 3 dias. Segundo os seus estudos a correlação neste período foi de 0,99. A alta correlação atribuída deve-se à influência do aumento da umidade na região não-saturada. Isso favorece a ligação entre a água precipitada que infiltra e a superfície do aqüífero, que responde mais rapidamente à precipitação.

Contin Neto (1987) identificou uma recarga profunda, através de balanço hídrico, na bacia do Ribeirão da Onça da ordem de 8\% da precipitação total no período de maio de 1985 a maio de 1986.

Pompêo (1990), também estudando a bacia do Ribeirão da Onça, Brotas-SP, estimou que a recarga do aqüífero foi de $8 \%$ da precipitação, $100 \mathrm{~mm}$. Tomando o seu estudo de balanço hídrico, constata-se que o valor da recarga se deve ao acréscimo observado à reserva do aqüífero, já que para encontrar esse valor da recarga foi retirado o escoamento de base. Esse valor poderia ser separado entre a recarga profunda do aqǘfero e a variação do armazenamento do aqüífero na bacia.

\subsection{Efeitos da Interceptação}

A interceptação vegetal é um fator que pode interferir diretamente na quantidade de fluido que atinge a região não-saturada do solo, já que não se pode considerar o valor da precipitação obtida em pluviômetros como a precipitação real que atinge a superfície do solo.

Soares e Almeida (2001) realizaram um balanço hídrico em área cultivada com eucaliptos entre os períodos de outubro de 1995 a setembro de 1996. A interceptação durante o período foi avaliada em $11 \%$ do valor da precipitação. Essa interceptação é notada com maior ênfase nos períodos mais secos, onde a intensidade das chuvas é menor. Resultados semelhantes foram encontrados no trabalho de Preble e Stirk (1980), que analisaram a interceptação em eucaliptos na Austrália. 
Ferreira et al. (2005) estudaram a interceptação em florestas da bacia amazônica, procurando quantificar as mudanças entre áreas manejadas e áreas intactas. Utilizaram para este estudo pluviômetros para medir a precipitação no topo das árvores, chamada de precipitação total, e pluviômetros para medir a precipitação que atinge o solo, chamada de precipitação interna. A interceptação foi calculada pela diferença entre a precipitação total e a interna. Para o período de um ano hidrológico a interceptação na área intacta da floresta variou entre $25,8 \%$ e $12,9 \%$ da precipitação total e na área manejada entre $7,1 \%$ e $13,1 \%$.

\subsection{Influências do uso do solo}

A recarga subterrânea é função do tipo de cobertura vegetal, que influencia no comportamento do escoamento superficial e na infiltração direta. Quando uma área florestada é transformada em pastagem, a evapotranspiração é reduzida ocorrendo maior percolação profunda, além da diminuição dos efeitos da interceptação que podem chegar a valores consideráveis e das mudanças no runoff.

Pompêo (1990) estudou os perfis de umidade do solo antes e depois da remoção de uma floresta de eucaliptos e observou a identificação direta do armazenamento de água no solo com o padrão de chuva, variação entre os perfis de umidade em locais com mesma cobertura e tipo de solo e grande influência do eucalipto na umidade armazenada no solo, uma vez que suas raízes extraem água a profundidades abaixo de 6 metros.

Mahe et al. (2005) estudaram o impacto da mudança no uso do solo na bacia do rio Nakambe, Burquina Faso. O impacto foi estudado sob o ponto de vista da capacidade de água disponível no solo, através de estudos do runoff, da evapotranspiração, do escoamento de base e de mapas de uso do solo. O trabalho contemplou os períodos do ano de 1955 e de $1965-$ 1998. Quatro janelas no tempo foram abertas para a avaliação dos resultados. Os resultados são apresentados na Tabela 3, onde a sigla WHC (water holding capacity) significa a capacidade de retenção de água no solo. Esses valores representam os valores máximos encontrados. 
Tabela 3: Mudança em três tipos de solo e impacto na $\boldsymbol{W H C}$

Modificado de Mahe et al. (2005)

\begin{tabular}{|c|c|c|c|c}
\hline Ano & $\begin{array}{c}\text { Vegetação } \\
\text { Natural }\end{array}$ & $\begin{array}{c}\text { Áreas } \\
\text { Cultivadas }\end{array}$ & $\begin{array}{c}\text { Solo } \\
\text { Descoberto }\end{array}$ & $\begin{array}{c}\text { Redução na } \\
W H C\end{array}$ \\
\hline Valores Iniciais & $100 \%$ & $0 \%$ & $0 \%$ & $0 \%$ \\
\hline $\mathbf{1 9 6 5}$ & $43 \%$ & $53 \%$ & $4 \%$ & $0 \%$ \\
\hline 1975 & $34 \%$ & $58 \%$ & $8 \%$ & $23 \%$ \\
\hline 1985 & $15 \%$ & $75 \%$ & $10 \%$ & $57 \%$ \\
\hline 1995 & $13 \%$ & $76 \%$ & $11 \%$ & $62 \%$ \\
\cline { 1 - 5 } & & & &
\end{tabular}

\subsection{Quantificação do escoamento superficial}

O escoamento superficial é à parte do ciclo hidrológico em que a água se desloca na superfície da bacia. Quando a bacia é rural e possui cobertura vegetal, o escoamento na superfície sofre a influência desta cobertura e grande parte da água infiltra (TUCCI, 1998).

A quantificação dessa componente do ciclo hidrológico, em geral, é feita através de medições periódicas em determinadas seções dos cursos d'água. Diariamente ou de forma contínua medem-se os níveis d'água nos rios e esses valores são transformados em vazão através de uma equação chamada curva-chave.

\subsubsection{Medição de vazão com molinete hidrométrico}

O molinete hidrométrico é um aparelho dotado basicamente de uma hélice e um contagiros. A medição com molinete hidrométrico convencional é universalmente utilizada para a determinação da vazão em cursos de água naturais e consiste em determinar a área da seção transversal e a velocidade média do fluxo que passa por esta seção (SANTOS et al., 2001).

Santos et al. (2001) apresenta uma tabela com expressões e parâmetros práticos para a determinação da velocidade média em uma vertical (Tabela 4) e outra com as distâncias mínimas entre as verticais (Tabela 5). 
Tabela 4: Parâmetros para o cálculo da velocidade média na vertical

\begin{tabular}{|c|c|c|c|}
\hline $\begin{array}{c}\mathbf{N}^{\circ} \\
\text { pontos }\end{array}$ & $\begin{array}{c}\text { Posição na vertical em relação à } \\
\text { profundidade (a partir da superfície) }\end{array}$ & $\begin{array}{c}\text { Cálculo da velocidade média }\left(\boldsymbol{v}_{\boldsymbol{m}}\right), \text { na } \\
\text { vertical }\end{array}$ & $\begin{array}{c}\text { Profundidade } \\
(\mathbf{m})\end{array}$ \\
\hline $\mathbf{1}$ & $0,6 \mathrm{p}$ & $v_{m}=v_{0,6}$ & $0,15-0,6$ \\
\hline $\mathbf{2}$ & $0,2 \mathrm{p} \mathrm{e} 0,6 \mathrm{p}$ & $v_{m}=\left(v_{0,2}+v_{0,8}\right) / 2$ & $0,6-1,2$ \\
\hline $\mathbf{3}$ & $0,2 \mathrm{p} ; 0,6 \mathrm{p} ; 0,8 \mathrm{p}$ & $v_{m}=\left(v_{0,2}+2 v_{0,6}+v_{0,8}\right) / 4$ & $1,2-2,0$ \\
\hline $\mathbf{4}$ & $0,2 \mathrm{p} ; 0,4 \mathrm{p} ; 0,6 \mathrm{p} ; 0,8 \mathrm{p}$ & $v_{m}=\left(v_{0,2}+2 v_{0,4}+2 v_{0,6}+v_{0,8}\right) / 6$ & $2,0-4,0$ \\
\hline $\mathbf{6}$ & $\mathrm{S} ; 0,2 \mathrm{p} ; 0,4 \mathrm{p} ; 0,6 \mathrm{p} ; 0,8 \mathrm{p} ; \mathrm{F}$ & $v_{m}=\left[v_{S}+\left(v_{0,2}+v_{0,4}+v_{0,6}+v_{0,8}\right)+v_{F}\right] / 10$ & $>4,0$ \\
\hline \multicolumn{4}{|l}{} \\
\hline
\end{tabular}

(DNAEE, $1967^{(10)}$ apud SANTOS et al., 2001)

Tabela 5: Distância recomendada entre as verticais

\begin{tabular}{|c|c|c|c|}
\hline Largura do rio (m) & Distância entre verticais (m) & Largura do rio (m) & Distância entre verticais (m) \\
\hline$\leq 3,00$ & 0,3 & $50,00-80,00$ & 4,00 \\
\hline $3,00-6,00$ & 0,5 & $80,00-150,00$ & 6,00 \\
\hline $6,00-15,00$ & 1,00 & $150,00-250,00$ & 8,00 \\
\hline $15,00-30,00$ & 2,00 & $\geq 250,00$ & 12,00 \\
\hline $30,00-50,00$ & 3,00 & & \\
\hline
\end{tabular}

(DNAEE, $1967^{(10)}$ apud SANTOS et al., 2001)

Queiroz (1991) realizando um estudo de propagação de onda cinemática na bacia do Ribeirão da Onça, Brotas-SP, utilizou para o cálculo da velocidade média, nas verticais, medições a 0,2 e 0,8 da profundidade, com uma distância entre as verticais de $0,30 \mathrm{~m}$. Não foi comentado nesse trabalho sobre a eficácia do método.

Em pequenos rios (profundidade $<1 \mathrm{~m}$ ), a medição é geralmente realizada a vau ou através de pequenas passarelas. Para medição da velocidade média nesses rios recomenda-se a utilização de micromolinetes (SANTOS et al., 2001), que conseguem medir velocidades baixas. Os micromolinetes são molinetes de tamanho reduzido que geralmente são fixados em uma haste.

\subsubsection{Métodos de cálculo da vazão}

Os métodos mais usados para a determinação da vazão a partir de medições realizadas com molinete hidrométrico são os métodos da meia seção e o método da seção média (SANTOS et al., 2001; PAIVA e PAIVA, 2003). A Tabela 6 apresenta os passos para encontrar a vazão pelos dois métodos, com as variáveis baseadas na Figura 5.

${ }^{(10)}$ DNAEE, Departamento Nacional de Águas e Esgotos e Enegia Elétrica (1967). Normas e recomendações hidrológicas estabelecidas pelo decreto n. 60.852, de junho de 1967. Rio de Janeiro, 1967/70. 6 anexos. Anexo II: Fluviometria. 
Tabela 6: Passos para cálculo da vazão

\section{MÉTODO DA SEÇÃO MÉDIA}

\section{MÉTODO DA MEIA SEÇÃO}

1. Cálculo das velocidades médias em cada segmento de área $\left(\overline{\mathrm{v}}_{\mathrm{i}}^{\mathrm{s}}\right)$

$$
\overline{\mathrm{v}}_{\mathrm{i}}^{\mathrm{s}}=\left(\frac{\overline{\mathrm{v}}_{\mathrm{i}}+\overline{\mathrm{v}}_{\mathrm{i}+1}}{2}\right) \quad \overline{\mathrm{v}}_{\mathrm{i}}^{\mathrm{s}}=\overline{\mathrm{v}}_{\mathrm{i}}
$$

2. Cálculo da largura de cada segmento de área $\left(\mathrm{L}_{\mathrm{i}}\right)$

$$
\begin{array}{l|l}
\mathrm{L}_{\mathrm{i}}=\mathrm{d}_{\mathrm{i}+1}-\mathrm{d}_{\mathrm{i}} & \mathrm{L}_{\mathrm{i}}=\left(\frac{\mathrm{d}_{\mathrm{i}+1}-\mathrm{d}_{\mathrm{i}-1}}{2}\right)
\end{array}
$$

3. Cálculo das áreas de cada segmento $\left(\mathrm{A}_{\mathrm{i}}\right)$

$$
\mathrm{A}_{\mathrm{i}}=\mathrm{L}_{\mathrm{i}} \frac{\left(\mathrm{h}_{\mathrm{i}}+\mathrm{h}_{\mathrm{i}+1}\right)}{2} \quad \mathrm{~A}_{\mathrm{i}}=\mathrm{L}_{\mathrm{i}} \mathrm{h}_{\mathrm{i}}
$$

4. Cálculo das vazões de cada segmento $\left(\mathrm{Q}_{\mathrm{i}}\right)$

$$
\mathrm{Q}_{\mathrm{i}}=\overline{\mathrm{v}}_{\mathrm{i}}^{\mathrm{s}} \mathrm{A}_{\mathrm{i}}
$$

5. Cálculo da vazão total (Q)

$$
\begin{array}{l|l}
\mathrm{Q}=\sum_{\mathrm{i}-1}^{\mathrm{n}-1} \mathrm{Q}_{\mathrm{i}} & \mathrm{Q}=\sum_{\mathrm{i}}^{\mathrm{n}-1} \mathrm{Q}_{\mathrm{i}}
\end{array}
$$

Modificado de Paiva e Paiva (2003) 


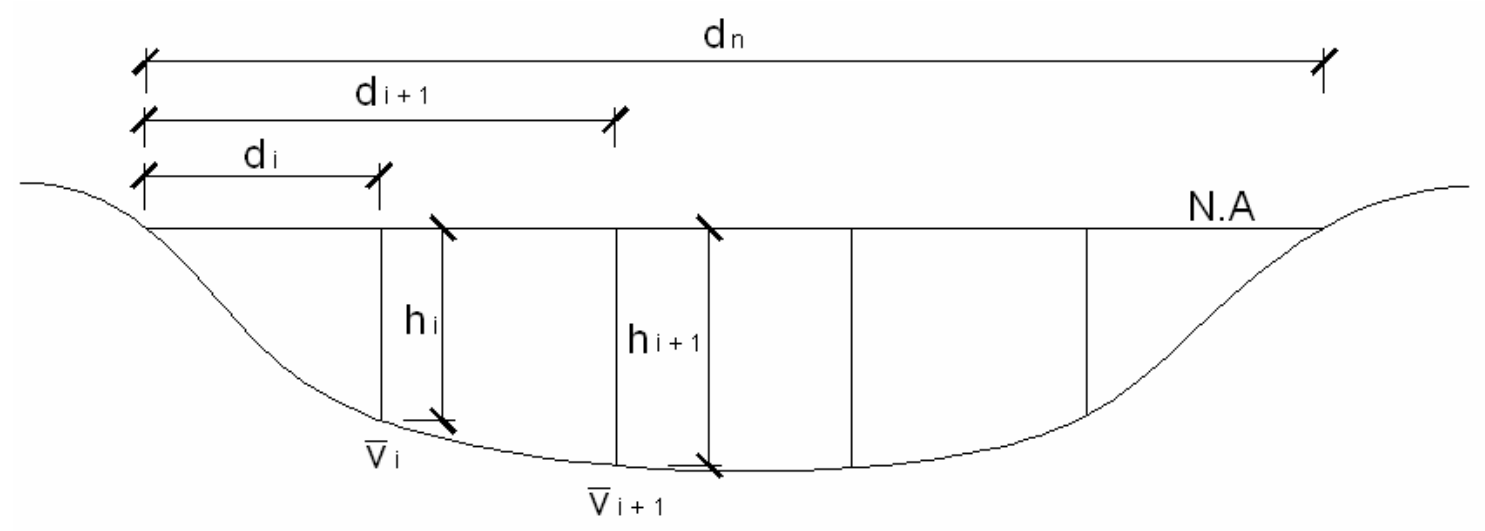

Figura 5: Desenho esquemático de decomposição da seção transversal de um curso de água para o cálculo de vazão, a partir de medição com molinete hidrométrico

O princípio de funcionamento é associar uma velocidade a certo número de giros da hélice do molinete. Essa função é a curva de calibração do molinete e, geralmente, é expressa por uma equação do tipo $V=a . n+b$, sendo $V$ igual à velocidade no ponto da seção; $a$ e $b$ são parâmetros característicos do aparelho e $n$ o número de giros da hélice em um intervalo de tempo definido.

\subsubsection{Curva-chave}

A medição da vazão de um curso d'água é um processo que envolve equipamentos e técnicos especializados. Não sendo viável a realização de medições de vazões de forma contínua, de modo a permitir ao hidrólogo o conhecimento pleno do regime fluvial dos rios, estas medições são feitas esporadicamente, procurando-se definir uma relação entre o nível d'água e a vazão. A relação entre cota e vazão, é denominada de curva-chave.

Dificuldades normais, tanto técnicas como operacionais, na medição das vazões para a determinação da curva-chave, muitas vezes impedem que se estenda a curva-chave tanto para as cotas mais baixas, como para as cotas mais altas registradas. Essa informação é necessária para obter as vazões mínimas e máximas que são, não raro, o ponto crucial de muitos estudos hidrológicos.

É importante notar que, geralmente, a seção transversal do rio sofre alterações no seu perfil, devido à erosão, deposição de sedimentos, ação antrópica, vegetação, etc., o que obriga a freqüentes ajustes na curva-chave, apoiados em novas medidas de vazão, que devem ser feitas periodicamente.

Calibrar uma curva-chave significa encontrar a função ou traçado que melhor se ajuste aos pares de pontos cota-vazão, obtidos das medições de vazão (AZEVEDO, 1994 ${ }^{(11)}$, apud 
SEFIONE, 2002). Essa correspondência entre a cota e a vazão, na prática pode ser impossível de se determinar, seja pela grande instabilidade do trecho onde se encontra a estação fluviométrica, seja pelas condições hidráulicas desfavoráveis, como por exemplo, o efeito de remanso. Não se trata, portanto, de um ajuste puramente matemático; essa tarefa requer uma análise de fatores como a geometria, sensibilidade e estabilidade da seção transversal, rugosidade e mobilidade do leito (SEFIONE, 2002).

Esse processo de ajuste é complexo, dado que a relação entre as duas variáveis não é perfeitamente unívoca, sofrendo modificações ao longo do tempo. A evolução no tempo pode ser avaliada analisando-se as medições sucessivas. Nesta etapa também são identificados eventuais erros cometidos no campo ou no processamento dos dados das medições, muitas vezes possibilitando sua correção.

As equações mais utilizadas para representar a curva-chave são as do tipo potencial, (Eq. 12), e as do tipo polinomial, (Eq. 13).

$$
\begin{gathered}
Q=a \cdot\left(H-H_{0}\right)^{n} \\
Q=a_{0}+a_{1} H+a_{2} H^{2}+\ldots+a_{n} H^{n}
\end{gathered}
$$

em que: $a$ e $n$ são coeficientes de ajuste para cada curva-chave

$H$ é a cota referente a uma vazão $Q$

$H_{0}$ é a cota referente à vazão nula

$a_{i}$ são os parametros da função

Contin Neto (1987), Pompêo (1990) e Arantes (2003) utilizaram a equação potencial para traçar a curva-chave na bacia do Ribeirão da Onça, Brotas-SP. Queiroz (1991), para o mesmo rio, utilizou uma função do tipo polinomial para o traçado da curva-chave.

A extrapolação da curva-chave é necessária quando há valores de cota máxima diária observada maior que a maior cota registrada nas medições de vazão - extrapolação superior ou quando a menor cota diária observada for menor que a menor cota registrada nas medições de vazão - extrapolação inferior.

A necessidade de extrapolação é a regra e não a exceção entre as estações fluviométricas, principalmente a extrapolação superior da curva. Isto se dá devido à dificuldade de dispor de um número suficiente de equipes a postos para efetuar medições de vazão nos momentos de cheia, ou quando isso acontece, pode haver a impossibilidade de se efetuar a medição devido aos riscos, em função das altas velocidades das águas no rio (TUCCI e SILVEIRA, 1985). 


\subsubsection{Métodos de extrapolação}

\section{Método logarítmico}

Aplicável a cursos d'água com seção aproximadamente trapezoidal (sem descontinuidade no intervalo de cotas de extrapolação), admite que a curva a ser extrapolada seja unívoca e se ajuste, pelo menos em sua parte superior, segundo a equação potencial. Também é aplicável para os casos de estações com medições de vazão em cotas suficientemente elevadas, para que a direção do trecho superior da curva (uma reta na escala logarítmica) esteja bem definida. O método não utiliza os parâmetros hidráulicos da seção transversal.

O procedimento usual, para verificar se a equação se aplica, consiste em plotar as medições, usando-se para as cotas o valor $\left(\mathrm{H}-\mathrm{H}_{0}\right)$, em papel bilogarítmico e verificar se os pontos se alinham segundo um ou mais segmentos de reta (Figura 6). Inicia-se com $\mathrm{H}_{0}=0$. Não ocorrendo o alinhamento, deve-se procurar o valor de $\mathrm{H}_{0}$ que retifique o conjunto superior dos pontos. Se a convexidade da curva for orientada para as vazões, $\mathrm{H}_{0}$ deverá ser positivo, caso contrário deverá ser negativo. Definido o valor de $\mathrm{H}_{0}$, faz-se novo ajuste que resultará em novos valores para os outros dois parâmetros a e n (Eq. 12).

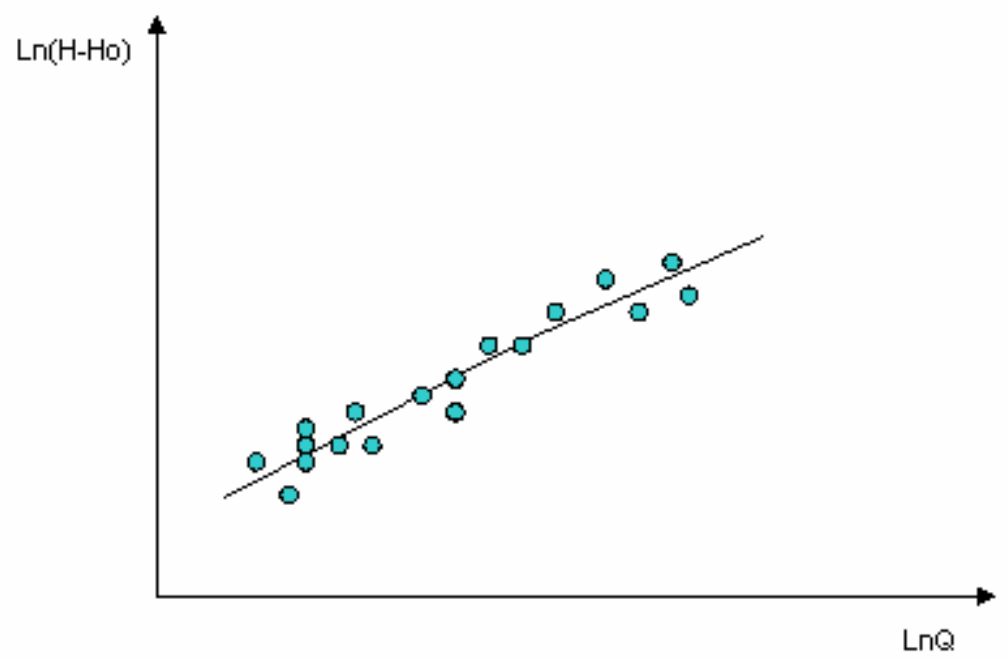

Figura 6: Representação gráfica da extrapolação da curva-chave pelo método logarítmico 


\section{Método de Stevens}

Este método consiste em aceitar como válida, na própria seção de medição, a fórmula de Chézy para o escoamento uniforme em canais.

O método é mais utilizado para rios largos em escoamento praticamente uniforme com perfil da linha d'água estável, sem variação entre cheia e depleção.

É um método gráfico que se fundamenta na fórmula de Chézy para o escoamento uniforme:

$$
Q=C \cdot A\left(R_{H} I\right)^{1 / 2}
$$

em que:

$Q$ é a vazão no rio $\left(\mathrm{m}^{3} / \mathrm{s}\right)$;

$A$ é área da seção transversal $\left(\mathrm{m}^{2}\right)$;

$R_{H}$ é raio hidráulico $(\mathrm{m})$;

I é declividade superficial da linha d'água $(\mathrm{m} / \mathrm{m})$;

$C$ é coeficiente dimensional $\left(\mathrm{m}^{1 / 2} \mathrm{~s}^{-1 / 2}\right)$.

sendo:

$A \cdot R_{H}{ }^{1 / 2}$ é o fator geométrico;

$C I^{1 / 2}$ é o fator de declividade, que pode ser considerado constante para os níveis superficiais dos cursos de água mais elevados.

Sendo assim:

$$
Q=f\left(A \cdot R_{H}^{1 / 2}\right)
$$

que é uma função que passa pela origem.

Para o cálculo do fator geométrico em cotas altas, utiliza-se do levantamento da seção transversal do curso d'água na seção de réguas.

Determina-se o valor de $A \cdot R_{H} I^{2}$ referente à cota que se deseja extrapolar, visto que é função da cota e pode ser calculado para qualquer valor desta, desde que dentro dos limites de levantamento da seção.

Prolonga-se a reta do gráfico de $A \cdot R_{H}{ }^{1 / 2}$ x $Q$ até o valor de $A \cdot R_{H}{ }^{1 / 2}$ calculado anteriormente, obtendo-se a vazão graficamente (Figura 7). 


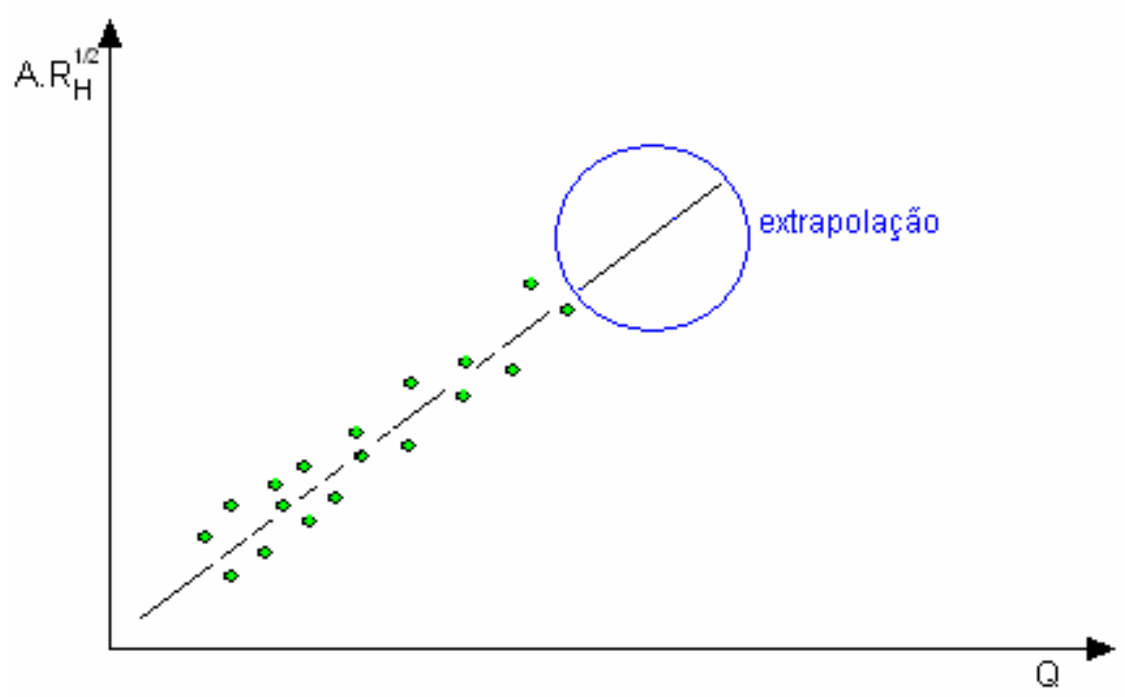

Figura 7: representação gráfica da extrapolação da curva-chave pelo método de Stevens

\section{Método de Manning}

Fundamenta-se na fórmula de Manning para o escoamento uniforme:

$$
Q=\frac{1}{n} A \cdot R_{H}^{2 / 3} \cdot I^{1 / 2}
$$

em que:

$Q$ é vazão $\left(\mathrm{m}^{3} / \mathrm{s}\right)$

$n$ é coeficiente de rugosidade de Manning (admensional)

$A$ é área da seção transversal $\left(\mathrm{m}^{2}\right)$

$R_{H}$ é raio hidráulico $(\mathrm{m})$

$I$ é declividade $(\mathrm{m} / \mathrm{m})$

Considerando para cotas altas a tendência

$$
\frac{1}{n} I^{1 / 2}=c t e=K
$$

Obtém-se:

$$
Q=K \cdot A \cdot R_{H}^{2 / 3} \text { ou } v=K \cdot R_{H}^{2 / 3}
$$

A partir do levantamento da seção transversal do curso d'água na seção de réguas, podem-se calcular: área, perímetro molhado e raio hidráulico. 
Através da velocidade $(v)$ e do raio hidráulico $\left(R_{H}\right)$, calculados para as diversas cotas, determinam-se os valores de $K$ para o trecho conhecido da curva. Plotando-se $H$ x $K$, obtémse uma curva com tendência vertical e assintótica para um determinado valor de $K$. Com o valor de $K$, limite para os níveis mais altos (verificado no gráfico), a área e o raio hidráulico da seção transversal, calculam-se os valores correspondentes de $Q$ (Figura 8).

A desvantagem principal do método é que nem sempre a função $K=f(H)$ estará bem definida graficamente pelas medições realizadas.

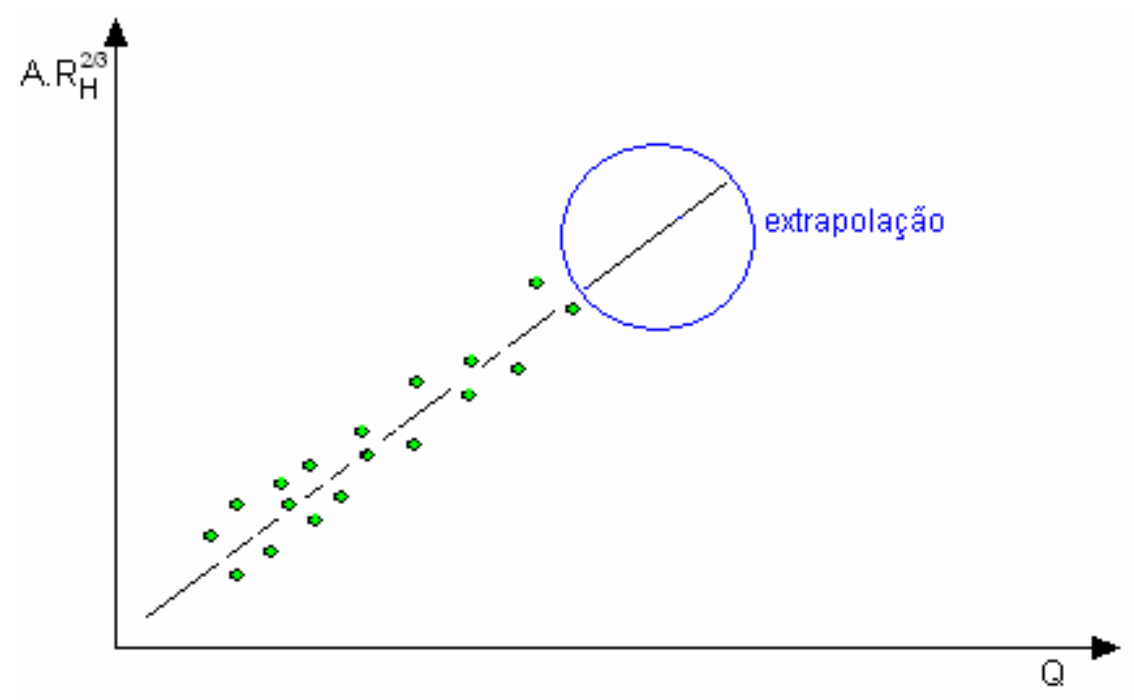

Figura 8: representação gráfica da extrapolação da curva-chave pelo método de Manning

\subsubsection{Modelos precipitação-vazão}

Existe um grande número de modelos precipitação-vazão, cada qual com variantes de algoritmos empíricos dos processos hidrológicos representados. Independente da classificação dos modelos, seu uso eficiente para calcular vazões em bacias hidrográficas está condicionado à sua validação (SILVEIRA et al. 1998).

Os principais usos desses modelos são (TUCCI, 1998):

- Melhor entender o comportamento dos fenômenos hidrológicos na bacia;

- Analisar a consistência de dados existentes e preencher falhas;

- Prever vazão em tempo atual;

- Dimensionar e prever cenários de planejamento;

- Analisar os efeitos resultantes da modificação do uso do solo. 
Germano et al. (1998) ainda acrescentam a utilidade desses modelos para a estimativa de vazões máximas e hidrogramas de projeto para bacias com poucos dados observados.

\subsubsection{O Modelo SCS}

Este modelo foi apresentado pelo Soil Conservation Service e tem sido muito utilizado para a simulação de hidrogramas de cheia de projeto de obras hidráulicas bem como para o estabelecimento do risco de enchentes para um determinado local (TUCCI, 1998).

O método SCS propõe uma relação precipitação-vazão como função da precipitação total, do volume de escoamento superficial e da capacidade de absorção da bacia hidrográfica. O modelo SCS utiliza o parâmetro $\mathrm{CN}$ de separação do escoamento superficial e da infiltração. O parâmetro $\mathrm{CN}$ é tabelado segundo o tipo de solo e as características da ocupação, como tamanho de lote, área comercial, industrial, entre outros.

O modelo utiliza uma função que relaciona a precipitação total $(P$, em mm), o volume superficial acumulado ( $Q$, em $\mathrm{mm})$, a infiltração e o escoamento da bacia, sendo definida a seguinte expressão:

$$
Q=\frac{\left(P-I_{a}\right)^{2}}{P+S-I_{a}}
$$

em que $I_{a}$ são as perdas iniciais e $S$ o armazenamento do solo. Pode-se considerar o valor de $I_{a}$, para condições médias, igual a $0,2 S$.

Para determinar a capacidade máxima da camada superior do solo $S$, foi estabelecida uma relação com o parâmetro $C N$, que pode variar de 1 a 100 .

$$
S=\frac{25400}{C N}-254
$$

sendo o valor de $\mathrm{S}$ obtido em $\mathrm{mm}$.

Para a propagação do escoamento superficial, o modelo utiliza o hidrograma unitário, que no caso é o hidrograma unitário sintético triangular, obtido com base no tempo de pico e no valor de pico. 
Este método apresenta resultados bastante contestados. Chahinian et al. (2005) compararam quatro métodos de infiltração, a equação de Morel-Seytoux, a equação de Horton, a equação de Philip e o método do SCS. O estudo foi realizado no sul da França, em uma bacia de aproximadamente $1200 \mathrm{~m}^{2}$ (60m de comprimento e $20 \mathrm{~m}$ de largura) e uma inclinação de $15 \%$ em média. Foram utilizados 14 eventos para a calibração dos modelos e 14 eventos para a verificação. Os métodos foram calibrados pelo volume total escoado para cada evento de chuva. O resultado da análise apresentou o método do SCS como o método que pior respondeu aos eventos. Para o volume total escoado, o método do SCS apresentou um erro de aproximadamente 16\% quando comparado com o real. O método de Philip melhor se apresentou quando comparado o volume total escoado simulado com o real, com erro de $3 \%$.

Michaud e Sorooshian (1994), em uma bacia de $150 \mathrm{~km}^{2}$, estudaram a utilização do modelo SCS, distribuído e concentrado espacialmente, e do modelo KINEROS. Foram utilizadas 6 tormentas para calibrar os modelos. A validação foi realizada com 24 eventos. Os resultados mostraram que o modelo KINEROS melhor se ajustou à realidade, sendo o método SCS concentrado menos preciso. Comparando-se o volume escoado, o resultado encontrado para o viés médio pela média dos eventos observados encontrado foi de $-16,9 \%$ para o modelo SCS concentrado, de $-27,6 \%$ para o modelo SCS distribuído e de $-26,6 \%$ para o modelo KINEROS. Ainda comparando-se os volumes totais calculados com os observados, o resultado para a raiz do erro médio quadrático comparado com a média observada foi de 104,4\%, para o modelo do SCS concentrado, 83,5\% para o modelo do SCS distribuído, e $73,1 \%$, para o modelo KINEROS.

\subsubsection{Interação rio-aqüífero}

Aqüíferos e águas superficiais não são componentes isoladas do ciclo hidrológico, mas interagem em uma grande variedade de casos, dependendo da fisiografia, geologia, fatores bióticos e da climatologia. Sendo assim, a preservação ou a contaminação de um afeta diretamente o outro. O entendimento básico da interação entre as águas subterrâneas e superficiais é necessário para um bom gerenciamento dos recursos hídricos (SOPHOCLEOUS, 2002).

De maneira geral, a interação pode ocorrer com passagem de água tanto do aqüífero para a superfície livre como da superfície livre para o aqüífero, sendo que em uma mesma seção podem ocorrer os dois fenômenos conjuntamente no tempo (Figura 9). 

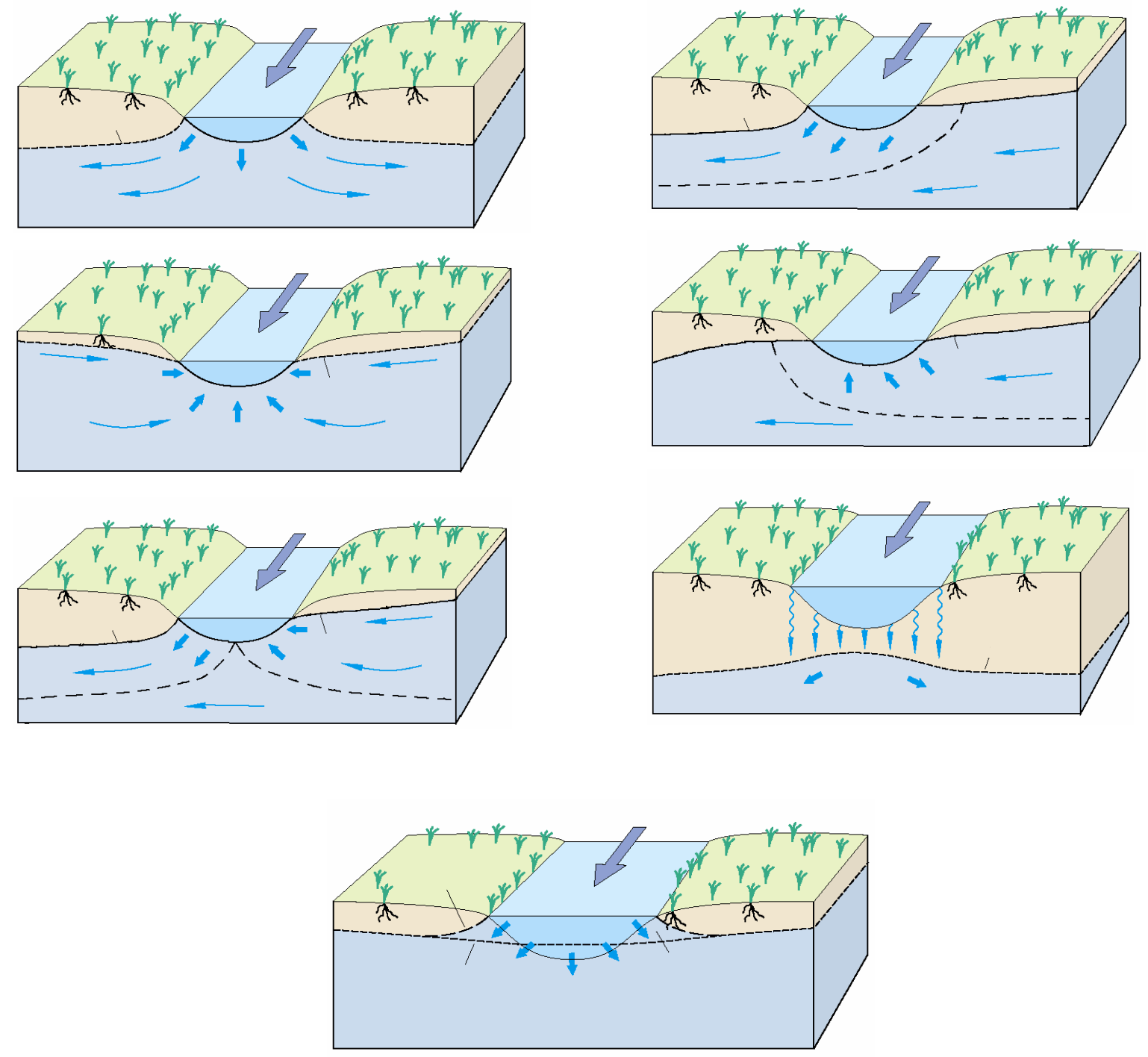

Figura 9: Possibilidades de interação rio-aqüífero

Fonte: Winter et al. (1998)

A distribuição espacial do sistema de fluxo (local ou regional) influencia a intensidade da descarga subterrânea natural. O rio principal de uma bacia pode receber água subterrânea de áreas próximas e possivelmente de áreas mais distantes (SOPHOCLEOUS, 2002).

Existem diversas técnicas para estimativa da descarga de aqüíferos em rios, no entanto é muito mais fácil estimar as perdas de transmissão (água que deixa o rio por fluxo descendente). De modo geral, as conexões da água subterrânea com a água superficial têm sido verificadas por medidas dos níveis d'água em poços de monitoramento e por comparação das características químicas da água subterrânea e do rio (WOESSNER, 2000).

Diversos métodos são utilizados para se determinar o escoamento de base. Os métodos mais comumente aplicados para estimar o fluxo subterrâneo para corpos d'água superficiais 
são o método do balanço hídrico, particularmente o método do balanço hídrico do canal, uso de infiltrômetros, mini-piezômetros, lisímetros de fundo de rio, traçadores e os modelos hidrométricos (aplicação da Lei de Darcy) em escala da bacia hidrográfica. Os métodos diferem, principalmente, quanto à escala de avaliação das trocas de água. A análise de hidrogramas (ou hidrógrafas) para estimativa da descarga subterrânea também pode ser um método razoável (LERNER, 2003).

Para sistemas rio-aqüífero hidraulicamente conectados, a mudança no fluxo é função da diferença entre o nível do rio e o nível superficial do aqüífero. Esse mecanismo, baseado na lei de Darcy, pode ser expresso pela seguinte função (SOPHOCLEOUS, 2002):

$$
q=\alpha . \Delta h
$$

em que $\Delta h$ é a diferença entre o nível superficial do rio e o nível do aqüífero e $\alpha$ é uma constante que representa o coeficiente de drenança do leito do rio.

Segundo Sophocleous (2002), assumir que a relação entre a vazão nos corpos d'água e o nível no aqüífero é linear é muito simplista. A recessão da vazão de base do rio é independente do coeficiente $\alpha$. No período de ascensão da vazão de base, o método pode apresentar valores, para a vazão, mais altos do que os reais.

Rushton e Tomlinson (1979) propuseram uma relação não-linear para representar essas variáveis, que pode ser escrita como:

$$
q=k_{1}\left(1-e^{-k_{2} \Delta h}\right)
$$

em que $k_{1}$ e $k_{2}$ são constantes. Esta relação impõe limites para a vazão de base. Quando $\Delta h$ tende a zero o valor de $q$ também tende a zero. Quando $\Delta h$ tende ao infinito, $q$ tende ao valor de $k_{1}$. Isso implica que, quanto mais próximo dos valores extremos da vazão de base, mais lentamente o modelo reage a variações na superfície do aqüífero.

A relação linear e a não-linear têm diferentes vantagens (SOPHOCLEOUS, 2002). Para casos em que não existe uma relação de máxima vazão possível, Rhuston e Tomlinson (1979) propõem a combinação das duas relações. A função então é dada por:

$$
q=k_{1} \cdot \Delta h+k_{2} \cdot\left(1-e^{-k_{3} \cdot \Delta h}\right)
$$

em que $k_{1}, k_{2}$, e $k_{3}$ são constantes. 
Contin Neto (1981) estudou a interação rio-aqüífero na bacia do Ribeirão da Onça, Brotas-SP. Baseado na equação de Darcy, o autor verificou que o nível em um poço de monitoramento estava relacionado com o fluxo de base do rio. Concluiu-se que somente através de um maior número de poços de monitoramento em várias seções ao longo do rio pode-se encontrar uma relação que descreva de maneira satisfatória a interação rio-aqüífero.

Contin Neto (1987), ainda em estudos sobre a interação rio-aqüífero na bacia do Ribeirão da Onça, Brotas-SP, separou o escoamento básico do escoamento superficial direto através da análise do hidrograma do rio (Figura 10).

Arantes (2003), também na bacia do Ribeirão da Onça, Brotas-SP, utilizou a separação do hidrograma do rio para encontrar os valores da vazão de base. A vazão de base encontrada ficou na faixa de $0,5 \mathrm{~m}^{3} / \mathrm{s}$ a $1,0 \mathrm{~m}^{3} / \mathrm{s}$.

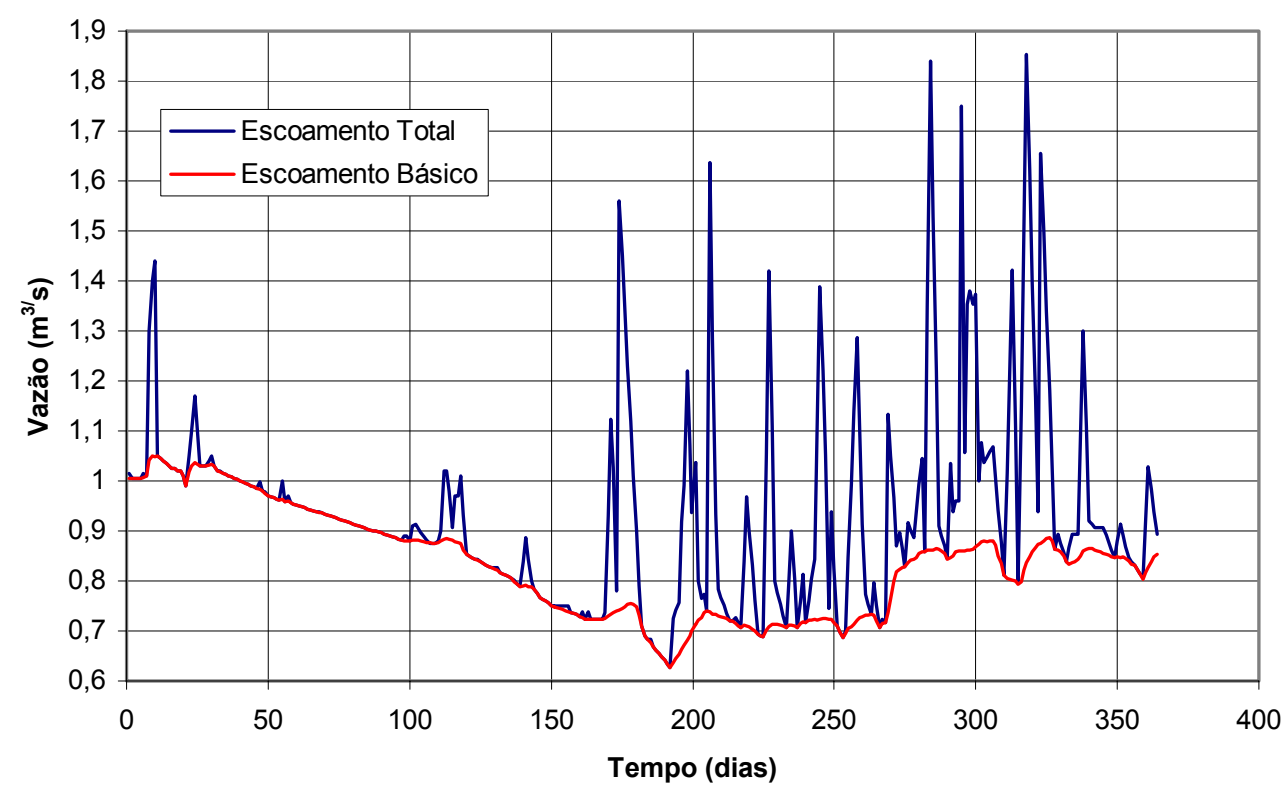

Figura 10: Separação do escoamento de base no Ribeirão da Onça, Brotas-SP, 1985-1986.

(Fonte: CONTIN NETO, 1987, modificado por ARANTES, 2003).

\subsection{Revisão de métodos utilizados para cálculo da evapotranspiração}

\subsubsection{Método de Penman-Monteith}

Em 1948, Penman ${ }^{(12)}$ combinou balanço de energia com o método da transferência de massa e derivou uma equação para computar a evaporação de uma superfície aberta de água, a partir de dados climatológicos padrões, como radiação, temperatura, umidade do ar e velocidade do vento. O então chamado método combinado foi posteriormente desenvolvido 
por outros pesquisadores e extrapolado para superfícies cultivadas, a partir da introdução de fatores de resistência.

A equação combinada de Penman-Monteith ${ }^{(13)}$ tem a seguinte forma:

$$
\lambda E T=\frac{\Delta\left(R_{n}-G\right)+\rho_{a p} \frac{\left(e_{s}-e_{a}\right)}{r_{a}}}{\Delta+\gamma\left(1+\frac{r_{s}}{r_{a}}\right)}
$$

em que $\lambda E T$ é a densidade de fluxo de calor latente $\left[\mathrm{J} /\left(\mathrm{m}^{2} . \mathrm{s}\right)\right],\left(e_{s}-e_{a}\right)$ é o déficit de pressão de vapor do ar para a altura de referência medida $(\mathrm{kPa}), \rho_{a}$ a massa específica do ar $\left(\mathrm{kg} \cdot \mathrm{m}^{-3}\right), c_{p} \mathrm{o}$ calor específico do ar a pressão constante $\left(\mathrm{MJ} \cdot \mathrm{kg}^{-1} \cdot{ }^{\circ} \mathrm{C}^{-1}\right), \Delta$ a declividade da curva de pressão de vapor em função da temperatura $\left(\mathrm{kPa} .{ }^{\circ} \mathrm{C}^{-1}\right), \gamma$ a constante psicrométrica $\left(\mathrm{kPa} .{ }^{\circ} \mathrm{C}^{-1}\right), r_{a}$ e $r_{s}$ as resistências, respectivamente, aerodinâmica e de superfície $\left(\mathrm{s} . \mathrm{m}^{-1}\right), R_{n}$ a radiação líquida no solo $\left(\mathrm{MJ} \cdot \mathrm{m}^{-2} \cdot \mathrm{d}^{-1}\right)$ e $G$ a densidade do fluxo de calor no solo $\left(\mathrm{MJ} \cdot \mathrm{m}^{-2} \cdot \mathrm{d}^{-1}\right)$.

As equações de resistência aerodinâmica e de superfície têm sido combinadas com o método de Penman-Monteith, visando descrever uma vegetação hipotética de referência. Pela combinação de expressões generalizadas de densidade do ar $\left(\rho_{a}\right)$, com expressões simplificadas de $r_{a}$ e $r_{s}$ para a grama, a equação de Penman-Monteith é reduzida para:

$$
\operatorname{ETo}_{P M}=\frac{0,408 \Delta\left(R_{n}-G\right)+\gamma \frac{900}{(T+273)} U_{2}\left(e_{s}-e_{a}\right)}{\Delta+\gamma\left(1+0,34 U_{2}\right)}
$$

em que $E T o_{P M}$ é a evapotranspiração de referencia ( $\left.\mathrm{mm} / \mathrm{dia}\right), R_{n}$ e $G$ têm as mesmas unidades $\left(\mathrm{MJ} \cdot \mathrm{m}^{-2} \cdot \mathrm{d}^{-1}\right), T$ é a temperatura média diária do ar $\left({ }^{\circ} \mathrm{C}\right), U_{2}$ é a velocidade média do vento medida a $2 \mathrm{~m}\left(\mathrm{~m}^{-1} \mathrm{~s}^{-1}\right), 0,408$ corresponde a $\lambda^{-1}$ sendo $\lambda$ o calor latente de evaporação da água, igual a $2,45 \mathrm{MJ} \cdot \mathrm{kg}^{-1}$ a $20^{\circ} \mathrm{C}, 900$ é um coeficiente para a cultura de referência $\left(\mathrm{kJ}{ }^{-1} \cdot \mathrm{kg} . \mathrm{K} \cdot \mathrm{d}^{-1}\right)$, que inclui os valores constantes da equação.

A seguir é apresentada a seqüência de cálculo do método em questão para o uso de dados coletados na maior parte das estações climatológicas. A declividade da curva de pressão de vapor pode ser calculada pela função a seguir:

$$
\Delta=\frac{4098 \cdot e_{s}}{(T+237,3)^{2}}
$$


em que: $T$ é a temperatura média do ar $\left({ }^{\circ} \mathrm{C}\right)$, dada pela média aritmética, diária ou mensal, entre a $T_{\operatorname{máx}}$ e a $T_{\min }$ e $e_{s}$ é a pressão de saturação de vapor. $\mathrm{O}$ valor de $e_{s}$ pode ser calculado pela expressão abaixo:

$$
e_{s}=\left[\frac{e^{o}\left(T_{\max }\right)+e^{o}\left(T_{\min }\right)}{2}\right]
$$

sendo $e^{0}\left(T_{\max }\right)$ a pressão de saturação de vapor à temperatura máxima e $e^{0}\left(T_{\min }\right)$ a pressão de saturação de vapor à temperatura mínima, as quais são expressas por:

$$
\begin{aligned}
& e^{o}\left(T_{\max }\right)=0,6108 \cdot \exp \left(\frac{17,27 \cdot T_{\max }}{T_{\text {max }}+237,3}\right) \\
& e^{o}\left(T_{\min }\right)=0,6108 \cdot \exp \left(\frac{17,27 \cdot T_{\min }}{T_{\text {min }}+237,3}\right)
\end{aligned}
$$

Para o cálculo do déficit de pressão de vapor $\left(e_{s}-e_{a}\right)$, tem-se que:

$$
e_{a}=\left[\frac{e^{o}\left(T_{\max }\right) \cdot U R_{\min }+e^{o}\left(T_{\min }\right) \cdot U R_{\max }}{2}\right]
$$

Em que $U R$ é a umidade relativa do ar e é um número adimensional.

O procedimento de cálculo do saldo de radiação $\left(R_{n}\right)$ é dado por:

$$
R_{n}=R_{n s}-R_{n l}
$$

em que: $R_{n s}$ é o saldo de radiação de ondas curtas e $R_{n l}$ é o saldo de radiação de ondas longas.

$R_{n s}$ é dado por:

$$
R_{n s}=(1-\alpha) \cdot R_{s}
$$

em que $\alpha$ é o albedo ou coeficiente de reflexão, cujo valor recomendado para cultura padrão é 0,23 , e $R_{s}$ é a radiação solar global que chega a superfície.

O saldo de radiação de ondas longas é dado por:

$$
R_{n l}=\sigma\left(\frac{T_{\max , k^{4}}+T_{\min , k^{4}}}{2}\right) \cdot\left(0,34-0,14 \sqrt{e_{a}}\right) \cdot\left(1,35 \frac{R}{R_{s o}}-0,35\right)
$$

em que $\sigma$ é a constante de Stefan-Boltzman $=\left(4,903 \times 10^{-9} \mathrm{MJ} \cdot \mathrm{K}^{-4} \cdot \mathrm{m}^{-2} \cdot \mathrm{d}^{-1}\right), e_{a}$ é a pressão parcial de vapor $(\mathrm{kPa})$ e $R_{s o}$ é a radiação solar em dias de céu claro, a qual é calculada por: 


$$
\begin{aligned}
& R_{s o}=\left(a_{s}+b_{s}\right) \cdot R_{a} \\
& R_{s}=\left(a_{s}+b_{s} \cdot \frac{n}{N}\right) \cdot R_{a}
\end{aligned}
$$

sendo $a_{s}$ e $b_{s}$ a fração da radiação extraterrestre em dias claros $(\mathrm{n}=\mathrm{N})$. Os coeficientes $a_{s}$ e $b_{s}$ são tabelados para cada localidade. Quando não se dispõe desses coeficientes, toma-se o valor de $a_{s}+b_{s}=0,75+2 \cdot 10^{-5} . z$, sendo $z$ a altitude local. A equação 35 é usada para o caso de dias com nuvens. $R_{a}$ é a radiação solar no topo da atmosfera $\left(\mathrm{MJ} \cdot \mathrm{m}^{-2} \cdot \mathrm{d}^{-1}\right)$, dada por:

$$
R_{a}=\frac{24 .(60)}{\pi} G_{s c} \cdot d_{r}\left[W_{s} \operatorname{sen}(\varphi) \operatorname{sen}(\delta)+\cos (\varphi) \cos (\delta) \operatorname{sen}\left(W_{s}\right)\right]
$$

em que: $G_{s c}$ é constante solar $=0,0820 \mathrm{MJ} \cdot \mathrm{m}^{-2} \cdot \mathrm{d}^{-1}, d_{r}$ é o quadrado da distância relativa (solterra) em radianos:

$$
d_{r}=1+0,033 \cdot \cos \left(\frac{2 \pi}{365} J\right)
$$

sendo $J$ o dia juliano, $\varphi$ a latitude local em radianos, $\delta$ a declinação solar, em radianos, e $W_{s}$ o ângulo horário ao pôr do sol, em radianos. As equações para cálculo desses parâmetros são:

$$
\begin{gathered}
\delta=0,49 \cdot \operatorname{sen}\left(\frac{2 \pi}{365} J-1,39\right) \\
W_{s}=\arccos [-\operatorname{tg}(\varphi) \cdot \operatorname{tg}(\delta)]
\end{gathered}
$$

O fluxo de calor no solo é dado por:

$$
G=c_{s}\left(\frac{T_{i}+T_{i-1}}{\Delta t}\right) \cdot \Delta z
$$

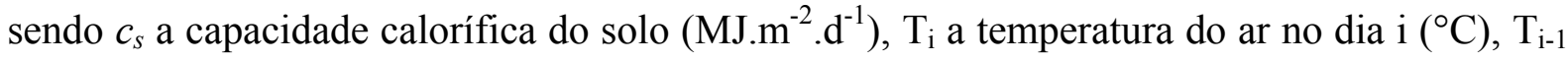
a temperatura no dia $\mathrm{i}-1, \Delta t$ o intervalo de tempo (dia) e $\Delta z$ a profundidade efetiva do solo (m). O boletim da FAO (Food and Agriculture Organization) 56 recomenda, entretanto, que $G$ pode ser desprezível para períodos diários.

A constante psicrométrica $(\gamma)$ é obtida por:

$$
\gamma=\frac{c_{P} \cdot P}{\varepsilon \cdot \lambda}
$$


sendo $c_{P}$ o calor específico à pressão constante $=1,013 \times 10^{-3}\left(\mathrm{MJ} \cdot \mathrm{kg}^{-1} \cdot{ }^{\circ} \mathrm{C}^{-1}\right)$ e $P$ é a pressão atmosférica $(\mathrm{Pa})$ :

$$
P=101,3\left(\frac{293-0,0065 . z}{293}\right)^{5,26}
$$

em que $z$ é a altitude local (m) e $\varepsilon=0,622$ a relação entre peso molecular do vapor da água e do ar seco. Para a região de São Carlos, pode ser adotado $\gamma=0,0626 \mathrm{kPa} .{ }^{\circ} \mathrm{C}^{-1}$.

O termo $\left(1+0,34 U_{2}\right)$ na equação reduzida de Penman-Monteith (Eq. 25) envolve as resistências de superfície e aerodinâmica, sendo $r_{s}=70 \mathrm{~s} \cdot \mathrm{m}^{-1}$ e $r_{a}$ calculada por:

$$
r_{a}=\frac{\ln \left(\frac{z_{w}-d}{z_{o m}}\right) \cdot \ln \left(\frac{z_{p}-d}{z_{o v}}\right)}{(0,41)^{2} \cdot U_{z}}
$$

$r_{a}$ é a resistência aerodinâmica à transferência turbulenta de vapor e calor sensível a partir de superfície da planta, $z_{w}$, a altura de medição da velocidade do vento, em metros (anemômetro), $z_{p}$, a altura de medição de temperatura e umidade, em metros (psicrômetro), $z_{o m}$, a altura da rugosidade da vegetação, em metros (cultura de referência), $z_{o v}$ a altura para transferência de vapor, em metros, $d$, o deslocamento do plano zero na altura da vegetação (m), e $U_{z}$ é a velocidade do vento medida a $2 \mathrm{~m}$.

Este método é o mais recomendado pela FAO. Entre os fatores de maior influência na estimativa de ETP nesse método, está a temperatura média e a umidade relativa do ar. Este método pode ser considerado um dos mais sofisticados, visto que necessita de uma maior quantidade de dados, incluindo entre eles a resistência aerodinâmica e de superfície, o coeficiente de reflexão da superfície (albedo) e o fluxo de calor no solo. Tem como vantagens fornecer valores diários de evapotranspiração e ser aplicado para uma vegetação hipotética de referência, e, posteriormente, ser extrapolado para a cultura em estudo, através de coeficientes de equivalência entre as culturas. 


\subsubsection{Método de Thornthwaite}

Thornthwaite e Wilm (1944) ${ }^{(14)}$ apresentaram sua primeira equação para determinação da evapotranspiração potencial (ETP), envolvendo o comprimento do dia, a temperatura média diária e a umidade relativa do ar. Ao refinar a equação, o termo de umidade relativa foi suprimido.

O método utiliza a temperatura média mensal para estimar a evapotranspiração potencial mensal, tendo por base um índice de eficiência de temperatura anual $I$, definido como a soma de 12 valores mensais de índice de calor $i$. Cada índice $i$ é uma função da temperatura média mensal $t_{i}$, em ${ }^{\circ} \mathrm{C}$ :

$$
i=\left(\frac{t_{i}}{5}\right)^{1,514}
$$

$\mathrm{e}$

$$
I=\sum_{1}^{12} i
$$

A evapotranspiração potencial, em mm, é dada por:

$$
E T P=16 . F_{c}\left(\frac{10 * t_{i}}{I}\right)^{a}
$$

em que $F c$ é o comprimento médio dos dias do mês e $a$ é calculado por:

$$
a=6,75 \cdot 10^{-7} \cdot I^{3}-7,71 \cdot 10^{-5} \cdot I^{2}+0,01791 \cdot I+0,492
$$

A eficácia da equação foi constatada através de numerosos balanços hídricos climáticos, realizados em várias partes do mundo, comparando-se os excedentes hídricos calculados com dados de escoamento de bacias hidrolgráficas. O modelo de Thornthwaite funciona adequadamente em regiões de clima úmido, independentemente da latitude e da altitude. Em condições de aridez, o modelo subestima com freqüência, a evapotranspiração potencial. Em situação de superumidade topoclimática, ao contrário, pode superestimar a ETP (CAMARGO e CAMARGO, 2000). 
Berlato e Molion (1981) citam que em regiões onde o clima difere daquele onde a equação foi desenvolvida, os resultados obtidos não são satisfatórios. Pressupõe-se que isso ocorra porque o método não contempla explicitamente a umidade do ar. Assim, deve-se ter muita cautela ao utilizar este método, particularmente em climas de verões úmidos e invernos secos. Apesar de tudo, a equação de Thornthwaite ganhou popularidade mundial, mais pelo fato de necessitar somente de dados de temperatura do ar, informação disponível em grande número de estações meteorológicas, do que pela sua precisão.

\subsubsection{Método de Blaney-Criddle}

Este método foi desenvolvido originalmente para estimativas de uso consuntivo em regiões semi-áridas, baseado na suposição de que a disponibilidade de água para a planta em crescimento não é um fator limitante. A evapotranspiração potencial ( $\mathrm{mm} /$ dia) é estimada por:

$$
E T P=(0,457 \cdot T+8,13) \cdot p
$$

em que: $T=$ temperatura média mensal do $\operatorname{ar} \mathrm{em}^{\circ} \mathrm{C}, p=$ porcentagem diária média de luz.

A equação de Blaney-Criddle não é recomendada para regiões equatoriais em que a temperatura se mantém estável, oscilando somente as demais variáveis meteorológicas.

O empirismo contido nos métodos baseados na temperatura do ar recomenda seu uso, exclusivamente, quando esta variável for a única informação meteorológica disponível.

\subsubsection{Método Makkink}

Makkink testando o modelo de Penman encontrou que a evapotranspiração potencial também era função da altura da cultura e sugeriu que, para efeito comparativo, seria necessário à inclusão dos parâmetros $Z_{0}$ e $d$ na função "vento" do modelo de Penman, ou uma padronização da rugosidade. Uma vez que o tipo de vegetação e a altura da cobertura vegetal não foram definidos, outras conceituações específicas foram apresentadas posteriormente.

O método de Makkink é baseado na radiação solar:

$$
E T_{0 M}=\left(0,61 \cdot R_{S} \cdot W\right)-0,12
$$

onde $E T o_{M}=$ evapotranspiração potencial, em gramado $(\mathrm{mm} / \mathrm{dia}), W=\Delta /(\Delta+\gamma)$ (fator que representa a fração de $R_{S}$ que é utilizada na $E T o$, para diferentes valores de temperatura e altitude) $\mathrm{e} R_{S}=$ radiação solar estimada $(\mathrm{mm} / \mathrm{dia})$ : 


$$
R_{S}=\frac{Q}{59} \cdot\left(a_{s}+b_{s} \cdot \frac{n}{N}\right)
$$

sendo que os valores de $\Delta, \gamma, Q, N, n, a$ e $b$ são obtidos através das formas descritas para o método de Penman-Monteith.

\subsubsection{Método de Hargreaves-Samani}

Este método é baseado na temperatura e na radiação solar. A equação de Hargreaves, modificada por Samani, onde o termo de correção, devido à umidade relativa do ar, foi excluído da equação original, teve como princípio o ajustamento dos índices da equação para as condições locais. O ajuste das constantes da equação foi realizado incorporando o termo de amplitude térmica média do mês.

$$
\lambda E T=0,0023 \cdot R_{A} \cdot T D^{0,5} \cdot(T S+17,8)
$$

em que $\lambda E T=$ fluxo de calor latente $\left(\mathrm{MJ}^{-\mathrm{m}^{-2}} \cdot \mathrm{d}^{-1}\right), R_{A}=$ radiação no topo da atmosfera $\left(\mathrm{MJ} \cdot \mathrm{m}^{-2} \cdot \mathrm{s}^{-1}\right), T D=$ diferença das temperaturas médias máxima e mínima $\left({ }^{\circ} \mathrm{C}\right), T S=$ temperatura média do $\operatorname{ar}\left({ }^{\circ} \mathrm{C}\right)$.

A radiação no topo da atmosfera é obtida pela equação:

$$
R_{A}=37,586\left[1+0,033 \cdot \cos \left(\frac{2 \pi}{365} J\right)\right]\left(\omega_{S} \cdot \operatorname{sen} \varphi \cdot \operatorname{sen} \delta+\cos \varphi \cdot \cos \delta \cdot \operatorname{sen} \omega_{S}\right)
$$

em que $J=$ dia do ano, $\omega s=$ ângulo horário do pôr do sol (radianos), $\varphi=$ latitude local (radianos), $\delta=$ declinação do sol (radianos), dado por:

$$
\delta=0,4093 \cdot \operatorname{sen}\left[\left(\frac{2 \pi}{365} J\right)-1,405\right]
$$

$\mathrm{O}$ referido método é recomendado pela $\mathrm{FAO}$ quando há somente disponibilidade de dados de temperatura do ar no local de estudo. 


\subsubsection{Método do Tanque Classe A - FAO}

A evaporação medida em tanque de evaporação implica no efeito integrado de radiação solar, vento, temperatura e umidade na superfície da água. A evaporação está relacionada à $E T_{0}$, como relata Medeiros (2002) citando Doorenbos e Pruitt (1977) ${ }^{(15)}$, Jensen et al (1990), entre outros, da seguinte forma:

$$
E T_{0} \text { FPan }=K_{p} . \text { Epan }
$$

em que $E T_{0} F P a n$ é a evapotranspiração de referência $(\mathrm{mm}) ; K_{p}$ é o coeficiente do tanque; Epan é a evaporação no tanque classe A (mm).

O coeficiente do tanque $\left(K_{p}\right)$ apresentado por Allen et al. (1998) ${ }^{(16)}$ apud Medeiros (2002) com bordadura seca, já que os dados foram obtidos na estação convencional, é o seguinte:

$$
\begin{gathered}
K_{p}=0,61+0,00341 \cdot U R_{\text {méd }^{-}} 0,000162 U_{2} \cdot U R_{\text {méd }^{-}} 0,00000959 \cdot U_{2} \cdot F E T+0,00327 \cdot U_{2} \ln (F E T)- \\
0,00289 \cdot U_{2} \ln \left(86,4 \cdot U_{2}\right)-0,0106 \ln \left(86,4 \cdot U_{2}\right) \cdot \ln (F E T)+0,00063 \cdot[\ln (F E T)]^{2} \cdot \ln \left(86,4 \cdot U_{2}\right)
\end{gathered}
$$

${ }^{(15)}$ DOORENBOS, J.;PRUITT,W. O. (1997). Guidelines for predicting crop water requirements. 2 ed. Roma: FAO. 179p. (FAO. Irrigation and Drainage Paper, 24).

${ }^{(16)}$ ALLEN, R. G.; PEREIRA, L. S.; RAES, D. MARTIN, S (1998). Crop evapotranspiration. Rome: FAO. 297p. (FAO, Irrigation and Drainage Paper, 56). 
em que $U_{2}$ é a velocidade do vento a uma altura de 2 metros de altura $(\mathrm{m} / \mathrm{s}) ; U R_{m e ́ d}$ é a umidade relativa média (\%); FET é a bordadura, em metros, que compreende o espaço entre o tanque e o final da área de contorno a favor dos ventos predominantes.

\subsection{Considerações finais}

A revisão bibliográfica teve como objetivo principal fornecer uma idéia geral dos assuntos que serão detalhados no capítulo de materiais e métodos desenvolvidos nesse trabalho.

A descrição do Sistema Aqüífero Guarani mostra a importância desse manancial para os países que o reservatório abrange. As informações da geologia e hidrogeologia apresentam uma idéia de como funcionam os fluxos de água dentro do aqüífero, ressaltando a importância das zonas de afloramento, objeto de estudo desse trabalho.

Existem diversos métodos para estimar a recarga de um aqüífero. Todos esses métodos apresentam vantagens e desvantagens e nenhum pode ser classificado como melhor ou pior. A representatividade dos valores obtidos vai de encontro à quantidade e qualidade dos dados coletados. Os métodos que utilizam a flutuação do nível de aqüífero têm sido amplamente usados.

As seções 3.3 a 3.7 conectam o processo de recarga com as diversas variáveis hidrológicas. O objetivo principal dessa revisão foi de adquirir sensibilidade no trato de cada componente do ciclo hidrológico e sua interação com a recarga. A noção da ordem de grandeza das variáveis hidrológicas e a sensibilidade para detecção de erros exagerados são fatores de fundamental importância para o hidrólogo, que deve sempre usar do bom senso para tomar decisões.

A seção 3.8 apresenta alguns processos necessários para estimar a vazão de um curso de água. A estimativa do escoamento superficial contínuo de um curso de água demanda uma série de atividades de campo e, em geral, a instalação de equipamentos automáticos. Foram apresentados na revisão bibliográfica os processos para estimativa de vazão através de curvachave e de medições com molinete hidrométrico, os quais são utilizados nesse trabalho. Em casos em que não há registro contínuo do nível do rio ou não existe a possibilidade de construir uma curva-chave que represente o comportamento do rio, pode-se estimar a vazão a partir de modelos hidrológicos. Existem diversos modelos que tentam representar o escoamento em rios. Neste trabalho foram utilizados o método do SCS para estimativa do 
escoamento superficial direto e um modelo de interação rio-aqǘfero para representar o escoamento de base.

O capítulo 3.9 traz uma revisão sobre alguns métodos utilizados para a estimativa da evapotranspiração. Nesse trabalho foi utilizado o programa BHÍDRICO*, que será apresentado posteriormente, para estimar essa variável na bacia do Ribeirão da Onça. Este programa estima a evapotranspiração pelos os métodos descritos nesta seção (3.9). 
4. ÁREA DE ESTUDO, MATERIAIS E MÉTODOS 

A área de estudo desse trabalho é a bacia do Ribeirão da Onça. Nela e nas bacias adjacentes estão instalados equipamentos capazes de medir as variáveis hidrológicas mais importantes. A bacia está a aproximadamente $1,5 \mathrm{~km}$ do Centro de Recursos Hídricos e Ecologia Aplicada da Universidade de São Paulo (CRHEA). No CRHEA são coletados os dados climatológicos.

O balanço hídrico é o método utilizado para estimar a recarga direta e profunda. Para tanto, é necessário estimar as componentes do ciclo hidrológico que têm representatividade na região. Os fenômenos do ciclo hidrológico que foram utilizados no balanço foram: a precipitação, a evapotranspiração, o escoamento superficial direto no ribeirão, o escoamento de base, recarga direta e a recarga profunda.

A recarga direta é estimada através da variação da superfície livre do aqüífero e a recarga profunda é o valor residual do balanço hídrico.

A avaliação dos métodos empíricos de estimativa de evapotranspiração é realizada através da comparação entre dois métodos de balanço hídrico fazendo uma avaliação dos termos residuais entre a diferença entre a estimativa um balanço hídrico, que não utiliza métodos empíricos de estimativa da evapotranspiração e as estimativas dos métodos empíricos.

Para quantificação do escoamento superficial do Ribeirão da Onça foi necessário utilizar diversos métodos, devido à impossibilidade de uso da curva-chave para todo o período do projeto. Utilizou-se o método do SCS para estimar o escoamento superficial direto e um modelo de interação rio-aqüífero para estimar a vazão de base.

\subsection{A Bacia do Ribeirão da Onça}

\subsubsection{Localização}

A bacia do Ribeirão da Onça localiza-se na região do município de Brotas-SP, ao centro-leste do estado de São Paulo, entre os paralelos $22^{\circ} 10^{\prime}$ e $22^{\circ} 15^{\prime}$ de latitude sul e entre os meridianos $47^{\circ} 55^{\prime}$ e $48^{\circ} 00^{\prime}$ de longitude oeste. O Ribeirão do Onça é um dos formadores do Rio Jacaré-Guaçú, afluente do Rio Tietê pela margem direita, conforme desenho esquemático apresentado na Figura 11.

Uma característica importante desta bacia é situar-se quase inteiramente em uma das regiões de afloramento do Sistema Aqüífero Guarani (SAG), podendo fornecer elementos de interesse para o aprofundamento dos conhecimentos sobre o comportamento desse sistema. 


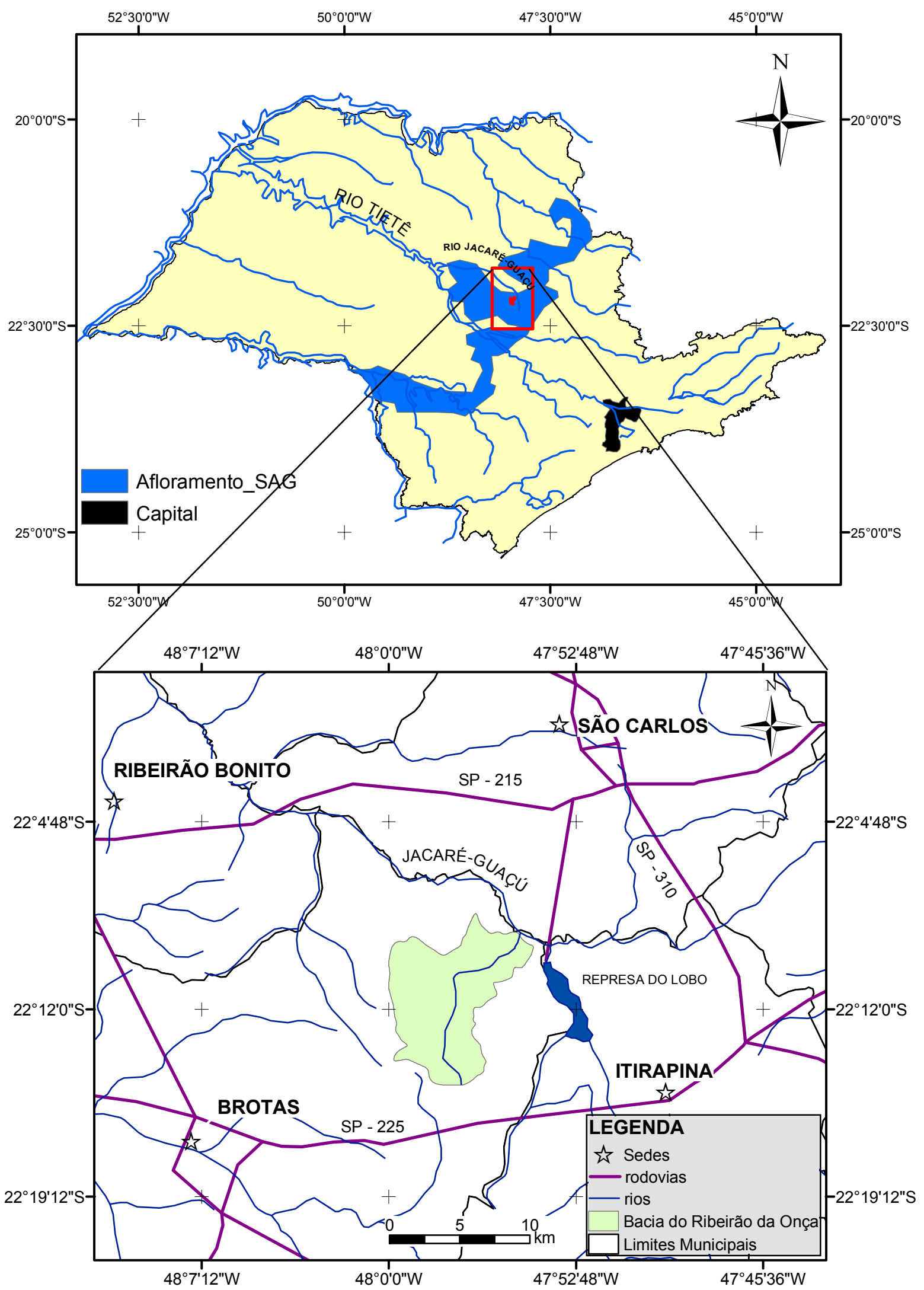

Figura 11: Localização da bacia do Ribeirão da Onça 
A Bacia do Ribeirão da Onça não tem proteção ambiental garantida por legislação, apesar de situar-se próxima a uma Área de Proteção Ambiental (APA) bem mais ampla que engloba o Ribeirão do Lobo, Represa do Lobo e o Córrego do Feijão. Dessa forma, a BaciaPiloto está sujeita a todo tipo de utilização econômica, estando exposta a mecanismos potenciais de contaminação decorrente de atividades agrícolas (aplicação de fertilizantes, herbicidas, pesticidas, etc.).

\subsubsection{Características físicas}

A caracterização fisiográfica da Bacia do Ribeirão da Onça foi elaborada por Mattos et al. $(1984)^{(17)}$ e Preto Filho $(1985)^{(18)}$ apud Pompêo (1990) sobre mapas em escala 1:10.000, sendo obtidos os elementos:

Área de drenagem

$65 \mathrm{~km}^{2}$

Perímetro

$42 \mathrm{~km}$

Comprimento axial

$11 \mathrm{~km}$

Extensão do curso d'água principal

$16 \mathrm{~km}$

Comprimento total dos cursos d'água

$55 \mathrm{~km}$

Altitude máxima

$840 \mathrm{~m}$

Altitude mínima

$640 \mathrm{~m}$

Declividade média

$7,6 \mathrm{~m} / \mathrm{km}$

A distribuição de áreas e cotas, que caracteriza o relevo da bacia, é apresentada na curva hipsométrica (Figura 12). O mapa de cotas é apresentado na Figura 13.

\footnotetext{
${ }^{(17)}$ MAtTOS, A., RIGHeTtO, A.M., CONTIN NETO, D. e POMPÊO, C.A. (1984) - Relações Hidrológicas e Hidrometeorológicas em Bacia Experimental na Região de Afloramento do Aquífero Botucatu. Departamento de Hidráulica e Saneamento, EESC-USP. Relatório apresentado à FAPESP. São Carlos.

${ }^{(18)}$ PRETO FILHO, V.O. (1985) - Implantação de uma Bacia Experimental para Estudos Hidrogeológicos e Hidrometeorológicos. Departamento de Hidráulica e Saneamento, EESC-USP. Primeiro relatório semestral jan.-ago.,apresentado à FAPESP. 16p.. São Carlos.
} 


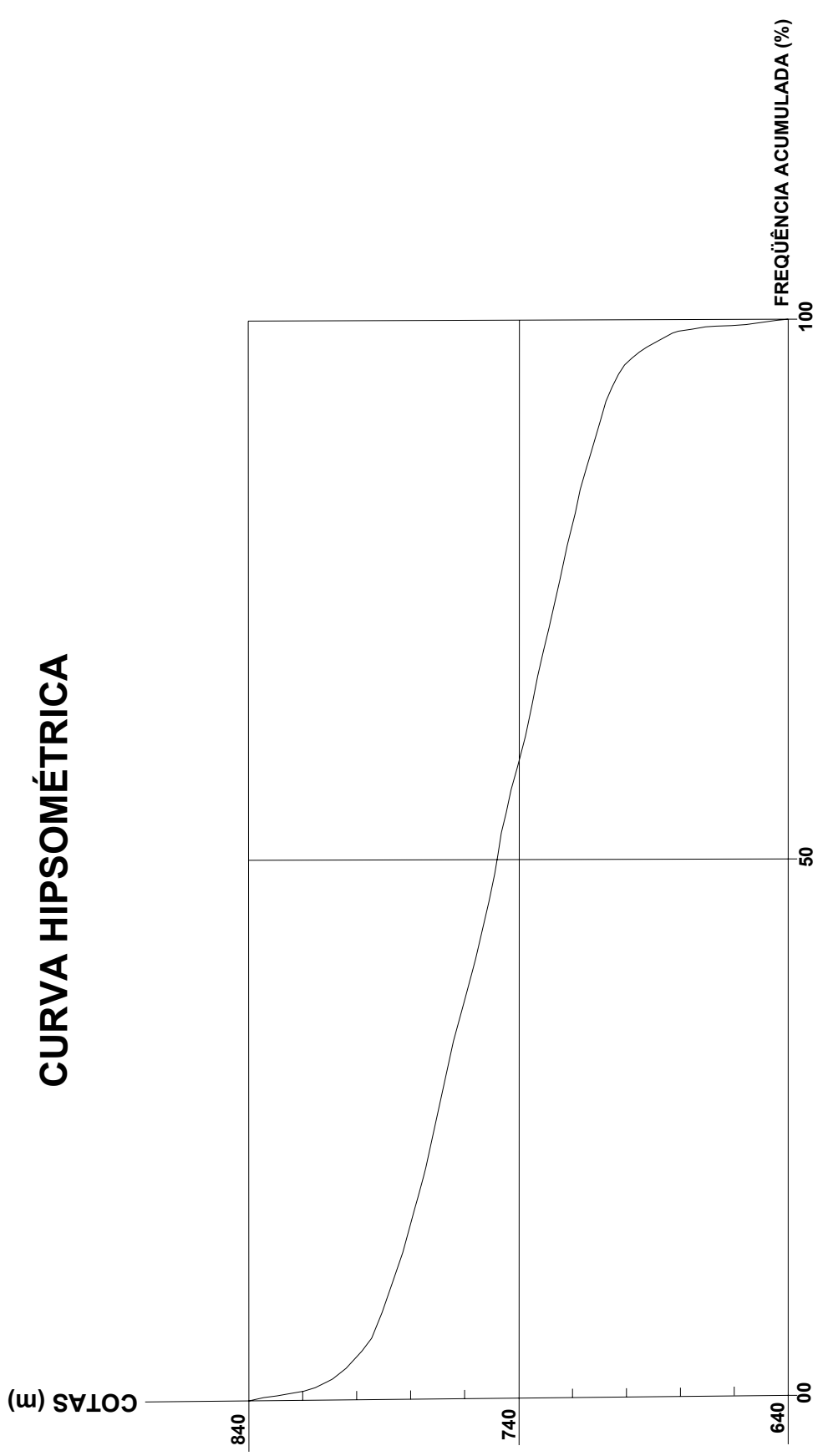

Figura 12 - Curva hipsométrica da bacia do Ribeirão da Onça

(Fonte: CONTIN NETO, 1987) 


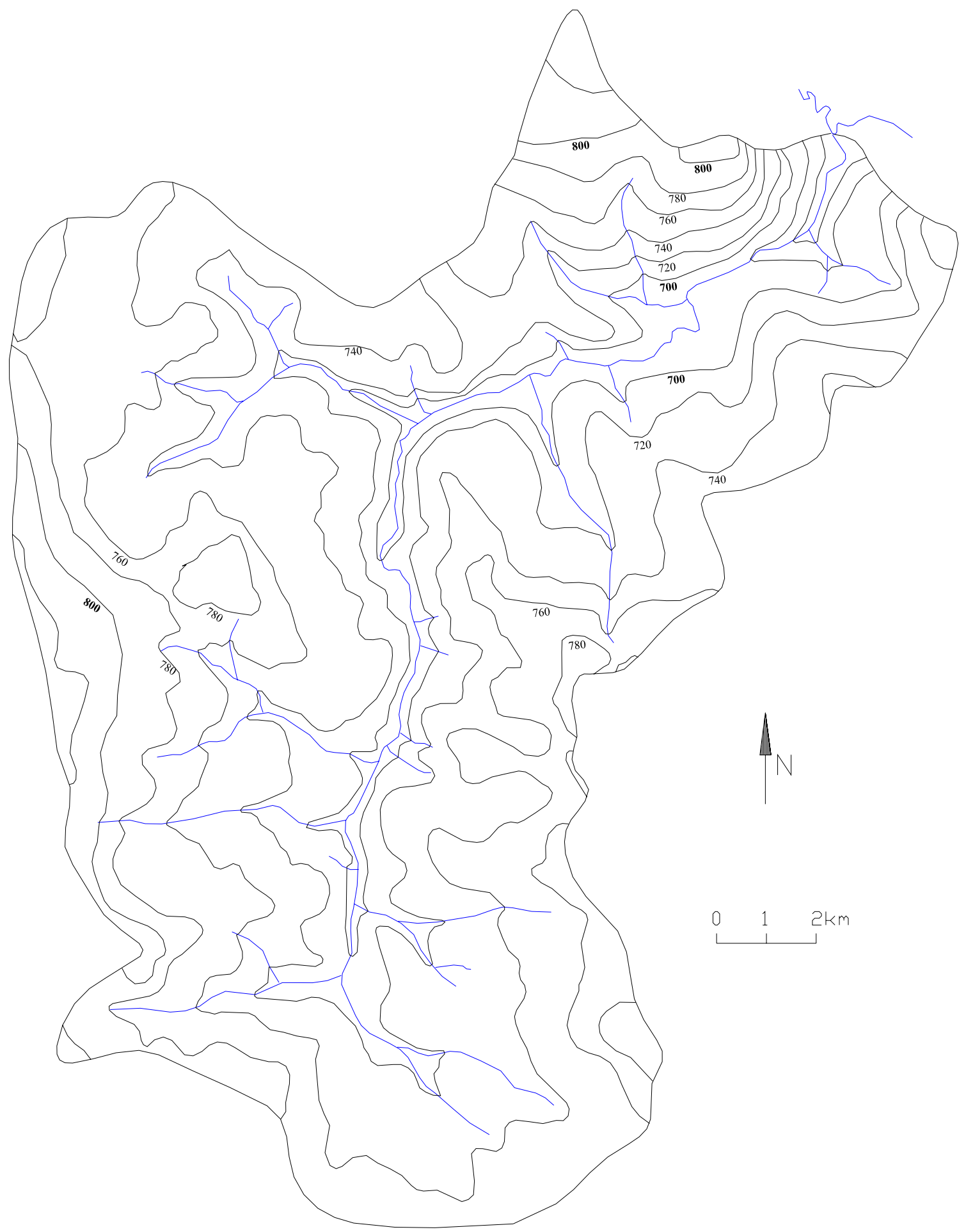

Figura 13: Altimetria da bacia do Ribeirão da Onça 
Queiroz (1991) afirma que as características físicas e hidráulicas do Ribeirão da Onça são próprias de um rio de pequeno porte.

Com relação à forma da bacia, a razão entre seu perímetro e a circunferência de área equivalente à área da bacia, denominada de coeficiente de compacidade (kc) tem o valor de 1,55. O coeficiente de compacidade, utilizado para comparações entre bacias, indica maior sujeição a enchentes quanto mais próximo da unidade for seu valor, correspondendo no limite a uma área circular. Para o valor obtido $\mathrm{kc}=1,55$ depreende-se que a Bacia do Ribeirão da Onça não é sujeita a enchentes (POMPÊO, 1990).

O desenvolvimento do sistema de drenagem é analisado pelo índice de densidade de drenagem (Dd), dado pela razão entre o comprimento total dos cursos d'água e a área de drenagem. Os valores limites são $0,75 \mathrm{~km} / \mathrm{km}^{2}$ para drenagem pobre e $1,5 \mathrm{~km} / \mathrm{km}^{2}$ para drenagem rica. A Bacia do Ribeirão da Onça cujo índice é Dd $=0,95 \mathrm{~km} / \mathrm{km}^{2}$ apresenta desenvolvimento mediano em seu sistema de drenagem (POMPÊO, 1990).

\subsubsection{Geologia}

O Ribeirão da Onça se desenvolve na maior parte do seu percurso sobre um pacote de arenito Botucatu, solos oriundos do intemperismo da Formação Botucatu e próximo ao exutório da bacia sobre o complexo Botucatu-diabásio. Ambas as unidades fazendo parte do Grupo São Bento, de idade mesozóica. Na maior parte da bacia a Formação Pirambóia se encontra dezenas de metros abaixo da superfície do solo. A geologia foi descrita por Preto Filho $^{(19)}$ (1985) e foi comprovada em perfurações feitas pelo DAEE (Departamento de águas e Energia Elétrica) em conjunto com a CPRM (Serviço Geológico do Brasil - Companhia de Recursos Minerais) (ver o ANEXO I). Porém, a indícios que a formação Pirambóia esteja aflorante próximo ao ribeirão no centro da bacia.

\subsubsection{Solos e vegetação}

Os solos da bacia do Ribeirão da Onça, provenientes de arenito desagregado, apresentam composição homogênea, não havendo presença de argilas com exceção da região próxima ao exutório da bacia.

A bacia pode ser considerada rural (Figura 14 à Figura 18), apresentando grupos pequenos e isolados de povoamento.

${ }^{(19)}$ PRETO FILHO, V.O. (1985) - Implantação de uma Bacia Experimental para Estudos Hidrogeológicos e Hidrometeorológicos. Departamento de Hidráulica e Saneamento, EESC-USP. Primeiro relatório semestral jan.-ago.,apresentado à FAPESP. 16p.. São Carlos. 
Para fazer o estudo de evapotranspiração da área e entender melhor o comportamento da recarga sob cada tipo de cultivo foi necessário produzir um mapa com o uso e ocupação do solo da região. A bacia do Ribeirão da Onça é exclusivamente de uso agrário e pecuário, não sendo observadas áreas consideradas de pavimentação e nenhuma área industrial. A distribuição espacial de cada área de cultivo pode ser visualizada no mapa apresentado na Figura 20 e nos mapas presentes no apêndice A.

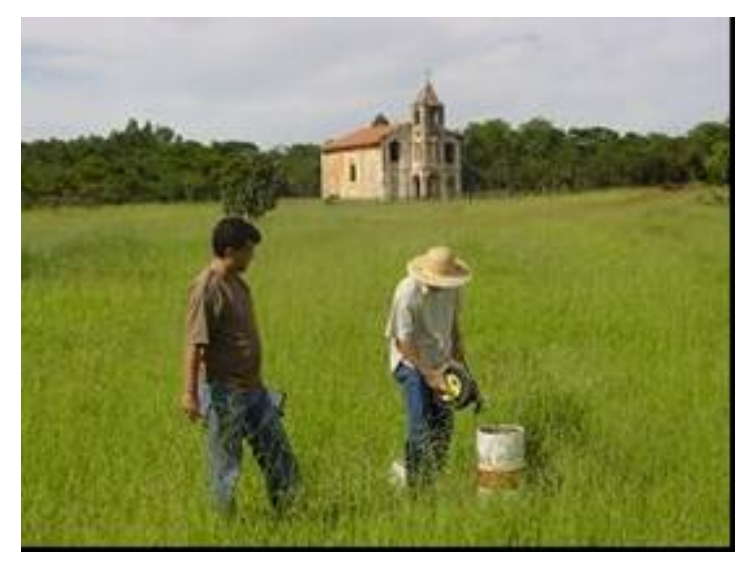

Figura 14: pastagem e cerrado ao fundo

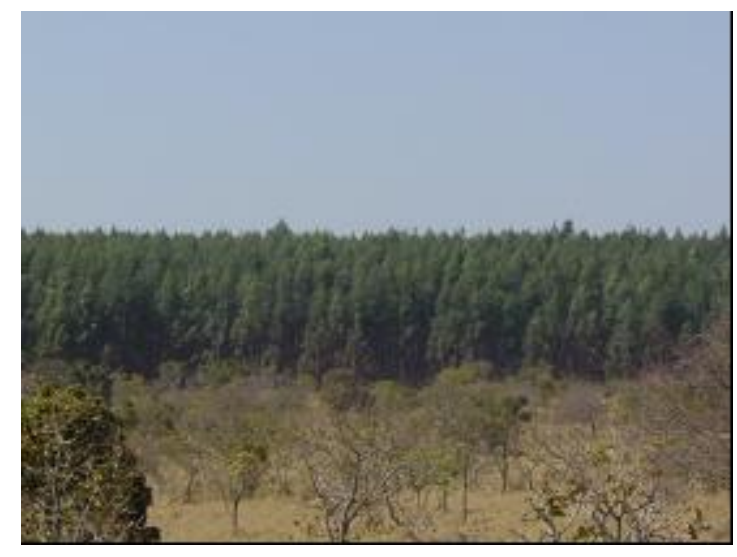

Figura 15: eucaliptos

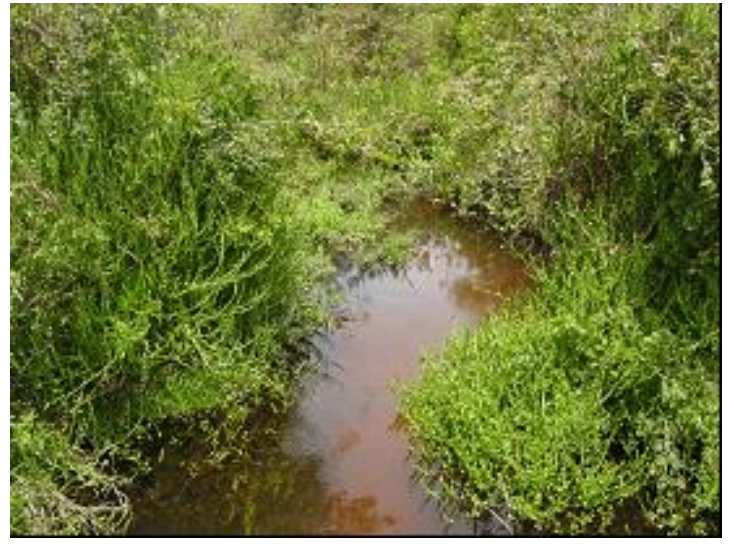

Figura 16: vegetação ciliar

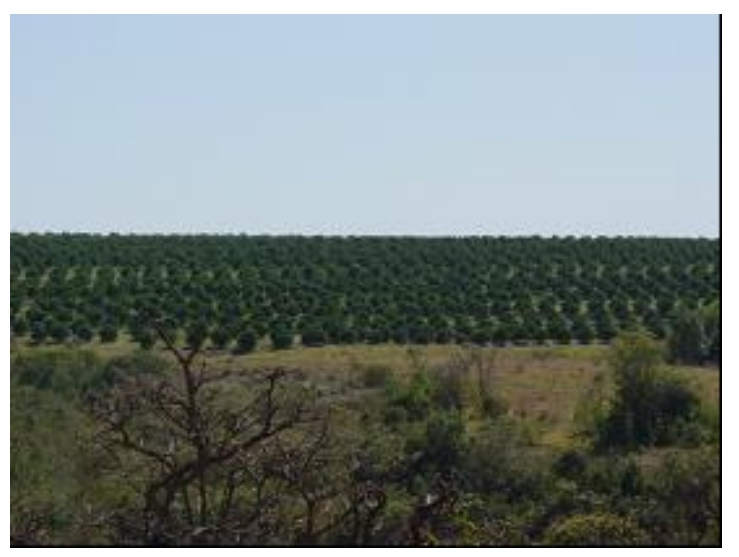

Figura 17: citros 


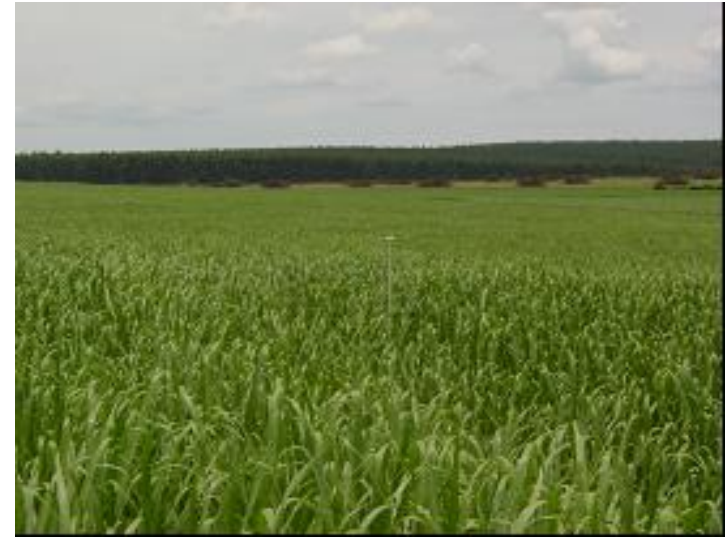

Figura 18: cana-de-açúcar

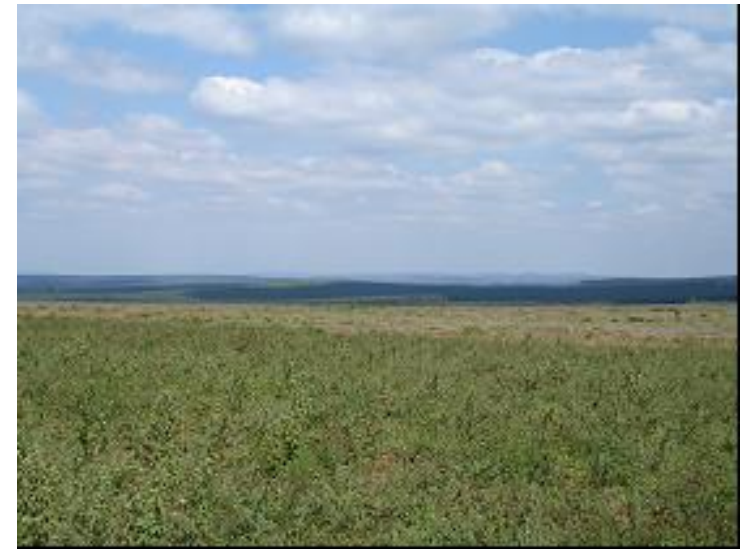

Figura 19: solo parcialmente descoberto

Para delimitar a área de cada região de cultivo usou-se a imagem de satélite (Figura 21) junto com medições de localização feitas com “GPS" em pontos de referência das culturas na imagem. Com esta associação de imagem e pontos conhecidos, utilizando o software ArcView 8.3, foi possível elaborar o mapa e encontrar a área de cada uma das plantações.

O monitoramento dessas áreas é feito em parceria com os fazendeiros que informam quando vão mudar as áreas de cultivo de suas fazendas. No período seco, a soja não é cultivada, passando o solo a ficar parcialmente descoberto. A mudança de cultivo em determinadas áreas ocorre por motivos de recuperação da capacidade produtiva do solo (rodízio de cultivo). 


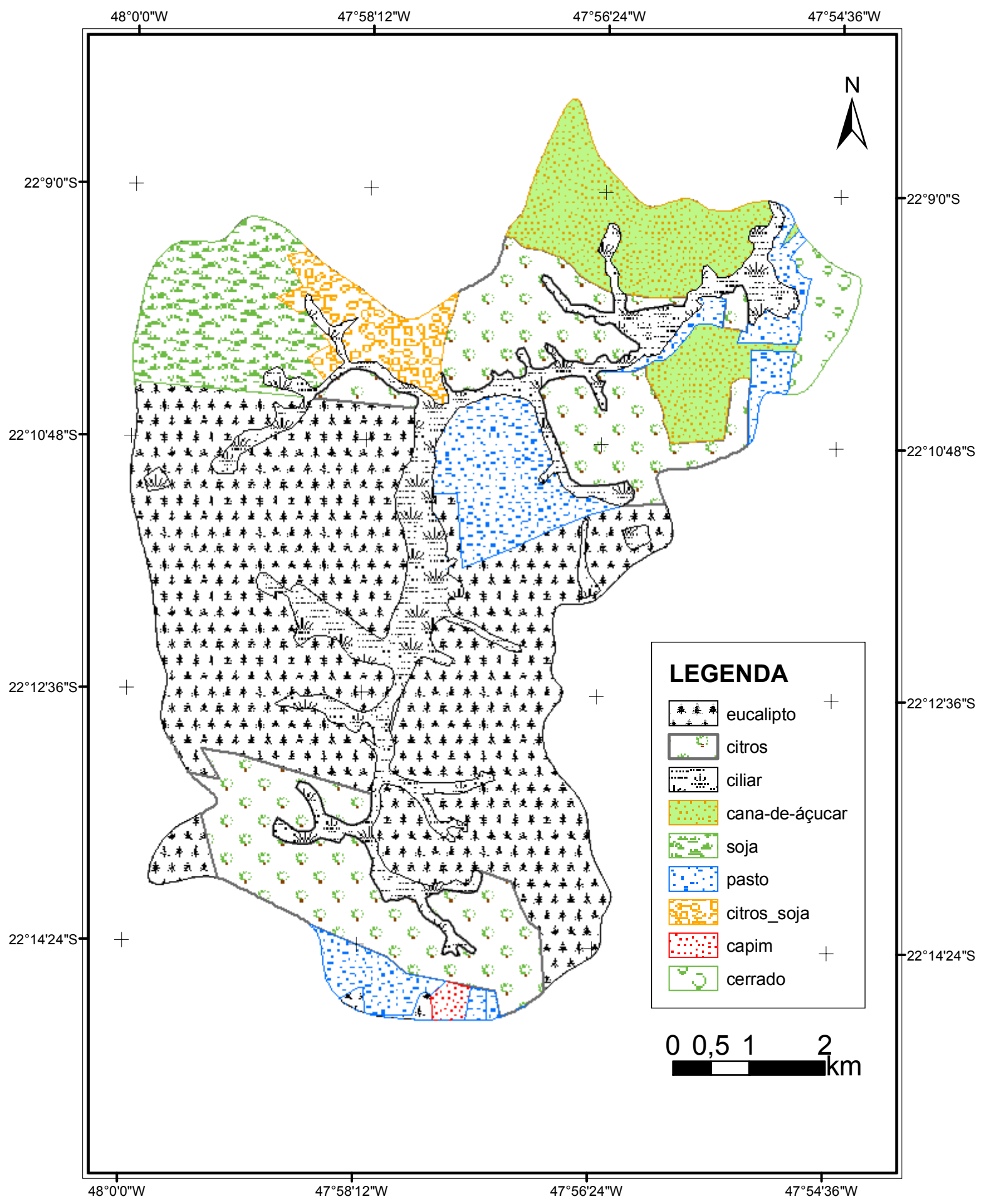

Figura 20: Mapa de uso e ocupação do solo (Dezembro/2004-Abril/2005) 


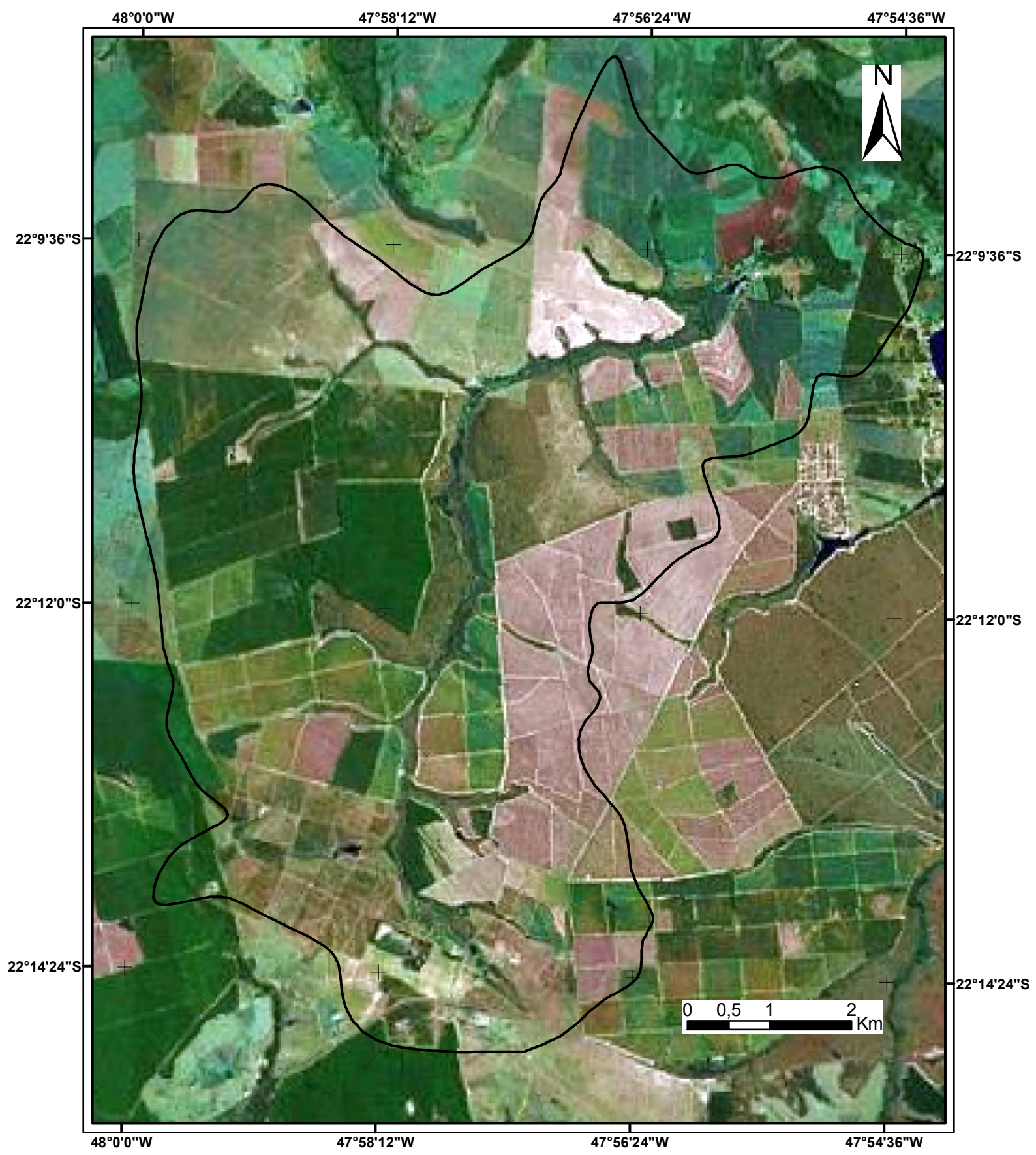

Figura 21: Imagem de satélite da bacia do Ribeirão da Onça

Fonte da imagem de satélite: Google Earth

\subsubsection{Climatologia}

A temperatura média anual da região é de $20,5^{\circ} \mathrm{C}$, valor obtido na Estação Climatológica do CRHEA. A classificação climática de Köppen para a região indica que a bacia possui clima subtropical úmido com chuvas de verão, apresentando variação para clima tropical úmido com inverno seco. A precipitação média anual é da ordem de 1300-1400 mm. 
A caracterização da ocorrência de precipitações na bacia do Ribeirão da Onça foi iniciada por Pompêo (1990), com medições em três pluviógrafos. As séries destes dados no triênio de 1985 a 1987 mostram que os totais diários apresentam-se bastante próximos. Pompêo (1990) adotou a média aritmética entre os totais diários nos postos como valor médio da bacia. Esse procedimento, apesar de imperfeito quando há ocorrência de chuvas convectivas muito localizadas, demonstra-se bastante útil quando ocorrem falhas na coleta de dados de algum posto.

Em seu trabalho, Pompêo (1990) apresenta uma média anual regional de longo tempo igual a $1302,4 \mathrm{~mm}$.

\subsection{Instrumentação e coletas de dados}

O modelo de balanço hídrico adotado para este trabalho está condicionado a existência de dados das principais variáveis do ciclo hidrológico local. Foram adotadas como componentes relevantes do ciclo hidrológico: a precipitação, a evapotranspiração, o escoamento superficial, os processos de recarga e armazenamento subterrâneo. Cada uma dessas componentes tem um determinado método, com suas próprias variáveis, para sua estimativa. Os dados necessários para estimar a evapotranspiração não são coletados dentro da própria bacia, no Centro de Recursos Hídricos e Ecologia Aplicada (CRHEA).

A bacia do Ribeirão da Onça conta com 23 poços de monitoramento, um pluviômetro, um linígrafo e uma régua linimétrica, instalados dentro da bacia e em suas proximidades. Os equipamentos utilizados na estação climatológica do CRHEA, nesse estudo, foram: heliógrafo, anemômetro, tanque classe A, medidor de temperatura e umidade relativa do ar. A localização dos aparelhos pode ser visualizada na Tabela 7 e na Figura 22. 
Tabela 7: Tabela de localização dos poços de monitoramento

\begin{tabular}{|c|c|c|c|c|c|c|}
\hline \multirow{3}{*}{ POÇO } & \multicolumn{2}{|c|}{ LOCALIZAÇÃO } & \multirow{2}{*}{\multicolumn{2}{|c|}{$\begin{array}{c}\text { LOCALIZAÇÃO ( UTM ) WGS } 84 \\
\text { ZONA } 22\end{array}$}} & \multirow{3}{*}{$\begin{array}{c}\text { ALTITUDE } \\
\text { APROXIMADA } \\
(\mathbf{m})\end{array}$} & \multirow{3}{*}{$\begin{array}{l}\text { CULTURA } \\
\text { NO ENTORNO }\end{array}$} \\
\hline & \multirow{2}{*}{$\frac{\text { LATITUDE }}{\text { SUL }}$} & \multirow{2}{*}{\begin{tabular}{|c|} 
LONGITUDE \\
OESTE \\
\end{tabular}} & & & & \\
\hline & & & $\mathbf{X}$ & $\mathbf{Y}$ & & \\
\hline 1 & $22^{\circ} 11^{\prime} 31,2^{\prime \prime}$ & $47^{\circ} 55^{\prime} 18,5^{\prime \prime}$ & 817414,23 & 7542698,40 & 734 & PASTO \\
\hline 2 & $22^{\circ} 11^{\prime} 34,5^{\prime \prime}$ & $47^{\circ} 55^{\prime} 18,7^{\prime \prime}$ & 817406,43 & 7542596,95 & 728 & PASTO \\
\hline 3 & $22^{\circ} 11^{\prime} 43,3^{\prime \prime}$ & $47^{\circ} 55^{\prime} 18,7^{\prime \prime}$ & 817400,93 & 7542326,10 & 715 & PASTO \\
\hline 4 & $22^{\circ} 14^{\prime} 37,6^{\prime \prime}$ & $47^{\circ} 57^{\prime} 46,5^{\prime \prime}$ & 813056,99 & 7537046,98 & 753 & PASTO \\
\hline 5 & $22^{\circ} 14^{\prime} 37,2^{\prime \prime}$ & $47^{\circ} 57^{\prime} 45,1^{\prime \prime}$ & 813097,35 & 7537058,48 & 754 & PASTO \\
\hline 6 & $22^{\circ} 12^{\prime} 07,9^{\prime \prime}$ & $47^{\circ} 56^{\prime} 49,0^{\prime \prime}$ & 814797,44 & 7541621,32 & 793 & EUCALIPTO \\
\hline 7 & $22^{\circ} 11^{\prime} 55,9^{\prime \prime}$ & $47^{\circ} 57^{\prime} 05,6^{\prime \prime}$ & 814329,11 & 7542000,24 & 770 & EUCALIPTO \\
\hline 8 & $22^{\circ} 11^{\prime} 12,0^{\prime \prime}$ & $47^{\circ} 55^{\prime} 53,8^{\prime \prime}$ & 816437,30 & 7543309,41 & 748 & LARANJAL \\
\hline 9 & $22^{\circ} 11^{\prime} 23,1^{\prime \prime}$ & $47^{\circ} 55^{\prime} 35,9^{\prime \prime}$ & 816920,54 & 7542957,83 & 748 & EUCALIPTO \\
\hline 10 & $22^{\circ} 11^{\prime} 23,3^{\prime \prime}$ & $47^{\circ} 55^{\prime} 36,2^{\prime \prime}$ & 816917,73 & 7542960,97 & 748 & EUCALIPTO \\
\hline 11 & $22^{\circ} 10^{\prime} 27,3^{\prime \prime}$ & $47^{\circ} 55^{\prime} 31,0^{\prime \prime}$ & 817095,82 & 7544672,43 & 735 & CANA \\
\hline 12 & $22^{\circ} 10^{\prime} 45,3^{\prime \prime}$ & $47^{\circ} 56^{\prime} 10,3^{\prime \prime}$ & 815958,02 & 7544141,22 & 743 & LARANJAL \\
\hline 13 & $22^{\circ} 10^{\prime} 22,2^{\prime \prime}$ & $47^{\circ} 56^{\prime} 20,0^{\prime \prime}$ & 815694,31 & 7544857,82 & 712 & LARANJAL \\
\hline 14 & $22^{\circ} 10^{\prime} 20,0^{\prime \prime}$ & $47^{\circ} 56^{\prime} 17,0^{\prime \prime}$ & 815781,68 & 7544923,80 & 708 & LARANJAL \\
\hline 15 & $22^{\circ} 10^{\prime} 15,0^{\prime \prime}$ & $47^{\circ} 55^{\prime} 56,5^{\prime \prime}$ & 816372,47 & 7545065,81 & 703 & CANA \\
\hline 16 & $22^{\circ} 10^{\prime} 30,33^{\prime \prime}$ & $47^{\circ} 57^{\prime} 14,3^{\prime \prime}$ & 814132,64 & 7544639,09 & 698 & PASTO \\
\hline 17 & $22^{\circ} 10^{\prime} 33,9^{\prime \prime}$ & $47^{\circ} 57^{\prime} 14,0^{\prime \prime}$ & 814138,29 & 7544528,77 & 708 & PASTO \\
\hline 18 & $22^{\circ} 10^{\prime} 36,8^{\prime \prime}$ & $47^{\circ} 57^{\prime} 14,6^{\prime \prime}$ & 814120,77 & 7544440,39 & 716 & PASTO \\
\hline 19 & $22^{\circ} 10^{\prime} 42,7^{\prime \prime}$ & $47^{\circ} 57^{\prime} 15,0^{\prime \prime}$ & 814105,58 & 7544258,83 & 718 & PASTO \\
\hline 20 & $22^{\circ} 10^{\prime} 17,3^{\prime \prime}$ & $47^{\circ} 56^{\prime} 24,1^{\prime \prime}$ & 815579,82 & 7545011,01 & 694 & CILIAR \\
\hline 21 & $22^{\circ} 10^{\prime} 14,3^{\prime \prime}$ & $47^{\circ} 56^{\prime} 24,8^{\prime \prime}$ & 815561,62 & 7545103,74 & 688 & CILIAR \\
\hline 22 & $22^{\circ} 10^{\prime} 08,3^{\prime \prime}$ & $47^{\circ} 56^{\prime} 11,5^{\prime \prime}$ & 815946,62 & 7545280,72 & 695 & CILIAR \\
\hline 23 & $22^{\circ} 10^{\prime} 08,5^{\prime \prime}$ & $47^{\circ} 56^{\prime} 11,5^{\prime \prime}$ & 815946,50 & 7545274,56 & 695 & CILIAR \\
\hline VAZÃO & $22^{\circ} 10^{\prime} 15,4^{\prime \prime}$ & $47^{\circ} 56^{\prime} 24,0^{\prime \prime}$ & 815583,87 & 7545069,43 & 693 & $\overline{\text { CILIAR }}$ \\
\hline PLUVIOMETRO & $22^{\circ} 11^{\prime} 20,7$ & $47^{\circ} 57^{\prime} 12,9^{\prime \prime}$ & 814141,66 & 7543087,83 & 733 & PASTO \\
\hline EST. CLIMAT. & $22^{\circ} 10^{\prime} 13,7$ & $47^{\circ} 53^{\prime} 55,5^{\prime \prime}$ & 819842,10 & 7545035,29 & 727 & GRAMÍNEA \\
\hline
\end{tabular}




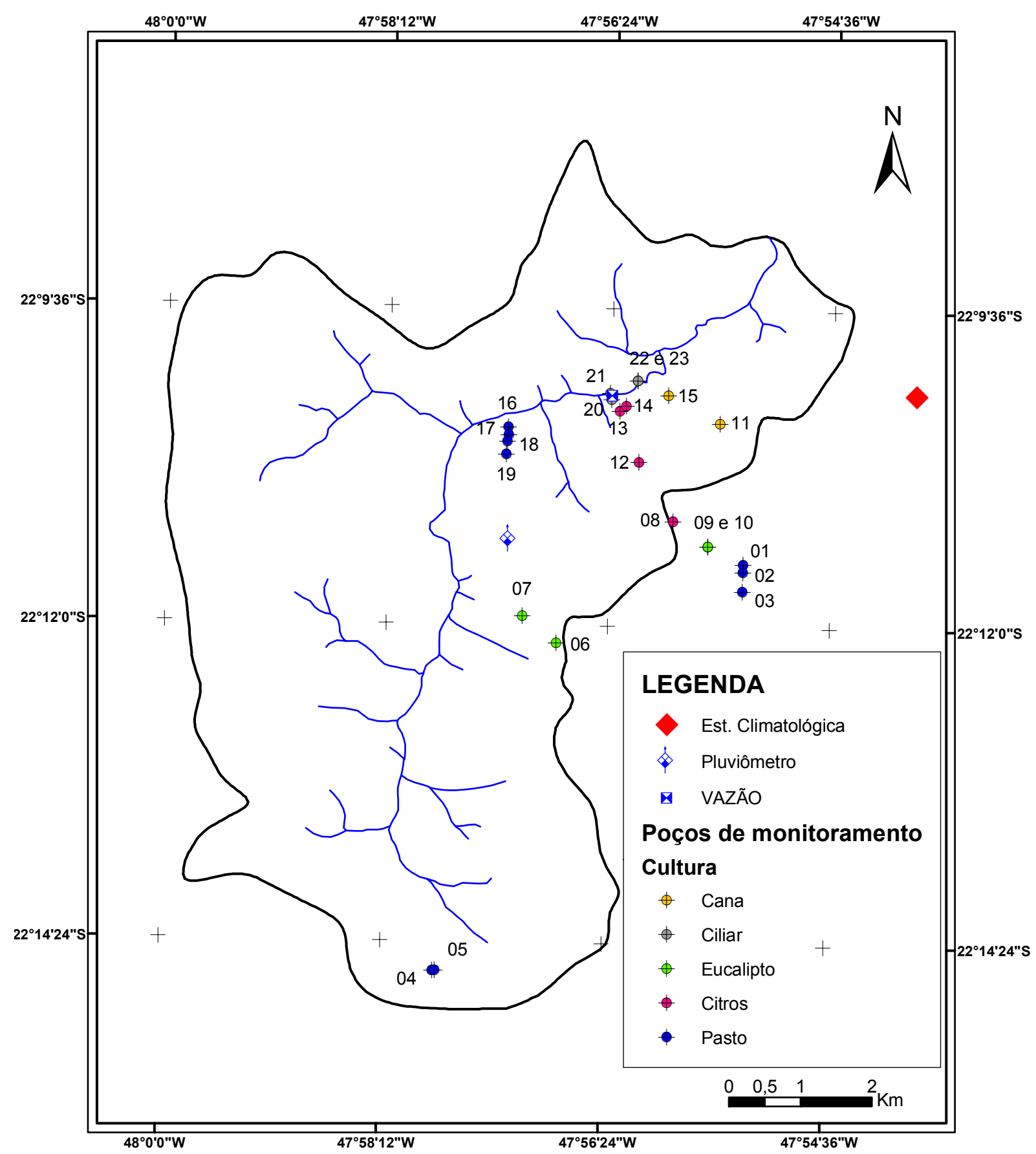

Figura 22: localização dos instrumentos de monitoramento instalados na área de estudo

Dos poços de monitoramento existentes, 19 poços foram construídos em trabalhos anteriores (CONTIN NETO, 1987; POMPÊO, 1990; ARANTES, 2003).

A localização destes, em campo, foi feita a partir de informações produzidas em trabalhos anteriores (CONTIN NETO, 1987; POMPÊO, 1990; ARANTES, 2003) e por meio de ajuda de pessoas que trabalhavam ou residiam na região. A posição geográfica foi determinada a partir de medição com aparelho "GPS", modelo GARMIN, etrexvista, com 
precisão de $10 \mathrm{~m}$ na horizontal. As medidas verticais devem ser consideradas apenas como ilustrativas. Alguns poços estavam danificados, o que em certos casos impossibilitou as medidas de nível, ou estavam secos (Poço 01, Poço 06, Poço 07, Poço 11).

Para o melhor desenvolvimento e embasamento dos resultados e conclusões foram construídos quatro poços de monitoramento em linha, ortogonais e próximos ao ribeirão.

Os poços construídos foram numerados como 16, 17, 18 e 19 (Figura 22)

A construção dos poços de monitoramento se deu entre os dias 30/08/2004 e 09/09/2004 e foram executados pela empresa "Sondagem e Mecânica MAGON Ltda.", com recursos do projeto do Fundo de Universidades do Projeto de Proteção Ambiental e Desenvolvimento Sustentável do Sistema Aqüífero Guarani (Figura 23, Figura 24, Figura 25 e Figura 26).

A execução de todos os poços obedeceu à mesma técnica, perfuração rotativa com fluido de perfuração. Os passos foram:

- Posicionamento de máquinas e equipamentos para perfuração;

- Construção dos "poços de lama";

- Perfuração;

- Coleta de amostras;

- Entubamento;

- Colocação de pré-filtro;

- Limpeza do poço;

- Acabamento.

Os detalhes construtivos dos poços podem ser observados no Apêndice G. 


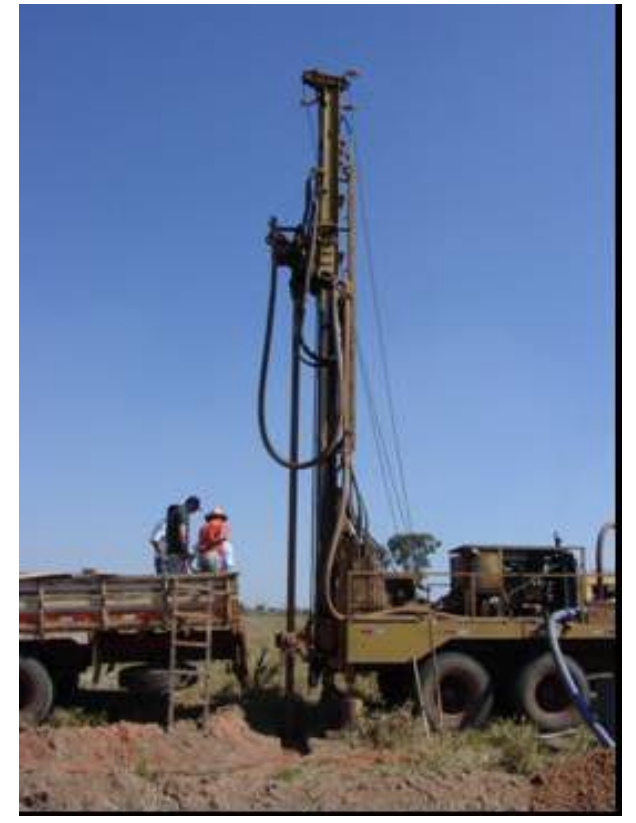

Figura 23: Máquina perfuratriz

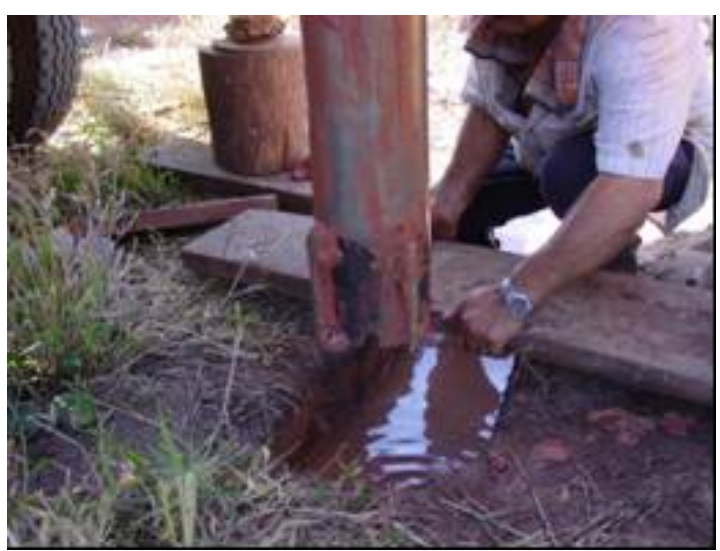

Figura 24: Broca de perfuração

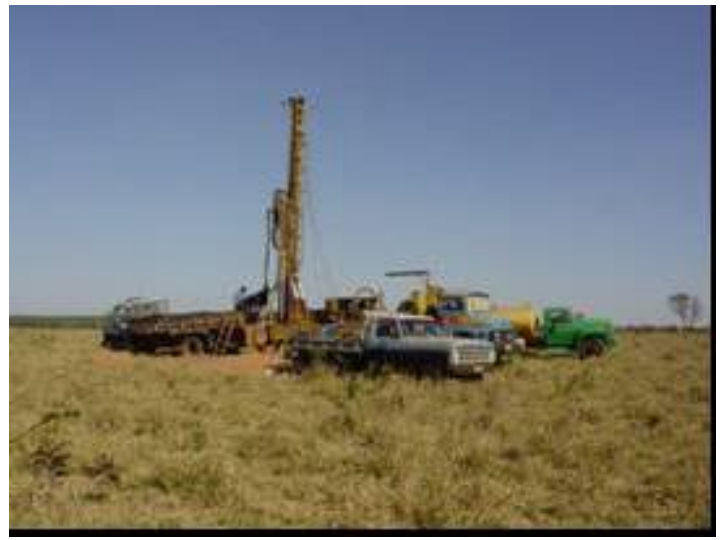

Figura 25: Máquinas utilizadas

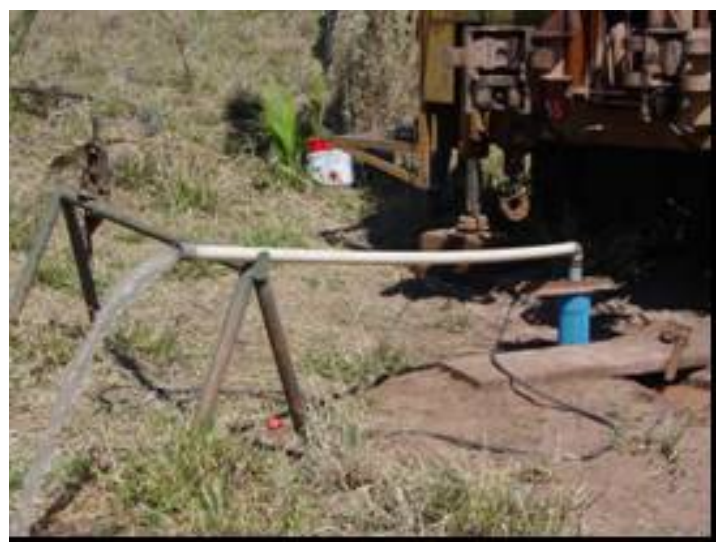

Figura 26: Limpeza do poço

Os poços de monitoramento estão distribuídos pelas seguintes culturas: 9 poços de monitoramento na cultura de pastagem, 4 na cultura de citros, 2 na cultura de cana-de-açúcar, 4 na cultura de eucaliptos e 4 na mata ciliar. 


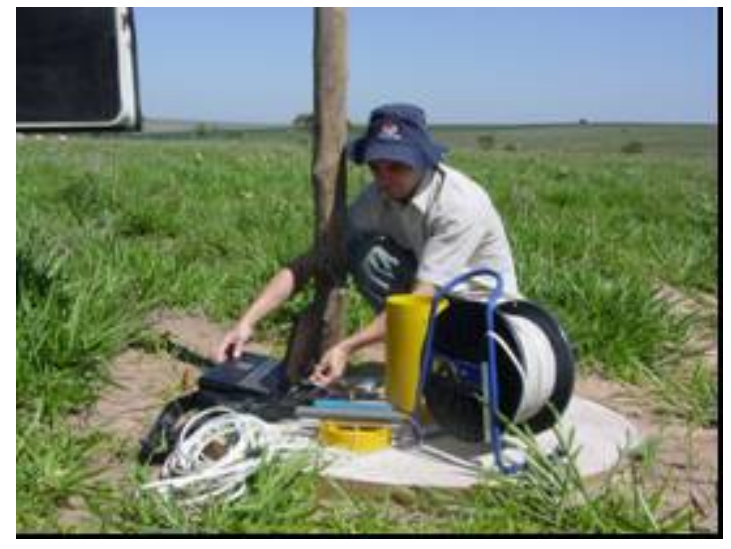

Figura 27: Poço instalado na cultura de pasto

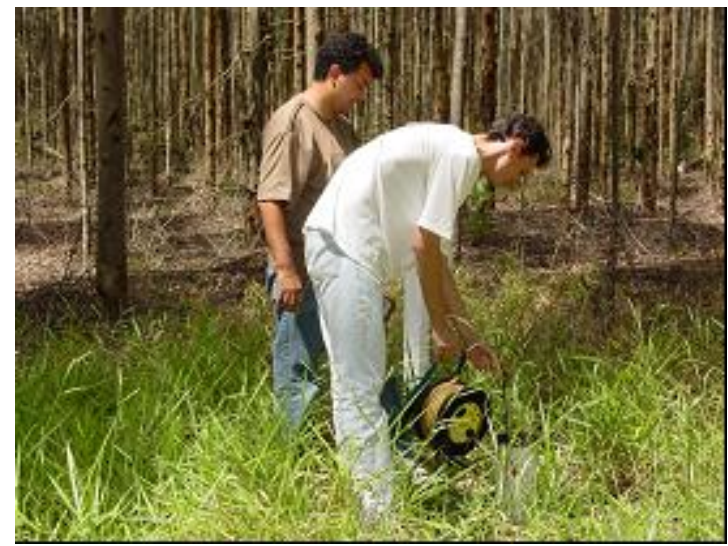

Figura 28: Poço instalado na cultura de eucaliptos

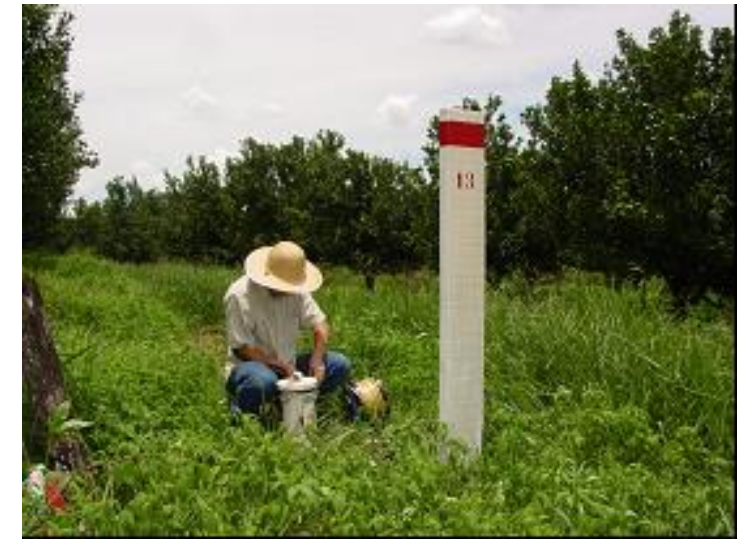

Figura 29: Poço instalado na cultura de citros

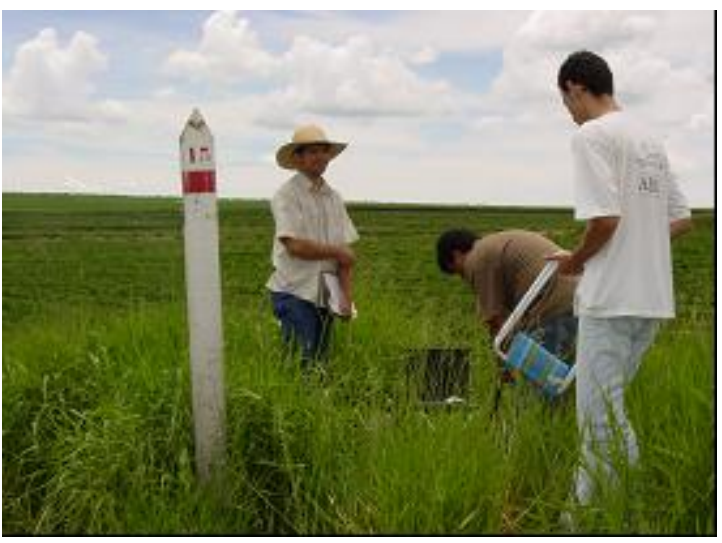

Figura 30: Poço instalado na cultura de amendoins

O pluviômetro foi instalado próximo ao centro da bacia. Para facilidade de acesso do operador, o equipamento foi instalado dentro da sede da fazenda, respeitando as distâncias recomendadas de objetos que possam vir a alterar os dados de precipitação (SANTOS et al., 2001). O pluviômetro está instalado com a boca a uma altura de 1,5 metros, preso a um mourão de madeira através de fitas metálicas perfuradas e aparafusadas, o que garante uma perfeita fixação e estabilidade (Figura 31 e Figura 32). 


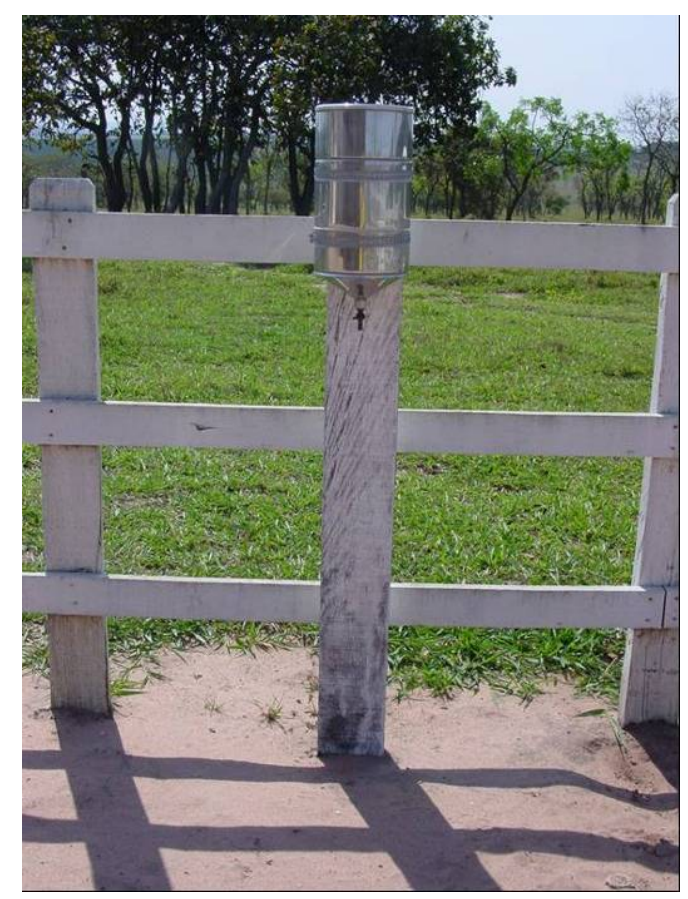

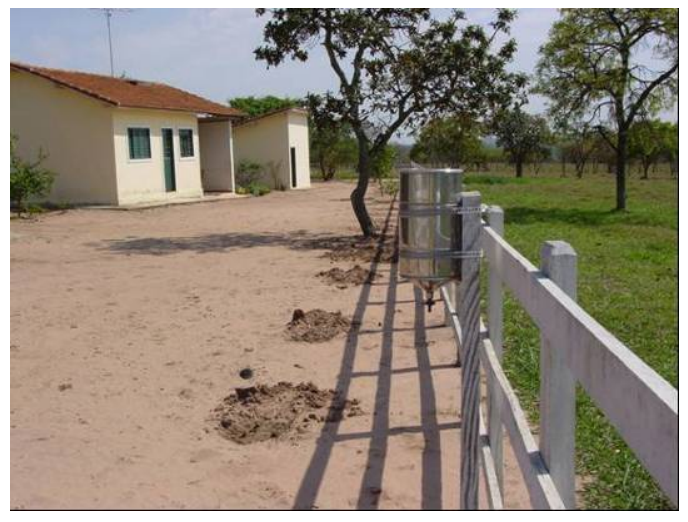

Figura 32: Vista lateral do pluviômetro

Figura 31: Pluviômetro instalado no centro da bacia

Para quantificar o escoamento superficial no Ribeirão da Onça foi necessário escolher uma seção de controle para instalar uma régua linimétrica e um linígrafo.

A seção do Ribeirão da Onça foi denominada de "VAZÃO". A escolha da seção deuse pelo fácil acesso ao posto de medição e porque o local não precisa de mudanças consideráveis para instalação dos equipamentos. O Ribeirão da Onça apresenta-se margeado por mata ciliar em quase todo o seu percurso, o que dificulta o acesso ao ribeirão. Além disso, essa mesma seção de controle foi utilizada em trabalhos anteriores. A seção de controle ainda apresenta a característica de estar a montante de um pequeno reservatório construído no rio, o que poderia acarretar problemas no balanço hídrico.

Instalou-se uma régua linimétrica para averiguar os dados do linígrafo. Foram colocados dois metros de régua metálica fixados em um mourão de madeira colocado em prumo (Figura 33 e Figura 34). 


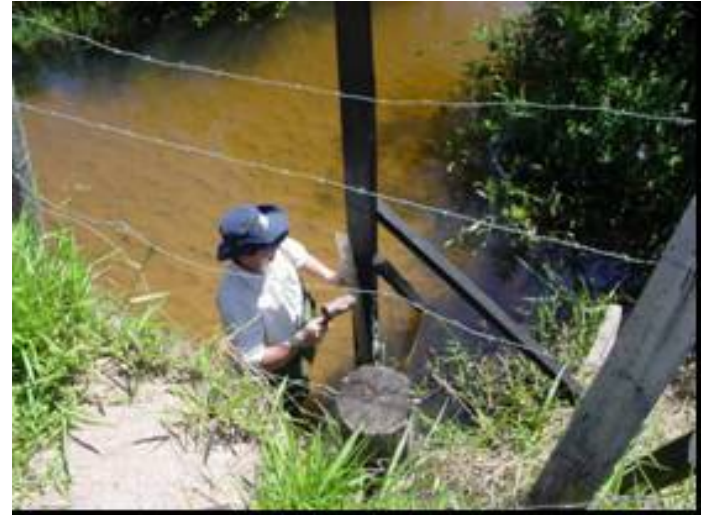

Figura 33: Instalação da régua linimétrica

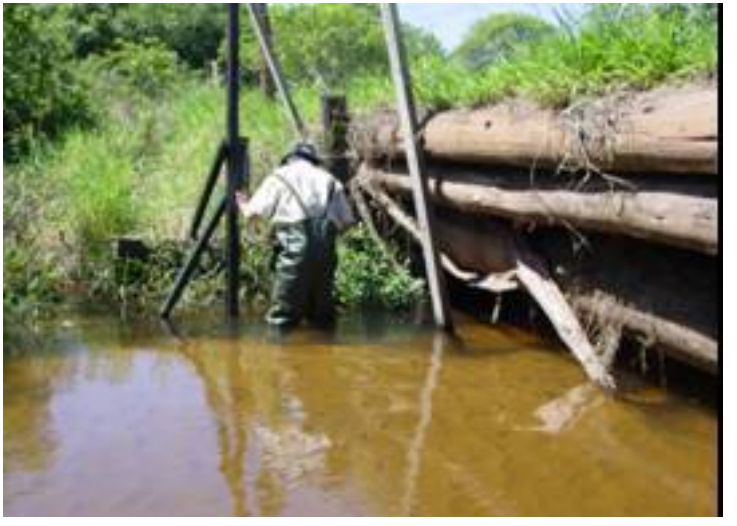

Figura 34: Instalação da régua linimétrica

Um linígrafo foi instalado para a coleta automática e contínua do nível de água do Ribeirão da Onça. O linígrafo foi construído com dois tubos de PVC $100 \mathrm{~mm}$ unidos por um joelho de mesmo material (Figura 35 e Figura 36). Para proteger o aparelho de coleta de dados (data logger) foi executada uma base de concreto, à qual foi fixado um tubo de ferro, como a boca de um poço (Figura 37).

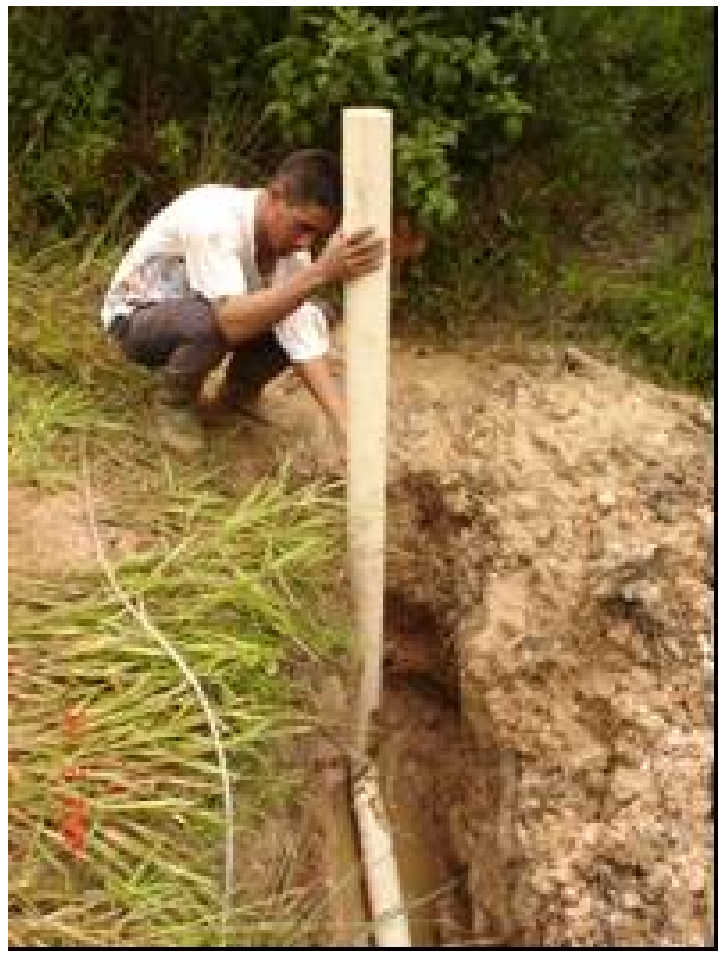

Figura 35: detalhe de construção do linígrafo

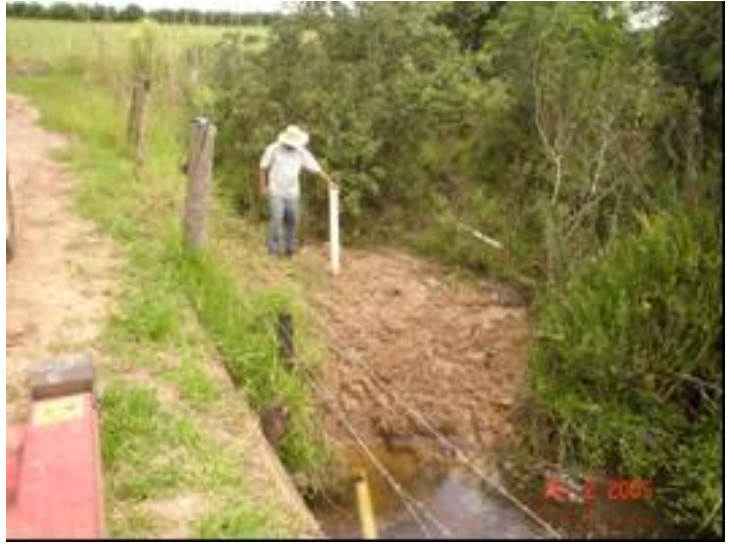

Figura 36: vista do tubo instalado 


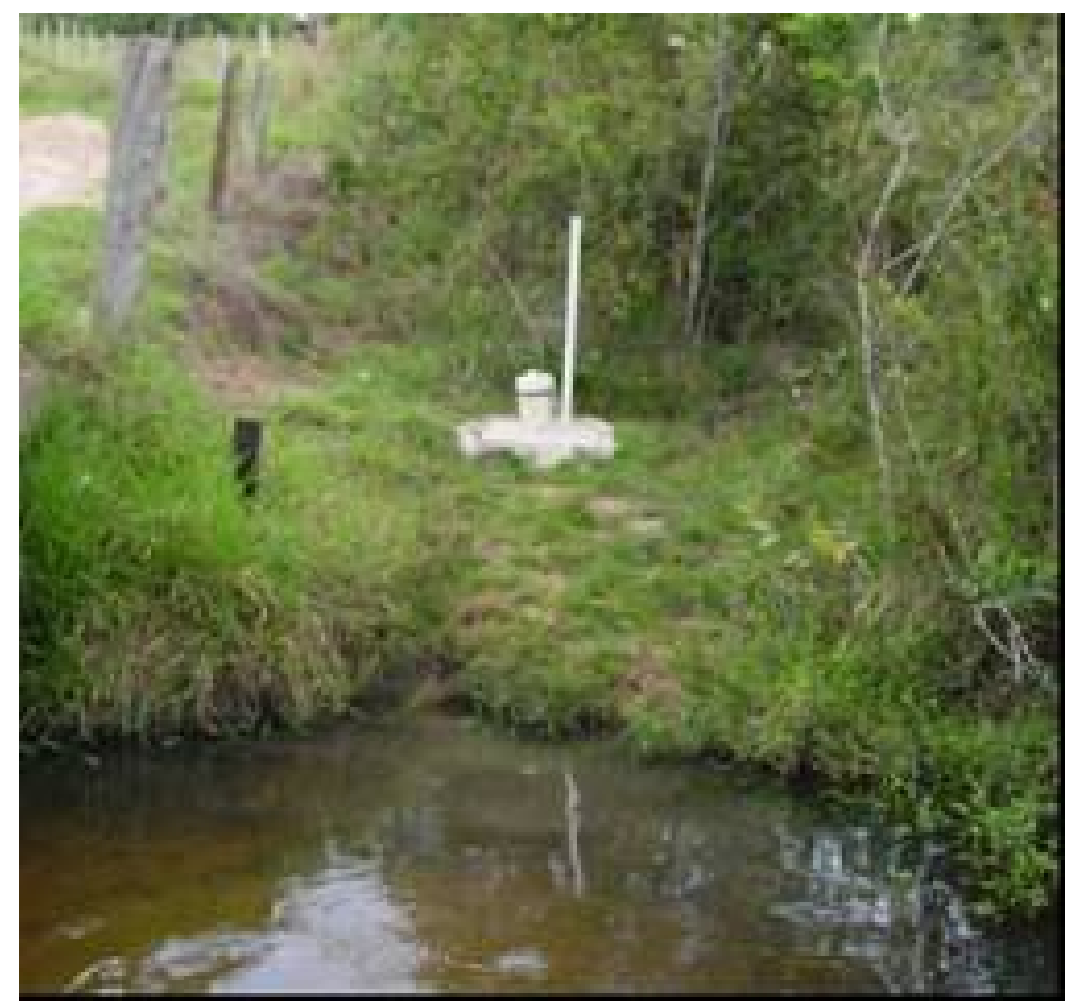

Figura 37: Vista da base de proteção do equipamento de medição e armazenamento

A Estação Climatológica instalada no CRHEA é capaz de coletar informações sobre precipitação, temperatura do ar, pressão atmosférica, vento, umidade relativa do ar, evaporação, radiação solar, brilho de luz solar, etc (Figura 38 à Figura 41). O CRHEA está localizado no paralelo $22^{\circ} 10^{\prime} 13,7^{\prime \prime}$ de latitude sul e no meridiano $47^{\circ} 53$ '55, $5^{\prime \prime}$ de longitude oeste, a uma distância aproximada de $1,5 \mathrm{~km}$ da Bacia do Ribeirão da Onça.

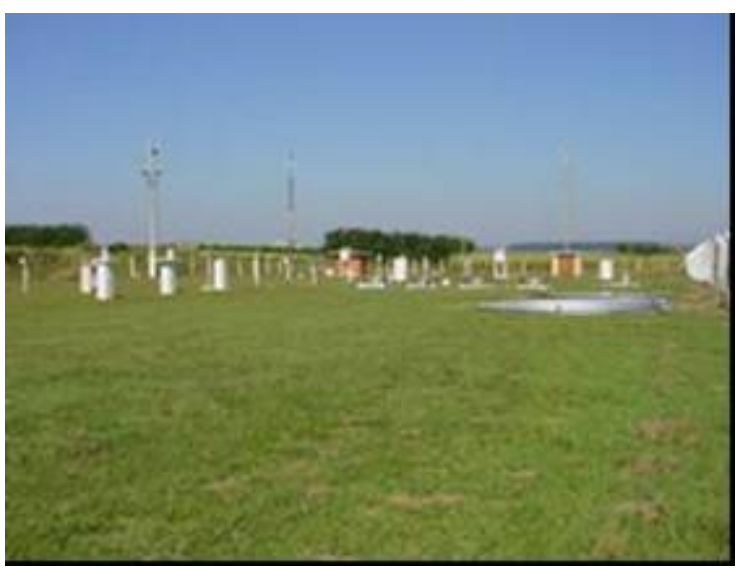

Figura 38: vista geral da Estação Climatológica do CRHEA

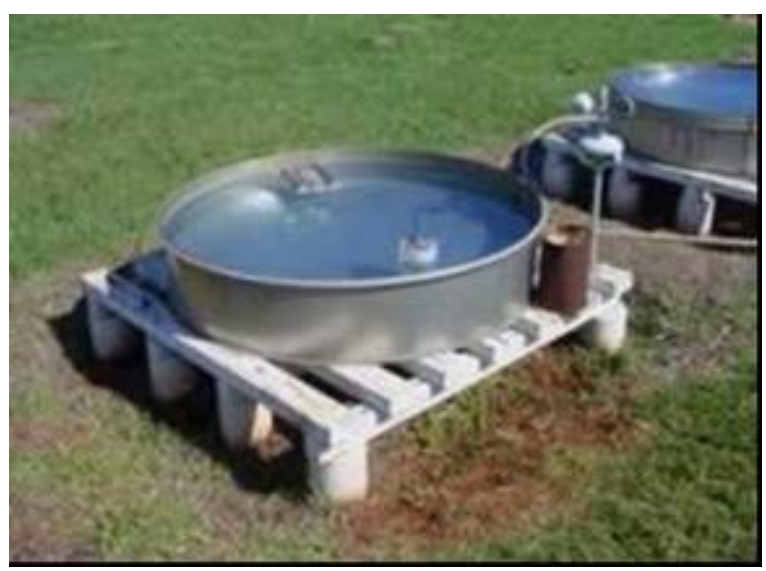

Figura 39: Tanque classe A instalado na Estação Climatológica do CRHEA 


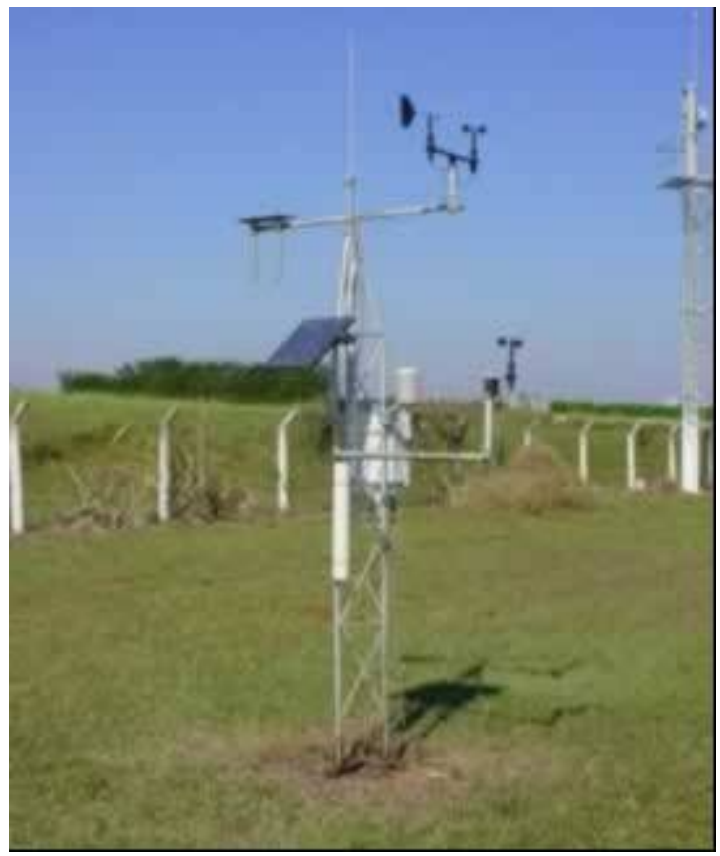

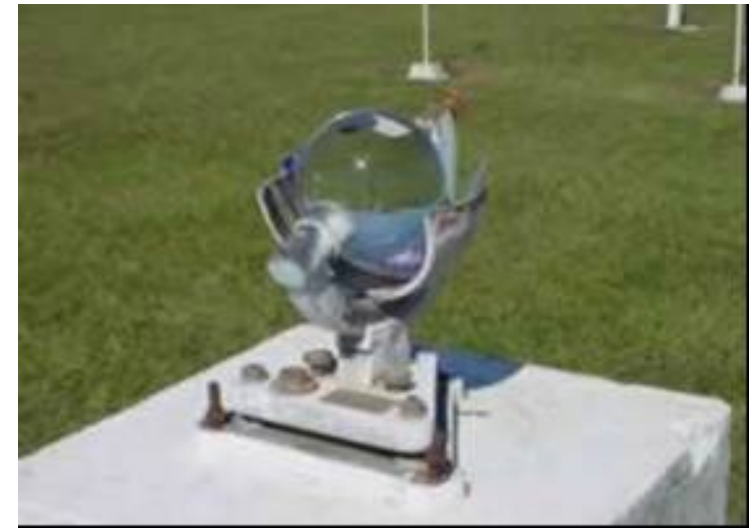

Figura 41: Heliógrafo instalado na Estação Climatológica do CRHEAMonitoramento Hidrogeológico

Figura 40: Estação Automática de coleta de dados climatológicos do CRHEA

Zhou (1996) estudou a freqüência de amostragem em poços de observação ao redor de uma estação de bombeamento de água para abastecimento em Spannenburg, Holanda, e concluiu que, para flutuações do nível d'água, a medição mensal do nível d'água era suficiente. Menegásse-Velásquez (1996) estudou a recarga freática nas sub-bacias Sumaré e Pompéia, São Paulo, e sugeriu um intervalo de medição menor que mensal para medição do nível d'água, devido a pequenas oscilações que certamente ocorrem entre sucessivas medições.

As medidas do nível do aqüífero feitas manualmente foram iniciadas assim que os poços foram localizados, usando o medidor de nível com aviso sonoro e trena graduada. As medições manuais foram realizadas em todos os poços de monitoramento. Essas medidas foram realizadas sempre em referência à boca do poço e anotadas em fichas próprias, sendo um método de leitura direta. O intervalo adotado entre as medições foi de 15 dias. Esse valor do intervalo variou devido à disponibilidade de veículos para a coleta de dados. Em geral, as medições foram executadas com um intervalo menor que 15 dias.

A medição automática de nível do aqüífero é realizada com o uso de um data logger, modelo MDS Floater, da empresa SEBA Hydrometrie. Esses equipamentos foram instalados em 6 poços de monitoramento, os poços $09,13,15,16,18$ e 19. O intervalo de tempo adotado entre medições foi de 12 horas. Os poço 09 se encontra instalado na cultura de eucaliptos, o 
poço 13 na cultura de laranja, o poço 15 na cultura de cana-de-açúcar, com rodízio de amendoim, e os poços 16, 18 e 19 estão instalados na cultura de pastagem.

\subsubsection{Medidas de precipitação}

As medidas de precipitação foram realizadas em um pluviômetro na bacia do Ribeirão da Onça, localizado na fazenda Monte Alegre próxima ao centro da bacia. A esse ponto de medição foi dado o nome de "Pluviômetro P-01".

Um funcionário da fazenda faz as medições, diárias, diretamente de uma proveta graduada. Quando há falha na medição da estação P-01, esse dado é corrigido através da precipitação medida na estação climatológica do CRHEA.

Esse tipo de correção pode ser justificado no trabalho de Pompêo (1990) que, observando diversos pluviômetros instalados na bacia, adotou esse preenchimento de falhas, por haver uma distribuição espacial homogênea das chuvas nesta bacia.

\subsubsection{Estimativa da evapotranspiração}

Estimou-se a evapotranspiração potencial de referência na bacia através de métodos empíricos e semi-empíricos. Para isto foram coletados dados, para uso nos modelos, na estação climatológica do CRHEA.

As variáveis medidas foram: velocidade média diária do vento a $2 \mathrm{~m}$ do solo, horas de brilho solar por dia, evaporação diária no tanque classe A, média diária da umidade relativa da atmosfera, temperatura diária máxima, média e mínima.

Os métodos utilizados para estimar a evapotranspiração foram: Penman-Monteith, Thornthwaite, Tanque Classe A (FAO), Blaney-Criddle, Hargreaves-Samani e Makkink. As estimativas foram realizadas através do uso do software BHÍDRICO ${ }^{(*)}$.

Para o cálculo da evapotranspiração real na bacia foi utilizada a seguinte expressão:

$$
E T=\sum_{i=1}^{n}\left(k_{c i} . E T P_{i} . A r_{i}\right)
$$

em que ET é a evapotranspiração real da bacia $(\mathrm{mm}), k_{c i}$ é o coeficiente de cultura para a cultura i (adimensional), ETP $P_{i}$ é a evapotranspiração potencial para a cultura i (mm) e $A r_{i}$ é a área relativa da cultura i em relação à área total da sub-bacia (adimensional). 
Os coeficientes $k_{c}$ são tabelados. Utilizou-se os coeficientes $k_{c}$ recomendados pela FAO (Food and Agriculture Organization ${ }^{*}$ ) apresentados na Tabela 8. Os coeficientes $k_{c}$ variam com o tempo para uma mesma cultura, dependendo do seu estágio de desenvolvimento. Na Tabela 8 os valores de kc são dados por etapa de desnvolvimento, sendo os valores os pesos de cada etapa. É necessário então a obtenção de $k_{c}$ 's médios para utilizar durante todo o ano. Os valores dos $k_{c}$ 's médios são retirados da média ponderada relativa ao período de duração de cada etapa de desenvolvimento da cultura.

Para o cálculo de $A r_{i}$ é necessário estimar as áreas de cada cultura dentro da sub-bacia do Ribeirão da Onça que fica a montante do posto fluviométrico (VAZÃO).

Tabela 8: Tabela de coeficientes $k_{c}$

\begin{tabular}{|c|c|c|c|c|c|c|}
\hline \multirow{2}{*}{ CULTURA } & & \multicolumn{4}{|c|}{ ETAPA DE DESENVOLVIMENTO } & \multirow{2}{*}{ Kc médio } \\
\hline & & I & II & III & IV & \\
\hline \multirow{2}{*}{ Mata Ciliar } & duração & - & - & - & - & \multirow{2}{*}{1,00} \\
\hline & kc & 1 & 1 & 1 & 1 & \\
\hline \multirow{2}{*}{ Cerrado } & duração & - & - & - & - & \multirow{2}{*}{1,00} \\
\hline & $\mathrm{kc}$ & 1 & 1 & 1 & 1 & \\
\hline \multirow{2}{*}{ Eucalipto } & duração & - & - & - & - & \multirow{2}{*}{1,00} \\
\hline & $\mathrm{kc}$ & 1 & 1 & 1 & 1 & \\
\hline \multirow{2}{*}{$\begin{array}{c}\text { Citros } \\
(50 \% \text { de cobertura })\end{array}$} & duração & 150 & 90 & 90 & 35 & \multirow{2}{*}{0,80} \\
\hline & $\mathrm{kc}$ & 0,8 & 0,8 & 0,8 & 0,8 & \\
\hline \multirow[t]{2}{*}{ Cana-de-açúcar } & duração & 8 & 15 & 45 & 24 & \multirow{2}{*}{1,04} \\
\hline & $\mathrm{kc}$ & 0,4 & 0,825 & 1,25 & 1 & \\
\hline \multirow{2}{*}{ Pasto } & duração & 140 & 60 & 120 & 45 & \multirow{2}{*}{0,90} \\
\hline & $\mathrm{kc}$ & 0,85 & 0,9 & 0,95 & 0,9 & \\
\hline \multirow{2}{*}{ Capim } & duração & 140 & 60 & 120 & 45 & \multirow{2}{*}{0,90} \\
\hline & $\mathrm{kc}$ & 0,85 & 0,9 & 0,95 & 0,9 & \\
\hline \multirow{2}{*}{ Soja } & duração & 20 & 30 & 60 & 25 & \multirow{2}{*}{0,90} \\
\hline & $\mathrm{kc}$ & 0,4 & 0,775 & 1,15 & 0,875 & \\
\hline \multirow{2}{*}{ Amendoim } & duração & 25 & 35 & 45 & 35 & \multirow{2}{*}{0,85} \\
\hline & $\mathrm{kc}$ & 0,4 & 0,775 & 1,15 & 0,875 & \\
\hline
\end{tabular}




\subsection{Descarga no Ribeirão da Onça}

\subsubsection{Medida direta}

O medidor de nível de água do ribeirão é um data logger MDS Floater, produzido pela empresa SEBA Hydrometrie. O medidor opera com um sistema de bóia e contra-peso, com leituras digitais. O tempo ajustado para a medição da cota foi inicialmente de $15 \mathrm{~min}$, depois passando para um tempo de 30min devido ao grande número de dados que esse intervalo geraria e o fato de não ter sido observado variações de cota que necessitassem de medições com períodos menores a 30min.

As medidas de vazão líquida na seção de controle foram realizadas através de um molinete hidrométrico associado ao método da seção média (seção 3.8.1, pág. 35). Para medida da velocidade média na vertical utilizou-se um ponto a uma distância de 0,6 da profundidade da vertical a partir da superfície e um tempo de 50 segundos para contagem dos giros da hélice. Foi adotado o valor de $0,5 \mathrm{~m}$ para a largura entre as verticais. A medição foi realizada a vau.

Devido à grande mudança na batimetria do ribeirão e às operações de um sistema de bombeamento a jusante da seção, a quantificação do volume total escoado no ribeirão por meio de uma única curva-chave tornou-se impraticável. A solução do problema deu-se por duas maneiras: quantificação do escoamento de base através da associação com o nível potenciométrico nos poços de observação e a quantificação do escoamento superficial direto através de um modelo chuva-vazão.

\subsubsection{Estimativa da vazão de base pela correlação com o nível do aqüífero}

A quantificação do escoamento de base através da associação com níveis potenciométricos é baseada no trabalho e nas funções apresentadas por Rushton e Tomlinson (1979). Essas equações foram apresentadas na seção 3.8.4, pág. 41, sendo as funções Eq. 22 e Eq. 23.

Esse método assume que quando há um acréscimo no nível do aqüífero há, também, um acréscimo no escoamento de base. Isto pode ser explicado pela lei de Darcy, já que, quando se tem um aumento no nível do aqüífero, tem-se um aumento no gradiente hidráulico do aqüífero para o curso de água. $\mathrm{O}$ inverso acontece quando se tem um decréscimo no nível do aqüífero. 
Então, pode-se afirmar que existe uma correlação entre os valores da descarga no curso de água e o nível do aqüífero.

A hipótese simplificadora que é feita nesse trabalho é que a variação do nível do aqüífero ocorre de forma homogênea, sendo assim, o nível do aqüífero pode ser representado pelo nível de água em poços de monitoramento.

As equações 22 e 23 podem ser utilizadas de diversas formas.

Uma das formas de utilização das equações 22 e 23 é definir que cada nível de água em um poço de monitoramento está associado a uma determina quantidade da vazão de base em um rio (Figura 42).

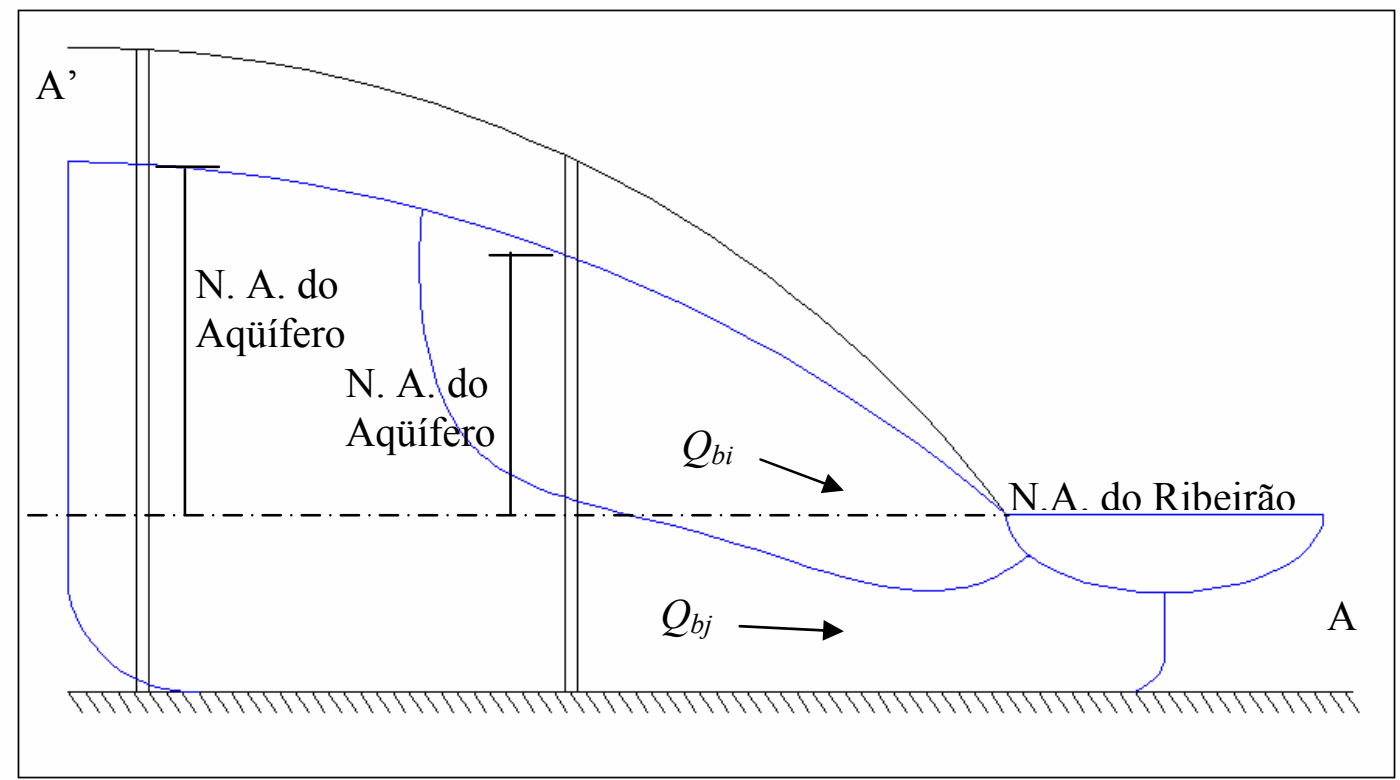

Figura 42: Corte esquemático representativo do fluxo entre um aqüífero e um ribeirão

O nível do aqüífero é referenciado em relação à cota do nível superficial do curso de água. Traça-se uma perpendicular ao curso de água passando pelo poço de monitoramento, mede-se a diferença entre a cota do nível superficial do curso de água, no ponto por onde passa a perpendicular, e o nível do aqüífero. Essa prática é utilizada para dar sentido físico à correlação, já que, para um caso mais simples, as linhas de fluxo, que partem de um ponto da superfície do aqǘfero livre, seguem uma reta que descarrega perpendicularmente ao curso de água (Figura 43). No entanto, qualquer referência para o nível do aqüífero é válida, já que é a variação do nível do aqüífero é que influencia a variação do escoamento básico em um curso de água. 


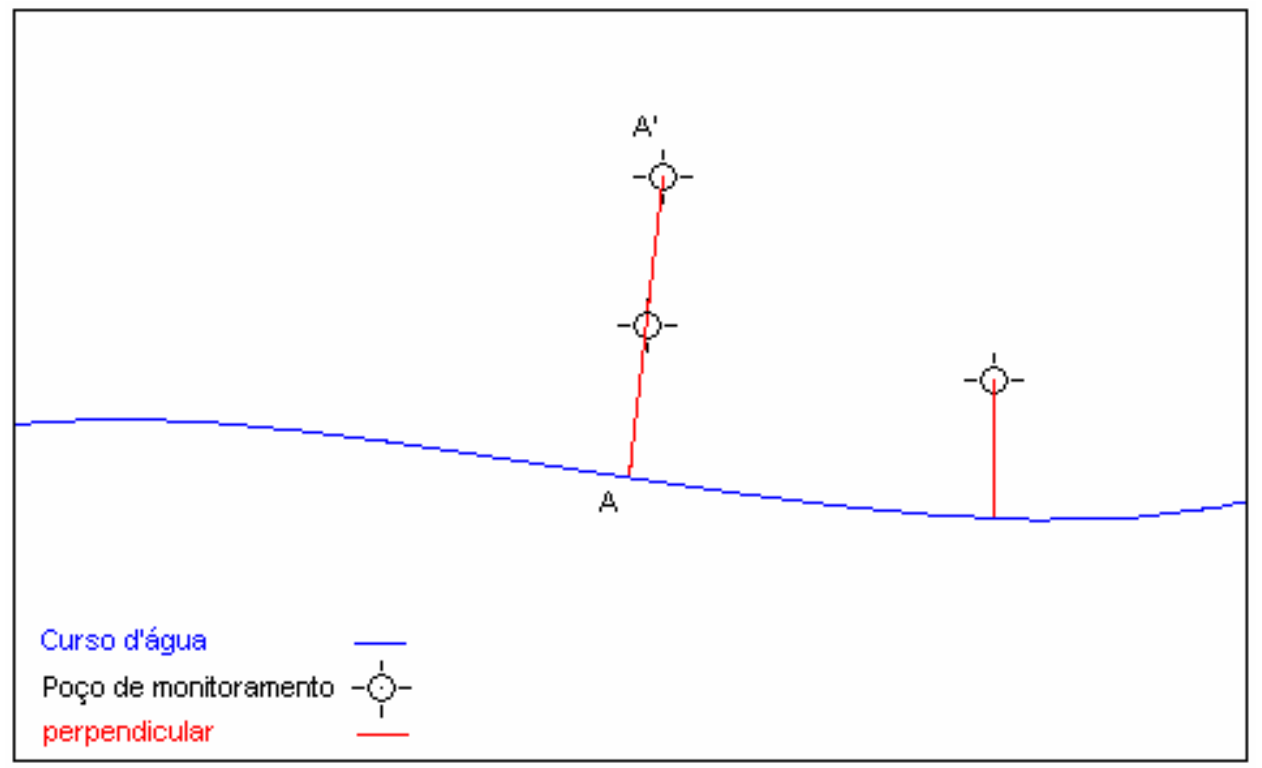

Figura 43: Esquema para determinação do ponto do curso d'água que deve ser considerado como referência para determinação do valor do nível do aqüífero

As equações 22 e 23, utilizando essa hipótese, são:

$$
\begin{gathered}
Q_{b}=b_{1} \cdot\left(1-e^{-c_{1} \cdot \Delta h_{1}}\right)+b_{2} \cdot\left(1-e^{-c_{2} \cdot \Delta h_{2}}\right)+\ldots+b_{n} \cdot\left(1-e^{-c_{n} \cdot \Delta h_{n}}\right) \\
Q_{b}=a_{1} \cdot \Delta h_{1}+b_{1} \cdot\left(1-e^{-c_{1} \cdot \Delta h_{1}}\right)+a_{2} \cdot \Delta h_{2}+b_{2} \cdot\left(1-e^{-c_{2} \cdot \Delta h_{2}}\right)+\ldots+a_{n} \cdot \Delta h_{n}+b_{n} \cdot\left(1-e^{-c_{n} \cdot \Delta h_{n}}\right)
\end{gathered}
$$

em que $Q_{b}$ é a vazão de base, $b_{n}$ e $c_{n}$ são os parâmetros da equação e $\Delta h_{n}$ é a variação do nível de água no poço de monitoramento em um determinado intervalo de tempo.

Outra forma de utilizar as equações 22 e 23 é assumir a hipótese de que uma unidade de variação no nível de água, em qualquer poço de monitoramento, causa a mesma variação no escoamento de base de um rio. As equações 22 e 23 assumem as seguintes formas:

$$
\begin{gathered}
Q_{b}=b_{n} \cdot\left(1-e^{-c_{1} \cdot \Sigma \Delta h n}\right) \\
Q_{b}=a_{n} \cdot \Sigma \Delta h_{n}+b_{n} \cdot\left(1-e^{-c_{1} \cdot \Sigma \Delta h_{n}}\right)
\end{gathered}
$$

em que $\Sigma \Delta h_{n}$ é a soma da variação do nível de água em poços de monitoramento em um determinado intervalo de tempo.

Para calibração dos parâmetros das equações foram escolhidas, dentre as vazões obtidas através de medições com o molinete, as que representassem a vazão de base, que estivessem distantes de eventos de chuva (Tabela 9). 
Tabela 9: Vazões medidas representativas da vazão de base

\begin{tabular}{|c|c|c|c|c|c|}
\hline DATA & $\begin{array}{c}\text { VAZÃO } \\
\left(\mathbf{m}^{3} / \mathbf{s}\right)\end{array}$ & DATA & $\begin{array}{c}\text { VAZÃO } \\
\left(\mathbf{m}^{3} / \mathbf{s}\right)\end{array}$ & DATA & $\begin{array}{c}\text { VAZÃO } \\
\left(\mathbf{m}^{3} / \mathbf{s}\right)\end{array}$ \\
\hline $28 / 10 / 04$ & 0,71 & $03 / 08 / 05$ & 0,70 & $14 / 10 / 05$ & 0,56 \\
\hline $29 / 04 / 05$ & 0,90 & $19 / 08 / 05$ & 0,70 & $11 / 11 / 05$ & 0,50 \\
\hline $03 / 06 / 05$ & 0,69 & $02 / 09 / 05$ & 0,83 & $22 / 12 / 05$ & 0,51 \\
\hline $01 / 07 / 05$ & 0,76 & $15 / 09 / 05$ & 0,53 & $13 / 01 / 06$ & 0,51 \\
\hline
\end{tabular}

Foram escolhidos os poços 13 e 08 para utilização nos modelos, por estarem próximos à linha imaginária da seção que corta a bacia, perpendicularmente ao ribeirão, no ponto da seção de controle, e por terem suas cotas, em relação ao ribeirão, conhecidas.

Para relacionar a vazão de base com dois poços simultaneamente, adotou-se que existe uma correlação entre o escoamento de base e a soma dos níveis do aqüífero nos poços de monitoramento

$$
\begin{gathered}
Q_{b}=k_{1} \cdot\left(1-e^{-\left(h_{8}+h_{13}\right) \cdot k_{2}}\right) \\
Q_{b}=k_{1} \cdot\left(h_{8}+h_{13}\right)+k_{2}\left(1-e^{-\left(h_{8}+h_{13}\right) \cdot k_{3}}\right)
\end{gathered}
$$

em que $k_{1}, k_{2}, k_{3}$, são os parâmetros, $Q_{b}$ é a vazão de base $h_{i}$ é o nível do aqüífero no poço “ $i$ ”, referente ao nível superficial do ribeirão (metros).

Com os níveis do aqüífero nos poços de observação, relativos ao nível de água no ribeirão, e os dados de vazão de base, estimaram-se os parâmetros através do método dos mínimos quadrados.

\subsubsection{Estimativa do escoamento superficial direto através de modelo chuva-vazão}

Para estimativa do escoamento superficial direto utilizou-se um modelo precipitaçãovazão. Foi escolhido o programa IPHS1, desenvolvido no Instituto de Pesquisas Hidráulicas da Universidade Federal do Rio Grande do Sul. Para simular o escoamento utilizou-se o método SCS distribuído por sub-bacias (Figura 44).

Foram escolhidas as sub-bacias que definem os principais afluentes do Ribeirão da Onça. 


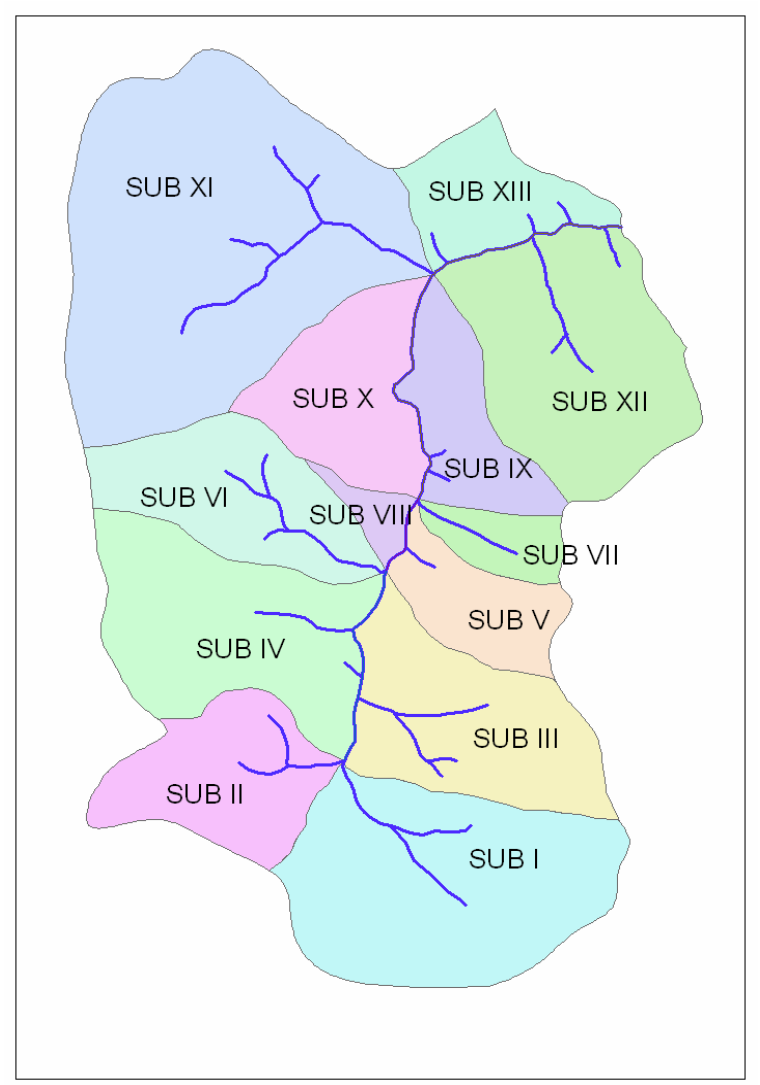

Figura 44: Representação das sub-bacias utilizadas na simulação do escoamento superficial direto pelo modelo de transformação chuva-vazão IPHS1

Para calibrar o modelo foi preciso escolher um período do linigrama do Ribeirão da Onça em que durante o qual não tenha se percebido alterações no leito do rio. O período escolhido foi de 14/11/05 a 16/12/05. O número de medições de vazão consideradas relevantes para o período foram 4 (medição número 17, 19, 20 e 22). Este período ainda apresenta a vantagem de apresentar um volume precipitado razoável para poder calibrar o modelo. Com a associação das medições feitas com molinete hidrométrico no período escolhido e as alturas do nível d'água no ribeirão, foi construída uma curva-chave válida para o intervalo de tempo considerado.

A função utilizada para representar a curva-chave foi do tipo potencial (Eq. 59). O parâmetro de potência foi fixado com o valor 2,0 para que a função tivesse um sentido físico

$$
Q=m^{*}\left(h-h_{0}\right)^{2}
$$


em que $Q$ é a vazão $\left(\mathrm{m}^{3} / \mathrm{s}\right), h(\mathrm{~m})$ é o nível de água no Ribeirão da Onça dado pela régua linimétrica, $m$ e $h_{0}$ são os parâmetros da função.

A função resultante foi:

$$
Q=6,59 *(h-0,59)^{2}
$$

Os parâmetros foram ajustados através do método dos mínimos quadrados. O viés foi igual a 0,00 , o erro médio quadrático 0,01 , a raiz do erro médio quadrático 0,11 , a média da raiz do erro médio quadrático foi igual a 0,03 e o coeficiente de correlação foi igual a 0,90 .

Realizou-se uma batimetria na bacia do Ribeirão da Onça com o objetivo de obter informações da geometria da seção para cotas mais altas (Figura 45).

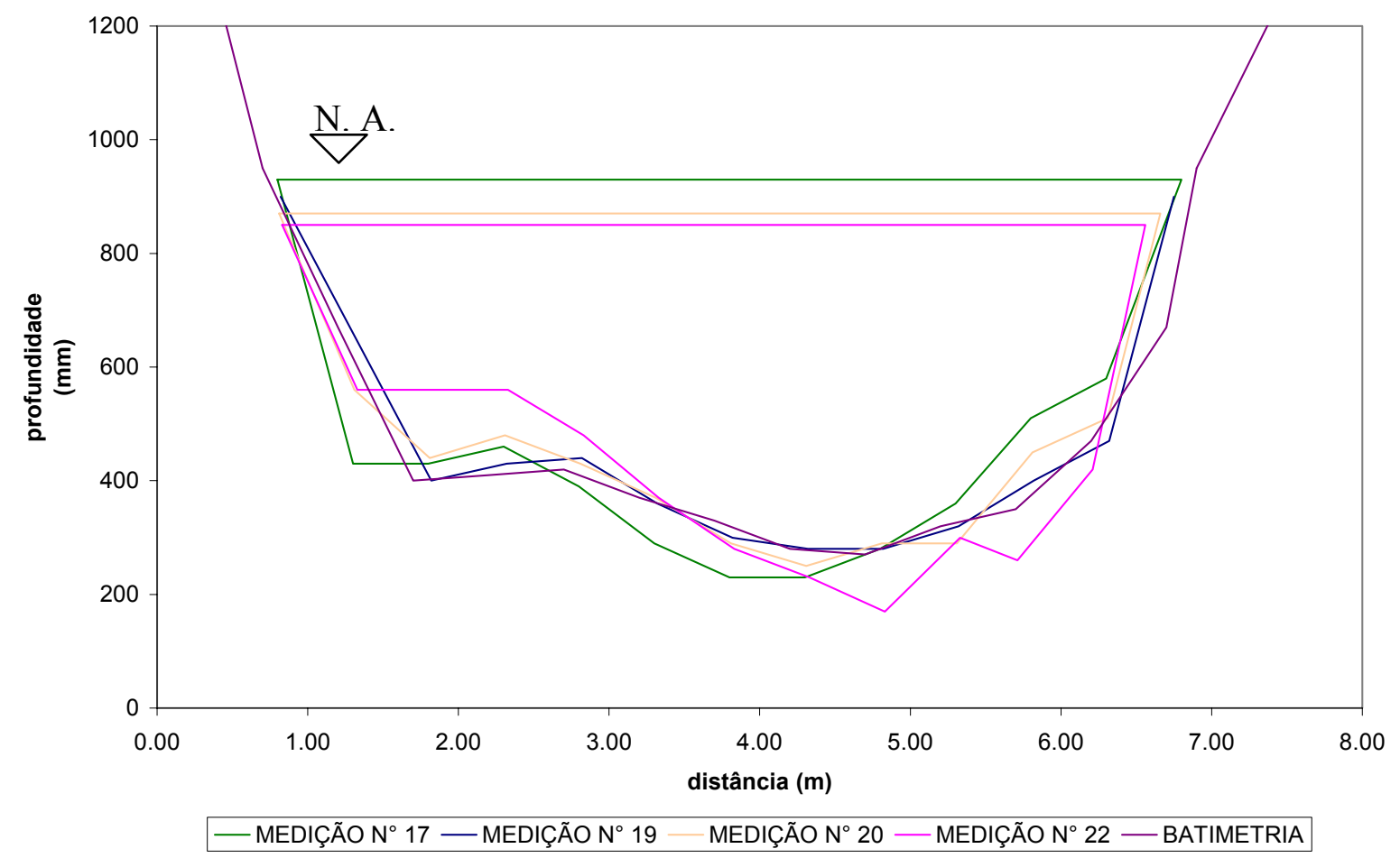

Figura 45: seção transversal do Ribeirão da Onça durante diferentes medições de vazão. Exagero vertical de aproximadamente $5 \mathrm{x}$.

Para a extrapolação da curva-chave foram comparados alguns métodos: Manning com $\mathrm{K}$ constante, Manning com $\mathrm{K}$ exponencial e o método logarítmico, conforme descrito na seção 3.8.2.1.

$$
Q=\frac{1}{n} A \cdot R_{H}^{2 / 3} \cdot I^{1 / 2} \quad \text { e } \quad \frac{1}{n} \cdot I^{1 / 2}=c t e=K
$$

O método de Manning mais utilizado considera o valor de $K$ como uma constante para os valores de cota mais alta. Para a seção do Ribeirão da Onça os valores de $K$ para as cotas 
mais altas não convergiram para um valor único. $\mathrm{O} K$ foi odotado igual a 0,$45 ; 0,50 ; 0,55$; 0,$60 ; 0,65$ e 0,70 .

Devido à não-convergência dos valores de $K$ para as cotas mais altas, resolveu-se utilizar uma função exponencial para representar os valores de $K$. Encontrou-se o valor de $K$ para as mesmas medições utilizadas para ajustar a curva-chave, a partir dos dados de vazão, área molhada e raio hidráulico. Tendo encontrado os valores reais de $K$, plotou-se em um gráfico do Excel $^{\odot}$ os valores de $K \mathrm{x}$ h, onde h é a cota do nível do ribeirão, e adicionou-se uma linha de tendência exponencial aos valores. A correlação dos dados observados com a linha de tendência foi muito baixa, 0,47. A função da linha de tendência:

$$
h=0,7147 . e^{0,5731 K}
$$

As relações entre cota, área e raio hidráulico para as seções estão apresentadas na Tabela 10.

Tabela 10: Relações geométricas da seção do Ribeirão da Onça

\begin{tabular}{|c|c|c|}
\hline COTA & ÁREA $\left(\mathbf{m}^{2}\right)$ & RAIO HIDRÁULICO $(\mathbf{m})$ \\
\hline $\mathbf{0 . 9 4}$ & 3.12 & 0.42 \\
\hline $\mathbf{0 . 9 5}$ & 3.18 & 0.42 \\
\hline $\mathbf{0 . 9 6}$ & 3.24 & 0.43 \\
\hline $\mathbf{0 . 9 7}$ & 3.30 & 0.43 \\
\hline $\mathbf{0 . 9 8}$ & 3.37 & 0.44 \\
\hline $\mathbf{0 . 9 9}$ & 3.43 & 0.45 \\
\hline $\mathbf{1 . 0 0}$ & 3.49 & 0.45 \\
\hline $\mathbf{1 . 0 1}$ & 3.56 & 0.46 \\
\hline $\mathbf{1 . 0 2}$ & 3.62 & 0.46 \\
\hline $\mathbf{1 . 0 3}$ & 3.68 & 0.47 \\
\hline $\mathbf{1 . 0 4}$ & 3.75 & 0.47 \\
\hline $\mathbf{1 . 0 5}$ & 3.81 & 0.48 \\
\hline $\mathbf{1 . 0 6}$ & 3.88 & 0.49 \\
\hline $\mathbf{1 . 0 7}$ & 3.94 & 0.49 \\
\hline $\mathbf{1 . 0 8}$ & 4.01 & 0.50 \\
\hline $\mathbf{1 . 0 9}$ & 4.07 & 0.50 \\
\hline $\mathbf{1 . 1 0}$ & 4.14 & 0.51 \\
\hline
\end{tabular}

Os gráficosGráfico 1 e Gráfico 2 mostram a extrapolação da curva-chave pelos métodos de Manning com K fixo, Manning com K variável e o método logarítmico. 


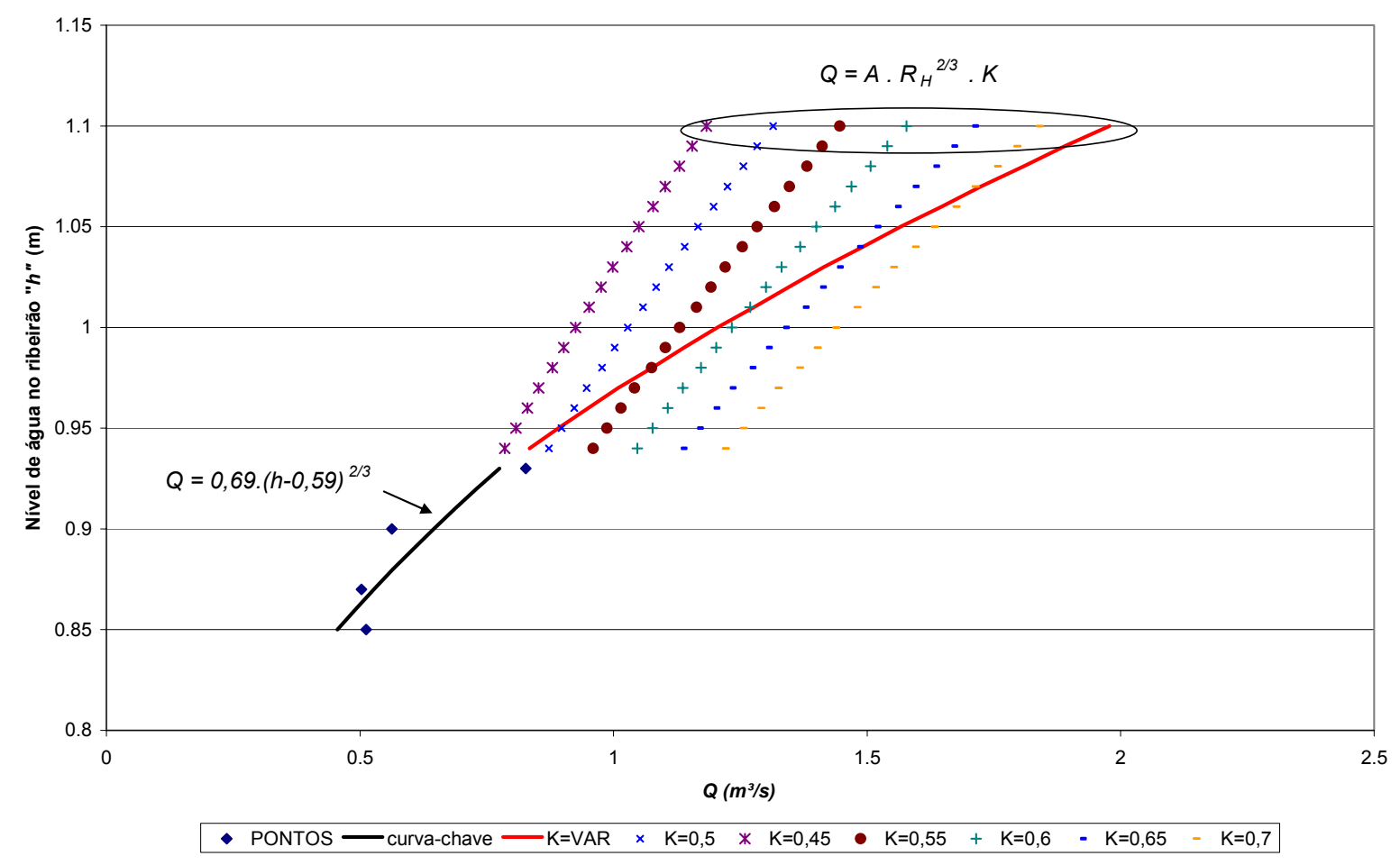

Gráfico 1: Extrapolação da curva-chave através do método de Manning com K constante e com K variável

Para obter-se a extrapolação através do método logarítmico basta aplicar a mesma função obtida para a curva-chave para as cotas mais altas.

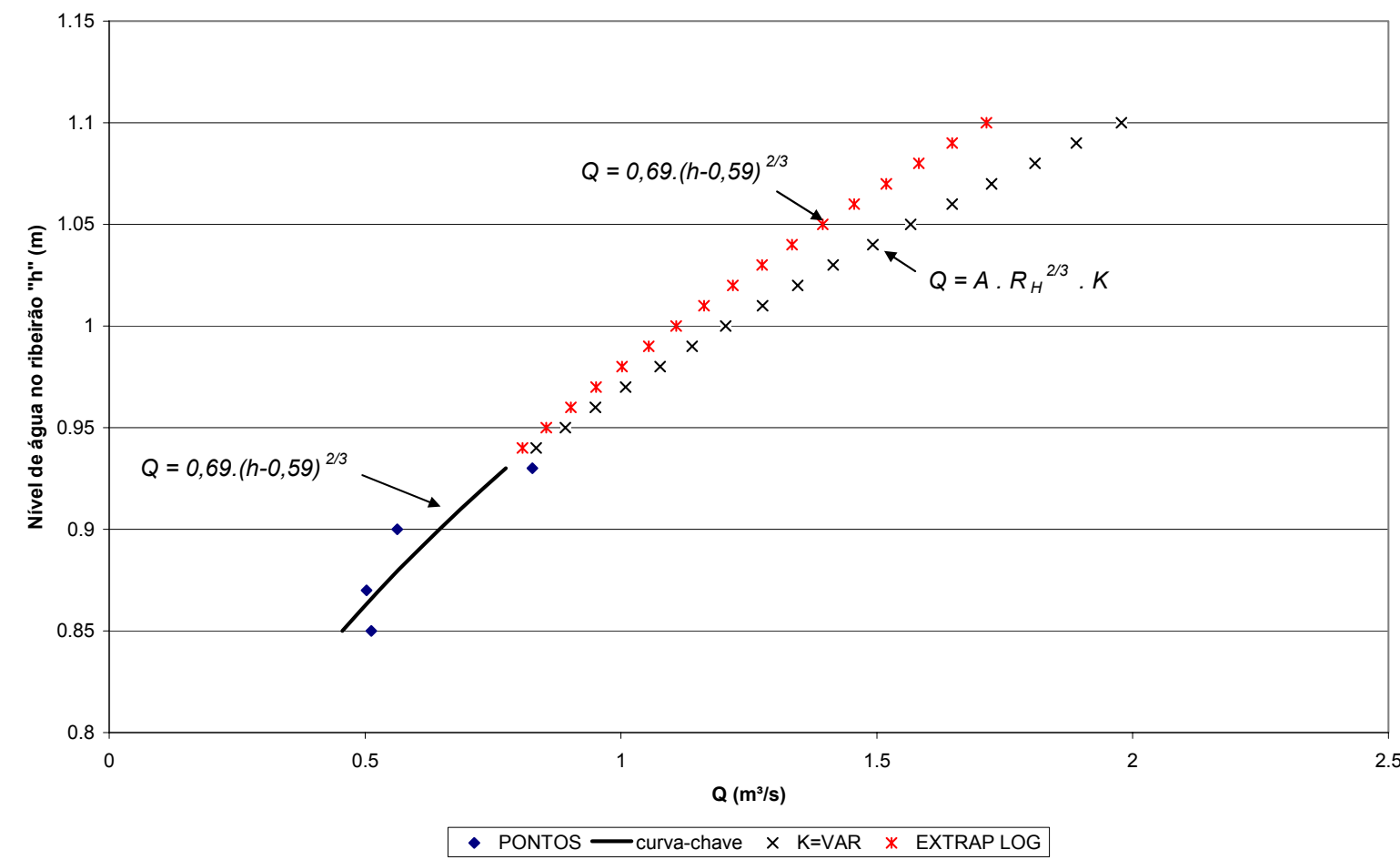

Gráfico 2: Extrapolação da curva-chave através dos métodos de Manning com K variável e do método de extrapolação logarítmico 
Comparando-se os valores dos resultados, visualizados nos gráficos Gráfico 1 e Gráfico 2 pode-se notar uma grande diferença entre eles. Uma análise visual inicial poderia apontar uma relação mais coerente para os métodos de Manning com K variável e para o método logarítmico. De acordo com Contin Neto (1987), a maior vazão encontrada para esta seção foi menor que $1,9 \mathrm{~m}^{3} / \mathrm{s}$.

Tendo em vista o baixo ajuste dos valores de $K$ à linha de tendência e que os valores encontrados para a vazão, nas cotas mais elevadas, são maiores que 1,90, em um mês onde a vazão de base é baixa, optou-se pelo método logarítmico para extrapolar a curva-chave.

Com a curva-chave e os valores da sua extrapolação, aplicou-se a relação entre cota e vazão para o período considerado.

Tendo sido determinada a curva-chave para o período considerado, separa-se o escoamento de base do escoamento superficial direto. Com o hidrograma plotado, traça-se uma reta entre os pontos onde se pode perceber o início e o fim do escoamento superficial direto, sendo a vazão resultado da integração da parte superior do hidrograma delimitado pela reta.

Com o valor do escoamento superficial direto e da precipitação calibra-se o modelo chuva-vazão. Nesse trabalho foi utilizado o programa IPHS II para simular o escoamento superficial.

Para o uso do programa IPHS1 é necessário o conhecimento das cotas da bacia, do valor do CN (ver seção 3.8.3, p. 37) e das precipitações diárias.

A simulação do modelo chuva-vazão sem calibração, utilizando valores tabelados do $\mathrm{CN}$, não produziu resultados satisfatórios. $\mathrm{O}$ valor do $\mathrm{CN}$ foi subestimado, sendo necessária a calibração do modelo.

A calibração do modelo chuva-vazão foi realizada em três períodos, um para condições de baixa umidade do solo e duas para condições de alta umidade do solo. A condição para o solo ser considerado de baixa umidade é a não ocorrência de uma precipitação total maior do que 36mm nos últimos 5 dias e em período menor não terem ocorrido precipitações que somadas totalizem $13 \mathrm{~mm}$. Em qualquer outra condição, o solo é considerado de alta umidade.

A calibração foi feita pelo parâmetro de volume escoado, sem verificação do tempo de pico nem do tempo de recessão do hidrograma simulado.

Para o período seco, calibrou-se o hidrograma a partir de dois dados de chuvas em dois dias consecutivos. As precipitações ocorreram nos dias 25 e 26/11/05. Para a calibração do 
período úmido foram usadas as precipitações ocorridas nos dias 1, 2, 3/12/05 para a primeira simulação e depois as precipitações ocorridas nos dias 5, 6 e 7/12/05.

\subsection{Determinação da variação do armazenamento subterrâneo de água}

A variação do armazenamento subterrâneo de água, em um aqüífero livre que descarrega em um curso de água, é igual à variação de água que ocorre quando o nível do aqüífero muda de posição em relação ao nível anterior.

A estimativa da variação do armazenamento subterrâneo se dá a partir dos dados dos níveis nos poços de monitoramento e da estimativa do coeficiente de rendimento específico do aqüífero, que para aqüíferos livres é igual à porosidade útil.

A porosidade útil pode ser entendida como a razão entre volume de água drenável por gravidade, em um solo inicialmente saturado com água, em um tempo infinito, pelo volume total do solo. Pode ser entendida, também, como a diferença ente a porosidade total e a capacidade de campo de um solo.

Com os gráficos da variação do nível do aqüífero nos poços de monitoramento em mãos determina-se a variação do nível do aqüífero para o período de tempo considerado. Em seguida, esse valor é multiplicado pelo coeficiente de rendimento específico

$$
\Delta S=\Delta h \cdot S_{y}
$$

em que $\Delta S$ é a variação do armazenamento subterrâneo, $\Delta h$ é a variação na altura do nível do aqüífero em um poço de monitoramento e $S_{y}$ é a porosidade útil.

A porosidade para a Formação Botucatu apresentada na literatura está na faixa de 10 a $30 \%$ (ver Tabela 1, p. 11). Os valores da porosidade útil estão um pouco abaixo destes valores. Utilizou-se para análise do armazenamento subterrâneo valores para a porosidade útil de $10,13,15,20$ e $25 \%$.

Esse método exige uma análise criteriosa dos poços de monitoramento que serão considerados para a estimativa da variação do armazenamento em toda a bacia. Há de se escolher poços distribuídos de forma a contabilizar eqüitativamente as várias características que interferem na variação do nível potenciométrico. Esses poços representam a cultura no entorno do poço, seu posicionamento na bacia e espessura de solo não-saturado. Só assim podem-se produzir resultados que não sejam tendenciosos.

Os poços escolhidos para representar a variação do armazenamento da bacia foram os poços $03,05,08,09,13,15,16,18$ e 19 . O cálculo final, então, é feito pela média aritmética 
entre os valores encontrados, para a variação do armazenamento subterrâneo de água, em cada poço de observação.

\subsection{Avaliação da recarga direta}

Estimou-se a recarga direta através da análise da variação do nível do aqüífero e pela identificação e extrapolação das curvas de recessão do nível do aqüífero, baseado na metodologia do método WTF, descrita na seção 3.2, pág, 18.

O método consiste em identificar os períodos em que não há recarga direta, observando a precipitação ocorrida no período e mudanças bruscas na declividade do nível do aqüífero. Após a identificação dos períodos recessivos, escolhe-se o maior entre eles e associa-se a esse trecho uma função do tipo potencial

$$
N_{a q}=a \cdot\left(p-p_{0}\right)^{b}
$$

em que $N_{a q}$ é o nível do aqüífero, $p$ é o número de dias contados a partir do primeiro dia de medição no poço, $a, b$ e $p_{0}$ são parâmetros.

Tendo identificados os parâmetros da função de recessão do poço, aplica-se a função aos outros períodos de recessão, mantendo a e b próximos aos valores encontrados para a primeira curva de recessão do nível do aqüífero.

Extrapola-se as curvas de recessão até o ponto em que inicia um novo período recessivo (ver Figura 4, seção 3.8, pág. 24).

A recarga mutiplicada pelo coeficiente de armazenamento específico para um período $t$, estimada para cada poço de observação, será igual a:

$$
R_{d} / S_{y}=\left(N_{a q i}-N_{r e c i}\right)-\left(N_{a q j}-N_{r e c j}\right)(\mathrm{i}>\mathrm{j})
$$

em que $R_{d}$ é a recarga direta, $S_{y}$ é a porosidade útil, $N_{a q i}$ é o nível real do aquifero no instante $i, N_{\text {reci }}$ é o nível da curva de ressão extrapolada no instante $i, N_{a q j}$ é o nível real do aquifero no instante $j, N_{\text {recj }}$ é o nível da curva de recessão extrapolada no instante $j$.

A recarga direta para toda a bacia é dada pela média aritmética da recarga direta encontrada para cada poço de observação considerado.

As mesmas observações feitas no item anterior servem para este método. 


\subsection{Irrigação}

Uma parcela da área da bacia do Ribeirão da Onça é irrigada. O sistema de irrigação utilizado é o sistema de irrigação localizada por gotejamento.

O conjunto de bombeamento está localizado a jusante da seção de medição de vazão, e parte da área irrigada está contida na sub-bacia do ribeirão, delimitada pela seção de controle. Não existem dados precisos sobre o funcionamento e vazão do sistema de bombeamento. A área irrigada pode ser visualizada na Figura 46.

Essa parcela do balanço, apesar de pequena, tem influência direta na recarga para períodos secos.

Para suprir a falta de dados, a irrigação local foi considerada como o déficit entre a precipitação e a evapotranspiração, com base mensal.

A cultura objeto de irrigação é a laranja, que possui coeficiente de cultura igual a 0,8 . A irrigação na sub-bacia do Ribeirão da Onça será calculada pela expressão:

$$
I r=-\left(P-E T_{l a r}\right) \cdot\left(\frac{A_{I r}}{A_{s b}}\right)
$$

em que $I r$ é a irrigação mensal $(\mathrm{mm}), P$ é a precipitação mensal $(\mathrm{mm}), E T_{\text {lar }}$, a evapotranspiração real mensal na laranja $(\mathrm{mm}), A_{i r}$ é a área irrigada contida na sub-bacia do Ribeirão da Onça $\left(\mathrm{km}^{2}\right)$ e $A_{s b}$ é área total da sub-bacia do Ribeirão da Onça $\left(\mathrm{km}^{2}\right)$.

Quando $I r$ é negativo seu valor é substituído por $0 \mathrm{~mm}$.

A área irrigada total na bacia do Ribeirão da Onça é de $4,12 \mathrm{~km}^{2}$ e a área da sub-bacia do Ribeirão da Onça é de $2,39 \mathrm{~km}^{2}$.

Deve ser observado que para cada método de estimativa da evapotranspiração obtémse um valor para a irrigação. 


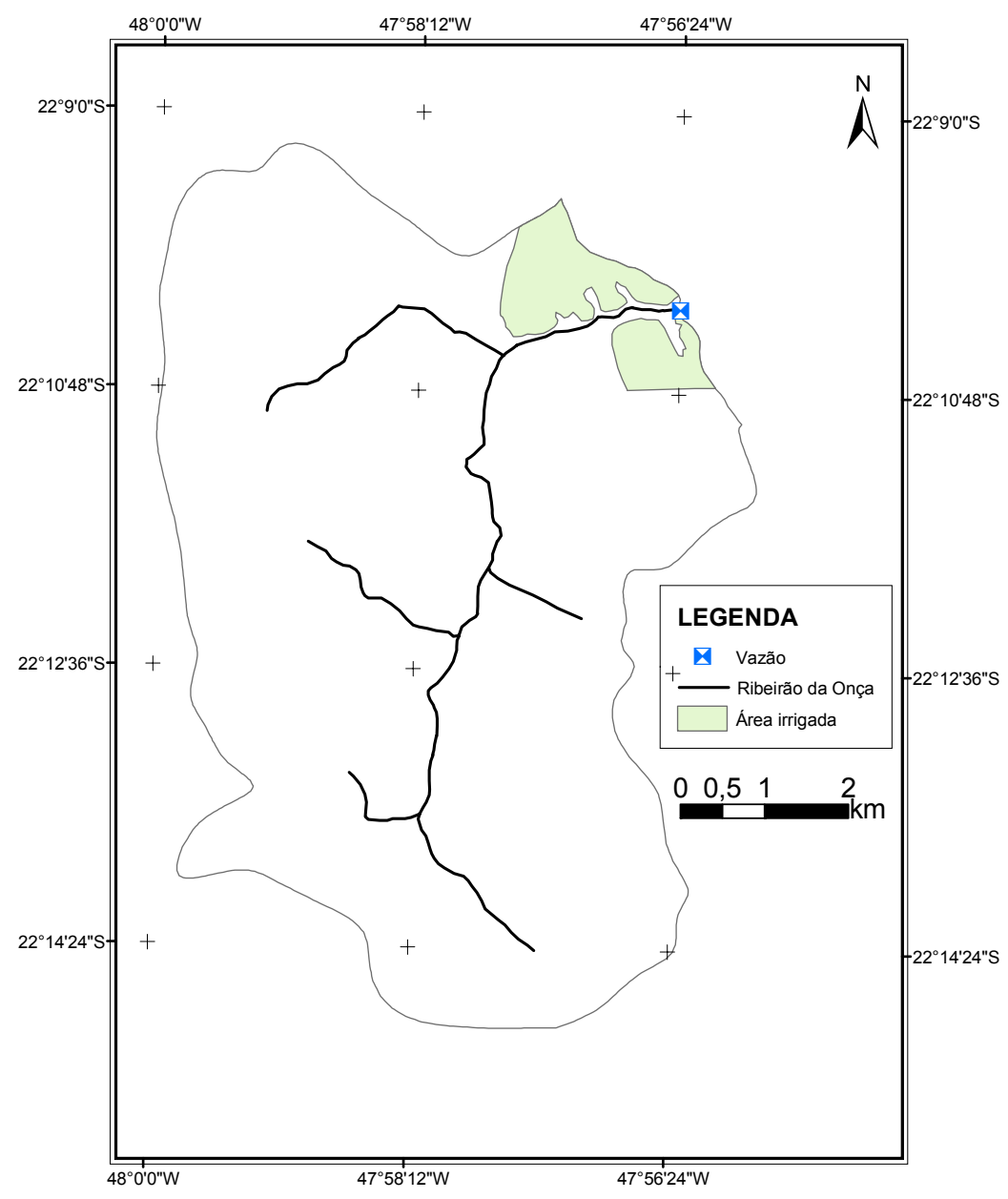

Figura 46: Localização da área irrigada

\subsection{Balanço Hídrico}

Este trabalho tem como objetivo principal a estimativa da recarga direta e profunda. A recarga direta está definida na seção 3.2, pág 19. Convencionou chamar por recarga profunda como aquela que, a partir da precipitação, atinge a zona saturada do solo e daí segue linhas de fluxo que não surgirão no curso de água principal da mesma bacia hidrográfica, atingindo camadas mais profundas do aqüífero.

Para estimar a recarga profunda propõe-se a utilização de equações de balanço hídrico para o período do ano de 2005. A incerteza na estimativa das diversas componentes do ciclo hidrológico é um fato suficiente para a utilização de mais de um método para a avaliação da recarga.

Os métodos apontados para determinação de um valor para a recarga profunda são apresentados a seguir: 


\subsubsection{Método 1}

O método 1 proposto assume o volume de controle do balanço hídrico como a região saturada do solo na bacia (Figura 47). A entrada no sistema será dada pela recarga direta, $R_{d}$, estimada pelo método descrito no item 3.10, pág. 93. As saídas do sistema são: o escoamento de base, $Q_{b}$, e a recarga profunda, $R_{p}$. A recarga profunda será o resíduo da equação. A variação do volume subterrâneo armazenado $(\Delta S)$, também, será obtida da variação do nível do aqüífero a partir de medições nos poços de monitoramento. A seguinte equação representará o balanço hídrico:

$$
R_{p}=R_{d}-Q_{b}-\Delta S
$$

Com esse método, eliminam-se as incertezas das estimativas da evapotranspiração, da variação da umidade do solo, da vazão total escoada pelo rio e dos fenômenos de interceptação. Em compensação existe um peso muito grande nas estimativas realizadas através da variação do nível potenciométrico (variação do armazenamento subterrâneo e recarga direta), devido às incertezas que acompanham a definição da porosidade útil.

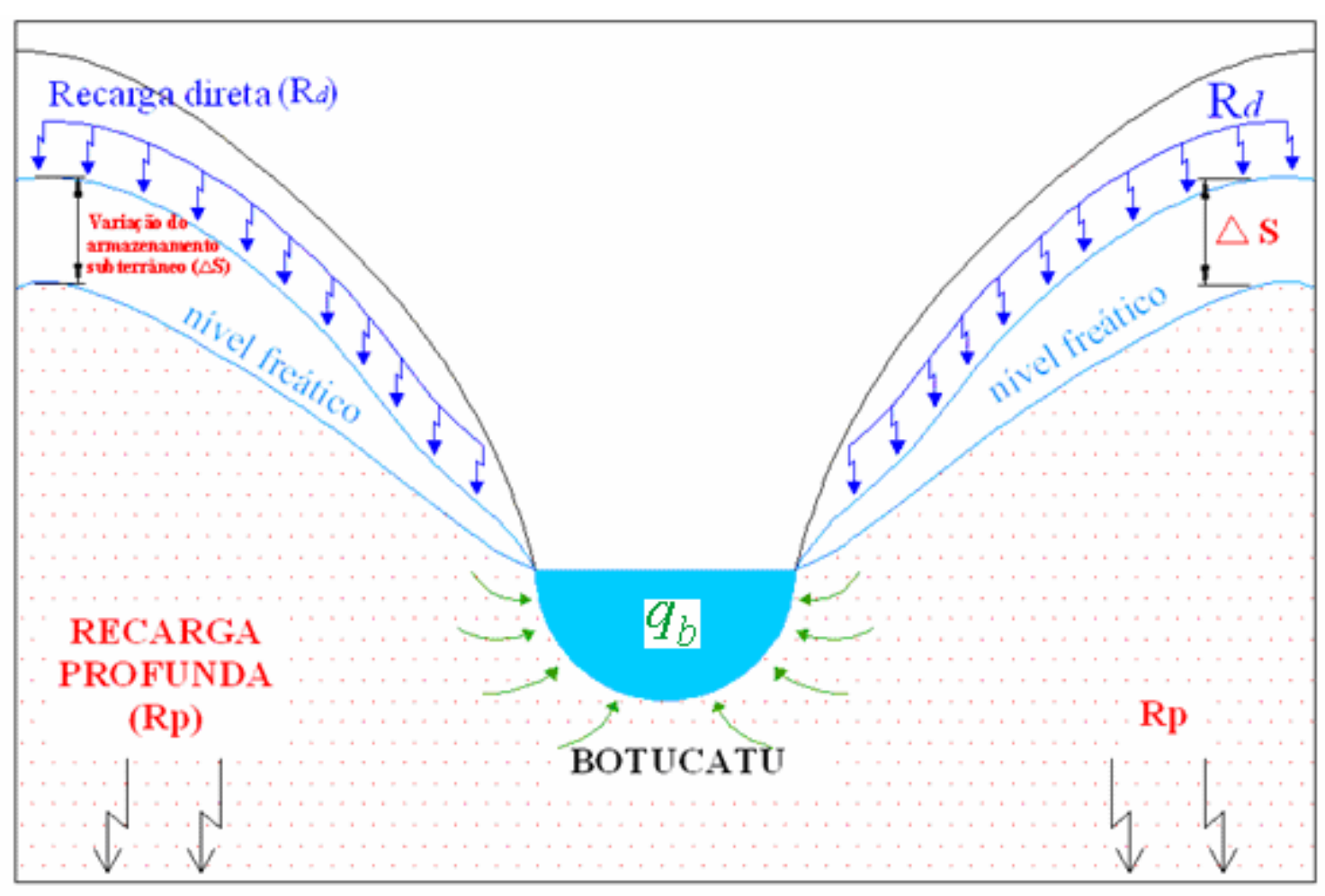

Figura 47: Volume de controle conceitual para balanço hídrico pelo método1 


\subsubsection{Método 2}

O método 2 proposto estima a recarga profunda através da seguinte equação de balanço hídrico para o volume de controle apresentado na Figura 48:

$$
R_{P}=P+I r-E S-Q_{b}-\Delta S-E T
$$

sendo:

$R_{p}$ é a recarga profunda $(\mathrm{mm}) ;$

$P$ é a precipitação $(\mathrm{mm})$;

Ir é a irrigação (mm);

$E S$ é o escoamento superficial direto $(\mathrm{mm})$;

$Q_{b}$ é o escoamento de base ( $\left.\mathrm{mm}\right)$

$\Delta S$ é a variação do armazenamento subterrâneo $(\mathrm{mm})$;

ET é a evapotranspiração real (mm).

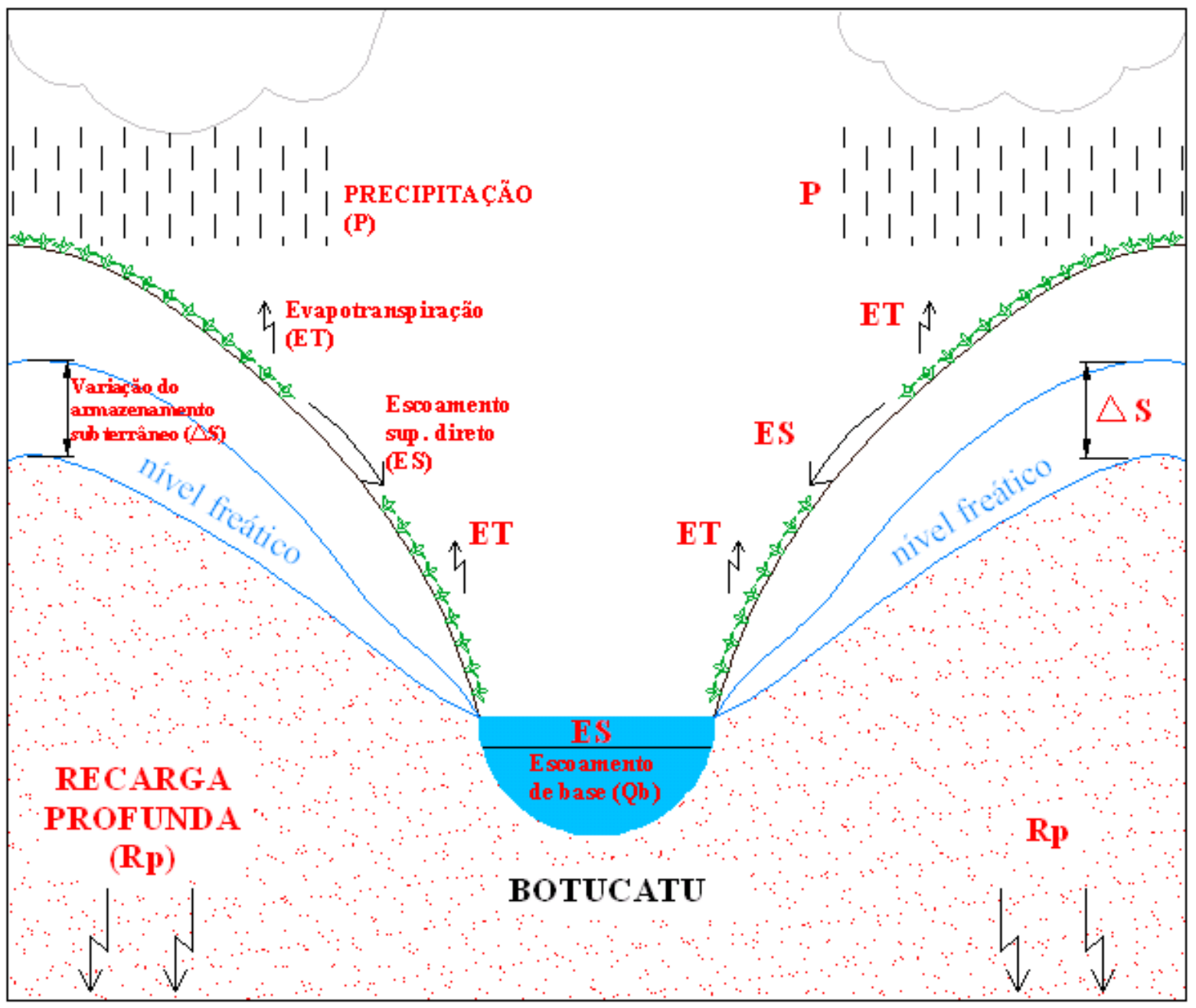

Figura 48: Volume de controle para balanço hídrico na a bacia do Ribeirão da Onça pelo método 2 
As entradas no sistema são a precipitação e a irrigação. As saídas são o escoamento de base $\left(Q_{b}\right)$, o escoamento superficial direto (run off), a evapotranspiração e a recarga profunda. A variação no armazenamento é considerada uma zona intermediária entre a entrada e a saída.

Este balanço pode ser executado com diversos métodos de estimativa da evapotranspiração. Com isso pretende-se avaliar as incertezas provocadas por estas estimativas.

O período para realização do balanço também é anual, apesar das parcelas da equação do balanço serem estimadas em intervalos mensais.

Pompêo (1990) afirma que o balanço de umidade do solo é nulo para o período anual. Mas essa variação se fará notar nos meses de mudança do período seco para o úmido.

\subsubsection{Método 3}

O método 3 proposto estima a evapotranspiração real a partir de dados de precipitação $(P)$, recarga direta $\left(R_{d}\right)$ e escoamento superficial direto $(E S$, run off). A Figura 49 apresenta o volume de controle utilizado no método 3.

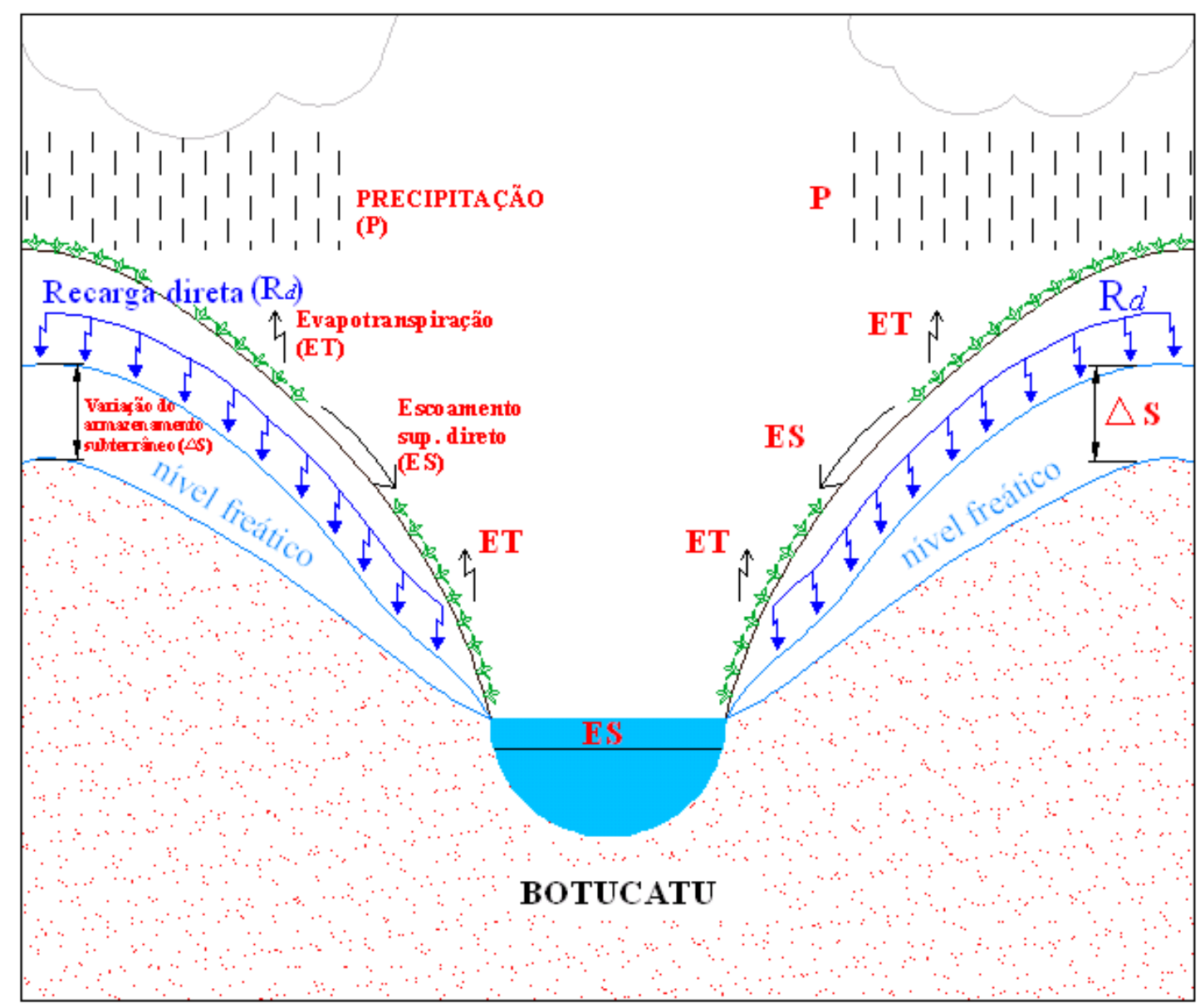

Figura 49: Volume de controle para balanço hídrico na a bacia do Ribeirão da Onça pelo método 3 
A equação de balanço hídrico utilizada foi:

$$
E T=P-E S-R_{d}
$$

Foi considerado que a variação da umidade do solo é nula para o período anual, como foi apresentado na seção anterior. 
5. RESULTADOS E DISCUSSÕES 

Essa seção apresenta os resultados do monitoramento da bacia, das estimativas das parcelas consideradas do ciclo hidrológico e o resultado dos 3 métodos de balanço hídrico. Os resultados obtidos do monitoramento foram bastante satisfatórios. Exceção se faz ao linígrafo, que, devido à variação do leito do ribeirão, não apresentou coerência entre os valores de nível e de vazão, e a alguns poços de monitoramento, que permaneceram secos por certo intervalo de tempo. As parcelas do balanço hídrico apresentaram um resultado dentro de uma faixa possível de valores para essas variáveis. Os resultados encontrados para o balanço hídrico indicam que a recarga direta está em torno de $400 \mathrm{~mm}$ e que a recarga profunda está entre zero $\mathrm{mm}$ e 40mm anuais. Os resultados obtidos pelo método 2 indicam que os métodos empíricos de cálculo da evapotranspiração superestimam o valor dessa variável do ciclo hidrológico. $\mathrm{O}$ método 3 confirma os valores superestimados da evapotranspiração, encontrados pelos métodos empíricos, com exceção do método de Thornthwaite que apresenta um valor de 3\% a $-6 \%$ quando comparado com a evapotranspiração estimada pelo método 3.

\subsection{Nível do aqüífero}

A bacia do Ribeirão da Onça conta com 23 poços de monitoramento.

As medidas realizadas manualmente, em relação à boca do poço, estão apresentadas no apêndice $F$.

Alguns poços permaneceram secos por um determinado intervalo de tempo. São eles os poços $01,02,06,07,11,12$ e 20. Os poços 20, 21, 22 e 23, localizados próximos às margens do ribeirão, não apresentaram uma boa resposta ao monitoramento quinzenal. Devido aos poços estarem locados em uma área com pequena camada de zona saturada, podese notar uma rápida elevação do nível do freático em resposta a um determinado evento de chuva. Para que essa rápida elevação fosse detectada, para todos os eventos de chuva, é necessário um monitoramento com um intervalo de tempo menor entre as medições.

Os gráficos a seguir (Gráfico 3 ao Gráfico 11) mostram a variação do nível do aqüífero em relação ao nível do solo. São apresentados apenas os gráficos do nível freático dos poços que foram considerados neste estudo.

O erro máximo para o valor coletado no data logger foi de $5 \mathrm{~cm}$, quando se compara este valor com os valores obtidos na medição manual. Esse erro é um erro sistemático do aparelho e foi encontrado em um único dado coletado de um único poço. Em média o erro sistemático apresentado pelo data logger foi igual a $1 \mathrm{~cm}$. 


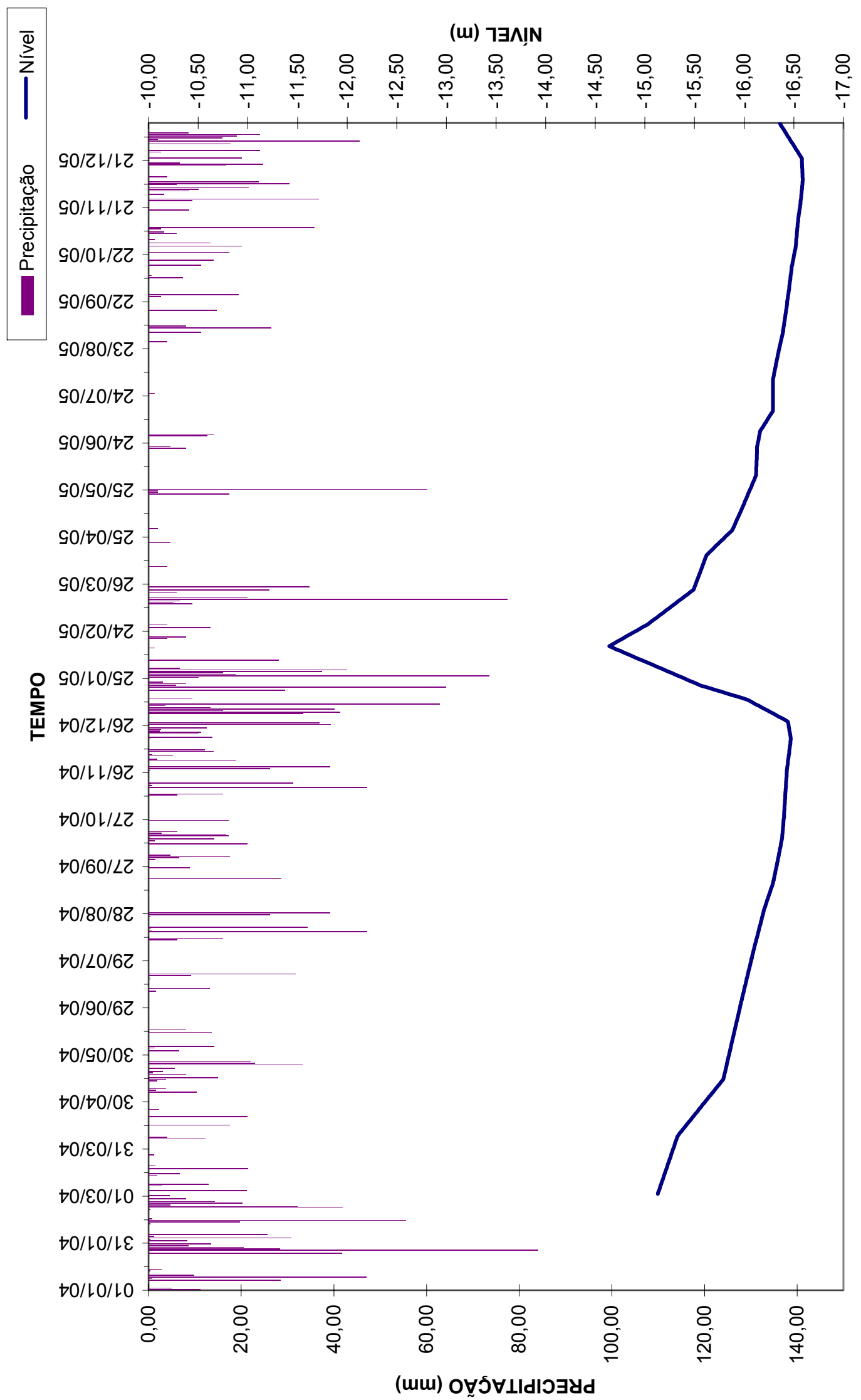

Gráfico 3: Nível do aqüífero em relação ao solo no poço 03 , locado entre as culturas de pastagem e de eucalipto. 
(u) $7 \exists \wedge ! ! N$

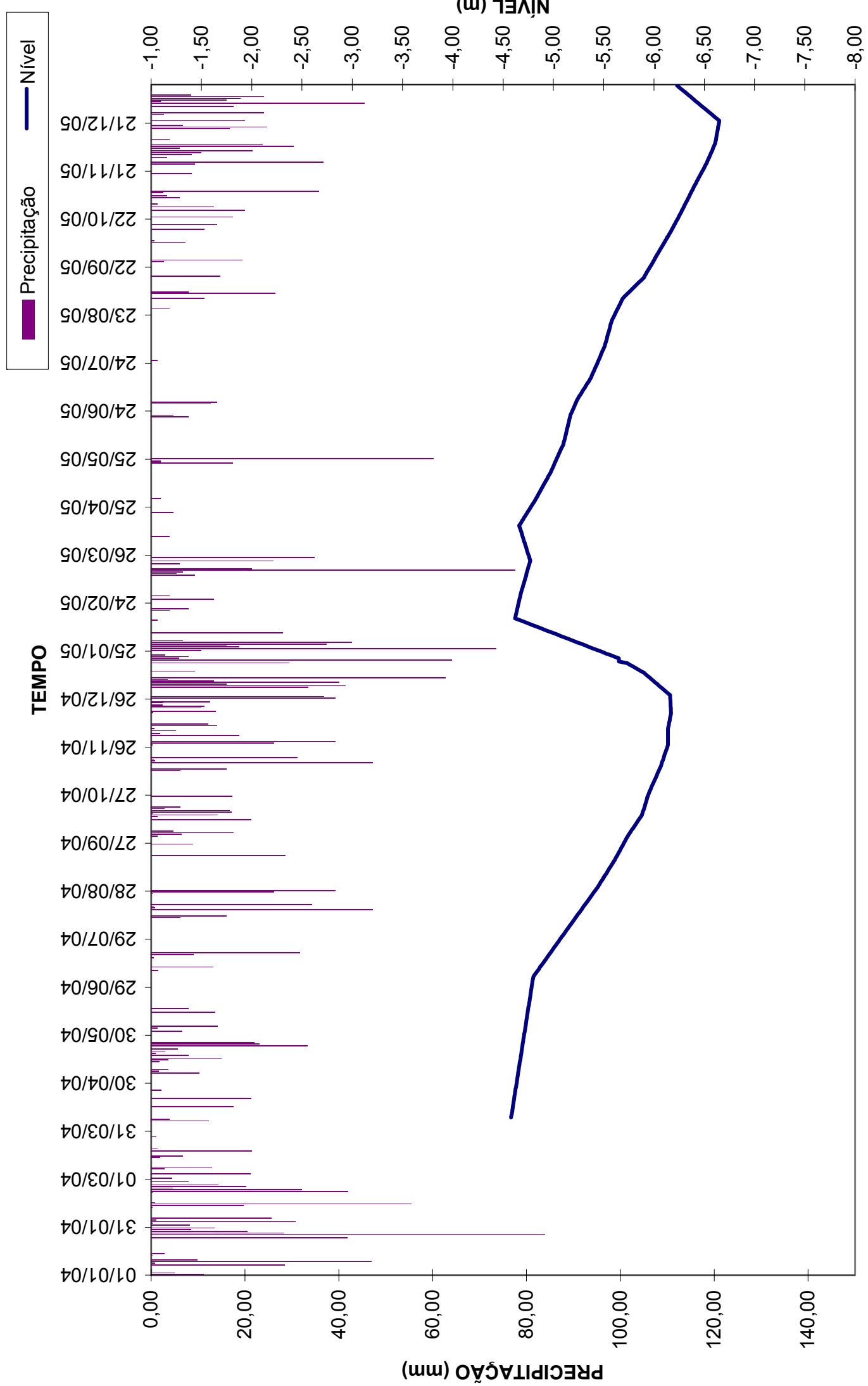

Gráfico 4: Nível do aqüífero em relação ao solo no poço 05 , locado em cultura de pastagem. 


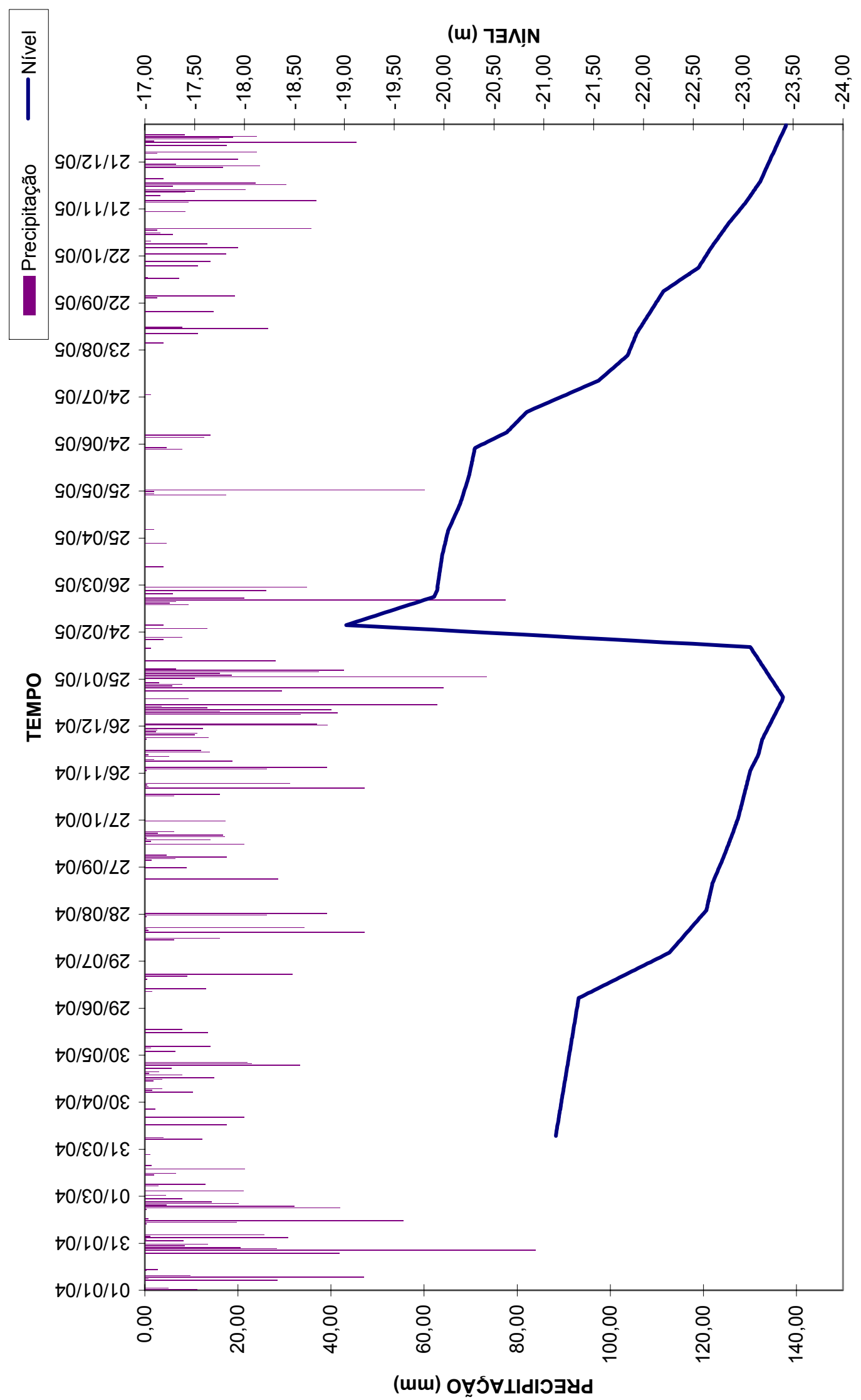

Gráfico 5: Nível do aqüífero em relação ao solo no poço 08 , locado em cultura de laranja. 


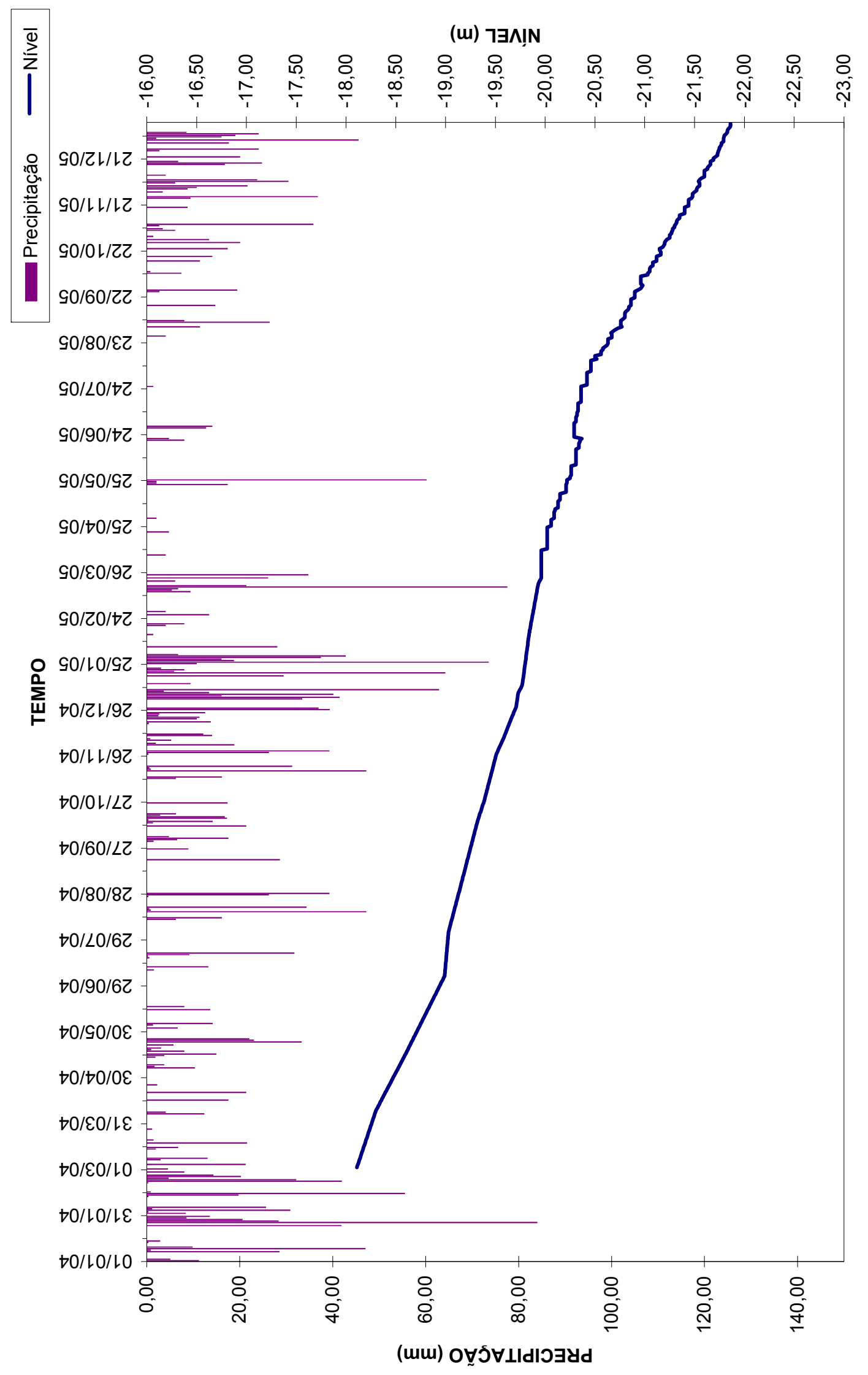

Gráfico 6: Nível do aqüífero em relação ao solo no poço 09 , locado em cultura de eucalipto. 


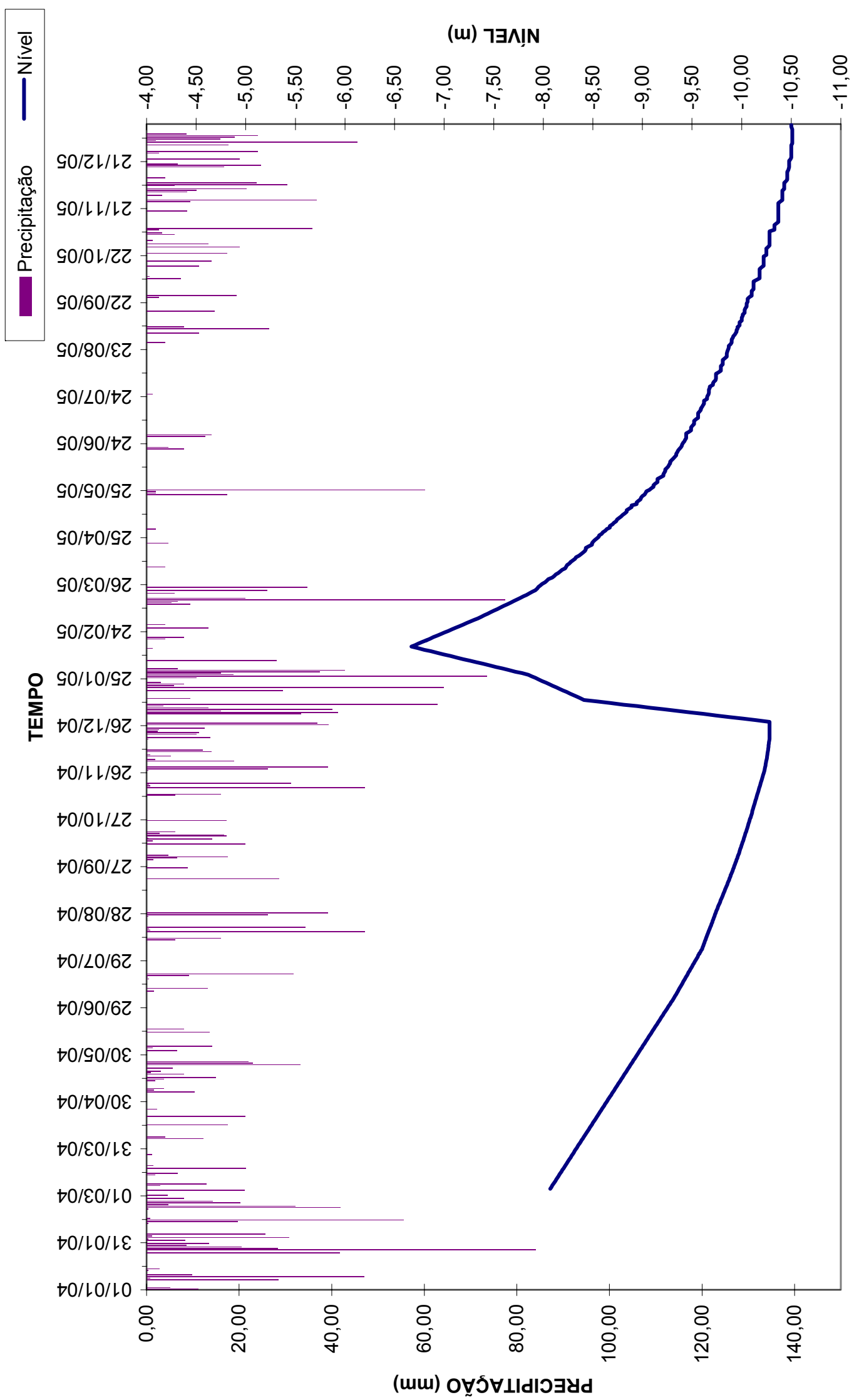

Gráfico 7: Nível do aqüífero em relação ao solo no poço 13, locado em cultura de laranja. 


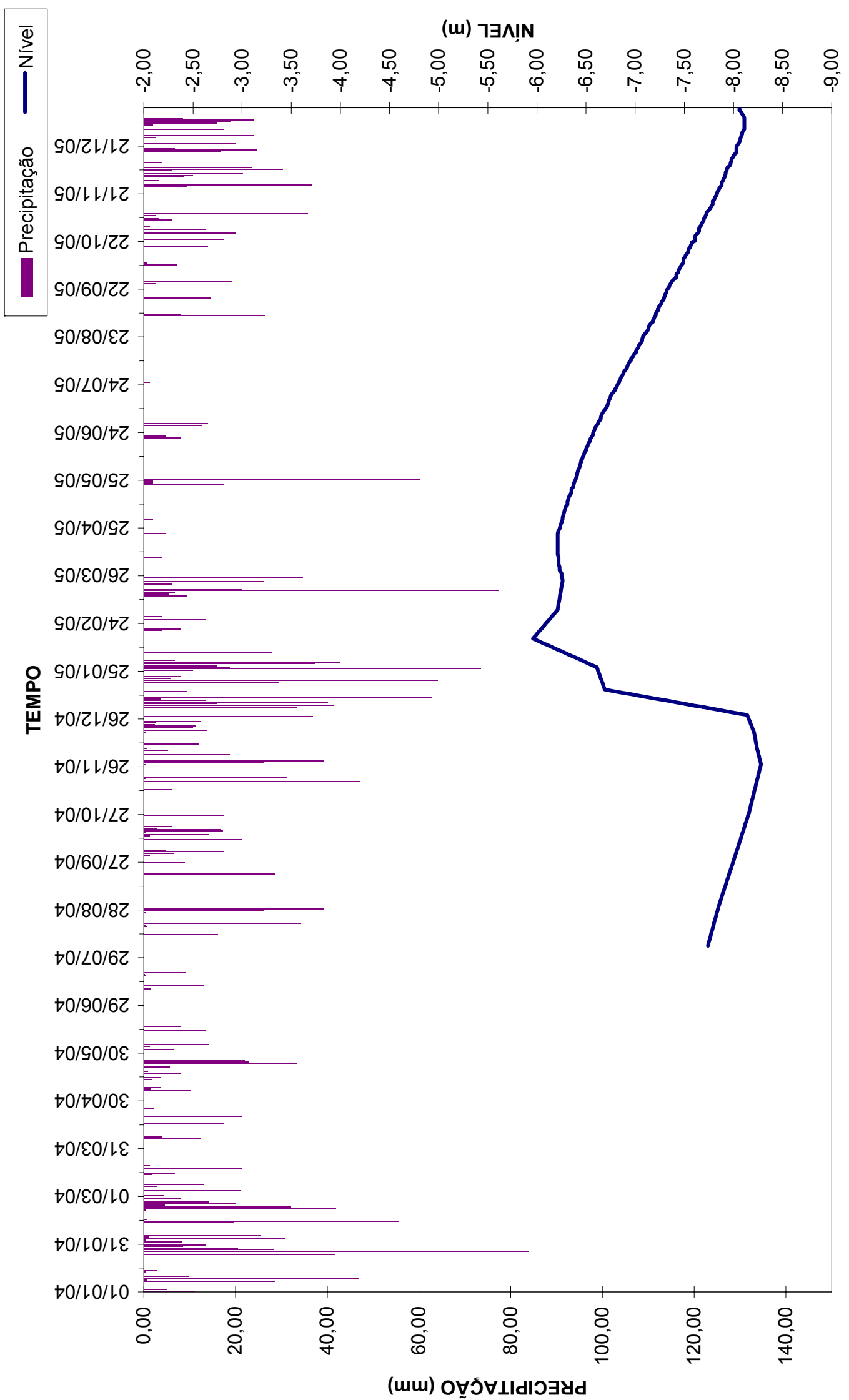

Gráfico 8: Nível do aqüífero em relação ao solo no poço 15 , locado em cultura de cana-de-açúcar com rodízio de culturas para amendoim. 
(w) $7 \exists \wedge I N$

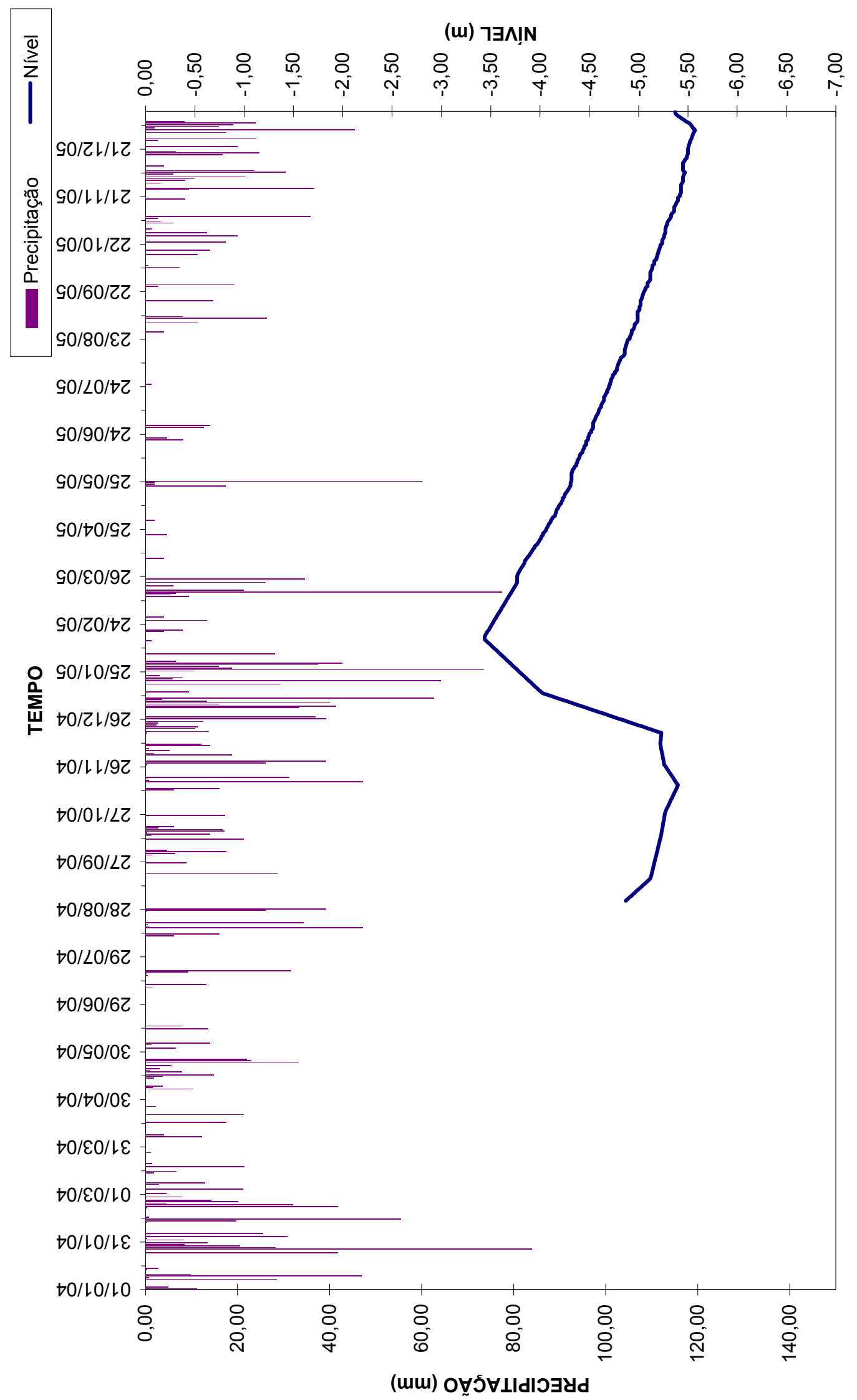

Gráfico 9: Nível do aqüífero em relação ao solo no poço 16, locado em cultura de pastagem. 


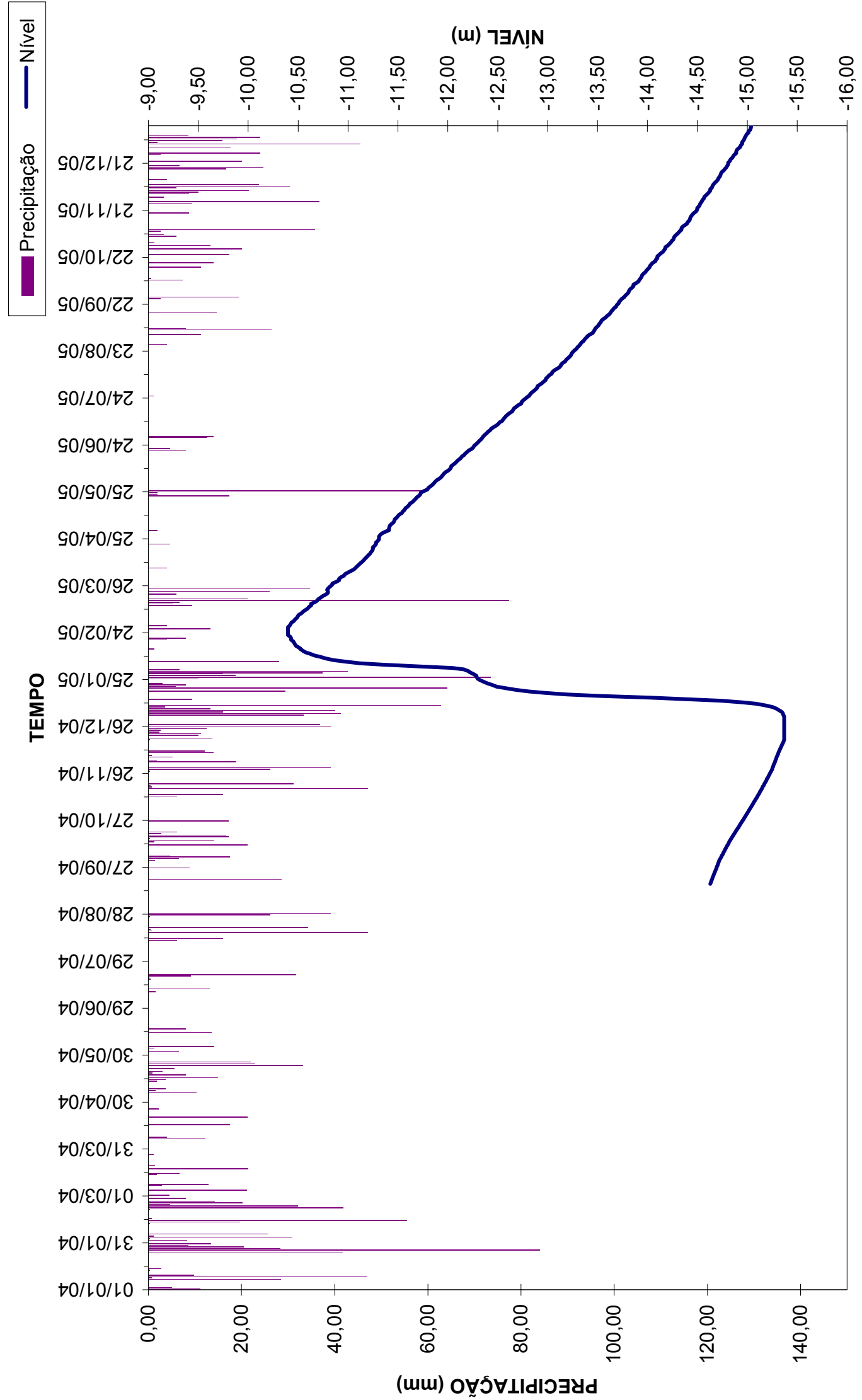

Gráfico 10: Nível do aqüífero em relação ao solo no poço 18 , locado em cultura de pastagem. 


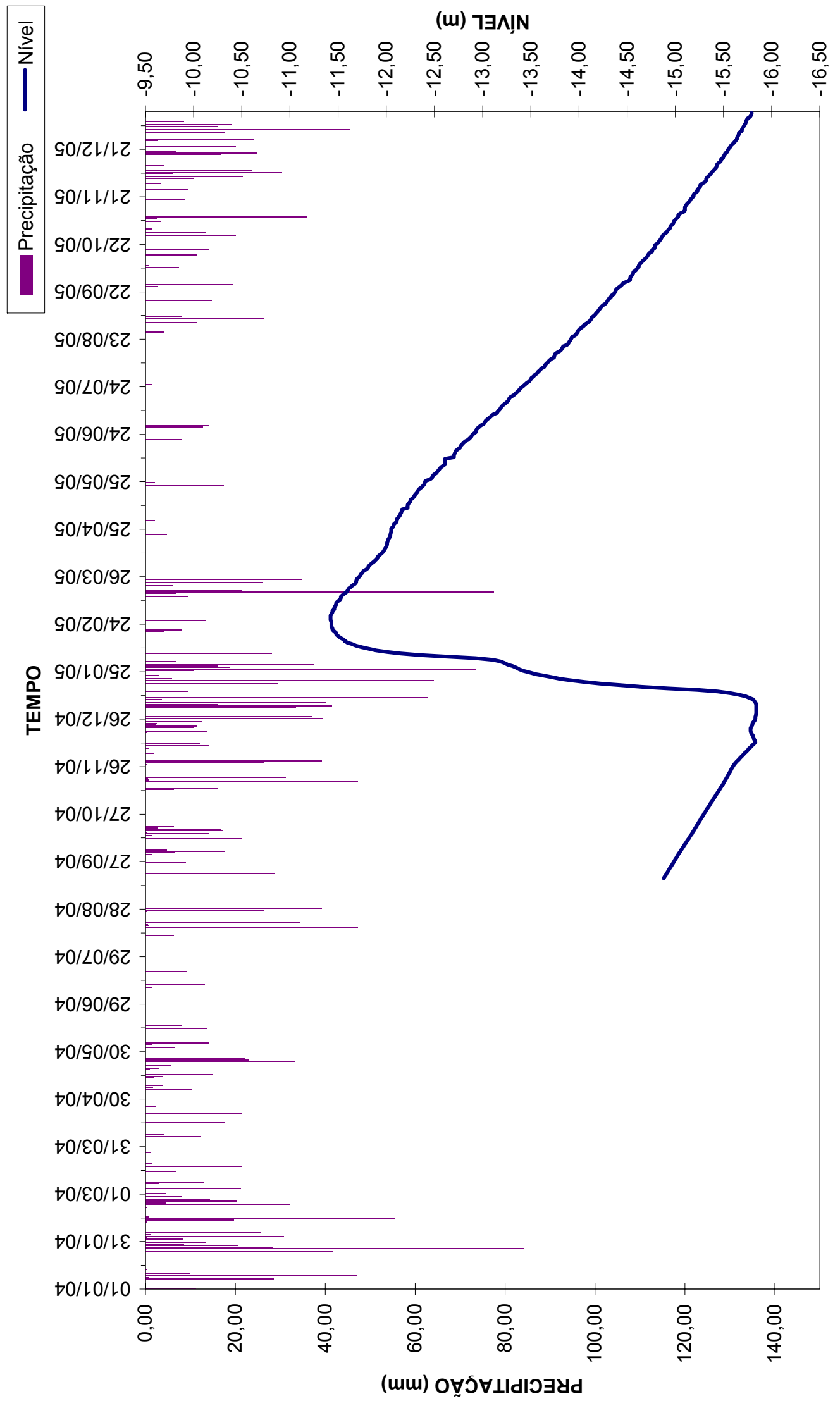

Gráfico 11: Nível do aqüífero em relação ao solo no poço 19, locado em cultura de pastagem. 


\subsection{Análise da variação do nível do aqüífero}

Esta seção trás uma análise do comportamento da variação do nível do aqüífero. Esta análise é feita sob o ponto de vista estatístico e pela análise visual dos gráficos de variação do nível do freático.

Para essa análise, foram excluídas as leituras do nível do aqüífero em alguns poços de monitoramento. Os poços $01,02,06,07,11,12$ e 20 permaneceram secos por algum intervalo de tempo e foram descartados. Os poços 04 e 10 foram preteridos pelos poços 05 e 09 , respectivamente, por estarem muito próximos um do outro, não sendo necessário a utilização de todos. As leituras quinzenais nos poços 21, 22, 23 não foram suficientes para acompanhar a variação do nível de água nesses poços e por isso foram excluídos (Gráfico 12). O poço 17 foi descartado por estar próximo aos poços 16 e 18, além disso, nesse poço as medições não puderam ser realizadas quinzenalmente.

Uma boa correlação entre o nível de água em poços de monitoramento é dependente de alguns fatores. Os principais fatores observados neste trabalho foram: a espessura da camada não-saturada do solo e a cultura no entorno do poço.

Para que a água precipitada, que chega a superfície do solo, alcance a zona saturada do solo, é necessário que a umidade da zona não-saturada permita a formação de água gravitacional. A água gravitacional é aquela que, no meio poroso, vence as tensões superficiais entre a água e os grãos e alcança níveis mais profundos, levada pela força gravitacional. No período seco, há um declínio da umidade na zona não-saturada do solo. Quanto maior a espessura da camada não-saturada maior será a quantidade de água necessária para que o solo atinja um nível de umidade que permita a formação de água gravitacional, após o período seco. Então, poços com uma espessura da zona não-saturada maior têm um retardo na ascensão do nível de água, quando comparados com poços onde a zona nãosaturada é menor.

A Figura 50 apresenta a variação dos níveis de água em poços de monitoramento locados em pastagem. A variação do nível de água é contada a partir do dia 16/09/2005, partindo do nível "zero". A espessura média da zona não-saturada do solo para os poços 05 , 16, 18 e 19 é de 5,64, 4,72, 13,30 e 13,97m, respectivamente. Para o primeiro período chuvoso, o poço 16 reage primeiro aos eventos de precipitação, e em seqüência o poço 05,18 e 19. O nível de água no poço 16 começa a subir no dia 16/11/2004, aproximadamente, enquanto que o poço 05 , no dia 29/11/2004, o poço 18 no dia no dia 16/12/2004 e o poço 19 no dia 23/12/04. 


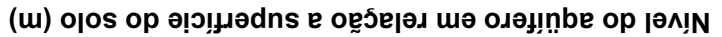

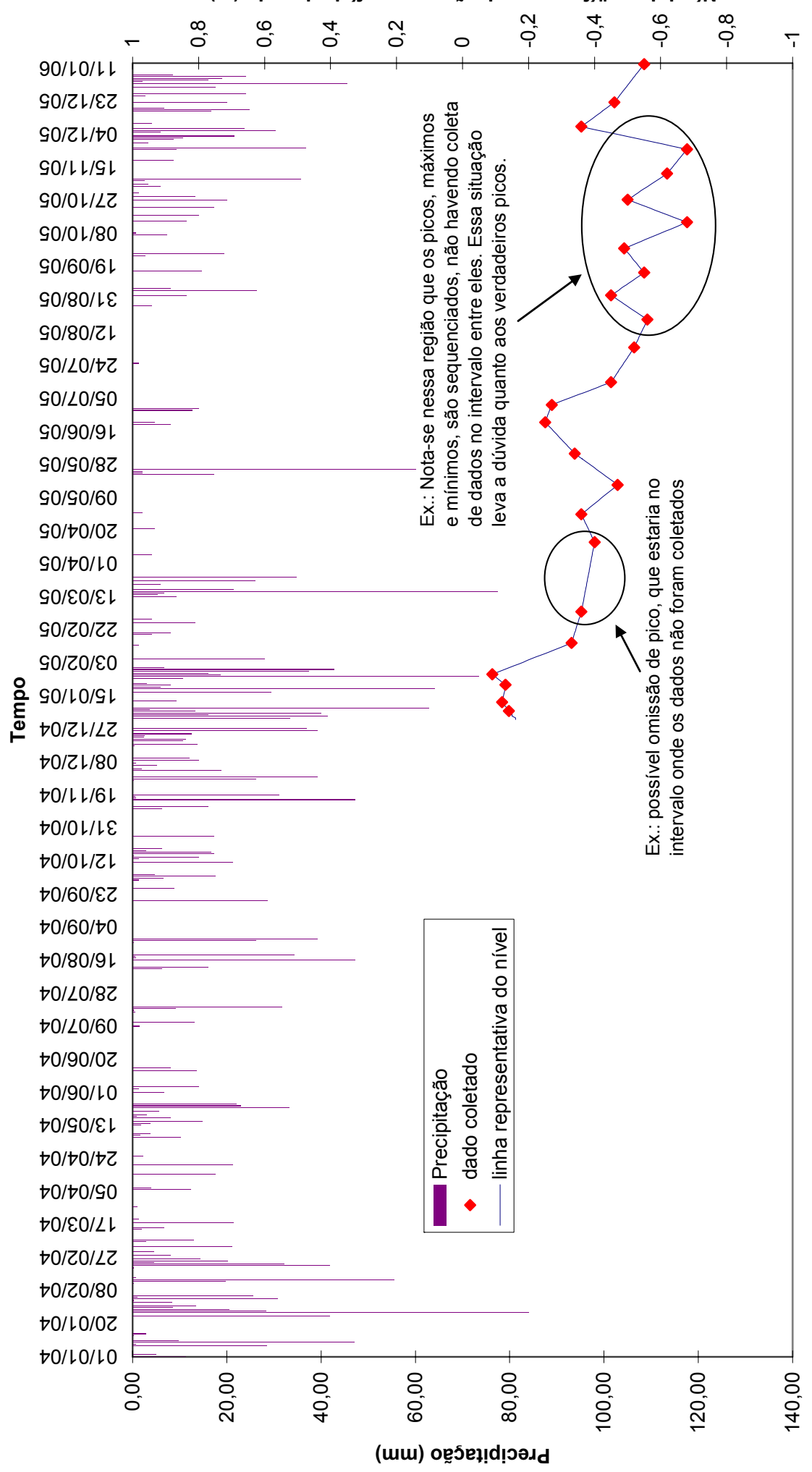

Gráfico 12: Nível do aqüífero em relação ao solo no poço 21 , locado próximo ao ribeirão 
O início do decréscimo dos níveis ocorre praticamente ao mesmo tempo em todos os poços.

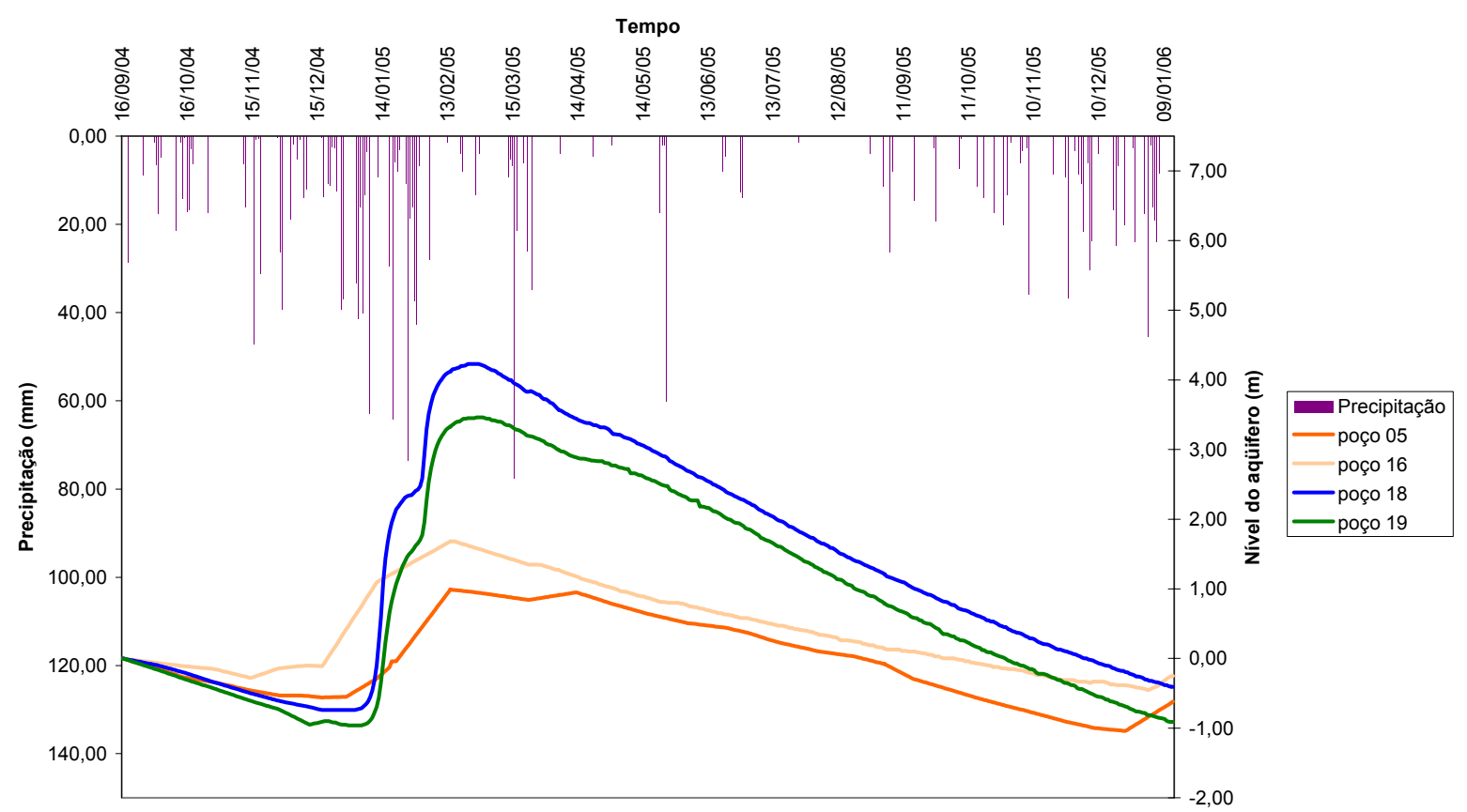

Figura 50: Variação do nível de água em poços de monitoramento locados na cultura de pastagem

A Figura 51 apresenta a variação do nível do aqüífero na seção formada pelos poços 16,18 e 19. Pode-se notar que no inicio do período chuvoso, 16/12/2005, apenas o poço 16 reage aos eventos de precipitação. Isso causa uma mudança na inclinação da linha d'água.

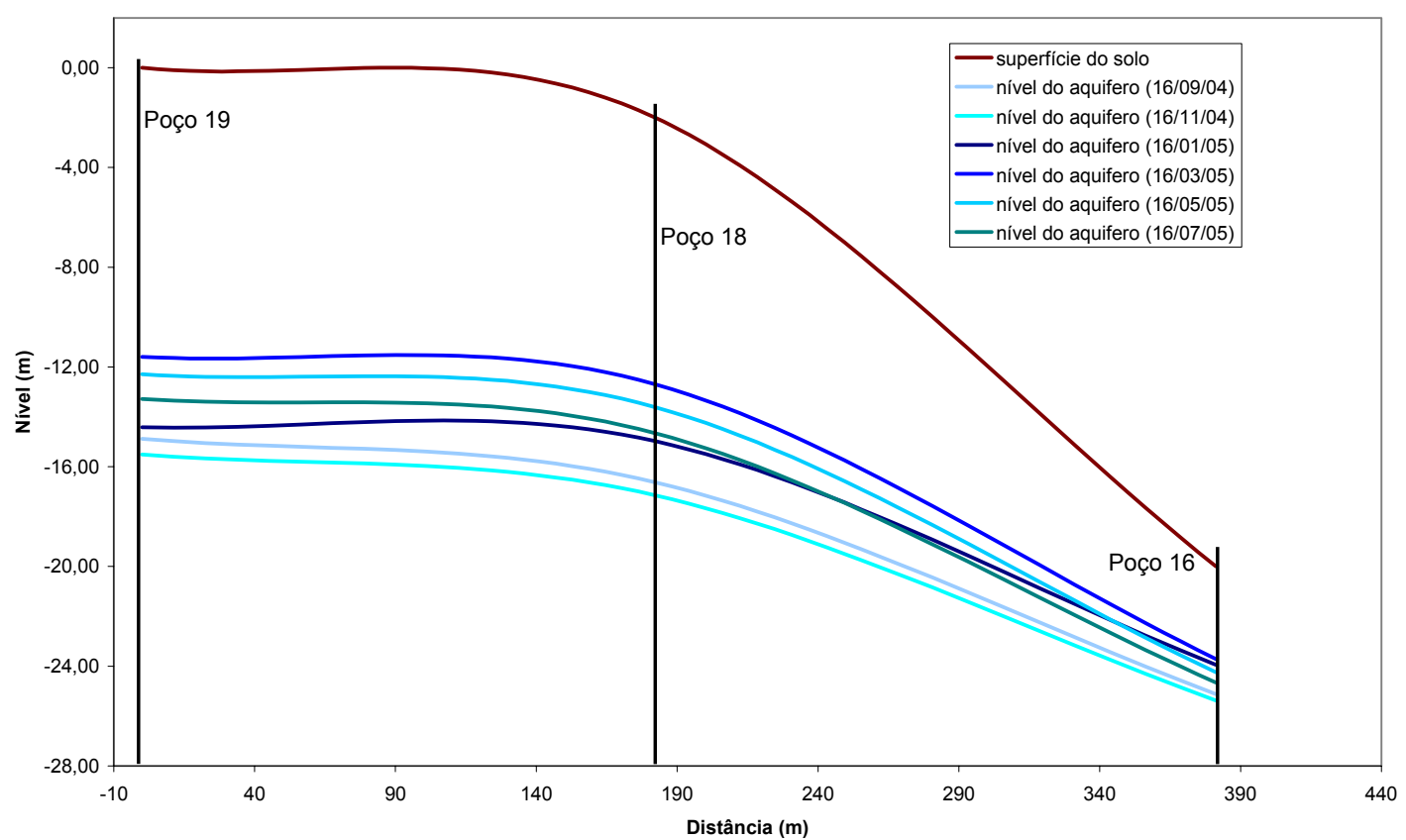

Figura 51: Variação do nível do aqüífero na seção formada pelos poços 16, 18 e 19. 
No período seco a mudança da inclinação na linha d'água é suavizada lentamente.

A correlação entre os níveis dos poços locados em cultura de pastagem apresenta valores entre 0,87 e 0,99 (Tabela 11 ).

Tabela 11: Tabela de correlação entre os dados de nível de água nos poços locados em cultura de pasto entre os dias 16/09/04 e 13/01/2006.

\begin{tabular}{|l|c|ccc|c|}
\hline \multicolumn{5}{|c|}{ CORRELAÇÃO } \\
\hline & Poço 05 & Poço 16 & Poço 18 & Poço 19 \\
\hline Poço 05 & - & - & - & - \\
\hline Poço 16 & 0,89 & - & - & - \\
\hline Poço 18 & 0,92 & 0,89 & - & - \\
\hline Poço 19 & 0,95 & 0,87 & 0,99 & - \\
\hline
\end{tabular}

A correlação entre os poços indica que, na cultura do pasto, a variação do nível do aqüífero ocorre de forma semelhante. O nível de correlação é reduzido no período entre o término da estação seca e o início da estação chuvosa.

A Figura 52 apresenta a variação dos níveis de água em poços de monitoramento locados em cultura de citros. A variação do nível de água é contada a partir do dia 16/09/2005, partindo do nível “zero". A espessura média da zona não-saturada do solo para os poços 08,13 e 14 é de 21,94, 9,44, 6,23m, respectivamente. Para o período chuvoso, os poços 13 e 14 reagiram primeiro aos eventos de precipitação, praticamente no mesmo instante, no dia 30/12/2004. O poço 08 começa a reagir aos eventos de precipitação a partir do dia $13 / 01 / 2005$.

O início do decréscimo dos níveis ocorre praticamente ao mesmo tempo nos poços 13 e 14, aproximadamente no dia 14/02/2005. O nível de água no poço 08 começa a cair, aproximadamente, no dia 28/02/2005.

O comportamento do nível de água no poço 08 é diferente do comportamento nos poços 13 e 14. No poço 08 o nível de água só começa a cair, aproximadamente, 14 dias após os níveis de água nos poços 13 e 14. Enquanto que nos poços 13 e 14 existe um declínio no nível de água de forma gradual, no poço 08 o declínio ocorre por etapas, com diferentes mudanças na inclinação da linha d'água.

A Figura 53 apresenta o nível do aqüífero em uma seção formada pelos poços 09, 08, 13, onde as curvas do nível do aqüífero são aproximadas por linhas suavizadas. A figura indica que o nível de água no poço 08 sofreu a influência da mudança da posição do divisor 
subterrâneo da bacia, explicando o comportamento atípico da variação do nível de água no poço 08 , quando comparado com os poços 13 e 14 .

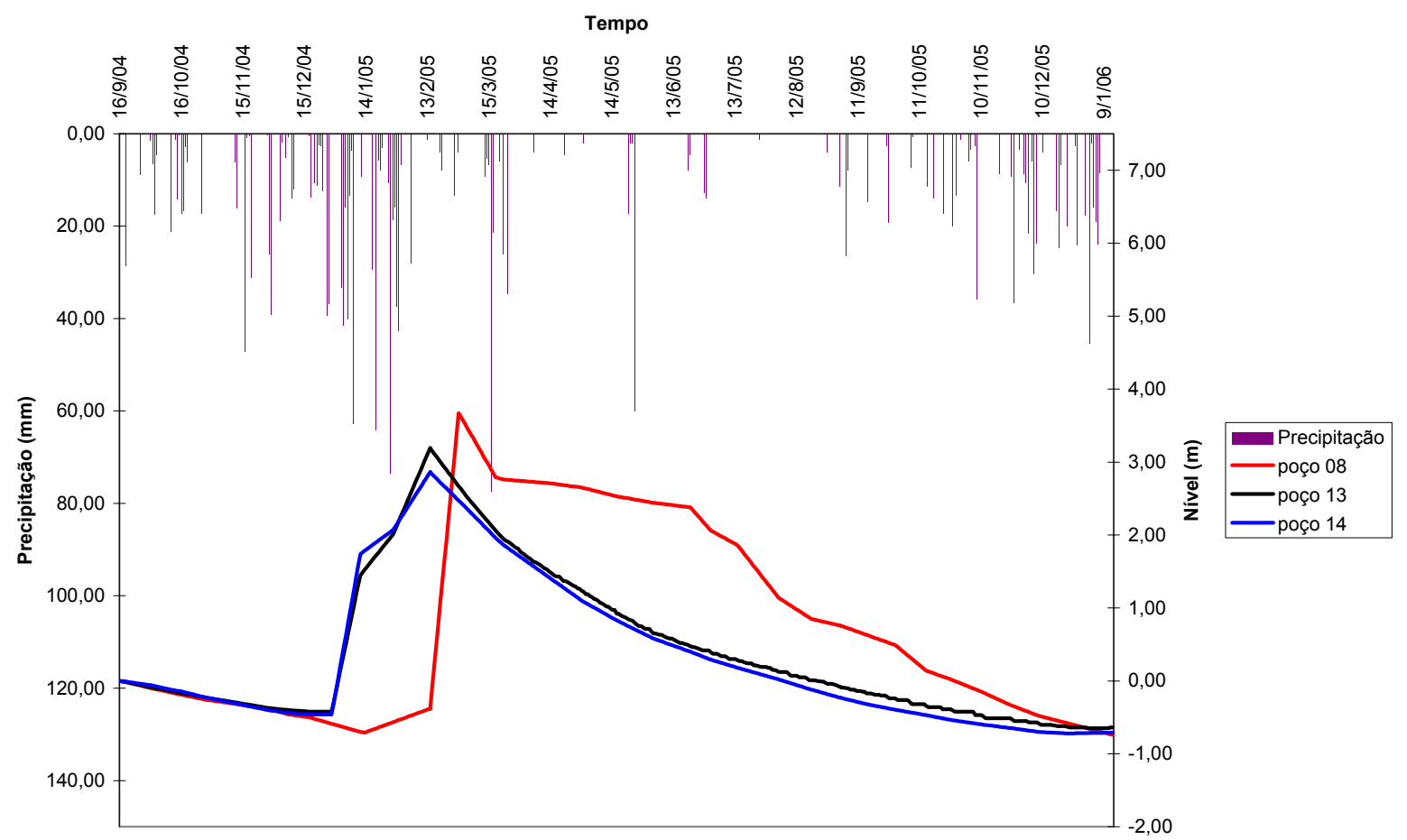

Figura 52: Variação do nível de água em poços de monitoramento locados na cultura de citros

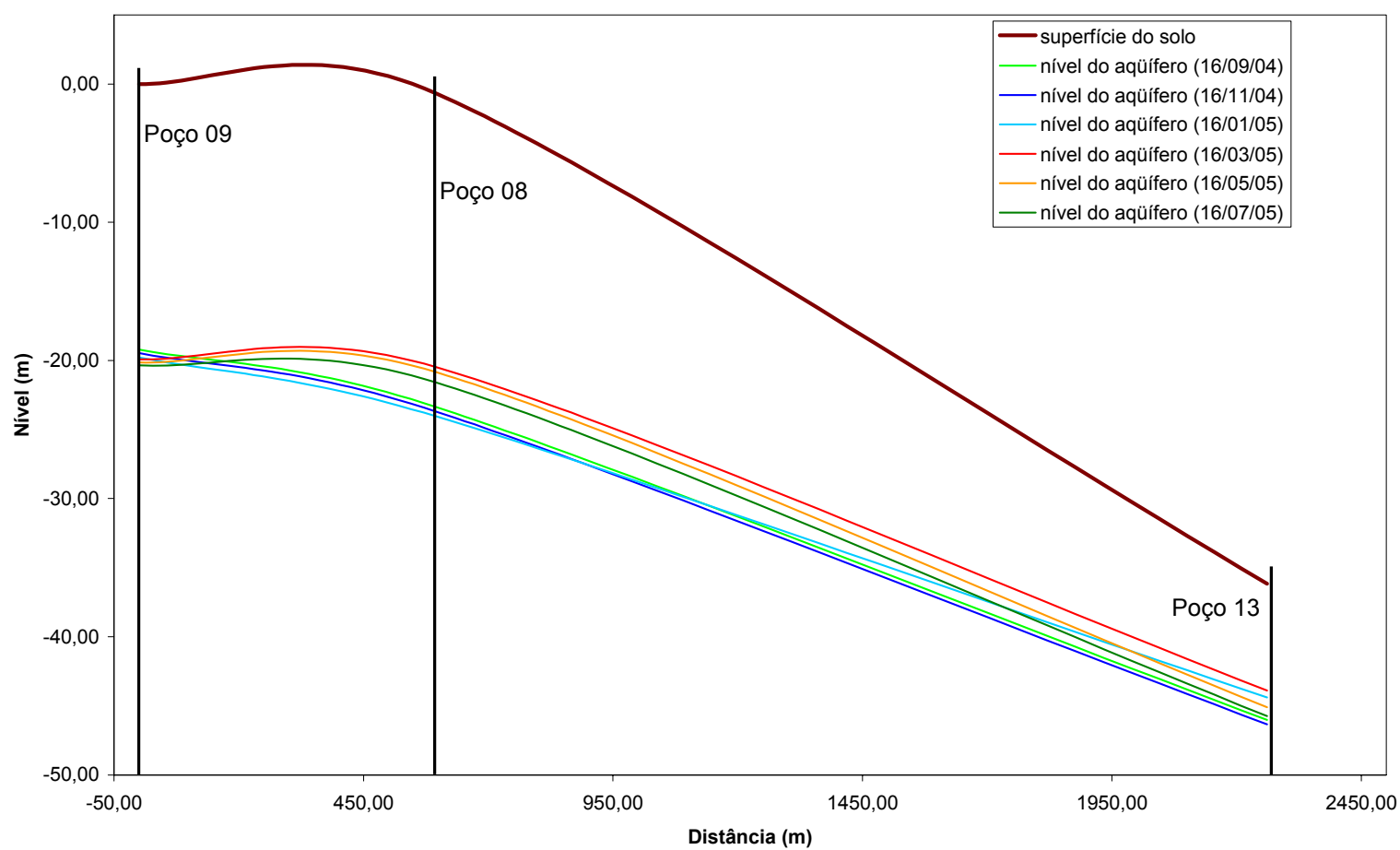

Figura 53: Variação do nível do aqüífero na seção formada pelos poços 09, 08 e 13. 
Conseqüência disso, a correlação entre o nível de água no poço 08 e nos poços 13 e 14 é baixa, enquanto que a correlação entre os níveis de água nos poços 13 e 14 é elevada (Tabela 12).

Tabela 12: Tabela de correlação entre os dados de nível de água nos poços locados em cultura de citros entre os dias 16/09/04 e 13/01/2006

\begin{tabular}{|c|c|c|c|}
\hline \multicolumn{4}{|c|}{ CORRELAÇÃO } \\
\hline & Poço 08 & Poço 13 & Poço 14 \\
\hline Poço 08 & - & - & - \\
\hline Poço 13 & 0,53 & - & - \\
\hline Poço 14 & 0,50 & 1,00 & - \\
\hline
\end{tabular}

Os poços de monitoramento existentes nas demais culturas não permitem uma análise entre o nível de água em diferentes poços de uma mesma cultura, por não existirem poços suficientes.

Para a maior parte dos poços de monitoramento, o nível de água baixou entre os dias 01/01/2005 e 31/12/2005 (Tabela 13).

Tabela 13: Variação do nível de água em poços de monitoramento para o ano de 2005.

\begin{tabular}{|c|c|c|c|c|c|c|ccc|c|c|c|}
\hline \multicolumn{1}{|c|}{ VARIAÇÃo ANUAL DE NÍVEL DE ÁGUA (m) } \\
\hline Poço 03 & Poço 05 & Poço 08 & Poço 09 & Poço 13 & Poço 14 & Poço 15 & Poço 16 & Poço 18 & Poço 19 \\
\hline$-0,17$ & $-0,39$ & $-0,03$ & $-2,05$ & $-0,75$ & $-0,88$ & $-0,33$ & $-1,05$ & 0,44 & 0,18 \\
\hline
\end{tabular}

Essa queda nos níveis pode ser explicada pelo fato de que, no ano de 2004, houve uma precipitação acima da média, $1614 \mathrm{~mm}$, aumentando os níveis do aqüífero a um patamar acima do normal.

No poço 09 houve uma queda de 2,05m no nível de água no poço. Essa queda acima do observado em outros poços pode ser atribuída ao desenvolvimento do eucalipto que pode consumir muita água, além de interceptar parte da chuva.

A correlação entre os níveis de água em poços locados em culturas diferentes é alta. A exceção se faz aos poços 08 e 09, que apresentam comportamento atípico (Tabela 14). A Figura 54 apresenta a variação dos níveis de água em poços de monitoramento locados na cultura de eucaliptos, poço 09, citros, poço 13, cana-de-açúcar, poço 15 e pasto, poço 19. A espessura média da zona vadosa para os poços 09, 13, 15 e 19 são 20,30m, 9,44m, 7,21m e 
13,97m, respectivamente. Pode-se observar um comportamento semelhante entre os poços 13, 15 e 19, não acontecendo o mesmo com o poço 09.

Tabela 14: correlação entre o nível de água em diferentes poços de monitoramento locados em diversas culturas, no período de 16/09/2004 a 13/01/2006.

\begin{tabular}{|l|c|c|c|c|cc|c|c|c|c|c|}
\hline \multicolumn{10}{|c|}{ CORRELAÇ̃̃o } \\
\hline & Poço 03 & Poço 05 & Poço 08 & Poço 09 & Poço 13 & Poço 14 & Poço 15 & Poço 16 & Poço 18 & Poço 19 \\
\hline Poço 03 & - & - & - & - & - & - & - & - & - & - \\
\hline Poço 05 & 0,81 & - & - & - & - & - & - & - & - & - \\
\hline Poço 08 & 0,46 & 0,82 & - & - & - & - & - & - & - & - \\
\hline Poço 09 & 0,39 & 0,46 & 0,13 & - & - & - & - & - & - & - \\
\hline Poço 13 & 0,98 & 0,85 & 0,53 & 0,40 & - & - & - & - & - & - \\
\hline Poço 14 & 0,98 & 0,84 & 0,50 & 0,44 & 1,00 & - & & & & \\
\hline Poço 15 & 0,78 & 0,90 & 0,79 & 0,13 & 0,84 & 0,82 & - & - & - & - \\
\hline Poço 16 & 0,93 & 0,89 & 0,62 & 0,40 & 0,97 & 0,97 & 0,91 & - & - & - \\
\hline Poço 18 & 0,83 & 0,92 & 0,82 & 0,14 & 0,86 & 0,83 & 0,97 & 0,89 & - & - \\
\hline Poço 19 & 0,80 & 0,95 & 0,86 & 0,19 & 0,84 & 0,81 & 0,96 & 0,87 & 0,99 & - \\
\hline
\end{tabular}

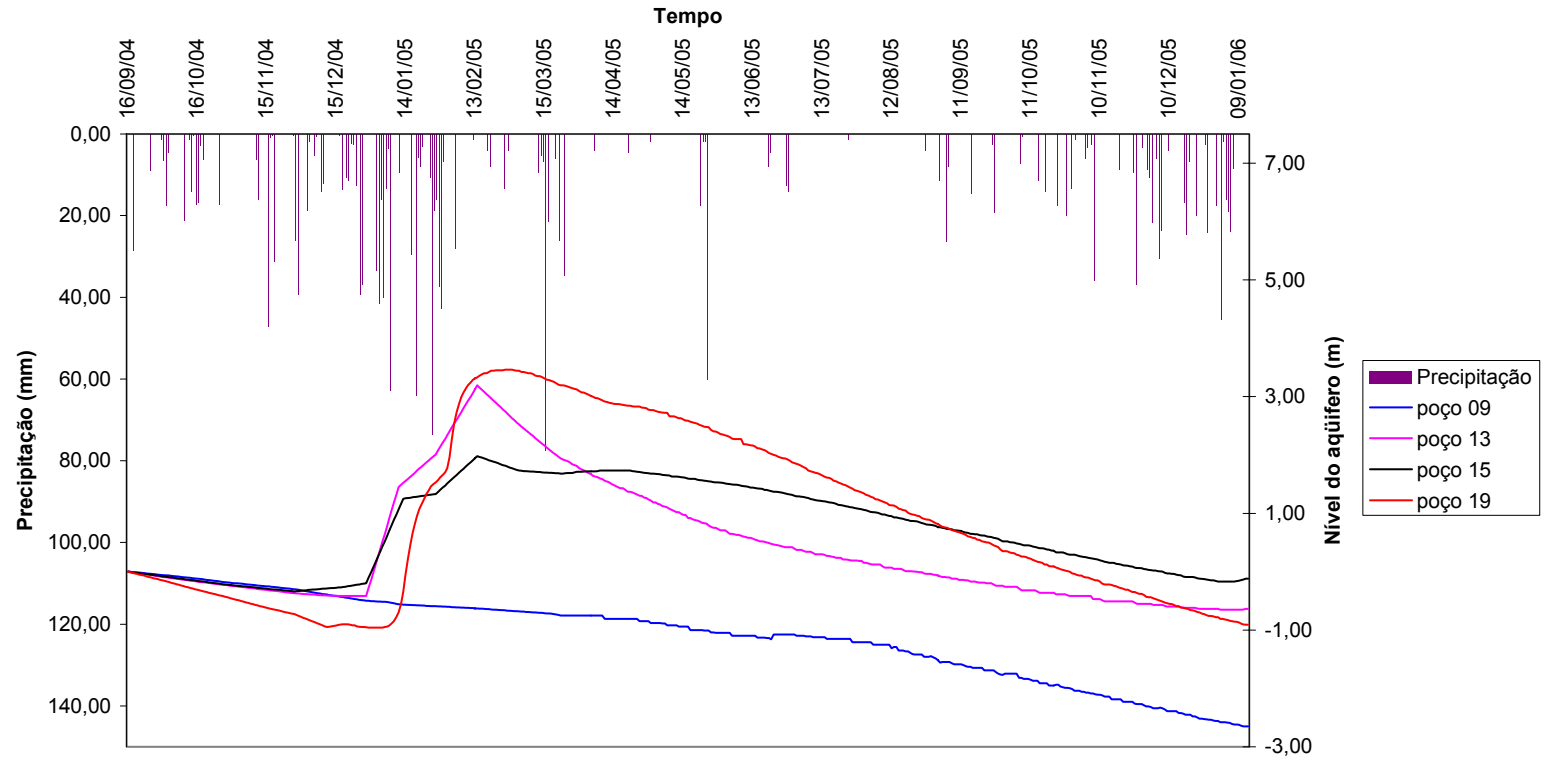

Figura 54: Variação do nível de água em poços de monitoramento locados nas culturas de eucaliptos, laranja, cana-de-açúcar e pasto. 


\subsection{Uso do solo}

A área total calculada da bacia do Ribeirão da Onça foi de $64,61 \mathrm{~km}^{2}$ e a área da subbacia, considerada para esse estudo, foi de $52,76 \mathrm{~km}^{2}$. As tabelas 13 e 14 apresentam a evolução do uso do solo por tipo de cultura e so mapas de uso do solo podem ser observados no apêndice A.

Tabela 15: Evolução temporal do uso do solo por tipo de cultura

\begin{tabular}{|c|c|c|c|c|c|c|c|c|c|c|c|}
\hline \multirow{3}{*}{$\begin{array}{c}\mathbf{P} \\
\mathbf{E} \\
\mathbf{R} \\
\mathbf{I} \\
\mathbf{O} \\
\mathbf{D} \\
\mathbf{O}\end{array}$} & \multicolumn{11}{|c|}{ CULTURA } \\
\hline & amendoim & citros & cerrado & $\begin{array}{l}\text { mata } \\
\text { ciliar }\end{array}$ & pasto & capim & eucalipto & Soja & soja/citros & $\begin{array}{c}\text { cana- } \\
\text { de- } \\
\text { açúcar }\end{array}$ & $\begin{array}{c}\text { solo } \\
\text { parcialmente } \\
\text { descoberto }\end{array}$ \\
\hline & \multicolumn{11}{|c|}{ Área Cultivada (\%) } \\
\hline $\mathrm{dez} / 04$ & 0,00 & 19,09 & 1,60 & 12,56 & 7,84 & 0,34 & 40,61 & 6,60 & 2,96 & 8,41 & 0,00 \\
\hline $\mathrm{jan} / 05$ & 0,00 & 19,09 & 1,60 & 12,56 & 7,84 & 0,34 & 40,61 & 6,60 & 2,96 & 8,41 & 0,00 \\
\hline fev/05 & 0,00 & 19,09 & 1,60 & 12,56 & 7,84 & 0,34 & 40,61 & 6,60 & 2,96 & 8,41 & 0,00 \\
\hline $\mathrm{mar} / 05$ & 0,00 & 19,09 & 1,60 & 12,56 & 7,84 & 0,34 & 40,61 & 6,60 & 2,96 & 8,41 & 0,00 \\
\hline $\mathrm{abr} / 05$ & 0,00 & 22,05 & 1,60 & 12,56 & 7,93 & 0,34 & 40,61 & 0,00 & 0,00 & 8,32 & 6,60 \\
\hline mai/05 & 0,00 & 22,05 & 1,60 & 12,56 & 7,93 & 0,34 & 40,61 & 0,00 & 0,00 & 8,32 & 6,60 \\
\hline jun/05 & 0,00 & 22,05 & 1,60 & 12,56 & 7,93 & 0,34 & 40,61 & 0,00 & 0,00 & 8,32 & 6,60 \\
\hline $\mathrm{jul} / 05$ & 0,00 & 22,05 & 1,60 & 12,56 & 7,93 & 0,34 & 40,61 & 0,00 & 0,00 & 8,32 & 6,60 \\
\hline ago/05 & 1,29 & 21,84 & 1,60 & 12,56 & 7,84 & 0,34 & 40,61 & 0,00 & 0,00 & 7,33 & 6,60 \\
\hline set/05 & 1,29 & 21,84 & 1,60 & 12,56 & 7,84 & 0,34 & 40,61 & 0,00 & 0,00 & 7,33 & 6,60 \\
\hline out $/ 05$ & 1,29 & 21,84 & 1,60 & 12,56 & 7,84 & 0,34 & 40,61 & 6,60 & 0,00 & 7,33 & 0,00 \\
\hline nov $/ 05$ & 1,29 & 21,84 & 1,60 & 12,56 & 7,84 & 0,34 & 40,61 & 6,60 & 0,00 & 7,33 & 0,00 \\
\hline dez/05 & 0,00 & 19,09 & 1,60 & 12,56 & 7,84 & 0,34 & 40,61 & 6,60 & 2,96 & 8,41 & 0,00 \\
\hline
\end{tabular}

Tabela 16: Área de cultivo na sub-bacia do Ribeirão da Onça

\begin{tabular}{|c|c|c|c|c|c|c|c|c|c|c|c|}
\hline \multirow{3}{*}{$\begin{array}{l}\mathbf{P} \\
\mathbf{E} \\
\mathbf{R} \\
\mathbf{I} \\
\mathbf{O} \\
\mathbf{D} \\
\mathbf{O}\end{array}$} & \multicolumn{11}{|c|}{ CULTURA } \\
\hline & amendoim & citros & cerrado & $\begin{array}{l}\text { mata } \\
\text { ciliar }\end{array}$ & pasto & capim & eucalipto & Soja & soja/citros & $\begin{array}{c}\text { cana- } \\
\text { de- } \\
\text { açúcar }\end{array}$ & $\begin{array}{c}\text { solo } \\
\text { parcialmente } \\
\text { descoberto }\end{array}$ \\
\hline & \multicolumn{11}{|c|}{ Área Cultivada (\%) } \\
\hline $\mathrm{dez} / 04$ & 0,00 & 18,36 & 0,00 & 12,39 & 7,42 & 0,41 & 49,72 & 8,08 & 3,62 & 0,00 & 0,00 \\
\hline $\mathrm{jan} / 05$ & 0,00 & 18,36 & 0,00 & 12,39 & 7,42 & 0,41 & 49,72 & 8,08 & 3,62 & 0,00 & 0,00 \\
\hline fev/05 & 0,00 & 18,36 & 0,00 & 12,39 & 7,42 & 0,41 & 49,72 & 8,08 & 3,62 & 0,00 & 0,00 \\
\hline $\operatorname{mar} / 05$ & 0,00 & 18,36 & 0,00 & 12,39 & 7,42 & 0,41 & 49,72 & 8,08 & 3,62 & 0,00 & 0,00 \\
\hline $\mathrm{abr} / 05$ & 0,00 & 21,98 & 0,00 & 12,39 & 7,42 & 0,41 & 49,72 & 0,00 & 0,00 & 0,00 & 8,08 \\
\hline $\mathrm{mai} / 05$ & 0,00 & 21,98 & 0,00 & 12,39 & 7,42 & 0,41 & 49,72 & 0,00 & 0,00 & 0,00 & 8,08 \\
\hline jun/05 & 0,00 & 21,98 & 0,00 & 12,39 & 7,42 & 0,41 & 49,72 & 0,00 & 0,00 & 0,00 & 8,08 \\
\hline $\mathrm{jul} / 05$ & 0,00 & 21,98 & 0,00 & 12,39 & 7,42 & 0,41 & 49,72 & 0,00 & 0,00 & 0,00 & 8,08 \\
\hline ago/05 & 0,00 & 21,98 & 0,00 & 12,39 & 7,42 & 0,41 & 49,72 & 0,00 & 0,00 & 0,00 & 8,08 \\
\hline set/05 & 0,00 & 21,98 & 0,00 & 12,39 & 7,42 & 0,41 & 49,72 & 0,00 & 0,00 & 0,00 & 8,08 \\
\hline out/05 & 0,00 & 21,98 & 0,00 & 12,39 & 7,42 & 0,41 & 49,72 & 8,08 & 0,00 & 0,00 & 0,00 \\
\hline nov/05 & 0,00 & 21,98 & 0,00 & 12,39 & 7,42 & 0,41 & 49,72 & 8,08 & 0,00 & 0,00 & 0,00 \\
\hline $\mathrm{dez} / 05$ & 0,00 & 18,36 & 0,00 & 12,39 & 7,42 & 0,41 & 49,72 & 8,08 & 3,62 & 0,00 & 0,00 \\
\hline
\end{tabular}




\subsection{Precipitação}

A precipitação obtida no pluviômetro P-01 e no pluviógrafo do CRHEA apresentam forte correlação mensal. A correlação diária é prejudicada pela diferença no horário das medições. Na estação climatológica do CRHEA as medições diárias são fechadas às $24 \mathrm{~h} 00$, no campo, a medição é feita às $7 \mathrm{~h} 00$, podendo variar, de acordo com a disponibilidade do operador.

Os resultados estão apresentados na Tabela 17:

Tabela 17: Precipitação mensal observada no ano de 2005

\begin{tabular}{|l|l|l|l|l|l|l|l|l|l|l|l|l|}
\cline { 2 - 12 } \multicolumn{1}{c|}{} & \multicolumn{10}{c|}{ VALORES MENSAIS (mm) } \\
\cline { 2 - 11 } & $J A N$ & $F E V$ & $M A R$ & $A B R$ & $M A I$ & $J U N$ & $J U L$ & $A G O$ & $S E T$ & $O U T$ & $N O V$ & $D E Z$ \\
\hline EST. P01 & $\mathbf{5 3 6 , 2 2}$ & $\mathbf{5 8 , 7 9}$ & $\mathbf{1 8 7 , 0 5}$ & $\mathbf{1 0 , 6 9}$ & $\mathbf{8 1 , 5 0}$ & $\mathbf{3 9 , 4 1}$ & $\mathbf{1 , 3 4}$ & $\mathbf{4 , 0 1}$ & $\mathbf{8 2 , 5 0}$ & $\mathbf{8 5 , 5 1}$ & $\mathbf{1 0 5 , 8 7}$ & $\mathbf{2 1 7 , 5 6}$ \\
\hline EST. CRHEA & $\mathbf{5 4 2 , 3 0}$ & $\mathbf{6 9 , 0 0}$ & $\mathbf{1 5 5 , 2 0}$ & $\mathbf{1 3 , 1 0}$ & $\mathbf{8 7 , 9 0}$ & $\mathbf{4 1 , 5 0}$ & $\mathbf{4 , 3 0}$ & $\mathbf{1 6 , 1 0}$ & $\mathbf{8 5 , 0 0}$ & $\mathbf{8 4 , 8 0}$ & $\mathbf{1 0 0 , 7 0}$ & $\mathbf{2 2 5 , 0 0}$ \\
\hline
\end{tabular}

O Gráfico 13 apresenta a correlação entre os totais mensais observados no pluviômetro P-01 e na estação climatológica do CRHEA.

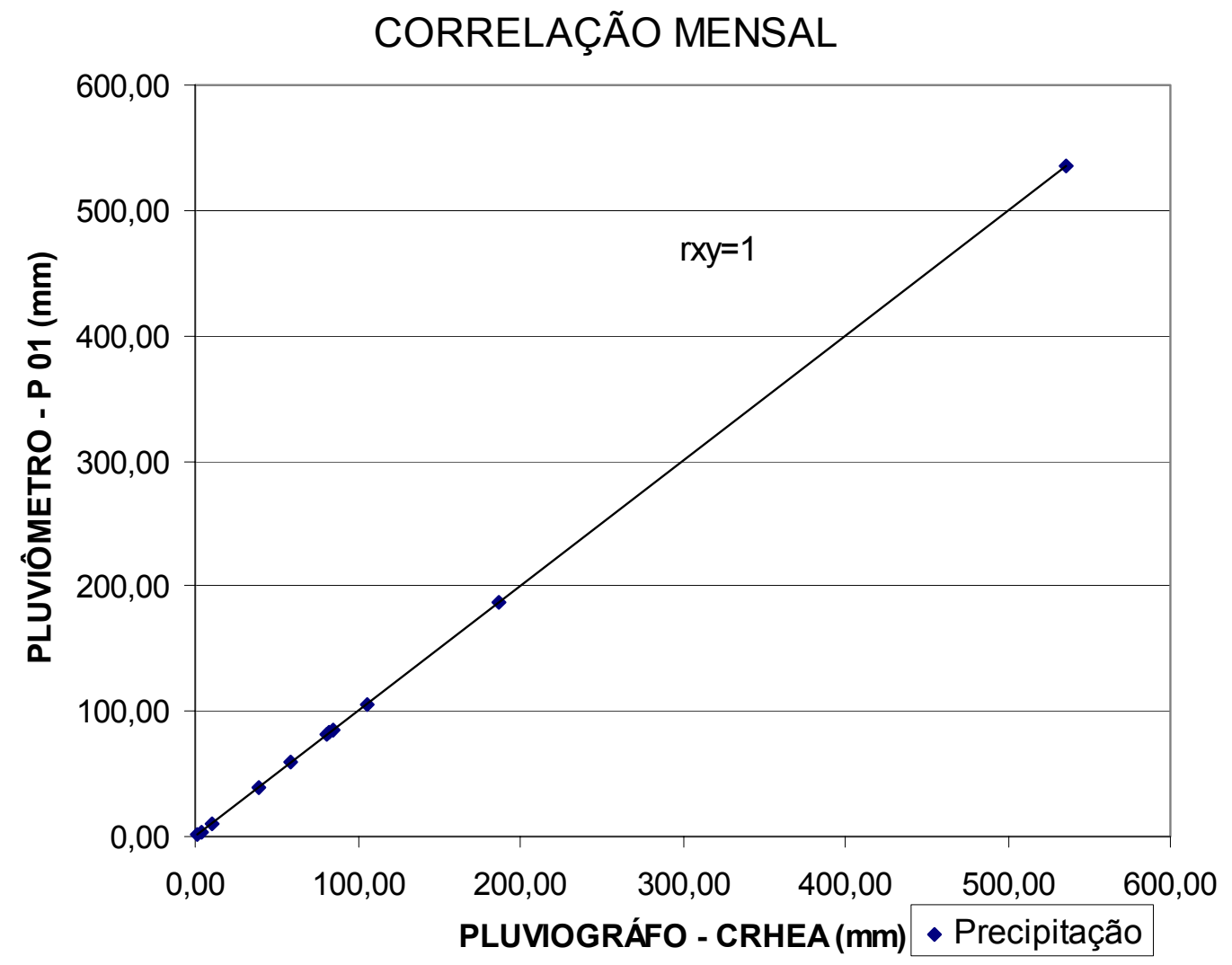

Gráfico 13: Gráfico de correlação mensal entre as precipitações observadas 
A precipitação anual para o estudo do balanço hídrico foi de $1410,44 \mathrm{~mm}$. È importante observar que $38 \%$ da precipitação anual concentrou-se no mês de janeiro. No período seco, de abril a setembro, precipitou apenas $11 \%$ do total.

Ocorreram raras falhas nos dados do pluviômetro P-01. Em dois dias ocorreu falha de medição na estação P-01, com registro de chuva na estação do CRHEA. Nesses casos recorreu-se ao cotagrama do rio para verificar as respostas do linígrafo a possíveis eventos de chuva. Essa observação conjunta possibilitou a correção dos dados desses dois dias. Isso vem a mostrar a importância de mais de uma fonte de informação para garantir a qualidade dos dados.

Os gráficos com todas as medições de chuva na bacia do Ribeirão da Onça estão apresentados no Apêndice B.

\subsection{Evapotranspiração}

Para estimar a evapotranspiração através de métodos empíricos foram coletados dados climatológicos na estação climatológica do CRHEA. Os dados coletados na estação climatológica do CRHEA estão apresentados na Tabela 18.

Tabela 18: Dados coletados na estação climatológica do CRHEA

\begin{tabular}{|c|c|c|c|c|c|c|c|c|}
\hline Tempo & $\begin{array}{c}\text { T. } \\
\text { máxima }\end{array}$ & $\begin{array}{c}\text { T. } \\
\text { mínima }\end{array}$ & $\begin{array}{c}\text { T. } \\
\text { média }\end{array}$ & $\begin{array}{c}\text { Umidade } \\
\text { Relativa }\end{array}$ & $\begin{array}{c}\text { Evaporação } \\
\text { Tanque C. A }\end{array}$ & Insolação & $\begin{array}{c}\text { Vento } \\
\text { 2 m }\end{array}$ & $\begin{array}{c}\text { Porcentagem de } \\
\text { luz solar (p). }\end{array}$ \\
\hline Meses & ${ }^{\circ} \mathrm{C}$ & ${ }^{\circ} \mathrm{C}$ & ${ }^{\circ} \mathrm{C}$ & $\%$ & $\mathrm{~mm}$ & horas & $\mathrm{m} / \mathrm{s}$ & 0,25 \\
\hline Jan & 32,0 & 13,4 & 23,1 & 88,0 & 171,9 & 4,1 & 1,0 & 0,26 \\
\hline Fev & 34,4 & 10,5 & 23,3 & 80,3 & 152,1 & 8,9 & 0,9 & 0,27 \\
\hline Mar & 33,3 & 11,9 & 23,7 & 83,5 & 149,8 & 6,8 & 0,7 & 0,28 \\
\hline Abr & 32,8 & 9,8 & 22,9 & 79,7 & 117,7 & 7,2 & 0,6 & 0,29 \\
\hline Mai & 30,2 & 6,0 & 18,7 & 71,2 & 127,9 & 7,5 & 0,5 & 0,30 \\
\hline Jun & 27,4 & 8,3 & 18,0 & 88,2 & 94,0 & 7,6 & 0,7 & 0,30 \\
\hline Jul & 28,8 & 7,0 & 16,1 & 84,9 & 112,9 & 7,8 & 1,1 & 0,29 \\
\hline Ago & 33,2 & 6,0 & 19,3 & 75,6 & 170,0 & 9,2 & 0,8 & 0,28 \\
\hline Set & 31,6 & 4,6 & 19,8 & 86,9 & 141,3 & 6,8 & 1,9 & 0,26 \\
\hline Out & 34,8 & 12,6 & 24,0 & 87,0 & 152,8 & 6,0 & 1,3 & 0,25 \\
\hline Nov & 33,4 & 10,5 & 24,1 & 86,2 & 173,6 & 6,7 & 1,6 & 0,25 \\
\hline Dez & 32,2 & 10,6 & 23,1 & 78,0 & 181,9 & 6,1 & 1,5 & 0,27 \\
\hline Média & 32,0 & 9,3 & 21,3 & 82,5 & 145,5 & 7,1 & 1,1 & \\
\hline
\end{tabular}

Os métodos empíricos e semi-empíricos, apresentam diferenças entre si que podem chegar a valores maiores do que $200 \%$ quando comparados os valores mensais, e maiores do que $100 \%$ quando comparados os valores anuais. O Gráfico 14 mostra as estimativas da 
evapotranspiração potencial de referência, para a região, utilizando diversos métodos. Pode-se notar que, dependendo do método utilizado em um balanço hídrico, a componente residual pode ser afetada de forma relevante.

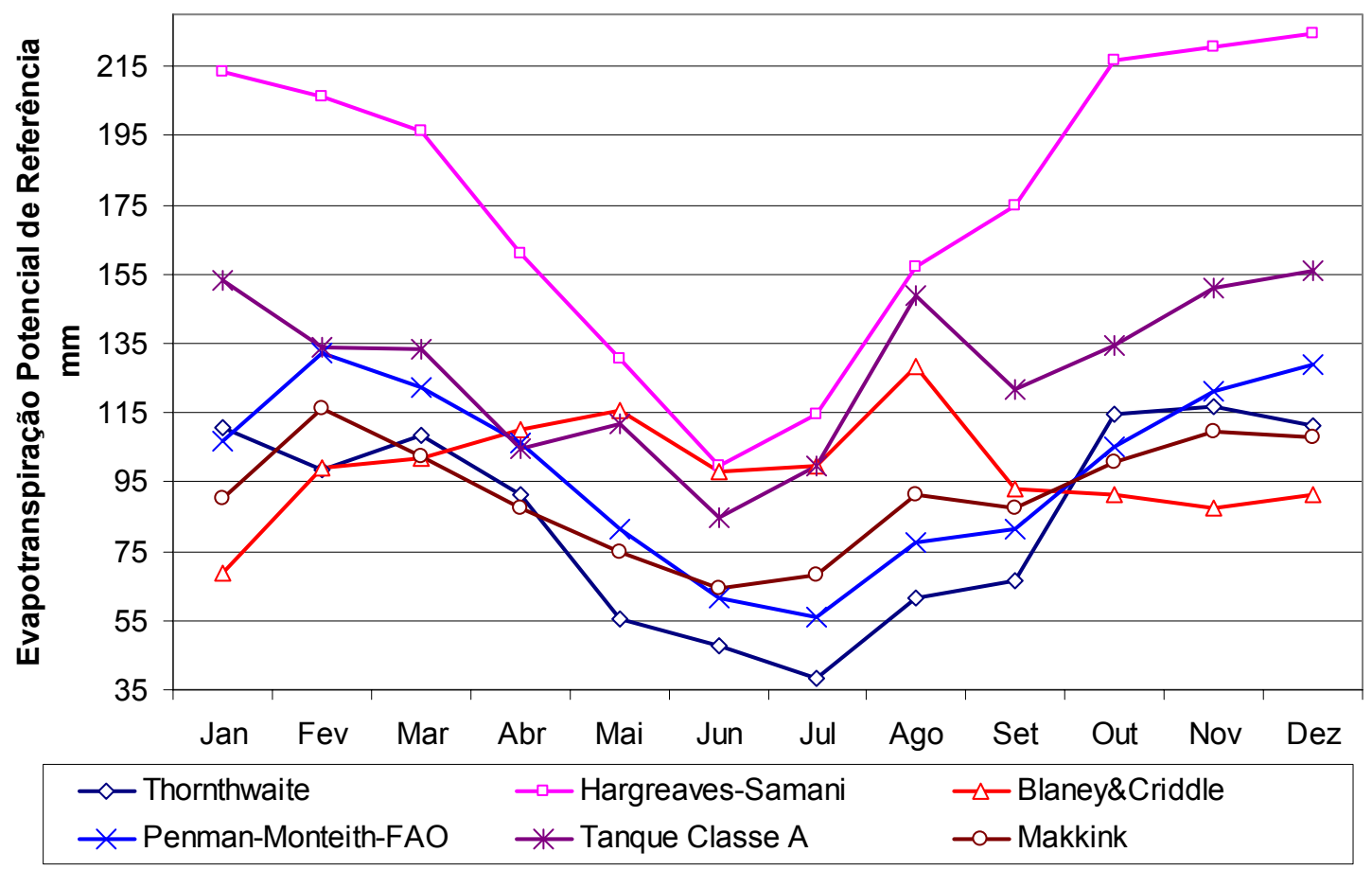

Gráfico 14: Estimativas mensais da evapotranspiração potencial de referência para o ano de 2005, a partir dos dados da estação climatológica do CRHEA.

A evapotranspiração real anual na bacia do Ribeirão da Onça estimada pelos métodos descritos na seção 3.9, estimada de acordo com a área relativa das diferentes culturas, está apresentada na Tabela 19 e no Gráfico 15.

Tabela 19: Estimativa da evapotranspiração anual na bacia do Ribeirão da Onça em 2005

\begin{tabular}{|l|c|c|}
\hline \multicolumn{1}{|c|}{ MÉTODO } & $\begin{array}{c}\text { EVAPOTRANSPIRAÇÃO } \\
\text { NA BACIA (mm) }\end{array}$ & $\begin{array}{c}\text { EVAPOTRANSPIRAÇÃO } \\
\text { NA SUB-BACIA (mm) }\end{array}$ \\
\hline PENMAN-MONTEITH (FAO) & 1091,23 & 1081,50 \\
\hline THORNTHWAITE & 944,16 & 935,69 \\
\hline TANQUE CLASSE A (FAO) & 1412,94 & 1399,37 \\
\hline HARGREAVES-SAMANI & 1951,83 & 1933,58 \\
\hline BLANEY-CRIDDLE & 1089,63 & 1078,75 \\
\hline MAKKINK & 1014,40 & 1004,76 \\
\hline
\end{tabular}

Para a sub-bacia do Ribeirão da Onça, a maior diferença entre os métodos foi entre o de Hargreaves-Samani e o de Thornthwaite, que foi de 997,89mm. Em termos percentuais foi de $106,65, \%$ da menor estimativa. A média entre os métodos foi igual a $1355,85 \mathrm{~mm}$ e o desvio padrão igual a $375,63 \mathrm{~mm}$. 


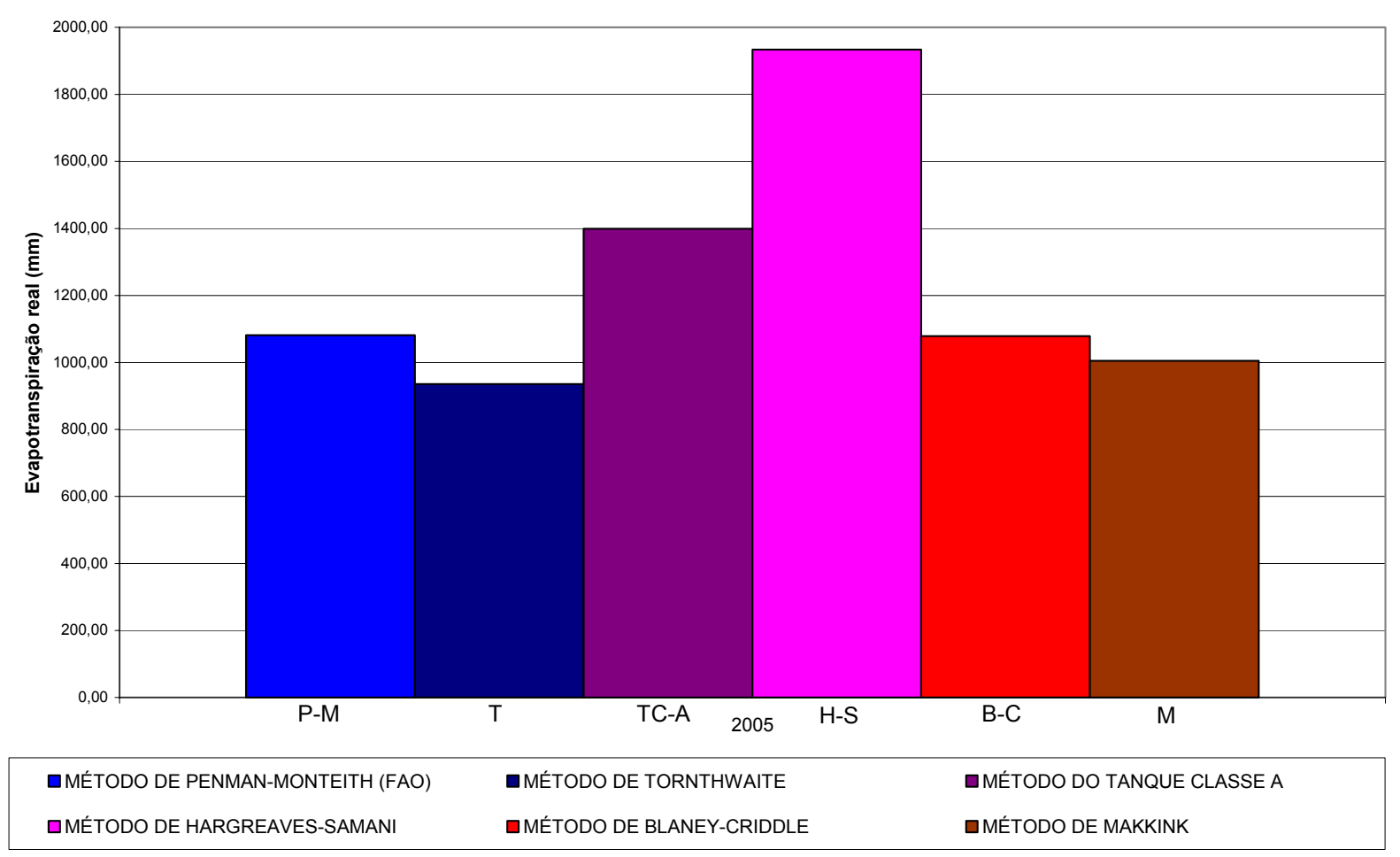

Gráfico 15: Estimativa anual da evapotranspiração na sub-bacia do Ribeirão da Onça no ano de 2005

Esta grande variabilidade entre os resultados obtidos por cada método evidencia a grande incerteza na estimativa desta componente.

O método de Thornthwaite vem sendo apontado como o melhor método para estimativa da evapotranspiração para a região (MATOS, 1987; CUNHA, 2003).

O método de Penman-Monteith é apontado pela FAO como o método que melhor representa as condições reais de evapotranspiração. Seu comportamento neste estudo não diferiu muito dos valores encontrados pelo método de Thornthwaite, apesar de apresentar-se na maior parte do tempo com um valor maior. A correlação entre os dois métodos foi de 0,92 . Esse comportamento semelhante entre os dois métodos pode indicar que as componentes da radiação solar e da temperatura são os fatores determinantes para a estimativa da evapotranspiração da região.

O método de Makkink apresentou comportamento bastante semelhante ao método de Penman-Monteith. Esse comportamento já poderia ser esperado, já que o método de Makkink é a derivada do método de Penman-Monteith. O coeficiente de correlação entre os métodos de Penman-Monteith e Makkink foi de 0,92 e entre os métodos de Thornthwaite e Makkink foi de 0,85 .

O método de Blaney-Criddle apresentou o comportamento mais divergente. Observouse um aumento na evapotranspiração entre os meses de janeiro a maio e uma queda na 
evapotranspiração a partir de agosto, enquanto os outros métodos tendem a apresentar seus valores de forma contrária. Isso pode ser explicado pelo fato do método ter sido desenvolvido para regiões áridas e semi-áridas, onde o período seco é também o período com temperatura mais elevada.

O método de Hargreaves-Samani estima os maiores valores para a evapotranspiração potencial anual, sendo maior que a precipitação. Valores de evapotranspiração maiores que a precipitação geralmente são observados em climas áridos, o que não condiz com a realidade local.

\subsection{Linimetria}

A Tabela 20 apresenta os dados coletados na régua linimétrica instalada na bacia do Ribeirão da Onça.

Tabela 20: Dados coletados na régua linimétrica

\begin{tabular}{|c|c|c|c|c|c|c|c|c|c|}
\hline Data & $\begin{array}{c}\text { Medida } \\
\text { (m) }\end{array}$ & Data & $\begin{array}{c}\text { Medida } \\
\text { (m) }\end{array}$ & Data & $\begin{array}{c}\text { Medida } \\
\text { (m) }\end{array}$ & Data & $\begin{array}{c}\text { Medida } \\
\text { (m) }\end{array}$ & Data & $\begin{array}{l}\text { Medida } \\
\text { (m) }\end{array}$ \\
\hline $14 / 11 / 04$ & 0,91 & $14 / 02 / 05$ & 0,77 & $16 / 05 / 05$ & 0,76 & $12 / 08 / 05$ & 0,81 & $25 / 11 / 05$ & 0,86 \\
\hline 27/11/04 & 0,91 & $22 / 02 / 05$ & 0,75 & $24 / 05 / 05$ & 0,83 & $19 / 08 / 05$ & 0,79 & $02 / 12 / 05$ & 0,93 \\
\hline $07 / 12 / 04$ & 0,91 & $04 / 03 / 05$ & 0,74 & $03 / 06 / 05$ & 0,82 & $02 / 09 / 05$ & 0,93 & $08 / 12 / 05$ & 0,95 \\
\hline $17 / 12 / 04$ & 0,73 & $18 / 03 / 05$ & 0,88 & $16 / 06 / 05$ & 0,75 & $15 / 09 / 05$ & 0,84 & $16 / 12 / 05$ & 0,86 \\
\hline $28 / 12 / 04$ & 0,77 & $13 / 04 / 05$ & 0,77 & 21/06/05 & 0,74 & 29/09/05 & 0,80 & $22 / 12 / 05$ & 0,85 \\
\hline $06 / 01 / 05$ & 0,84 & $20 / 04 / 05$ & 0,79 & $24 / 06 / 05$ & 0,74 & $14 / 10 / 05$ & 0,90 & $13 / 01 / 05$ & 0,92 \\
\hline $11 / 01 / 05$ & 0,75 & $29 / 04 / 05$ & 0,77 & $01 / 07 / 05$ & 0,82 & 27/10/05 & 1,00 & & \\
\hline 27/01/05 & 0,90 & $06 / 05 / 05$ & 0,77 & $03 / 08 / 05$ & 0,79 & $11 / 11 / 05$ & 0,87 & & \\
\hline
\end{tabular}

A linimetria do rio apresentou o inconveniente de ser afetada pelo funcionamento de bombas de captação para a irrigação, instaladas a jusante do linígrafo. Tal interferência é percebida no Gráfico 16 como as quedas bruscas do nível do ribeirão.

A mudança no leito do rio foi outro fator que prejudicou a qualidade dos dados coletados. Essa mudança no leito ocorre principalmente nas épocas de chuva, quando o material do leito é carreado, diminuindo a cota do fundo do leito. Nos períodos sem chuva observa-se sedimentação de materiais. O apêndice D mostra a evolução da calha do rio ao longo do ano de 2005 


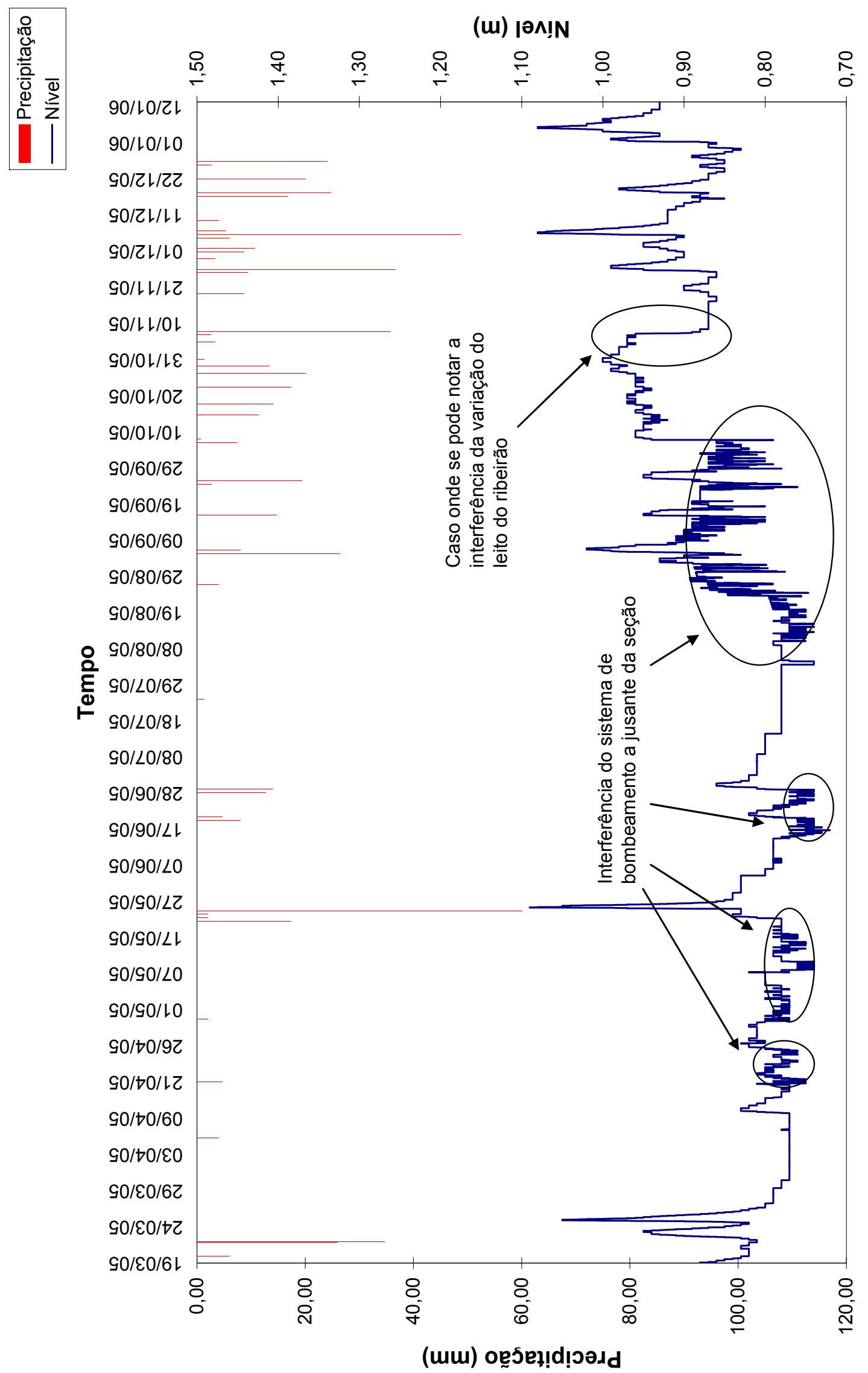

Gráfico 16: Cotagrama da seção de controle de descarga no Ribeirão da Onça 
O Gráfico 17 mostra o comportamento do nível com a vazão. Observa-se no Gráfíco 17 que se torna difícil relacionar o nível com a vazão, já que os métodos que relacionam essas duas variáveis são baseados na hidráulica dos canais, em que, para um mesmo regime de escoamento, no caso o ribeirão escoa em regime fluvial, é impossível ter um acréscimo no nível do canal e um aumento na vazão para certo intervalo de tempo.

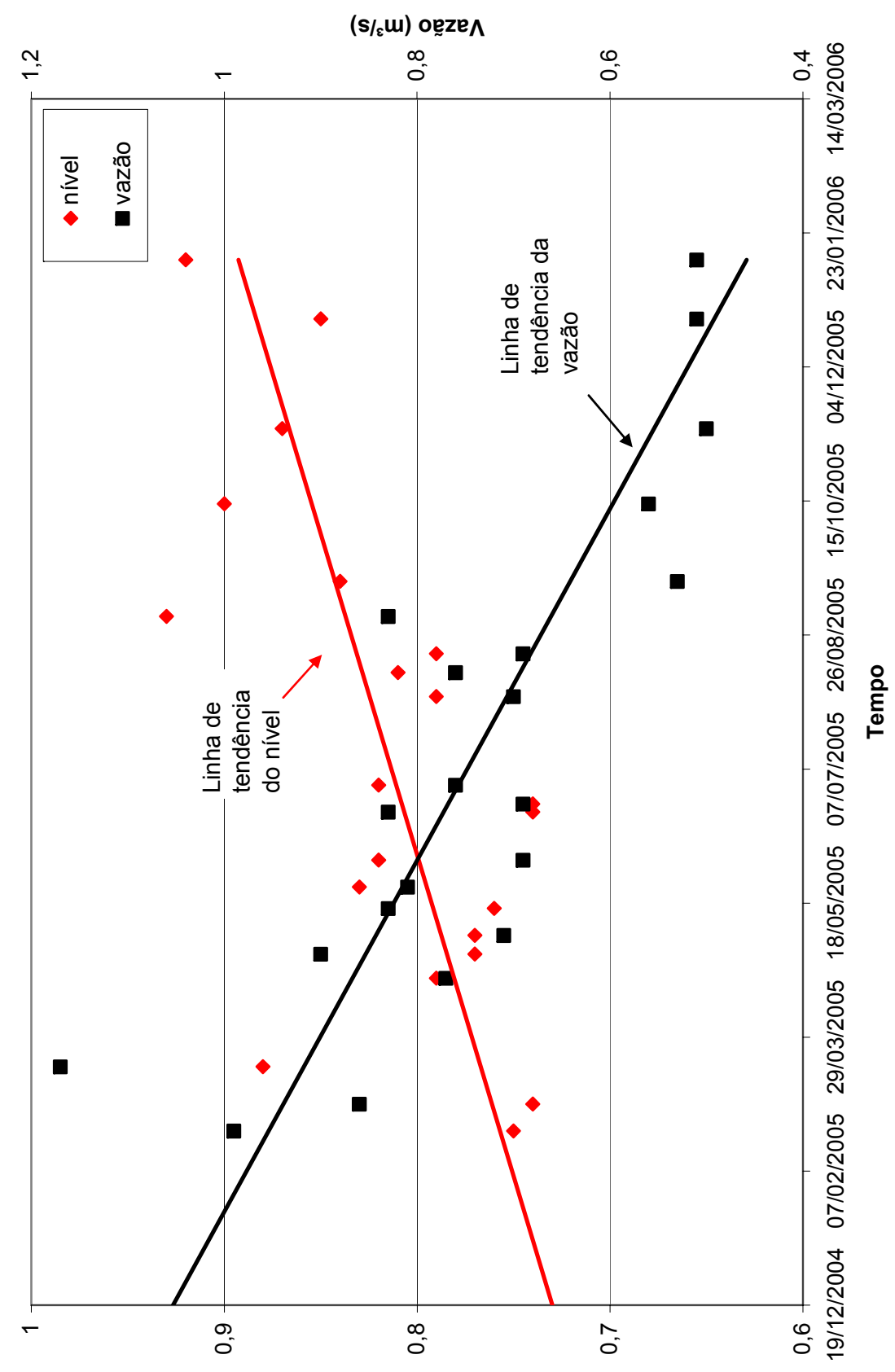

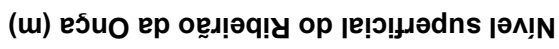

Gráfico 17: Níveis e vazões em uma seção de controle no Ribeirão da Onça e suas respectivas linhas de tendência 


\subsection{Medição de vazão líquida}

A vazão máxima medida foi de $1,17 \mathrm{~m}^{3} / \mathrm{s}$, o que deve estar aquém das vazões máximas que o rio produz nesta seção. Arantes (2003) estimou a vazão nesta mesma seção e encontrou valores máximos acima de $2 \mathrm{~m}^{3} / \mathrm{s}$. A implicação é direta no traçado e extrapolação da curvachave. As medidas de valores mínimos se apresentaram em torno de $0,50 \mathrm{~m}^{3} / \mathrm{s}$. Na medição de número $21^{(*)}$, a vazão estimada foi de $0,41 \mathrm{~m}^{3} / \mathrm{s}$, mas o contador de giros apresentou problema nessa coleta, o que fez que essa medição fosse desconsiderada. As planilhas com os resultados das medições são apresentadas no apêndice C. As vazões observadas são apresentadas na Tabela 21.

Tabela 21: Vazões medidas na seção "VAZÃO" do Ribeirão da Onça

\begin{tabular}{|c|c|c|c|c|c|}
\hline NÚMERO DA MEDIÇÃO & DATA & VAZÃO $\left(\mathbf{m}^{3} / \mathbf{s}\right)$ & $\begin{array}{c}\text { NÚMERO DA } \\
\text { MEDIÇÃO }\end{array}$ & DATA & $\operatorname{VAZÃO}\left(\mathbf{m}^{3} / \mathbf{s}\right)$ \\
\hline 1 & $28 / 10 / 04$ & 0,71 & 13 & $01 / 07 / 05$ & 0,76 \\
\hline 2 & $22 / 02 / 05$ & 0,99 & 14 & $03 / 08 / 05$ & 0,70 \\
\hline 3 & $04 / 03 / 05$ & 0,86 & 15 & $12 / 08 / 05$ & 0,76 \\
\hline 4 & $18 / 03 / 05$ & 1,17 & 16 & $19 / 08 / 05$ & 0,69 \\
\hline 5 & $20 / 04 / 05$ & 0,77 & 17 & $02 / 09 / 05$ & 0,83 \\
\hline 6 & $29 / 04 / 05$ & 0,90 & 18 & $15 / 09 / 05$ & 0,53 \\
\hline 7 & $06 / 05 / 05$ & 0,71 & 19 & $14 / 10 / 05$ & 0,56 \\
\hline 8 & $16 / 05 / 05$ & 0,83 & 20 & $11 / 11 / 05$ & 0,50 \\
\hline 9 & $24 / 05 / 05$ & 0,81 & $21^{(*)}$ & $08 / 12 / 05$ & 0,41 \\
\hline 10 & $03 / 06 / 05$ & 0,69 & 22 & $22 / 12 / 05$ & 0,51 \\
\hline 11 & $21 / 06 / 05$ & 0,83 & 23 & $13 / 01 / 06$ & 0,51 \\
\hline 12 & $24 / 06 / 05$ & 0,69 & & & \\
\hline
\end{tabular}




\subsection{Escoamento de base}

A escolha da melhor função para descrever a interação rio-aqüífero foi realizada quantificando, entre as vazões calculadas e medidas, o viés, o erro médio, o coeficiente de correlação e a vazão de pico.

A equação 60 foi a que melhor se ajustou aos valores observados, utilizando os níveis de água nos poços $05,08,13,15,16,18,19$ (Gráfico 18 e Gráfico 19). Os parâmetros estatísticos encontrados entre a vazão simulada e a vazão observada foram: viés igual a zero, erro médio igual a 0,02 , coeficiente de correlação igual a 0,92 e vazão de pico simulada foi $0,87 \mathrm{~m}^{3} / \mathrm{s}$.

Os parâmetros encontrados para a equação foram: $\alpha=0,0143, b=2,2600$ e c $=$ 8,2819 .

O volume anual do escoamento de base foi estimado em $22.115 .035 \mathrm{~m}^{3}$, o que corresponde a um fluxo total escoado de $419 \mathrm{~mm}$ no ano de 2005. A Gráfico 20 apresenta os valores encontrados para o período de um mês.

Para a situação em que o aqüífero alimenta os rios, as áreas do aqüífero próximas ao curso d'água sofrem uma maior variação da sua cota potenciométrica (Figura 55). Esse fenômeno causa uma deformação na superfície do aqüífero. Observa-se a ação desse fenômeno pelo acréscimo na vazão de base observada no hidrograma de um rio após um evento de chuva. Esta variação, porém, pode representar uma pequena parte do escoamento em relação aos volumes anuais.

Sendo assim, para uma boa representação da interação rio-aqüífero faz-se necessária a utilização de poços de observação próximos aos cursos d'água como também a distâncias maiores.

Os poços de observação mais próximos do Ribeirão da Onça foram descartados desse estudo de interação rio-aqüífero por não haver dados coletados durante todo o ano de 2005. Além do mais, as coletas de dados quinzenais estão aquém das necessidades de acompanhamento dos níveis nesses poços. 


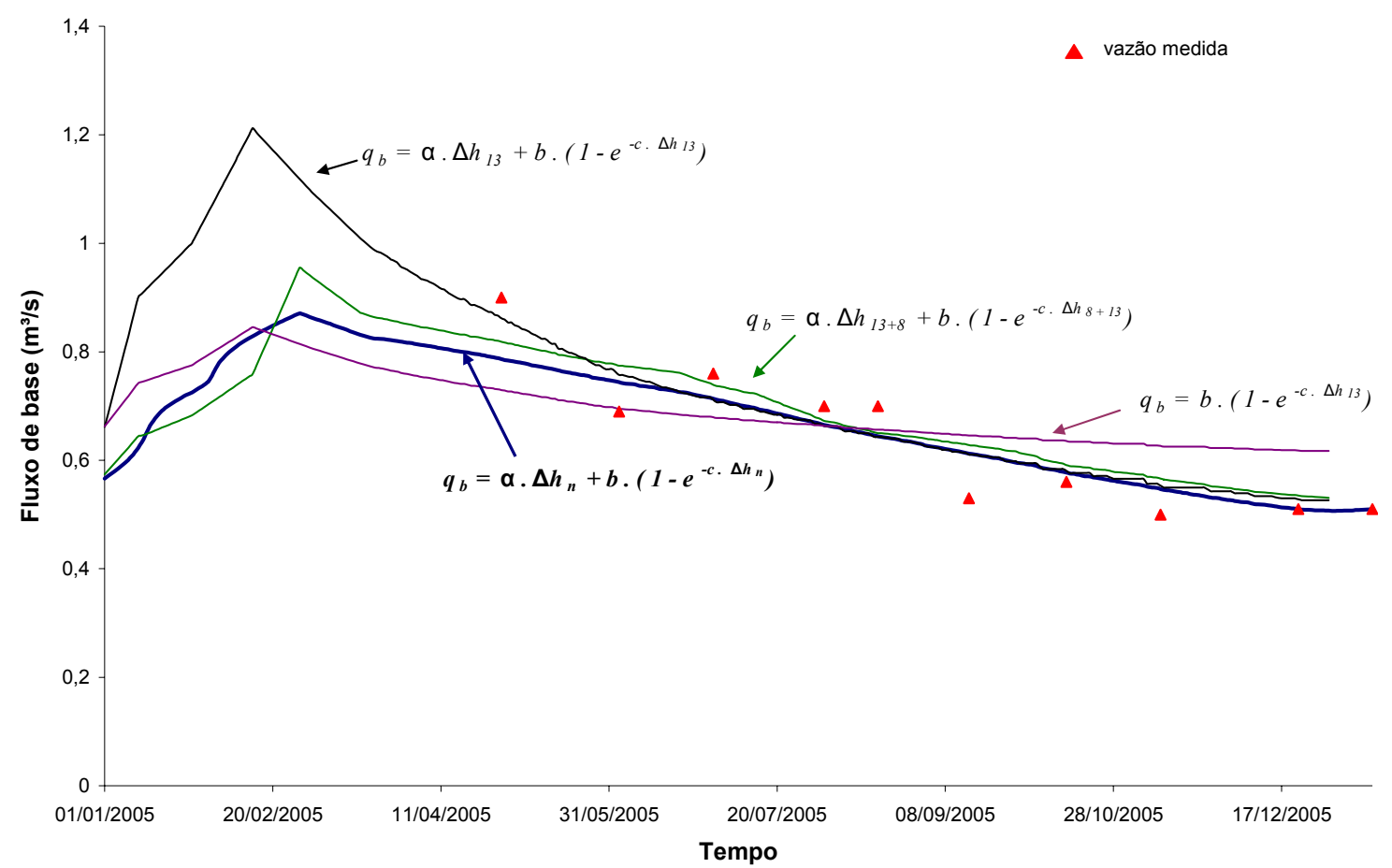

Gráfico 18: Vazão de base simulada através de equação de interação rio-aqüífero

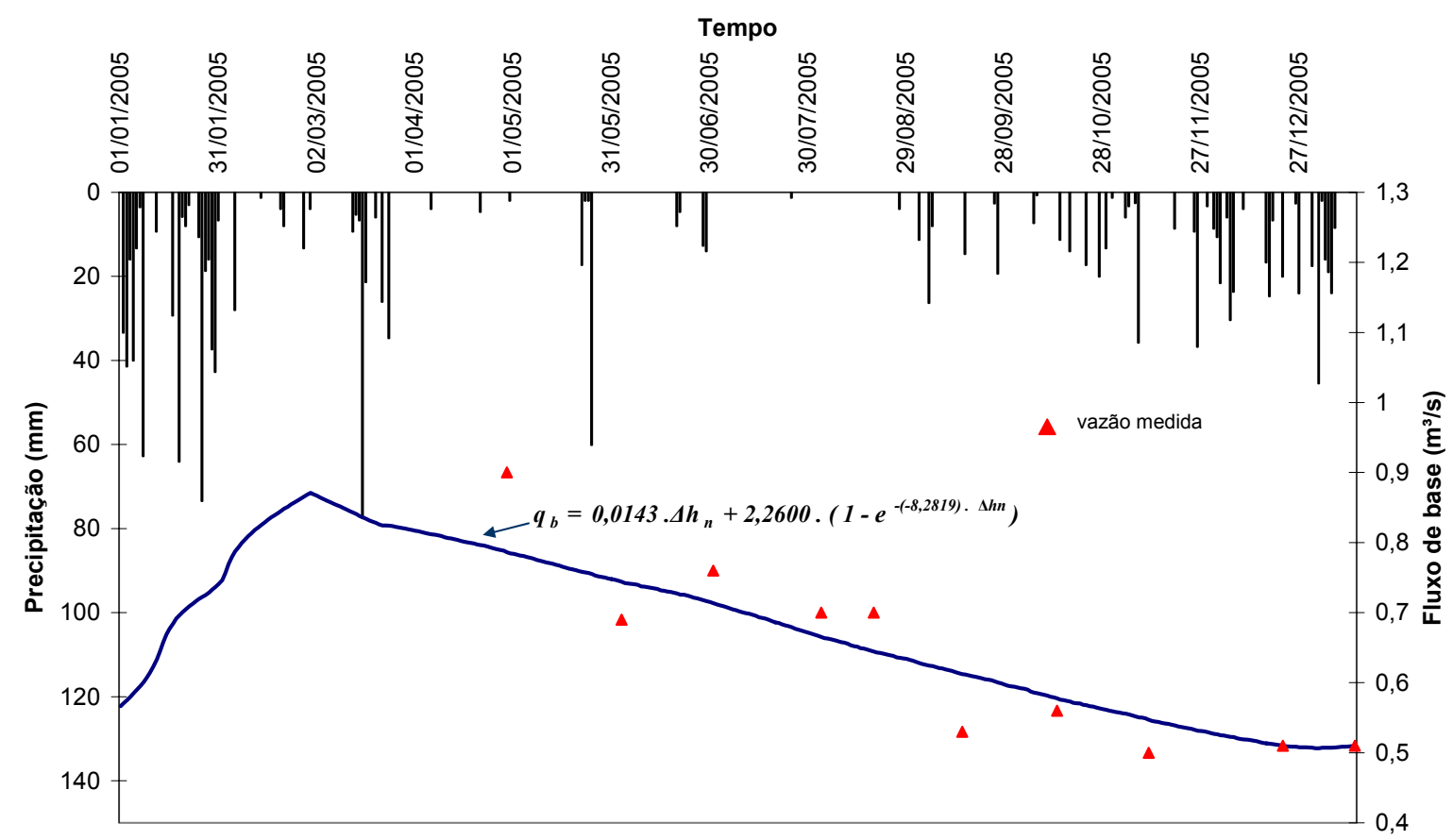

Gráfico 19: função de melhor ajuste para o fluxo de base 


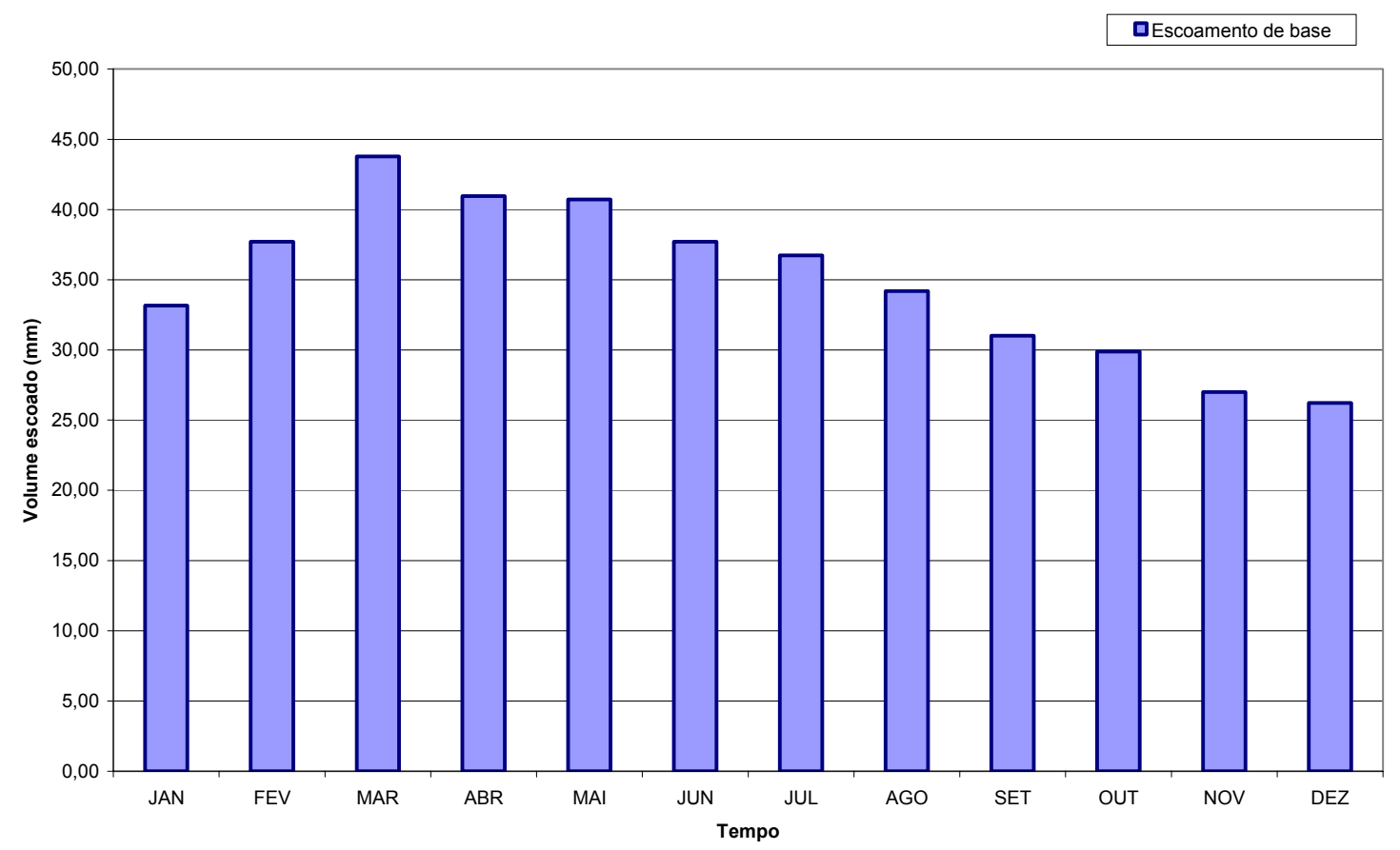

Gráfico 20: Estimativa mensal do escoamento básico no Ribeirão da Onça para o ano de 2005, utilizando a altura equivalente de água relativa à área de drenagem.

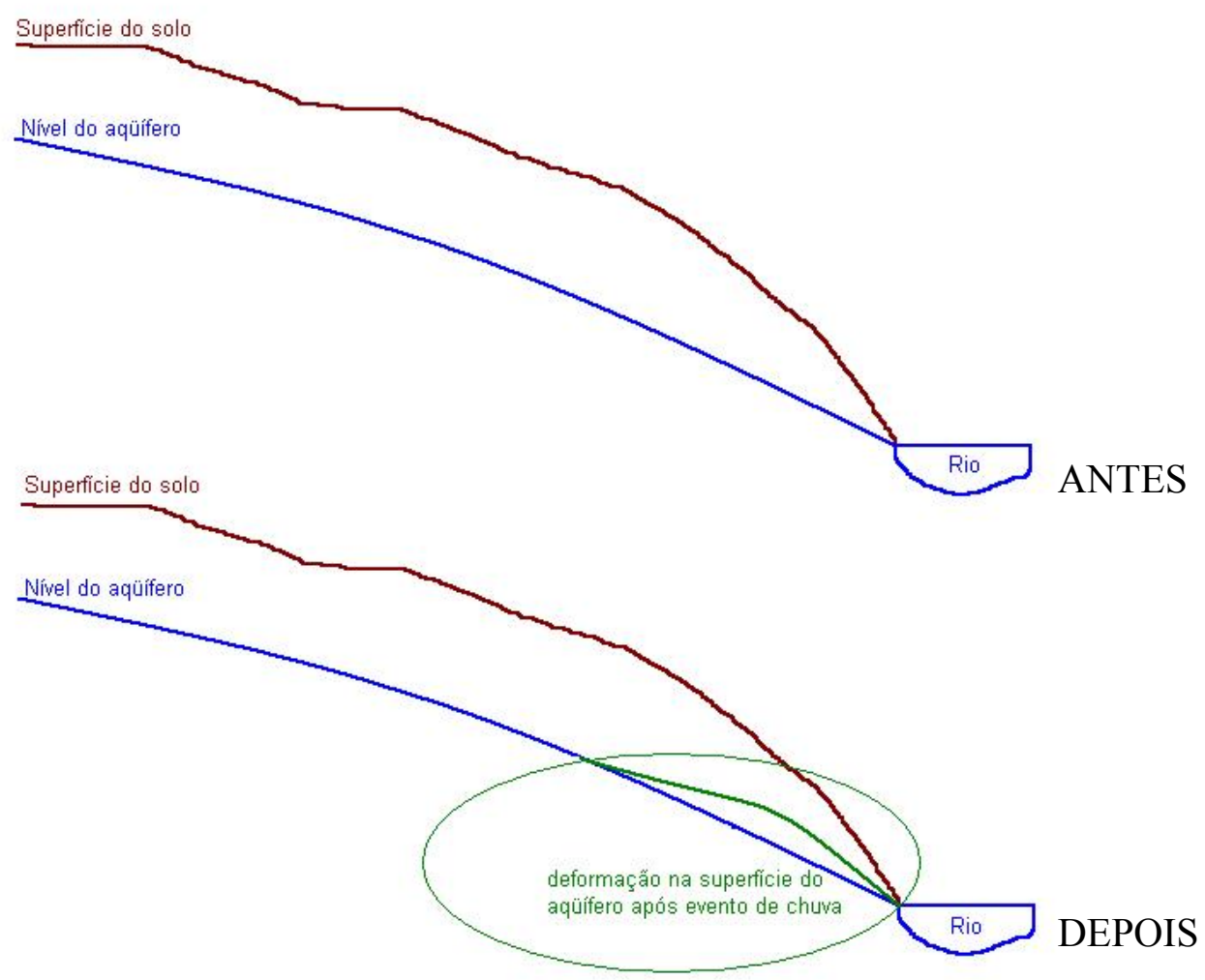

Figura 55: Esquema de deformação na superfície do aqüífero após evento de chuva 


\subsection{Escoamento superficial direto}

O hidrograma encontrado a partir da curva-chave construída, para o período de 14/11/05 a 16/12/05, está apresentado no Gráfico 21.

Com o hidrograma em mãos separou-se o escoamento básico e o escoamento superficial direto graficamente. O escoamento direto é mostrado no Gráfico 22 e o escoamento de base, no Gráfico 23.

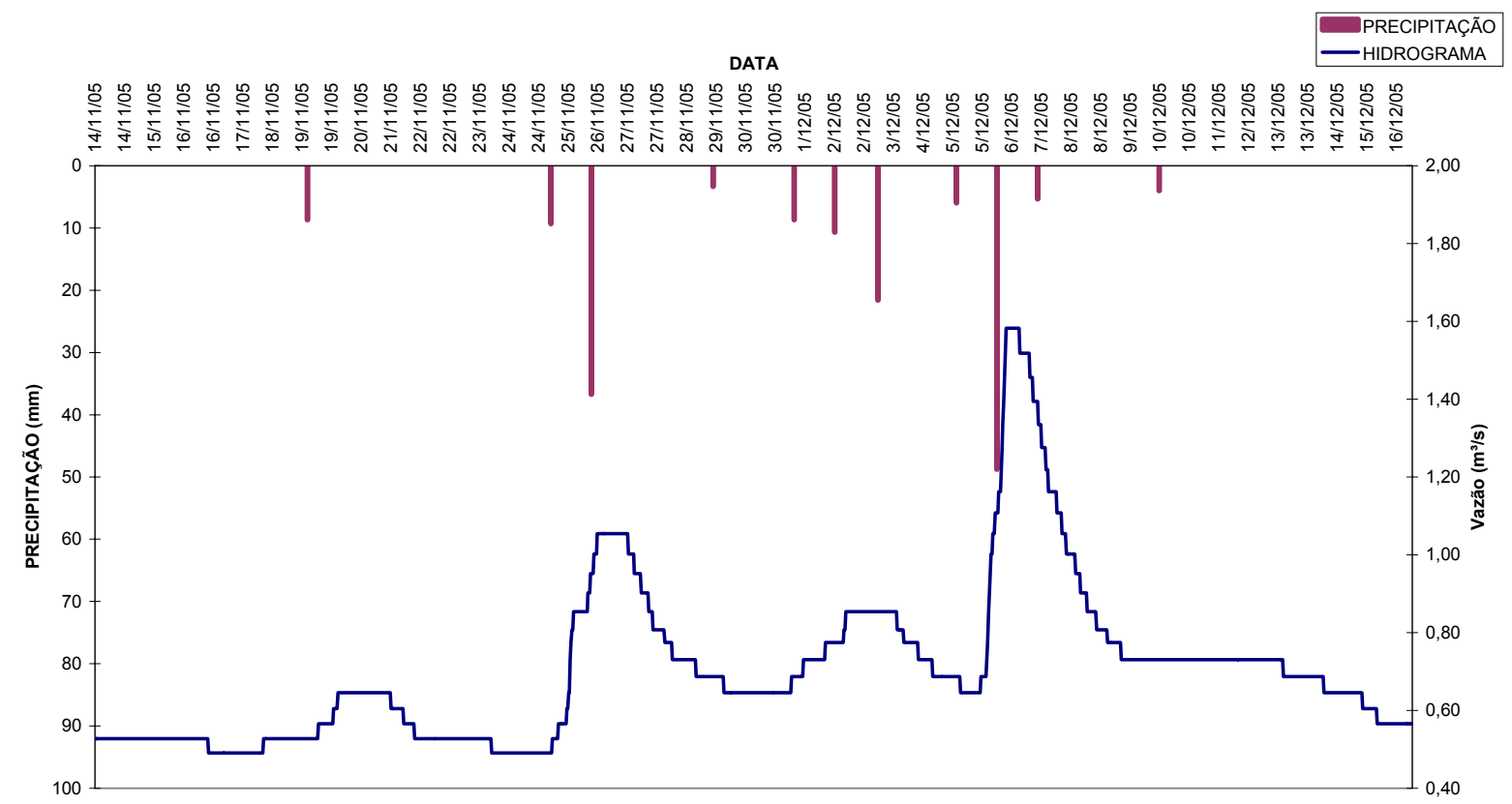

Gráfico 21: Hidrograma simulado a partir da curva-chave traçada e extrapolada pelo método logarítmico 


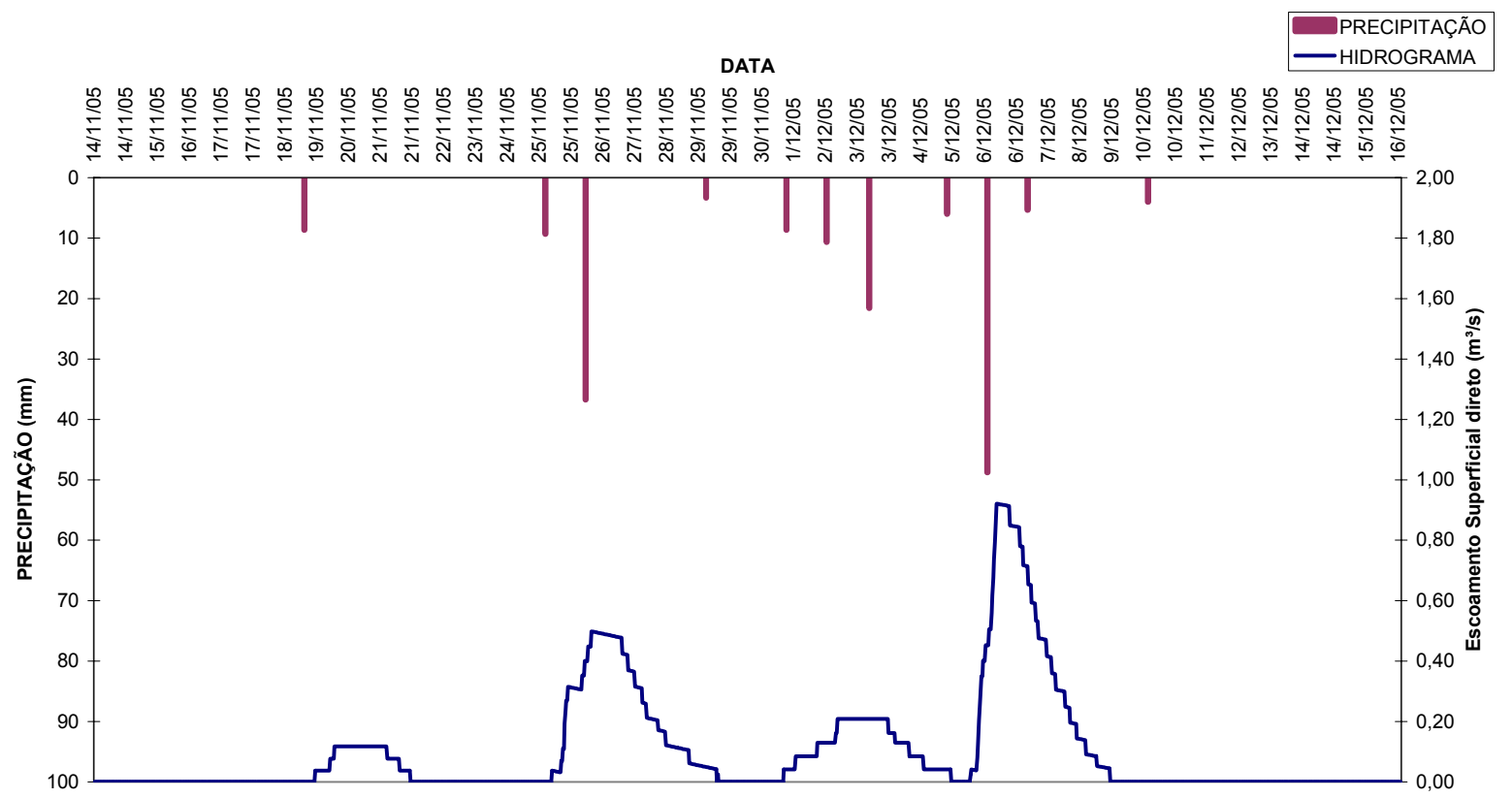

Gráfico 22: Hidrograma de escoamento superficial separado do escoamento de base a partir do método gráfico

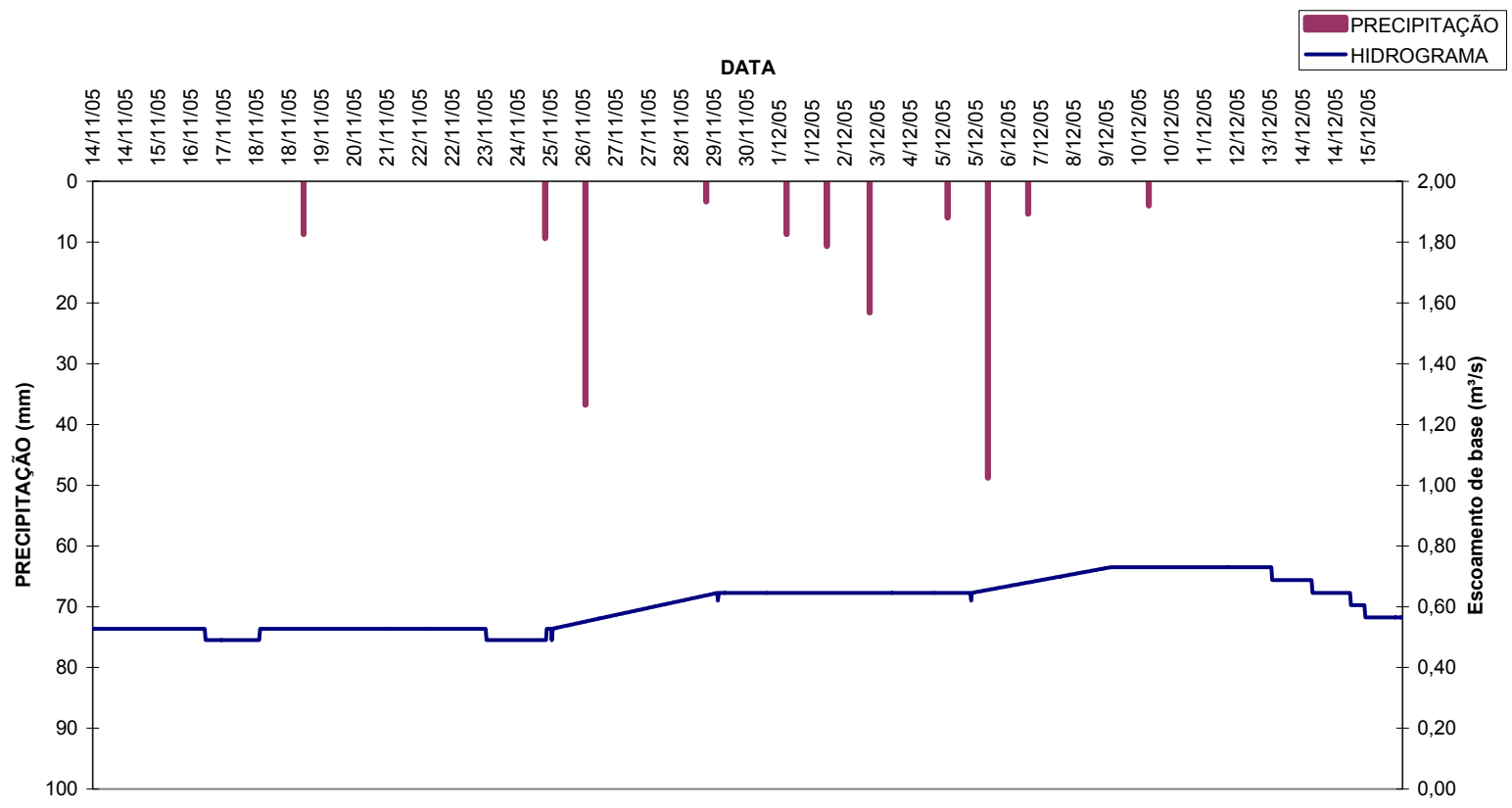

Gráfico 23: Hidrograma de escoamento de base separado do escoamento superficial direto a partir do método gráfico 
Os dados com os valores do $\mathrm{CN}$ encontrados para o período seco e úmido estão na Tabela 22.

Tabela 22: Valor do CN para transformação chuva-vazão na bacia do Ribeirão da Onça

\begin{tabular}{|c|c|c|}
\hline \multirow{2}{*}{ SUB-BACIA } & \multicolumn{2}{|c|}{ CN } \\
\cline { 2 - 3 } & Período Seco & Período Úmido \\
\hline I & 72 & 80 \\
\hline II & 73 & 81 \\
\hline III+IV & 72 & 80 \\
\hline V+VIII & 74 & 81 \\
\hline VI & 73 & 81 \\
\hline VII & 74 & 81 \\
\hline IX+X & 73 & 81 \\
\hline $\mathbf{X I}$ & 72 & 80 \\
\hline $\mathbf{X I I + X I I I ~}$ & 72 & 80 \\
\hline
\end{tabular}

O gráfico com o escoamento direto para o período seco está ilustrado no Gráfico 24.

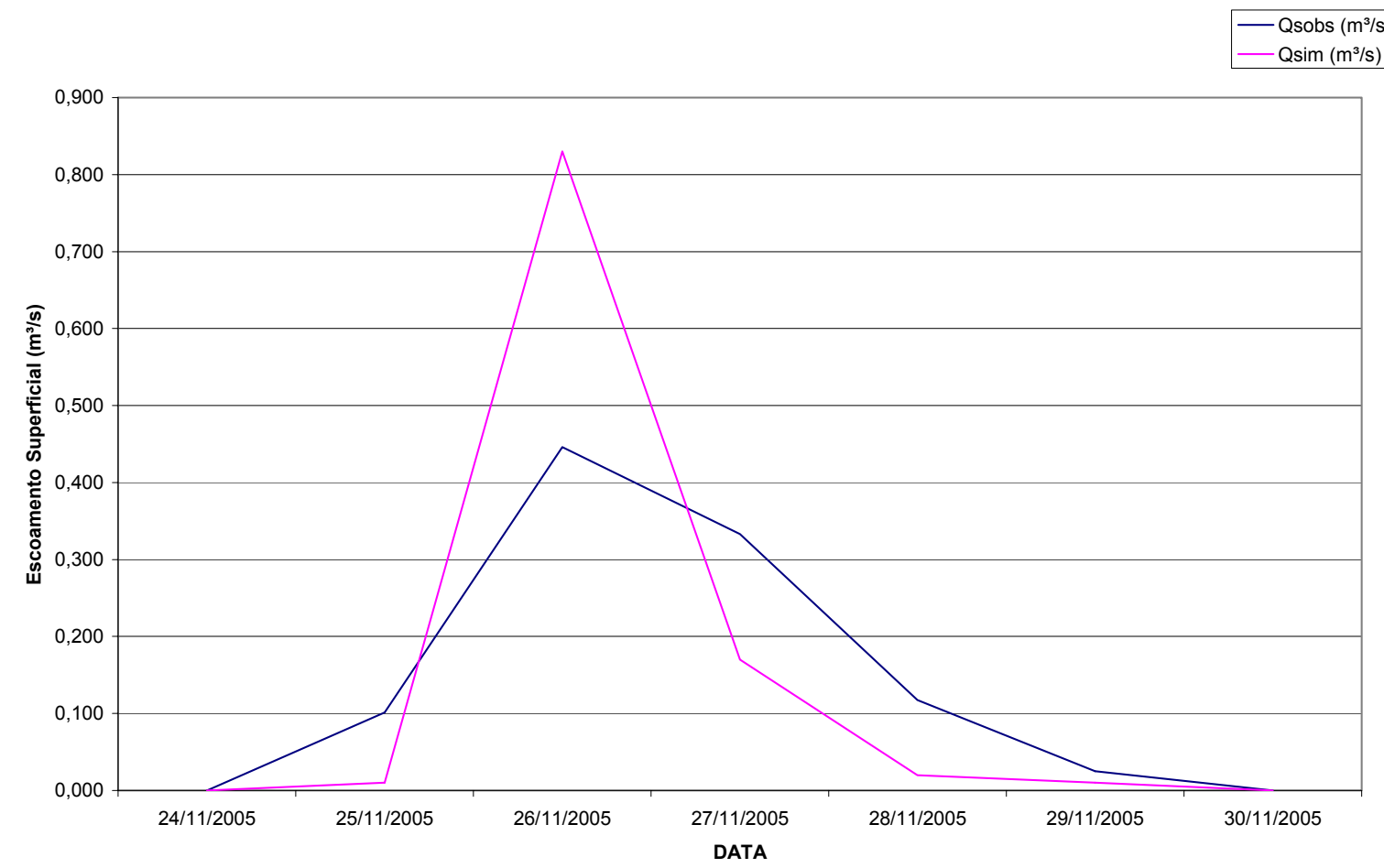

Gráfico 24: Escoamento superficial direto observado e simulado pelo IPHS1 para os eventos de chuva ocorridos nos dias $25 / 11$ e $26 / 11$ 
O volume escoado observado, para as precipitações ocorridas nos dias 25/11 e 26/11, foi de $88.408 \mathrm{~m}^{3}$ para os dois eventos, de acordo com o Gráfico 25 . O volume simulado foi de $89.856 \mathrm{~m}^{3}$. A diferença entre os dois é menor que $2 \%$.

O volume escoado diretamente observado para as precipitações ocorridas nos primeiro dias de dezembro, período úmido, foi de $39.033 \mathrm{~m}^{3}$. O volume simulado para os mesmos eventos foi de $36.288 \mathrm{~m}^{3}$. A diferença entre os dois valores foi de $-7 \%$.

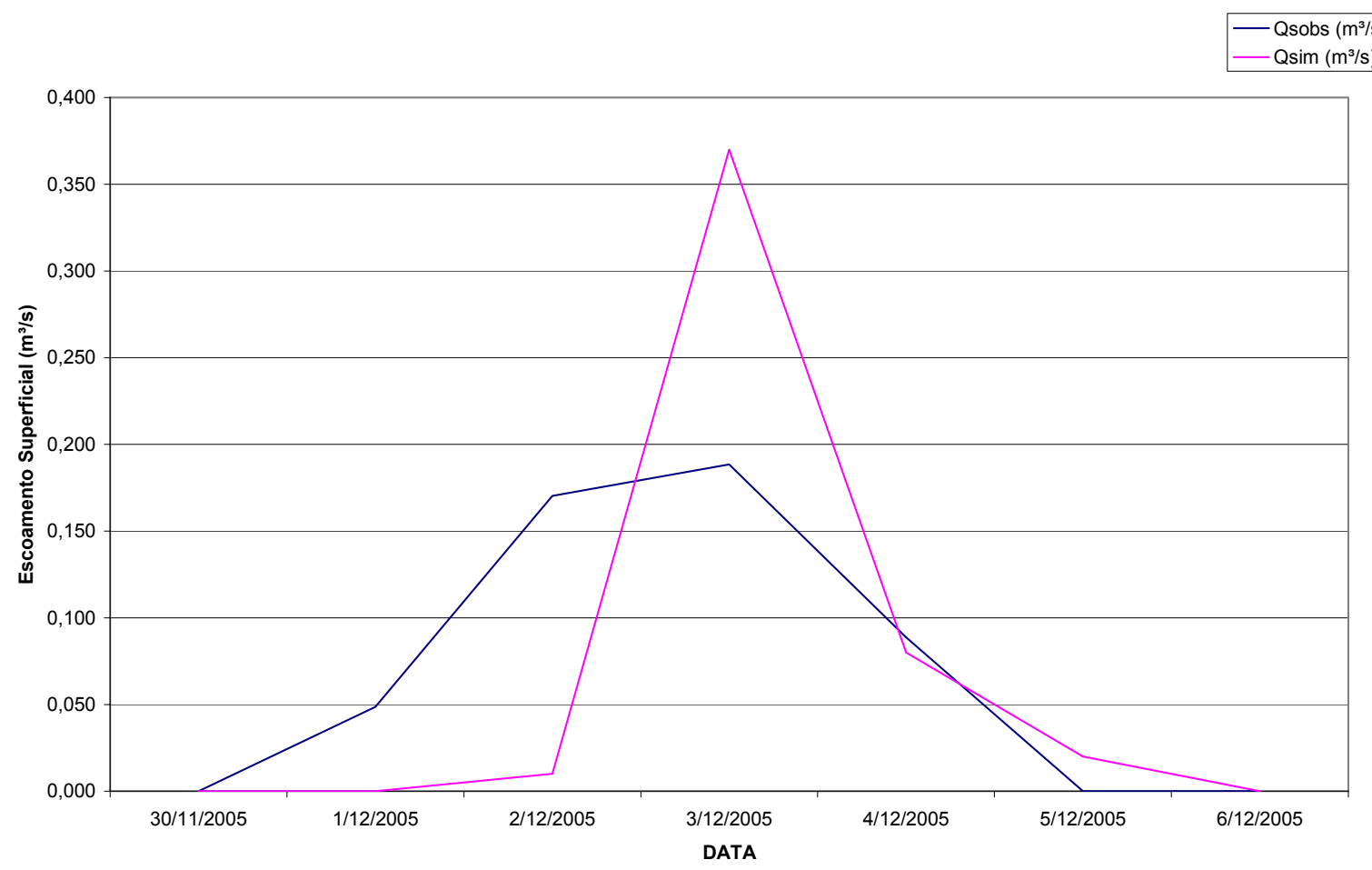

Gráfico 25: Escoamento direto observado e simulado pelo IPHS1 para os eventos de chuva dos dia 1, 2 e $3 / 12$

O volume escoado diretamente observado para as precipitações ocorridas nos dias 5, 6 e $7 / 12$, período úmido, foi de $124.286 \mathrm{~m}^{3}$. O volume simulado foi de $134.352 \mathrm{~m}^{3}$, divergindo $8 \%$ do valor observado (Gráfico 26). 


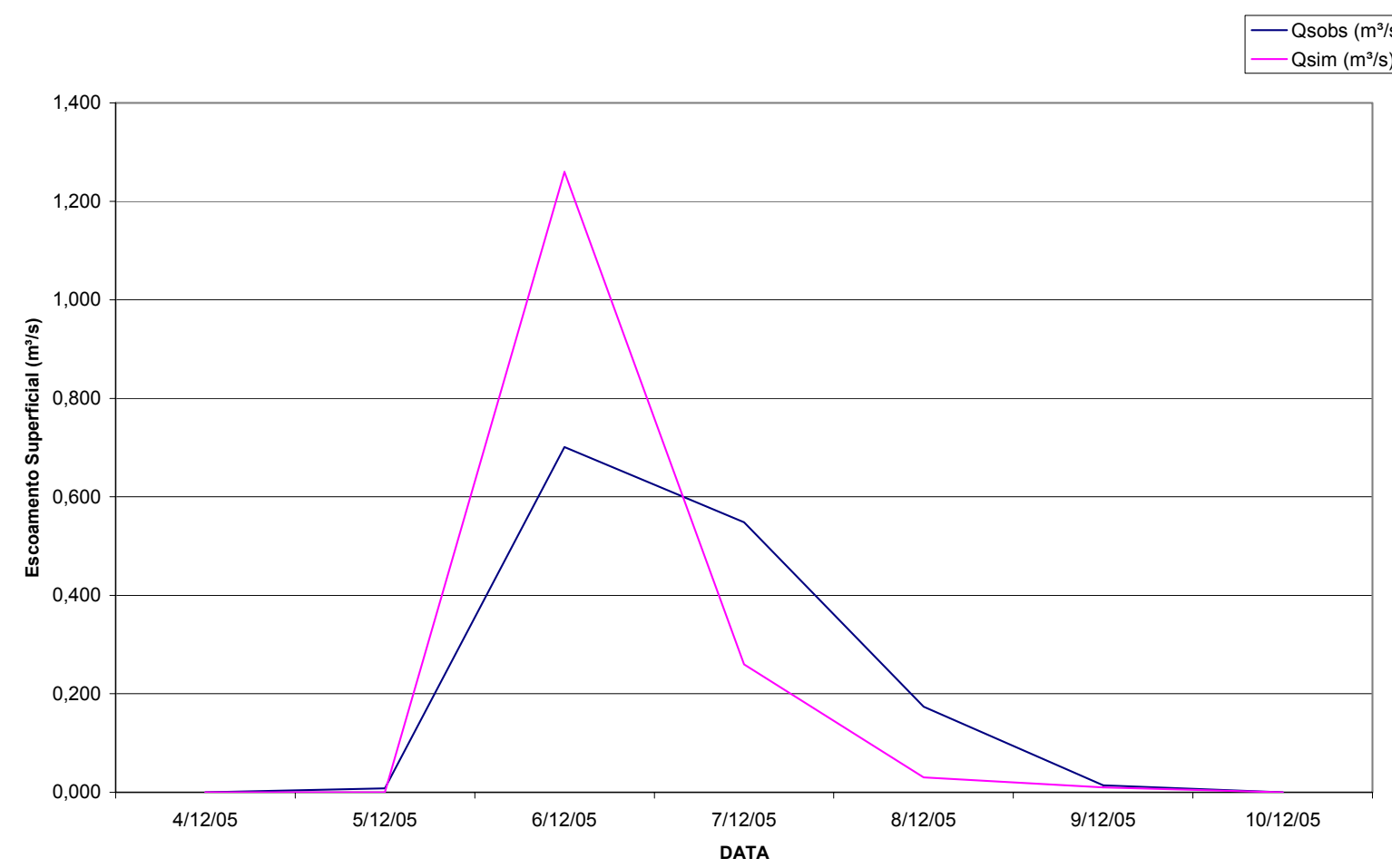

Gráfico 26: Escoamento direto observado e simulado para os eventos de chuva dos dia 4, 5 e 6/12

Os valores simulados apresentam um pico do hidrograma maior do que o observado. Isso se deve ao fato de a simulação no IPHS1 ser realizada com o evento de chuva concentrado. Outro fator que pode contribuir para que o pico do hidrograma simulado seja maior que o observado é a utilização da fórmula de Kirpich, que pode não ser adequada para a bacia. A intensidade do pico do hidrograma simulado não altera os resultados, já que o volume é que será utilizado no trabalho, e a calibração do modelo se deu pelo volume escoado.

Com os valores de CN para os dois períodos considerados efetuou-se a simulação de todos os eventos de chuva do ano. Os eventos foram simulados um a um, sendo somados quando seus efeitos são observados em um mesmo dia.

Os gráficos com a simulação para todos os meses podem ser observados no apêndice E.

O volume total de escoamento direto estimado pelo modelo chuva-vazão utilizando o método do SCS foi de $5.415 .552 \mathrm{~m}^{3}$ no ano de 2005 . O volume escoado transformado em altura equivalente de água sobre a área da bacia foi de $102,28 \mathrm{~mm}$

Este resultado corresponde a $7 \%$ da precipitação anual. O trabalho de Contin Neto (1987) apresenta um resultado para o escoamento direto na bacia na ordem da $1,5 \%$ da precipitação, sendo que foi utilizado o método gráfico de separação do escoamento de base e 
do escoamento superficial. Isto poderia indicar um valor superestimado para esta componente. Porém, o valor precipitado no período estudado por Contin Neto (1987) foi da ordem de $1000 \mathrm{~mm}$, abaixo da média histórica, podendo reduzir consideravelmente o volume escoado diretamente por superfície.

O mês de janeiro correspondeu a mais de $68 \%$ do escoamento direto anual. O mês de janeiro de 2005 apresentou um comportamento atípico (Gráfico 27). A média a longo termo de chuva para o mês de janeiro nessa região está em torno de $240,00 \mathrm{~mm}$. O precipitado para este mês na bacia do Ribeirão da Onça foi de 536,22mm, mais que o dobro esperado para o mês, o que afeta diretamente o escoamento superficial direto. Para o mês de fevereiro a média de longo termo está em torno de 200,00mm. A precipitação na bacia do Ribeirão da Onça para o mês de fevereiro de 2005 foi de $58,79 \mathrm{~mm}$, o que ocasionou um escoamento superficial direto abaixo do esperado para este mês.

A inexistência de dados para a verificação do modelo utilizado pode gerar dúvidas quanto ao escoamento direto estimado. Porém, devido essa parcela ser relativamente pequena, quando comparada com outras parcelas do balanço hídrico, os efeitos de um possível erro são minimizados.

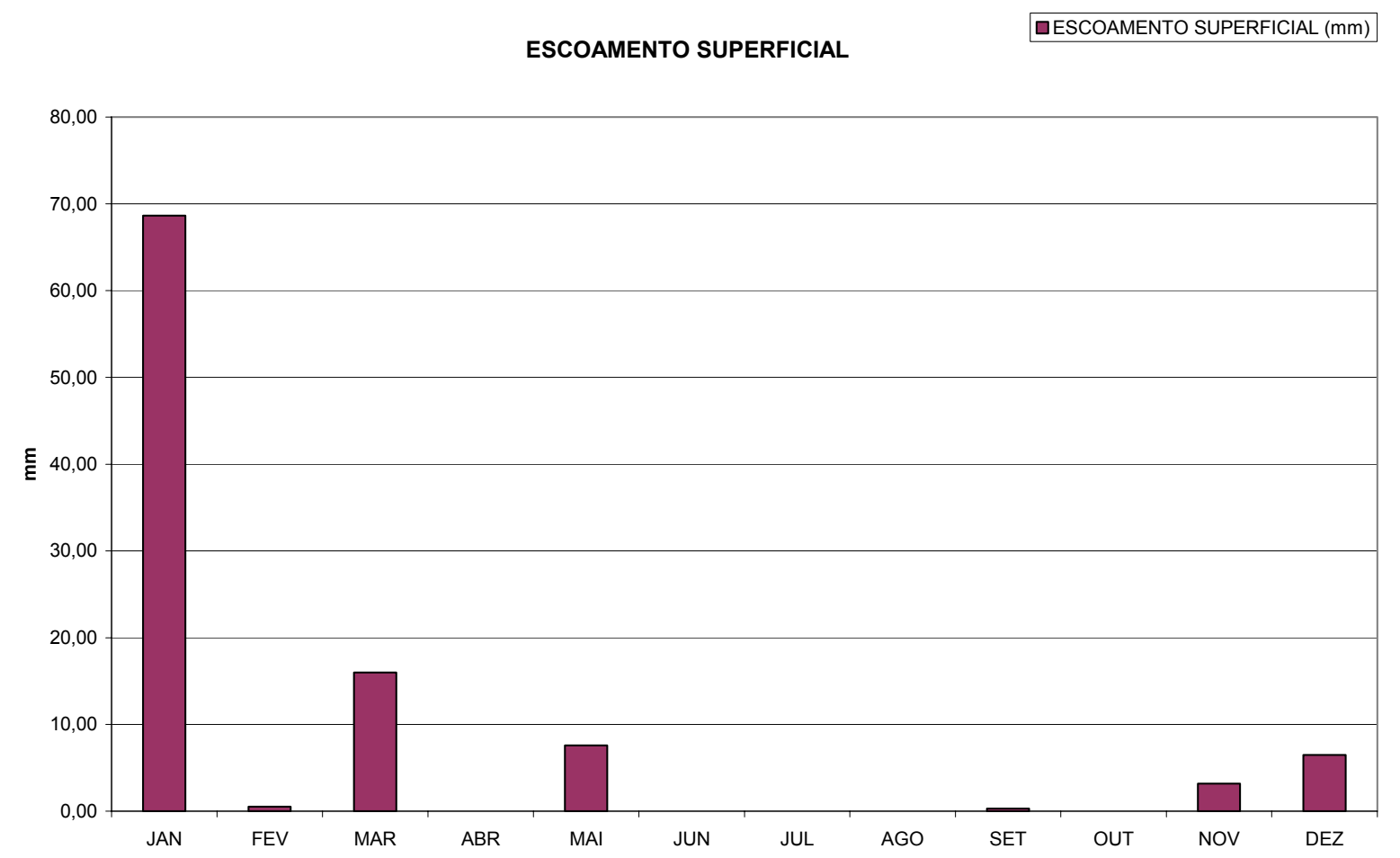

Gráfico 27: escoamento superficial mensal simulado pelo método de transformação chuva-vazão para o ano de 2005, em altura equivalente de água sobre a área da bacia. 


\subsection{Variação do armazenamento subterrâneo}

As estimativas anuais de variação de $S_{y}$ para cada valor da porosidade útil estão apresentadas na Tabela 23.

Tabela 23: Avaliação do armazenamento subterrâneo anual para diferentes valores de porosidade útil

\begin{tabular}{|c|c|c|c|c|c|}
\hline $\boldsymbol{S}_{\boldsymbol{y}}(\mathbf{\%})$ & 10 & 13 & 15 & 20 & 25 \\
\hline $\begin{array}{c}\text { Variação anual do } \\
\text { armazenamento }(\mathbf{m m})\end{array}$ & $-46,66$ & $-60,65$ & $-69,99$ & $-93,31$ & $-116,64$ \\
\hline
\end{tabular}

Em geral os poços, considerados para o estudo, apresentaram um declínio na cota do nível potenciométrico anual. A exceção ocorre nos poços 18 e 19, locados na cultura de pastagem (ver seção 5.2).

Esses dois poços estão em uma região relativamente plana recoberta com pastagem, o que favorece a infiltração, além de ser uma cultura como menor consumo de água. É de se esperar, também, que a evapotranspiração nessa cultura seja menor que em outras, devido ao seu pequeno desenvolvimento.

O poço 09 apresentou o maior declínio anual. O nível potenciométrico baixou mais de dois metros, que pode representar uma variação de $-207,1 \mathrm{~mm}$ a $-517,8 \mathrm{~mm}$, utilizando os coeficientes de porosidade útil (10 e 25\%). O poço 09 está locado em uma região de eucaliptos, relativamente plana, que permite pouco escoamento superficial. O rebaixamento pode ser conseqüência da evapotranspiração e interceptação da chuva. Além disso, o poço 09 apresenta uma zona vadosa espessa, $>20 \mathrm{~m}$, que diminui a recarga direta.

O Gráfico 28 apresenta os valores para a média mensal do armazenamento subterrâneo nos poços de monitoramento considerados para esse estudo, poços 03, 05, 08, 09, 13, 15, 16, 18 e 19 (ver seção 4.4). 


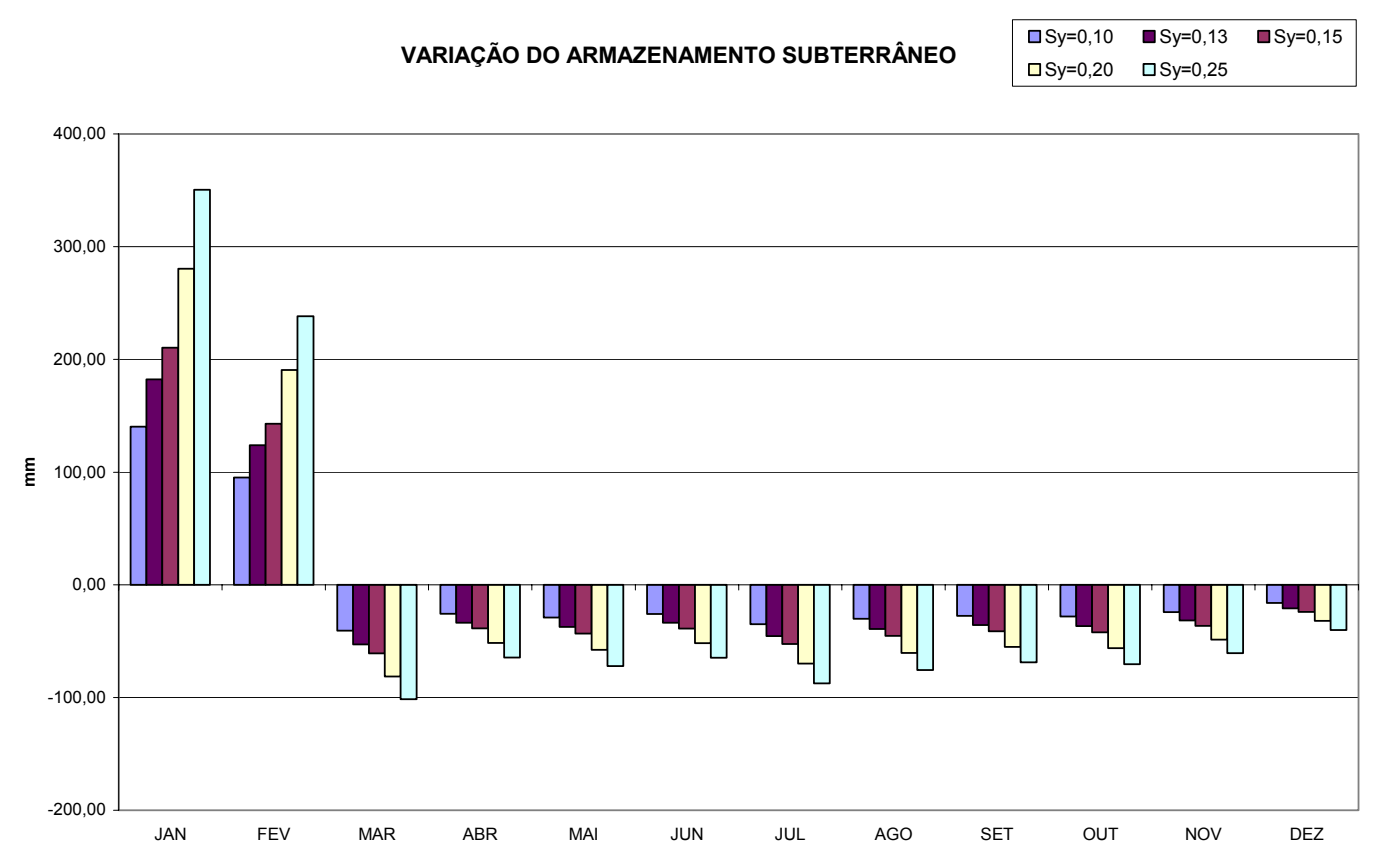

Gráfico 28: Variação do armazenamento subterrâneo mensal no ano de 2005

\subsection{Recarga direta}

Os gráficos Gráfico 29 ao Gráfico 37 apresentam as curvas de recessão extrapoladas e suas devidas equações.

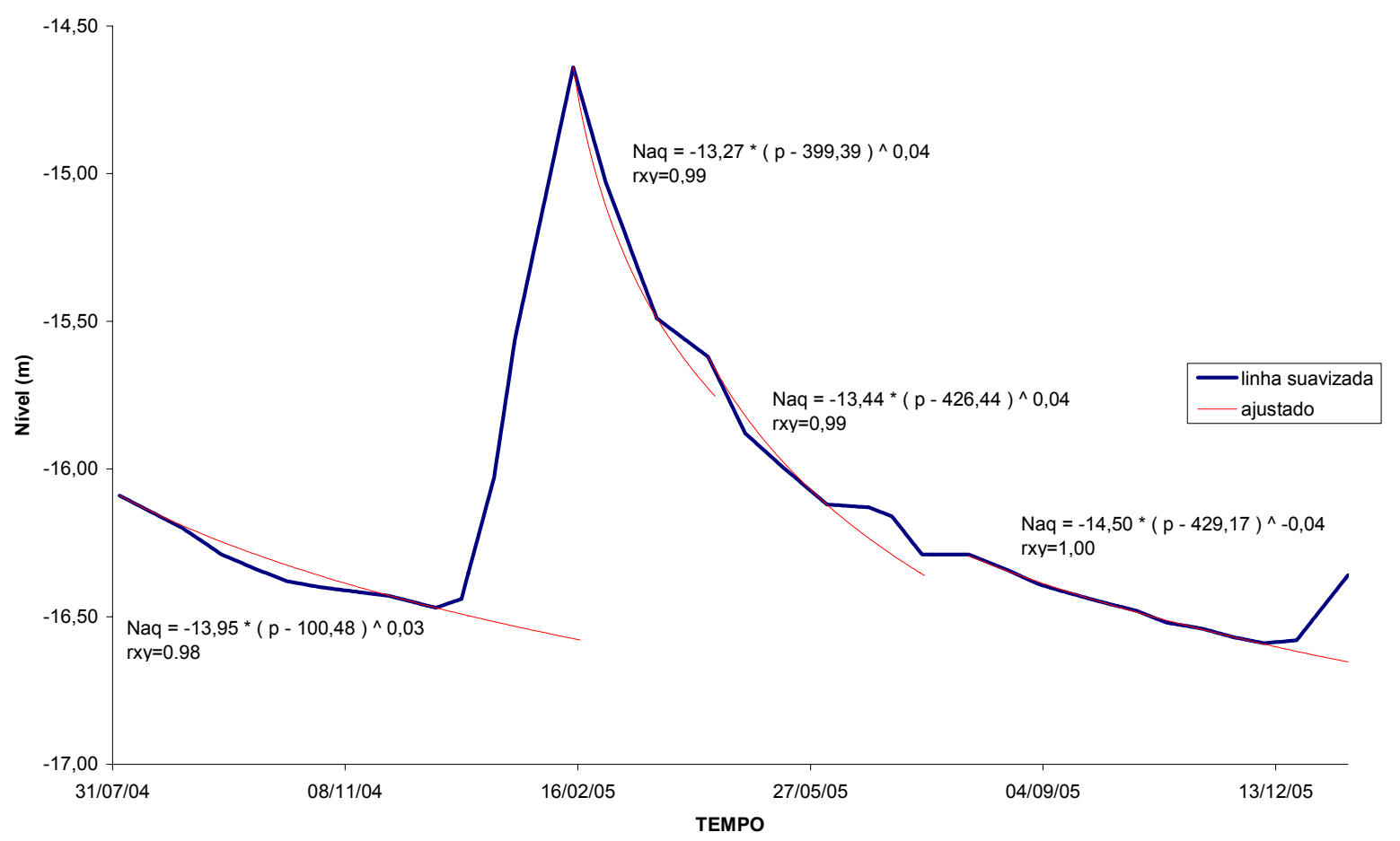

Gráfico 29: Cota potenciométrica e curva de recessão extrapolada para o poço 03 


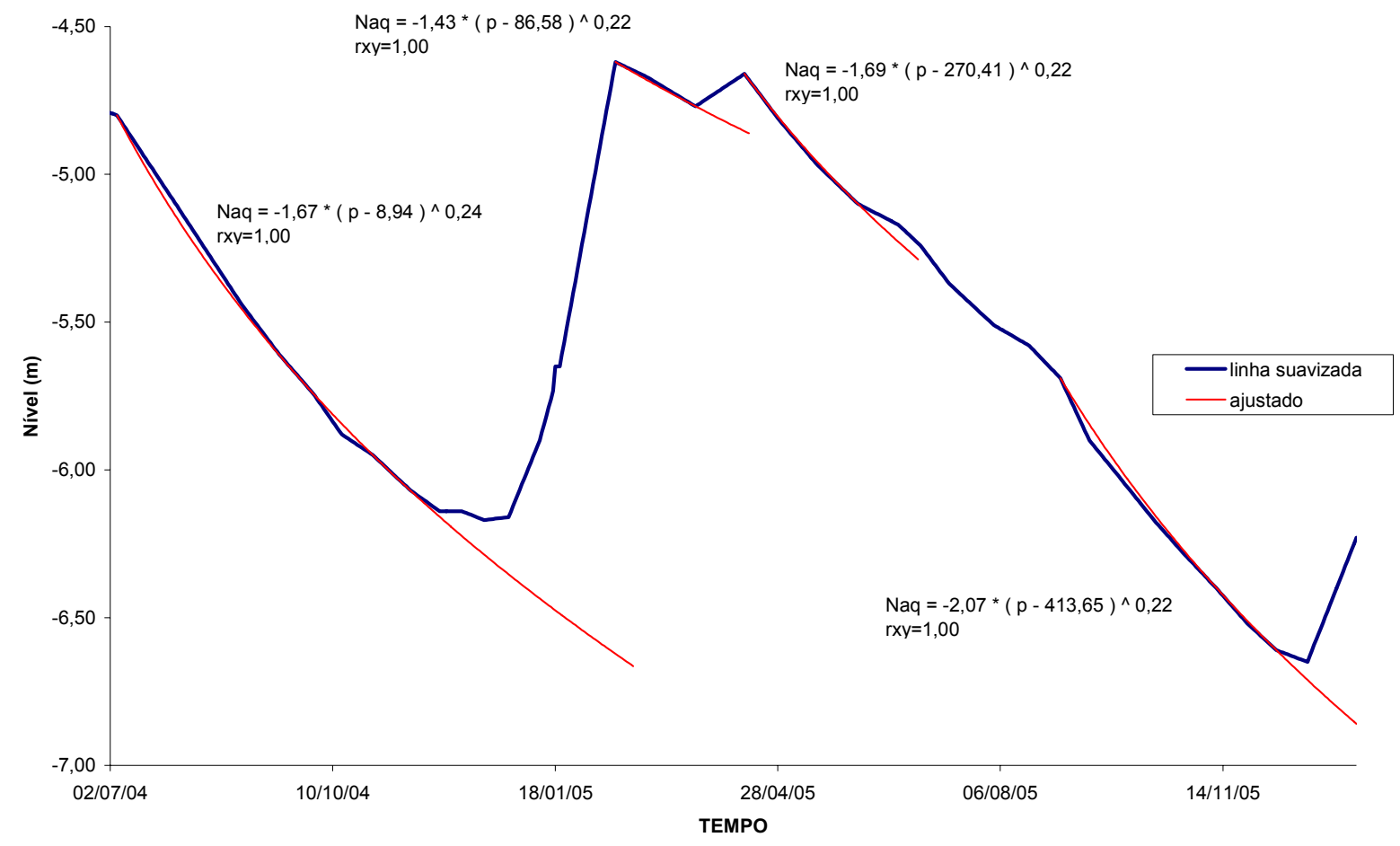

Gráfico 30: Cota potenciométrica e curva de recessão extrapolada para o poço 05

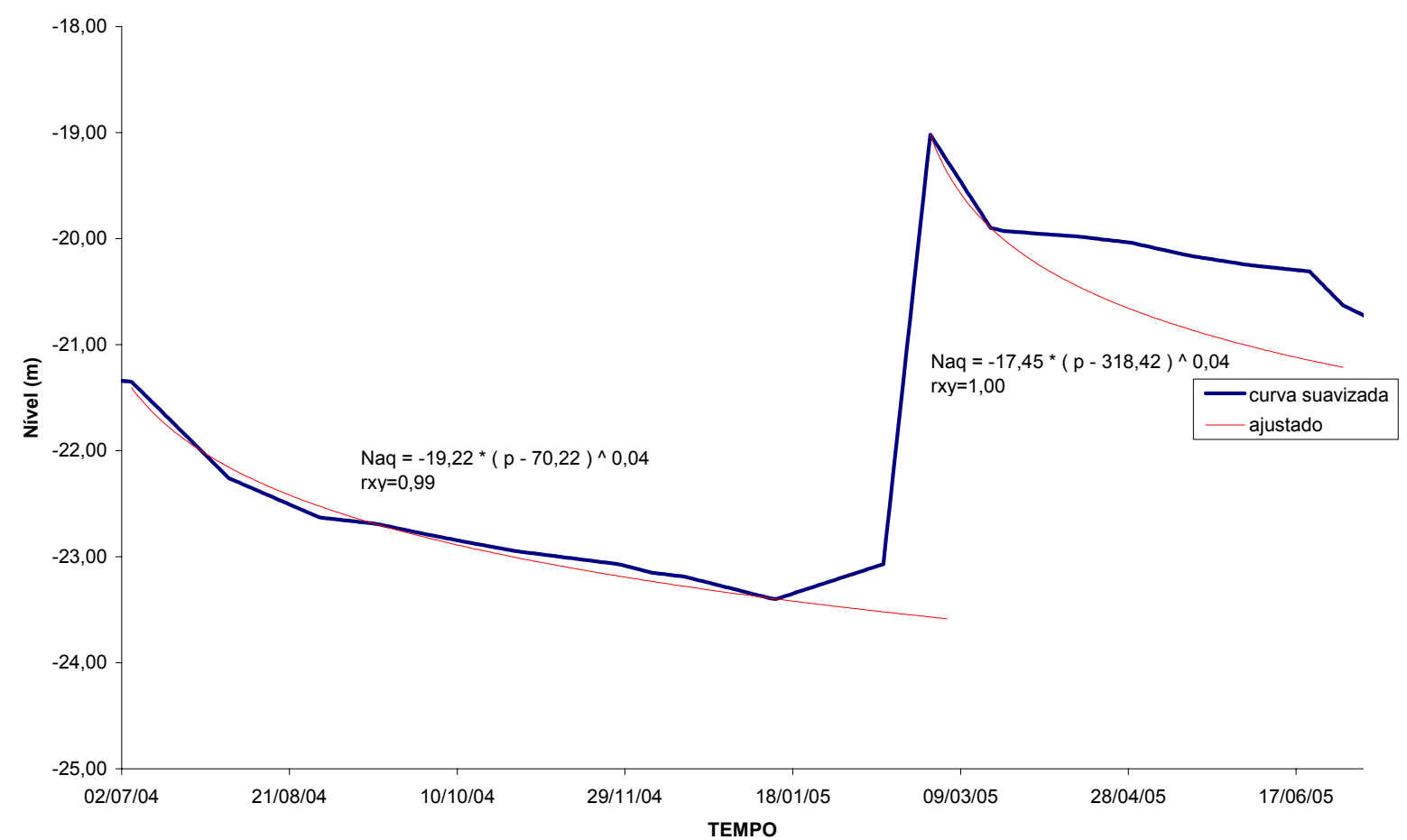

Gráfico 31: Cota potenciométrica e curva de recessão extrapolada para o poço 08 


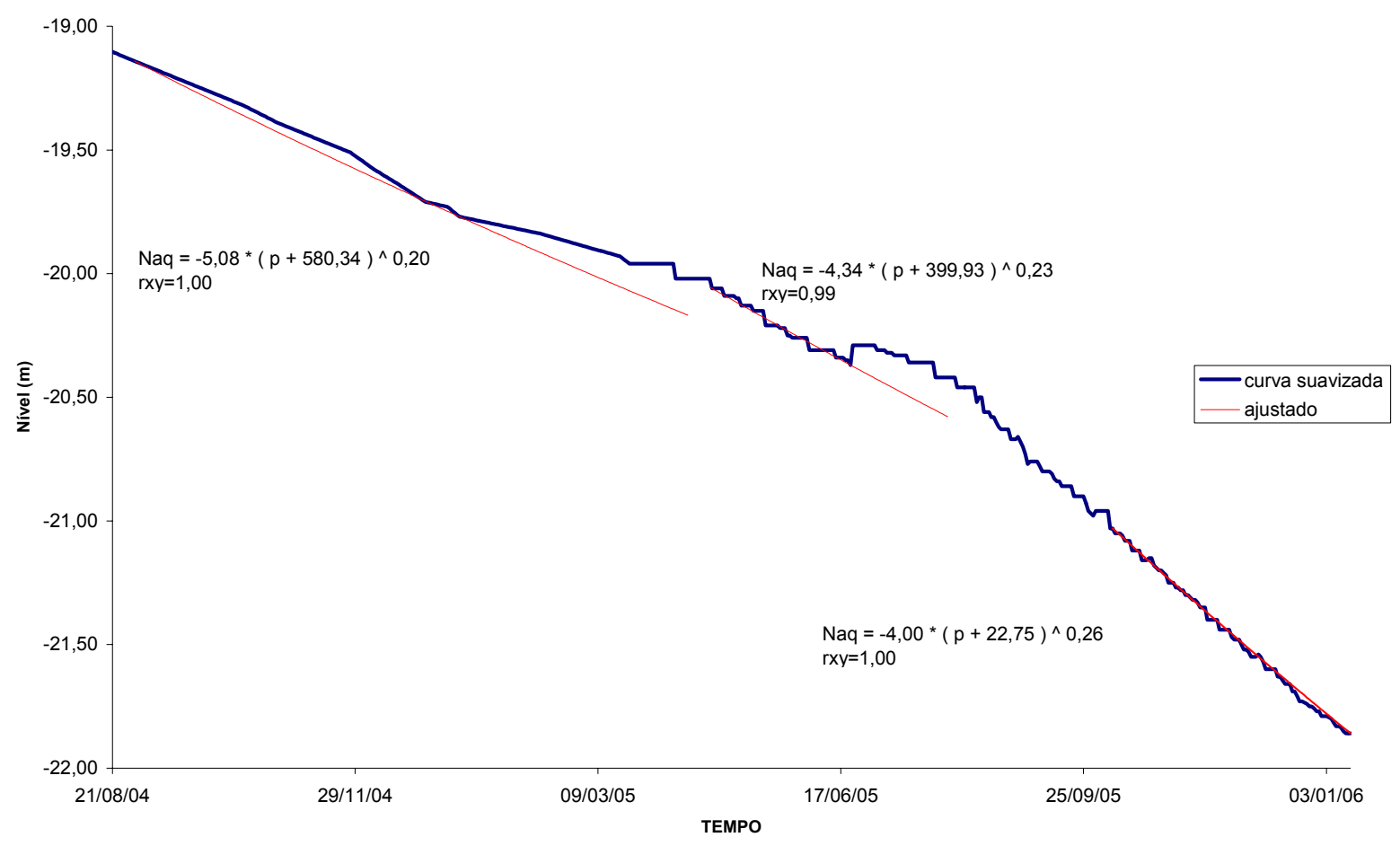

Gráfico 32: Cota potenciométrica e curva de recessão extrapolada para o poço 09

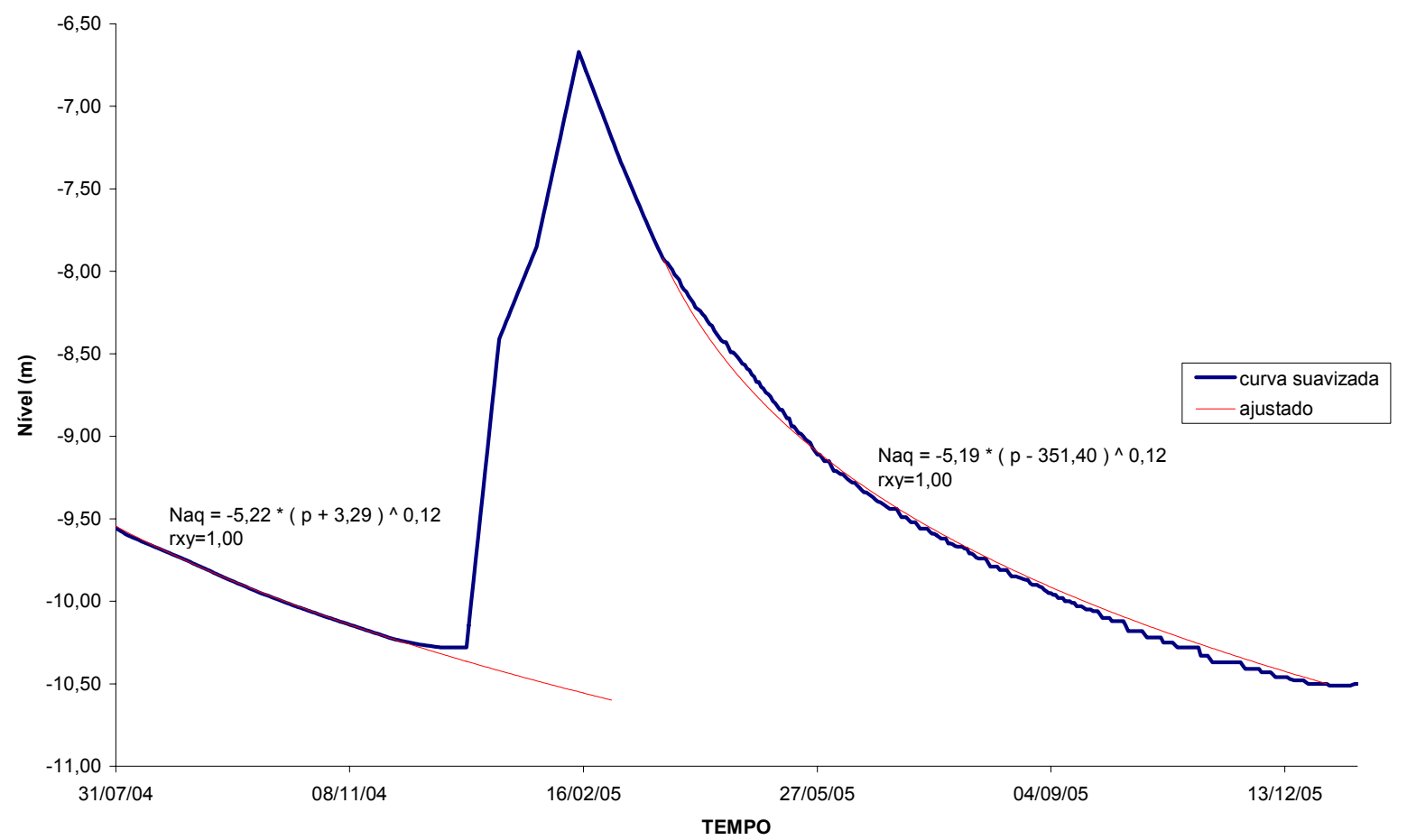

Gráfico 33: Cota potenciométrica e curva de recessão extrapolada para o poço 13 


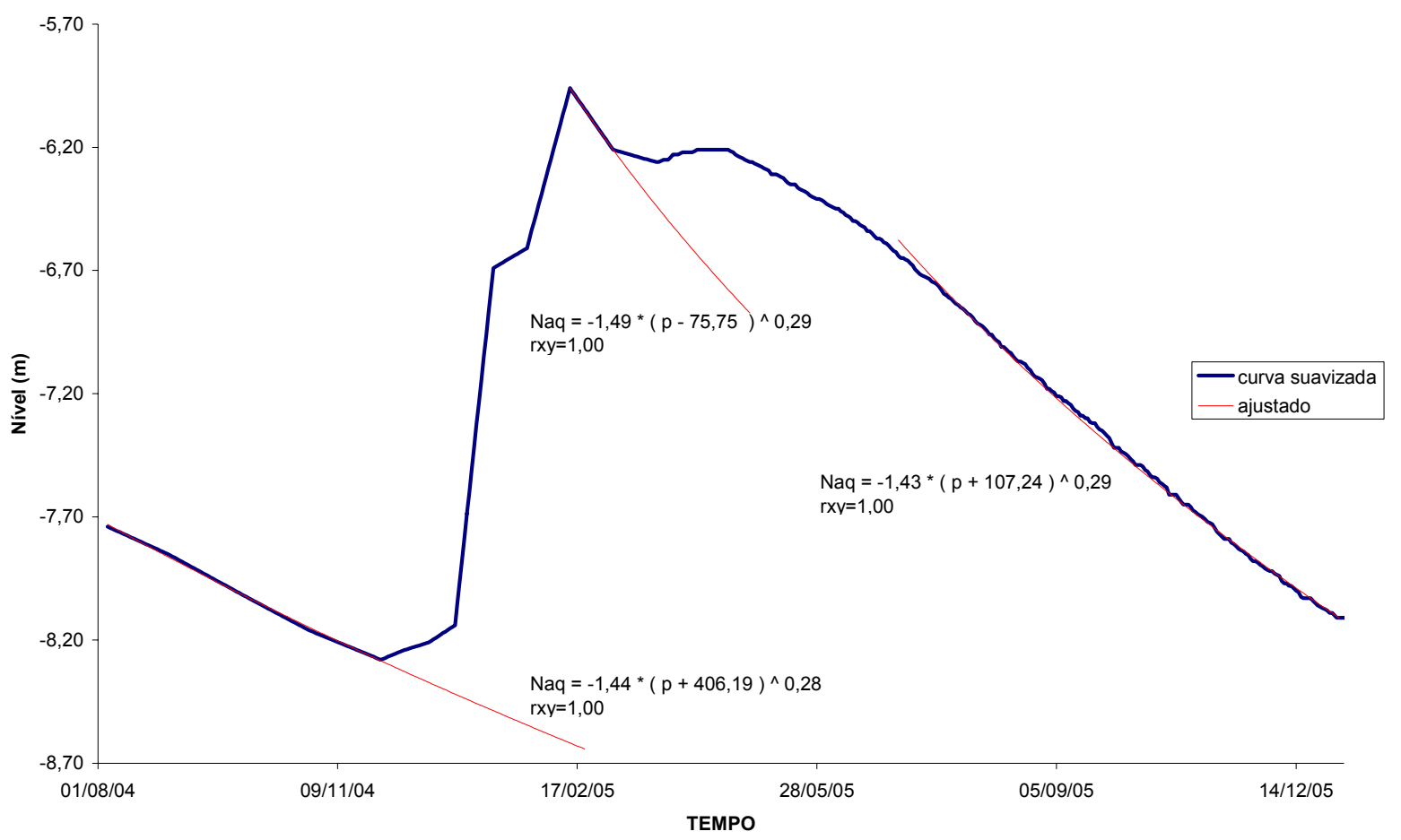

Gráfico 34: Cota potenciométrica e curva de recessão extrapolada para o poço 15

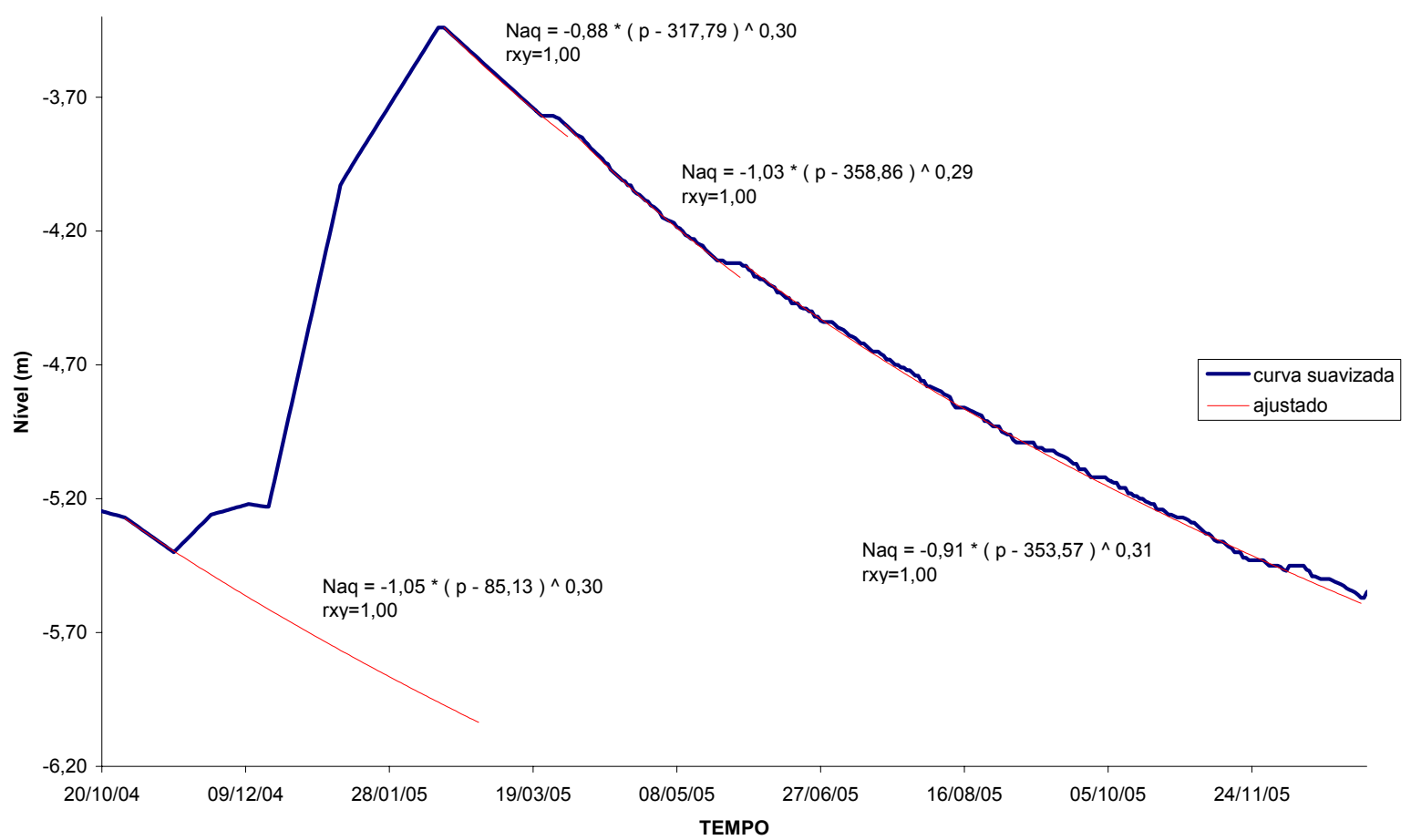

Gráfico 35: Cota potenciométrica e curva de recessão extrapolada para o poço 16 


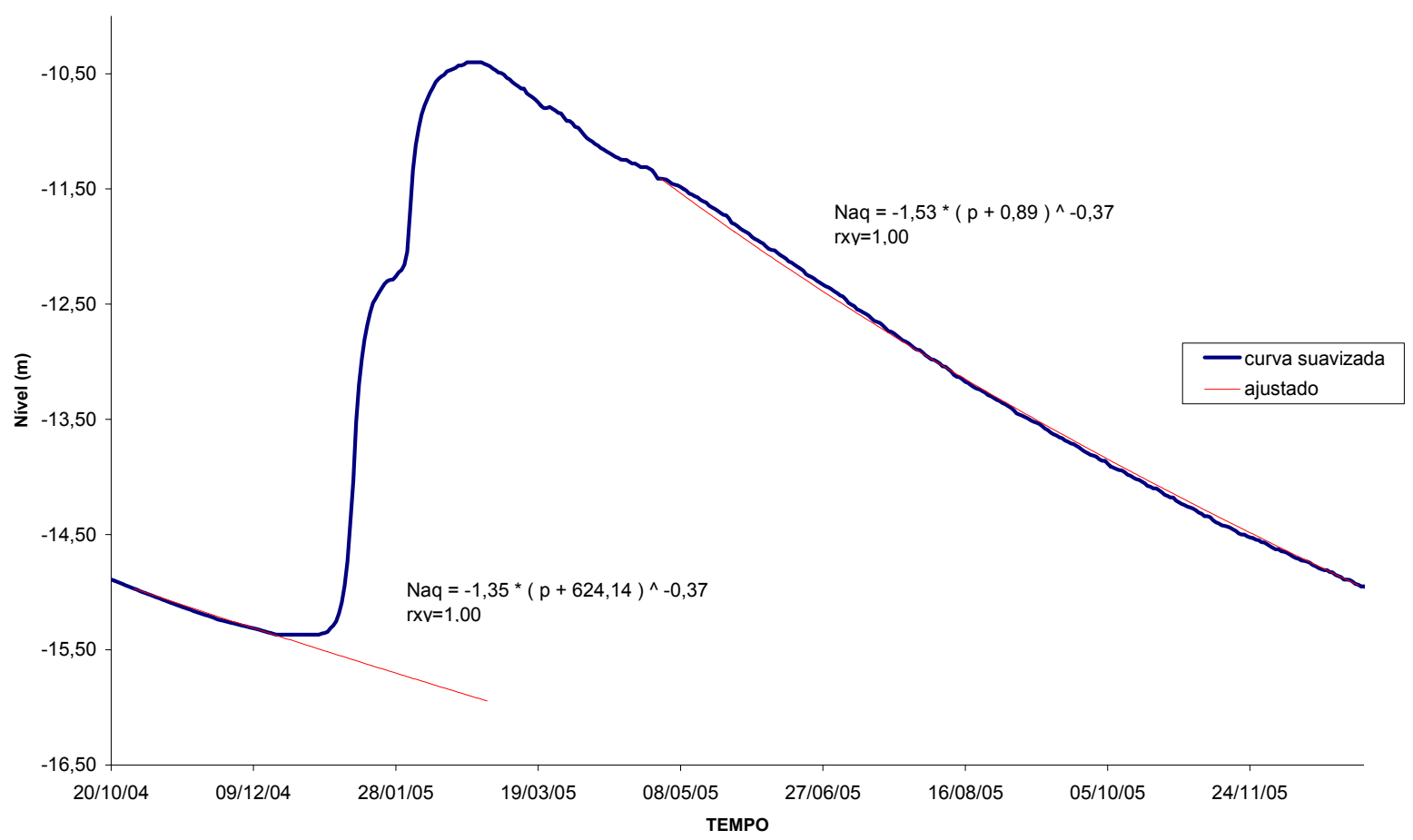

Gráfico 36: Cota potenciométrica e curva de recessão extrapolada para o poço 18

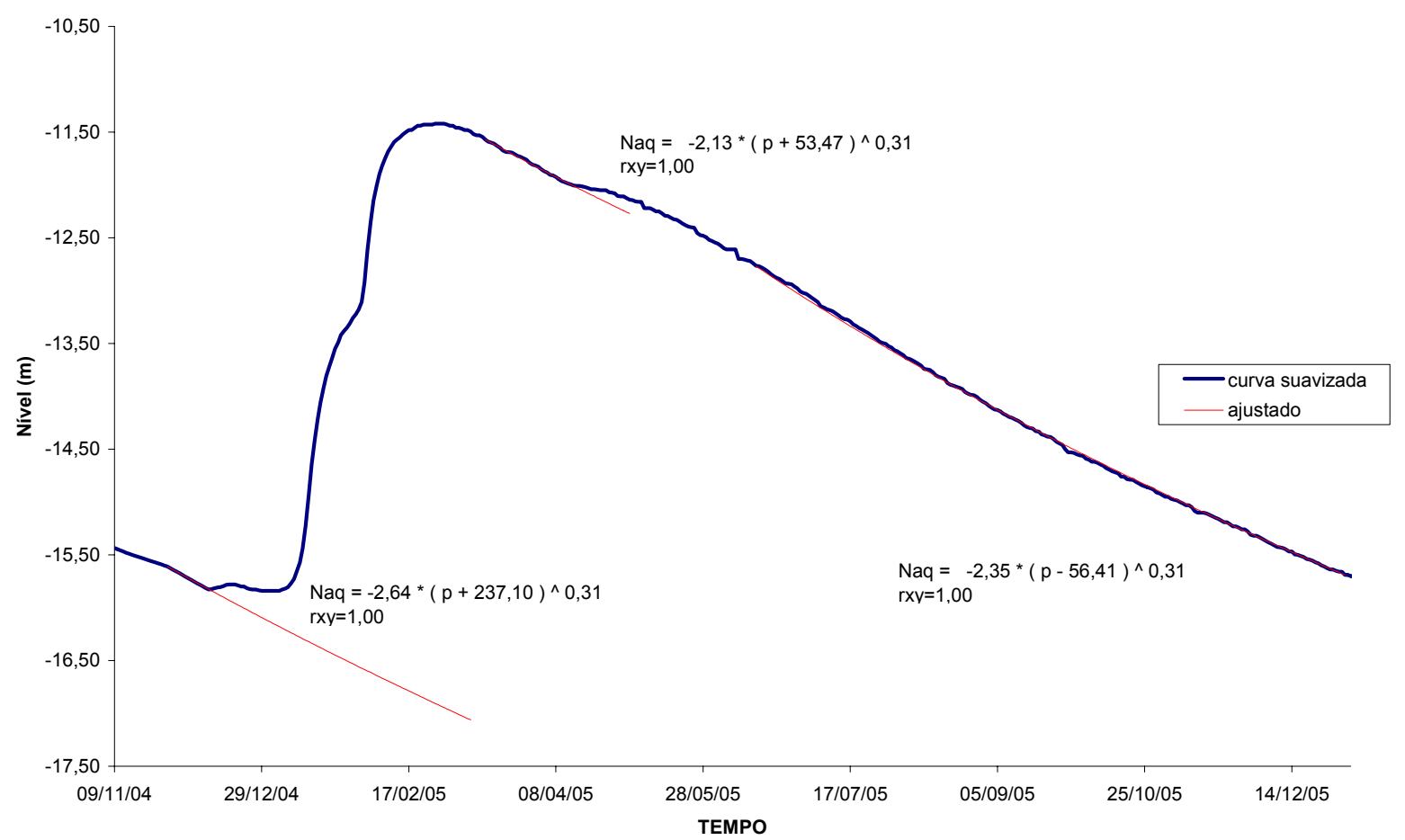

Gráfico 37: Cota potenciométrica e curva de recessão extrapolada para o poço 19 
Com as curvas de recessão extrapoladas, os valores encontrados para a diferença entre a curva de recessão e o nível real do aqüífero e para a recarga direta podem ser calculados. Esses resultados são apresentados nas Tabela 24 a Tabela 32.

Tabela 24: Valores calculados para a diferença entre o nível real do aqüífero e a curva de recessão $(\Delta \mathrm{h})$ e para a recarga direta no poço 03

\begin{tabular}{|c|c|c|c|c|c|c|}
\hline DATA & $\begin{array}{l}\text { RECARGA DIRETA } / \text { Sy }= \\
\Delta \mathrm{h}(\mathrm{mm})\end{array}$ & $\begin{array}{c}\text { RECARGA } \\
\text { DIRETA } \\
(\mathrm{mm})(\mathrm{Sy}= \\
10 \%)\end{array}$ & $\begin{array}{c}\text { RECARGA } \\
\text { DIRETA } \\
(\mathrm{mm})(\mathrm{Sy}= \\
13 \%)\end{array}$ & $\begin{array}{c}\text { RECARGA } \\
\text { DIRETA } \\
(\mathrm{mm})(\mathrm{Sy}= \\
15 \%)\end{array}$ & $\begin{array}{c}\text { RECARGA } \\
\text { DIRETA } \\
(\mathrm{mm})(\mathrm{Sy}= \\
20 \%)\end{array}$ & $\begin{array}{c}\text { RECARGA } \\
\text { DIRETA } \\
(\mathrm{mm})(\mathrm{Sy}= \\
25 \%)\end{array}$ \\
\hline JAN & 1259,01 & 125,90 & 163,67 & 188,85 & 251,80 & 314,75 \\
\hline FEV & 499,65 & 49,97 & 64,95 & 74,95 & 99,93 & 124,91 \\
\hline MAR & 59,48 & 5,95 & 7,73 & 8,92 & 11,90 & 14,87 \\
\hline$A B R$ & 47,67 & 4,77 & 6,20 & 7,15 & 9,53 & 11,92 \\
\hline MAI & 0,00 & 0,00 & 0,00 & 0,00 & 0,00 & 0,00 \\
\hline JUN & 129,70 & 12,97 & 16,86 & 19,46 & 25,94 & 32,43 \\
\hline JUL & 0,00 & 0,00 & 0,00 & 0,00 & 0,00 & 0,00 \\
\hline$A G O$ & 0,00 & 0,00 & 0,00 & 0,00 & 0,00 & 0,00 \\
\hline SET & 0,00 & 0,00 & 0,00 & 0,00 & 0,00 & 0,00 \\
\hline OUT & 0,00 & 0,00 & 0,00 & 0,00 & 0,00 & 0,00 \\
\hline NOV & 0,00 & 0,00 & 0,00 & 0,00 & 0,00 & 0,00 \\
\hline$D E Z$ & 154,16 & 15,42 & 20,04 & 23,12 & 30,83 & 38,54 \\
\hline
\end{tabular}

Tabela 25: Valores calculados para a diferença entre o nível real do aqüífero e a curva de recessão $(\Delta \mathrm{h})$ e para a recarga direta no poço 05

\begin{tabular}{|c|c|c|c|c|c|c|}
\hline DATA & $\begin{array}{c}\text { RECARGA DIRETA / Sy = } \\
\Delta \mathrm{h}(\mathrm{mm})\end{array}$ & $\begin{array}{c}\text { RECARGA } \\
\text { DIRETA } \\
(\mathrm{mm})(\mathrm{Sy}= \\
10 \%)\end{array}$ & $\begin{array}{c}\text { RECARGA } \\
\text { DIRETA } \\
(\mathrm{mm})(\mathrm{Sy}= \\
13 \%)\end{array}$ & $\begin{array}{c}\text { RECARGA } \\
\text { DIRETA } \\
(\mathrm{mm})(\mathrm{Sy}= \\
15 \%)\end{array}$ & $\begin{array}{c}\text { RECARGA } \\
\text { DIRETA } \\
(\mathrm{mm})(\mathrm{Sy}= \\
20 \%)\end{array}$ & $\begin{array}{c}\text { RECARGA } \\
\text { DIRETA } \\
(\mathrm{mm})(\mathrm{Sy}= \\
25 \%)\end{array}$ \\
\hline JAN & 1105,70 & 110,57 & 143,74 & 165,86 & 221,14 & 276,43 \\
\hline FEV & 605,02 & 60,50 & 78,65 & 90,75 & 121,00 & 151,26 \\
\hline MAR & 88,79 & 8,88 & 11,54 & 13,32 & 17,76 & 22,20 \\
\hline$A B R$ & 108,79 & 10,88 & 14,14 & 16,32 & 21,76 & 27,20 \\
\hline MAI & 0,00 & 0,00 & 0,00 & 0,00 & 0,00 & 0,00 \\
\hline JUN & 57,46 & 5,75 & 7,47 & 8,62 & 11,49 & 14,36 \\
\hline JUL & 0,00 & 0,00 & 0,00 & 0,00 & 0,00 & 0,00 \\
\hline$A G O$ & 0,00 & 0,00 & 0,00 & 0,00 & 0,00 & 0,00 \\
\hline SET & 0,00 & 0,00 & 0,00 & 0,00 & 0,00 & 0,00 \\
\hline OUT & 0,00 & 0,00 & 0,00 & 0,00 & 0,00 & 0,00 \\
\hline NOV & 0,00 & 0,00 & 0,00 & 0,00 & 0,00 & 0,00 \\
\hline$D E Z$ & 320,75 & 32,07 & 41,70 & 48,11 & 64,15 & 80,19 \\
\hline
\end{tabular}


Tabela 26: Valores calculados para a diferença entre o nível real do aqǘfero e a curva de recessão

$(\Delta \mathrm{h})$ e para a recarga direta no poço 08

\begin{tabular}{|c|c|c|c|c|c|c|}
\hline DATA & $\begin{array}{c}\text { RECARGA DIRETA / Sy }= \\
\Delta \mathrm{h}(\mathrm{mm})\end{array}$ & $\begin{array}{c}\text { RECARGA } \\
\text { DIRETA } \\
(\mathrm{mm})(\mathrm{Sy}= \\
10 \%) \\
\end{array}$ & $\begin{array}{c}\text { RECARGA } \\
\text { DIRETA } \\
(\mathrm{mm})(\mathrm{Sy}= \\
13 \%) \\
\end{array}$ & $\begin{array}{c}\text { RECARGA } \\
\text { DIRETA } \\
(\mathrm{mm})(\mathrm{Sy}= \\
15 \%) \\
\end{array}$ & $\begin{array}{c}\text { RECARGA } \\
\text { DIRETA } \\
(\mathrm{mm})(\mathrm{Sy}= \\
20 \%) \\
\end{array}$ & $\begin{array}{c}\text { RECARGA } \\
\text { DIRETA } \\
(\mathrm{mm})(\mathrm{Sy}= \\
25 \%) \\
\end{array}$ \\
\hline JAN & 268,44 & 26,84 & 34,90 & 40,27 & 53,69 & 67,11 \\
\hline FEV & 4234,54 & 423,45 & 550,49 & 635,18 & 846,91 & 1058,64 \\
\hline MAR & 286,94 & 28,69 & 37,30 & 43,04 & 57,39 & 71,73 \\
\hline$A B R$ & 351,69 & 35,17 & 45,72 & 52,75 & 70,34 & 87,92 \\
\hline$M A I$ & 117,69 & 11,77 & 15,30 & 17,65 & 23,54 & 29,42 \\
\hline JUN & 81,49 & 8,15 & 10,59 & 12,22 & 16,30 & 20,37 \\
\hline$J U L$ & 0,00 & 0,00 & 0,00 & 0,00 & 0,00 & 0,00 \\
\hline$A G O$ & 0,00 & 0,00 & 0,00 & 0,00 & 0,00 & 0,00 \\
\hline SET & 0,00 & 0,00 & 0,00 & 0,00 & 0,00 & 0,00 \\
\hline OUT & 0,00 & 0,00 & 0,00 & 0,00 & 0,00 & 0,00 \\
\hline NOV & 0,00 & 0,00 & 0,00 & 0,00 & 0,00 & 0,00 \\
\hline$D E Z$ & 0,00 & 0,00 & 34,90 & 0,00 & 0,00 & 0,00 \\
\hline
\end{tabular}

Tabela 27: Valores calculados para a diferença entre o nível real do aqǘffero e a curva de recessão $(\Delta \mathrm{h})$ e para a recarga direta no poço 09

\begin{tabular}{|c|c|c|c|c|c|c|}
\hline DATA & $\begin{array}{c}\text { RECARGA DIRETA } / \text { Sy }= \\
\Delta \mathrm{h}(\mathrm{mm})\end{array}$ & $\begin{array}{c}\text { RECARGA } \\
\text { DIRETA } \\
(\mathrm{mm})(\mathrm{Sy}= \\
10 \%) \\
\end{array}$ & $\begin{array}{c}\text { RECARGA } \\
\text { DIRETA } \\
(\mathrm{mm})(\mathrm{Sy}= \\
13 \%) \\
\end{array}$ & $\begin{array}{c}\text { RECARGA } \\
\text { DIRETA } \\
(\mathrm{mm})(\mathrm{Sy}= \\
15 \%) \\
\end{array}$ & $\begin{array}{c}\text { RECARGA } \\
\text { DIRETA } \\
(\mathrm{mm})(\mathrm{Sy}= \\
20 \%) \\
\end{array}$ & $\begin{array}{c}\text { RECARGA } \\
\text { DIRETA } \\
(\mathrm{mm})(\mathrm{Sy}= \\
25 \%) \\
\end{array}$ \\
\hline JAN & 48,55 & 4,85 & 6,31 & 7,28 & 9,71 & 12,14 \\
\hline FEV & 50,25 & 5,03 & 6,53 & 7,54 & 10,05 & 12,56 \\
\hline MAR & 52,14 & 5,21 & 6,78 & 7,82 & 10,43 & 13,04 \\
\hline$A B R$ & 32,85 & 3,28 & 4,27 & 4,93 & 6,57 & 8,21 \\
\hline$M A I$ & 0,00 & 0,00 & 0,00 & 0,00 & 0,00 & 0,00 \\
\hline JUN & 132,77 & 13,28 & 17,26 & 19,92 & 26,55 & 33,19 \\
\hline JUL & 54,80 & 5,48 & 7,12 & 8,22 & 10,96 & 13,70 \\
\hline$A G O$ & 0,00 & 0,00 & 0,00 & 0,00 & 0,00 & 0,00 \\
\hline SET & 0,00 & 0,00 & 0,00 & 0,00 & 0,00 & 0,00 \\
\hline OUT & 0,00 & 0,00 & 0,00 & 0,00 & 0,00 & 0,00 \\
\hline NOV & 0,00 & 0,00 & 0,00 & 0,00 & 0,00 & 0,00 \\
\hline$D E Z$ & 0,00 & 0,00 & 0,00 & 0,00 & 0,00 & 0,00 \\
\hline
\end{tabular}


Tabela 28: Valores calculados para a diferença entre o nível real do aqüífero e a curva de recessão

$(\Delta \mathrm{h})$ e para a recarga direta no poço 13

\begin{tabular}{|c|c|c|c|c|c|c|}
\hline DATA & $\begin{array}{c}\text { RECARGA DIRETA / Sy }= \\
\Delta \mathrm{h}(\mathrm{mm})\end{array}$ & $\begin{array}{c}\text { RECARGA } \\
\text { DIRETA } \\
(\mathrm{mm})(\mathrm{Sy}= \\
10 \%) \\
\end{array}$ & $\begin{array}{c}\text { RECARGA } \\
\text { DIRETA } \\
(\mathrm{mm})(\mathrm{Sy}= \\
13 \%) \\
\end{array}$ & $\begin{array}{c}\text { RECARGA } \\
\text { DIRETA } \\
(\mathrm{mm})(\mathrm{Sy}= \\
15 \%) \\
\end{array}$ & $\begin{array}{c}\text { RECARGA } \\
\text { DIRETA } \\
(\mathrm{mm})(\mathrm{Sy}= \\
20 \%) \\
\end{array}$ & $\begin{array}{c}\text { RECARGA } \\
\text { DIRETA } \\
(\mathrm{mm})(\mathrm{Sy}= \\
25 \%) \\
\end{array}$ \\
\hline JAN & 2344,28 & 234,43 & 304,76 & 351,64 & 468,86 & 586,07 \\
\hline FEV & 899,99 & 90,00 & 117,00 & 135,00 & 180,00 & 225,00 \\
\hline MAR & 0,00 & 0,00 & 0,00 & 0,00 & 0,00 & 0,00 \\
\hline$A B R$ & 0,00 & 0,00 & 0,00 & 0,00 & 0,00 & 0,00 \\
\hline$M A I$ & 0,00 & 0,00 & 0,00 & 0,00 & 0,00 & 0,00 \\
\hline JUN & 0,00 & 0,00 & 0,00 & 0,00 & 0,00 & 0,00 \\
\hline$J U L$ & 0,00 & 0,00 & 0,00 & 0,00 & 0,00 & 0,00 \\
\hline$A G O$ & 0,00 & 0,00 & 0,00 & 0,00 & 0,00 & 0,00 \\
\hline SET & 0,00 & 0,00 & 0,00 & 0,00 & 0,00 & 0,00 \\
\hline OUT & 0,00 & 0,00 & 0,00 & 0,00 & 0,00 & 0,00 \\
\hline NOV & 0,00 & 0,00 & 0,00 & 0,00 & 0,00 & 0,00 \\
\hline$D E Z$ & 0,00 & 0,00 & 0,00 & 0,00 & 0,00 & 0,00 \\
\hline
\end{tabular}

Tabela 29: Valores calculados para a diferença entre o nível real do aqüífero e a curva de recessão

$(\Delta \mathrm{h})$ e para a recarga direta no poço 15

\begin{tabular}{|c|c|c|c|c|c|c|}
\hline DATA & $\begin{array}{l}\text { RECARGA DIRETA / Sy }= \\
\Delta \mathrm{h}(\mathrm{mm})\end{array}$ & $\begin{array}{c}\text { RECARGA } \\
\text { DIRETA } \\
(\mathrm{mm})(\mathrm{Sy}= \\
10 \%) \\
\end{array}$ & $\begin{array}{c}\text { RECARGA } \\
\text { DIRETA } \\
(\mathrm{mm})(\mathrm{Sy}= \\
13 \%) \\
\end{array}$ & $\begin{array}{c}\text { RECARGA } \\
\text { DIRETA } \\
(\mathrm{mm})(\mathrm{Sy}= \\
15 \%) \\
\end{array}$ & $\begin{array}{c}\text { RECARGA } \\
\text { DIRETA } \\
(\mathrm{mm})(\mathrm{Sy}= \\
20 \%) \\
\end{array}$ & $\begin{array}{c}\text { RECARGA } \\
\text { DIRETA } \\
(\mathrm{mm})(\mathrm{Sy}= \\
25 \%) \\
\end{array}$ \\
\hline JAN & 1477,15 & 147,72 & 192,03 & 221,57 & 295,43 & 369,29 \\
\hline FEV & 522,12 & 52,21 & 67,88 & 78,32 & 104,42 & 130,53 \\
\hline MAR & 330,88 & 33,09 & 43,01 & 49,63 & 66,18 & 82,72 \\
\hline$A B R$ & 248,39 & 24,84 & 32,29 & 37,26 & 49,68 & 62,10 \\
\hline MAI & 0,00 & 0,00 & 0,00 & 0,00 & 0,00 & 0,00 \\
\hline JUN & 0,00 & 0,00 & 0,00 & 0,00 & 0,00 & 0,00 \\
\hline$J U L$ & 0,00 & 0,00 & 0,00 & 0,00 & 0,00 & 0,00 \\
\hline$A G O$ & 0,00 & 0,00 & 0,00 & 0,00 & 0,00 & 0,00 \\
\hline SET & 0,00 & 0,00 & 0,00 & 0,00 & 0,00 & 0,00 \\
\hline OUT & 0,00 & 0,00 & 0,00 & 0,00 & 0,00 & 0,00 \\
\hline NOV & 0,00 & 0,00 & 0,00 & 0,00 & 0,00 & 0,00 \\
\hline$D E Z$ & 0,00 & 0,00 & 0,00 & 0,00 & 0,00 & 0,00 \\
\hline
\end{tabular}


Tabela 30: Valores calculados para a diferença entre o nível real do aqǘfero e a curva de recessão

$(\Delta \mathrm{h})$ e para a recarga direta no poço 16

\begin{tabular}{|c|c|c|c|c|c|c|}
\hline DATA & $\begin{array}{c}\text { RECARGA DIRETA } / \text { Sy }= \\
\Delta \mathrm{h}(\mathrm{mm})\end{array}$ & $\begin{array}{c}\text { RECARGA } \\
\text { DIRETA } \\
(\mathrm{mm})(\mathrm{Sy}= \\
10 \%) \\
\end{array}$ & $\begin{array}{c}\text { RECARGA } \\
\text { DIRETA } \\
(\mathrm{mm})(\mathrm{Sy}= \\
13 \%) \\
\end{array}$ & $\begin{array}{c}\text { RECARGA } \\
\text { DIRETA } \\
(\mathrm{mm})(\mathrm{Sy}= \\
15 \%) \\
\end{array}$ & $\begin{array}{c}\text { RECARGA } \\
\text { DIRETA } \\
(\mathrm{mm})(\mathrm{Sy}= \\
20 \%) \\
\end{array}$ & $\begin{array}{c}\text { RECARGA } \\
\text { DIRETA } \\
(\mathrm{mm})(\mathrm{Sy}= \\
25 \%) \\
\end{array}$ \\
\hline JAN & 1028,01 & 102,80 & 133,64 & 154,20 & 205,60 & 257,00 \\
\hline FEV & 295,79 & 29,58 & 38,45 & 44,37 & 59,16 & 73,95 \\
\hline MAR & 38,19 & 3,82 & 4,96 & 5,73 & 7,64 & 9,55 \\
\hline$A B R$ & 0,00 & 0,00 & 0,00 & 0,00 & 0,00 & 0,00 \\
\hline$M A I$ & 0,00 & 0,00 & 0,00 & 0,00 & 0,00 & 0,00 \\
\hline JUN & 43,12 & 4,31 & 5,61 & 6,47 & 8,62 & 10,78 \\
\hline$J U L$ & 0,00 & 0,00 & 0,00 & 0,00 & 0,00 & 0,00 \\
\hline$A G O$ & 0,00 & 0,00 & 0,00 & 0,00 & 0,00 & 0,00 \\
\hline SET & 0,00 & 0,00 & 0,00 & 0,00 & 0,00 & 0,00 \\
\hline OUT & 0,00 & 0,00 & 0,00 & 0,00 & 0,00 & 0,00 \\
\hline NOV & 0,00 & 0,00 & 0,00 & 0,00 & 0,00 & 0,00 \\
\hline$D E Z$ & 48,38 & 4,84 & 6,29 & 7,26 & 9,68 & 12,10 \\
\hline
\end{tabular}

Tabela 31: Valores calculados para a diferença entre o nível real do aqǘfero e a curva de recessão

$(\Delta \mathrm{h})$ e para a recarga direta no poço 18

\begin{tabular}{|c|c|c|c|c|c|c|}
\hline DATA & $\begin{array}{c}\text { RECARGA DIRETA } / \mathrm{Sy}= \\
\Delta \mathrm{h}(\mathrm{mm})\end{array}$ & $\begin{array}{c}\text { RECARGA } \\
\text { DIRETA } \\
(\mathrm{mm})(\mathrm{Sy}= \\
10 \%)\end{array}$ & $\begin{array}{c}\text { RECARGA } \\
\text { DIRETA } \\
(\mathrm{mm})(\mathrm{Sy}= \\
13 \%) \\
\end{array}$ & $\begin{array}{c}\text { RECARGA } \\
\text { DIRETA } \\
(\mathrm{mm})(\mathrm{Sy}= \\
15 \%)\end{array}$ & $\begin{array}{c}\text { RECARGA } \\
\text { DIRETA } \\
(\mathrm{mm})(\mathrm{Sy}= \\
20 \%) \\
\end{array}$ & $\begin{array}{c}\text { RECARGA } \\
\text { DIRETA } \\
(\mathrm{mm})(\mathrm{Sy}= \\
25 \%) \\
\end{array}$ \\
\hline JAN & 3564,57 & 356,46 & 463,39 & 534,69 & 712,91 & 891,14 \\
\hline FEV & 1841,24 & 184,12 & 239,36 & 276,19 & 368,25 & 460,31 \\
\hline MAR & 0,00 & 0,00 & 0,00 & 0,00 & 0,00 & 0,00 \\
\hline$A B R$ & 0,00 & 0,00 & 0,00 & 0,00 & 0,00 & 0,00 \\
\hline MAI & 0,00 & 0,00 & 0,00 & 0,00 & 0,00 & 0,00 \\
\hline JUN & 0,00 & 0,00 & 0,00 & 0,00 & 0,00 & 0,00 \\
\hline$J U L$ & 0,00 & 0,00 & 0,00 & 0,00 & 0,00 & 0,00 \\
\hline$A G O$ & 0,00 & 0,00 & 0,00 & 0,00 & 0,00 & 0,00 \\
\hline SET & 0,00 & 0,00 & 0,00 & 0,00 & 0,00 & 0,00 \\
\hline OUT & 0,00 & 0,00 & 0,00 & 0,00 & 0,00 & 0,00 \\
\hline NOV & 0,00 & 0,00 & 0,00 & 0,00 & 0,00 & 0,00 \\
\hline$D E Z$ & 0,00 & 0,00 & 0,00 & 0,00 & 0,00 & 0,00 \\
\hline
\end{tabular}


Tabela 32: Valores calculados para a diferença entre o nível real do aqǘfero e a curva de recessão $(\Delta \mathrm{h})$ e para a recarga direta no poço 19

\begin{tabular}{|c|c|c|c|c|c|c|}
\hline DATA & $\begin{array}{c}\text { RECARGA DIRETA } / \text { Sy }= \\
\Delta \mathrm{h}(\mathrm{mm})\end{array}$ & $\begin{array}{c}\text { RECARGA } \\
\text { DIRETA } \\
(\mathrm{mm})(\mathrm{Sy}= \\
10 \%) \\
\end{array}$ & $\begin{array}{c}\text { RECARGA } \\
\text { DIRETA } \\
(\mathrm{mm})(\mathrm{Sy}= \\
13 \%) \\
\end{array}$ & $\begin{array}{c}\text { RECARGA } \\
\text { DIRETA } \\
(\mathrm{mm})(\mathrm{Sy}= \\
15 \%) \\
\end{array}$ & $\begin{array}{c}\text { RECARGA } \\
\text { DIRETA } \\
(\mathrm{mm})(\mathrm{Sy}= \\
20 \%) \\
\end{array}$ & $\begin{array}{c}\text { RECARGA } \\
\text { DIRETA } \\
(\mathrm{mm})(\mathrm{Sy}= \\
25 \%) \\
\end{array}$ \\
\hline JAN & 3166,09 & 316,61 & 411,59 & 474,91 & 633,22 & 791,52 \\
\hline FEV & 2063,04 & 206,30 & 268,20 & 309,46 & 412,61 & 515,76 \\
\hline MAR & 0,00 & 0,00 & 0,00 & 0,00 & 0,00 & 0,00 \\
\hline$A B R$ & 134,20 & 13,42 & 17,45 & 20,13 & 26,84 & 33,55 \\
\hline$M A I$ & 0,00 & 0,00 & 0,00 & 0,00 & 0,00 & 0,00 \\
\hline JUN & 0,00 & 0,00 & 0,00 & 0,00 & 0,00 & 0,00 \\
\hline$J U L$ & 0,00 & 0,00 & 0,00 & 0,00 & 0,00 & 0,00 \\
\hline$A G O$ & 0,00 & 0,00 & 0,00 & 0,00 & 0,00 & 0,00 \\
\hline SET & 0,00 & 0,00 & 0,00 & 0,00 & 0,00 & 0,00 \\
\hline OUT & 0,00 & 0,00 & 0,00 & 0,00 & 0,00 & 0,00 \\
\hline NOV & 0,00 & 0,00 & 0,00 & 0,00 & 0,00 & 0,00 \\
\hline$D E Z$ & 0,00 & 0,00 & 0,00 & 0,00 & 0,00 & 0,00 \\
\hline
\end{tabular}

Os valores encontrados para a recarga direta anual estão apresentados na tabela a seguir:

Tabela 33: Recarga direta anual

\begin{tabular}{|c|c|c|c|c|}
\hline$S_{y} \mathbf{1 0} \%$ & $S_{y} \mathbf{1 3 \%}$ & $S_{y} \mathbf{1 5 \%}$ & $S_{y} \mathbf{2 0 \%}$ & $S_{y} \mathbf{2 5 \%}$ \\
\hline $313,26 \mathrm{~mm}$ & $407,24 \mathrm{~mm}$ & $469,90 \mathrm{~mm}$ & $626,53 \mathrm{~mm}$ & $783,16 \mathrm{~mm}$ \\
\hline
\end{tabular}

A diferença de recarga para os valores de porosidade útil chegam a 469,90mm, o que equivale a $250 \%$ de variação para a faixa de valores considerada.

Algumas conclusões podem ser retiradas da análise da recarga direta estimada para a região de cada poço, isto é, observando o comportamento de cada poço mensalmente.

O poço que apresentou o maior valor para a recarga direta foi o poço 18. Analisando os meses em que houve recarga neste poço temos que a recarga direta, para os meses de janeiro e fevereiro, foi: 
Tabela 34: Recarga direta no poço 18.

\begin{tabular}{|c|c|c|c|c|c|}
\hline & $\boldsymbol{S}_{\boldsymbol{y}} \mathbf{1 0} \%$ & $\boldsymbol{S}_{\boldsymbol{y}} \mathbf{1 3 \%}$ & $\boldsymbol{S}_{\boldsymbol{y}} \mathbf{1 5 \%}$ & $\boldsymbol{S}_{\boldsymbol{y}} \mathbf{2 0 \%}$ & $\boldsymbol{S}_{\boldsymbol{y}} \mathbf{2 5 \%}$ \\
\hline Jan & $356,15 \mathrm{~mm}$ & $463,00 \mathrm{~mm}$ & $534,23 \mathrm{~mm}$ & $712,31 \mathrm{~mm}$ & $890,38 \mathrm{~mm}$ \\
\hline Fev & $183,75 \mathrm{~mm}$ & $238,88 \mathrm{~mm}$ & $275,63 \mathrm{~mm}$ & $367,50 \mathrm{~mm}$ & $459,38 \mathrm{~mm}$ \\
\hline
\end{tabular}

Comparando esses valores com a precipitação nos meses de janeiro e fevereiro, que foram de 536,22mm e 58,79mm, respectivamente, temos uma precipitação menor que a recarga direta. Isto é um fator determinante já que a recarga direta ocorre devido à precipitação.

Tem-se, assim, uma indicação que a porosidade útil deve estar abaixo dos 13\%. A utilização de uma porosidade útil de $13 \%$ leva o valor da recarga direta a ser, aproximadamente, $18 \%$ maior que o valor da precipitação, para os meses de janeiro e fevereiro. Este valor obtido para a recarga direta pode ser fruto de uma propagação das chuvas do mês anterior (dezembro de 2004). A precipitação para o mês de dezembro de 2004 foi de $182,05 \mathrm{~mm}$.

O valor da recarga direta observada no poço 18 pode estar perto do valor da precipitação para os meses em que há favorecimento de uma alta umidade do solo. O poço 18 encontra-se locado em uma área relativamente plana, o que favorece a infiltração e diminui a possibilidade de haver escoamento superficial.

A mesma análise pode ser feita tomando os poços 08 e 19 como base.

A partir dos estudos geológicos feitos na década de 80, que apresentam a bacia do Ribeirão da Onça como uma bacia de solo homogêneo, pode-se afirmar que a porosidade útil média da bacia deve ficar abaixo dos 13\%.

Contin Neto (1987) afirma que a porosidade média na bacia do Ribeirão da Onça é de $35 \%$. Ensaios realizados por Barreto e Gomes (2005) analisando a porosidade do solo da formação Botucatu, extraído da bacia do Ribeirão da Onça encontraram valores para a porosidade na ordem de 35\% (informação obtida de relatório de disciplina do curso de pósgraduação em Hidráulica e Saneamento)*. Este valor está muito acima do esperado para a zona de afloramento do Sistema Aqüífero Guarani. 
Os ensaios que apresentaram valores tão altos foram realizados a partir de amostras deformadas. Esses ensaios podem modificar propriedades estruturais do solo ou da rocha. Analisando visualmente a rocha da Formação Botucatu na bacia do Ribeirão da Onça pode-se notar certa litificação dos grãos de areia nesta formação (Figura 56). Esta pode ser a causa de valores tão discrepantes entre a porosidade média da bacia e a porosidade útil média na bacia. No destorroamento do rocha, para se fazer os ensaios de porosidade, a litificação dos grãos de areia é quebrada, aumentando a porosidade da amostra.

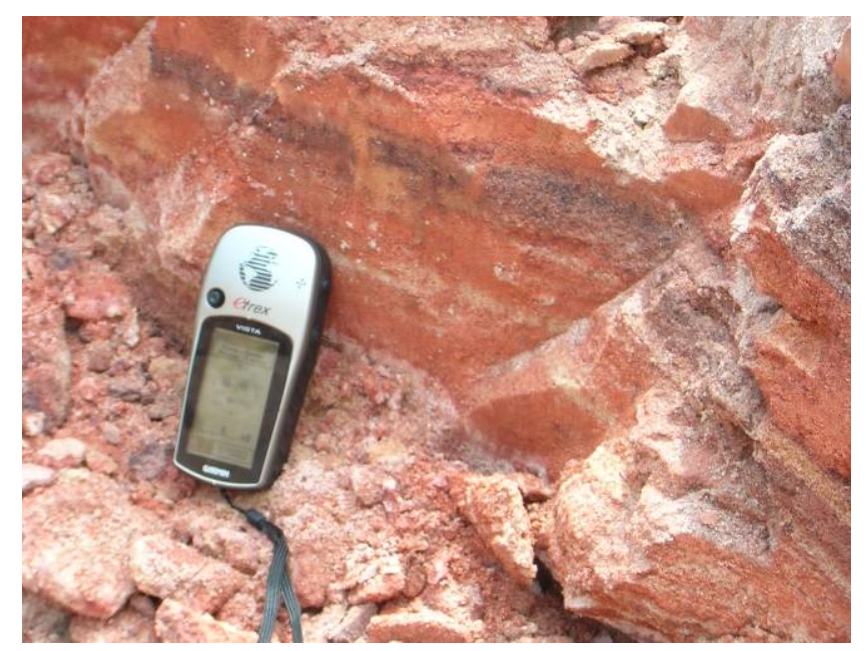

Figura 56: Detalhe do afloramento da Formação Botucatu na bacia do Ribeirão da Onça

A recarga direta ocorre basicamente nos meses de janeiro, fevereiro e março. As precipitações que ocorrem nos outros meses, em geral, não conseguem vencer a zona nãosaturada. A exceção ocorre nos poços muito próximos ao ribeirão (poços 20, 21, 22 e 23).

\subsection{Balanço Hídrico}

\subsubsection{Método 1}

O método 1 de balanço hídrico utiliza como variáveis do sistema a recarga direta, $R d$, o escoamento de base, $Q b$, a variação do armazenamento de base, $\Delta S$, e como termo residual do balanço hídrico, a recarga profunda $R p$. A equação utilizada foi:

$$
R_{p}=R_{d}-Q_{b}-\Delta S
$$


O valor residual do balanço hídrico anual, assumido como sendo a recarga profunda, para o método 1 esta mostrado na Tabela 27.

Tabela 35: Recarga profunda estimada pelo método do balanço hídrico

\begin{tabular}{|c|c|}
\hline$S_{y} \mathbf{1 0} \%$ & $S_{y} \mathbf{1 3} \%$ \\
\hline$-59,08 \mathrm{~mm}$ & $48,90 \mathrm{~mm}$ \\
\hline
\end{tabular}

As observações feitas na seção anterior indicam que a porosidade útil deve ser menor que $13 \%$.

O valor negativo da recarga, para $S_{y}=10 \%$, poderia ser entendido como o fluxo lateral de bacias circunvizinhas que entra na bacia do Ribeirão da Onça. Porém, a bacia do Ribeirão da Onça está situada entre as cotas mais elevadas da bacia do Jacaré-Guaçú o que inviabiliza este tipo de contribuição lateral. Esta análise indica que uma contribuição de bacias adjacentes, favorecendo o Ribeirão da Onça, é improvável. Sendo assim a porosidade útil na bacia deve ser maior que $10 \%$.

O valor da recarga profunda no Ribeirão da Onça calculada pelo método 1, assumindo as hipóteses para o valor da porosidade útil, entre 10 e 13\%, no ano de estudo, estaria na faixa de $0 \mathrm{~mm}$ a $40 \mathrm{~mm}$.

\subsubsection{Método 2}

O método 2 de balanço hídrico utiliza como variáveis do sistema a precipitação, $P$, o escoamento de base, $Q b$, o escoamento superficial direto $(E S)$, a variação do armazenamento de base, $\Delta S$, a evapotranspiração (ET) e a irrigação (Ir) e como termo residual do balanço hídrico, a recarga profunda $R p$. A equação utilizada foi:

$$
R_{P}=P+I r-E S-Q_{b}-\Delta S-E T
$$

O valor residual do balanço hídrico anual para o método 2, assumido como sendo a recarga profunda, é apresentado na Tabela 36. 
Tabela 36: Recarga Profunda estimada pelo Método 2 (mm)

\begin{tabular}{|l|c|c|}
\hline \multicolumn{1}{|c|}{ MÉTODO } & $\begin{array}{c}\text { Porosidade } \\
\text { (EVAPOTRANSPIRAÇÃO) }\end{array}$ & $\begin{array}{c}\text { Porosidade } \\
\text { útil } 13 \%\end{array}$ \\
\hline PENMAN-MONTEITH (FAO) & $-138,88 \mathrm{~mm}$ & $-124,88 \mathrm{~mm}$ \\
\hline THORNTHWAITE & $11,67 \mathrm{~mm}$ & $25,66 \mathrm{~mm}$ \\
\hline TANQUE CLASSE A (FAO) & $-434,62 \mathrm{~mm}$ & $-420,62 \mathrm{~mm}$ \\
\hline HARGREAVES-SAMANI & $-948,49 \mathrm{~mm}$ & $-934,49 \mathrm{~mm}$ \\
\hline BLANEY-CRIDDLE & $-120,67 \mathrm{~mm}$ & $-106,67 \mathrm{~mm}$ \\
\hline MAKKINK & $-53,52 \mathrm{~mm}$ & $-39,52 \mathrm{~mm}$ \\
\hline
\end{tabular}

Apenas o método de Thornthwaite apresenta valores de recarga profunda positiva. Com a porosidade útil de $13 \%$, este método estima uma recarga profunda de $25,66 \mathrm{~mm}$, um resultado bastante próximo ao encontrado pelo método 1 utilizando a mesma porosidade útil. Considerando todas as incertezas em todos os métodos pode-se afirmar que o resultado é semelhante.

O método de Thornthwaite é o único método que apresenta um valor para a recarga profunda coerente com o valor estimado pelo método 1, mas a variabilidade demonstra mais uma vez a incerteza associada à estimativa da evapotranspiração.

\subsubsection{Método 3}

Subtraindo da precipitação o valor do escoamento superficial pode-se estimar a infiltração média que ocorreu na bacia. Da parcela que infiltra parte chega à zona saturada (recarga direta) e parte fica na zona não-saturada, podendo sair do sistema por evapotranspiração. Com o valor da infiltração e o valor da recarga direta estimada, e assumindo a hipótese que o balanço da umidade na zona não-saturada é nulo, pode-se chegar a um valor para a evapotranspiração na bacia.

O valor estimado para a evapotranspiração através da recarga direta, da precipitação e do escoamento superficial é de $900 \mathrm{~mm}$, para uma porosidade útil de $13 \%$, e de $994 \mathrm{~mm}$, para uma porosidade de $10 \%$. Comparando este valor com a estimativa da evapotranspiração na bacia pelo método de Thornthwaite, que foi de $936 \mathrm{~mm}$, temos uma diferença entre os dois métodos de 3\% e -6\%. De acordo com essa análise, a evapotranspiração na bacia representativa, em média, é igual a $67 \%$ da precipitação. 
Pode-se afirmar então que a estimativa pelo método de Thornthwaite é o que mais se aproxima da evapotranspiração real na bacia. Essa conclusão foi apresentada por Cunha (2003), a partir de estudos com lisímetro na mesma região. O lisímetro foi coberto com grama, sendo que a evapotranspiração estimada pelo método de Thornthwaite foi $180 \%$ maior que a evapotranspiração estimada no lisímetro. Mesmo assim o método de Thornthwaite foi o que mais se aproximou.

O Gráfico 38 apresenta em formato de pizza uma desagregação do ciclo hidrológico a partir da precipitação, para uma porosidade útil de $13 \%$.

O Gráfico 39 apresenta em formato de pizza a desagregação da água infiltrada no solo em recarga direta e evapotranspiração, considerando uma porosidade útil de $13 \%$.

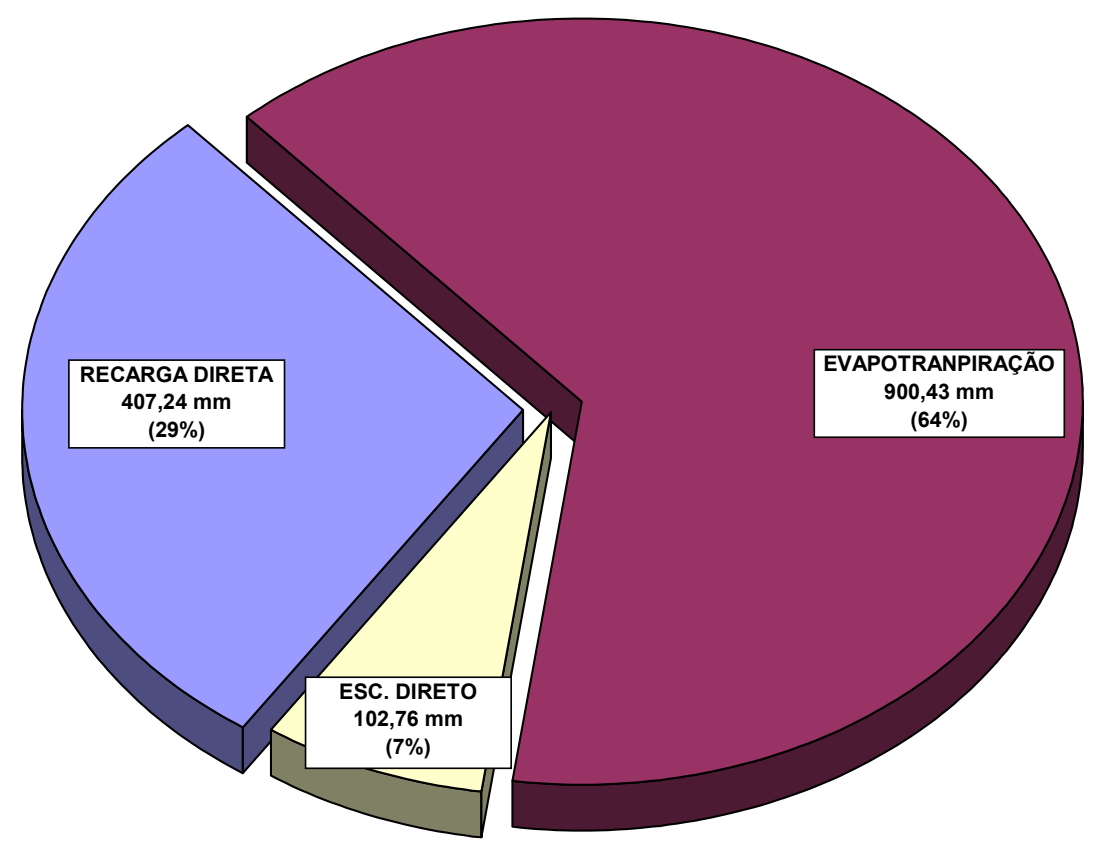

Gráfico 38: Parcelas desagregadas da precipitação 


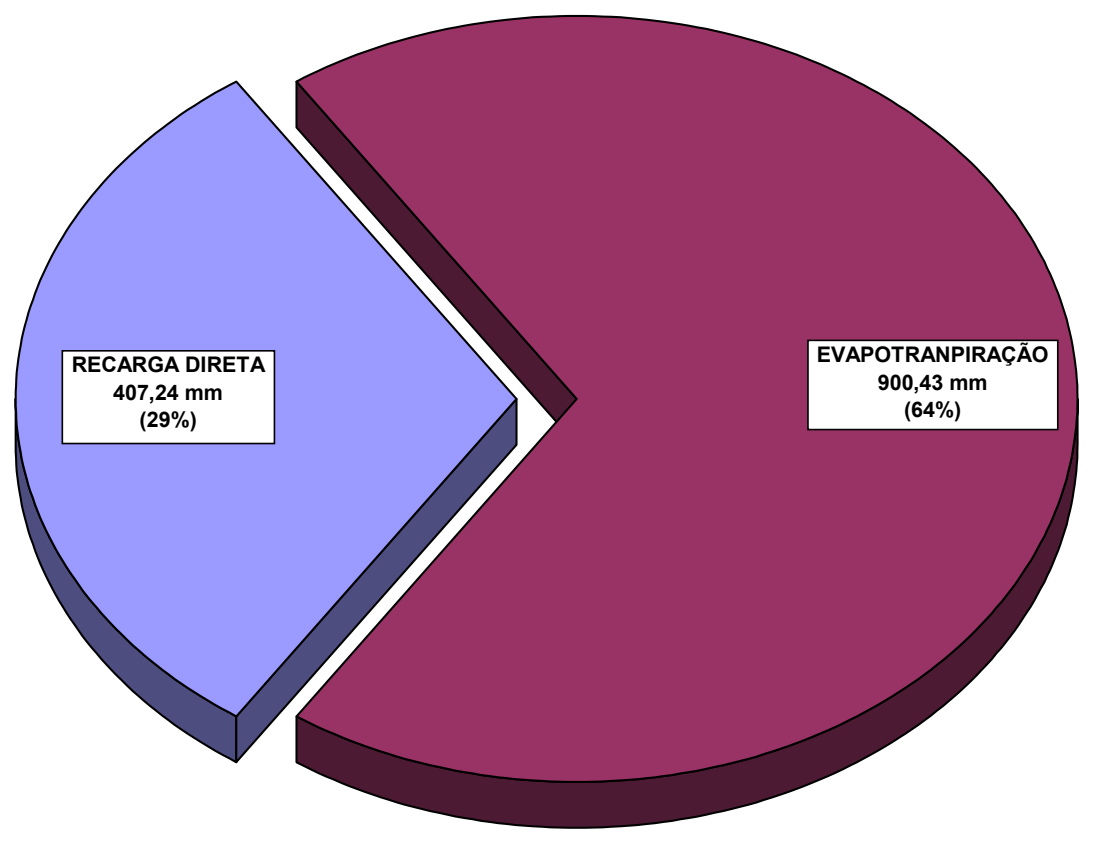

Gráfico 39: parcelas desagregadas da infiltração

Em poços de monitoramento locados em terrenos bastante planos, pode-se admitir que o escoamento superficial direto seja igual a zero para a região no entorno do poço. Então se pode fazer uma análise individual, por poço, da evapotranspiração. Dois poços que tem essa característica são os poços 19 , locado em região de pastagem, e o poço 09 , locado em terreno coberto de eucaliptos.

Subtraindo-se do valor da precipitação a recarga direta estimada para o poço, pode-se chegar a uma estimativa da evapotranspiração anual, considerando que o balanço de umidade do solo é nulo para esse período. O resultado dessa análise individual foi de uma evapotranspiração de $747 \mathrm{~mm}$, para o poço 19 e de $1359 \mathrm{~mm}$, para o poço 09 . O resultado indica que a evapotranspiração na cultura de eucaliptos é $80 \%$ maior que na cultura de pastagem. 
Um resumo dos resultados está mostrado na Tabela 37.

Tabela 37: resumo dos valores das componentes do ciclo hidrológico usadas no método 3

\begin{tabular}{|c|c|c|}
\hline \multicolumn{3}{|c|}{ Método 3} \\
\hline $\begin{array}{l}\text { Componente do ciclo } \\
\text { Precipitação }\end{array}$ & $S_{y}=10 \%$ & $S_{y}=13 \%$ \\
\hline Recarga direta & 313 & 407 \\
\hline Armazenamento subterrâneo & -47 & -61 \\
\hline Fluxo de base & 419 & 419 \\
\hline Recarga profunda & -59 & 49 \\
\hline
\end{tabular}


6. CONCLUSÃO 



\subsection{Conclusão}

Este trabalho visou obter uma estimativa da recarga direta e da recarga profunda através do método de balanço hídrico, utilizando dados de monitoramento hidrogeológico. Foram estimadas, medidas ou calculadas as seguintes variáveis do ciclo hidrológico: precipitação, nível do aqüífero, vazão em curso de água e a coleta de dados climatológicos. Os dados do nível do aqǘ́fero foram utilizados para estimativa da recarga direta, do escoamento de base e da variação do armazenamento subterrâneo.

A instrumentação da bacia se mostrou eficiente, exceto o linígrafo.

A estimativa recarga direta no ano de 2005 através do balanço hídrico na bacia do Ribeirão da Onça foi de aproximadamente $400 \mathrm{~mm}$, aproximadamente $29 \%$ da precipitação. Esta estimativa deve ser avaliada com valores mais seguros do coeficiente de armazenamento específico.

A estimativa da recarga profunda no ano de 2005 através do balanço hídrico foi estimada na faixa de zero a $40 \mathrm{~mm}$, aproximadamente $3 \%$ do valor precipitado. Este resultado indica que o fluxo vertical é muito baixo. Isto pode representar que as descargas e a explotação no Sistema Aqüífero Guarani ainda não afetaram de forma relevante esta zona de afloramento. A influência das conexões com bacias vizinhas deve ser analisada com mais detalhes.

Os valores de evapotranspiração estimados pelo método de Thornthwaite são os que mais se aproximam da evapotranspiração real na bacia. Para verificação da eficácia deste método é necessário um estudo mais prolongado. Os valores obtidos com os métodos de evapotranspiração variam muito segundo as condições climáticas anuais. Estimativas através de um método podem ficar próximas à realidade em um ano e em outro não. O percentual estimado da evapotranspiração em relação à precipitação variou de $67 \%$ a $137 \%$, sendo os métodos de Thornthwaite e de Hargreaves-Samani, respectivamente.

A coleta de dados diários em poços de monitoramento é suficiente para representar o comportamento do aqüífero. O monitoramento quinzenal mostra-se eficiente em poços onde a camada de solo não-saturada é relativamente grande. Em poços de monitoramento onde o nível do aqüífero está próximo à superfície, os dados coletados quinzenalmente podem não representar a variabilidade temporal. 
Não existem sinais que contrariem a qualidade dos dados observados. A aferição dos equipamentos automáticos com as medidas manuais mostra-se suficiente. A comparação dos dados de pluviometria entre as estações de campo e a estação do CRHEA mostra uma forte correlação mensal. Os valores de vazão, medidos com molinete hidrométrico, mostram-se coerentes com as vazões observadas em anos anteriores, principalmente para as vazões de base. O escoamento de base foi estimado em $30 \%$ do total precipitado na bacia do Ribeirão da Onça.

O linígrafo não apresentou os dados esperados. A vazão só pode ser estimada em um período muito curto de tempo, menor que um mês. A mudança do leito do rio e a influência de um sistema de bombeamento a jusante foram a causa da má qualidade dos dados. A influência da modificação do leito do rio impõe a necessidade de outros métodos de estimativa da vazão para o Ribeirão da Onça, como vertedores e calhas.

Para a estimativa da recarga direta foi utilizado o método da variação da superfície potenciométrica. A utilização de uma função potencial para a extrapolação da curva de recessão em poços mostrou-se eficiente. Os valores para a correlação entre os dados reais e os valores simulados ficaram muito próximos de 1 e os valores para o erro médio quadrático foram muito baixos, da ordem de milímetros. $\mathrm{O}$ uso deste método mostra-se eficiente quando se tem um grande número de dados do nível do aqüífero. Só assim podem ser definidos com eficiência os parâmetros da função.

Os modelos de interação rio-aqüífero só devem ser usados em casos onde não se tenham dados contínuos de vazão. $\mathrm{O}$ mesmo pode ser dito para modelos chuva-vazão. $\mathrm{O}$ uso desses modelos deve ser acompanhado, sempre que possível, de uma verificação.

Sendo a grande maioria dos modelos, computacionais e conceituais, baseados na homogeneidade do solo com relação ao fluxo, é importante que existam bacias experimentais que tenham essa característica. As bacias representativas servem tanto para a calibração e testes dos modelos quanto para obtenção de resultados que correspondam a valores mais próximos à realidade.

Para melhorar os resultados sugere-se a construção de novos poços de monitoramento. Os poços devem ser construídos em áreas com cultivo de eucaliptos, soja e cana-de-açúcar. Essas culturas possuem poucos poços de monitoramento em suas áreas. Se possível, locá-los em zonas de diferentes espessuras da camada de solo não-saturado.

Não é recomendado o uso de amostras deformadas de solo para a estimativa da porosidade do solo na bacia do Ribeirão da Onça, já que estas produzem resultados bastante elevados e inconsistentes com os valores observados para as componentes hidrológicas. 
A análise do monitoramento da bacia do Ribeirão da Onça só vem a confirmar a representatividade dos estudos feitos nessa região e grande relevância que esses estudos terão para o gerenciamento desse importante reservatório que é o Aqüífero Guarani. 
7. REFERÊNCIAS BIBLIOGRÁFICAS 

ALLEN, R. G.; PEREIRA, L. S.; RAES, D. MARTIN, S. (1998). Crop evapotranspiration. Rome: FAO. 297p. (FAO, Irrigation and Drainage Paper, 56).

ALLISON G.B.; HUGHES M.W. (1978). The use of environmental chloride and tritium to estimate total local recharge to an unconfined aquifer, Aust. J. Soil Res, 16, p.181195.

ALLISON, G.B.; BARNES, C.J.; HUGHES, M.W.; LEANEY, F.W.J. (1983). Effect of climate and vegetation on oxygen-18 and deuterium profiles in soils. In: Clark, I.D. and Fritz, P. (1997). Environmental isotopes in hydrogeology. Lewis Publishers, New York, 328p.

ARANTES, E. J. (2003) Emprego de Infiltrômetros na caracterização da interação rio e aqüífero. Dissertação de Mestrado. São Carlos, SHS-EESC-USP.

ARAÚJO, L. M., FRANÇA, A. B., POTTER, P. E. (1999). Hydrogeology of the Mercosul aquifer system in the Paraná d Chaco- Paraná Basins, South america, and comparison with the Navajo-Nugget aquifer system, USA. Hydrogeology Journal, v. 7, p. 317-336.

BALEK, J. (1988). Groundwater recharge concepts. In: Simmers (ed.), Estimation of natural groundwater recharge. D. Reidel Publishing Company, Dordrecht, Holland, p.3-9.

BANCO MUNDIAL (1998). “Gerenciamento de Recursos Hidricos” RODRIGUES, F. (coord.), Brasília; SRH, Bsb, p.24-107.

BARRETT, M.H.; HISCOCK, K.M.; PEDLEY, S.; LERNER, D.N.; TELLAM, J.H.; FRENCH, M.J. (1999). Marker species for identifying urban groundwater recharge sources - the Nottingham case study. Water Resources, 33 (14), p.3083-3097.

BEEKMAN, H.E.; GIESKE, A.; SELAOLO, E.T. (1996). GRES: Groundwater Recharge Studies in Botswana 1987-1996. Botswana, J. of Earth Science, Vol. III, p.1-17.

BERLATO, M. A., MOLION, L. B. (1981). Evaporação e evapotranspiração. Boletim Técnico IPAGRO. Porto Alegre, n.7, p.3-95.

BLACK, P. E. (1996) Watershed Hydrology. 2.ed. Lewis Publisher, Boca Raton, Florida. 
BORGHETt, N. R. B.; BORGUETTI, J. R.; ROSA FILHO, E. F. H. (2004). Aqüifero Guarani: a verdadeira integração dos países do Mercosul. Editora Maxigráfica Curitiba, Paraná.

BOUWER, H.; RICE, R.C. (1976). A slug test for determining hydraulic conductivity of unconfined aquifers with completely or partially penetrating wells. Water Resources Research, v.12, n.3, p.423-428.

BRAS, R. L. (1990). Hydrology: An Introduction to Hydrology Science. Massachusetts Institute of Technology: Addison-Wesley Publishing Company.

BREDENKAMP, D.B.; BOTHA, L.J.; VAN TONDER, G.J.; van RENSBURG, H.J. (1995). Manual on Quantitative Estimation of Groundwater Recharge and Aquifer Storativity. Water Research Commission, Pretoria.

CAMARGO, A. P. DE; CAMARGO, M. B. P. DE (2000). Uma revisão analítica da evapotranspiração potencial. Bragantia, Campinas, 59 (2), p. 125-137.

CHAHINIAN, N.; MOUSSA, R.; ANDRIEUX, P.; VOLTZ, M. (2005). Comparison of infiltration models to simulate flood events at the field scale. Journal of Hydrology, 306, p. 191-214.

CORRÊA, U. M. P. (1995). Estudo das Águas Subterrâneas das Bacias Hidrográficas dos Rios Jacaré-Guaçu e Jacaré-Pepira no Estado de São Paulo. Dissertação de Mestrado, EESC-USP. 2 v., 107 p.

CONTIN NETO, D. (1981). Interação rio-aqüifero: Relatório Final, Convênio DNAEE/EESC-010/81. São Carlos, SP.

CONTIN NETO, D. (1987)- Balanço Hídrico em Bacia Hidrográfica situada em Região de Recarga do Aqüifero Botucatu. Tese de Doutorado. São Carlos, SHS-EESC-USP.

CUNHA, A T. (2003). Estimativa experimental da taxa de recarga na zona de afloramento do Aqüifero Guarani ,para a região de São Paulo - SP. Dissertação de Mestrado. São Carlos, EESC-USP-SHS.

DE VRIES, J. J. SIMMERS, I. Groundwater recharge: an overview of processes and challenges. Hydrogeology Journal, v. 10, p. 5-17. 
EILERS, V H. M. (2004). Estimativa de Recarga de Águas Subterrâneas Utilizando o Método do Balanço Hídrico. XIII Congresso Brasileiro de Águas Subterrâneas, 2004, Cuiabá-MT. Proceedings do XIII Congresso Brasileiro de Águas Subterrâneas.

FERREIRA, S. J. F.; LUIZÃO, F. J.; DALLAROSA, R. L. G. (2005). Precipitação Interna e Interceptação da Chuva em Floresta de Terra Firme Submetida à Extração Seletiva de Madeira na Amazônia Central. Acta Amazonica, Manaus: v. 35, n. 1, p. 55-62.

GARCEZ, L. N. (1967). Hidrologia. $1^{\text {a }}$ edição. Editora Edgar Blücher Ltda.

GATMANS, D.; KIANG, C. H. (2006). Avaliação da hidrogeologia e hidroquímica do Sistema Aqüifero Guarani (SAG) no estado de Mato Grosso do Sul. Revista Brasileira de Águas Subterrâneas. v. 19, n.1 - Jan-Jun, p. 35 - 48.

GAU, H.S.; LIU, C.W. (2000) Estimation of the effective precipitation recharge coefficient in an unconfined aquifer using stochastic analysis. Hydrology Process, v.14, p. 811830.

GERMANO, A.; TUCCI, C E. M.; SILVEIRA, A. L. L. (1998). Estimativas dos parâmetros do modelo IPH-II para algumas bacias urbanas brasileiras. Revista Brasileira de Recursos Hídricos, v. 3, n. 4, págs. 103-120.

GIAMPÁ, C. E. Q.; SOUZA, J. C. (1982). Potencial Aqüifero dos Basaltos da Formação Serra Geral no Estado de São Paulo. $2^{\circ}$ CABAS, Salvador - BA: p. 3-15.

GILBOA, Y.; MERO, F.; MARIANO, I. B. (1976). The Botucatu Aquifer of South America. Model of an Untapped Continental Aquifer. Journal of Hydrology, New York: v. 29, p. $165-179$.

HEALY, R.W.; COOK, P.G. (2002). Using groundwater levels to estimate recharge. Hydrogeology Journal, v.10, n.1, p. 91-109. DOI 10.1007/s10040-001-0178-0.

HOWARD, K.W.F and LLOYD, J.W.,1979. The sensitivity of parameters in the Penman evaporation equations and direct recharge balance. Journal of Hydrology, v.41, p. 329-344. 
HUANG, Y. S.; CHEN, S. S.; LIN, T. P. 2005. Continuous Monitoring of Water Loading of Tree and Canopy Rainfall Interceptation Using the Strain Gauge Method. Journal of Hydrology, New York: v. 311, p. 1-7.

JAMES, L. G. (1988). Irrigation requirements and scheduling. IN: JAMES, L. G. Principles of farm irrigation system design. New York, John Wiley. Cap. 1. p. 1- 50.

KETCHUM Jr., J.N.; DONOVAN, J.J.; AVERY, W.H. (2000). Recharge characteristics of a phreatic aquifer as determined by storage accumulation. Hydrogeology Journal, v. 8, n. 6 p. $579-593$.

KINZELBACH, W. (Org). (2002) A Survey of Methods for Groundwater Recharge in Arid and Semi-Arid Regions. Early Warning and Assessment Report Series, UNEP/DEWA/RS.02/2. United Nations Environment Programme, Nairobe, Kenia. ISBN 92-80702131-3.

LERNER, D.N.; ISSAR, A.S. e SIMMERS, I. (1990). Groundwater recharge: a guide to understanding and estimating natural recharge. International Contributions to Hydrogeology, v. 8. International Association of Hydrogeologists, Verlag Heinz Heise.

LERNER, D.N. (2003). Surface water - groundwater interactions in the context of groundwater resources. In: XU, Y.; BEEKMAN, H.E. (Org) (2003). Groundwater recharge estimation in Southern Africa. UNESCO IHP. Series n. 64, UNESCO, Paris.

MAgAlHÃes JR., A. P., (2000). A Situação do Monitoramento das Águas no Brasil Instituições e Iniciativas. Revista Brasileira de Recursos Hídricos, v. 5, n.3, Jul/Set 2000, p. 113-135.

MAHE, G.; PATUREL, J.; SERVAT, E.; CONWAY, D.; D, A. (2005). The Impact of Land Use Change on Soil Water Holding Capacity and River Flow Modelling in the Nakambe River, Burkina-Faso. Journal of Hydrology, New York: v. 300, p. 33-43.

MATOS, I. S. (1987). Aplicação de um Modelo de Balanço Hídrico na Bacia do Rio JacaréGuaçu. Dissertação de Mestrado. São Carlos, SHS-EESC-USP. 
MATTOS, A. (1991). Evapotranspiração Real: Como Determiná-la em Estudos Hidrológicos. Simpósio Luso Brasileiro de Hidráulica E Recursos Hídricos, 5/Simpósio Brasileiro de Recursos Hídricos, 9. Anais Rio de Janeiro : Aprh.

MAZIERO, T. A. (2005) Monitoramento de água subterrânea em Área Urbana: Aspectos Quantitativos - Dissertação de Mestrado. São Carlos, SHS-EESC-USP.

MENEGÁSSE-VELÁSQUEZ, L.N. (1996). Efeitos da Urbanização sobre o Sistema Hidrológico: Aspectos da Recarga no Aqüifero Freático e Escoamento Superficial Área Piloto: Sub-bacias Sumaré e Pompéia, Município de São Paulo. Tese de Doutorado.São Paulo, IGC-USP.

MEDEIROS, A. T. (2002). Estimativa da Evapotranspiração de Referência a partir da Equação de Penman-Monteith, de Medidas Lisimétricas e de Equações Empíricas, em Praipaba, CE. Tese de Doutorado. Piracicaba, Escola Superior de Agricultura “Luiz de Queiroz" (ESALQ).

MICHAUD, J., SOROOSHIAN, S., (1994). Comparison of simple versus complex distributed runoff models on a midsize semiarid watershed. Water Resources Research, v. 30, n.3, p.593-605.

MOON, S.; WOO, N.C.; LEE, K.S. (2004). Statistical analysis of hydrographs and watertable fluctuation to estimate groundwater recharge. Journal of Hydrology, v.292, p. 198-209.

NOVElli, A. S. (1996). Diagnóstico de Recursos Hídricos Superficiais da Bacia Hidrográfica do Rio Jacaré-Guaçu. Dissertação de Mestrado, EESC-USP.

OAS/GEF. - Organization of American States / Global Environment Facility. (2001). Proyecto para la Protección Ambiental y Desarrollo Sostenible Integrado del SAG. Montevideo. $133 \mathrm{p}$.

OSTENDORF, D.W.; REES, P.L.S.; KELLEY, S.P.; LUTENEGGER, A.J. (2004). Steady, annual, and monthly recharge implied by deep unconfined aquifer flow. Journal of Hydrology. v.290, p. 259-274. 
PAIVA, J. B. D. de; PAIVA, E. M. C. D. de, (orgs.) (2003). Hidrologia Aplicada à Gestão de Pequenas Bacias Hidrográficas. Editora Evangraf. Reimpressão revista e ampliada. Porto Alegre.

PARALTA, E. A.; OLIVEIRA, M. M.; LUBCZYNSKI, M. W.; RIBEIRO, L. F. (2003). Avaliação da recarga do sistema aqüifero dos Gabros de Beja segundo critérios múltiplos: Disponibilidades hídricas e implicações agro-ambientais. $6^{\circ}$ SILUSBA Simpósio de Hidráulica e Recursos Hídricos dos países de língua oficial Portuguesa, Cabo Verde, Portugal.

POMPÊO, C. A. (1983). A precipitação na bacia do Jacaré-Guaçú: Caracterização e Modelação Matemática. Dissertação de Mestrado. São Carlos, SHS-EESC-USP.

POMPÊO, C. A. (1990). Balanço Hídrico da Zona Não-Saturada do Solo na Bacia do Ribeirão do Onça (SP). Tese de Doutorado. São Carlos, SHS-EESC-USP.

PORTO, R. M.(1999). Hidráulica Básica. 2ª edição. EDUSP São Carlos, EESC-USP-SHS.

PREBBLE, R. E.; STIRK, G. B. 1980. Throughfall and Steamflow on Solver Leaf Ironbark (Eucaliptus Melanopholia) trees. Australia. Journal of Ecology. v.5, p. 419-427.

QUEIROZ, O. M. (1991). Propagação de cheias: aplicação do modelo de onda cinemática ao Ribeirão da Onça-SP. Dissertação de Mestrado. São Carlos, SHS-EESC-USP.

RAI, S.N.; MANGLIK, A.; SINGH, R. N. (1994). Water table fluctuation in response to transient recharge from a rectangular basin. Water Resources Management., v. 8, p. $1-10$.

REBOUÇAS, A. C.; AMORE, L. (2002). O Sistema Aqüifero Guarani. Revista Brasileira de Águas Subterrâneas. v. 16, Maio/2002, p. 135 - 143.

RENNOLS, K.; CARNELL, R.; TEE, V. (1980). A Descriptive Model of the Relationship Between Rainfall and Soil Water Table. Journal of Hydrology, New York: v. 47, p. 103-114.

RIGHETTO, A. M. (1998). Hidrologia e Recursos Hidricos. São Carlos, EESC/USP. EDUSP, 819p. 
RUSHTON, K. R.; TOMLINSON, L. M. (1979). Possible mechanisms for leakage between aquifers and rivers. Journal of Hydrology, v.40, p. 49-65.

SANFORD, W. (2002). Recharge and groundwater: an overview. Hydrogeology Journal, v. 10, n. 1, p. 110-120.

SANTOS, I. dos; FILL, H. D.; SUGAI, M. R. V. B.; BUBA, H.; KISHI, R. T.; MARONE, E.; LAUTERT, L. F. (2001). Hidrometria Aplicada. Curitiba: Instituto de Tecnologia para o Desenvolvimento. ISBN 85-88519-01-1.

SCANLON, B.R.; HEALY, R.W.; COOK, P.G. (2002). Choosing appropriate techniques for quantifying groundwater recharge. Hydrogeology Journal, v. 10, n. 1, p. 18-39.

SCHICHT, R.J.; WALTON, W.C. (1961). Hydrologic budgets for three small watersheds in Illinois. III State Water Surv. Rep. Invest., 40:40.

SEFIONE, A. L. (2002). Estudo Comparativo de Métodos de Extrapolação Superior de Curvas-Chave. Dissertação de Mestrado. Porto Alegre, Universidade Federal do Rio Grande do Sul.

SILVEIRA, G. L.; TUCCI, C. E. M.; SILVEIRA, A. L. L. (1998). Quantificação da vazão em pequenas bacias sem dados. Revista Brasileira de Recursos Hídricos, v. 3, n.3, p. 111-131.

SIMMERS, I. (1989). Natural groundwater recharge estimation in semiarid zones: some state-of-art observations. Proceedings of the Sahel Forum, the State-of-Art of Hydrology and Hydrogeology in the Arid and Semi-Arid Areas of Africa, Ouagadougou, Burkina Faso, February, p. 374-386.

SOARES, J. V.; ALMEIDA, A. C. (2001). Modeling the Water Balance and Soil Water Fluxes in a Fast Growing Eucalyptus Plantation in Brazil. Journal of Hydrology, New York: v. 253, p. 130-147.

SOPHOCLEOUS, M. (2002) Interaction between groundwater and surface water; the state of the science. Hydrogeology Journal, v. 10, n. 1, p. 52-67. 
STRELTSOVA, T. D. (1974). Method of additional seepage resistance - theory and application. Journal of the Hydraulics Division. Proceeding of the American Society of Civil Engineering, 100 (HY8):1119-1131.

SU, N. (1994). A formula for computation of time varying recharge of groundwater. Journal of Hydrology, v.160, p. 123-135.

TONDER, G. J. van; BEAN, J, (2003). Challenges in estimating groundwater recharge. In. XU, Y.; BEEKMAN, H.E (Eds) (2003). Groundwater recharge estimation in Southern Africa. UNESCO IHP Series nº 64, UNESCO, Paris. ISBN 92-9220-000-3.

TUCCI, C. E. M.; SILVEIRA, R. L. (1985). Análises de Consistência de Dados Fluviométricos. Porto Alegre: Instituto de Pesquisas Hidráulicas da UFRGS.

TUCCI, C. E. M. (1998). Modelos hidrológicos. 1ed. Editora da Universidade Federal do Rio Grande do Sul, Porto Alegre, RS.

TUCCI, C. E. M. (org.) (2002). Hidrologia: Ciência e Aplicação. $3^{a}$ edição, Porto Alegre: Editora UFRGS/ABRH.

VIESSMAN, WARREN, Jr.; LEWIS, GARY L. (1996) Introduction to Hydrology. 4th ed. New York: HaperCollins College Publishers.

VIVES, L.; CAMPOS, H.; CANDELA, L.; GUARRACINO, L. (2001). Modelación Del Acuífero Guaraní. Boletín Geológico y Minero. v. 112, p. 51-64.

VASCONCELOS, S.M.S. (1999). Recarga do aqüifero Dunas/Paleodunas, Fortaleza-CE. 2v. Tese de Doutorado. Instituto de Geociências, Universidade de São Paulo, São Paulo, 100 .

VISWANATHAN, M. N. (1983). The rainfall/Water-Table Level Relationshp of an Unconfined Aquifer. Ground Water, v. 21, n. 1, p. 49-56.

WINTER, T. C.; HARVEY J. W.; FRANKE, O.L.; ALLEY, W.M. (1998). Ground Water and Surface Water. A Single Resource. U. S. Geological Survey, circular 1139.79 p.

WOESSNER, W.W. (2000). Stream and fluvial plain ground water interactions: rescaling hydro geologic thought. Ground Water, v. 38, p.423-429. 
XU, Y.; BEEKMAN, H.E (Eds) (2003). Groundwater recharge estimation in Southern Africa. UNESCO IHP Series nº 64, UNESCO, Paris. ISBN 92-9220-000-3.

XU, Y.; VAN TONDER, HG. (2001). Estimation of recharge using a revised CRD method. Water SA, v.27, n. 3, p. 341-343.

ZHOU, Y. (1996). Sampling Frequency for Monitoring the Actual State of Groundwater Systems. Journal of Hydrology, v. 180, p. 301-318. 


\section{APENDICE A}

(Mapas de uso do solo) 



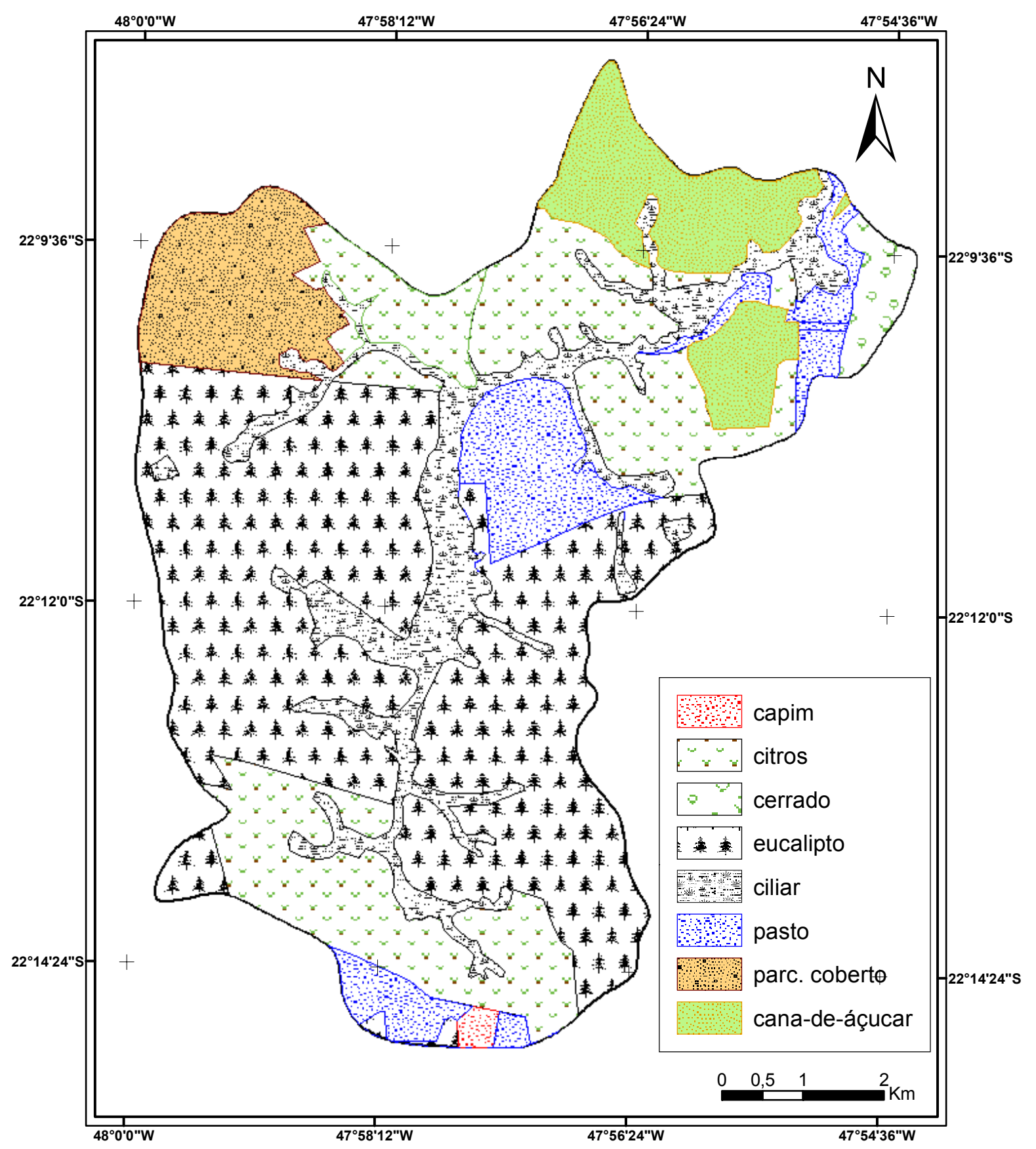

Figura 57: Mapa de uso e ocupação do solo (Maio/2005-Agosto/2005) 


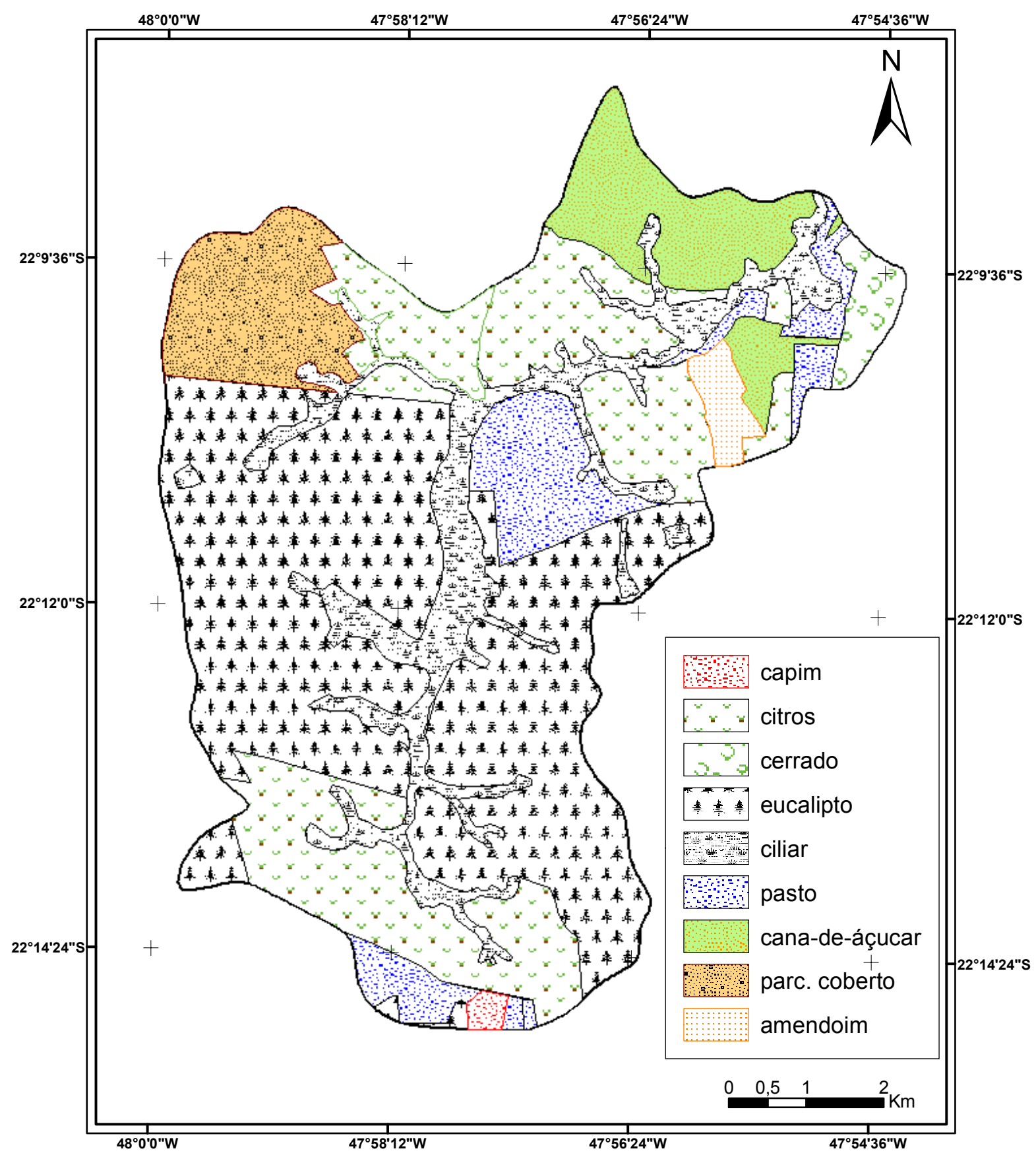

Figura 58: Mapa de uso e ocupação do solo (Setembro/2005-Outubro/2005) 


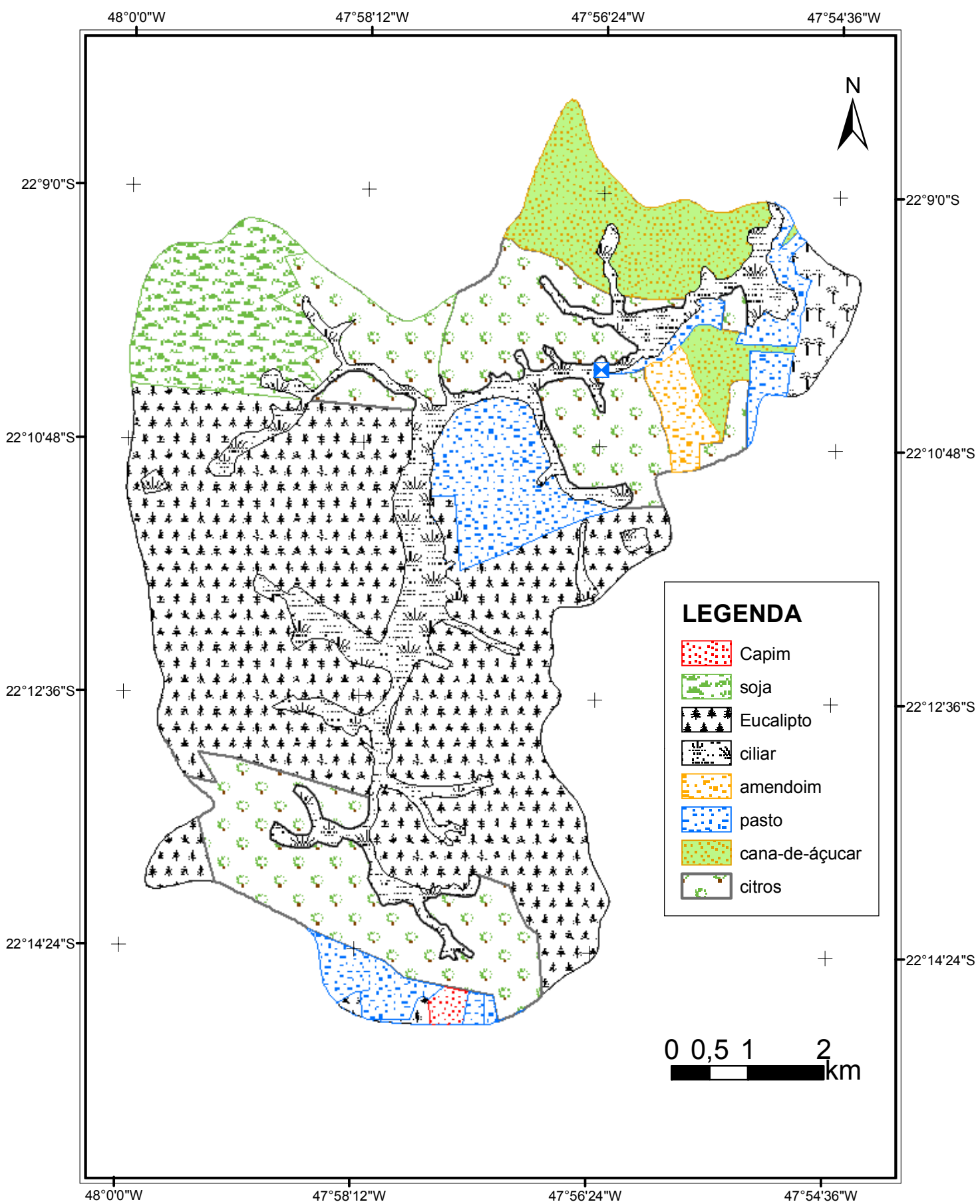

Figura 59: Mapa de uso e ocupação do solo (Novembro/2005-Janeiro/2006) 


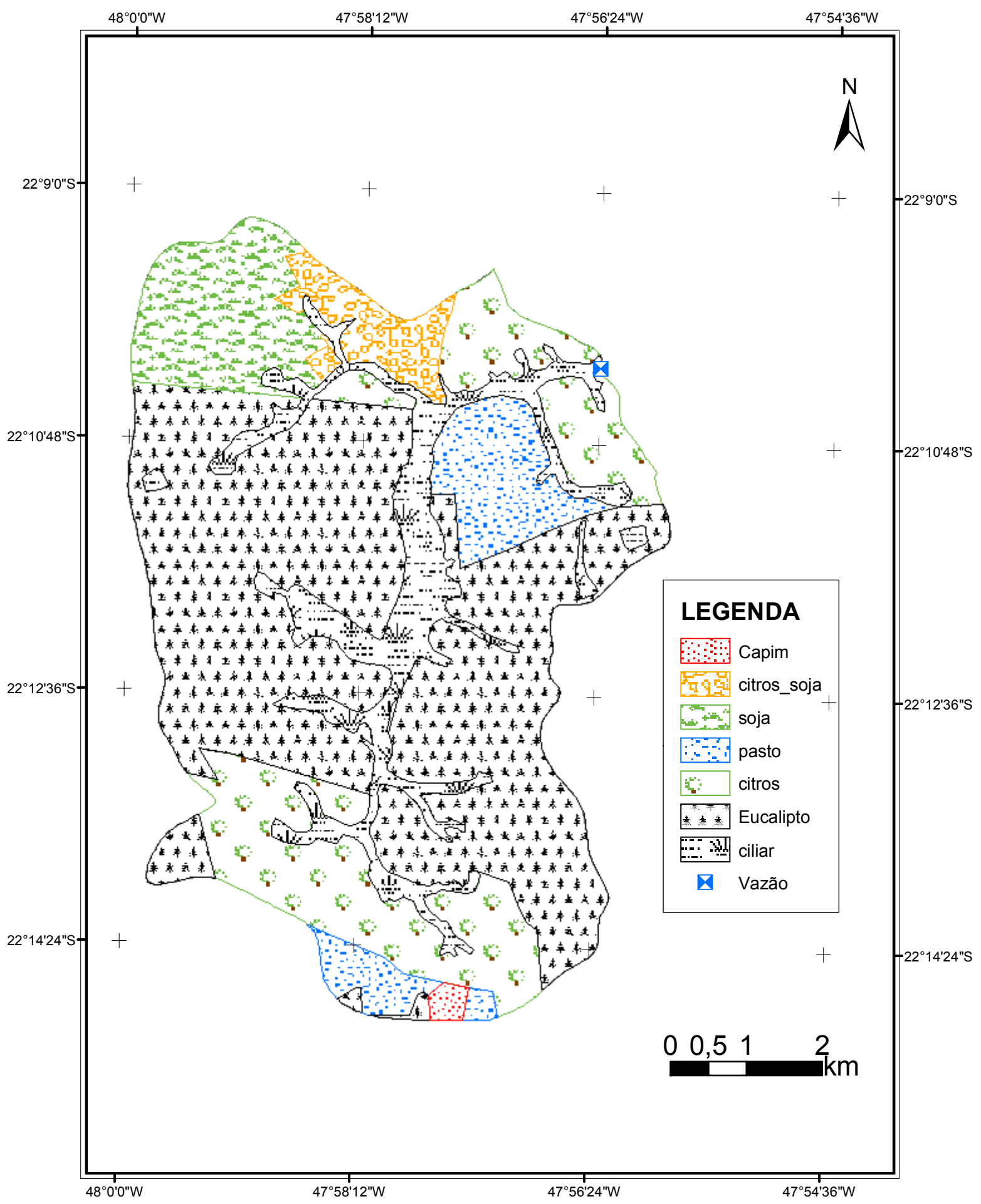

Figura 60: Mapa de uso e ocupação do solo (Dezembro/2004-Abril/2005) 


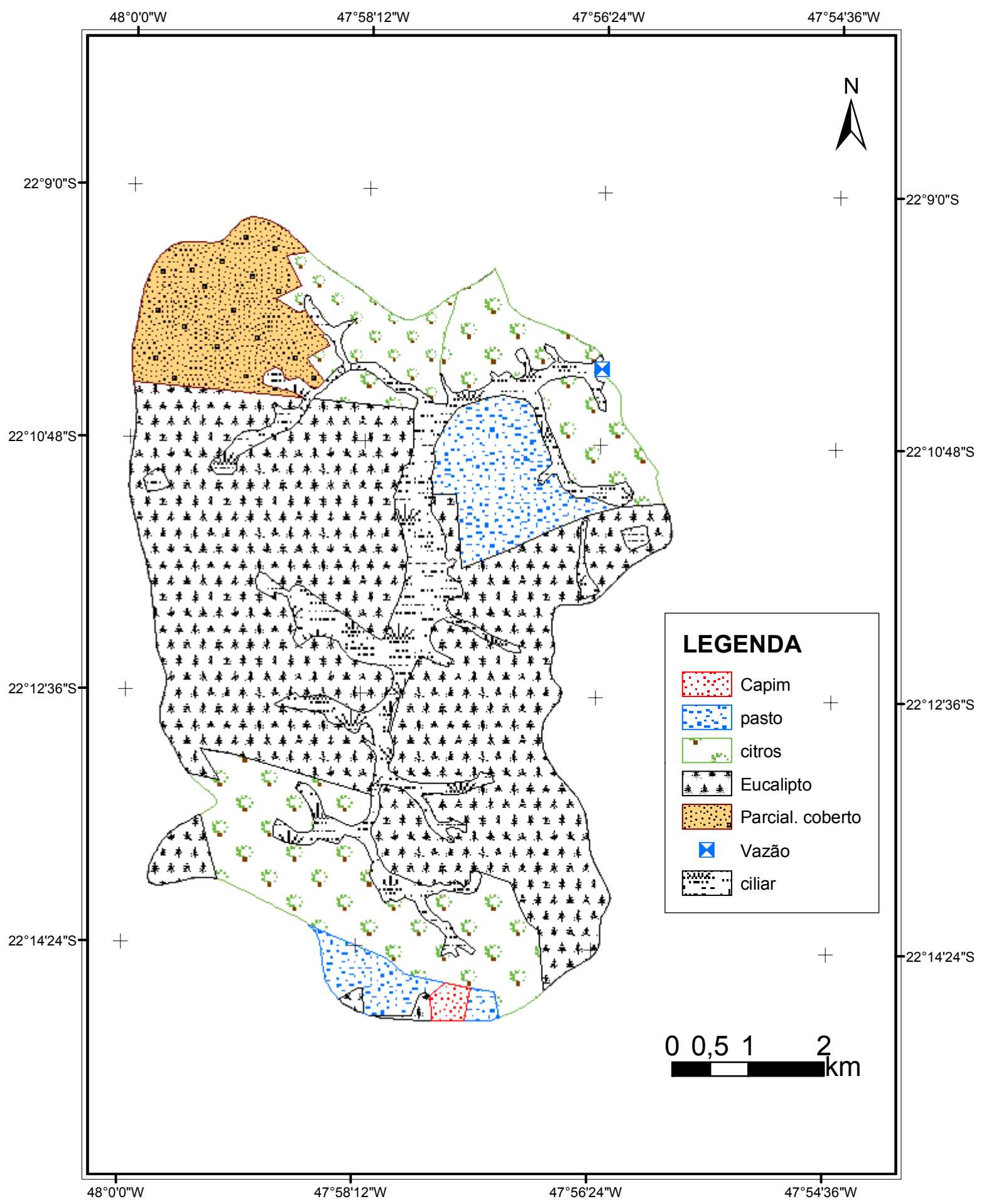

Figura 61: Mapa de uso e ocupação do solo (Maio/2005-Outubro/2005) 


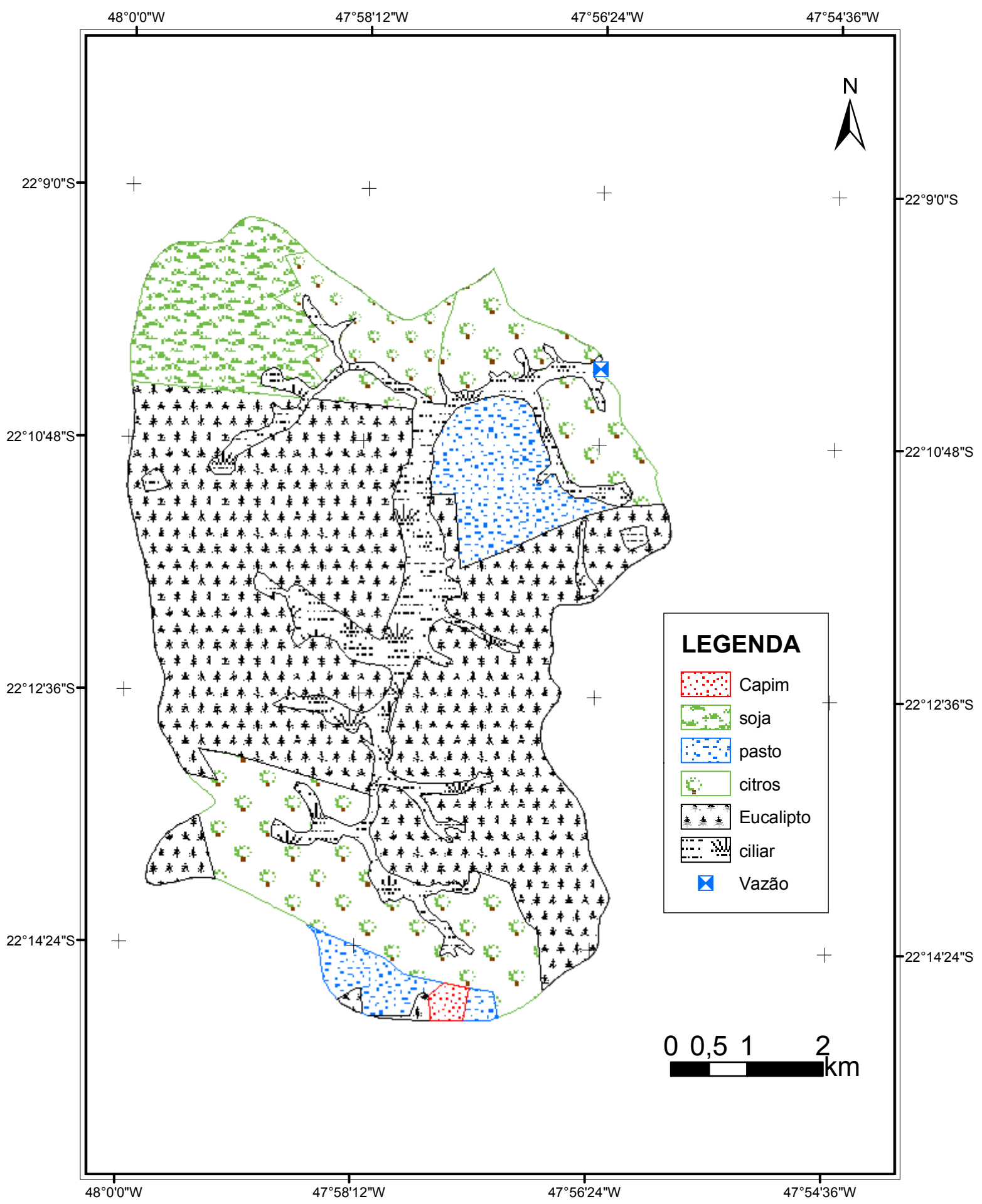

Figura 62: Mapa de uso e ocupação do solo (Novembro/2005-Janeiro/2006) 


\section{APENDICE B}

(Gráficos mensais de precipitação no período de jan/2005 a dez/2005) 



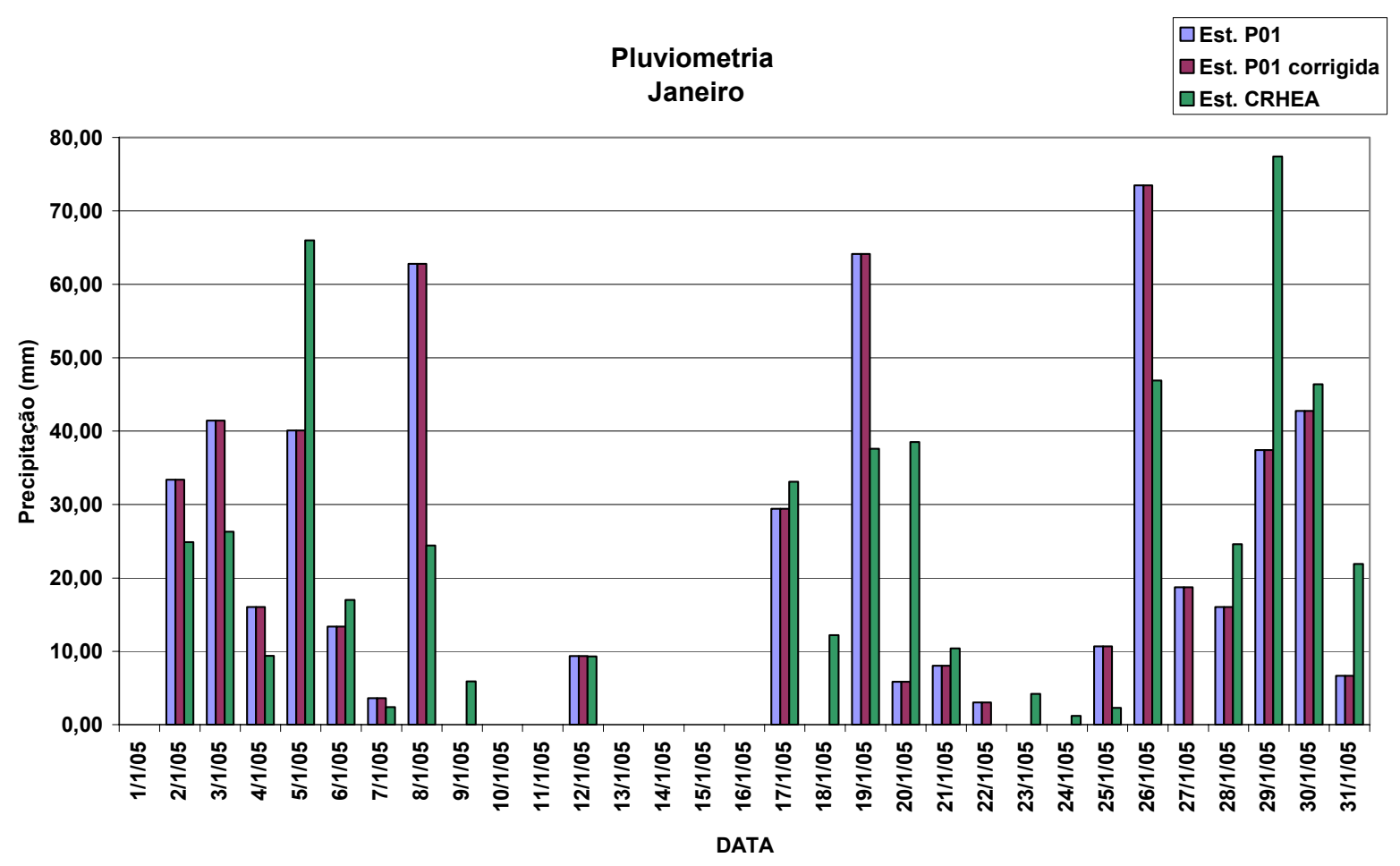

Gráfico 40: Pluviometria no mês de janeiro de 2005

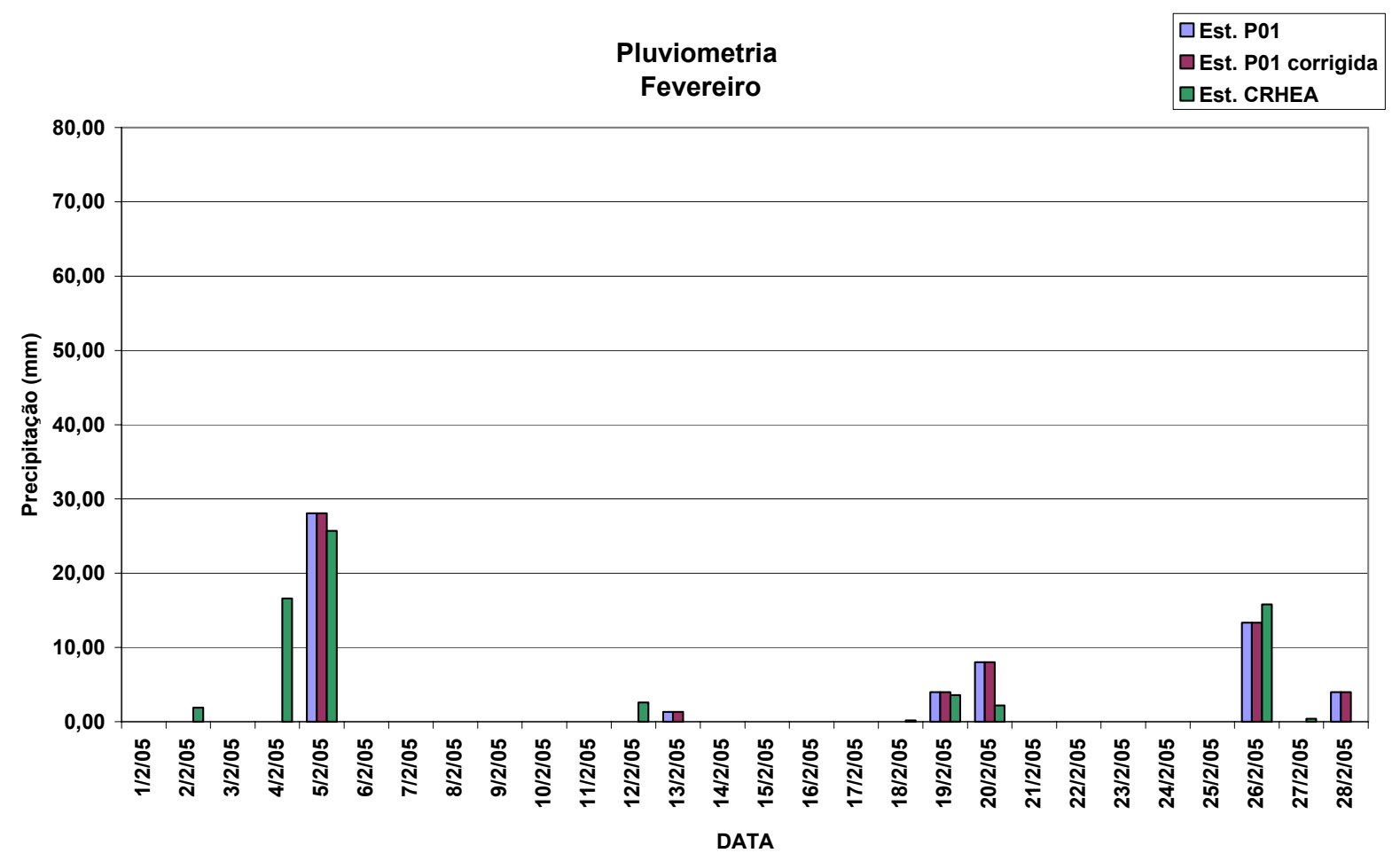

Gráfico 41: Pluviometria no mês de fevereiro de 2005 


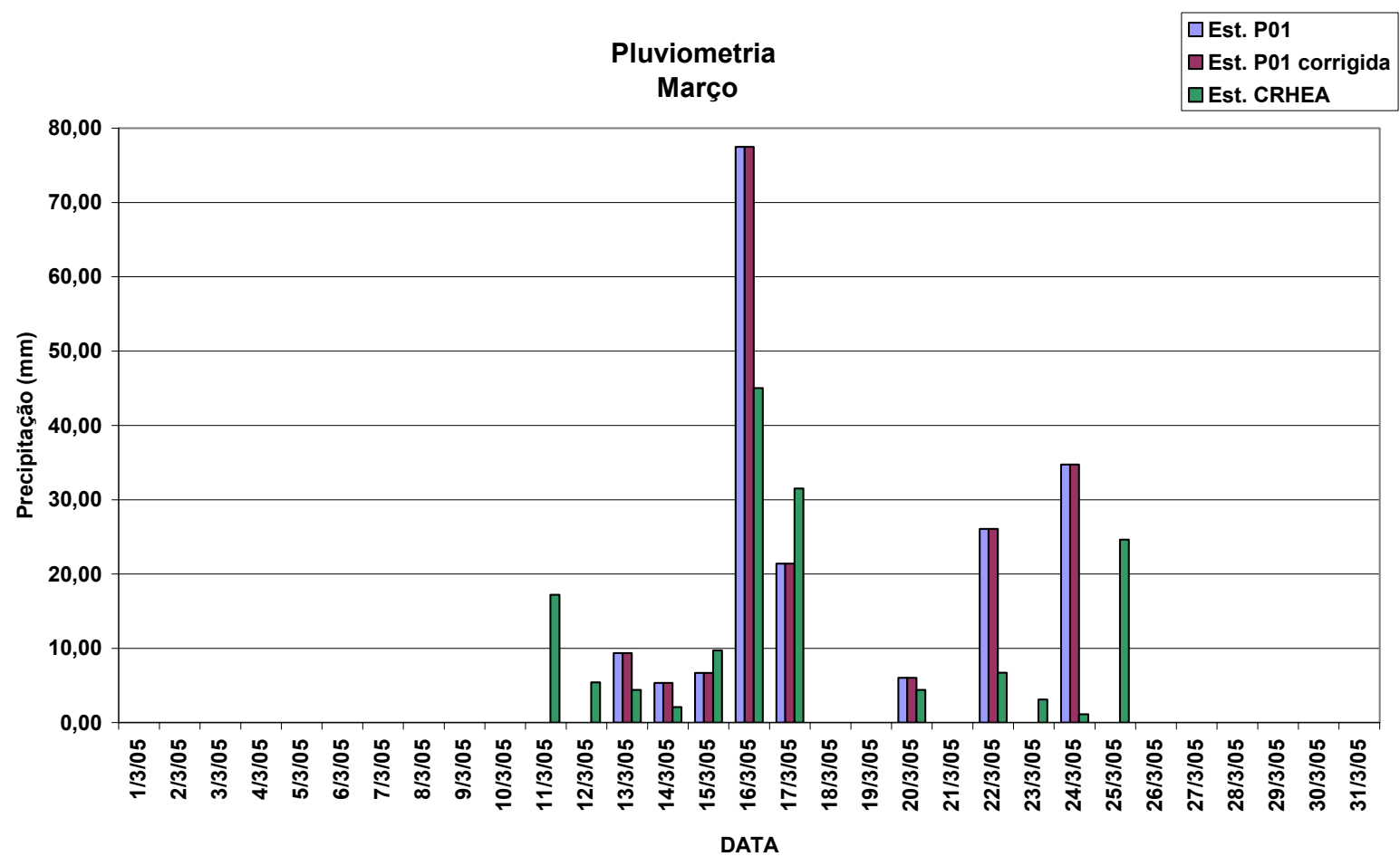

Gráfico 42: Pluviometria no mês de março de 2005

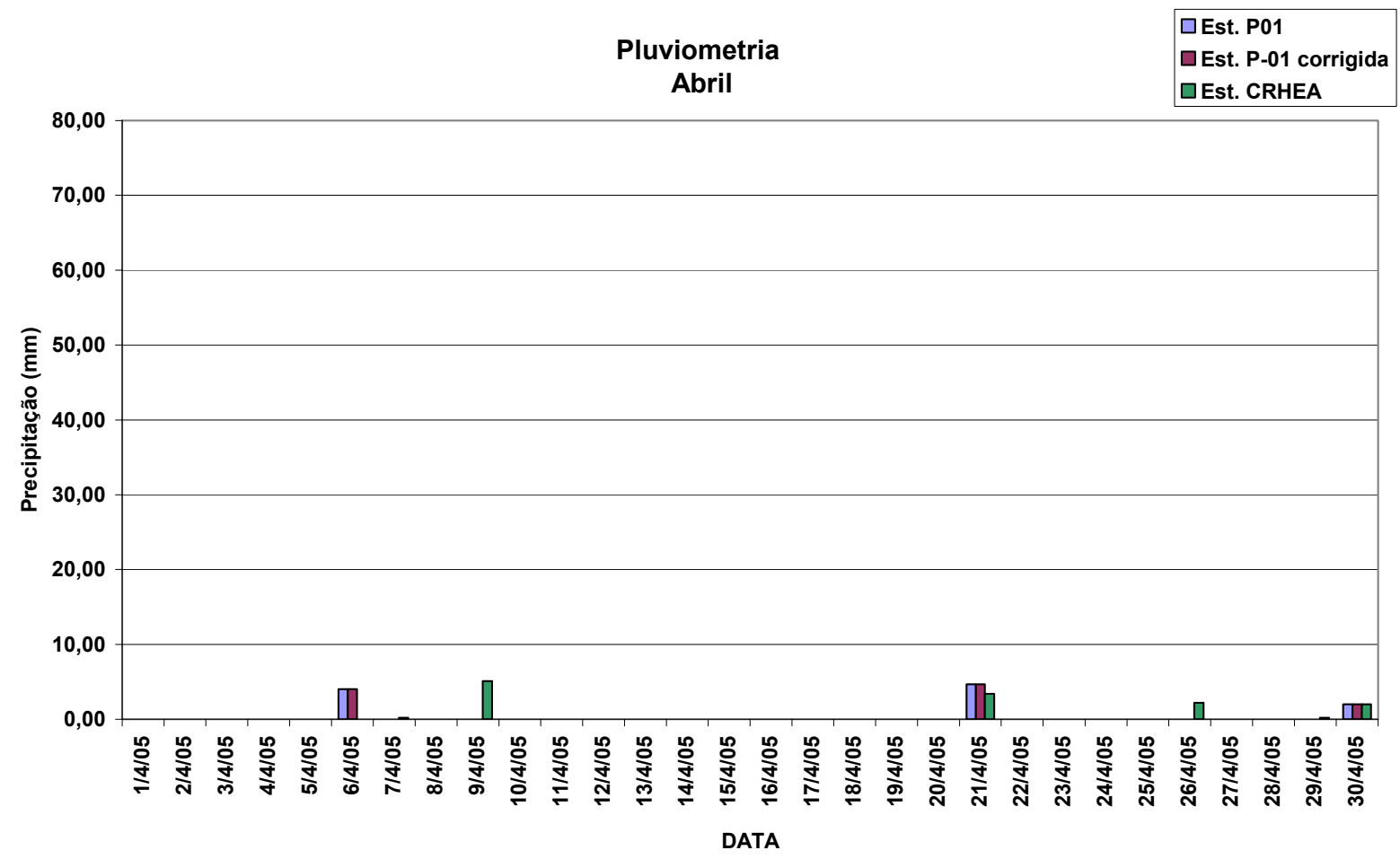

Gráfico 43: Pluviometria no mês de abril de 2005 


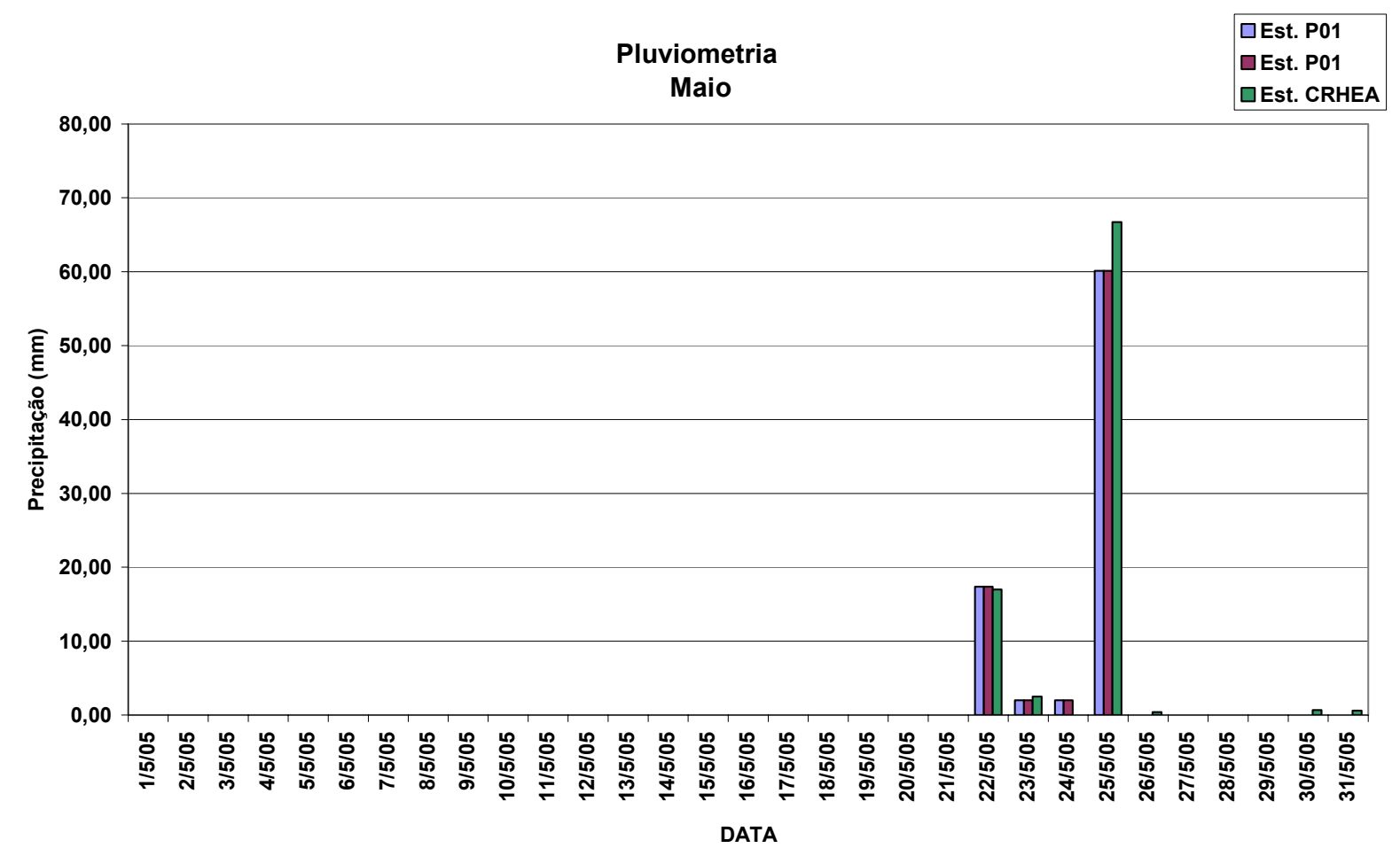

Gráfico 44: Pluviometria no mês de maio de 2005

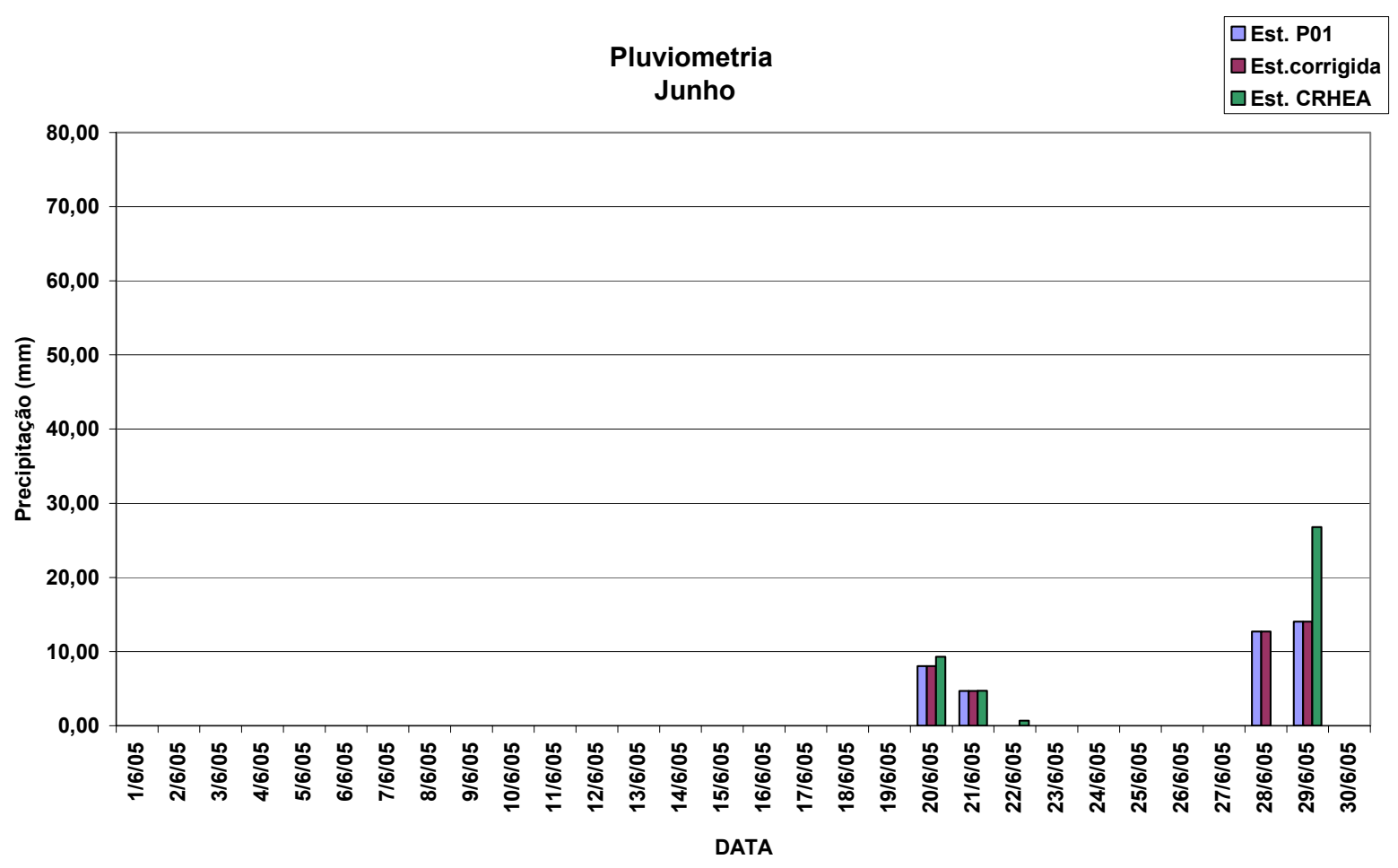

Gráfico 45: Pluviometria no mês de junho de 2005 


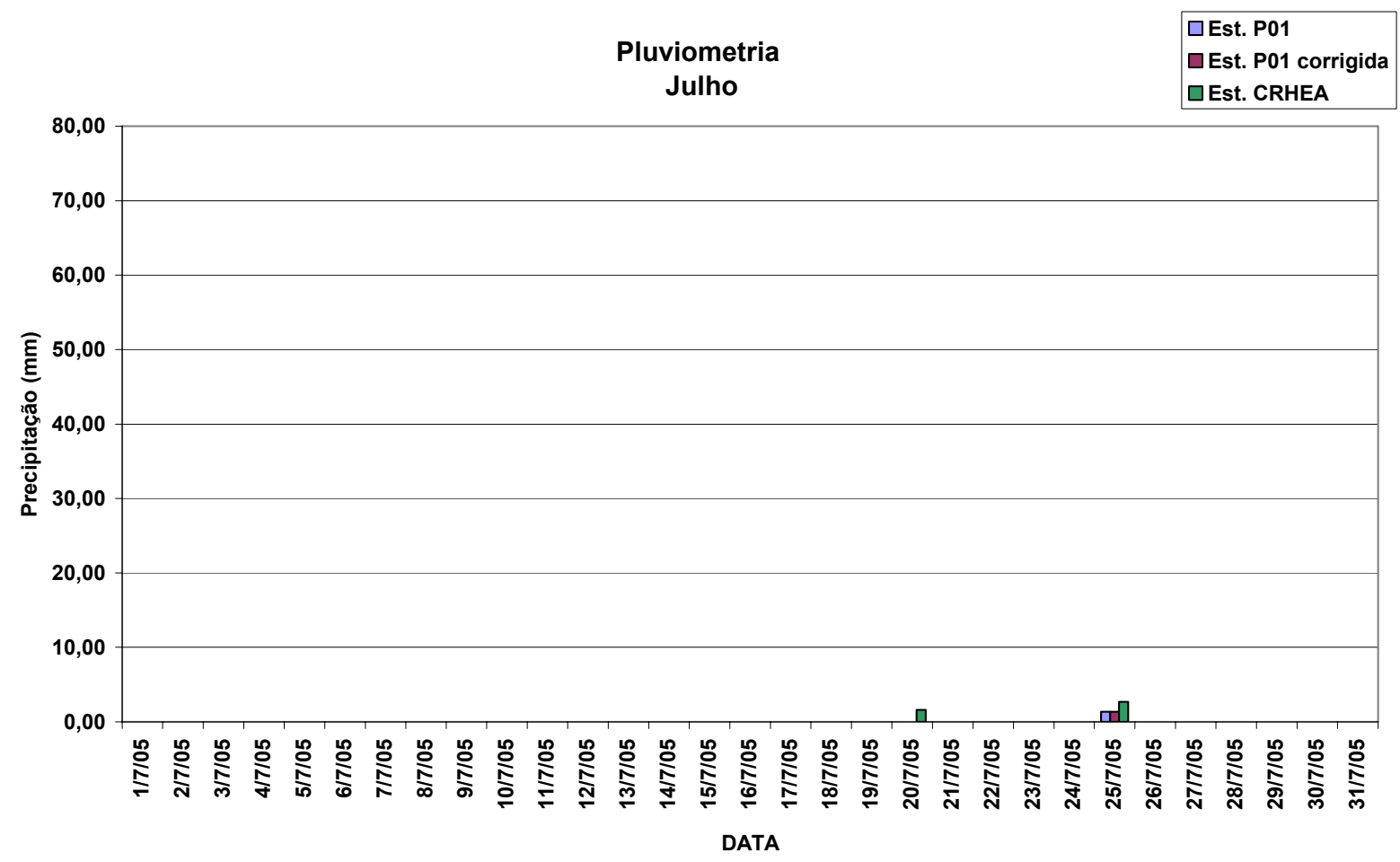

Gráfico 46: Pluviometria no mês de julho de 2005

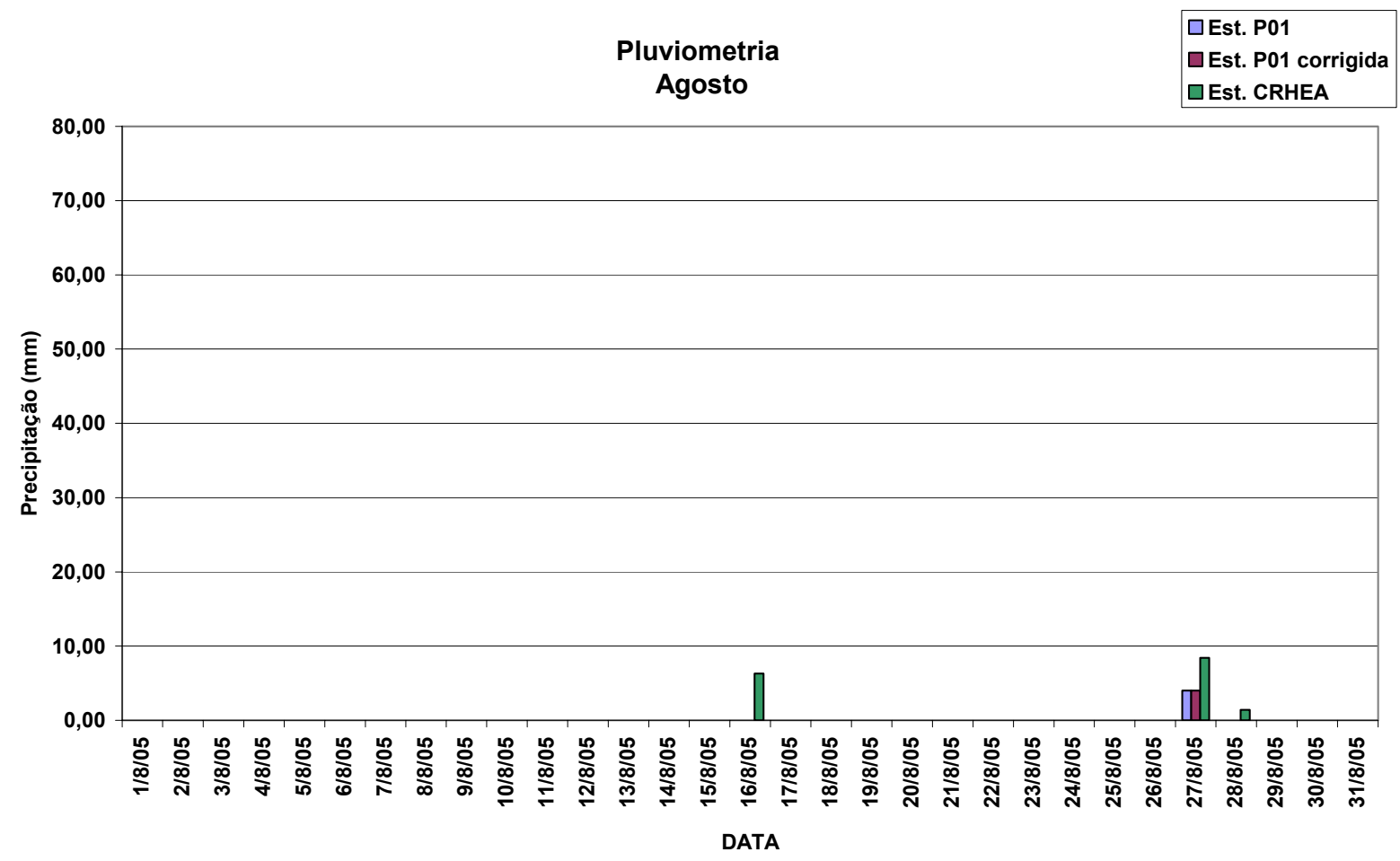

Gráfico 47: Pluviometria no mês de agosto de 2005 


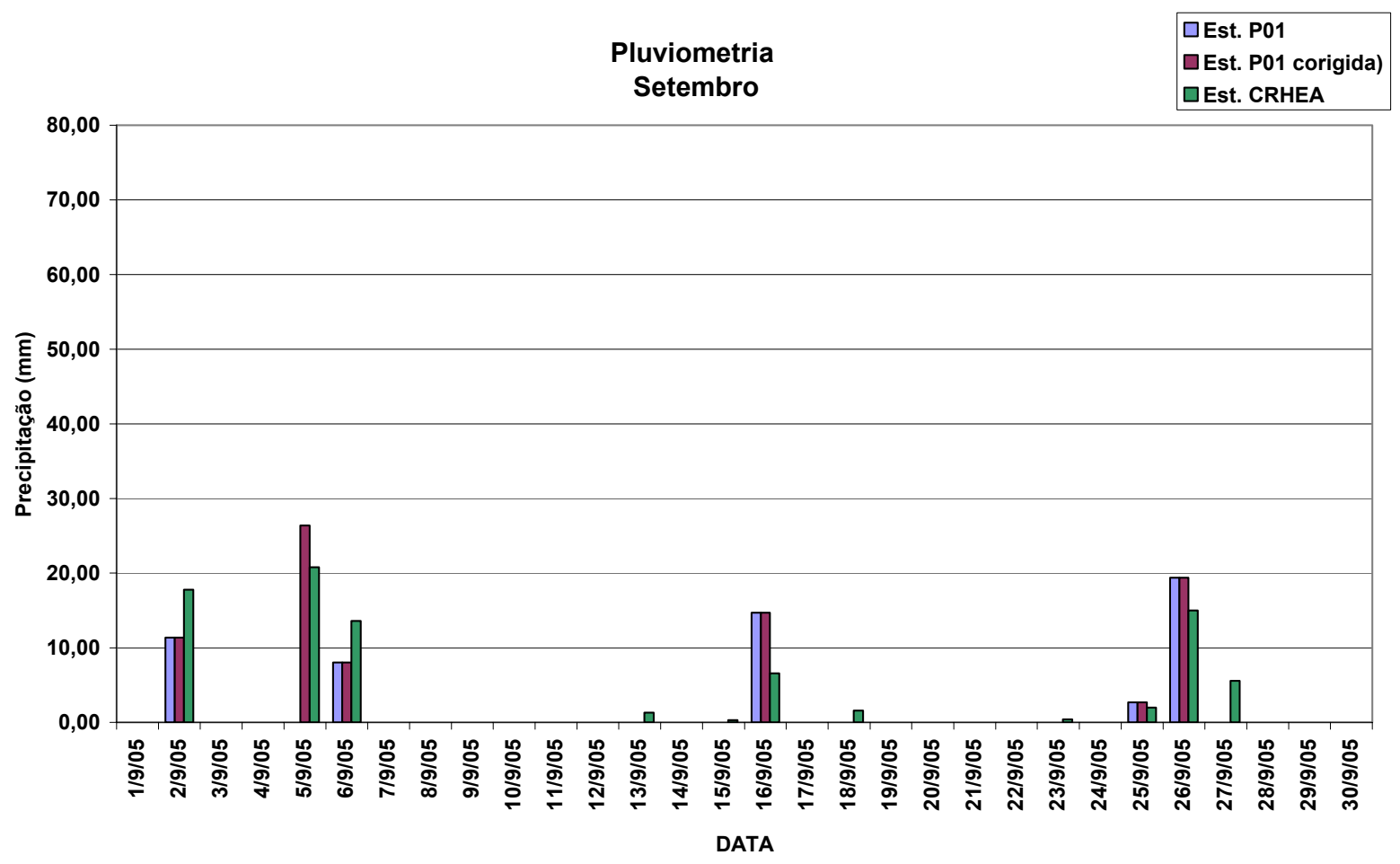

Gráfico 48: Pluviometria no mês de setembro de 2005

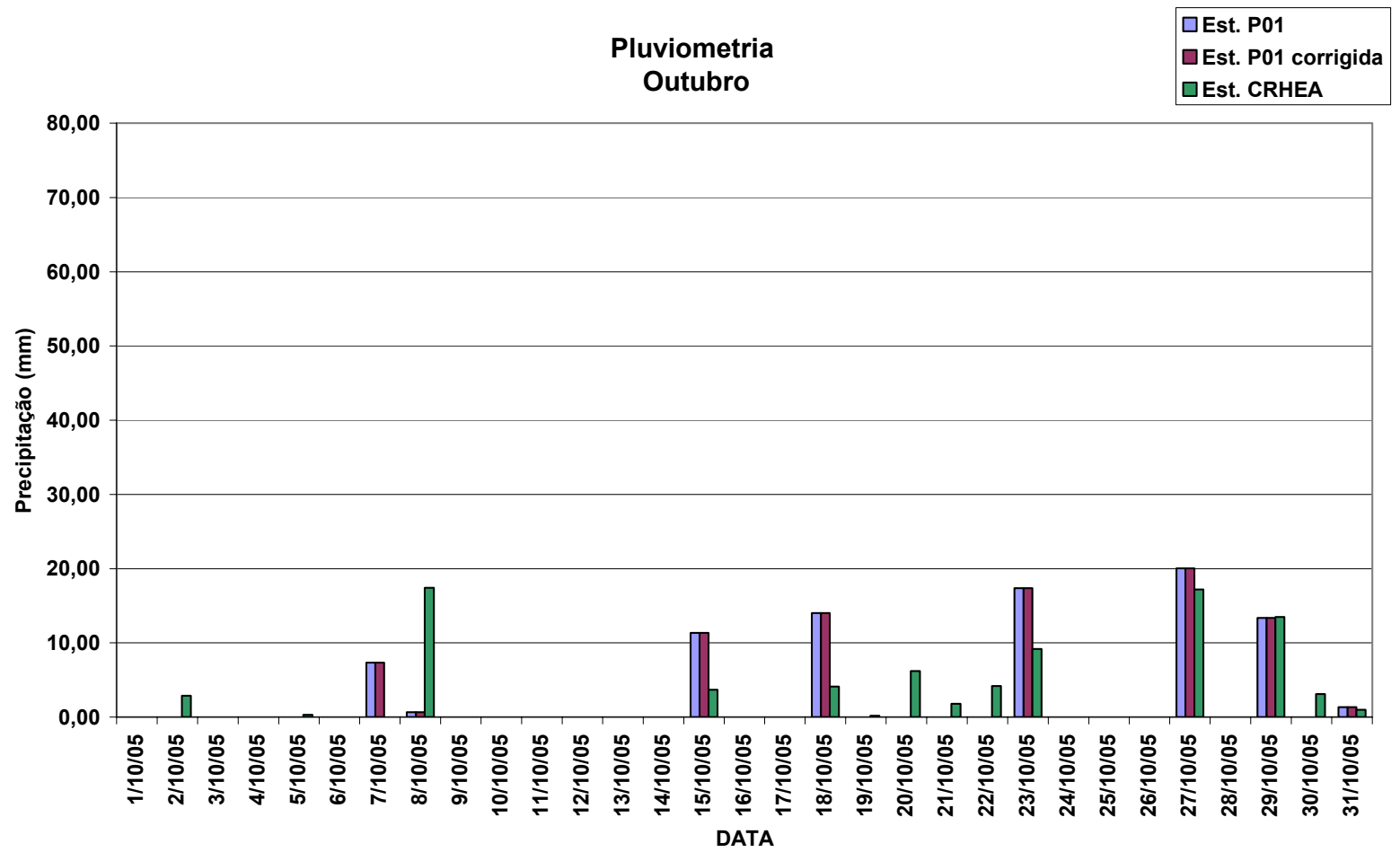

Gráfico 49: Pluviometria no mês de outubro de 2005 


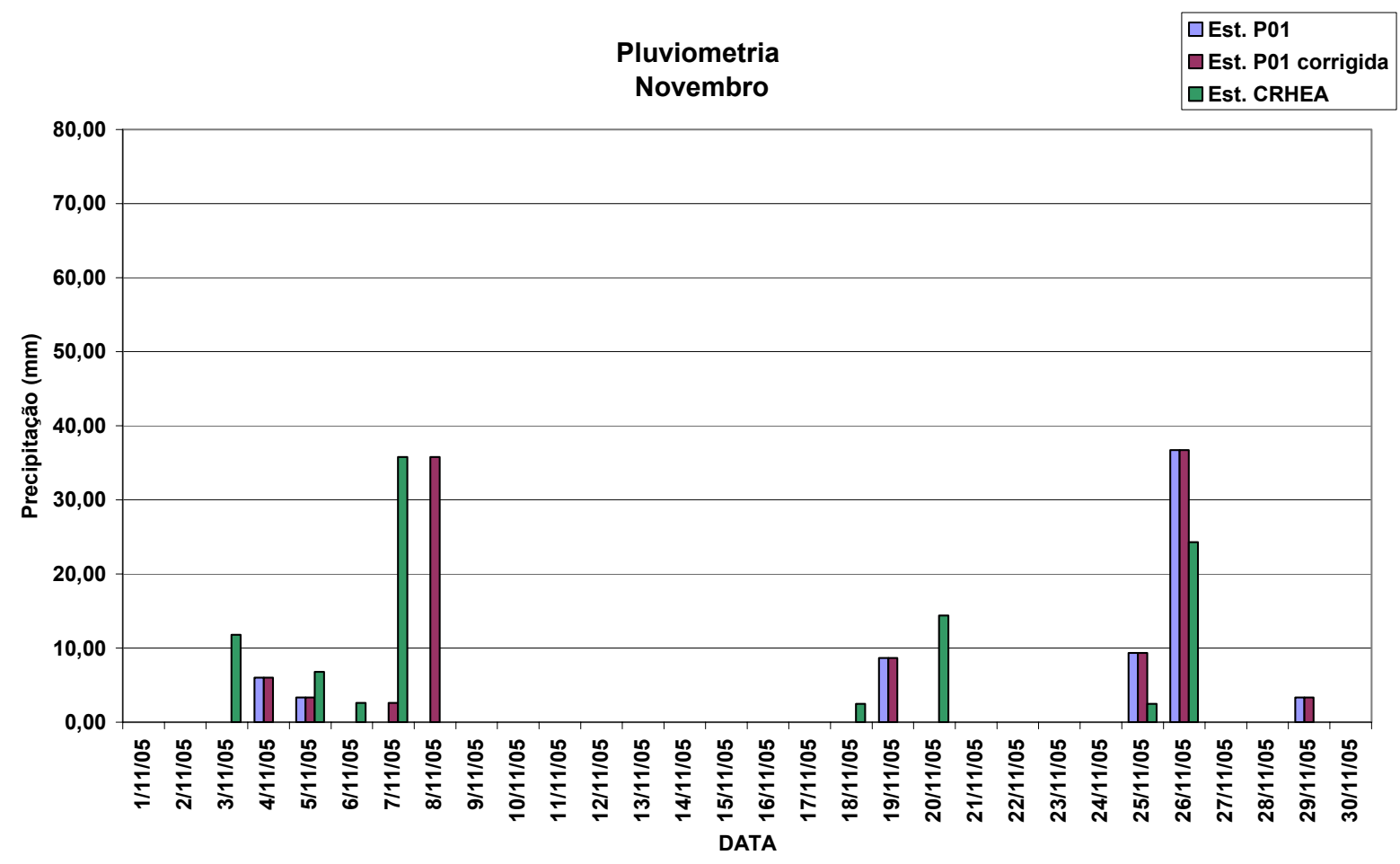

Gráfico 50: Pluviometria no mês de novembro de 2005

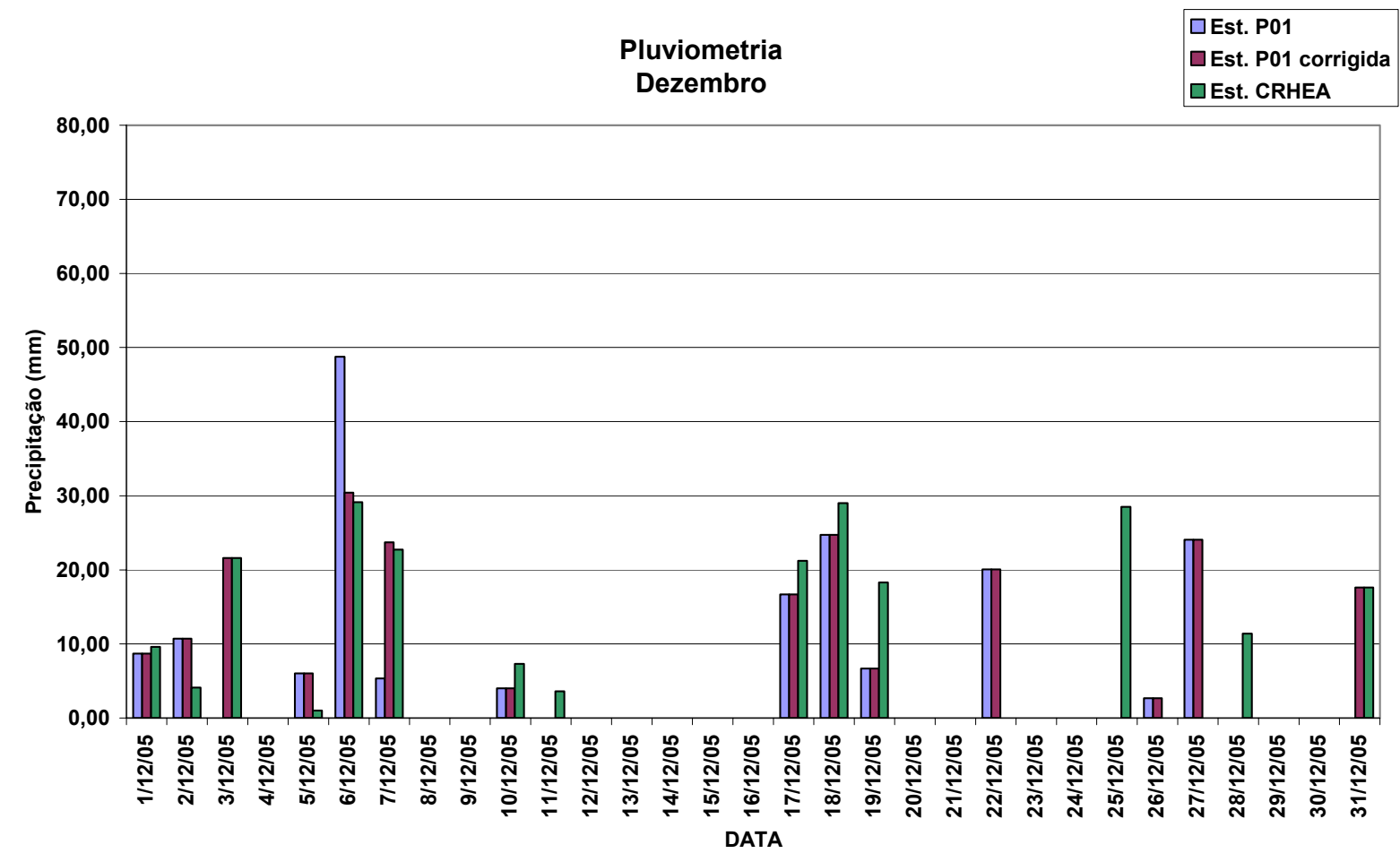

Gráfico 51: Pluviometria no mês de dezembro de 2005 


\section{APENDICE C}

(Planilhas de medição de vazão) 



\section{MEDIĊ̃̃O NÚMERO 1}

\begin{tabular}{|c|c|c|c|c|c|c|c|c|c|}
\hline$\underbrace{}_{\text {USP-EESC-SHS }}$ & : & & $\begin{array}{l}\text { ESCOLA } \\
\text { PARTAM } \\
\text { TOR DE } \\
\text { NÚCL }\end{array}$ & $\begin{array}{l}\text { A DE ENGEI } \\
\text { IENTO DE H } \\
\text { MONITORA } \\
\text { _EO DE HID } \\
\text { Medição de }\end{array}$ & $\begin{array}{l}\text { IARIA DE } \\
\text { RÁULICA } \\
\text { ENTO HID } \\
\text { DMETRIA } \\
\text { escarga lí }\end{array}$ & $\begin{array}{l}\text { SAO CARLOS } \\
\text { E SANEAME } \\
\text { ROGEOLÓG } \\
\text { DO CRHEA } \\
\text { quida }\end{array}$ & $\begin{array}{l}\text { ITO } \\
\text { CO }\end{array}$ & & \\
\hline RIO: & Ribeirão da $\mathrm{O}$ & nça & & & & & & DATA: & $28 / 10 / 2004$ \\
\hline Largura (m) & 6,20 & Prof. Med(m) & 0,50 & Vel.méd.(m/s) & 0,23 & Área $\left(\mathrm{m}^{2}\right)$ & 3,11 & Descarga $\left(\mathrm{m}^{3} / \mathrm{s}\right)$ & 0,71 \\
\hline $\begin{array}{c}\text { distância do P.I. } \\
(\mathrm{m})\end{array}$ & $\begin{array}{c}\text { larg.entre } \\
\text { verticais }(\mathrm{m})\end{array}$ & $\begin{array}{l}\text { prof. na vertical } \\
(\mathrm{m})\end{array}$ & Hélice & $\begin{array}{c}\text { número de } \\
\text { giros }\end{array}$ & Tempo (s) & $\begin{array}{c}\text { Vel méd na } \\
\text { vertical }(\mathrm{m} / \mathrm{s})\end{array}$ & $\begin{array}{l}\text { Vel. Media entre } \\
\text { verticais }(\mathrm{m} / \mathrm{s})\end{array}$ & $\begin{array}{c}\text { Area entre } \\
\text { verticais }\left(\mathrm{m}^{2}\right)\end{array}$ & $\begin{array}{c}\text { Descarga } \\
\left(\mathrm{m}^{3} / \mathrm{s}\right)\end{array}$ \\
\hline 1,00 & - & 0 & - & - & - & 0 & - & 0 & Name \\
\hline 1,50 & 0,50 & 0,23 & - & 0 & 0 & 0 & 0,00 & 0,0575 & 0 \\
\hline 2,00 & 0,50 & 0,55 & - & 20 & 40.0 & 0.13 & 0.07 & 0.195 & 0013 \\
\hline & & & & & & & & & \\
\hline 2,50 & 0,50 & 0,54 & - & 30 & 38,0 & 0,20 & 0,17 & 0,2725 & 0,046 \\
\hline 3,00 & 0,50 & 0,53 & - & 60 & 40,0 & 0,38 & 0,29 & 0,2675 & 0,078 \\
\hline 3,50 & 0,50 & 0,58 & - & 60 & 42,5 & 0,35 & 0,37 & 0,2775 & 0,101 \\
\hline 4,00 & 0,50 & 0,59 & - & 60 & 37,8 & 0,40 & 0,38 & 0,2925 & 0,110 \\
\hline 4,50 & 0,50 & 0,61 & - & 60 & 46,1 & 0,33 & 0,36 & 0,3 & 0,109 \\
\hline 5,00 & 0,50 & 0,6 & - & 60 & 48,3 & 0,31 & 0,32 & 0,3025 & 0,097 \\
\hline 5,50 & 0,50 & 0,61 & - & 60 & 49,9 & 0,30 & 0,31 & 0,3025 & 0,093 \\
\hline 6,00 & 0,50 & 0,62 & - & 30 & 60,3 & 0,13 & 0,22 & 0,3075 & 0,067 \\
\hline 650 & 050 & 054 & - & 0 & 00 & 000 & 007 & 029 & 0000 \\
\hline & & & & & & & & & \\
\hline 7,00 & 0,50 & 0,42 & - & 0 & 0,0 & 0,00 & 0,00 & 0,24 & 0,000 \\
\hline 7,20 & 0,20 & 0,00 & - & - & - & - & - & - & Namd \\
\hline & & & & & & & & & \\
\hline & & & & & & & & 3,105 & 0,714 \\
\hline Totais & & & & & & & & & $0,714 \mathrm{~m}^{3} / \mathrm{s}$ \\
\hline
\end{tabular}

Figura 63: Planilha de medição de vazão no dia 28/10/2004 


\section{MEDIČ̃̃O NÚMERO 2}

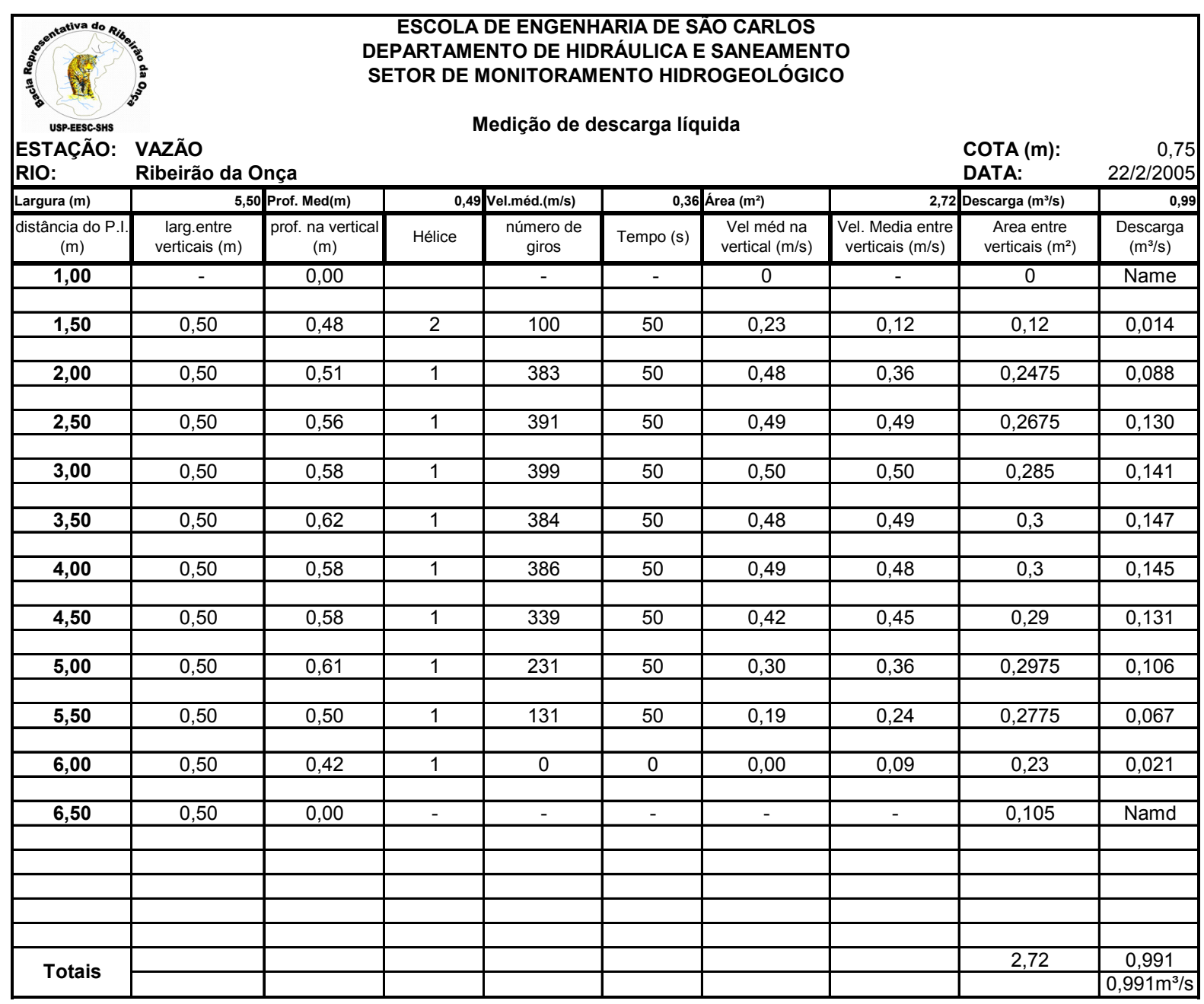

Figura 64: Planilha de medição de vazão no dia 22/02/2005 


\section{MEDIČ̃̃O NÚMERO 3}

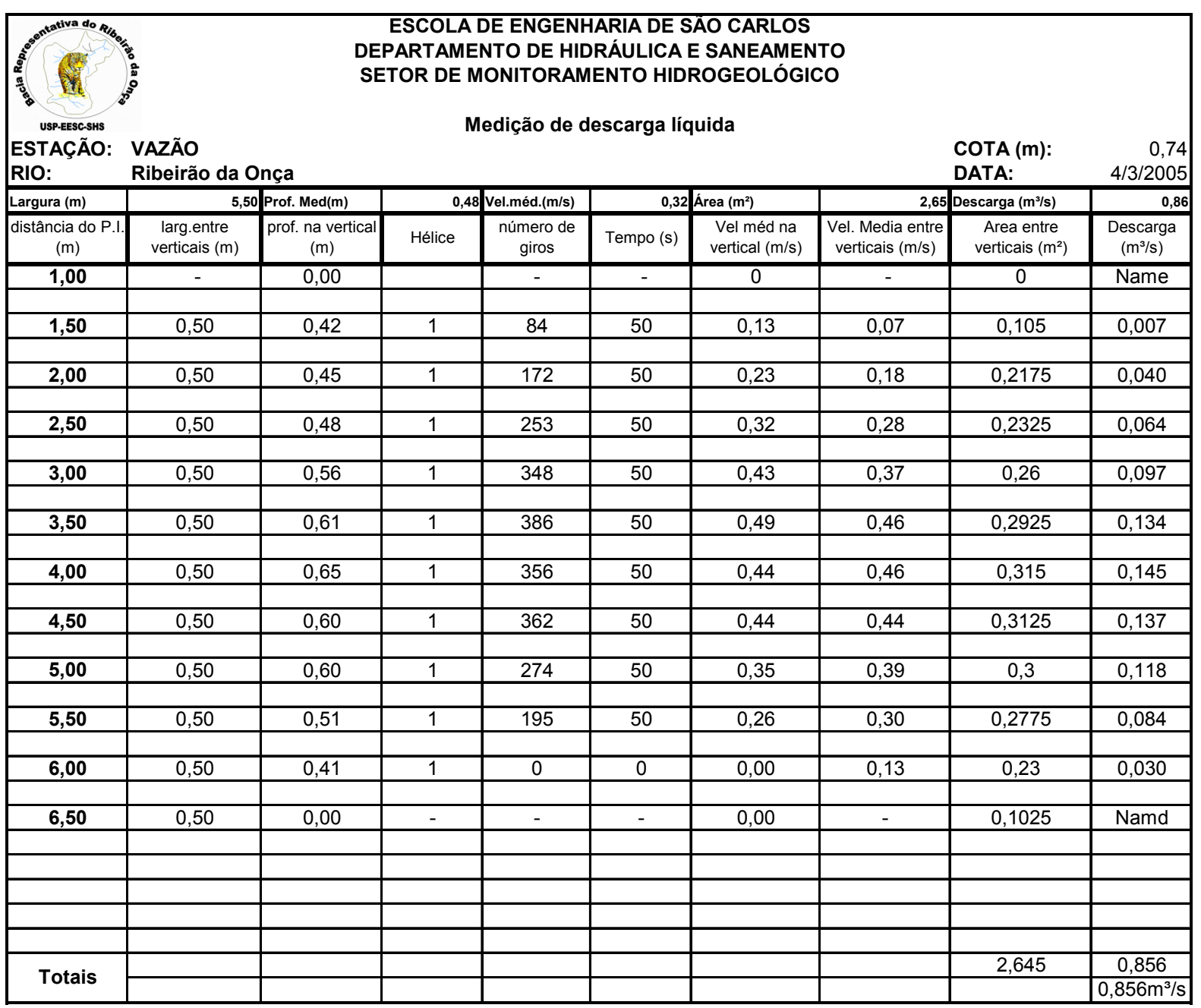

Figura 65: Planilha de medição de vazão no dia 04/03/2005 


\section{MEDIČ̃̃O NÚMERO 4}

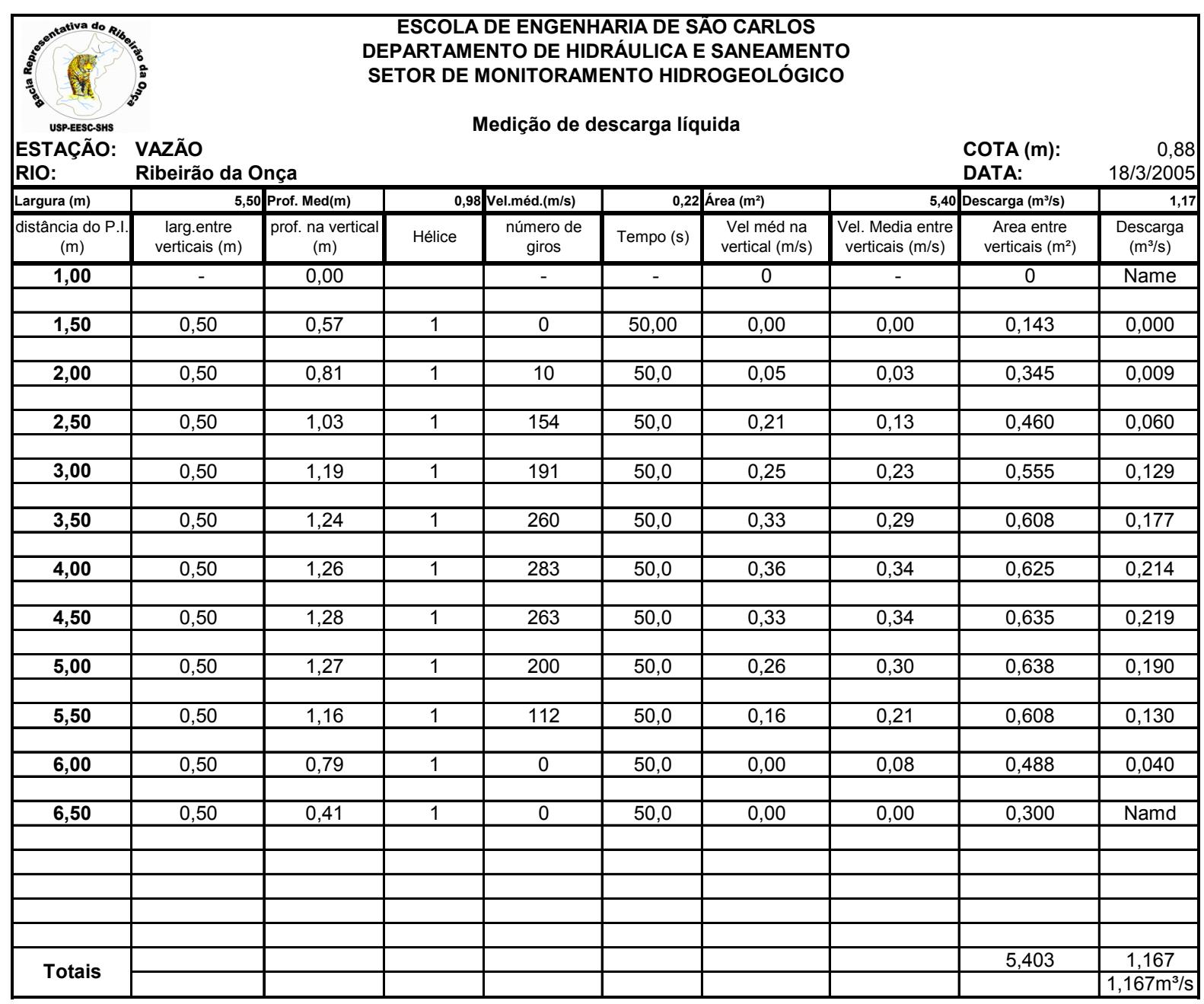

Figura 66: Planilha de medição de vazão no dia 18/03/2005 


\section{MEDIČ̃̃O NÚMERO 5}

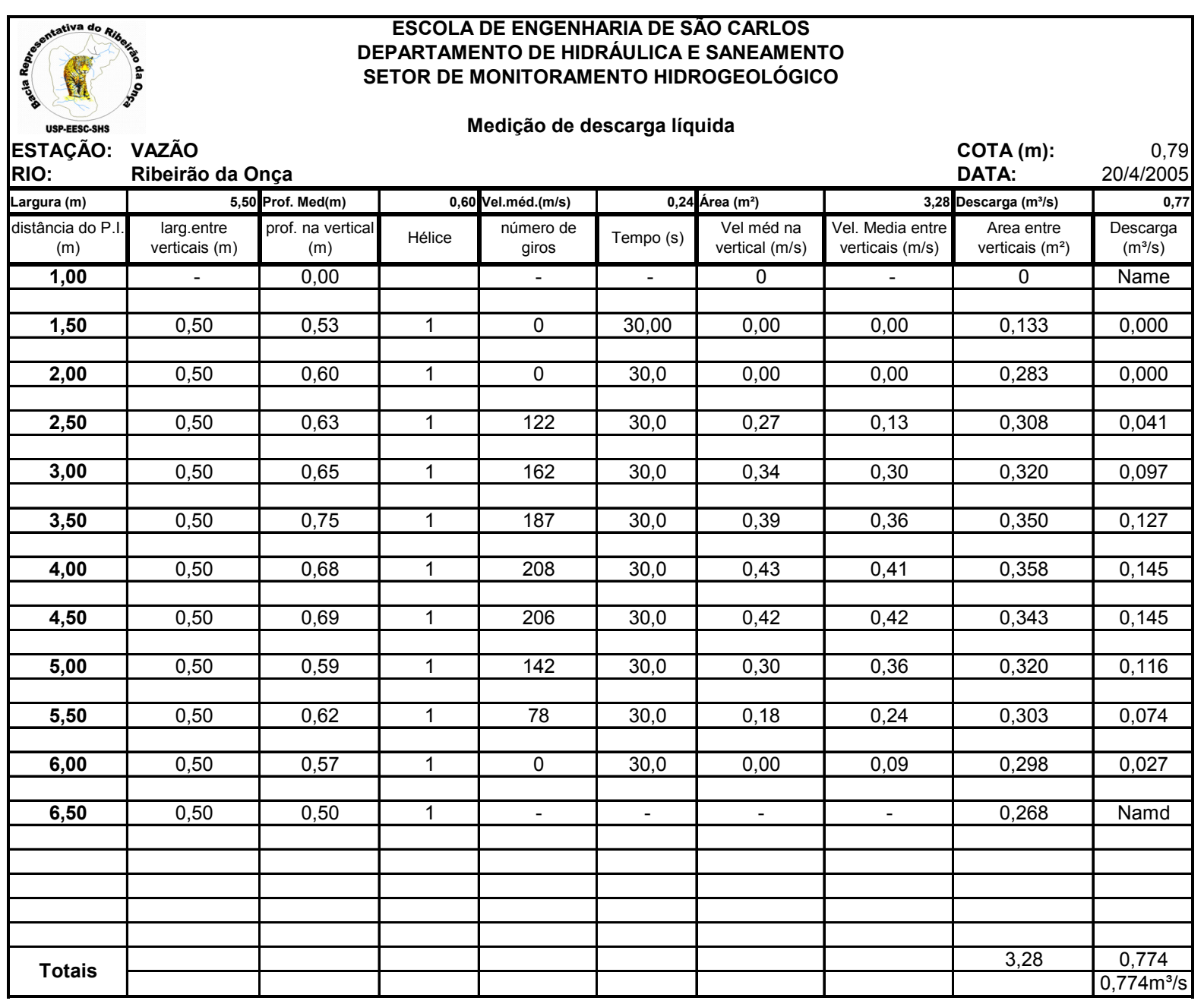

Figura 67: Planilha de medição de vazão no dia 20/04/2005 


\section{MEDIČ̃̃O NÚMERO 6}

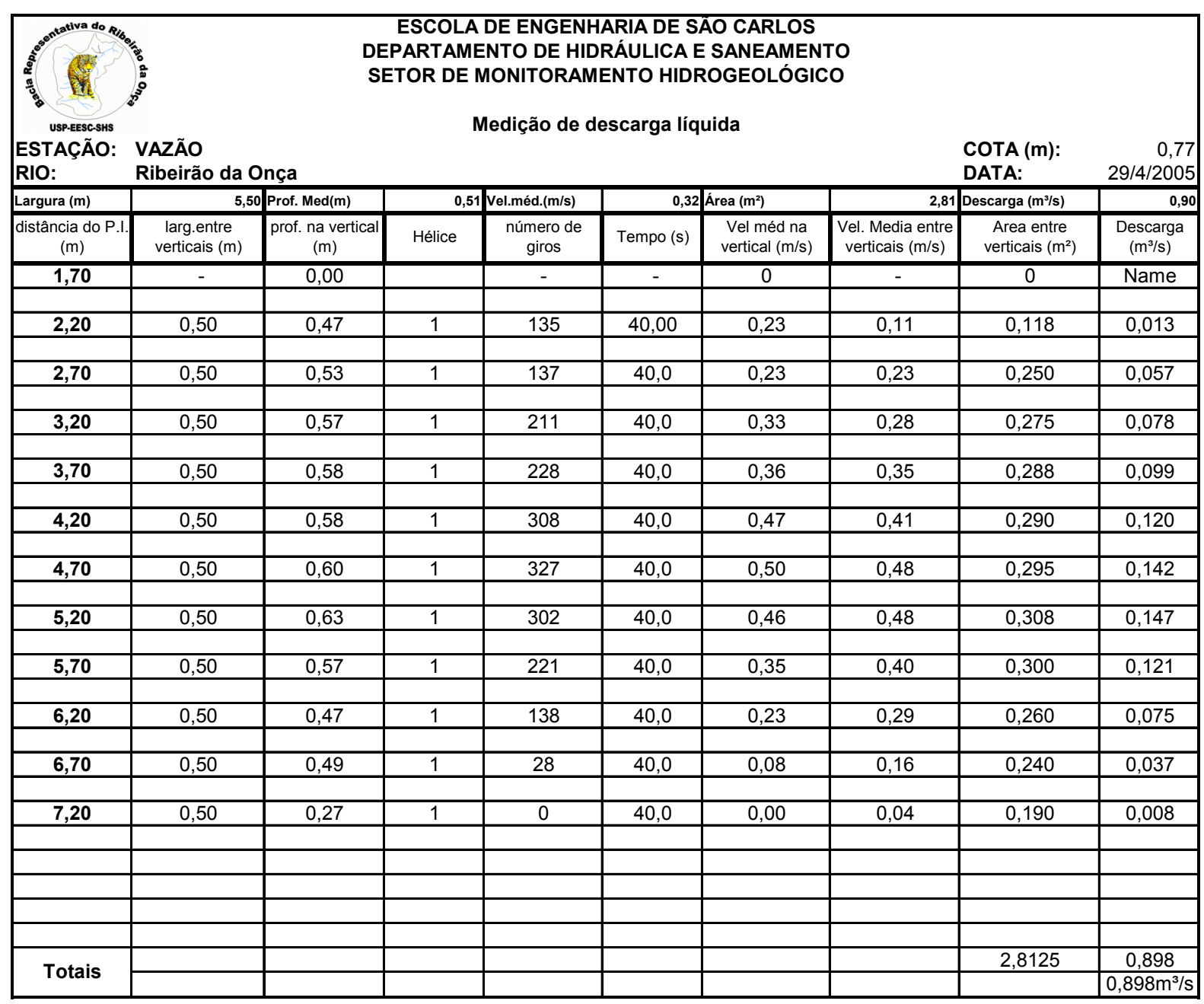

Figura 68: Planilha de medição de vazão no dia 29/04/2005 


\section{MEDIĈ̃̃O NÚMERO 7}

\begin{tabular}{|c|c|c|c|c|c|c|c|c|c|}
\hline $\begin{array}{l}\text { USP-EESC-SHS } \\
\text { ESTAÇÃO: } \\
\text { RIO: }\end{array}$ & $\begin{array}{l}\text { VAZÃo } \\
\text { Ribeirão da O }\end{array}$ & nça & $\begin{array}{l}\text { ESCOL } \\
\text { PARTAM } \\
\text { TOR DE }\end{array}$ & $\begin{array}{l}\text { DE ENGENH } \\
\text { ENTO DE HID } \\
\text { MONITORAM }\end{array}$ & $\begin{array}{l}\text { ARIA DE S } \\
\text { RÁULICA E } \\
\text { ENTO HIDF }\end{array}$ & $\begin{array}{l}\text { AO CARLOS } \\
\text { SANEAMEN } \\
\text { ROGEOLÓGI }\end{array}$ & & $\begin{array}{l}\text { COTA }(m): \\
\text { DATA: }\end{array}$ & $\begin{array}{r}0,78 \\
6 / 5 / 2005\end{array}$ \\
\hline Largura (m) & 5,70 & Prof. Med(m) & 0,5 & 2 Vel.méd.(m/s) & 0,24 & Área $\left(\mathrm{m}^{2}\right)$ & 2,97 & Descarga $\left(\mathrm{m}^{3} / \mathrm{s}\right)$ & 0,71 \\
\hline $\begin{array}{c}\text { distância do P.I. } \\
(\mathrm{m})\end{array}$ & $\begin{array}{c}\text { larg.entre } \\
\text { verticais }(\mathrm{m})\end{array}$ & $\begin{array}{c}\text { prof. na vertical } \\
(\mathrm{m})\end{array}$ & Hélice & número de giros & Tempo (s) & $\begin{array}{l}\text { Vel méd na } \\
\text { vertical }(\mathrm{m} / \mathrm{s})\end{array}$ & $\begin{array}{l}\text { Vel. Media entre } \\
\text { verticais }(\mathrm{m} / \mathrm{s})\end{array}$ & $\begin{array}{c}\text { Area entre verticais } \\
\left(\mathrm{m}^{2}\right)\end{array}$ & $\begin{array}{c}\text { Descarga } \\
\left(\mathrm{m}^{3} / \mathrm{s}\right)\end{array}$ \\
\hline 1,50 & - & 0,00 & & - & - & 0 & - & 0 & Name \\
\hline 2,00 & 0,50 & 0,51 & 1 & 0 & 50 & 0,00 & 0,00 & 0,1275 & 0,000 \\
\hline 2,50 & 0,50 & 0,53 & 1 & 111 & 50 & 0,16 & 0,08 & 0,26 & 0,021 \\
\hline 3,00 & 0,50 & 0,52 & 1 & 160 & 50 & 0,22 & 0,19 & 0,2625 & 0,050 \\
\hline 3,50 & 0,50 & 0,60 & 1 & 256 & 50 & 0,33 & 0,27 & 0,28 & 0,076 \\
\hline 4,00 & 0,50 & 0,64 & 1 & 360 & 50 & 0,44 & 0,38 & 0,31 & 0,119 \\
\hline 4,50 & 0,50 & 0,64 & 1 & 299 & 50 & 0,37 & 0,41 & 0,32 & 0,130 \\
\hline & & & & & & & & & \\
\hline 5,00 & 0,50 & 0,62 & 1 & 297 & 50 & 0,37 & 0,37 & 0,315 & 0,117 \\
\hline 5,50 & 0,50 & 0,62 & 1 & 194 & 50 & 0,26 & 0,31 & 0,31 & 0,097 \\
\hline 6,00 & 0,50 & 0,51 & 1 & 158 & 50 & 0,22 & 0,24 & 0,2825 & 0,067 \\
\hline 6.50 & 0.50 & 0.53 & 1 & 51 & 50 & 0.00 & 0.11 & 026 & 0.028 \\
\hline & & & & & & & & & \\
\hline 7,00 & 0,50 & 0,31 & 1 & 0 & 50 & 0,00 & 0,00 & 0,21 & 0,000 \\
\hline 7,20 & 0,20 & 0,00 & - & - & - & & - & 0,031 & Namd \\
\hline & & & & & & & & & \\
\hline & & & & & & & & & \\
\hline & & & & & & & & & \\
\hline Totais & & & & & & & & 2,9685 & 0,706 \\
\hline lotals & & & & & & & & & $0,706 \mathrm{~m}^{3} / \mathrm{s}$ \\
\hline
\end{tabular}

Figura 69: Planilha de medição de vazão no dia 06/05/2005 


\section{MEDIČ̃̃O NÚMERO 8}

\begin{tabular}{|c|c|c|c|c|c|c|c|c|c|}
\hline \multirow{2}{*}{ 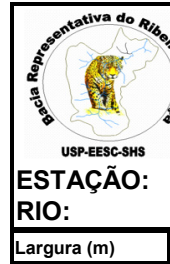 } & \multicolumn{7}{|c|}{$\begin{array}{c}\text { ESCOLA DE ENGENHARIA DE SÃO CARLOS } \\
\text { DEPARTAMENTO DE HIDRÁULICA E SANEAMENTO } \\
\text { SETOR DE MONITORAMENTO HIDROGEOLÓGICO } \\
\text { Medição de descarga líquida }\end{array}$} & \multirow{2}{*}{$\begin{array}{l}\text { COTA }(\mathrm{m}): \\
\text { DATA: } \\
\text { Descarga }\left(\mathrm{m}^{3} / \mathrm{s}\right)\end{array}$} & \multirow{2}{*}{$\begin{array}{r}0,76 \\
16 / 5 / 2005 \\
\mathbf{0 , 8 4} \\
\end{array}$} \\
\hline & \multicolumn{2}{|c|}{\begin{tabular}{|l|l|}
5,70 & Prof. $\operatorname{Med}(\mathrm{m})$ \\
\end{tabular}} & \multicolumn{2}{|c|}{$\begin{array}{l}0,48 \mid \text { Vel.méd.(m/s) } \\
\end{array}$} & \multicolumn{2}{|c|}{0,31 Área $\left(\mathrm{m}^{2}\right)$} & 2,73 & & \\
\hline $\begin{array}{c}\text { distância do P.I. } \\
(\mathrm{m})\end{array}$ & $\begin{array}{c}\text { larg.entre } \\
\text { verticais }(\mathrm{m})\end{array}$ & \begin{tabular}{|c} 
prof. na vertical \\
(m)
\end{tabular} & Hélice & $\begin{array}{l}\text { número de } \\
\text { giros }\end{array}$ & Tempo (s) & $\begin{array}{c}\text { Vel méd na } \\
\text { vertical }(\mathrm{m} / \mathrm{s})\end{array}$ & $\begin{array}{l}\text { Vel. Media entre } \\
\text { verticais }(\mathrm{m} / \mathrm{s})\end{array}$ & $\begin{array}{c}\text { Area entre } \\
\text { verticais }\left(\mathrm{m}^{2}\right)\end{array}$ & $\begin{array}{c}\text { Descarga } \\
\left(\mathrm{m}^{3} / \mathrm{s}\right)\end{array}$ \\
\hline 1,60 & - & 0,00 & & - & - & 0 & - & 0 & Name \\
\hline 2,10 & 0,50 & 0,42 & 1 & 0 & 50,00 & 0,00 & 0,00 & 0,105 & 0,000 \\
\hline & & & & & & & & & \\
\hline 2,60 & 0,50 & 0,49 & 1 & 175 & 50,0 & 0,23 & 0,12 & 0,228 & 0,027 \\
\hline 3,10 & 0,50 & 0,53 & 1 & 272 & 50,0 & 0,34 & 0,29 & 0,255 & 0,074 \\
\hline & & & & & & & & & \\
\hline 3,60 & 0,50 & 0,57 & 1 & 256 & 50,0 & 0,33 & 0,33 & 0,275 & 0,092 \\
\hline 4,10 & 0,50 & 0,59 & 1 & 342 & 50,0 & 0,42 & 0,37 & 0,290 & 0,108 \\
\hline & & & & & & & & & \\
\hline 4,60 & 0,50 & 0,59 & 1 & 386 & 50,0 & 0,49 & 0,45 & 0,295 & 0,134 \\
\hline 5,10 & 0,50 & 0,60 & 1 & 431 & 50,0 & 0,54 & 0,51 & 0,298 & 0,152 \\
\hline & & & & & & & & & \\
\hline 5,60 & 0,50 & 0,54 & 1 & 270 & 50,0 & 0,34 & 0,44 & 0,285 & 0,125 \\
\hline & & & & & & & & & \\
\hline 6,10 & 0,50 & 0,45 & 1 & 176 & 50,0 & 0,24 & 0,29 & 0,248 & 0,071 \\
\hline 6,60 & 0,50 & 0,49 & 1 & 76 & 50,0 & 0,12 & 0,18 & 0,235 & 0,042 \\
\hline & & & & & & & & & \\
\hline 7,10 & 0,50 & 0,28 & 1 & 0 & 50,0 & 0,00 & 0,06 & 0,193 & 0,012 \\
\hline & & & & & & & & & \\
\hline 7,30 & 0,20 & 0,00 & - & - & - & - & - & 0,028 & Namd \\
\hline & & & & & & & & & \\
\hline & & & & & & & & & \\
\hline & & & & & & & & & \\
\hline Totais & & & & & & & & 2,733 & 0,837 \\
\hline Iotals & & & & & & & & & $0,837 \mathrm{~m}^{3} / \mathrm{s}$ \\
\hline
\end{tabular}

Figura 70: Planilha de medição de vazão no dia 16/05/2005 


\section{MEDIČ̃̃O NÚMERO 9}

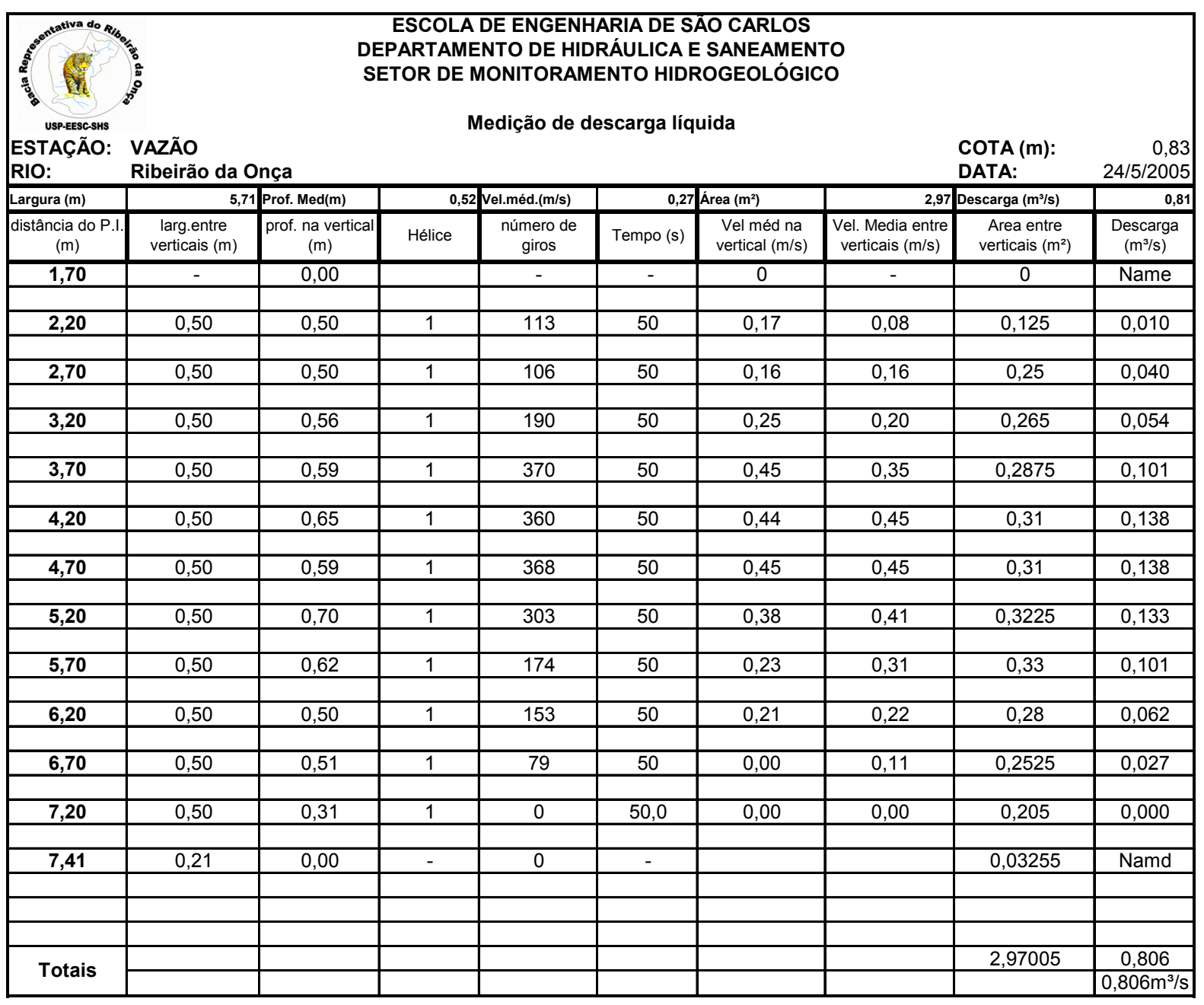

Figura 71: Planilha de medição de vazão no dia 24/05/2005 


\section{MEDIÇÃO NÚMERO 10}

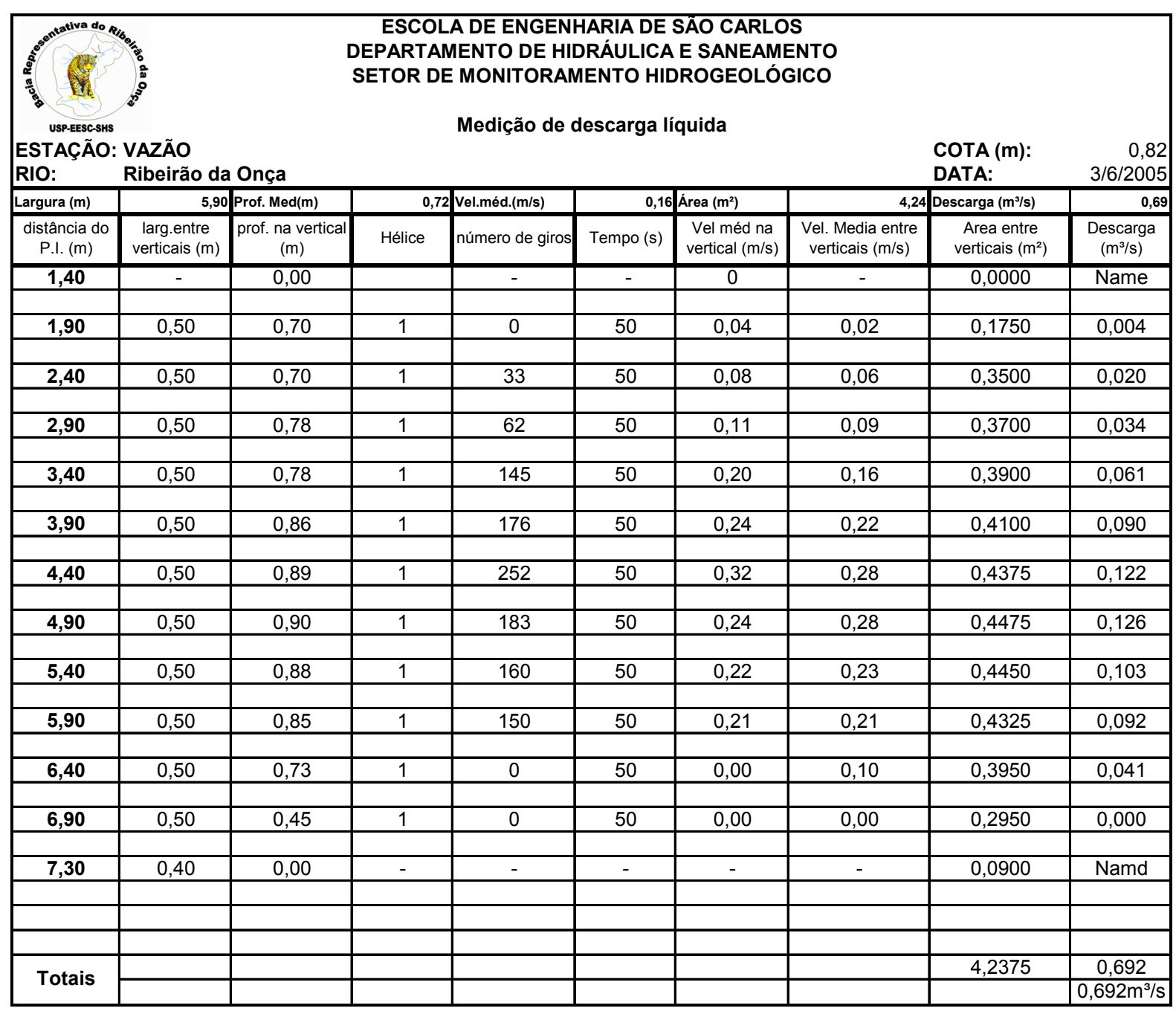

Figura 72: Planilha de medição de vazão no dia 03/06/2005 


\section{MEDIÇÃO NÚMERO 11}

\begin{tabular}{|c|c|c|c|c|c|c|c|c|c|}
\hline $\begin{array}{l}\text { UsP-EESC-SHS } \\
\text { ESTAÇÃO: } \\
\text { RIO: }\end{array}$ & \multicolumn{7}{|c|}{$\begin{array}{c}\text { ESCOLA DE ENGENHARIA DE SÁO CARLOS } \\
\text { DEPARTAMENTO DE HIDRÁULICA E SANEAMENTO } \\
\text { SETOR DE MONITORAMENTO HIDROGEOLÓGICO } \\
\text { Medição de descarga líquida }\end{array}$} & $\begin{array}{l}\text { COTA }(m): \\
\text { DATA: }\end{array}$ & $\begin{array}{r}0,82 \\
21 / 6 / 2005 \\
\end{array}$ \\
\hline Largura $(m)$ & 5,80 & Prof. Med(m) & 0,47 & Vel.méd.(m/s) & 0,30 & Área $\left(m^{2}\right)$ & 2,75 & Descarga $\left(\mathrm{m}^{3} / \mathrm{s}\right)$ & 0,83 \\
\hline $\begin{array}{c}\text { distância do P.I. } \\
(\mathrm{m})\end{array}$ & $\begin{array}{c}\text { larg.entre } \\
\text { verticais }(\mathrm{m})\end{array}$ & $\begin{array}{l}\text { prof. na vertical } \\
(\mathrm{m})\end{array}$ & Hélice & $\begin{array}{l}\text { número de } \\
\text { giros }\end{array}$ & Tempo (s) & $\begin{array}{c}\text { Vel méd na } \\
\text { vertical }(\mathrm{m} / \mathrm{s})\end{array}$ & $\begin{array}{c}\text { Vel. Media entre } \\
\text { verticais }(\mathrm{m} / \mathrm{s})\end{array}$ & $\begin{array}{c}\text { Area entre } \\
\text { verticais }\left(\mathrm{m}^{2}\right)\end{array}$ & $\begin{array}{c}\text { Descarga } \\
\left(\mathrm{m}^{3} / \mathrm{s}\right)\end{array}$ \\
\hline 1,60 & - & 0,00 & & - & - & 0 & - & 0 & Name \\
\hline 2,10 & 0,50 & 0,52 & 1 & 0 & 50 & 0,00 & 0,00 & 0,13 & 0,000 \\
\hline 2,60 & 0,50 & 0,43 & 1 & 211 & 50 & 0,28 & 0,14 & 0,2375 & 0,033 \\
\hline 3,10 & 0,50 & 0,44 & 1 & 261 & 50 & 0,33 & 0,30 & 0,2175 & 0,066 \\
\hline 3,60 & 0,50 & 0,52 & 1 & 347 & 50 & 0,43 & 0,38 & 0,24 & 0,091 \\
\hline 4,10 & 0,50 & 0,60 & 1 & 327 & 50 & 0,40 & 0,42 & 0,28 & 0,116 \\
\hline 4,60 & 0,50 & 0,67 & 1 & 371 & 50 & 0,45 & 0,43 & 0,3175 & 0,136 \\
\hline 5,10 & 0,50 & 0,50 & 1 & 313 & 50 & 0,39 & 0,42 & 0,2925 & 0,123 \\
\hline 5,60 & 0,50 & 0,50 & 1 & 271 & 50 & 0,34 & 0,37 & 0,25 & 0,091 \\
\hline 6,10 & 0,50 & 0,49 & 1 & 250 & 50 & 0,32 & 0,33 & 0,2475 & 0,082 \\
\hline 6,60 & 0,50 & 0,55 & 1 & 142 & 50 & 0,20 & 0,26 & 0,26 & 0,067 \\
\hline 7,10 & 0,50 & 0,34 & 1 & 0 & 50,0 & 0,00 & 0,10 & 0,2225 & 0,022 \\
\hline 7,40 & 0,30 & 0,00 & - & - & - & - & - & 0,051 & Namd \\
\hline & & & & & & & & & \\
\hline & & & & & & & & & \\
\hline & & & & & & & & 2,746 & 0,827 \\
\hline Iotals & & & & & & & & & $0,827 \mathrm{~m}^{3} / \mathrm{s}$ \\
\hline
\end{tabular}

Figura 73: Planilha de medição de vazão no dia 21/06/2005 


\section{MEDIČ̃̃O NÚMERO 12}

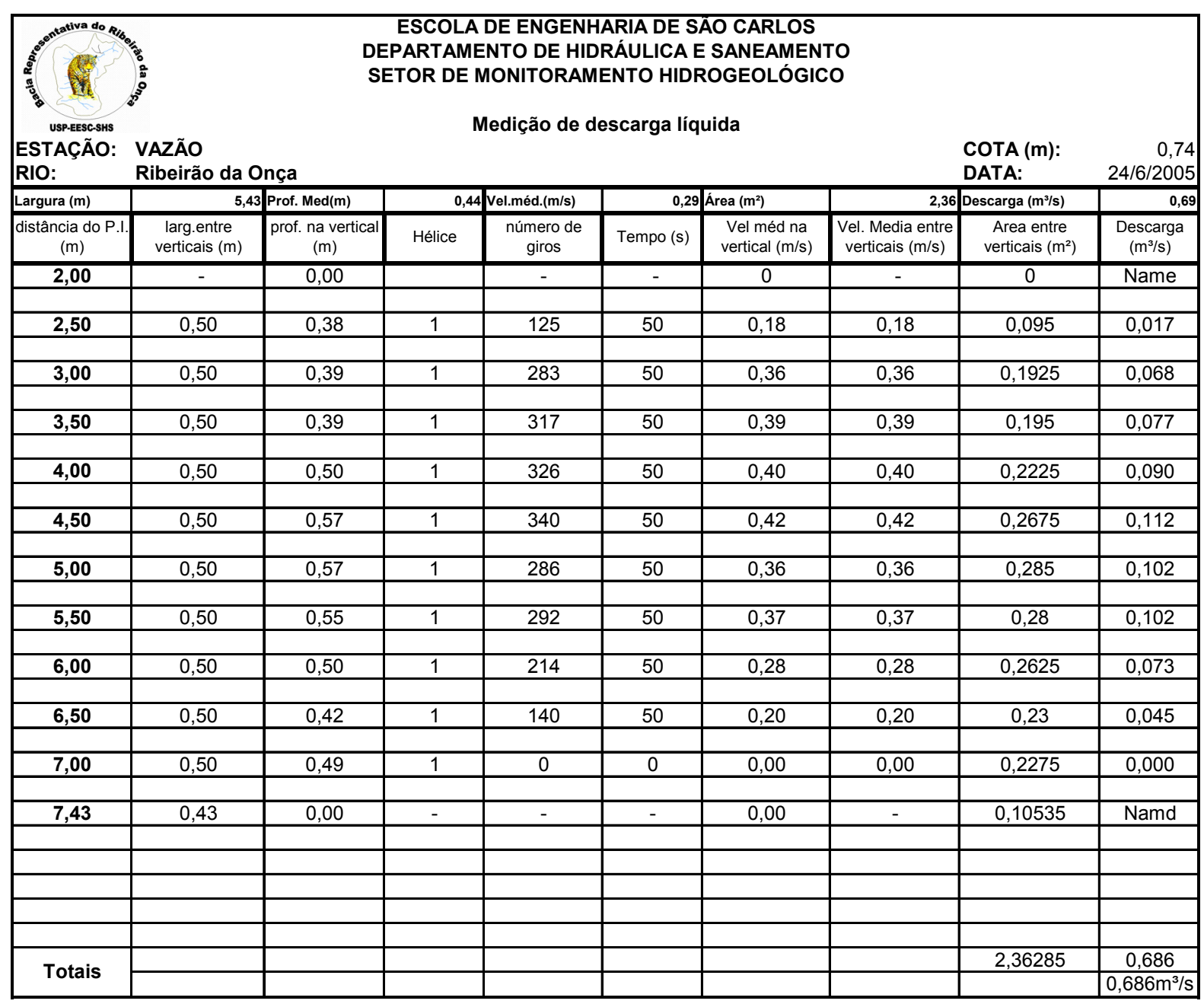

Figura 74: Planilha de medição de vazão no dia 24/06/2005 


\section{MEDIĊÃO NÚMERO 13}

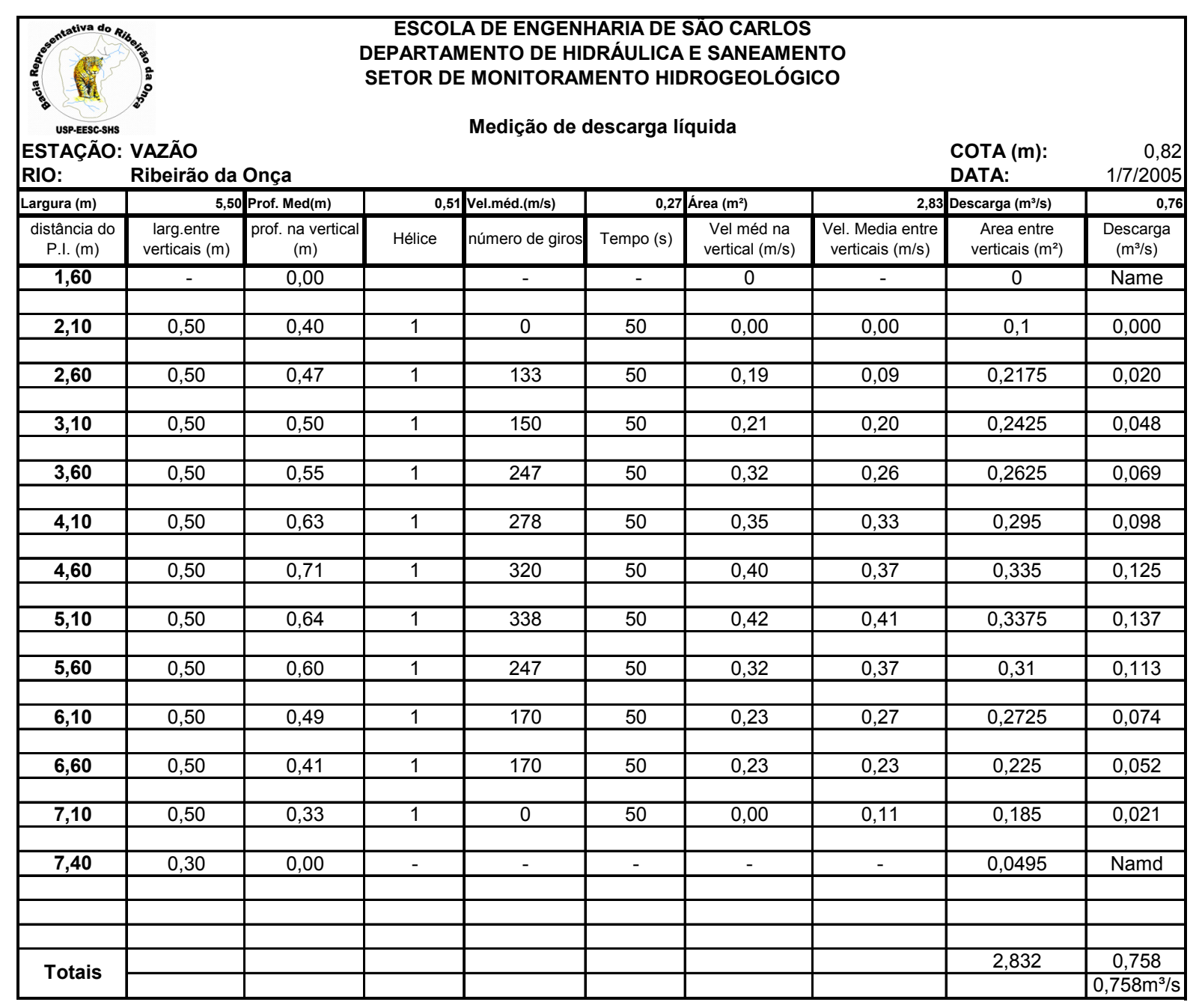

Figura 75: Planilha de medição de vazão no dia 01/07/2005 


\section{MEDIĊ̃̃O NÚMERO 14}

\begin{tabular}{|c|c|c|c|c|c|c|c|c|c|}
\hline \multirow{2}{*}{ 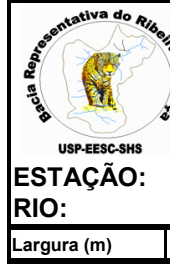 } & \multicolumn{7}{|c|}{$\begin{array}{c}\text { ESCOLA DE ENGENHARIA DE SÃO CARLOS } \\
\text { DEPARTAMENTO DE HIDRÁULICA E SANEAMENTO } \\
\text { SETOR DE MONITORAMENTO HIDROGEOLÓGICO } \\
\text { Medição de descarga líquida }\end{array}$} & \multirow{2}{*}{$\begin{array}{l}\text { COTA }(\mathrm{m}): \\
\text { DATA: } \\
\text { Descarga }\left(\mathrm{m}^{3} / \mathrm{s}\right)\end{array}$} & \multirow{2}{*}{$\begin{array}{r}0,79 \\
3 / 8 / 2005 \\
\mathbf{0 , 7 0} \\
\end{array}$} \\
\hline & \multicolumn{2}{|c|}{\begin{tabular}{|l|l|}
5,70 & Prof. $\operatorname{Med}(\mathrm{m})$ \\
\end{tabular}} & \multicolumn{2}{|c|}{$\begin{array}{ll}0,42 & \text { Vel.méd.(m/s) } \\
\end{array}$} & \multicolumn{2}{|c|}{\begin{tabular}{l|l}
0,29 & Área $\left(\mathrm{m}^{2}\right)$ \\
\end{tabular}} & 2,39 & & \\
\hline $\begin{array}{c}\text { distância do P.I. } \\
(\mathrm{m})\end{array}$ & $\begin{array}{c}\text { larg.entre } \\
\text { verticais }(\mathrm{m})\end{array}$ & \begin{tabular}{|c} 
prof. na vertical \\
(m)
\end{tabular} & Hélice & $\begin{array}{l}\text { número de } \\
\text { giros }\end{array}$ & Tempo (s) & $\begin{array}{c}\text { Vel méd na } \\
\text { vertical }(\mathrm{m} / \mathrm{s})\end{array}$ & $\begin{array}{l}\text { Vel. Media entre } \\
\text { verticais }(\mathrm{m} / \mathrm{s})\end{array}$ & $\begin{array}{c}\text { Area entre } \\
\text { verticais }\left(\mathrm{m}^{2}\right)\end{array}$ & $\begin{array}{c}\text { Descarga } \\
\left(m^{3} / s\right)\end{array}$ \\
\hline 1,30 & - & 0,00 & & - & - & 0 & - & 0 & Name \\
\hline 1,80 & 0,50 & 0,40 & 1 & 55 & 50 & 0,10 & 0,05 & 0,1 & 0,005 \\
\hline & & & & & & & & & \\
\hline 2,30 & 0,50 & 0,40 & 1 & 159 & 50 & 0,22 & 0,16 & 0,2 & 0,032 \\
\hline 2,80 & 0,50 & 0,42 & 1 & 258 & 50 & 0,33 & 0,27 & 0,205 & 0,056 \\
\hline & & & & & & & & & \\
\hline 3,30 & 0,50 & 0,48 & 1 & 344 & 50 & 0,42 & 0,38 & 0,225 & 0,084 \\
\hline 3,80 & 0,50 & 0,52 & 1 & 353 & 50 & 0,43 & 0,43 & 0,25 & 0,107 \\
\hline & & & & & & & & & \\
\hline 4,30 & 0,50 & 0,60 & 1 & 354 & 50 & 0,43 & 0,43 & 0,28 & 0,121 \\
\hline 4,80 & 0,50 & 0,50 & 1 & 297 & 50 & 0,37 & 0,40 & 0,275 & 0,111 \\
\hline 5,30 & 0,50 & 0,47 & 1 & 250 & 50 & 0,32 & 0,34 & 0,2425 & 0,084 \\
\hline & & & & & & & & & \\
\hline 5,80 & 0,50 & 0,44 & 1 & 140 & 50 & 0,20 & 0,26 & 0,2275 & 0,059 \\
\hline 6,30 & 0,50 & 0,40 & 1 & 70 & 50 & 0,12 & 0,16 & 0,21 & 0,033 \\
\hline & & & & & & & & & \\
\hline 6,80 & 0,50 & 0,20 & 1 & 0 & 50 & 0,00 & 0,06 & 0,15 & 0,009 \\
\hline & & & & & & & & & \\
\hline 7,00 & 0,20 & 0,00 & - & - & - & - & & 0,02 & Namd \\
\hline & & & & & & & & & \\
\hline & & & & & & & & & \\
\hline & & & & & & & & & \\
\hline Totais & & & & & & & & 2,385 & 0,700 \\
\hline Iotals & & & & & & & & & $0,700 \mathrm{~m}^{3} / \mathrm{s}$ \\
\hline
\end{tabular}

Figura 76: Planilha de medição de vazão no dia 03/08/2005 


\section{MEDIĊ̃̃O NÚMERO 15}

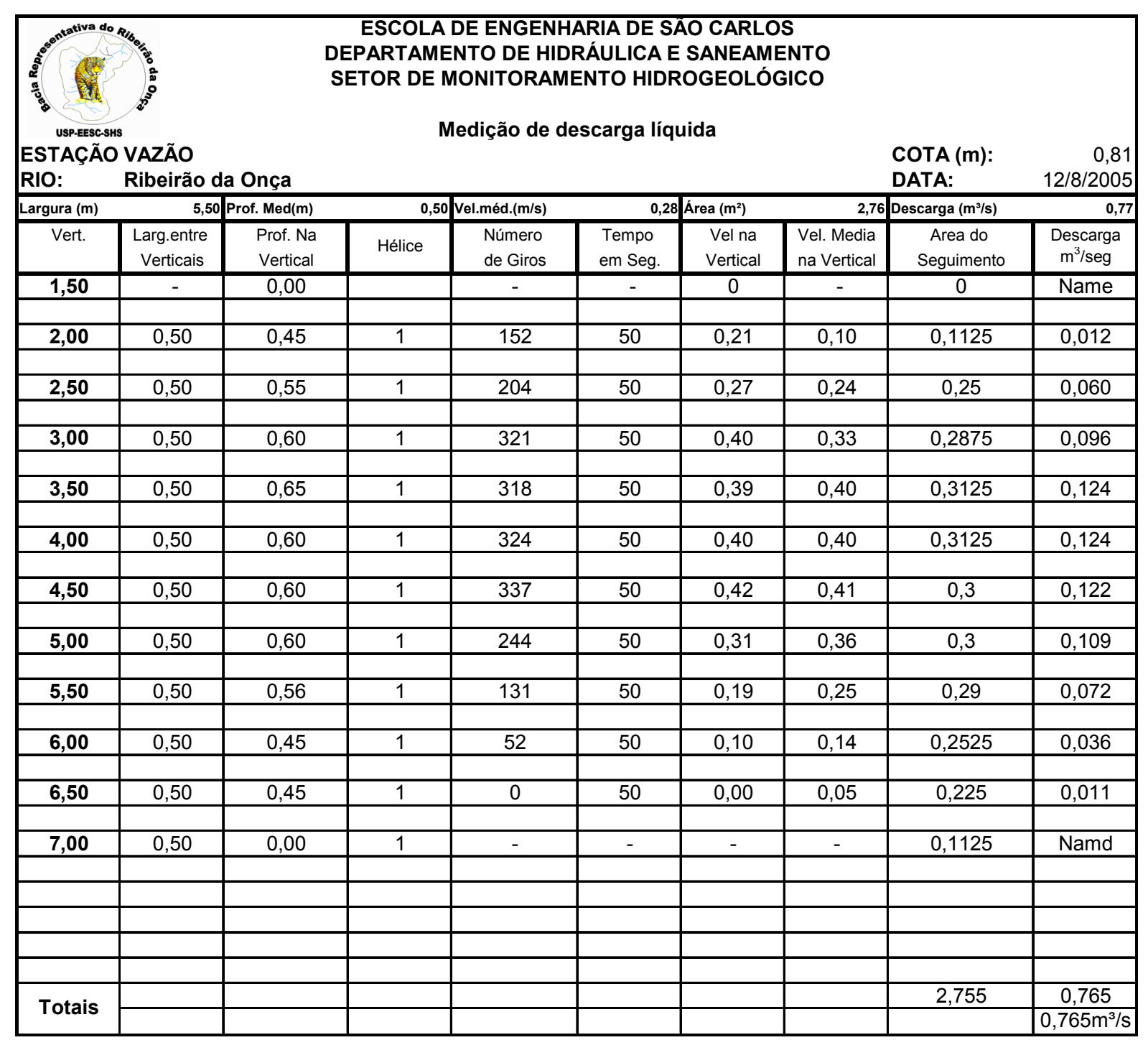

Figura 77: Planilha de medição de vazão no dia 12/08/2005 


\section{MEDIĊ̃̃O NÚMERO 16}

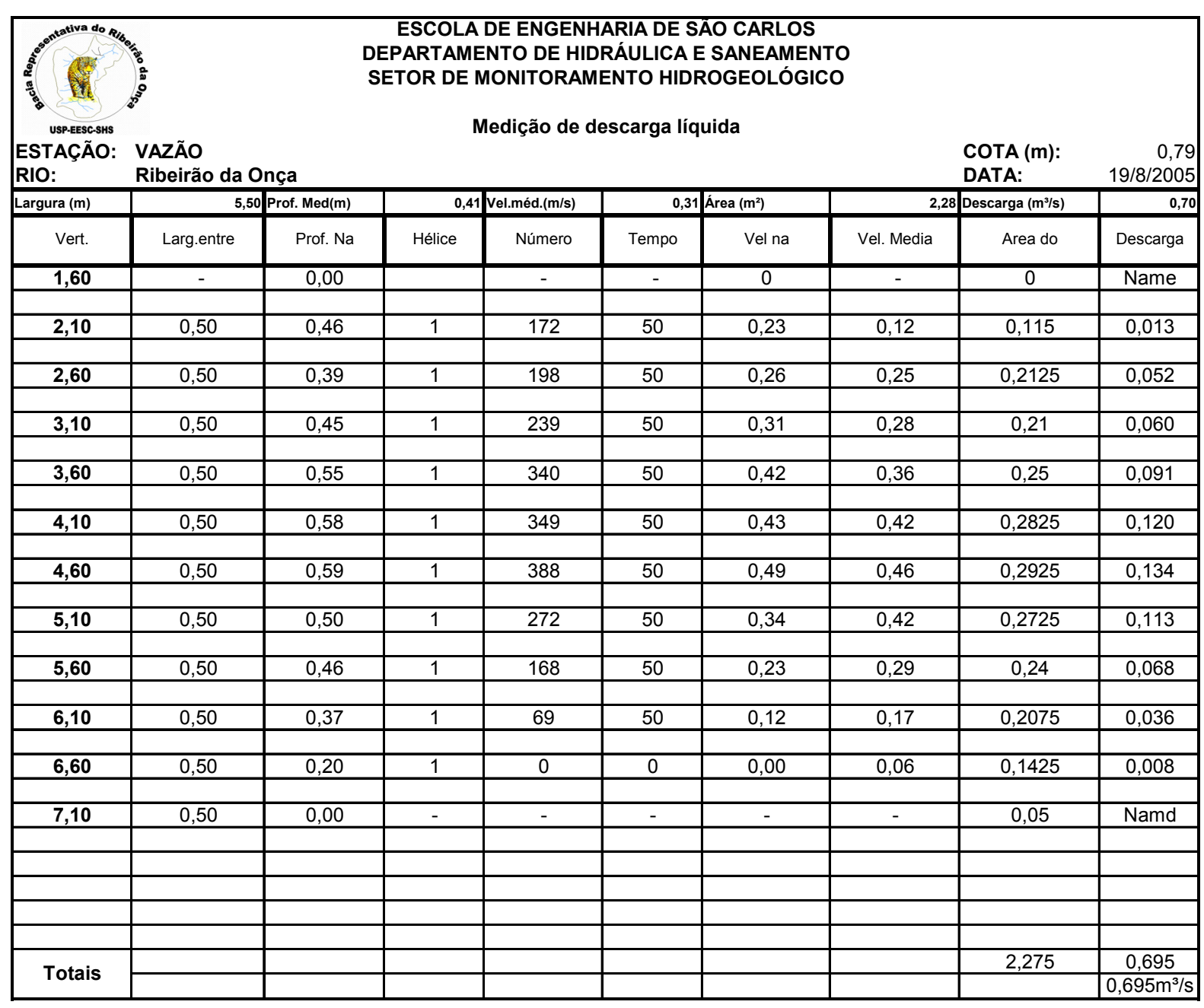

Figura 78: Planilha de medição de vazão no dia 19/08/2005 
MEDIĊ̃̃O NÚMERO 17

\begin{tabular}{|c|c|c|c|c|c|c|c|c|c|}
\hline$\underbrace{}_{\text {USP-ESSC.SHS }}$ & 施 & $\begin{array}{l}\mathrm{DEI} \\
\mathrm{SE}\end{array}$ & $\begin{array}{l}\text { SCOL } \\
\text { ARTAM } \\
\text { AR DE }\end{array}$ & $\begin{array}{l}\text { E ENGEN } \\
\text { TO DE HI } \\
\text { ONITORAI }\end{array}$ & $\begin{array}{l}\text { ARIA DE } \\
\text { RÁULICA } \\
\text { ENTO HID }\end{array}$ & $\begin{array}{l}\text { ĀO CARLOS } \\
\text { S SANEAME } \\
\text { ROGEOLÓG }\end{array}$ & & & \\
\hline Largura (m) & 6,0 & Prof. Med(m) & & el.méd.(m/s) & 0,27 & Área $\left(\mathrm{m}^{2}\right)$ & 3,04 & Descarga $\left(\mathrm{m}^{3} / \mathrm{s}\right)$ & 0,83 \\
\hline $\begin{array}{c}\text { distância do P.I. } \\
\text { (m) }\end{array}$ & $\begin{array}{c}\text { larg.entre } \\
\text { verticais }(\mathrm{m})\end{array}$ & \begin{tabular}{|l|} 
prof. na vertical \\
(m)
\end{tabular} & Hélice & $\begin{array}{c}\text { número de } \\
\text { giros }\end{array}$ & Tempo (s) & $\begin{array}{c}\text { Vel méd na } \\
\text { vertical }(\mathrm{m} / \mathrm{s})\end{array}$ & $\begin{array}{l}\text { Vel. Media entre } \\
\text { verticais }(\mathrm{m} / \mathrm{s})\end{array}$ & $\begin{array}{c}\text { Area entre } \\
\text { verticais }\left(\mathrm{m}^{2}\right)\end{array}$ & $\begin{array}{c}\text { Descarga } \\
\left(\mathrm{m}^{3} / \mathrm{s}\right)\end{array}$ \\
\hline 0,80 & - & 0,00 & & - & - & 0 & - & 0 & Name \\
\hline 1,30 & 0,50 & 0,50 & 1 & 0 & 50 & 0,00 & 0,00 & 0,125 & 0,000 \\
\hline 1,80 & 0,50 & 0,50 & 1 & 181 & 50 & 0,24 & 0,12 & 0,25 & 0,030 \\
\hline & & & & & & & & & \\
\hline 2,30 & 0,50 & 0,47 & 1 & 194 & 50 & 0,26 & 0,25 & 0,2425 & 0,060 \\
\hline 2,80 & 0,50 & 0,54 & 1 & 216 & 50 & 0,28 & 0,27 & 0,2525 & 0,068 \\
\hline & & & & & & & & & \\
\hline 3,30 & 0,50 & 0,64 & 1 & 354 & 50 & 0,43 & 0,36 & 0,295 & 0,105 \\
\hline 3,80 & 0,50 & 0,70 & 1 & 323 & 50 & 0,40 & 0,42 & 0,335 & 0,140 \\
\hline & & & & & & & & & \\
\hline 4,30 & 0,50 & 0,70 & 1 & 367 & 50 & 0,45 & 0,42 & 0,35 & 0,149 \\
\hline 4,80 & 0,50 & 0,65 & 1 & 290 & 50 & 0,36 & 0,41 & 0,3375 & 0,137 \\
\hline & & & & & & & & & \\
\hline 5,30 & 0,50 & 0,57 & 1 & 145 & 50 & 0,20 & 0,28 & 0,305 & 0,086 \\
\hline & & & & & & & & & \\
\hline 5,80 & 0,50 & 0,42 & 1 & 76 & 50 & 0,12 & 0,16 & 0,2475 & 0,040 \\
\hline 6.30 & 0.50 & 0,35 & 1 & 0 & 50.0 & 000 & 006 & 01925 & 0012 \\
\hline & & & & & & & & & \\
\hline 6,80 & 0,50 & 0,00 & - & - & - & - & - & 0,105 & Namd \\
\hline & & & & & & & & & \\
\hline & & & & & & & & & \\
\hline & & & & & & & & & \\
\hline & & & & & & & & & \\
\hline & & & & & & & & & \\
\hline Tatic & & & & & & & & 3,0375 & 0,827 \\
\hline Totais & & & & & & & & & $0,827 \mathrm{~m}^{3} / \mathrm{s}$ \\
\hline
\end{tabular}

Figura 79: Planilha de medição de vazão no dia 02/09/2005 


\section{MEDIĊ̃̃O NÚMERO 18}

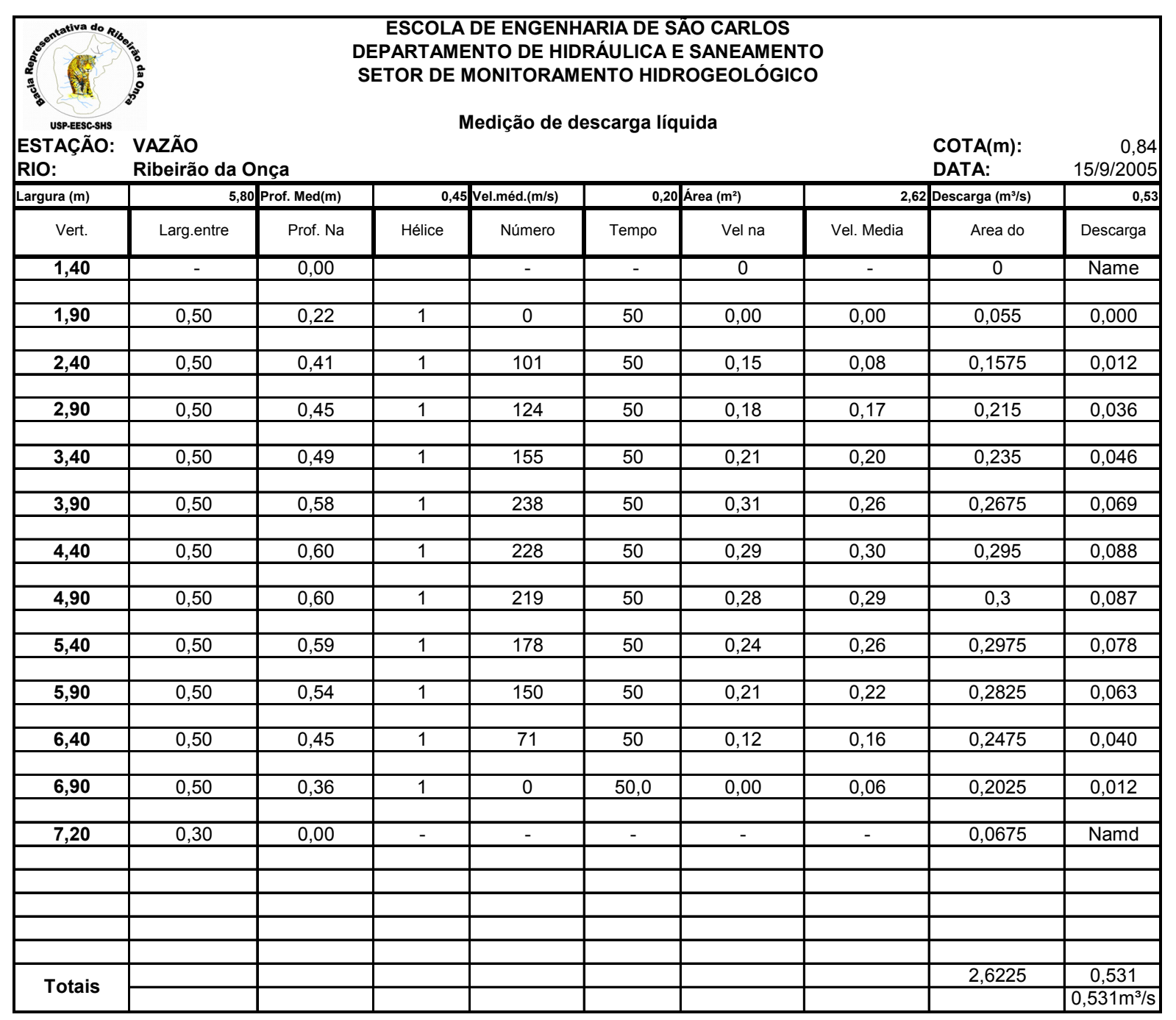

Figura 80: Planilha de medição de vazão no dia 15/09/2005 
MEDIČÃO NÚMERO 19

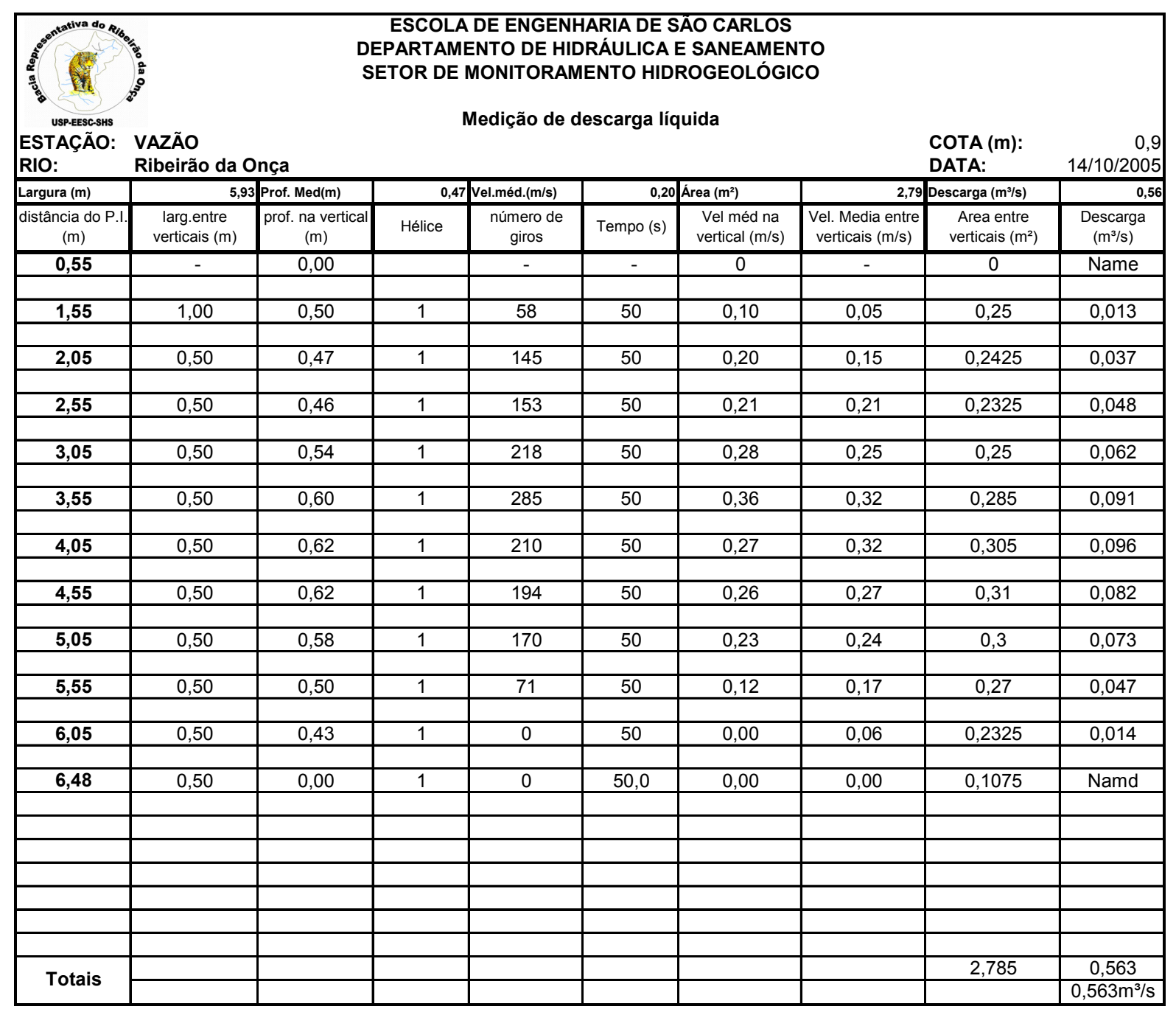

Figura 81: Planilha de medição de vazão no dia 14/10/2005 


\section{MEDIÇÃO NÚMERO 20}

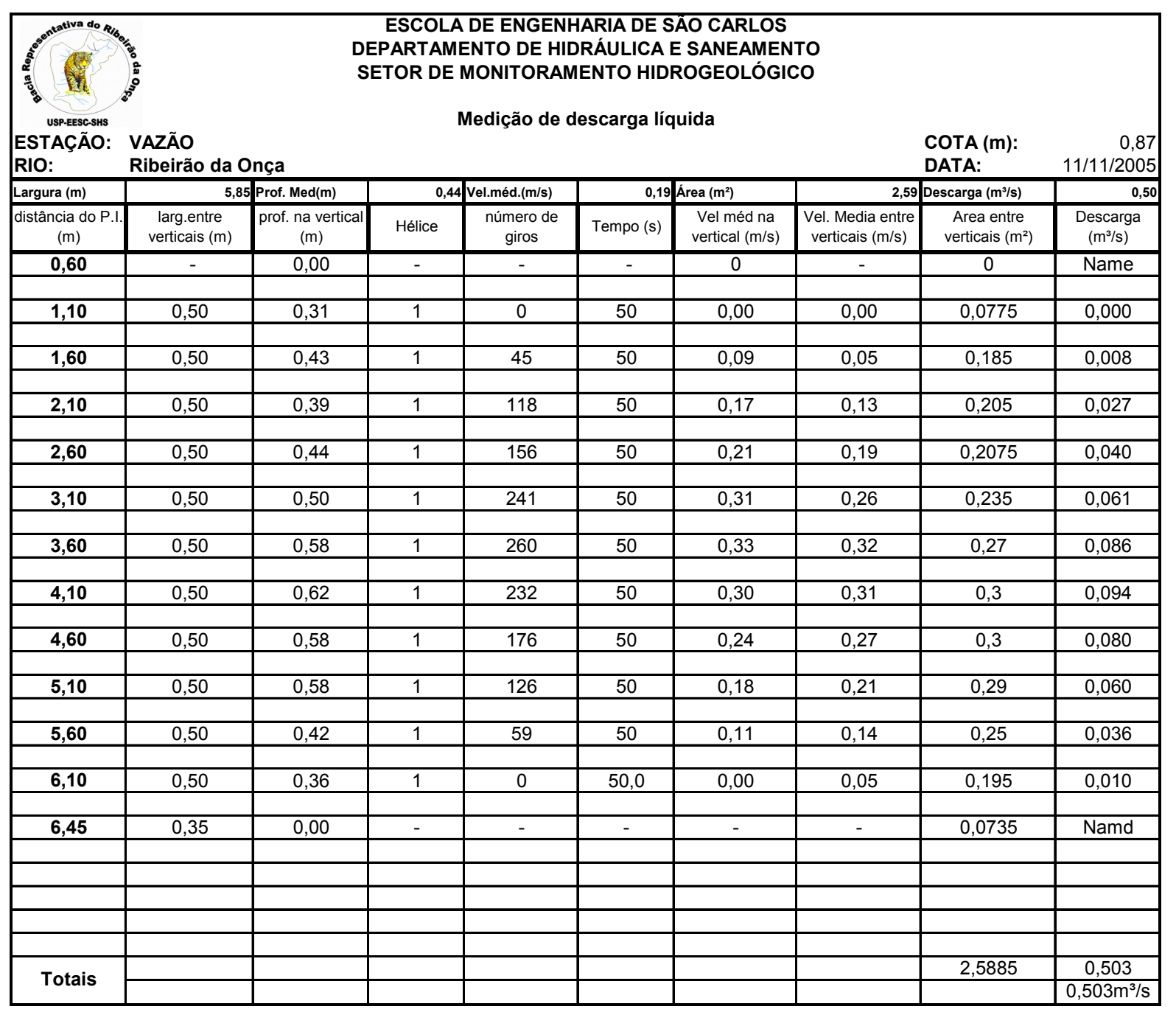

Figura 82: Planilha de medição de vazão no dia 11/11/2005 


\section{MEDIÇÃO NÚMERO 21}

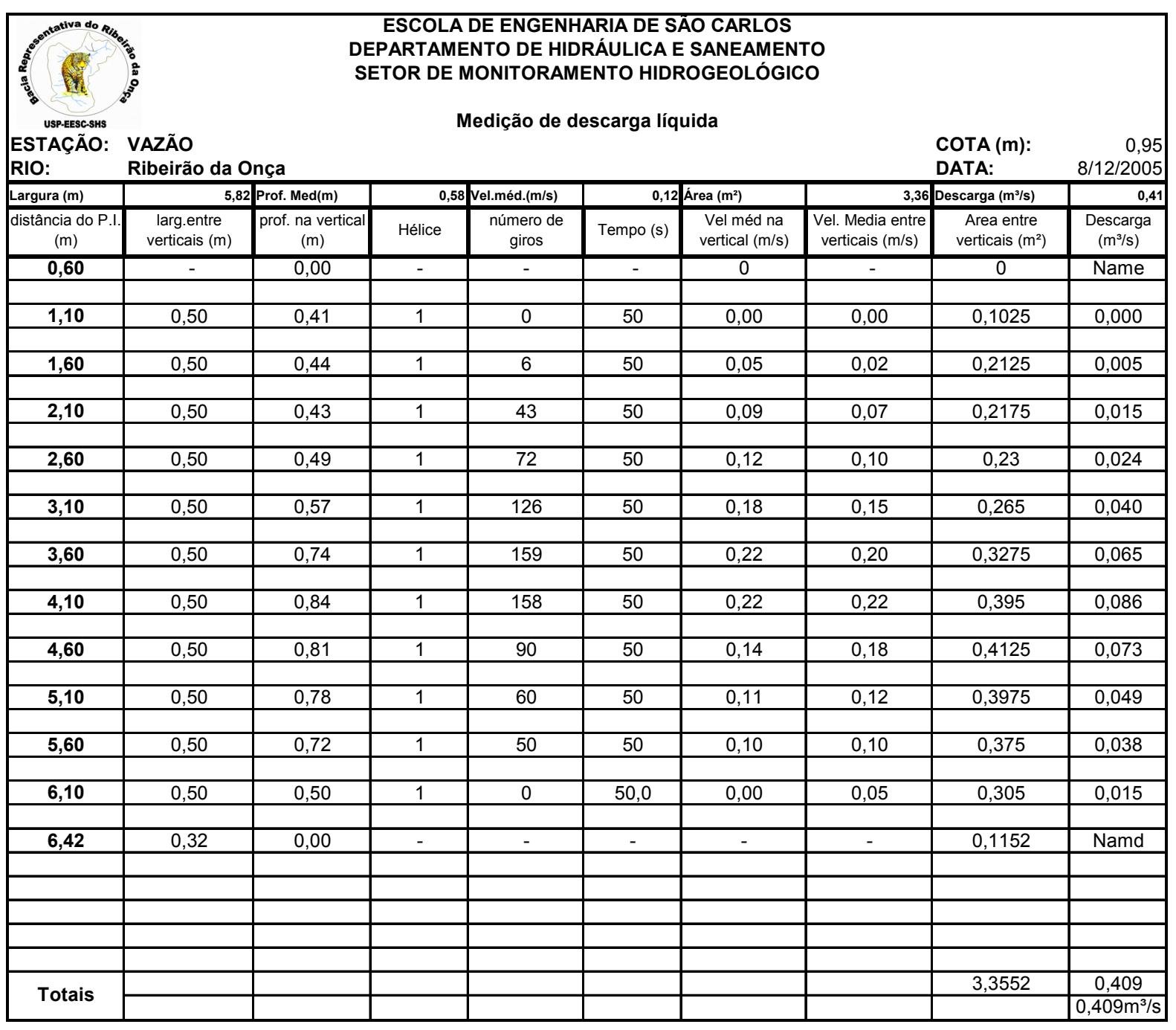

Figura 83: Planilha de medição de vazão no dia 08/12/2005 


\section{MEDIĊ̃̃O NÚMERO 22}

\begin{tabular}{|c|c|c|c|c|c|c|c|c|c|}
\hline $\begin{array}{l}\text { USP.EESC.SHS } \\
\text { ESTAÇÃO: } \\
\text { RIO: }\end{array}$ & $\begin{array}{l}\text { VAZÃO } \\
\text { Ribeirão da }\end{array}$ & nça & $\begin{array}{l}\text { ESCOLA } \\
\text { ARTAM } \\
\text { TOR DE }\end{array}$ & $\begin{array}{l}\text { DE ENGEN } \\
\text { ENTO DE HI } \\
\text { MONITORA } \\
\text { Medição de }\end{array}$ & $\begin{array}{l}\text { ARIA DE S } \\
\text { RÁULICA } \\
\text { ENTO HID } \\
\text { scarga líc }\end{array}$ & $\begin{array}{l}\text { ȦO CARLOS } \\
\text { E SANEAMEN } \\
\text { ROGEOLÓGI }\end{array}$ & & $\begin{array}{l}\text { COTA }(m) \text { : } \\
\text { DATA: }\end{array}$ & $\begin{array}{r}0,85 \\
22 / 12 / 2005\end{array}$ \\
\hline Largura $(m)$ & 5,7 & Prof. Med(m) & 0,44 & Vel.méd.(m/s) & 0,20 & Área $\left(m^{2}\right)$ & 2,51 & Descarga $\left(\mathrm{m}^{3} / \mathrm{s}\right)$ & 0,51 \\
\hline $\begin{array}{l}\text { distância do P.I. } \\
(\mathrm{m})\end{array}$ & $\begin{array}{c}\text { larg.entre } \\
\text { verticais }(\mathrm{m})\end{array}$ & $\begin{array}{l}\text { prof. na vertical } \\
(\mathrm{m})\end{array}$ & Hélice & $\begin{array}{l}\text { número de } \\
\text { giros }\end{array}$ & Tempo (s) & $\begin{array}{l}\text { Vel méd na } \\
\text { vertical }(\mathrm{m} / \mathrm{s})\end{array}$ & $\begin{array}{l}\text { Vel. Media entre } \\
\text { verticais }(\mathrm{m} / \mathrm{s})\end{array}$ & $\begin{array}{c}\text { Area entre } \\
\text { verticais }\left(\mathrm{m}^{2}\right)\end{array}$ & $\begin{array}{c}\text { Descarga } \\
\left(\mathrm{m}^{3} / \mathrm{s}\right)\end{array}$ \\
\hline 0,72 & - & 0,00 & - & - & - & 0 & - & 0 & Name \\
\hline 1,22 & 0,50 & 0,29 & 1 & 0 & 50 & 0,00 & 0,00 & 0,0725 & 0,000 \\
\hline 1,72 & 0,50 & 0,29 & 1 & 120 & 50 & 0,17 & 0,09 & 0,145 & 0,013 \\
\hline 2,22 & 0,50 & 0,29 & 1 & 141 & 50 & 0,20 & 0,19 & 0,145 & 0,027 \\
\hline 2,72 & 0,50 & 0,37 & 1 & 195 & 50 & 0,26 & 0,23 & 0,165 & 0,037 \\
\hline 3,22 & 0,50 & 0,48 & 1 & 229 & 50 & 0,30 & 0,28 & 0,2125 & 0,059 \\
\hline 3,72 & 0,50 & 0,57 & 1 & 288 & 50 & 0,36 & 0,33 & 0,2625 & 0,086 \\
\hline 4,22 & 0,50 & 0,62 & 1 & 269 & 50 & 0,34 & 0,35 & 0,2975 & 0,104 \\
\hline 4,72 & 0,50 & 0,68 & 1 & 134 & 50 & 0,19 & 0,26 & 0,325 & 0,086 \\
\hline 5,22 & 0,50 & 0,55 & 1 & 110 & 50 & 0,16 & 0,18 & 0,3075 & 0,054 \\
\hline 5,60 & 0,38 & 0,59 & 1 & 74 & 50 & 0,12 & 0,14 & 0,2166 & 0,031 \\
\hline 6,10 & 0,50 & 0,43 & 1 & 0 & 50,0 & 0,00 & 0,06 & 0,255 & 0,016 \\
\hline 6,45 & 0,35 & 0,00 & - & - & - & - & - & 0,10325 & Namd \\
\hline & & & & & & & & & \\
\hline & & & & & & & & & \\
\hline & & & & & & & & & \\
\hline & & & & & & & & & \\
\hline & & & & & & & & & \\
\hline Totaic & & & & & & & & 2,50735 & 0,512 \\
\hline Iotals & & & & & & & & & $0,512 \mathrm{~m}^{3} / \mathrm{s}$ \\
\hline
\end{tabular}

Figura 84: Planilha de medição de vazão no dia 22/12/2005 


\section{MEDIĊÃO NÚMERO 23}

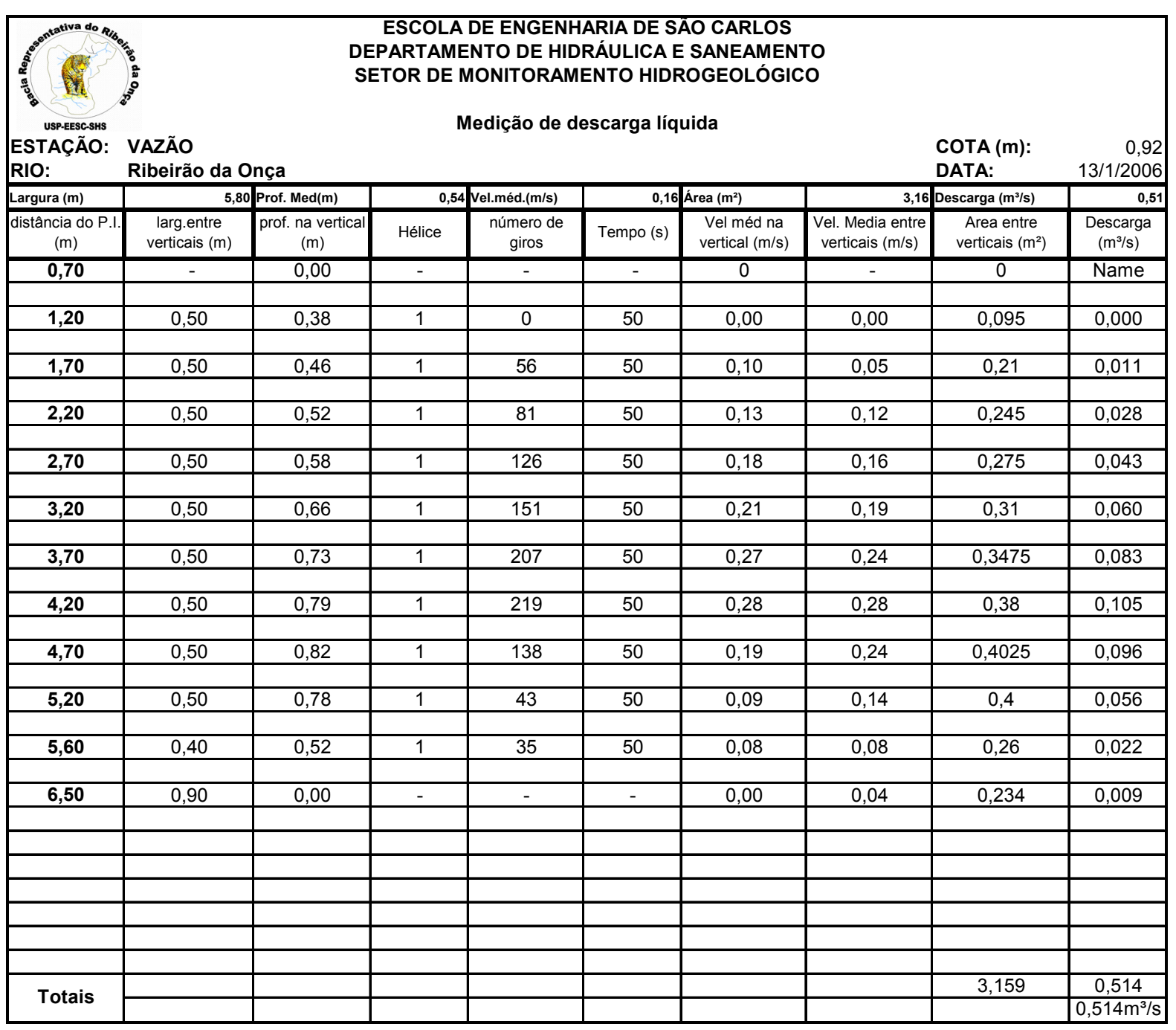

Figura 85: Planilha de medição de vazão no dia 13/01/2006 


\section{APENDICE D}

(Variação da seção transversal (batimetria) na seção de controle de medição de vazão no Ribeirão da Onça) 



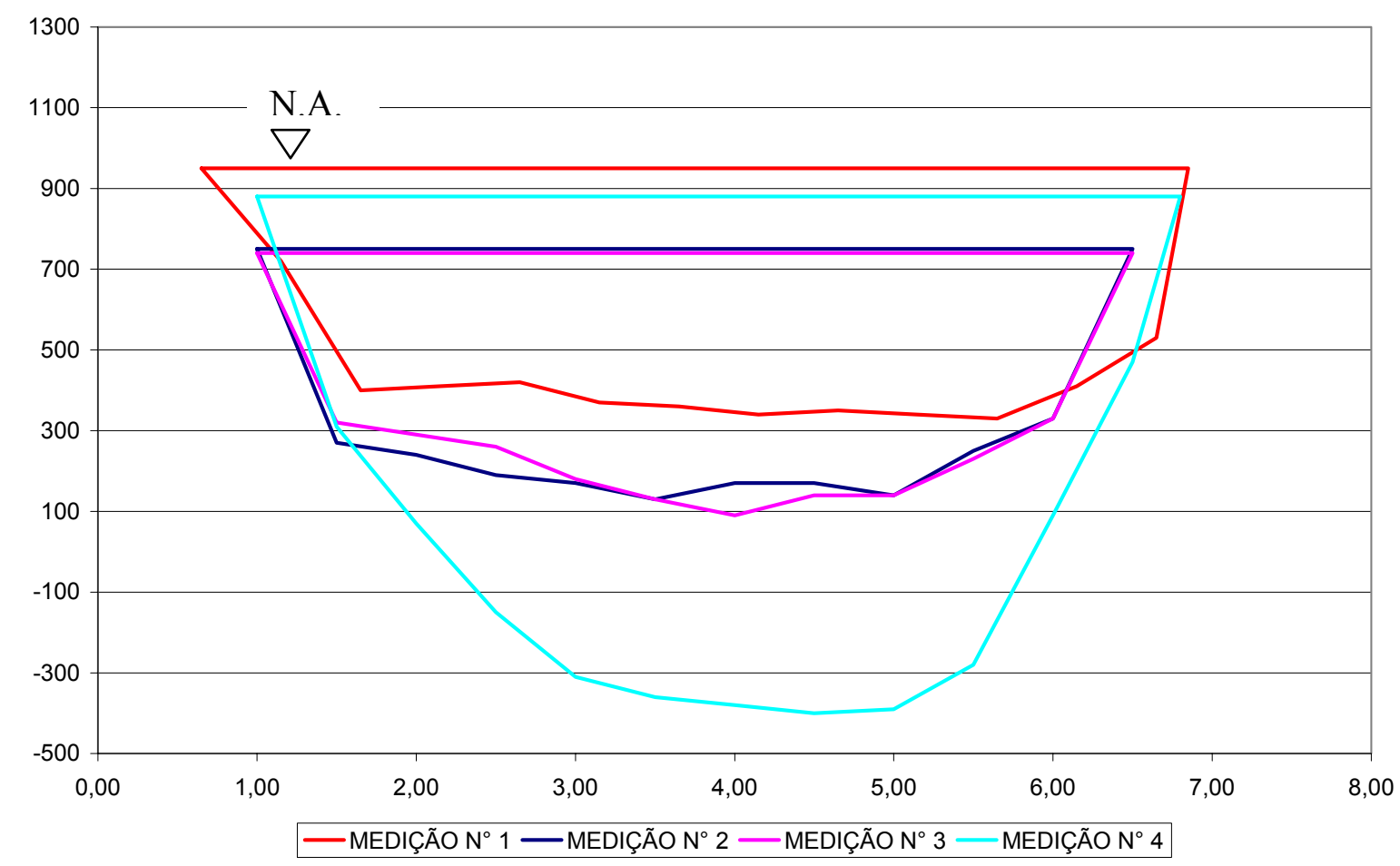

Figura 86: Seção transversal (batimetria) no ponto de medição de vazão nos dias 28/10/2004, $2 / 02 / 2005,04 / 03 / 2005$ e $18 / 03 / 2005$ 


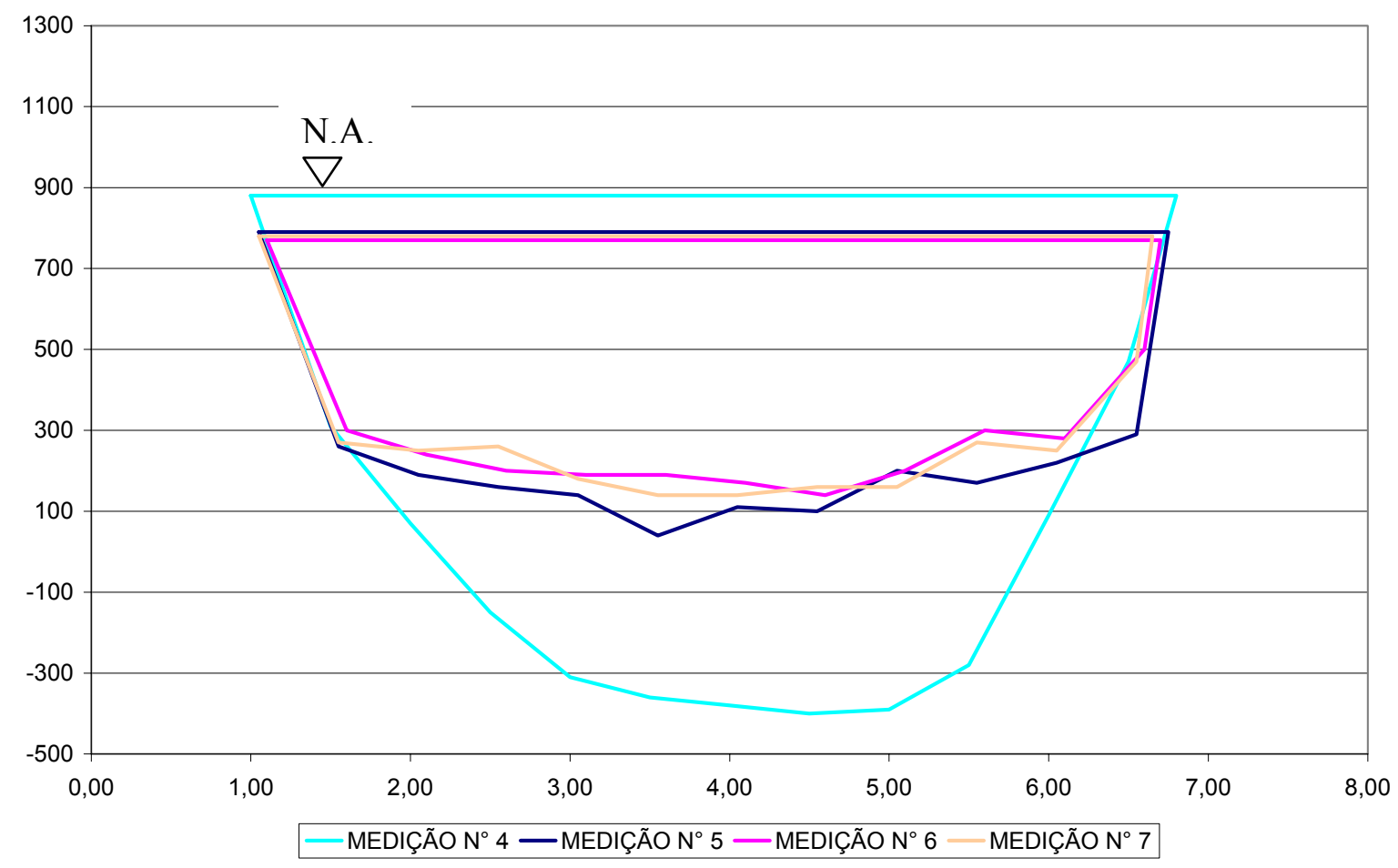

Figura 87: Seção transversal (batimetria) no ponto de medição de vazão nos dias 18/03/2005, 20/04/2005, 29/04/2005 e 06/05/2005

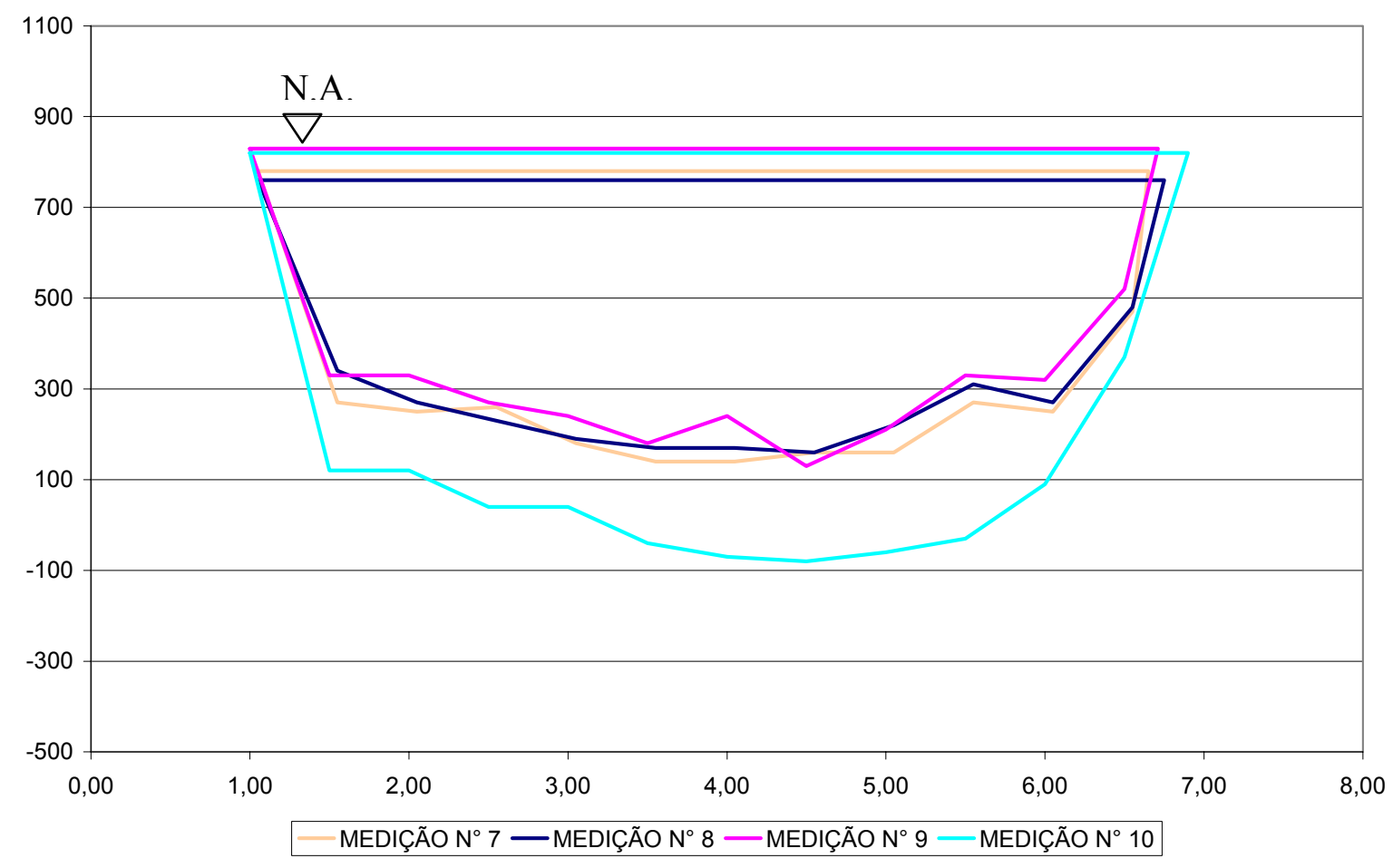

Figura 88: Seção transversal (batimetria) no ponto de medição de vazão nos dias 06/05/2005, 


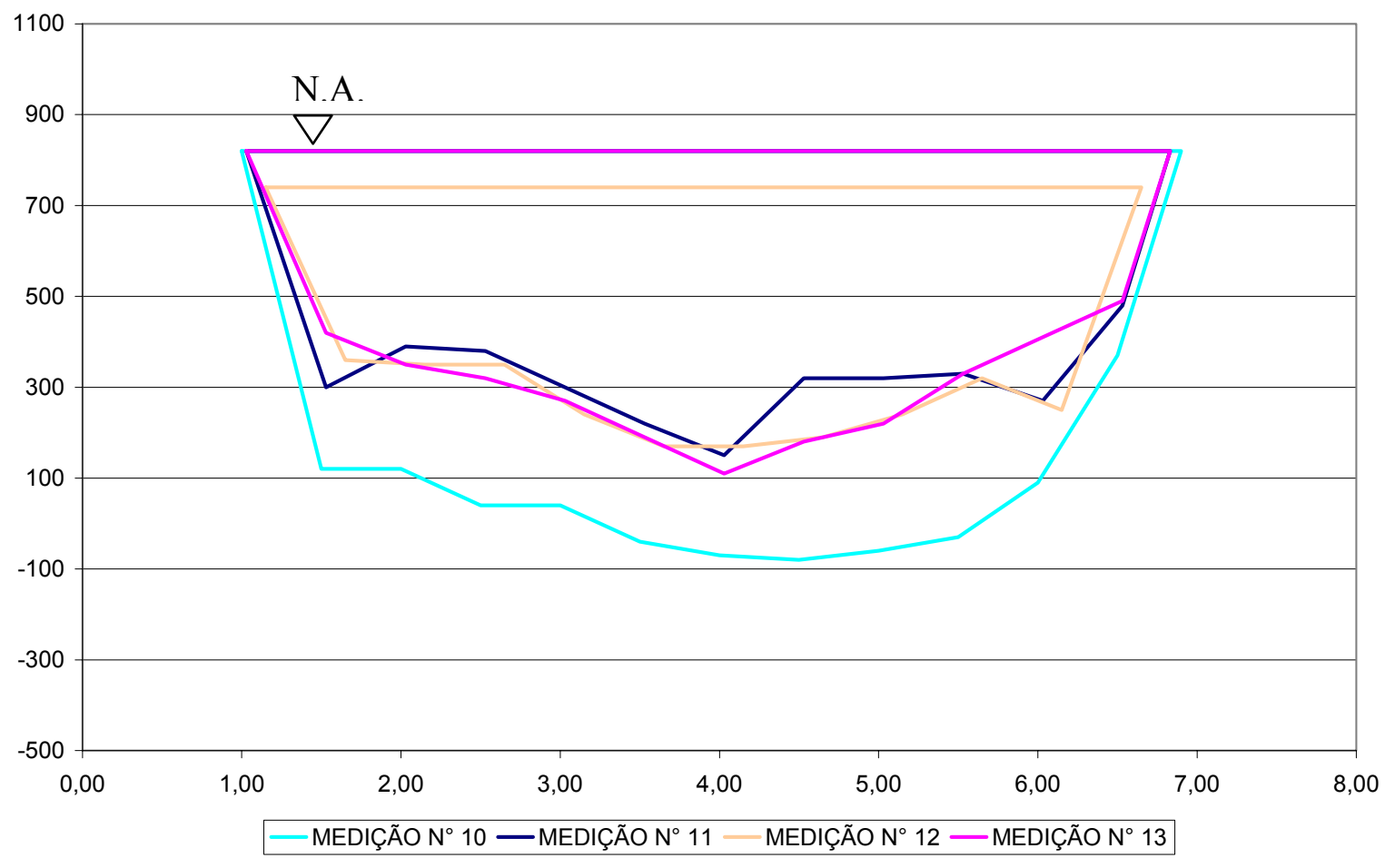

Figura 89: Seção transversal (batimetria) no ponto de medição de vazão nos dias 03/06/2005, $21 / 06 / 2005,24 / 06 / 2005$ e $01 / 07 / 2005$

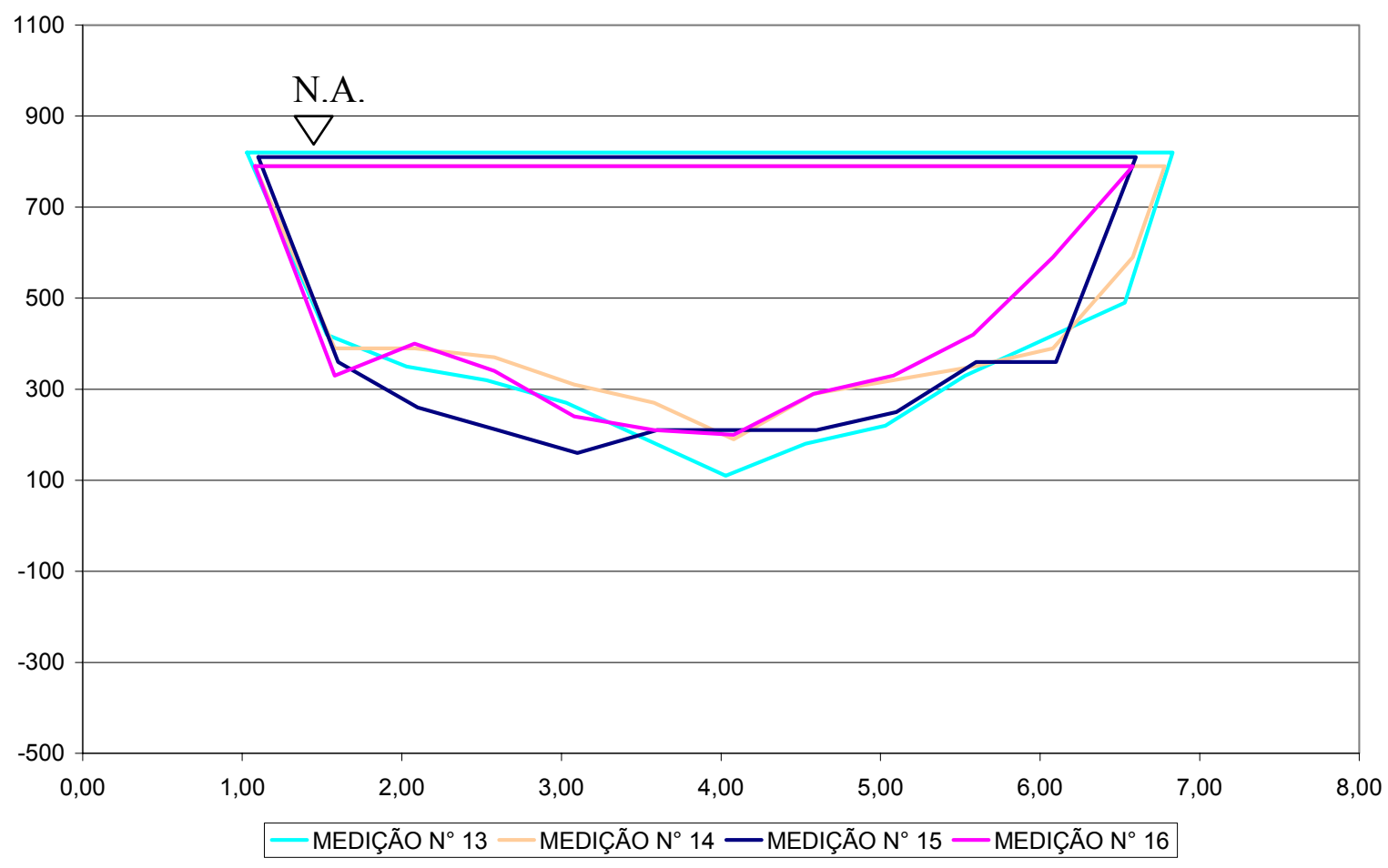

Figura 90: Seção transversal (batimetria) no ponto de medição de vazão nos dias 01/07/2005, 


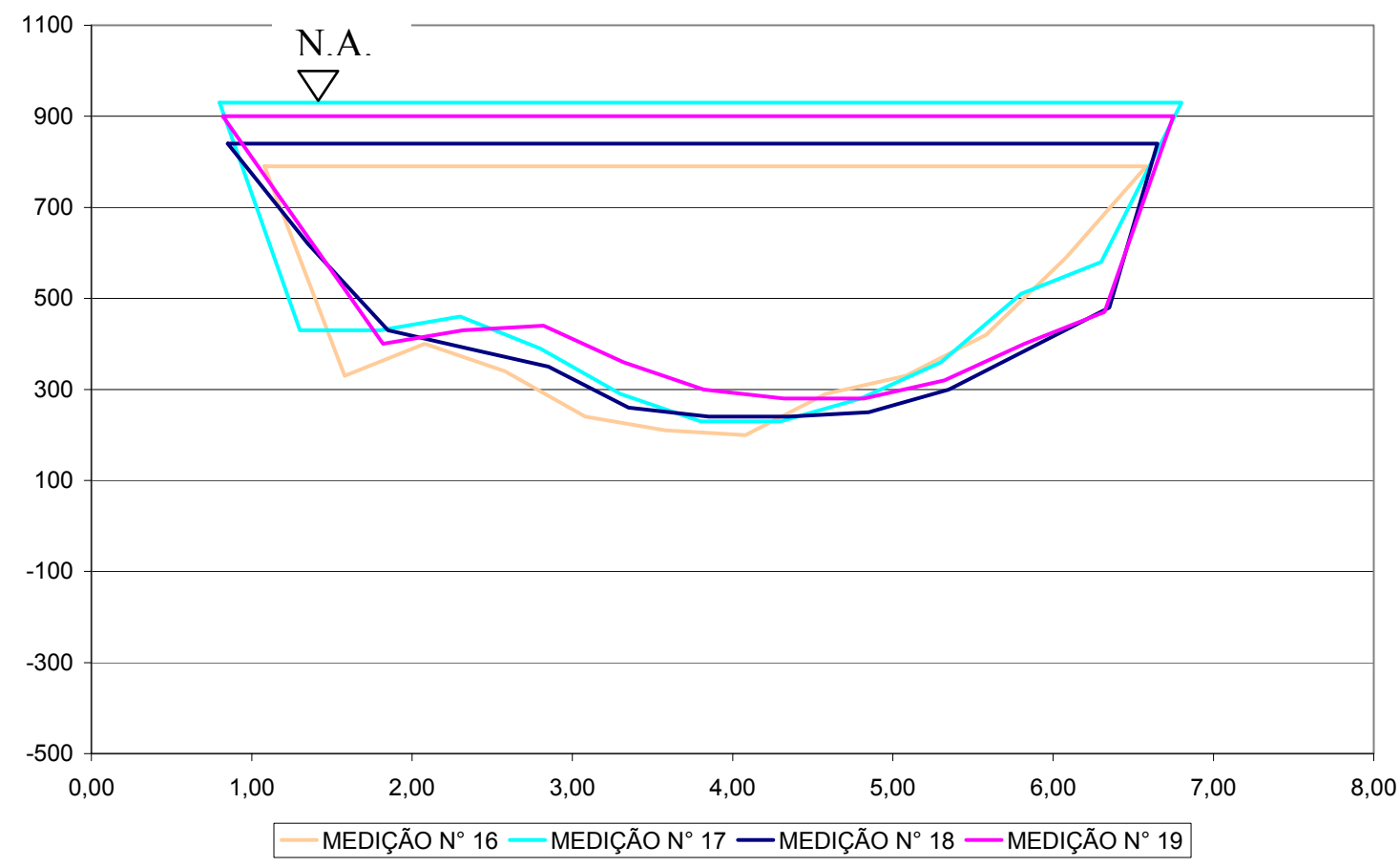

Figura 91: Seção transversal (batimetria) no ponto de medição de vazão nos dias 19/08/2005, 02/09/2005, 15/09/2005 e 14/10/2005

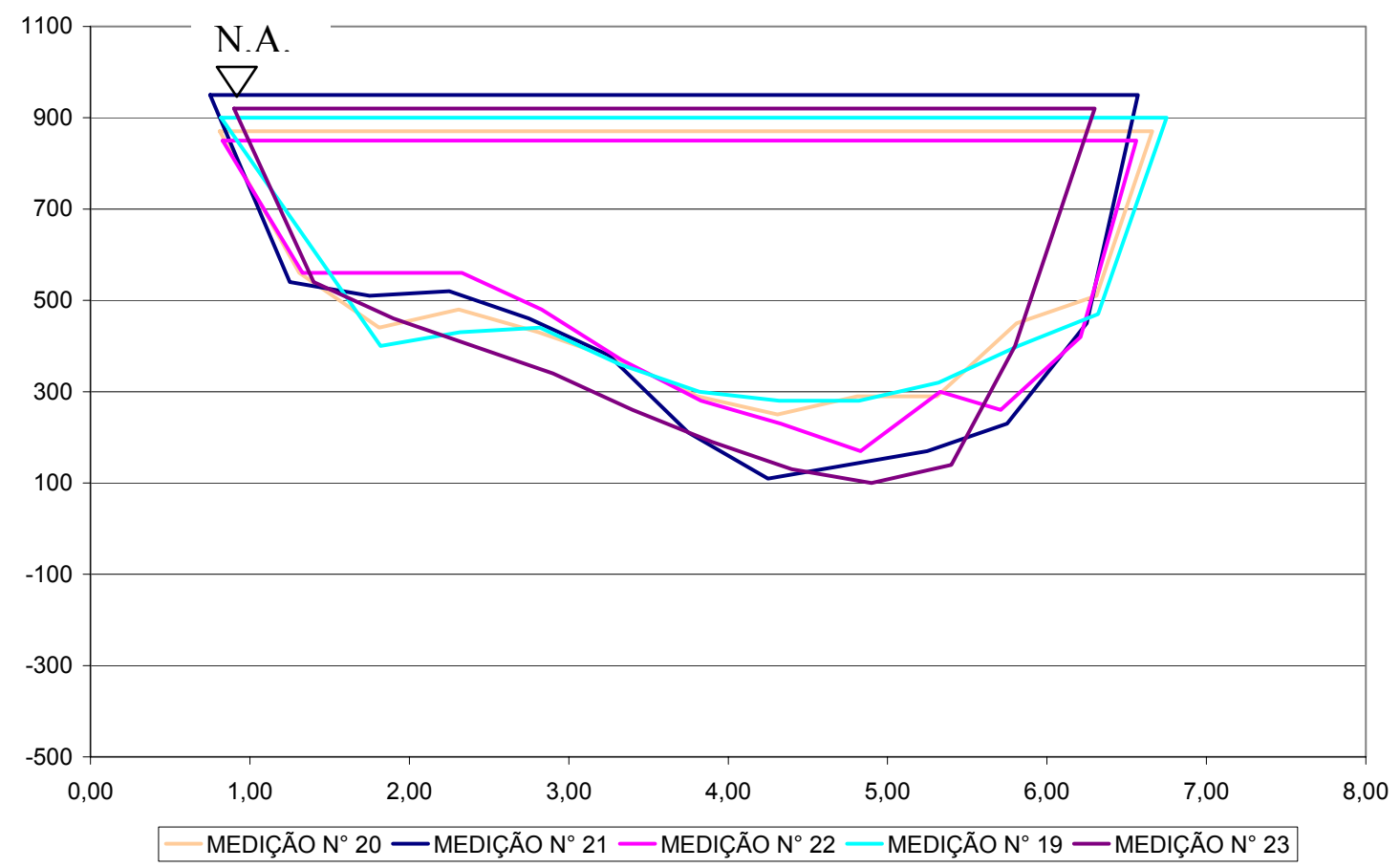

Figura 92: Seção transversal (batimetria) no ponto de medição de vazão nos dias 14/10/2005, $11 / 11 / 2005,08 / 12 / 2005,22 / 12 / 2005$ e $13 / 01 / 2006$ 


\section{APENDICE E}

(Escoamento superficial no Ribeirão da Onça simulado pelo IPHS1) 



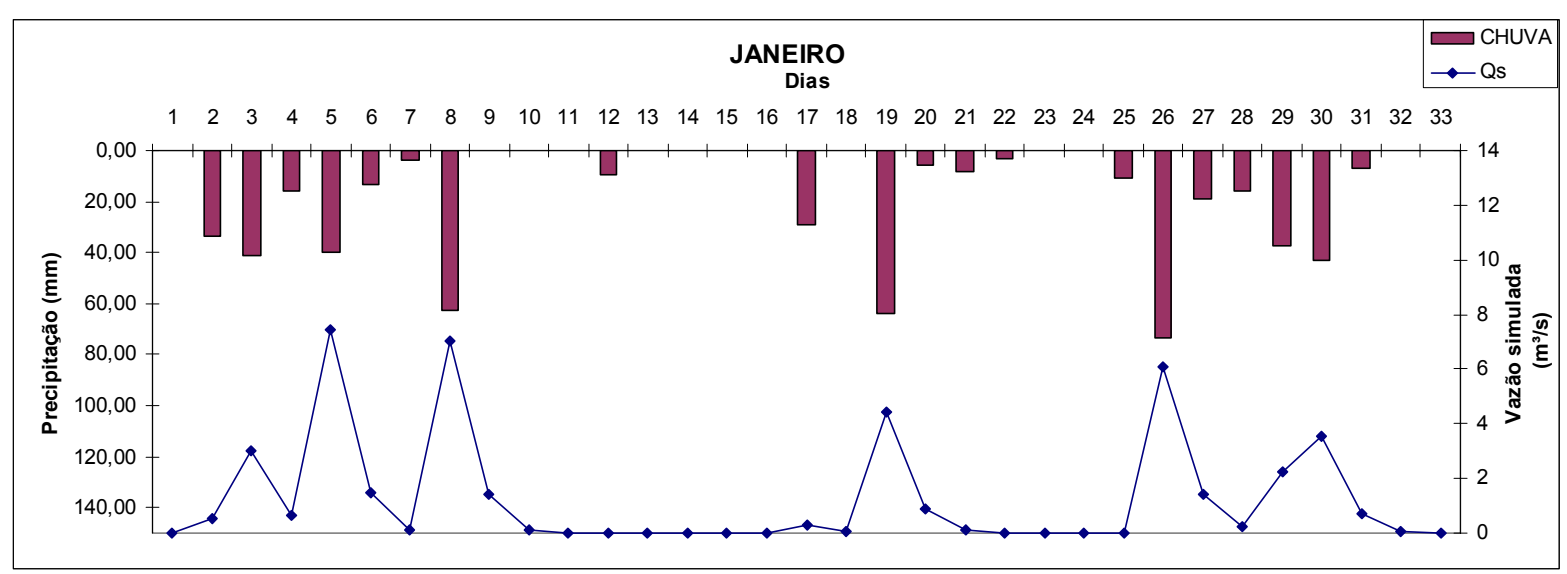

Gráfico 52: Escoamento superficial no Ribeirão da Onça simulado pelo IPHS1 para o mês de janeiro de 2005

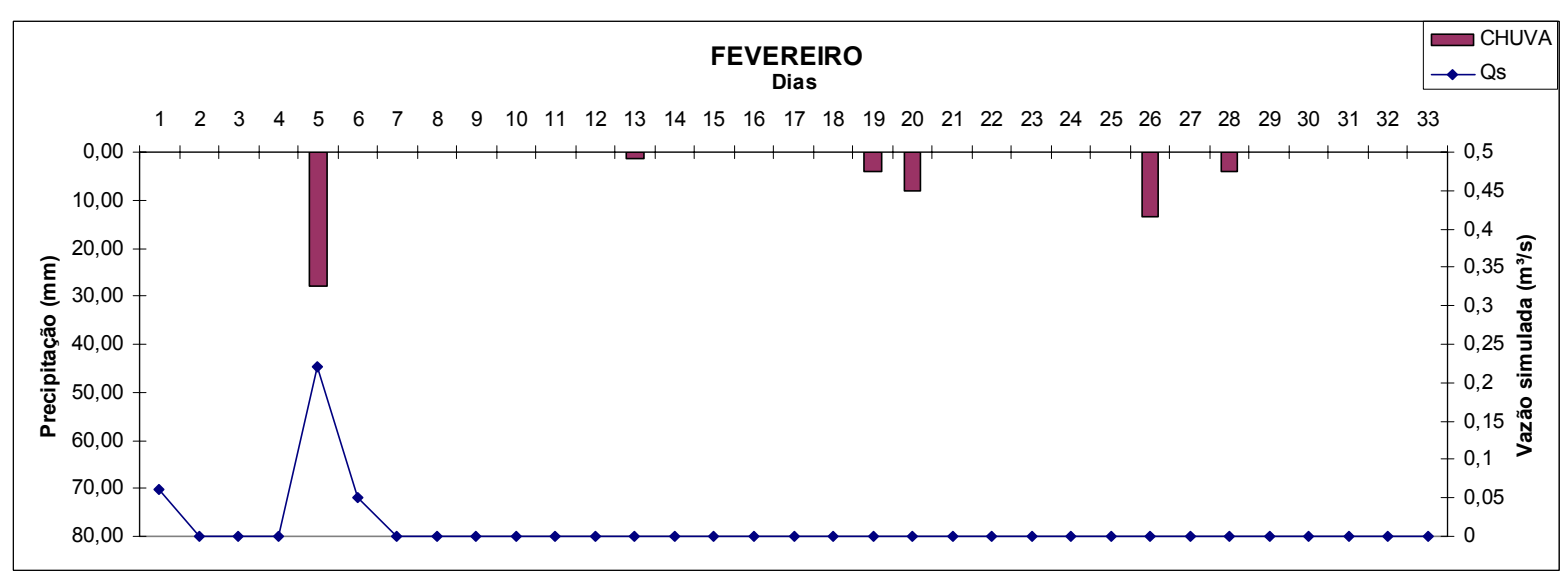

Gráfico 53: Escoamento superficial no Ribeirão da Onça simulado pelo IPHS1 para o mês de fevereiro de 2005 


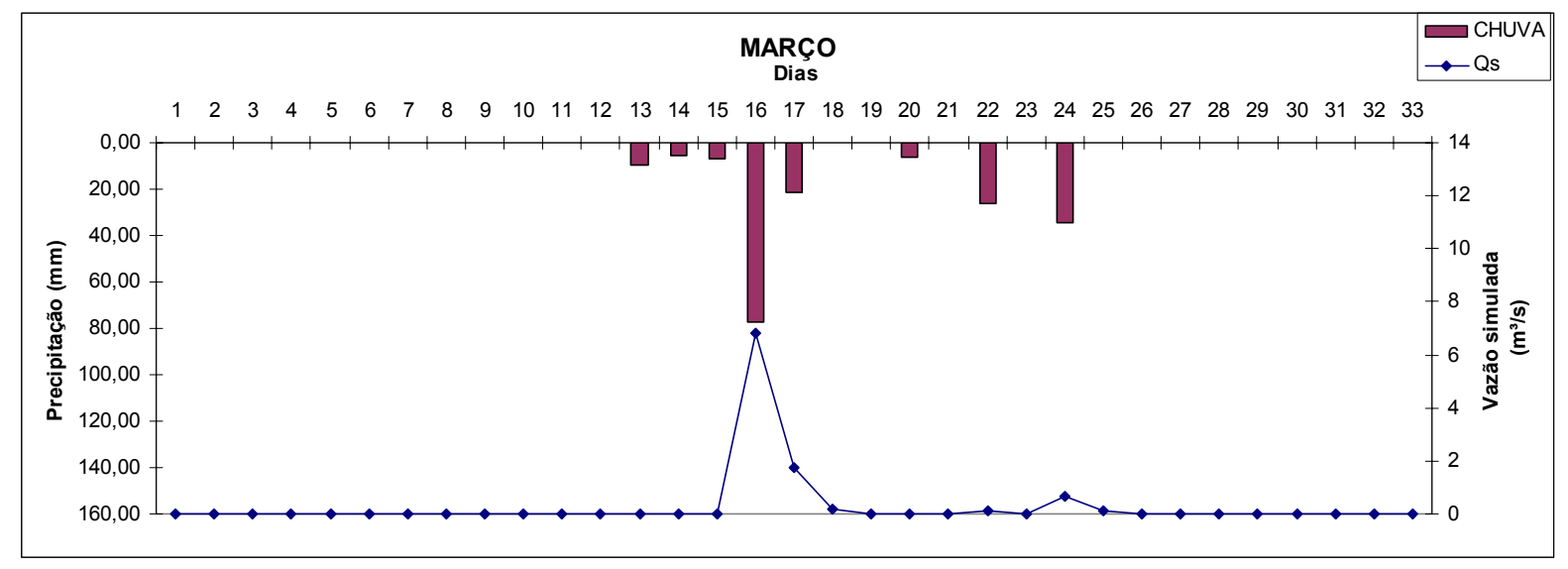

Gráfico 54: Escoamento superficial no Ribeirão da Onça simulado pelo IPHS1 para o mês de março de 2005

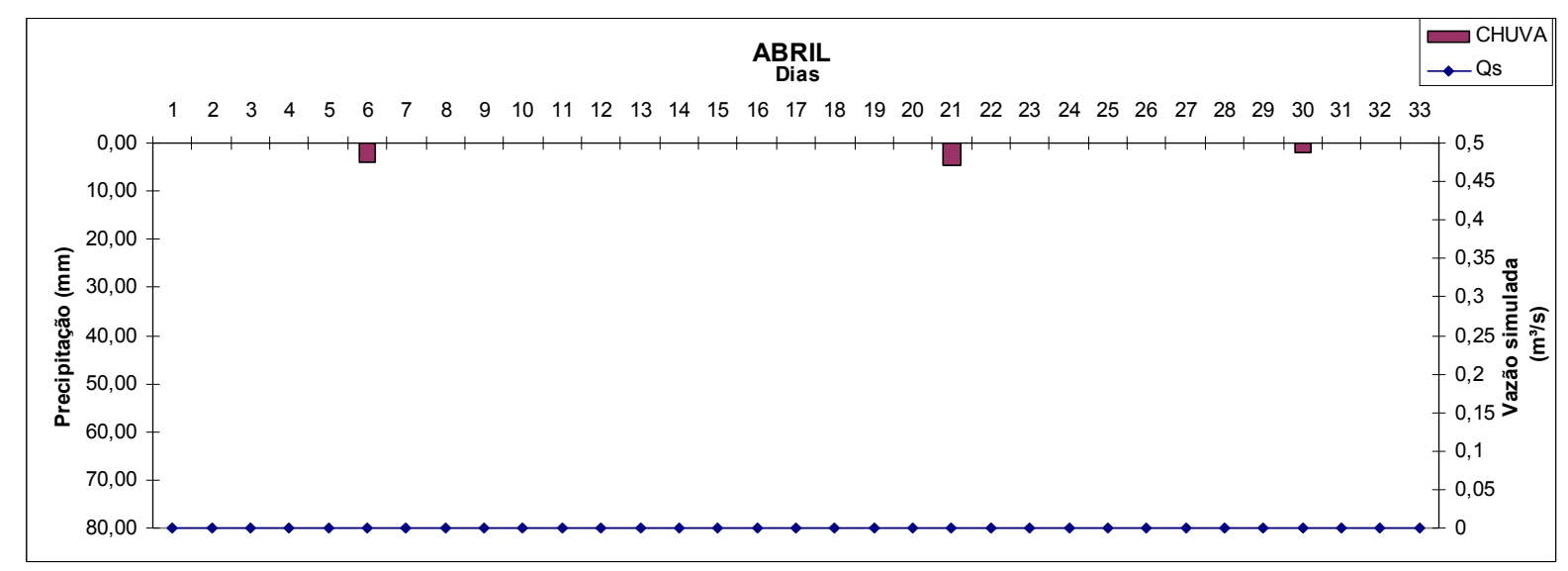

Gráfico 55: Escoamento superficial no Ribeirão da Onça simulado pelo IPHS1 para o mês de abril de 2005

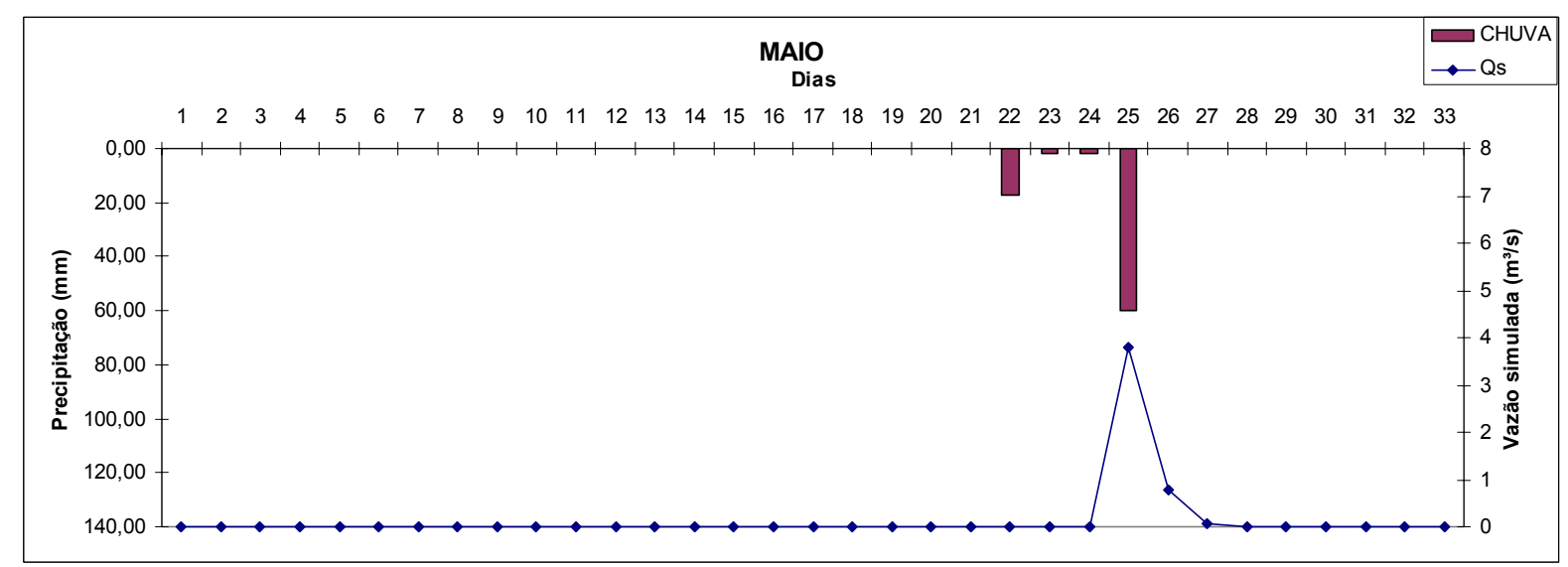

Gráfico 56: Escoamento superficial no Ribeirão da Onça simulado pelo IPHS1 para o mês de maio de 


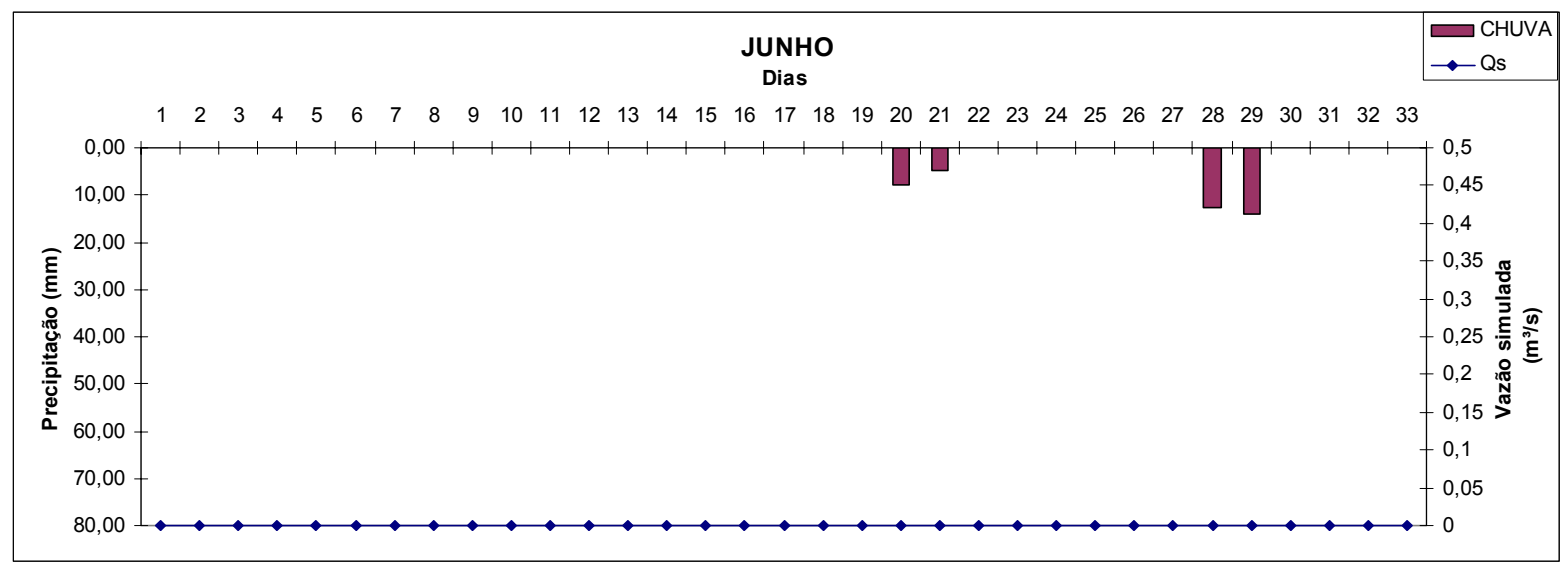

Gráfico 57: Escoamento superficial no Ribeirão da Onça simulado pelo IPHS1 para o mês de junho de 2005

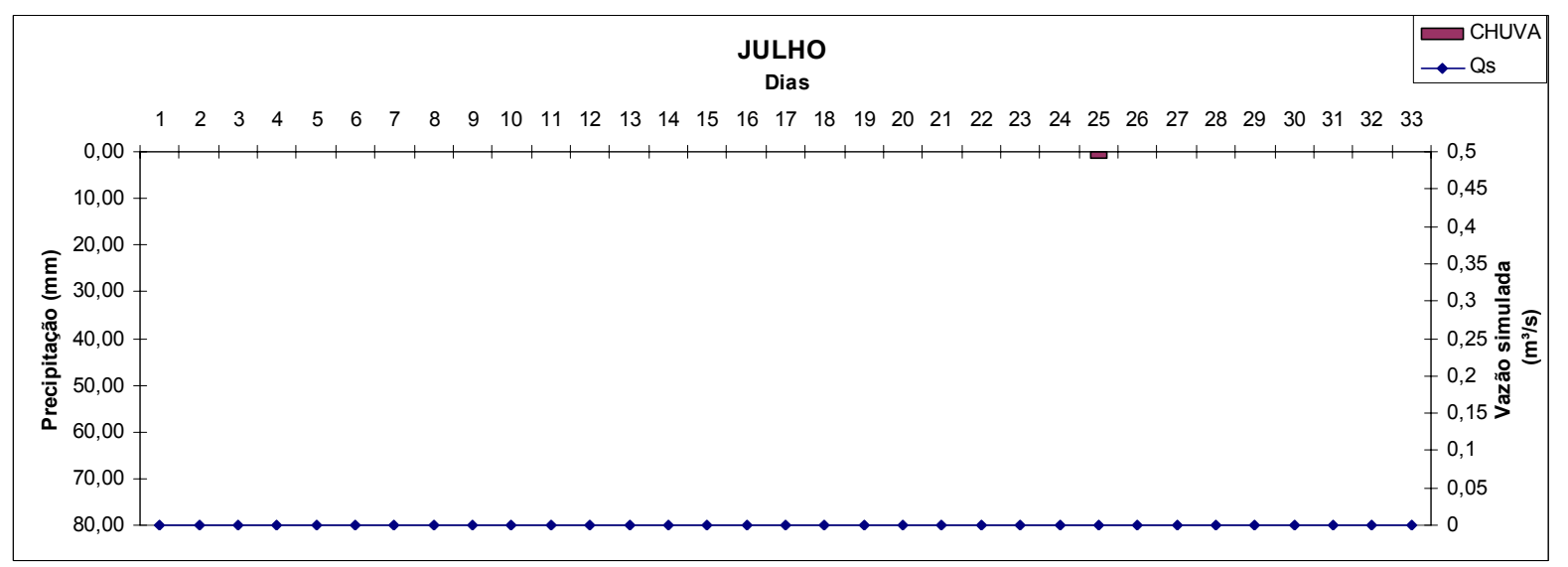

Gráfico 58: Escoamento superficial no Ribeirão da Onça simulado pelo IPHS1 para o mês de julho de 2005

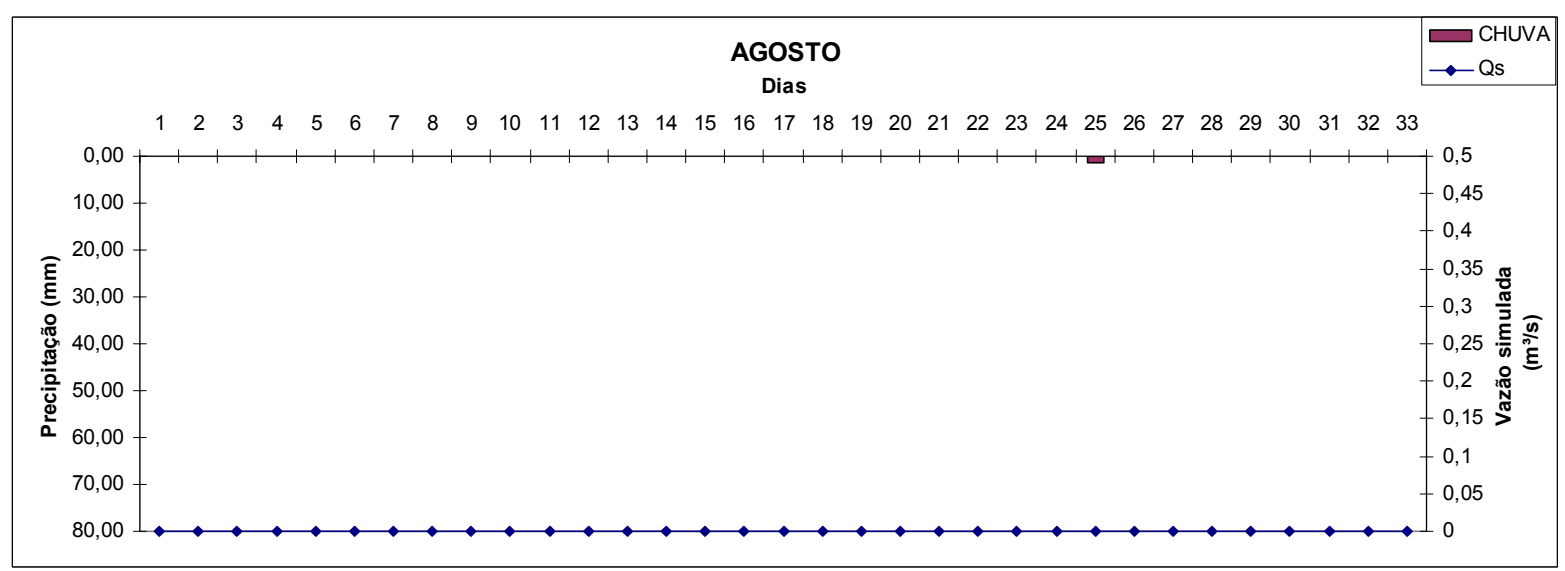

Gráfico 59: Escoamento superficial no Ribeirão da Onça simulado pelo IPHS1 para o mês de agosto de 2005 


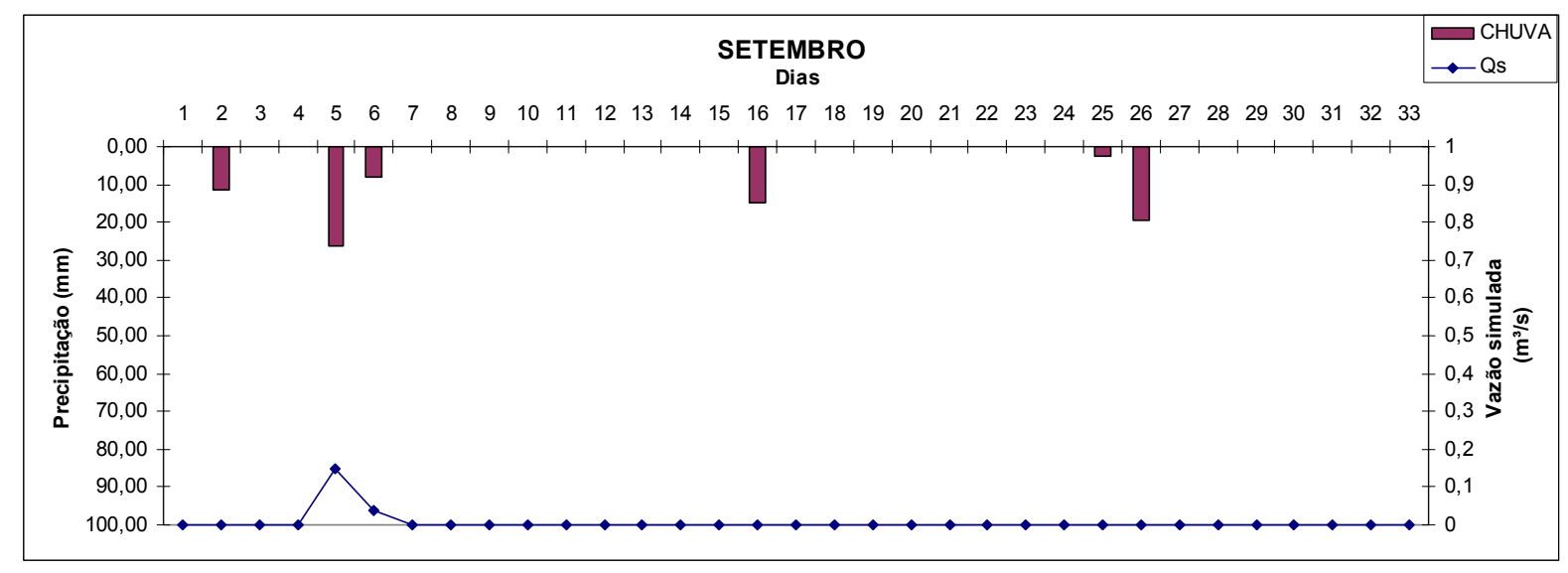

Gráfico 60: Escoamento superficial no Ribeirão da Onça simulado pelo IPHS1 para o mês de setembro de 2005

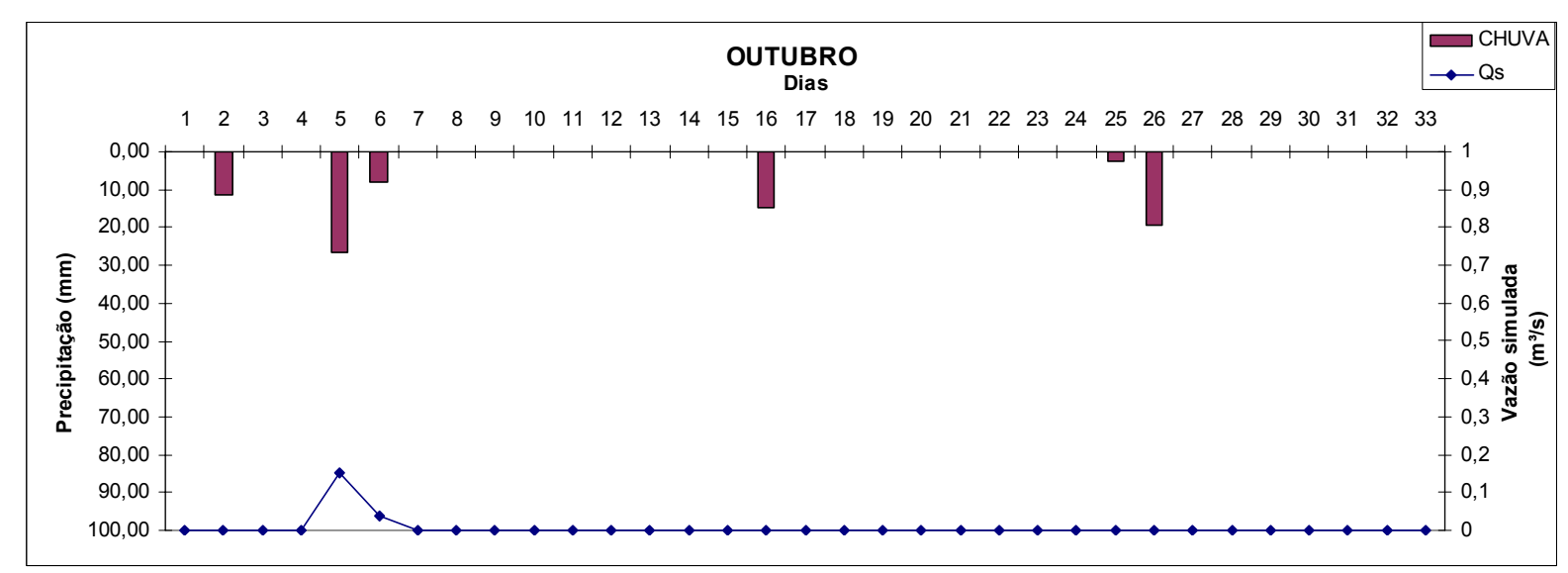

Gráfico 61: Escoamento superficial no Ribeirão da Onça simulado pelo IPHS1 para o mês de outubro de 2005

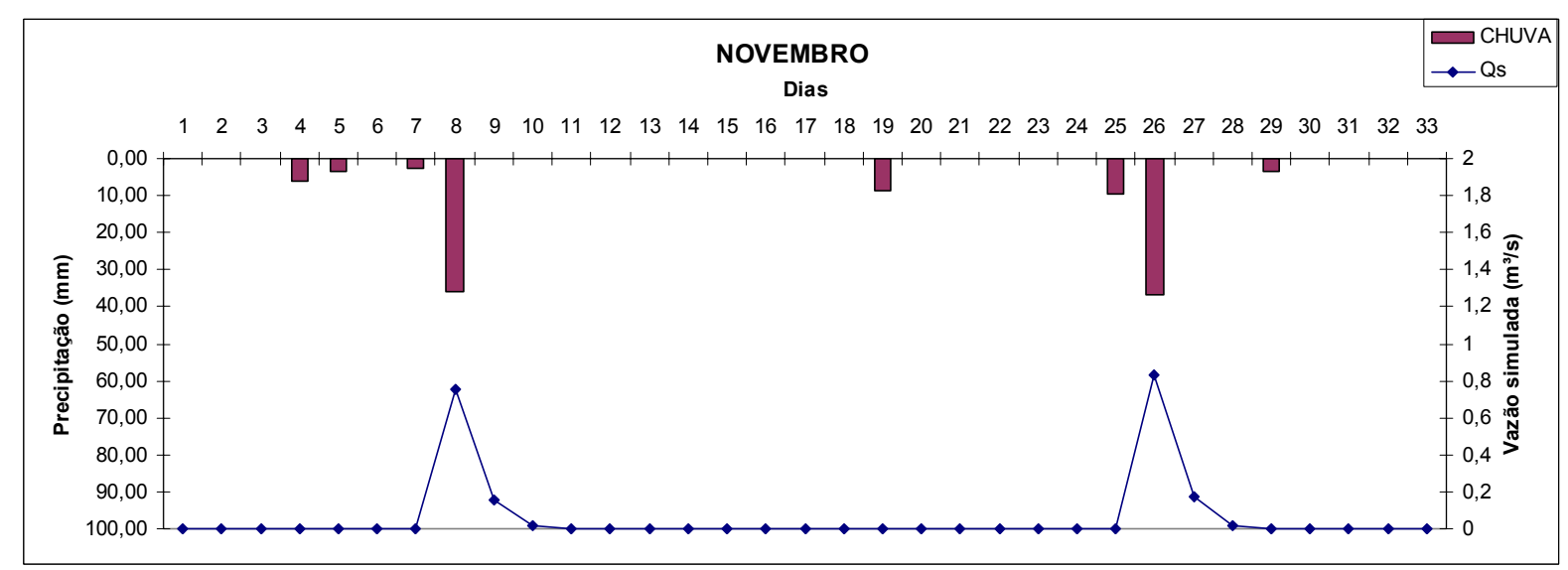

Gráfico 62: Escoamento superficial no Ribeirão da Onça simulado pelo IPHS1 para o mês de novembro de 2005 


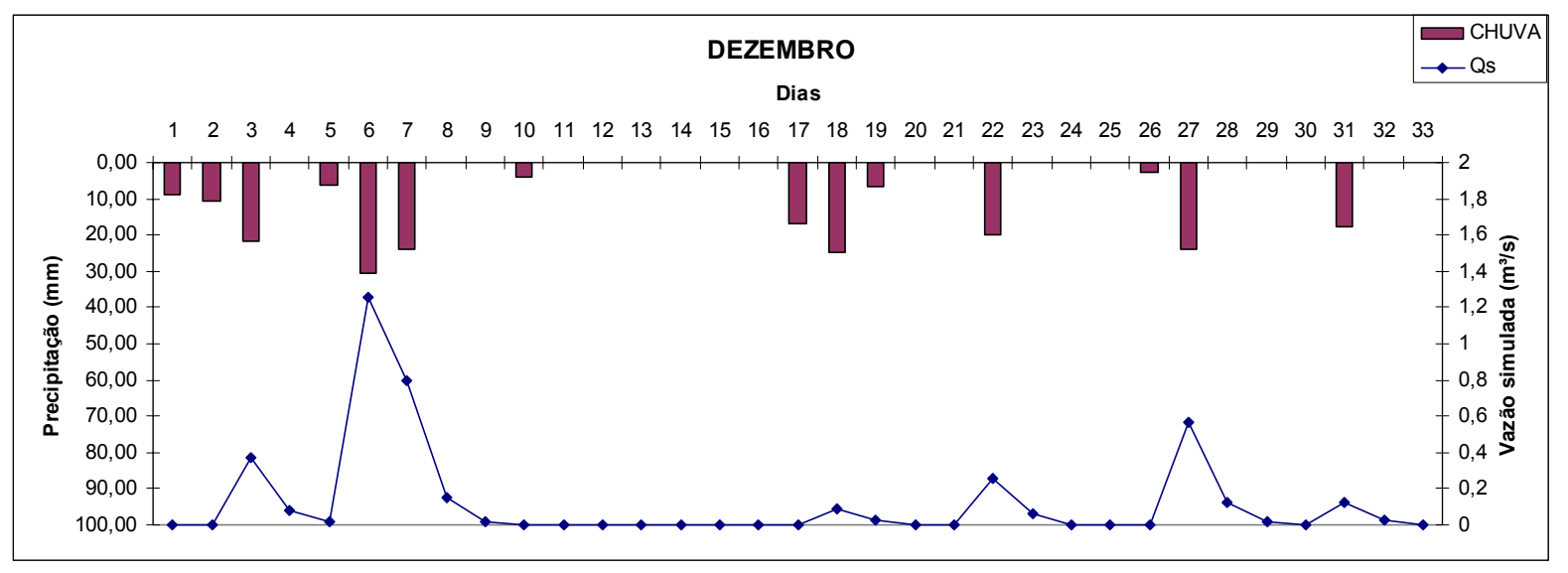

Gráfico 63: Escoamento superficial no Ribeirão da Onça simulado pelo IPHS1 para o mês de dezembro de 2005 


\section{APENDICE F}

(Medição do nível do aqǘf́ero nos 23 poços de monitoramento) 

Tabela 38: Medição de nível potenciométrico, 12/03/2004 - 03/08/2004

\begin{tabular}{|c|c|c|c|c|c|c|}
\hline \multirow{3}{*}{ POÇO } & \multicolumn{6}{|c|}{ DATAS } \\
\hline & $02 / 03 / 04$ & $05 / 03 / 04$ & $08 / 04 / 04$ & $14 / 05 / 04$ & $05 / 07 / 04$ & $03 / 08 / 04$ \\
\hline & \multicolumn{6}{|c|}{ NÍVEIS $(\mathrm{m})$} \\
\hline 1 & - & - & - & seco & seco & seco \\
\hline 2 & 10,83 & - & 11,04 & 12,77 & 14,42 & 14,62 \\
\hline 3 & 15,40 & - & 15,60 & 16,06 & 16,25 & 16,36 \\
\hline 4 & 16,87 & - & 16,71 & 16,82 & 16,88 & 17,00 \\
\hline 5 & - & - & 5,23 & 5,32 & 5,45 & 5,78 \\
\hline 6 & - & - & - & $*$ & & seco \\
\hline 7 & - & - & - & 8,74 & 8,63 & 8,59 \\
\hline 8 & - & - & 21,89 & - & 22,12 & 23,03 \\
\hline 9 & 18,48 & - & 18,67 & 18,96 & 19,36 & 19,40 \\
\hline 10 & - & - & - & - & 18,70 & 18,80 \\
\hline 11 & - & 16,59 & - & - & seco & - \\
\hline 12 & - & seco & - & - & seco & - \\
\hline 13 & - & 8,34 & - & - & 9,59 & - \\
\hline 14 & - & - & - & - & 6,30 & - \\
\hline 15 & - & - & - & - & - & - \\
\hline 16 & - & - & - & - & - & - \\
\hline 17 & - & - & - & - & - & - \\
\hline 18 & - & - & - & - & - & - \\
\hline 19 & - & - & - & - & - & - \\
\hline 20 & - & - & - & - & - & - \\
\hline 21 & - & - & - & - & - & - \\
\hline 22 & - & - & - & - & - & - \\
\hline 23 & - & - & - & - & - & - \\
\hline
\end{tabular}

Tabela 39 Medição de nível potenciométrico, 05/08/2004 - 14/10/2004

\begin{tabular}{|c|c|c|c|c|c|c|}
\hline \multirow{3}{*}{ POÇO } & \multicolumn{6}{|c|}{ DATA } \\
\hline & $05 / 08 / 04$ & $30 / 08 / 04$ & $02 / 09 / 04$ & $16 / 09 / 04$ & $01 / 10 / 04$ & $14 / 10 / 04$ \\
\hline & \multicolumn{6}{|c|}{ NÍVEIS $(\mathrm{m})$} \\
\hline 1 & - & seco & - & seco & seco & seco \\
\hline 2 & - & 15,48 & - & 16,20 & 16,65 & 16,83 \\
\hline 3 & - & 16,47 & - & 16,56 & 16,61 & 16,65 \\
\hline 4 & - & 17,22 & - & 17,33 & 17,44 & 17,48 \\
\hline 5 & - & 6,09 & - & 6,26 & 6,39 & 6,53 \\
\hline 6 & - & seco & - & seco & seco & seco \\
\hline 7 & - & 8,60 & - & 8,59 & 8,55 & 8,55 \\
\hline 8 & - & 23,40 & - & 23,46 & 23,56 & 23,64 \\
\hline 9 & - & 19,51 & - & - & - & 19,69 \\
\hline 10 & - & 18,88 & - & 18,94 & 18,99 & 19,03 \\
\hline 11 & seco & seco & - & seco & seco & - \\
\hline 12 & seco & seco & - & seco & seco & seco \\
\hline 13 & 9,87 & 10,02 & - & 10,13 & 10,22 & 10,29 \\
\hline 14 & 6,62 & 6,75 & - & 6,86 & 6,92 & 7,00 \\
\hline 15 & 8,08 & 8,19 & - & 8,28 & 8,36 & - \\
\hline 16 & - & - & 5,24 & 5,49 & 5,55 & 5,60 \\
\hline 17 & - & - & - & 12,00 & 12,08 & 12,16 \\
\hline 18 & - & - & - & 15,20 & 15,29 & 15,40 \\
\hline 19 & - & - & - & 15,29 & 15,44 & 15,58 \\
\hline 20 & - & - & - & - & - & - \\
\hline 21 & - & - & - & - & - & - \\
\hline 22 & - & - & - & - & - & - \\
\hline 23 & - & - & - & - & - & - \\
\hline
\end{tabular}


Tabela 40: Medição de nível potenciométrico, 28/10/2004 - 17/12/04

\begin{tabular}{|c|c|c|c|c|c|c|}
\hline \multirow{3}{*}{ POÇO } & \multicolumn{6}{|c|}{ DATA } \\
\hline & $28 / 10 / 04$ & $14 / 11 / 04$ & $27 / 11 / 04$ & $07 / 12 / 04$ & $10 / 12 / 04$ & $17 / 12 / 04$ \\
\hline & \multicolumn{6}{|c|}{ NÍVEIS (m) } \\
\hline 1 & - & - & seco & seco & - & seco \\
\hline 2 & 16,98 & - & 17,31 & seco & - & seco \\
\hline 3 & 16,67 & - & 16,70 & 16,72 & - & 16,74 \\
\hline 4 & 17,56 & 17,63 & 17,62 & 17,68 & - & 17,69 \\
\hline 5 & 6,60 & 6,72 & 6,79 & 6,79 & - & 6,82 \\
\hline 6 & seco & - & seco & seco & - & seco \\
\hline 7 & 8,54 & 8,54 & 8,55 & 8,55 & - & 8,53 \\
\hline 8 & 23,72 & - & 23,84 & 23,92 & - & 23,96 \\
\hline 9 & 19,76 & - & 19,88 & 19,95 & - & 20,01 \\
\hline 10 & 19,09 & - & 19,21 & 19,37 & - & 19,33 \\
\hline 11 & - & - & destruído & destruído & - & - \\
\hline 12 & seco & - & seco & seco & - & seco \\
\hline 13 & 10,36 & - & 10,50 & 10,53 & - & 10,55 \\
\hline 14 & 7,09 & - & 7,26 & 7,30 & - & 7,32 \\
\hline 15 & 8,50 & - & 8,62 & 8,58 & - & 8,55 \\
\hline 16 & 5,64 & 5,77 & 5,63 & - & 5,59 & 5,60 \\
\hline 17 & 12,24 & 12,35 & 12,38 & - & 12,36 & 12,35 \\
\hline 18 & 15,54 & 15,70 & 15,81 & - & 15,89 & 15,94 \\
\hline 19 & 15,72 & 15,90 & 16,02 & - & 16,12 & 16,19 \\
\hline 20 & - & - & - & - & - & - \\
\hline 21 & - & - & - & - & - & - \\
\hline 22 & - & - & - & - & - & - \\
\hline 23 & & - & - & - & - & - \\
\hline
\end{tabular}

Tabela 41: Medição de nível potenciométrico, 27/12/04 - 18/01/2005

\begin{tabular}{|c|c|c|c|c|c|c|}
\hline \multirow{3}{*}{ POÇO } & \multicolumn{6}{|c|}{ DATA } \\
\hline & $28 / 12 / 04$ & $05 / 01 / 05$ & $06 / 01 / 05$ & $11 / 01 / 05$ & $13 / 01 / 05$ & $18 / 01 / 05$ \\
\hline & \multicolumn{6}{|c|}{ NÍVEIS $(\mathrm{m})$} \\
\hline 1 & seco & - & - & seco & - & - \\
\hline 2 & seco & - & - & 16,72 & - & - \\
\hline 3 & 16,71 & - & - & 16,30 & - & - \\
\hline 4 & 17,68 & - & - & 17,54 & - & - \\
\hline 5 & 6,81 & - & - & 6,55 & - & 6,30 \\
\hline 6 & seco & - & - & seco & - & - \\
\hline 7 & 8,52 & - & - & 8,53 & - & - \\
\hline 8 & - & - & - & 24,16 & 24,17 & - \\
\hline 9 & 20,08 & - & 20,10 & 20,14 & - & - \\
\hline 10 & 19,37 & - & 19,42 & 19,46 & - & - \\
\hline 11 & seco & - & - & - & - & - \\
\hline 12 & seco & - & - & - & - & - \\
\hline 13 & 10,55 & - & - & 8,68 & - & - \\
\hline 14 & 7,32 & - & - & 5,12 & - & - \\
\hline 15 & 8,48 & - & - & - & 7,03 & - \\
\hline 16 & - & - & - & 4,40 & 4,36 & - \\
\hline 17 & - & - & - & 10,99 & 10,38 & - \\
\hline 18 & - & - & - & 15,25 & 13,36 & - \\
\hline 19 & - & - & - & 15,93 & 15,50 & - \\
\hline 20 & - & - & 2,16 & 1,96 & - & - \\
\hline 21 & - & - & 0,32 & 0,30 & - & - \\
\hline 22 & - & - & 0,90 & 1,39 & - & - \\
\hline 23 & - & - & 1,34 & 0,92 & - & - \\
\hline
\end{tabular}


Tabela 42: Medição de nível potenciométrico, 20/10/2005 - 18/02/2005

\begin{tabular}{|c|c|c|c|c|c|c|}
\hline \multirow{2}{*}{ POÇO } & \multicolumn{7}{|c|}{ DATA } \\
\cline { 2 - 7 } & $20 / 01 / 05$ & $21 / 01 / 05$ & \multicolumn{7}{c|}{$27 / 01 / 05$} & \multicolumn{2}{c|}{$14 / 02 / 05$} & $16 / 02 / 05$ & $18 / 02 / 05$ \\
\hline & \multicolumn{7}{|c|}{ NIVEIS (m) } & - \\
\hline $\mathbf{1}$ & - & - & - & 13,09 & - & - \\
\hline $\mathbf{2}$ & - & - & - & 10,45 & - & - \\
\hline $\mathbf{3}$ & 15,83 & - & - & 14,91 & - & - \\
\hline $\mathbf{4}$ & 17,50 & - & - & 16,81 & - & - \\
\hline $\mathbf{5}$ & 6,30 & - & - & 5,27 & - & - \\
\hline $\mathbf{6}$ & - & - & - & seco & - & - \\
\hline $\mathbf{7}$ & 8,45 & - & - & 11,42 & - & - \\
\hline $\mathbf{8}$ & - & - & - & 23,84 & - & - \\
\hline $\mathbf{9}$ & - & - & - & 20,21 & - & - \\
\hline $\mathbf{1 0}$ & 19,50 & - & - & 19,62 & - & 15,43 \\
\hline $\mathbf{1 1}$ & - & - & - & - & - & - \\
\hline $\mathbf{1 2}$ & - & - & - & $5 e c 0$ & - & - \\
\hline $\mathbf{1 3}$ & - & - & 8,12 & 6,94 & - & - \\
\hline $\mathbf{1 4}$ & - & - & 4,79 & 4,00 & - & - \\
\hline $\mathbf{1 5}$ & - & - & 6,95 & 6,30 & - & - \\
\hline $\mathbf{1 6}$ & - & - & - & 3,81 & 3,81 & - \\
\hline $\mathbf{1 7}$ & - & - & - & 8,76 & 8,76 & - \\
\hline $\mathbf{1 8}$ & - & - & - & 10,94 & 10,94 & - \\
\hline $\mathbf{1 9}$ & - & - & - & 11,80 & 11,80 & - \\
\hline $\mathbf{2 0}$ & - & 2,00 & 1,91 & 1,90 & - & - \\
\hline $\mathbf{2 1}$ & - & 0,31 & 0,27 & 0,51 & - & - \\
\hline $\mathbf{2 2}$ & - & 1,39 & 1,31 & 1,50 & - & - \\
\hline $\mathbf{2 3}$ & - & 0,90 & 0,83 & 0,97 & - & \\
\hline
\end{tabular}

Tabela 43: Medição de nível potenciométrico, 28/02/2005 - 29/04/2005

\begin{tabular}{|c|c|c|c|c|c|c|}
\hline \multirow{3}{*}{ POÇO } & \multicolumn{6}{|c|}{ DATA } \\
\hline & $28 / 02 / 05$ & $04 / 03 / 05$ & $18 / 03 / 05$ & $22 / 03 / 05$ & $13 / 04 / 05$ & $29 / 04 / 05$ \\
\hline & \multicolumn{6}{|c|}{ NÍVEIS $(\mathrm{m})$} \\
\hline 1 & 13,55 & - & - & 13,97 & 14,17 & 14,30 \\
\hline 2 & 11,73 & - & - & 13,08 & 13,73 & 14,03 \\
\hline 3 & 15,30 & - & - & 15,76 & 15,89 & 16,15 \\
\hline 4 & 16,79 & - & - & 16,72 & 16,71 & 16,78 \\
\hline 5 & 5,32 & - & - & 5,42 & 5,31 & 5,47 \\
\hline 6 & seco & - & - & seco & seco & - \\
\hline 7 & 11,42 & - & - & 11,42 & 11,41 & 11,42 \\
\hline 8 & 19,79 & - & 20,67 & 20,70 & 20,75 & 20,81 \\
\hline 9 & 20,25 & - & 20,30 & 20,33 & 20,41 & 20,48 \\
\hline 10 & - & - & - & 19,78 & - & 19,93 \\
\hline 11 & - & 15,80 & - & 16,26 & 17,04 & 17,80 \\
\hline 12 & - & - & - & 25,85 & 25,08 & 25,03 \\
\hline 13 & - & 7,61 & 8,07 & 8,19 & 8,66 & 8,92 \\
\hline 14 & - & 4,50 & 4,90 & 5,00 & 5,44 & 5,76 \\
\hline 15 & - & 6,55 & 6,61 & 6,59 & 6,54 & 6,59 \\
\hline 16 & - & - & - & 4,13 & - & 4,48 \\
\hline 17 & - & - & - & 9,52 & - & 10,00 \\
\hline 18 & - & - & - & 11,36 & - & 11,96 \\
\hline 19 & - & - & - & 12,10 & - & 12,50 \\
\hline 20 & - & 2,30 & - & - & - & 2,83 \\
\hline 21 & - & 0,54 & - & - & 0,58 & 0,54 \\
\hline 22 & - & 1,78 & - & - & 1,99 & 2,04 \\
\hline 23 & - & 1,09 & - & - & 1,20 & 1,23 \\
\hline
\end{tabular}


Tabela 44: Medição de nível potenciométrico, 06/05/05 - 01/07/2005

\begin{tabular}{|c|c|c|c|c|c|c|}
\hline \multirow{3}{*}{ POÇO } & \multicolumn{6}{|c|}{ DATA } \\
\hline & $06 / 05 / 05$ & $16 / 05 / 05$ & $03 / 06 / 05$ & $16 / 06 / 05$ & $21 / 06 / 05$ & $01 / 07 / 05$ \\
\hline & \multicolumn{6}{|c|}{ NÍVEIS (m) } \\
\hline 1 & - & 14,43 & seco & - & seco & seco \\
\hline 2 & - & 14,35 & 14,68 & - & 15,13 & 15,38 \\
\hline 3 & - & 16,27 & 16,39 & - & 16,40 & 16,43 \\
\hline 4 & - & 16,87 & 16,90 & - & 16,91 & 16,93 \\
\hline 5 & - & 5,62 & 5,75 & - & 5,82 & 5,89 \\
\hline 6 & - & seco & - & - & - & - \\
\hline 7 & - & 11,42 & 11,42 & - & 11,37 & 11,36 \\
\hline 8 & - & 20,93 & 21,02 & - & 21,08 & 21,40 \\
\hline 9 & 20,50 & 20,57 & 20,68 & - & 20,65 & 20,69 \\
\hline 10 & - & 19,99 & 20,05 & - & 19,98 & 20,00 \\
\hline 11 & - & 18,17 & seco & - & seco & seco \\
\hline 12 & - & 25,12 & 25,28 & - & 25,34 & 25,46 \\
\hline 13 & 9,04 & - & 9,49 & - & 9,64 & 9,72 \\
\hline 14 & - & 6,03 & 6,28 & - & 6,46 & 6,57 \\
\hline 15 & 6,62 & - & - & - & 6,87 & 6,95 \\
\hline 16 & - & - & - & 4,81 & - & - \\
\hline 17 & - & - & - & 10,54 & - & - \\
\hline 18 & - & - & - & 12,67 & - & - \\
\hline 19 & - & - & - & 13,13 & - & - \\
\hline 20 & - & - & 2,66 & - & 2,91 & 2,81 \\
\hline 21 & - & 0,65 & 0,52 & - & 0,43 & 0,45 \\
\hline 22 & - & 2,08 & 2,05 & - & 2,10 & 2,11 \\
\hline 23 & - & 1,27 & 1,23 & - & 1,24 & 1,25 \\
\hline
\end{tabular}

Tabela 45: Medição de nível potenciométrico, 14/07/2005 - 15/09/2005

\begin{tabular}{|c|c|c|c|c|c|c|}
\hline \multirow{3}{*}{ POÇO } & \multicolumn{6}{|c|}{ DATA } \\
\hline & $14 / 07 / 05$ & $03 / 08 / 05$ & $12 / 08 / 05$ & $19 / 08 / 05$ & $02 / 09 / 05$ & $15 / 09 / 05$ \\
\hline & \multicolumn{6}{|c|}{ NÍVEIS (m) } \\
\hline 1 & seco & seco & - & seco & seco & seco \\
\hline 2 & 15,89 & 16,08 & - & 16,25 & 16,46 & seco \\
\hline 3 & 16,56 & 16,56 & - & 16,61 & 16,66 & 16,69 \\
\hline 4 & 17,06 & 17,01 & - & 17,08 & 17,15 & 17,21 \\
\hline 5 & 6,02 & 6,16 & - & 6,23 & 6,34 & 6,55 \\
\hline 6 & - & - & - & - & - & - \\
\hline 7 & 11,43 & 11,37 & - & 11,37 & 11,37 & 11,37 \\
\hline 8 & 21,60 & 22,32 & - & 22,61 & 22,70 & 22,83 \\
\hline 9 & 20,85 & 20,84 & 20,87 & 20,99 & 21,12 & 21,23 \\
\hline 10 & 20,13 & 20,05 & - & 20,08 & 20,11 & 20,13 \\
\hline 11 & seco & seco & - & seco & seco & seco \\
\hline 12 & 25,75 & 25,88 & - & 26,10 & 26,25 & 26,41 \\
\hline 13 & 9,88 & 9,98 & 10,05 & 10,09 & 10,19 & 10,28 \\
\hline 14 & 6,68 & 6,84 & - & 6,98 & 7,09 & 7,18 \\
\hline 15 & 7,08 & 7,23 & 7,31 & 7,37 & 7,49 & 7,60 \\
\hline 16 & 5,02 & - & 5,19 & - & 5,33 & 5,39 \\
\hline 17 & 10,94 & - & 11,20 & - & 11,44 & 11,56 \\
\hline 18 & 13,26 & - & 13,65 & - & 13,98 & 14,16 \\
\hline 19 & 13,69 & - & 14,10 & - & 14,46 & 14,64 \\
\hline 20 & 3,05 & 3,17 & - & 3,26 & 3,30 & 3,32 \\
\hline 21 & 0,63 & 0,70 & - & 0,74 & 0,63 & 0,73 \\
\hline 22 & 2,18 & 2,20 & - & 2,24 & 2,24 & 2,27 \\
\hline 23 & 1,31 & 1,33 & - & 1,37 & 1,35 & 1,39 \\
\hline
\end{tabular}


Tabela 46: Medição de nível potenciométrico, 28/09/2005 - 25/11/2005

\begin{tabular}{|c|c|c|c|c|c|c|}
\hline \multirow{2}{*}{ POÇO } & \multicolumn{7}{|c|}{ DATA } \\
\cline { 2 - 7 } & $28 / 09 / 05$ & $29 / 09 / 05$ & \multicolumn{7}{|c|}{$14 / 10 / 05$} & $27 / 10 / 05$ & $11 / 11 / 05$ & $25 / 11 / 05$ \\
\cline { 2 - 7 } & \multicolumn{7}{|c|}{ NÍVEIS (m) } & seco \\
\hline $\mathbf{1}$ & - & seco & seco & seco & seco & seco \\
\hline $\mathbf{2}$ & - & seco & 16,85 & 17,01 & 17,16 & 16,84 \\
\hline $\mathbf{3}$ & - & 16,72 & 16,75 & 16,79 & 16,81 & 17,61 \\
\hline $\mathbf{4}$ & 17,31 & - & 17,41 & 17,47 & 17,54 & 7,17 \\
\hline $\mathbf{5}$ & 6,67 & - & 6,82 & 6,93 & 7,05 & - \\
\hline $\mathbf{6}$ & - & - & - & - & - & - \\
\hline $\mathbf{7}$ & - & 11,37 & 11,37 & 11,37 & 11,37 & 23,80 \\
\hline $\mathbf{8}$ & - & 22,97 & 23,32 & 23,45 & 23,62 & 21,85 \\
\hline $\mathbf{9}$ & 21,35 & 21,32 & 21,48 & 21,60 & 21,70 & 20,33 \\
\hline $\mathbf{1 0}$ & 20,17 & 20,18 & 20,21 & 20,24 & 20,28 & seco \\
\hline $\mathbf{1 1}$ & - & seco & seco & seco & seco & 27,30 \\
\hline $\mathbf{1 2}$ & - & 26,57 & 26,77 & 26,94 & 27,12 & 10,65 \\
\hline $\mathbf{1 3}$ & - & 10,36 & 10,45 & 10,52 & 10,59 & 7,51 \\
\hline $\mathbf{1 4}$ & 7,25 & - & 7,33 & 7,40 & 7,46 & 8,19 \\
\hline $\mathbf{1 5}$ & 7,70 & 7,72 & 7,84 & 7,96 & 8,07 & - \\
\hline $\mathbf{1 6}$ & 5,46 & - & - & - & 5,71 & - \\
\hline $\mathbf{1 7}$ & 11,69 & - & - & - & 12,06 & - \\
\hline $\mathbf{1 8}$ & 14,34 & - & - & - & 14,91 & - \\
\hline $\mathbf{1 9}$ & 14,84 & - & - & - & 15,41 & 3,52 \\
\hline $\mathbf{2 0}$ & - & 3,34 & 3,41 & 3,45 & seco & 0,86 \\
\hline $\mathbf{2 1}$ & - & 0,67 & 0,86 & 0,68 & 0,80 & 2,32 \\
\hline $\mathbf{2 2}$ & - & 2,28 & 2,31 & 2,31 & 2,29 & 1,42 \\
\hline $\mathbf{2 3}$ & - & 1,40 & 1,45 & 1,40 & 1,41 & \\
\hline
\end{tabular}

Tabela 47: Medição de nível potenciométrico, 08/12/2005 - 13/01/06

\begin{tabular}{|c|c|c|c|}
\hline \multirow{2}{*}{ POÇO } & \multicolumn{3}{|c|}{ DATA } \\
\cline { 2 - 4 } & $08 / 12 / 05$ & NÍVEIS $(\mathrm{m})$ & $13 / 01 / 06$ \\
\hline \multirow{2}{*}{$\mathbf{2}$} & seco & seco & seco \\
\hline $\mathbf{3}$ & seco & seco & seco \\
\hline $\mathbf{4}$ & 16,86 & 16,85 & 16,63 \\
\hline $\mathbf{5}$ & 17,62 & 17,65 & 6,58 \\
\hline $\mathbf{6}$ & 7,26 & 7,30 & - \\
\hline $\mathbf{7}$ & - & - & 11,37 \\
\hline $\mathbf{8}$ & 11,37 & 11,37 & 24,20 \\
\hline $\mathbf{9}$ & 23,94 & 24,04 & 22,25 \\
\hline $\mathbf{1 0}$ & 21,98 & 22,10 & 20,48 \\
\hline $\mathbf{1 1}$ & 20,37 & 20,41 & seco \\
\hline $\mathbf{1 2}$ & seco & seco & seco \\
\hline $\mathbf{1 3}$ & 27,48 & 27,65 & 10,71 \\
\hline $\mathbf{1 4}$ & 10,70 & 10,74 & 7,57 \\
\hline $\mathbf{1 5}$ & 7,56 & 7,58 & 8,35 \\
\hline $\mathbf{1 6}$ & 8,28 & 8,37 & 5,79 \\
\hline $\mathbf{1 7}$ & - & - & 12,42 \\
\hline $\mathbf{1 8}$ & - & - & 15,59 \\
\hline $\mathbf{1 9}$ & - & - & 16,15 \\
\hline $\mathbf{2 0}$ & - & - & 3,12 \\
\hline $\mathbf{2 1}$ & 3,46 & 3,45 & 0,73 \\
\hline $\mathbf{2 2}$ & 0,54 & 0,64 & 2,17 \\
\hline $\mathbf{2 3}$ & 2,26 & 2,27 & 1,33 \\
\hline & 1,35 & 1,38 & \\
\hline
\end{tabular}





\section{APENDICE G}

(Detalhes construtivos dos poços 16, 17, 18 e 19) 



\section{POÇO 16}

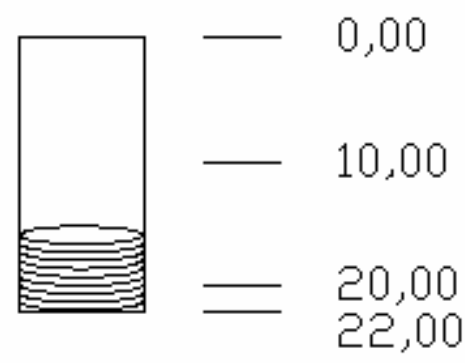

\begin{tabular}{|c|c|c|c|c|c|c|c|c|}
\hline Localização: & \multicolumn{7}{|c|}{ Fazenda Monte Alegre, Brotas-SP } & \\
\hline \multicolumn{8}{|c|}{ Perfuração } & \\
\hline Data & \multicolumn{3}{|c|}{ Profundidade inicial $(\mathrm{m})$} & \multicolumn{2}{|c|}{$\begin{array}{l}\text { Profundidade } \\
\text { Final (m) }\end{array}$} & Perfurador & Método & \\
\hline $31 / 08 / 2004$ & \multicolumn{3}{|c|}{0} & \multicolumn{2}{|c|}{22} & Magon & Rotativo & \\
\hline \multicolumn{8}{|c|}{ Diâmetro } & \\
\hline De (m) & \multicolumn{3}{|c|}{ Até $(\mathrm{m})$} & \multicolumn{2}{|c|}{ Polegadas } & \multicolumn{2}{|c|}{ Milímetros } & \\
\hline 0 & \multicolumn{3}{|c|}{22} & \multicolumn{2}{|l|}{4} & \multicolumn{2}{|c|}{100,00} & \\
\hline \multicolumn{9}{|c|}{ Características Técnicas } \\
\hline \multicolumn{3}{|c|}{ Perfuração } & \multicolumn{3}{|c|}{ Revestimento } & \multicolumn{3}{|c|}{ Filtros } \\
\hline De $(\mathrm{m})$ & $\begin{array}{l}\text { Até } \\
\text { (m) }\end{array}$ & pol & $\begin{array}{l}\text { De } \\
\text { (m) }\end{array}$ & Até $(\mathrm{m})$ & pol & $\operatorname{De}(\mathrm{m})$ & Até $(\mathrm{m})$ & pol \\
\hline 0,00 & 22,00 & 6 & 0,00 & 22,00 & 4 & 18,00 & 22,00 & 4 \\
\hline
\end{tabular}


POÇO 17

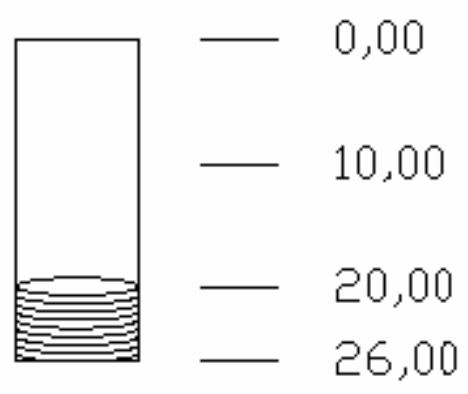

\begin{tabular}{|c|c|c|c|c|c|c|c|c|}
\hline Localização: & \multicolumn{7}{|c|}{ Fazenda Monte Alegre, Brotas-SP } & \\
\hline \multicolumn{8}{|c|}{ Perfuração } & \\
\hline Data & \multicolumn{3}{|c|}{ Profundidade inicial (m) } & \multicolumn{2}{|c|}{$\begin{array}{c}\text { Profundidade } \\
\text { Final (m) }\end{array}$} & Perfurador & Método & \\
\hline $31 / 08 / 2004$ & \multicolumn{3}{|c|}{0} & \multicolumn{2}{|c|}{26} & Magon & Rotativo & \\
\hline \multicolumn{8}{|c|}{ Diâmetro } & \\
\hline $\operatorname{De}(\mathrm{m})$ & \multicolumn{3}{|c|}{ Até (m) } & \multicolumn{2}{|c|}{ Polegadas } & \multicolumn{2}{|c|}{ Milímetros } & \\
\hline 0 & \multicolumn{3}{|c|}{26} & \multicolumn{2}{|l|}{4} & \multicolumn{2}{|c|}{100,00} & \\
\hline \multicolumn{9}{|c|}{ Características Técnicas } \\
\hline \multicolumn{3}{|c|}{ Perfuração } & \multicolumn{3}{|c|}{ Revestimento } & \multicolumn{3}{|c|}{ Filtros } \\
\hline $\operatorname{De}(\mathrm{m})$ & $\begin{array}{l}\text { Até } \\
(\mathrm{m})\end{array}$ & pol & $\begin{array}{l}\text { De } \\
(\mathrm{m})\end{array}$ & Até $(\mathrm{m})$ & pol & $\operatorname{De}(\mathrm{m})$ & Até $(\mathrm{m})$ & pol \\
\hline 0,00 & 26,00 & 6 & 0,00 & 26,00 & 4 & 20,00 & 26,00 & 4 \\
\hline
\end{tabular}




\section{POÇO 18}

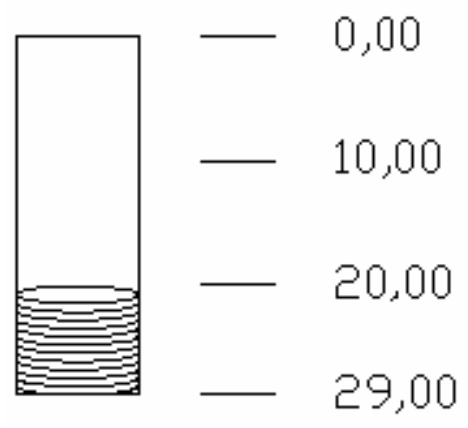

\begin{tabular}{|c|c|c|c|c|c|c|c|c|}
\hline Localização: & \multicolumn{7}{|c|}{ Fazenda Monte Alegre, Brotas-SP } & \\
\hline \multicolumn{8}{|c|}{ Perfuração } & \\
\hline Data & \multicolumn{3}{|c|}{ Profundidade inicial (m) } & \multicolumn{2}{|c|}{$\begin{array}{c}\text { Profundidade } \\
\text { Final (m) }\end{array}$} & Perfurador & Método & \\
\hline $01 / 09 / / 2004$ & \multicolumn{3}{|c|}{0} & \multicolumn{2}{|l|}{29} & Magon & Rotativo & \\
\hline \multicolumn{8}{|c|}{ Diâmetro } & \\
\hline $\operatorname{De}(\mathrm{m})$ & \multicolumn{3}{|c|}{ Até (m) } & \multicolumn{2}{|c|}{ Polegadas } & \multicolumn{2}{|c|}{ Milímetros } & \\
\hline 0 & \multicolumn{3}{|c|}{29} & \multicolumn{2}{|l|}{4} & \multicolumn{2}{|c|}{100,00} & \\
\hline \multicolumn{9}{|c|}{ Características Técnicas } \\
\hline \multicolumn{3}{|c|}{ Perfuração } & \multicolumn{3}{|c|}{ Revestimento } & \multicolumn{3}{|c|}{ Filtros } \\
\hline De (m) & $\begin{array}{l}\text { Até } \\
(\mathrm{m})\end{array}$ & pol & $\begin{array}{l}\mathrm{De} \\
\text { (m) }\end{array}$ & Até (m) & pol & De $(m)$ & Até $(\mathrm{m})$ & pol \\
\hline 0,00 & 29,00 & 6 & 0,00 & 29,00 & 4 & 21,00 & 29,00 & 4 \\
\hline
\end{tabular}




\section{POÇO 19}

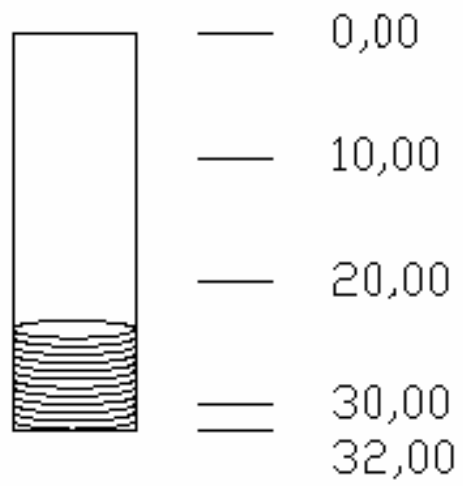

\begin{tabular}{|c|c|c|c|c|c|c|c|c|}
\hline Localização: & \multicolumn{7}{|c|}{ Fazenda Monte Alegre, Brotas-SP } & \\
\hline \multicolumn{8}{|c|}{ Perfuração } & \\
\hline Data & \multicolumn{3}{|c|}{ Profundidade inicial (m) } & \multicolumn{2}{|c|}{$\begin{array}{l}\text { Profundidade } \\
\text { Final (m) }\end{array}$} & Perfurador & Método & \\
\hline $02 / 09 / / 2004$ & \multicolumn{3}{|c|}{0} & \multicolumn{2}{|c|}{32} & Magon & Rotativo & \\
\hline \multicolumn{8}{|c|}{ Diâmetro } & \\
\hline De $(m)$ & \multicolumn{3}{|c|}{ Até (m) } & \multicolumn{2}{|c|}{ Polegadas } & \multicolumn{2}{|c|}{ Milímetros } & \\
\hline 0 & \multicolumn{3}{|c|}{32} & \multicolumn{2}{|l|}{4} & \multicolumn{2}{|c|}{100,00} & \\
\hline \multicolumn{9}{|c|}{ Características Técnicas } \\
\hline \multicolumn{3}{|c|}{ Perfuração } & \multicolumn{3}{|c|}{ Revestimento } & \multicolumn{3}{|c|}{ Filtros } \\
\hline De (m) & $\begin{array}{l}\text { Até } \\
\text { (m) }\end{array}$ & pol & $\begin{array}{l}\text { De } \\
\text { (m) }\end{array}$ & Até $(\mathrm{m})$ & pol & $\operatorname{De}(\mathrm{m})$ & Até $(\mathrm{m})$ & pol \\
\hline 0,00 & 32,00 & 6 & 0,00 & 32,00 & 4 & 24,00 & 32,00 & 4 \\
\hline
\end{tabular}




\section{ANEXO I}

(Detalhes construtivos dos poços 04 e 05)

(Dados retirados do site:

http://siagas.cprm.gov.br/wellshow/index.asp?id=\&poco camada=on\&rodovia camada $=\&$ rio camada $=\&$ municipio camada $=\& 0 p c a 0=S a 0 \% 20$ Paulo $\& w=1280 \& h=768$, visitado em 08/07/2006) 



\section{POÇO 04}

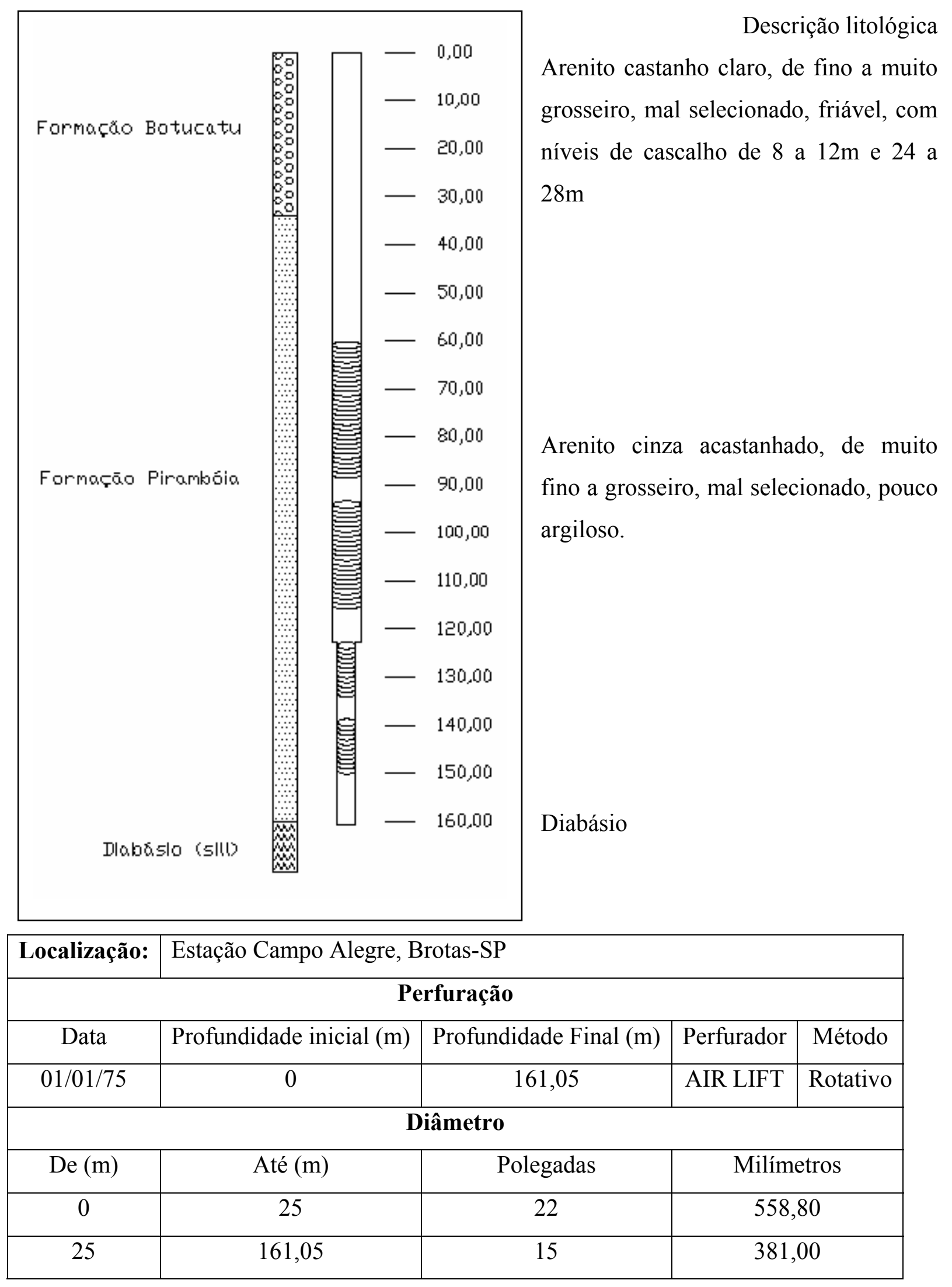




\begin{tabular}{|c|c|c|c|c|c|c|c|c|}
\hline \multicolumn{9}{|c|}{ Perfil Geológico } \\
\hline \multicolumn{3}{|c|}{ De (m) } & \multicolumn{3}{|c|}{ Até (m) } & \multicolumn{3}{|c|}{ Formação } \\
\hline \multicolumn{3}{|c|}{0,00} & \multicolumn{3}{|c|}{34,00} & \multicolumn{3}{|c|}{ Botucatu } \\
\hline \multicolumn{3}{|c|}{34,00} & \multicolumn{3}{|c|}{160,00} & \multicolumn{3}{|c|}{ Pirambóia } \\
\hline \multicolumn{3}{|c|}{160,00} & \multicolumn{3}{|c|}{161,05} & \multicolumn{3}{|c|}{ Diabásio } \\
\hline \multicolumn{9}{|c|}{ Características Técnicas } \\
\hline \multicolumn{3}{|c|}{ Perfuração } & \multicolumn{3}{|c|}{ Revestimento } & \multicolumn{3}{|c|}{ Filtros } \\
\hline De $(m)$ & Até (m) & pol & $\operatorname{De}(\mathrm{m})$ & Até $(\mathrm{m})$ & pol & $\operatorname{De}(\mathrm{m})$ & Até $(\mathrm{m})$ & pol \\
\hline 0,00 & 25,00 & 22 & 0,00 & 25,00 & 16 & 60,87 & 87,72 & 10 \\
\hline \multirow[t]{3}{*}{25,00} & 161,05 & 15 & 25,00 & 121,87 & 10 & 94,07 & 115,61 & 10 \\
\hline & & & 121,87 & 161,05 & 8 & 123,43 & 133,16 & 8 \\
\hline & & & & & & 139,42 & 149,14 & 8 \\
\hline
\end{tabular}




\section{POÇO 05}

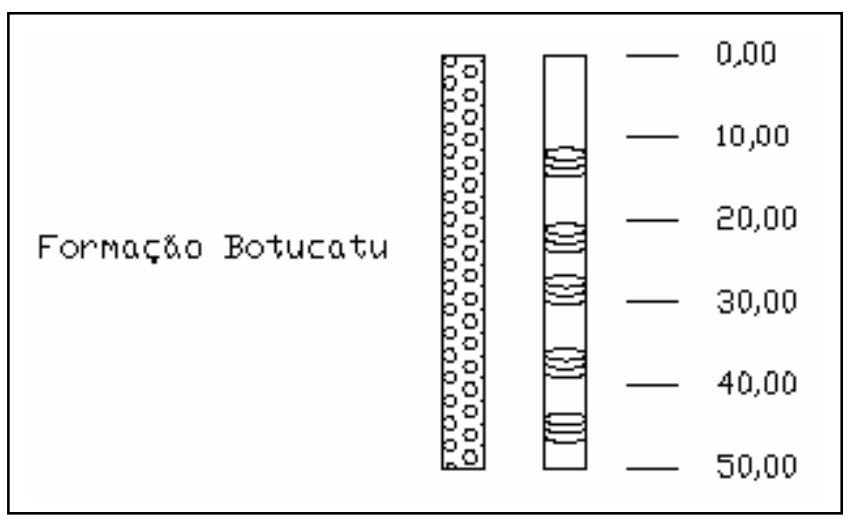

Descrição litológica

Arenito castanho claro, de fino a muito grosseiro, mal selecionado, friável.

\begin{tabular}{|c|c|c|c|c|c|c|c|c|}
\hline Localização: & \multicolumn{7}{|c|}{ Estação Campo Alegre, Brotas-SP } & \\
\hline \multicolumn{8}{|c|}{ Perfuração } & \\
\hline Data & \multicolumn{3}{|c|}{ Profundidade inicial (m) } & \multicolumn{2}{|c|}{$\begin{array}{l}\text { Profundidade } \\
\text { Final (m) }\end{array}$} & Perfurador & Método & \\
\hline $01 / 01 / 76$ & \multicolumn{3}{|c|}{0} & \multicolumn{2}{|c|}{50,00} & AIR LIFT & Rotativo & \\
\hline \multicolumn{8}{|c|}{ Diâmetro } & \\
\hline De (m) & \multicolumn{3}{|c|}{ Até $(\mathrm{m})$} & \multicolumn{2}{|c|}{ Polegadas } & \multicolumn{2}{|c|}{ Milímetros } & \\
\hline 0 & \multicolumn{3}{|c|}{50} & \multicolumn{2}{|l|}{2} & \multicolumn{2}{|c|}{50,8} & \\
\hline \multicolumn{9}{|c|}{ Perfil Geológico } \\
\hline \multicolumn{3}{|c|}{$\operatorname{De}(\mathrm{m})$} & \multicolumn{3}{|c|}{ Até $(\mathrm{m})$} & \multicolumn{3}{|c|}{ Formação } \\
\hline \multicolumn{3}{|c|}{0,00} & \multicolumn{3}{|c|}{50,00} & \multicolumn{3}{|c|}{ Botucatu } \\
\hline \multicolumn{9}{|c|}{ Características Técnicas } \\
\hline \multicolumn{3}{|c|}{ Perfuração } & \multicolumn{3}{|c|}{ Revestimento } & \multicolumn{3}{|c|}{ Filtros } \\
\hline De (m) & $\begin{array}{l}\text { Até } \\
\text { (m) }\end{array}$ & pol & $\begin{array}{l}\text { De } \\
(\mathrm{m})\end{array}$ & Até $(\mathrm{m})$ & pol & De (m) & Até $(\mathrm{m})$ & pol \\
\hline \multirow[t]{5}{*}{0,00} & 50,00 & 6 & 0,00 & 50,00 & 2 & 12 & 14 & 2 \\
\hline & & & & & & 20 & 22 & 2 \\
\hline & & & & & & 28 & 30 & 2 \\
\hline & & & & & & 36 & 38 & 2 \\
\hline & & & & & & 44 & 46 & 2 \\
\hline
\end{tabular}

